\title{
Catalytic Asymmetric Synthesis of $\alpha$-Trifluoromethyl Homoallylic Amines via Umpolung Allylation/2-aza-Cope Rearrangement: Stereoselectivity and Mechanistic Insight
}

Li-Min Shi, Xi-Shang Sun, Chong Shen, Zuo-Fei Wang, Hai-Yan Tao, and Chun-Jiang Wang*

E-mail: cjwang@whu.edu.cn

\section{Table of Contents}

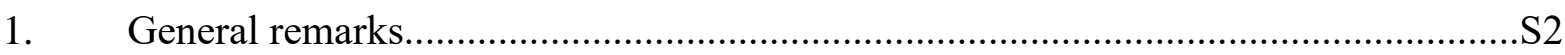

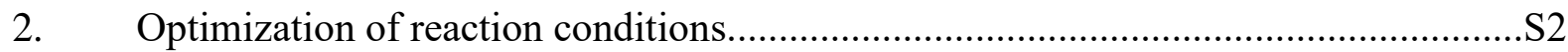

3. Substrate scope of trifluoroethylisatin ketimines.......................................................... 3

4. General procedure for the cascade asymmetric umpolung allylation/2-aza-Cope

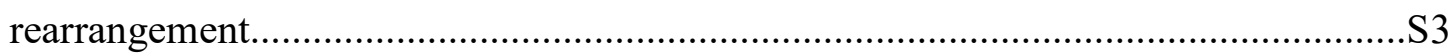

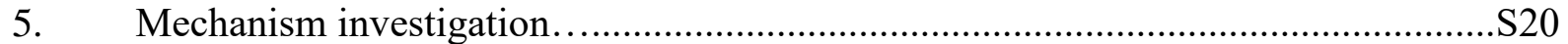

6. Rationale for the experimental results of the reaction of isatin ketamine 1a and methyl

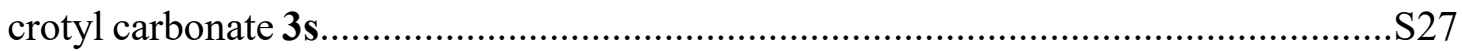

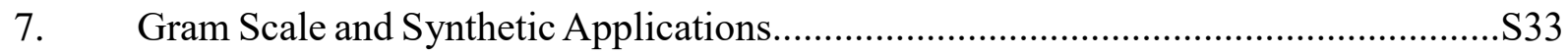

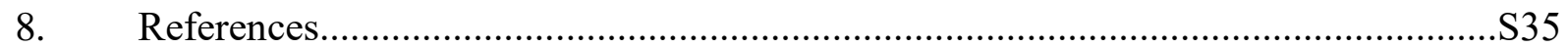

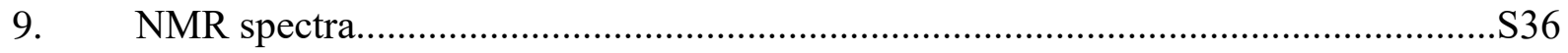

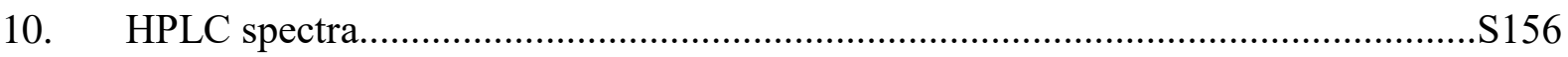




\section{General remarks}

${ }^{1} \mathrm{H}$ NMR spectra were recorded on a Bruker $400 \mathrm{MHz}$ spectrometer in $\mathrm{CDCl}_{3}$. Chemical shifts are reported in ppm with the internal TMS signal at $0.0 \mathrm{ppm}$ as a standard. The data are reported as $(\mathrm{s}=$ single, $\mathrm{d}=$ double, $\mathrm{t}=$ triple, $\mathrm{q}=$ quarte, $\mathrm{m}=$ multiple or unresolved, brs $=$ broad single, coupling constant(s) in $\mathrm{Hz}$, integration). ${ }^{13} \mathrm{C}$ NMR spectra were recorded on a Bruker $100 \mathrm{MHz}$ spectrometer in $\mathrm{CDCl}_{3} .{ }^{19} \mathrm{~F} \mathrm{NMR}$ spectra were recorded on a Bruker $376 \mathrm{MHz}$ spectrometer in $\mathrm{CDCl}_{3}$. Chemical shifts are reported in ppm. Chemical shifts are reported in ppm. Commercially obtained reagents were used without further purification. All reactions were monitored by TLC with silica gel-coated plates. Enantiomeric ratios were determined by HPLC, using a chiralpak AD-H, IE, IA, IB and AS column, chiralcel OD-H and OJ-H column with hexane and $i$-PrOH. The absolute configurations of $\mathbf{5 g a}, \mathbf{7 b}$, tosylated $\mathbf{8 a} / \mathbf{8 b}$ and tosylated 8b were determined based on X-ray diffraction analysis, and those of other adducts were deduced on the basis of these results.

\section{Optimization of reaction conditions}

Table S1. Optimization of reaction conditions ${ }^{a}$
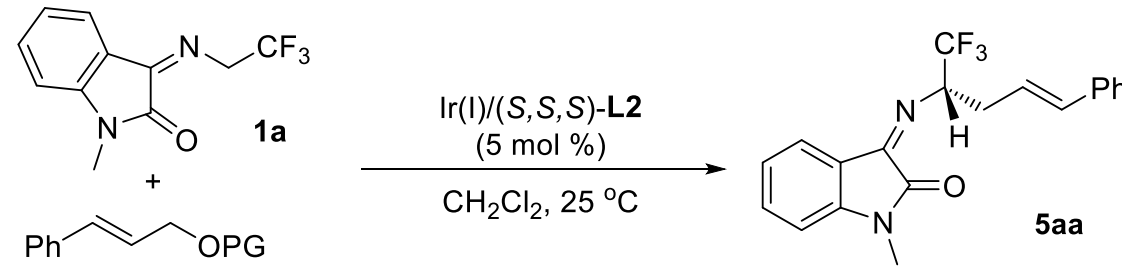

3

\begin{tabular}{ccccc}
\hline Entry & $\mathrm{PG}$ & solvent & yield $^{b}$ & ee $^{c}$ \\
\hline 1 & $\mathrm{Boc}$ & $\mathrm{CH}_{2} \mathrm{Cl}_{2}$ & 82 & 93 \\
2 & $\mathrm{Ac}$ & $\mathrm{CH}_{2} \mathrm{Cl}_{2}$ & 45 & 92 \\
3 & $\mathrm{Ms}$ & $\mathrm{CH}_{2} \mathrm{Cl}_{2}$ & - & - \\
4 & $\mathrm{PO}(\mathrm{OEt})_{2}$ & $\mathrm{CH}_{2} \mathrm{Cl}_{2}$ & 86 & 11 \\
5 & COOMe & Toluene & 92 & 92 \\
6 & COOMe & THF & 69 & 78 \\
\hline
\end{tabular}

${ }^{a}$ All reaction were carried out with $0.20 \mathrm{mmol}$ of $1 \mathrm{a}$ and $0.22 \mathrm{mmol}$ of $3 \mathrm{in} 2 \mathrm{~mL}$ of DCM.

${ }^{b}$ Isolated yield. ${ }^{c}$ Ee was determined by HPLC analysis. 


\section{Substrate scope of trifluoroethylisatin ketimines}

Table S2. Substrate scope of $N$-trifluoroethylisatin ketimines ${ }^{a, b, c}$

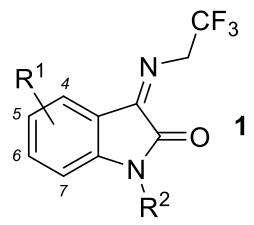

$+$

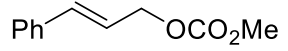

$3 a$

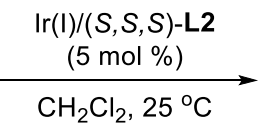

$\mathrm{CH}_{2} \mathrm{Cl}_{2}, 25^{\circ} \mathrm{C}$

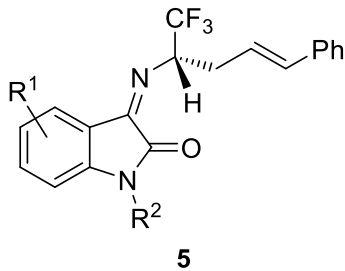

5

\begin{tabular}{|c|c|c|c|c|c|}
\hline entry & $\mathrm{R}^{1}$ & $\mathrm{R}^{2}$ & 5 & yield $(\%)^{b}$ & ee $(\%)^{c}$ \\
\hline 1 & $\mathrm{H}$ & $\mathrm{Me}$ & $5 \mathbf{a a}$ & 99 & 95 \\
\hline 2 & $5-\mathrm{Me}$ & $\mathrm{Me}$ & $5 \mathbf{b a}$ & 90 & 93 \\
\hline 3 & 6-Me & $\mathrm{Me}$ & $5 \mathrm{ca}$ & 99 & 90 \\
\hline 4 & 7-Me & $\mathrm{Me}$ & $5 \mathrm{da}$ & 88 & 94 \\
\hline 5 & $5-\mathrm{MeO}$ & $\mathrm{Me}$ & 5 ea & 92 & 92 \\
\hline 6 & $5-\mathrm{Br}$ & $\mathrm{Me}$ & $5 \mathrm{fa}$ & 91 & 92 \\
\hline 7 & $5-\mathrm{Cl}$ & $\mathrm{Me}$ & 5 ga & 81 & 95 \\
\hline 8 & $4-\mathrm{Cl}$ & $\mathrm{Me}$ & 5 ha & 99 & 89 \\
\hline 9 & $\mathrm{H}$ & $n \mathrm{Bu}$ & 5 ia & 99 & 93 \\
\hline 10 & $\mathrm{H}$ & allyl & $5 \mathbf{j a}$ & 84 & 93 \\
\hline 11 & $\mathrm{H}$ & $\mathrm{Bn}$ & $5 \mathrm{ka}$ & 99 & 91 \\
\hline 12 & 4-Cl & $\mathrm{Bn}$ & 5la & 99 & 89 \\
\hline
\end{tabular}

${ }^{a}$ All reactions were carried out with $0.20 \mathrm{mmol} 1$ and $0.22 \mathrm{mmol} \mathrm{3a}$ in $2 \mathrm{~mL}$ of $\mathrm{CH}_{2} \mathrm{Cl}_{2} .{ }^{b}$ Yields refer to the isolated products after chromatographic purification. ${ }^{c}$ The ee value was determined by HPLC analysis.

\section{General procedure for the cascade umpolung allylation/2-aza-Cope rearrangement}

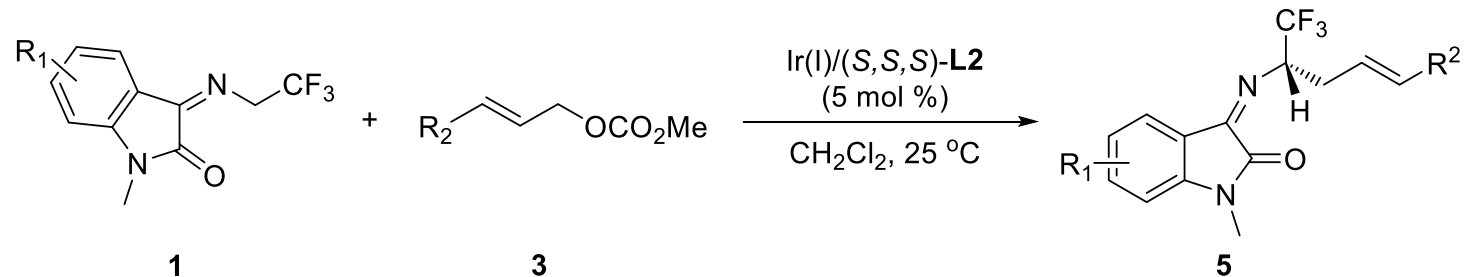

In a $25 \mathrm{~mL}$ nitrogen-filled dry Schlenk tube, $[\operatorname{Ir}(\mathrm{COD}) \mathrm{Cl}]_{2}(3.3 \mathrm{mg}, 0.005 \mathrm{mmol})$, phosphoramidite ligand $(S, S, S)$-L2 $(5.6 \mathrm{mg}, 0.01 \mathrm{mmol})$, degassed THF $(0.5 \mathrm{~mL})$ and degassed propylamine $(0.5 \mathrm{~mL})$ were added. After stirring at $50{ }^{\circ} \mathrm{C}$ for $30 \mathrm{mins}$, the reaction was concentrated via rotary evaporation under reduced pressure to give the iridium complex as a pale yellow solid ${ }^{[1]}$. Then, $N$-2,2,2-trifluoroethylisatin ketamine $1(0.20 \mathrm{mmol})$, allylic carbonates $3(0.22 \mathrm{mmol})$ and dry $\mathrm{CH}_{2} \mathrm{Cl}_{2}(2 \mathrm{~mL})$ was added into the nitrogen-refilled Schlenk tube. Once starting material was consumed (monitored by TLC), the reaction mixture was 
concentrated via rotary evaporation under reduced pressure, and then purified by flash chromatography on silica gel $(\mathrm{PE} / \mathrm{EA}=20: 1)$ to give the racemic product 5 .

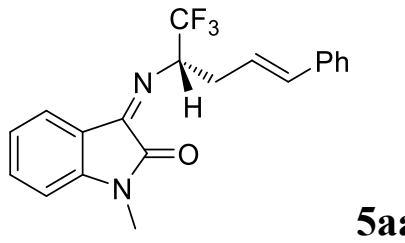

\section{(Z)-1-methyl-3-(((S,E)-1,1,1-trifluoro-5-phenylpent-4-en-2-yl)imino)indolin-2-one:}

Yellow oil; yield (71.0 mg, 99\%). $[\alpha]^{25} \mathrm{D}=-90.0\left(c\right.$ 0.18, $\left.\mathrm{CH}_{2} \mathrm{Cl}_{2}\right) .{ }^{1} \mathrm{H} \mathrm{NMR}\left(400 \mathrm{MHz}, \mathrm{CDCl}_{3}\right)$ $\delta 7.70(\mathrm{~d}, J=7.6 \mathrm{~Hz}, 1 \mathrm{H}), 7.41(\mathrm{t}, J=7.6 \mathrm{~Hz}, 1 \mathrm{H}), 7.26-7.14(\mathrm{~m}, 5 \mathrm{H}), 7.09(\mathrm{t}, J=7.6 \mathrm{~Hz}$, $1 \mathrm{H}), 6.70(\mathrm{~d}, J=7.6 \mathrm{~Hz}, 1 \mathrm{H}), 6.23(\mathrm{~d}, J=16.0 \mathrm{~Hz}, 1 \mathrm{H}), 6.17-6.05(\mathrm{~m}, 2 \mathrm{H}), 3.04-2.93(\mathrm{~m}$, 4H), $2.64-2.53(\mathrm{~m}, 1 \mathrm{H}) .{ }^{13} \mathrm{C} \mathrm{NMR}\left(101 \mathrm{MHz}, \mathrm{CDCl}_{3}\right) \delta 159.0,155.9,145.8,135.5,133.8$, $132.9,132.5,128.6,127.4,125.4(\mathrm{q}, J=280.1 \mathrm{~Hz}), 125.6,123.4,123.0,120.7,108.7,59.9$ (q, $J=28.3 \mathrm{~Hz}), 34.0,25.6 .{ }^{19} \mathrm{~F}$ NMR $\left(376 \mathrm{MHz}, \mathrm{CDCl}_{3}\right) \delta-74.47(\mathrm{~d}, J=7.3 \mathrm{~Hz})$. HRMS Calcd. For $\mathrm{C}_{20} \mathrm{H}_{17} \mathrm{~F}_{3} \mathrm{~N}_{2} \mathrm{ONa}\left([\mathrm{M}+\mathrm{Na}]^{+}\right): 381.1185$, found: 381.1185 . The product was analyzed by HPLC to determine the enantiomeric excess: $95 \%$ ee (Chiralpak AS-H, $i$-propanol/hexane $=$ $5 / 95$, flow rate $1.0 \mathrm{~mL} / \mathrm{min}, \lambda=254 \mathrm{~nm}) ; \mathrm{t}_{\mathrm{r}}=4.88$ and $5.29 \mathrm{~min}$.

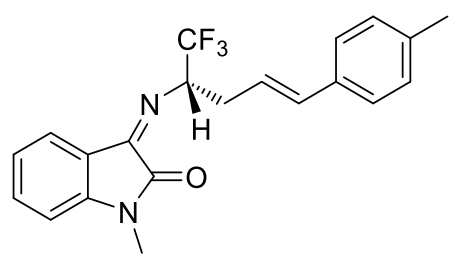

$5 \mathbf{a b}$

(Z)-1-methyl-3-(((S,E)-1,1,1-trifluoro-5-(p-tolyl)pent-4-en-2-yl)imino)indolin-2-one:

Yellow solid; yield (67.0 mg, 90\%). m.p. 80-82 ${ }^{\circ} \mathrm{C}$; $[\alpha]^{25} \mathrm{D}=-124.6\left(c 0.13, \mathrm{CH}_{2} \mathrm{Cl}_{2}\right) .{ }^{1} \mathrm{H}$ NMR $\left(400 \mathrm{MHz}, \mathrm{CDCl}_{3}\right) \delta 7.69(\mathrm{dd}, J=7.6,0.8 \mathrm{~Hz}, 1 \mathrm{H}), 7.41(\mathrm{td}, J=7.9,1.2 \mathrm{~Hz}, 1 \mathrm{H}), 7.13-6.98$ $(\mathrm{m}, 5 \mathrm{H}), 6.70(\mathrm{~d}, J=8.0 \mathrm{~Hz}, 1 \mathrm{H}), 6.21(\mathrm{~d}, J=15.6 \mathrm{~Hz}, 1 \mathrm{H}), 6.16-5.98(\mathrm{~m}, 2 \mathrm{H}), 3.03(\mathrm{~s}, 3 \mathrm{H})$, $3.01-2.92(\mathrm{~m}, 1 \mathrm{H}), 2.63-2.52(\mathrm{~m}, 1 \mathrm{H}), 2.30(\mathrm{~s}, 3 \mathrm{H}) .{ }^{13} \mathrm{C} \mathrm{NMR}\left(101 \mathrm{MHz}, \mathrm{CDCl}_{3}\right) \delta 159.00$, $155.82,145.79,137.11,134.30,133.67,133.65,129.11,126.86,125.47$ (q, $J=280.2 \mathrm{~Hz})$, 123.73, 123.34, 122.92, 120.80, 108.60, 59.98 (q, $J=28.1 \mathrm{~Hz}), 34.06,25.59,21.20 .{ }^{19} \mathrm{~F} \mathrm{NMR}$ $\left(376 \mathrm{MHz}, \mathrm{CDCl}_{3}\right) \delta-74.44(\mathrm{~d}, J=7.3 \mathrm{~Hz})$. HRMS Calcd. For $\mathrm{C}_{21} \mathrm{H}_{19} \mathrm{~F}_{3} \mathrm{~N}_{2} \mathrm{ONa}\left([\mathrm{M}+\mathrm{Na}]^{+}\right)$: 395.1342, found: 395.1342 . The product was analyzed by HPLC to determine the enantiomeric excess: 93\% ee (Chiralpak AS-H, $i$-propanol/hexane $=5 / 95$, flow rate $1.0 \mathrm{~mL} / \mathrm{min}, \lambda=254 \mathrm{~nm})$; 
$\mathrm{t}_{\mathrm{r}}=4.62$ and $4.83 \mathrm{~min}$.

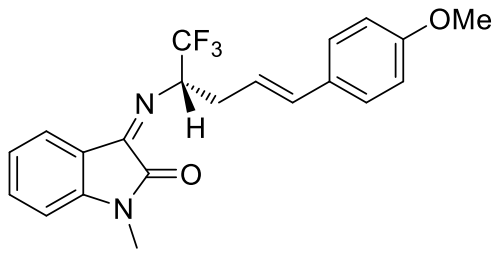

5 ac

(Z)-1-methyl-3-(((S,E)-1,1,1-trifluoro-5-(4-methoxyphenyl)pent-4-en-2-yl)imino)indolin-

\section{2-one:}

Yellow oil; yield (71.5 mg, 92\%). $[\alpha]^{25} \mathrm{D}=-81.0\left(c 0.20, \mathrm{CH}_{2} \mathrm{Cl}_{2}\right) .{ }^{1} \mathrm{H} \mathrm{NMR}\left(400 \mathrm{MHz}, \mathrm{CDCl}_{3}\right)$ $\delta 7.69(\mathrm{~d}, J=7.2 \mathrm{~Hz}, 1 \mathrm{H}), 7.41(\mathrm{td}, J=8.0,1.2 \mathrm{~Hz}, 1 \mathrm{H}), 7.15-7.05(\mathrm{~m}, 3 \mathrm{H}), 6.77(\mathrm{~d}, J=8.8$ $\mathrm{Hz}, 2 \mathrm{H}), 6.70(\mathrm{~d}, J=7.6 \mathrm{~Hz}, 1 \mathrm{H}), 6.16(\mathrm{~d}, J=16.0 \mathrm{~Hz}, 1 \mathrm{H}), 6.11-6.01(\mathrm{~m}, 1 \mathrm{H}), 6.01-5.88$ $(\mathrm{m}, 1 \mathrm{H}), 3.77(\mathrm{~s}, 3 \mathrm{H}), 3.02(\mathrm{~s}, 3 \mathrm{H}), 2.99-2.89(\mathrm{~m}, 1 \mathrm{H}), 2.60-2.49(\mathrm{~m}, 1 \mathrm{H}) .{ }^{13} \mathrm{C}$ NMR $(101$ $\left.\mathrm{MHz}, \mathrm{CDCl}_{3}\right) \delta 158.99,158.96,155.74,145.73,133.59,133.18,129.88,127.25,125.44(\mathrm{~d}, J$ $=280.1 \mathrm{~Hz}), 123.30,122.88,122.56,120.78,113.76,108.54,60.02(\mathrm{q}, J=28.1 \mathrm{~Hz}), 55.29$, 34.01, 25.58. ${ }^{19} \mathrm{~F}$ NMR $\left(376 \mathrm{MHz}, \mathrm{CDCl}_{3}\right) \delta-74.46(\mathrm{~d}, J=7.3 \mathrm{~Hz})$. HRMS Calcd. For $\mathrm{C}_{21} \mathrm{H}_{19} \mathrm{~F}_{3} \mathrm{~N}_{2} \mathrm{O}_{2} \mathrm{Na}\left([\mathrm{M}+\mathrm{Na}]^{+}\right)$: 411.1292, found: 411.1291. HRMS Calcd. For $\mathrm{C}_{21} \mathrm{H}_{19} \mathrm{~F}_{3} \mathrm{~N}_{2} \mathrm{O}_{2} \mathrm{Na}^{+}$: 411.1291, found: 411.1291. The product was analyzed by HPLC to determine the enantiomeric excess: $94 \%$ ee (Chiralpak AS-H, $i$-propanol/hexane $=5 / 95$, flow rate $1.0 \mathrm{~mL} / \mathrm{min}, \lambda=254 \mathrm{~nm}$ ); $\mathrm{t}_{\mathrm{r}}=6.48$ and $6.78 \mathrm{~min}$.

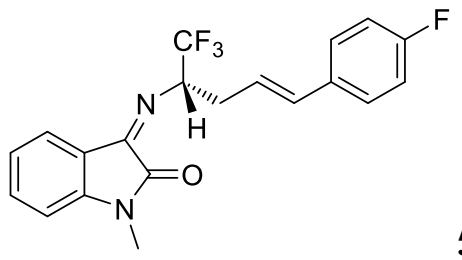

5 ad

(Z)-1-methyl-3-(((S,E)-1,1,1-trifluoro-5-(4-fluorophenyl)pent-4-en-2-yl)imino)indolin-2-

one:

Yellow solid; yield (74.5 mg, 99\%). m.p. $85-87^{\circ} \mathrm{C} ;[\alpha]^{25} \mathrm{D}=-134.2\left(c 0.12, \mathrm{CH}_{2} \mathrm{Cl}_{2}\right) .{ }^{1} \mathrm{H}$ NMR $\left(400 \mathrm{MHz}, \mathrm{CDCl}_{3}\right) \delta 7.69(\mathrm{~d}, J=7.2 \mathrm{~Hz}, 1 \mathrm{H}), 7.42(\mathrm{t}, J=7.6 \mathrm{~Hz}, 1 \mathrm{H}), 7.20-7.06(\mathrm{~m}, 3 \mathrm{H})$, $6.92(\mathrm{t}, J=8.4 \mathrm{~Hz}, 2 \mathrm{H}), 6.71(\mathrm{~d}, J=8.0 \mathrm{~Hz}, 1 \mathrm{H}), 6.19(\mathrm{~d}, J=16.0 \mathrm{~Hz}, 1 \mathrm{H}), 6.13-5.96(\mathrm{~m}$, $2 \mathrm{H}), 3.03(\mathrm{~s}, 3 \mathrm{H}), 3.00-2.86(\mathrm{~m}, 1 \mathrm{H}), 2.62-2.50(\mathrm{~m}, 1 \mathrm{H}) .{ }^{13} \mathrm{C} \mathrm{NMR}\left(101 \mathrm{MHz}, \mathrm{CDCl}_{3}\right) \delta$ $162.2(\mathrm{~d}, J=246.4 \mathrm{~Hz}), 159.0,155.8,145.8,133.7,133.2(\mathrm{~d}, J=3.3 \mathrm{~Hz}), 132.6,127.6$ (d, $J=$ $7.9 \mathrm{~Hz}), 124.6(\mathrm{~d}, J=2.0 \mathrm{~Hz}), 124.0(\mathrm{~d}, J=280.1 \mathrm{~Hz}), 123.4,123.0,120.8,115.3(\mathrm{~d}, J=21.5$ 
$\mathrm{Hz}), 108.62,59.9(\mathrm{q}, J=28.3 \mathrm{~Hz}), 33.99,25.60 .{ }^{19} \mathrm{~F} \mathrm{NMR}\left(376 \mathrm{MHz}, \mathrm{CDCl}_{3}\right) \delta-74.47(\mathrm{~d}, J=$ $7.3 \mathrm{~Hz}),-114.89$ (m). HRMS Calcd. For $\mathrm{C}_{20} \mathrm{H}_{16} \mathrm{~F}_{4} \mathrm{~N}_{2} \mathrm{ONa}\left([\mathrm{M}+\mathrm{Na}]^{+}\right)$: 399.1091, found: 399.1091. The product was analyzed by HPLC to determine the enantiomeric excess: $93 \%$ ee $($ Chiralpak AS-H, $i$-propanol/hexane $=5 / 95$, flow rate $1.0 \mathrm{~mL} / \mathrm{min}, \lambda=254 \mathrm{~nm}) ; \mathrm{t}_{\mathrm{r}}=5.24$ and $5.54 \mathrm{~min}$.

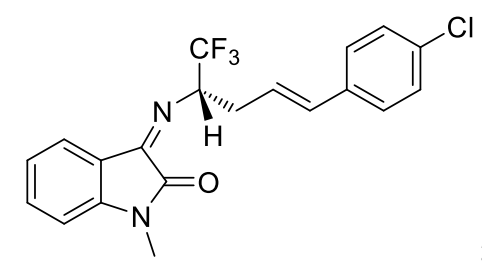

5ae

(Z)-3-(((S,E)-5-(4-chlorophenyl)-1,1,1-trifluoropent-4-en-2-yl)imino)-1-methylindolin-2one:

Yellow solid; yield (73.1 mg, 93\%). m.p. 88-90 ${ }^{\circ} \mathrm{C} ;[\alpha]^{25} \mathrm{D}=-172.9\left(c 0.21, \mathrm{CH}_{2} \mathrm{Cl}_{2}\right) .{ }^{1} \mathrm{H}$ NMR $\left(400 \mathrm{MHz}, \mathrm{CDCl}_{3}\right) \delta 7.69(\mathrm{~d}, J=6.8 \mathrm{~Hz}, 1 \mathrm{H}), 7.42(\mathrm{td}, J=7.6,1.2 \mathrm{~Hz}, 1 \mathrm{H}), 7.24-7.17(\mathrm{~m}$, 2H), $7.15-7.07(\mathrm{~m}, 3 \mathrm{H}), 6.72(\mathrm{~d}, J=7.6 \mathrm{~Hz}, 1 \mathrm{H}), 6.19(\mathrm{~d}, J=16.0 \mathrm{~Hz}, 1 \mathrm{H}), 6.15-6.01(\mathrm{~m}$, 2H), $3.04(\mathrm{~s}, 3 \mathrm{H}), 3.01-2.92(\mathrm{~m}, 1 \mathrm{H}), 2.62-2.51(\mathrm{~m}, 1 \mathrm{H}) .{ }^{13} \mathrm{C} \mathrm{NMR}\left(101 \mathrm{MHz}, \mathrm{CDCl}_{3}\right) \delta$ $158.9,155.8,145.7,135.5,133.7,132.9,132.5,128.5,127.3,125.5,125.4$ (q, $J=280.8 \mathrm{~Hz})$, 123.4, 122.9, 120.7, 108.6, 59.8 (q, $J=28.3 \mathrm{~Hz}), 34.0,25.6 .{ }^{19} \mathrm{~F}$ NMR $\left(376 \mathrm{MHz}, \mathrm{CDCl}_{3}\right) \delta-$ $74.48(\mathrm{~d}, J=7.3 \mathrm{~Hz})$. HRMS Calcd. For $\mathrm{C}_{20} \mathrm{H}_{16} \mathrm{ClF}_{3} \mathrm{~N}_{2} \mathrm{ONa}\left([\mathrm{M}+\mathrm{Na}]^{+}\right)$: 415.0795, found: 415.0795. The product was analyzed by HPLC to determine the enantiomeric excess: $94 \%$ ee $($ Chiralpak AS-H, $i$-propanol/hexane $=5 / 95$, flow rate $1.0 \mathrm{~mL} / \mathrm{min}, \lambda=254 \mathrm{~nm}) ; \mathrm{t}_{\mathrm{r}}=6.74$ and $7.56 \mathrm{~min}$.

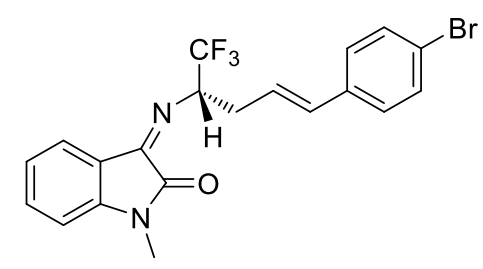

5af

(Z)-3-(((S,E)-5-(4-bromophenyl)-1,1,1-trifluoropent-4-en-2-yl)imino)-1-methylindolin-2one:

Yellow solid; yield (81.3 mg, 93\%). m.p. $100-102{ }^{\circ} \mathrm{C} ;[\alpha]^{25} \mathrm{D}=-205.5\left(c 0.11, \mathrm{CH}_{2} \mathrm{Cl}_{2}\right) .{ }^{1} \mathrm{H}$ NMR $\left(400 \mathrm{MHz}, \mathrm{CDCl}_{3}\right) \delta 7.69(\mathrm{~d}, J=6.8 \mathrm{~Hz}, 1 \mathrm{H}), 7.42(\mathrm{td}, J=8.0,1.2 \mathrm{~Hz}, 1 \mathrm{H}), 7.38-7.28(\mathrm{~m}$, 2H), $7.13-7.02(\mathrm{~m}, 3 \mathrm{H}), 6.73(\mathrm{~d}, J=7.6 \mathrm{~Hz}, 1 \mathrm{H}), 6.21-6.01(\mathrm{~m}, 3 \mathrm{H}), 3.04(\mathrm{~s}, 3 \mathrm{H}), 2.99-$ 
$2.91(\mathrm{~m}, 1 \mathrm{H}), 2.62-2.51(\mathrm{~m}, 1 \mathrm{H}) .{ }^{13} \mathrm{C} \mathrm{NMR}\left(101 \mathrm{MHz}, \mathrm{CDCl}_{3}\right) \delta 159.0,155.9,145.8,136.0$, 133.8, 132.6, 131.52, 127.7, 125.7, 125.4 (q, $J=280.1 \mathrm{~Hz}), 123.4,123.0,121.1,120.7,108.7$, $59.8(\mathrm{q}, J=28.2 \mathrm{~Hz}), 34.0,25.7 .{ }^{19} \mathrm{~F} \mathrm{NMR}\left(376 \mathrm{MHz}, \mathrm{CDCl}_{3}\right) \delta-74.50(\mathrm{~d}, J=7.2 \mathrm{~Hz})$. HRMS Calcd. For $\mathrm{C}_{20} \mathrm{H}_{16} \mathrm{BrF}_{3} \mathrm{~N}_{2} \mathrm{ONa}\left([\mathrm{M}+\mathrm{Na}]^{+}\right)$: 459.0290, found: 459.0290. The product was analyzed by HPLC to determine the enantiomeric excess: 94\% ee (Chiralpak AS-H, $i$ propanol $/$ hexane $=5 / 95$, flow rate $1.0 \mathrm{~mL} / \mathrm{min}, \lambda=254 \mathrm{~nm}$ ); $\mathrm{t}_{\mathrm{r}}=5.44$ and $5.86 \mathrm{~min}$.

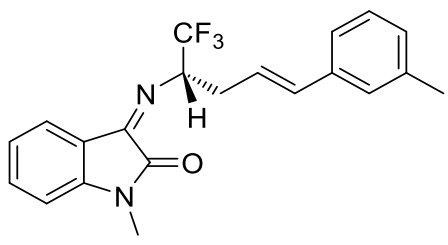

\section{5 ag}

(Z)-1-methyl-3-(((S,E)-1,1,1-trifluoro-5-(m-tolyl)pent-4-en-2-yl)imino)indolin-2-one:

Yellow oil; yield (71.0 mg, 99\%). $[\alpha]^{25} \mathrm{D}=-67.9\left(c\right.$ 0.29, $\left.\mathrm{CH}_{2} \mathrm{Cl}_{2}\right) .{ }^{1} \mathrm{H}$ NMR $\left(400 \mathrm{MHz}, \mathrm{CDCl}_{3}\right)$ $\delta 7.70(\mathrm{~d}, J=6.8 \mathrm{~Hz}, 1 \mathrm{H}), 7.45-7.38(\mathrm{~m}, 1 \mathrm{H}), 7.16-7.06(\mathrm{~m}, 2 \mathrm{H}), 7.06-6.93(\mathrm{~m}, 3 \mathrm{H}), 6.70$ $(\mathrm{d}, J=8.0 \mathrm{~Hz}, 1 \mathrm{H}), 6.27-6.01(\mathrm{~m}, 3 \mathrm{H}), 3.06-2.90(\mathrm{~m}, 4 \mathrm{H}), 2.62-2.52(\mathrm{~m}, 1 \mathrm{H}), 2.28(\mathrm{~s}, 3 \mathrm{H})$. ${ }^{13} \mathrm{C}$ NMR $\left(101 \mathrm{MHz}, \mathrm{CDCl}_{3}\right) \delta 158.9,155.8,145.7,137.9,136.9,133.9,133.6,128.2,128.0$, $126.8,125.4(\mathrm{q}, J=280.1 \mathrm{~Hz}), 124.5,123.3,123.1,122.8,120.7,108.5,59.9(\mathrm{q}, J=28.1$ Hz).34.0, 25.4, 21.3. ${ }^{19} \mathrm{~F}$ NMR (376 MHz, $\left.\mathrm{CDCl}_{3}\right) \delta-74.47$ (d, $\left.J=7.3 \mathrm{~Hz}\right)$. HRMS Calcd. For $\mathrm{C}_{21} \mathrm{H}_{19} \mathrm{~F}_{3} \mathrm{~N}_{2} \mathrm{ONa}\left([\mathrm{M}+\mathrm{Na}]^{+}\right): 395.1342$, found: 395.1342 . The product was analyzed by HPLC to determine the enantiomeric excess: $94 \%$ ee (Chiralpak AS-H, $i$-propanol/hexane $=5 / 95$, flow rate $1.0 \mathrm{~mL} / \mathrm{min}, \lambda=254 \mathrm{~nm}) ; \mathrm{t}_{\mathrm{r}}=4.99$ and $5.26 \mathrm{~min}$.

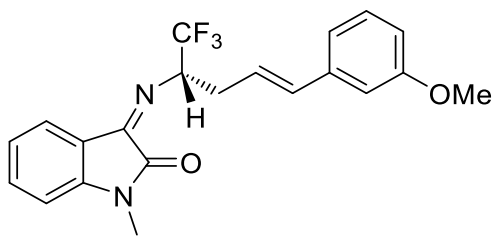

\section{5ah}

(Z)-1-methyl-3-(((S,E)-1,1,1-trifluoro-5-(3-methoxyphenyl)pent-4-en-2-yl)imino)indolin-

\section{2-one:}

Yellow oil; yield (73.0 mg, 94\%). $[\alpha]^{25} \mathrm{D}=-107.2\left(c 0.26, \mathrm{CH}_{2} \mathrm{Cl}_{2}\right) .{ }^{1} \mathrm{H} \mathrm{NMR}\left(400 \mathrm{MHz}, \mathrm{CDCl}_{3}\right)$ $\delta 7.69(\mathrm{~d}, J=7.6 \mathrm{~Hz}, 1 \mathrm{H}), 7.41(\mathrm{t}, J=7.6 \mathrm{~Hz}, 1 \mathrm{H}), 7.15(\mathrm{t}, J=8.0 \mathrm{~Hz}, 1 \mathrm{H}), 7.09(\mathrm{t}, J=7.6 \mathrm{~Hz}$, $1 \mathrm{H}), 6.80(\mathrm{~d}, J=7.6 \mathrm{~Hz}, 1 \mathrm{H}), 6.77-6.66(\mathrm{~m}, 3 \mathrm{H}), 6.20(\mathrm{~d}, J=15.6 \mathrm{~Hz}, 1 \mathrm{H}), 6.16-6.05(\mathrm{~m}$, 2H), $3.75(\mathrm{~s}, 3 \mathrm{H}), 3.06-2.91(\mathrm{~m}, 4 \mathrm{H}), 2.64-2.52(\mathrm{~m}, 1 \mathrm{H}) .{ }^{13} \mathrm{C} \mathrm{NMR}\left(100 \mathrm{MHz}, \mathrm{CDCl}_{3}\right) \delta$ 
159.7, 159.0, 155.9, 145.8, 138.5, 133.8, 133.7, 129.4, 125.4 (q, $J=280.8$ Hz), 125.2, 123.4, 122.9, 120.8, 118.7, 113.1, 111.4, 108.6, 59.9 (q, $J=28.2 \mathrm{~Hz}), 55.2,34.0,25.6 .{ }^{19} \mathrm{~F}$ NMR (376 $\left.\mathrm{MHz}, \mathrm{CDCl}_{3}\right) \delta-74.45(\mathrm{~d}, J=7.3 \mathrm{~Hz})$. HRMS Calcd. For $\mathrm{C}_{21} \mathrm{H}_{19} \mathrm{~F}_{3} \mathrm{~N}_{2} \mathrm{O}_{2} \mathrm{Na}\left([\mathrm{M}+\mathrm{Na}]^{+}\right)$: 411.1291, found: 411.1296. The product was analyzed by HPLC to determine the enantiomeric excess: $92 \%$ ee (Chiralpak AS-H, $i$-propanol/hexane $=5 / 95$, flow rate $1.0 \mathrm{~mL} / \mathrm{min}, \lambda=254 \mathrm{~nm}$ ); $\mathrm{t}_{\mathrm{r}}=6.64$ and $7.18 \mathrm{~min}$.

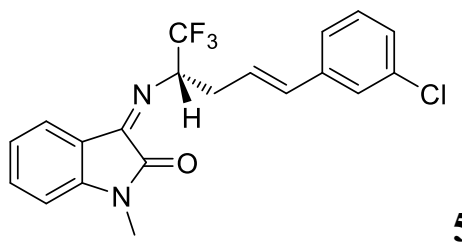

5ai

(Z)-3-(((S,E)-5-(3-chlorophenyl)-1,1,1-trifluoropent-4-en-2-yl)imino)-1-methylindolin-2one:

Yellow solid; yield (76.2 mg, 97\%). m.p. $78-80{ }^{\circ} \mathrm{C} ;[\alpha]^{25} \mathrm{D}=-175.8\left(c 0.12, \mathrm{CH}_{2} \mathrm{Cl}_{2}\right) .{ }^{1} \mathrm{H}$ NMR $\left(400 \mathrm{MHz}, \mathrm{CDCl}_{3}\right) \delta 7.66(\mathrm{~d}, J=7.6 \mathrm{~Hz}, 1 \mathrm{H}), 7.58-7.35(\mathrm{~m}, 1 \mathrm{H}), 7.17-7.02(\mathrm{~m}, 5 \mathrm{H}), 6.73$ $(\mathrm{d}, J=7.8 \mathrm{~Hz}, 1 \mathrm{H}), 6.25-5.93(\mathrm{~m}, 3 \mathrm{H}), 3.05(\mathrm{~s}, 3 \mathrm{H}), 3.02-2.91(\mathrm{~m}, 1 \mathrm{H}), 2.66-2.44(\mathrm{~m}, 1 \mathrm{H})$. ${ }^{13} \mathrm{C}$ NMR $\left(101 \mathrm{MHz}, \mathrm{CDCl}_{3}\right) \delta 159.0,156.0,145.8,139.0,134.4,133.8,132.5,129.7,127.3$, 126.6, 126.1, 125.4 (q, $J=280.8 \mathrm{~Hz}), 124.4,123.5,123.0,120.7,108.7,59.8$ (q, $J=28.4 \mathrm{~Hz})$, 33.97, 25.65. ${ }^{19} \mathrm{~F}$ NMR $\left(376 \mathrm{MHz}, \mathrm{CDCl}_{3}\right) \delta-74.53(\mathrm{~d}, J=7.2 \mathrm{~Hz})$. HRMS Calcd. For $\mathrm{C}_{20} \mathrm{H}_{16} \mathrm{ClF}_{3} \mathrm{~N}_{2} \mathrm{ONa}\left([\mathrm{M}+\mathrm{Na}]^{+}\right)$: 415.0795, found: 415.0796 . The product was analyzed by HPLC to determine the enantiomeric excess: 93\% ee (Chiralpak AS-H, $i$-propanol/hexane $=$ $5 / 95$, flow rate $1.0 \mathrm{~mL} / \mathrm{min}, \lambda=254 \mathrm{~nm}) ; \mathrm{t}_{\mathrm{r}}=5.50$ and $6.00 \mathrm{~min}$.

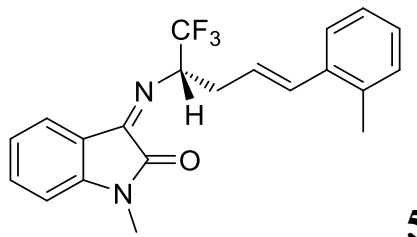

5aj

\section{(Z)-1-methyl-3-(((S,E)-1,1,1-trifluoro-5-(o-tolyl)pent-4-en-2-yl)imino)indolin-2-one:}

Yellow oil; yield (61.1 mg, 82\%). [ $\alpha]^{25} \mathrm{D}=-109.4\left(c 0.18, \mathrm{CH}_{2} \mathrm{Cl}_{2}\right) .{ }^{1} \mathrm{H} \mathrm{NMR}\left(400 \mathrm{MHz}, \mathrm{CDCl}_{3}\right)$ $\delta 7.70(\mathrm{~d}, J=6.8 \mathrm{~Hz}, 1 \mathrm{H}), 7.42(\mathrm{t}, J=7.6,1 \mathrm{H}), 7.16-7.06(\mathrm{~m}, 2 \mathrm{H}), 7.05-6.94(\mathrm{~m}, 3 \mathrm{H}), 6.70$ $(\mathrm{d}, J=8.0 \mathrm{~Hz}, 1 \mathrm{H}), 6.19(\mathrm{~d}, J=16.0 \mathrm{~Hz}, 1 \mathrm{H}), 6.15-5.98(\mathrm{~m}, 2 \mathrm{H}), 3.05-2.87(\mathrm{~m}, 4 \mathrm{H}), 2.62-$ $2.52(\mathrm{~m}, 1 \mathrm{H}), 2.28(\mathrm{~s}, 3 \mathrm{H}) .{ }^{13} \mathrm{C}$ NMR (101 MHz, $\left.\mathrm{CDCl}_{3}\right) .159 .0,155.9,145.8,138.0,137.0$, 
134.0, 133.7, 128.3, 128.1, 126.9, 125.4 (q, $J=280.1 \mathrm{~Hz}), 124.6,123.4,123.2,122.9,120.8$, 108.6, $59.95(\mathrm{q}, J=28.1 \mathrm{~Hz}) 34.1,25.5,21.4 .{ }^{19} \mathrm{~F} \mathrm{NMR}\left(376 \mathrm{MHz}, \mathrm{CDCl}_{3}\right) \delta-74.47(\mathrm{~d}, J=7.3$ Hz). HRMS Calcd. For $\mathrm{C}_{21} \mathrm{H}_{19} \mathrm{~F}_{3} \mathrm{~N}_{2} \mathrm{ONa}\left([\mathrm{M}+\mathrm{Na}]^{+}\right)$: 395.1342 , found: 395.1342 . The product was analyzed by HPLC to determine the enantiomeric excess: $-75 \%$ ee (Chiralpak AS- $\mathrm{H}, i$ propanol $/$ hexane $=5 / 95$, flow rate $1.0 \mathrm{~mL} / \mathrm{min}, \lambda=254 \mathrm{~nm}) ; \mathrm{t}_{\mathrm{r}}=5.13$ and $5.53 \mathrm{~min}$.

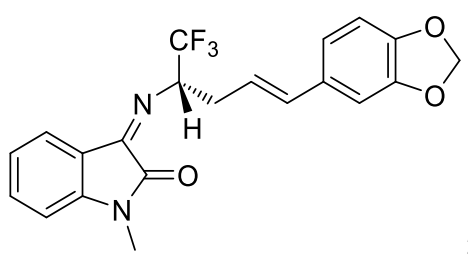

5ak

(Z)-3-(((S,E)-5-(benzo[d][1,3]dioxol-5-yl)-1,1,1-trifluoropent-4-en-2-yl)imino)-1methylindolin-2-one:

Yellow solid; yield (73.2 mg, 91\%). m.p. 80-82 ${ }^{\circ} \mathrm{C} ;[\alpha]^{25} \mathrm{D}=-87.9\left(c 0.24, \mathrm{CH}_{2} \mathrm{Cl}_{2}\right) .{ }^{1} \mathrm{H}$ NMR $\left(400 \mathrm{MHz}, \mathrm{CDCl}_{3}\right) \delta 7.68(\mathrm{~d}, J=7.2 \mathrm{~Hz}, 1 \mathrm{H}), 7.41$ (t, $\left.J=7.6,1 \mathrm{H}\right), 7.09$ (t, $\left.J=7.2 \mathrm{~Hz}, 1 \mathrm{H}\right)$, $6.76(\mathrm{~s}, 1 \mathrm{H}), 6.72(\mathrm{~d}, J=8.0 \mathrm{~Hz}, 1 \mathrm{H}), 6.66(\mathrm{~d}, J=8.0 \mathrm{~Hz}, 1 \mathrm{H}), 6.59(\mathrm{~d}, J=8.0 \mathrm{~Hz}, 1 \mathrm{H}), 6.19-$ $6.03(\mathrm{~m}, 2 \mathrm{H}), 6.00-5.87(\mathrm{~m}, 3 \mathrm{H}), 3.06(\mathrm{~s}, 3 \mathrm{H}), 2.98-2.89(\mathrm{~m}, 1 \mathrm{H}), 2.60-2.50(\mathrm{~m}, 1 \mathrm{H}) .{ }^{13} \mathrm{C}$ NMR (101 MHz, $\left.\mathrm{CDCl}_{3}\right) \delta 159.0,155.8,147.9,147.0,145.8,133.7,133.3,131.6,125.4(\mathrm{q}, J$ $=280.8 \mathrm{~Hz}), 123.4,123.0,122.9,120.8,120.6,108.6,108.1,105.6,101.0,60.0$ (q, $J=28.1$ $\mathrm{Hz}), 34.0,25.6 .{ }^{19} \mathrm{~F}$ NMR $\left(376 \mathrm{MHz}, \mathrm{CDCl}_{3}\right) \delta-74.46(\mathrm{~d}, J=7.3 \mathrm{~Hz})$. HRMS Calcd. For $\mathrm{C}_{21} \mathrm{H}_{17} \mathrm{~F}_{3} \mathrm{~N}_{2} \mathrm{O}_{3} \mathrm{Na}\left([\mathrm{M}+\mathrm{Na}]^{+}\right): 425.1083$, found: 425.1089 . The product was analyzed by HPLC to determine the enantiomeric excess: $90 \%$ ee (Chiralcel OD-H, $i$-propanol/hexane $=5 / 95$, flow rate $1.0 \mathrm{~mL} / \mathrm{min}, \lambda=254 \mathrm{~nm}) ; \mathrm{t}_{\mathrm{r}}=10.52$ and $11.43 \mathrm{~min}$.

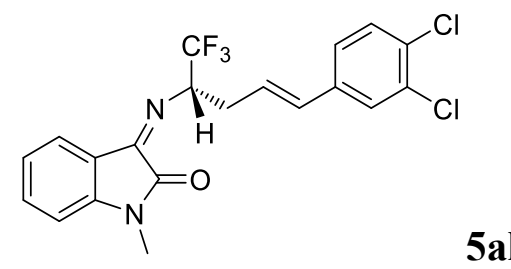

\section{(Z)-3-(((S,E)-5-(3,4-dichlorophenyl)-1,1,1-trifluoropent-4-en-2-yl)imino)-1-}

\section{methylindolin-2-one:}

Yellow solid; yield (70.9 mg, 83\%). m.p. $90-92{ }^{\circ} \mathrm{C} ;[\alpha]^{25} \mathrm{D}=-228.8\left(c 0.16, \mathrm{CH}_{2} \mathrm{Cl}_{2}\right) .{ }^{1} \mathrm{H}$ NMR $\left(400 \mathrm{MHz}, \mathrm{CDCl}_{3}\right) \delta 7.69(\mathrm{~d}, J=7.2 \mathrm{~Hz}, 1 \mathrm{H}), 7.52-7.38(\mathrm{~m}, 1 \mathrm{H}), 7.29(\mathrm{~d}, J=8.4,1 \mathrm{H}), 7.25$ $(\mathrm{d}, J=2.0 \mathrm{~Hz}, 1 \mathrm{H}), 7.14-7.08(\mathrm{~m}, 1 \mathrm{H}), 7.08-6.99(\mathrm{~m}, 1 \mathrm{H}), 6.75(\mathrm{~d}, J=8.0 \mathrm{~Hz}, 1 \mathrm{H}), 6.17-$ 
$6.01(\mathrm{~m}, 3 \mathrm{H}), 3.08(\mathrm{~s}, 3 \mathrm{H}), 3.02-2.88(\mathrm{~m}, 1 \mathrm{H}), 2.67-2.30(\mathrm{~m}, 1 \mathrm{H}) .{ }^{13} \mathrm{C} \mathrm{NMR}(101 \mathrm{MHz}$, $\left.\mathrm{CDCl}_{3}\right) \delta 159.0,155.9,145.8,137.2,133.9,132.5,131.4,131.0,130.3,127.8,127.1,125.5(\mathrm{q}$ $J=280.1 \mathrm{~Hz}), 125.4,123.5,123.0,120.7,108.7,59.8$ (q, $J=28.3 \mathrm{~Hz}), 34.0,25.7 .{ }^{19} \mathrm{~F} \mathrm{NMR}$ $\left(376 \mathrm{MHz}, \mathrm{CDCl}_{3}\right) \delta-74.54(\mathrm{~d}, J=7.2 \mathrm{~Hz})$. HRMS Calcd. For $\mathrm{C}_{20} \mathrm{H}_{15} \mathrm{Cl}_{2} \mathrm{~F}_{3} \mathrm{~N}_{2} \mathrm{ONa}\left([\mathrm{M}+\mathrm{Na}]^{+}\right)$: 449.0406, found: 449.0415. The product was analyzed by HPLC to determine the enantiomeric excess: $90 \%$ ee (Chiralpak AS-H, $i$-propanol $/$ hexane $=5 / 95$, flow rate $1.0 \mathrm{~mL} / \mathrm{min}, \lambda=254 \mathrm{~nm}$ ); $\mathrm{t}_{\mathrm{r}}=5.78$ and $6.35 \mathrm{~min}$.

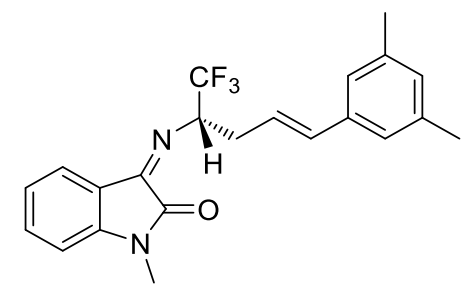

5am

\section{(Z)-3-(((S,E)-5-(3,5-dimethylphenyl)-1,1,1-trifluoropent-4-en-2-yl)imino)-1-} methylindolin-2-one:

Yellow solid; yield (75.7 mg, 98\%). m.p. $110-112^{\circ} \mathrm{C} ;[\alpha]^{25} \mathrm{D}=-45.0\left(c 0.47, \mathrm{CH}_{2} \mathrm{Cl}_{2}\right) .{ }^{1} \mathrm{H}$ NMR $\left(400 \mathrm{MHz}, \mathrm{CDCl}_{3}\right) \delta 7.70(\mathrm{~d}, J=7.6 \mathrm{~Hz}, 1 \mathrm{H}), 7.42(\mathrm{td}, J=8.0,1.2 \mathrm{~Hz}, 1 \mathrm{H}), 7.10(\mathrm{td}, J=7.6$, $0.8 \mathrm{~Hz}, 1 \mathrm{H}), 6.85-6.78(\mathrm{~m}, 3 \mathrm{H}), 6.70(\mathrm{~d}, J=8.0 \mathrm{~Hz}, 1 \mathrm{H}), 6.21-6.02(\mathrm{~m}, 3 \mathrm{H}), 3.05-2.92(\mathrm{~m}$, $4 \mathrm{H}), 2.62-2.51(\mathrm{~m}, 1 \mathrm{H}), 2.25(\mathrm{~s}, 6 \mathrm{H}) .{ }^{13} \mathrm{C} \mathrm{NMR}\left(101 \mathrm{MHz}, \mathrm{CDCl}_{3}\right) \delta 159.0,155.9,145.8$, 137.9, 137.0, 134.2, 133.62, 129.0, 125.5 (q, $J=280.1 \mathrm{~Hz}$ ), 124.4, 124.0, 123.3, 122.9, 120.8, 108.6, $60.0(\mathrm{q}, J=28.3 \mathrm{~Hz}), 34.1,25.5,21.3 .{ }^{19} \mathrm{~F} \mathrm{NMR}\left(376 \mathrm{MHz}, \mathrm{CDCl}_{3}\right) \delta-74.42(\mathrm{~d}, J=7.3$ Hz). HRMS Calcd. For $\mathrm{C}_{22} \mathrm{H}_{21} \mathrm{~F}_{3} \mathrm{~N}_{2} \mathrm{ONa}\left([\mathrm{M}+\mathrm{Na}]^{+}\right)$: 409.1498, found: 409.1501. The product was analyzed by HPLC to determine the enantiomeric excess: 95\% ee (Chiralcel OD-H, $i$ propanol $/$ hexane $=5 / 95$, flow rate $1.0 \mathrm{~mL} / \mathrm{min}, \lambda=254 \mathrm{~nm}$ ); $\mathrm{t}_{\mathrm{r}}=5.59$ and $6.29 \mathrm{~min}$.

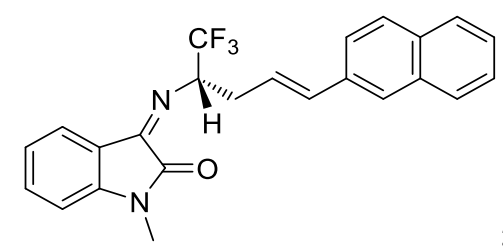

5an

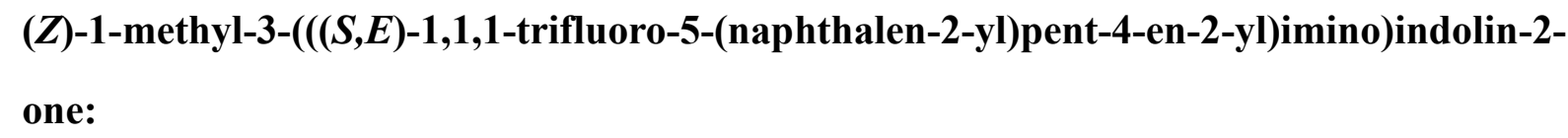
one: 
Yellow oil; yield (71.1 mg, 87\%). $[\alpha]^{25} \mathrm{D}=-79.2\left(c\right.$ 0.37, $\left.\mathrm{CH}_{2} \mathrm{Cl}_{2}\right) .{ }^{1} \mathrm{H} \mathrm{NMR}\left(400 \mathrm{MHz}, \mathrm{CDCl}_{3}\right)$ $\delta 7.8--7.68(\mathrm{~m}, 4 \mathrm{H}), 7.50-7.33(\mathrm{~m}, 5 \mathrm{H}), 7.10(\mathrm{t}, J=7.2 \mathrm{~Hz}, 1 \mathrm{H}), 6.61(\mathrm{~d}, J=8.0 \mathrm{~Hz}, 1 \mathrm{H})$, $6.37(\mathrm{~d}, J=16.0 \mathrm{~Hz}, 1 \mathrm{H}), 6.32-6.07(\mathrm{~m}, 2 \mathrm{H}), 3.09-3.00(\mathrm{~m}, 1 \mathrm{H}), 2.92(\mathrm{~s}, 3 \mathrm{H}), 2.69-2.59$ (m, 1H). ${ }^{13} \mathrm{C} \mathrm{NMR}\left(101 \mathrm{MHz}, \mathrm{CDCl}_{3}\right) \delta 159.0,155.9,145.7,134.5,134.0,133.7,133.5,132.8$, 128.0, 127.9, 127.6, 126.2, 125.8, 125.5 (q, $J=280.0$ Hz). 125.3, 123.5, 123.4, 122.9, 120.8, 108.6, 60.0 (q, $J=28.2 \mathrm{~Hz}), 34.2,25.5 .{ }^{19} \mathrm{~F}$ NMR $\left(376 \mathrm{MHz}, \mathrm{CDCl}_{3}\right) \delta-74.48(\mathrm{~d}, J=7.2 \mathrm{~Hz})$. HRMS Calcd. For $\mathrm{C}_{24} \mathrm{H}_{19} \mathrm{~F}_{3} \mathrm{~N}_{2} \mathrm{ONa}\left([\mathrm{M}+\mathrm{Na}]^{+}\right)$: 431.1342, found: 431.1342 . The product was analyzed by HPLC to determine the enantiomeric excess: 99\% ee (Chiralpak AS-H, $i$ propanol $/$ hexane $=5 / 95$, flow rate $1.0 \mathrm{~mL} / \mathrm{min}, \lambda=254 \mathrm{~nm}) ; \mathrm{t}_{\mathrm{r}}=5.65$ and $5.98 \mathrm{~min}$.

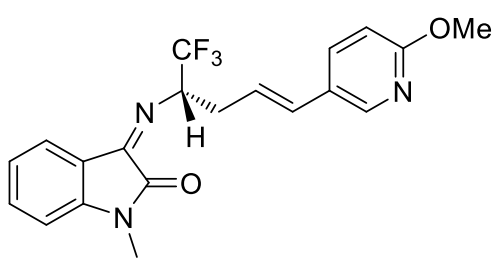

\section{(Z)-1-methyl-3-(((S,E)-1,1,1-trifluoro-5-(6-methoxypyridin-3-yl)pent-4-en-2-}

\section{yl)imino)indolin-2-one:}

Yellow solid; yield (71.6 mg, 92\%). m.p. 80-82 ${ }^{\circ} \mathrm{C} ;[\alpha]^{25} \mathrm{D}=-93.2\left(\right.$ c 0.19, $\left.\mathrm{CH}_{2} \mathrm{Cl}_{2}\right) .{ }^{1} \mathrm{H}$ NMR $\left(400 \mathrm{MHz}, \mathrm{CDCl}_{3}\right) \delta 7.90(\mathrm{~d}, J=2.4 \mathrm{~Hz}, 1 \mathrm{H}), 7.76-7.64(\mathrm{~m}, 1 \mathrm{H}), 7.52(\mathrm{dd}, J=8.4,2.4 \mathrm{~Hz}$, 1H), 7.42 (t, $J=7.6,1 \mathrm{H}), 7.08$ (t, $J=7.6 \mathrm{~Hz}, 1 \mathrm{H}), 6.73$ (d, $J=8.0 \mathrm{~Hz}, 1 \mathrm{H}), 6.64$ (d, $J=8.4 \mathrm{~Hz}$, $1 \mathrm{H}), 6.19(\mathrm{~d}, J=16.0 \mathrm{~Hz}, 1 \mathrm{H}), 6.11-5.91(\mathrm{~m}, 2 \mathrm{H}), 3.89(\mathrm{~s}, 3 \mathrm{H}), 3.07(\mathrm{~s}, 3 \mathrm{H}), 3.02-2.87(\mathrm{~m}$, 1H), $2.64-2.52(\mathrm{~m}, 1 \mathrm{H}) .{ }^{13} \mathrm{C}$ NMR $\left(101 \mathrm{MHz}, \mathrm{CDCl}_{3}\right) \delta 163.5,159.0,155.8,145.8,145.1$, $135.5,133.8,129.8,128.0,125.4(\mathrm{q}, J=282.0 \mathrm{~Hz}), 123.5,123.0,120.7,110.8,108.7,59.8(\mathrm{q}$, $J=28.2 \mathrm{~Hz}), 53.5,34.1,25.7 .{ }^{19} \mathrm{~F}$ NMR $\left(376 \mathrm{MHz} \mathrm{CDCl}_{3}\right) \delta-74.45$ (d, $\left.J=7.3 \mathrm{~Hz}\right) . \mathrm{HRMS}$ Calcd. For $\mathrm{C}_{20} \mathrm{H}_{18} \mathrm{~F}_{3} \mathrm{~N}_{3} \mathrm{O}_{2} \mathrm{Na}\left([\mathrm{M}+\mathrm{Na}]^{+}\right)$: 412.1243, found: 412.1243. The product was analyzed by HPLC to determine the enantiomeric excess: $90 \%$ ee (Chiralpak AS-H, $i$-propanol/hexane $=$ $5 / 95$, flow rate $1.0 \mathrm{~mL} / \mathrm{min}, \lambda=254 \mathrm{~nm}) ; \mathrm{t}_{\mathrm{r}}=8.65$ and $9.71 \mathrm{~min}$.

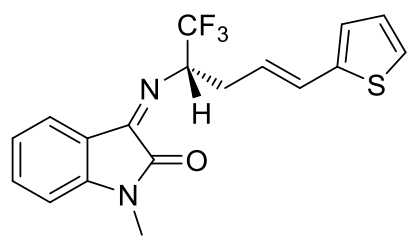

5 ap 


\section{(Z)-1-methyl-3-(((S,E)-1,1,1-trifluoro-5-(thiophen-2-yl)pent-4-en-2-yl)imino)indolin-2-}

one:

Yellow oil; yield (61.2 mg, 84\%). $[\alpha]^{25}{ }_{\mathrm{D}}=-108.52\left(c 0.27, \mathrm{CH}_{2} \mathrm{Cl}_{2}\right) .{ }^{1} \mathrm{H} \mathrm{NMR}\left(400 \mathrm{MHz}, \mathrm{CDCl}_{3}\right)$ $\delta 7.69(\mathrm{~d}, J=7.9,1 \mathrm{H}), 7.42(\mathrm{t}, J=7.6,1 \mathrm{H}), 7.16-7.04(\mathrm{~m}, 2 \mathrm{H}), 6.92-6.83(\mathrm{~m}, 1 \mathrm{H}), 6.78-$ $6.69(\mathrm{~m}, 2 \mathrm{H}), 6.37(\mathrm{~d}, J=15.6 \mathrm{~Hz}, 1 \mathrm{H}), 6.13-6.02(\mathrm{~m}, 1 \mathrm{H}), 6.00-5.87(\mathrm{~m}, 1 \mathrm{H}), 3.07(\mathrm{~s}, 3 \mathrm{H})$, 2.97 - $2.87(\mathrm{~m}, 1 \mathrm{H}), 2.63-2.43(\mathrm{~m}, 1 \mathrm{H}) .{ }^{13} \mathrm{C} \mathrm{NMR}\left(101 \mathrm{MHz}, \mathrm{CDCl}_{3}\right) \delta 158.9,156.0,145.9$, $142.1,133.7,127.2,127.0,125.5$ (q, $J=282.0 \mathrm{~Hz}), 125.0,124.5,124.0,123.4,123.0,120.8$, 108.6, 60.0 (q, $J=28.2 \mathrm{~Hz}), 33.9,25.7 .{ }^{19} \mathrm{~F} \mathrm{NMR}\left(376 \mathrm{MHz}, \mathrm{CDCl}_{3}\right) \delta-74.48(\mathrm{~d}, J=7.2 \mathrm{~Hz})$. HRMS Calcd. For $\mathrm{C}_{18} \mathrm{H}_{15} \mathrm{~F}_{3} \mathrm{~N}_{2} \mathrm{OSNa}\left([\mathrm{M}+\mathrm{Na}]^{+}\right)$: 387.0749 , found: 387.0727 . The product was analyzed by HPLC to determine the enantiomeric excess: 94\% ee (Chiralpak AS-H, $i$ propanol $/$ hexane $=5 / 95$, flow rate $1.0 \mathrm{~mL} / \mathrm{min}, \lambda=254 \mathrm{~nm}$ ); $\mathrm{t}_{\mathrm{r}}=6.33$ and $6.72 \mathrm{~min}$.

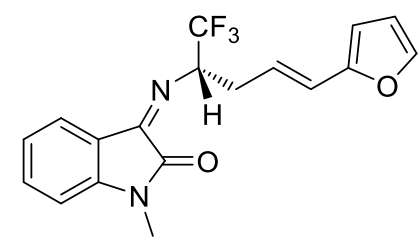

$5 \mathbf{a q}$

(Z)-1-methyl-3-(((S,E)-1,1,1-trifluoro-5-(furan-2-yl)pent-4-en-2-yl)imino)indolin-2-one:

Yellow oil; yield (65.5 mg, 94\%). $[\alpha]^{25} \mathrm{D}=-136.8\left(c 0.44, \mathrm{CH}_{2} \mathrm{Cl}_{2}\right) .{ }^{1} \mathrm{H} \mathrm{NMR}\left(400 \mathrm{MHz}, \mathrm{CDCl}_{3}\right)$ $\delta 7.69(\mathrm{~d}, J=6.8 \mathrm{~Hz}, 1 \mathrm{H}), 7.43(\mathrm{t}, J=8.0,1 \mathrm{H}), 7.28(\mathrm{~d}, J=1.2 \mathrm{~Hz}, 1 \mathrm{H}), 7.10(\mathrm{t}, J=7.6 \mathrm{~Hz}$, $1 \mathrm{H}), 6.76(\mathrm{~d}, J=8.0 \mathrm{~Hz}, 1 \mathrm{H}), 6.29(\mathrm{dd}, J=3.2,1.8 \mathrm{~Hz}, 1 \mathrm{H}), 6.21-5.98(\mathrm{~m}, 4 \mathrm{H}), 3.13(\mathrm{~s}, 3 \mathrm{H})$, $2.97-2.88(\mathrm{~m}, 1 \mathrm{H}), 2.65-2.54(\mathrm{~m}, 1 \mathrm{H}) .{ }^{13} \mathrm{C} \mathrm{NMR}\left(101 \mathrm{MHz}, \mathrm{CDCl}_{3}\right) \delta 158.9,156.0,152.6$, 145.9, 141.8, 133.8, 125.4 (q, $J=282.0 \mathrm{~Hz}$ ), 123.4, 123.3, 123.0, 122.2, 120.8, 111.1, 108.6, 107.1, 60.0 (q, $J=28.0 \mathrm{~Hz}), 34.0,25.8 .{ }^{19} \mathrm{~F} \mathrm{NMR}\left(376 \mathrm{MHz}, \mathrm{CDCl}_{3}\right) \delta-74.30$ (d, $\left.J=7.3 \mathrm{~Hz}\right)$. HRMS Calcd. For $\mathrm{C}_{18} \mathrm{H}_{15} \mathrm{~F}_{3} \mathrm{~N}_{2} \mathrm{O}_{2} \mathrm{Na}\left([\mathrm{M}+\mathrm{Na}]^{+}\right)$: 371.0978 , found: 371.0978 . The product was analyzed by HPLC to determine the enantiomeric excess: $88 \%$ ee (Chiralpak AS-H, $i$ propanol $/$ hexane $=5 / 95$, flow rate $1.0 \mathrm{~mL} / \mathrm{min}, \lambda=254 \mathrm{~nm}$ ); $\mathrm{t}_{\mathrm{r}}=6.84$ and $7.50 \mathrm{~min}$.

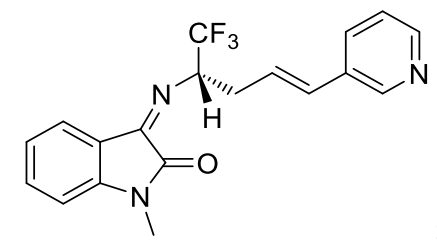

5ar

(Z)-1-methyl-3-(((S,E)-1,1,1-trifluoro-5-(pyridin-3-yl)pent-4-en-2-yl)imino)indolin-2-one: 
Yellow solid; yield (71.2 mg, 99\%). m.p. $95-97^{\circ} \mathrm{C} ;[\alpha]^{25} \mathrm{D}=-91.0\left(c 0.31, \mathrm{CH}_{2} \mathrm{Cl}_{2}\right) .{ }^{1} \mathrm{H}$ NMR $\left(400 \mathrm{MHz}, \mathrm{CDCl}_{3}\right) \delta 8.44-8.34(\mathrm{~m}, 2 \mathrm{H}), 7.69(\mathrm{~d}, J=7.6 \mathrm{~Hz}, 1 \mathrm{H}), 7.56(\mathrm{~d}, J=8.0 \mathrm{~Hz}, 1 \mathrm{H})$, $7.43(\mathrm{t}, J=7.2 \mathrm{~Hz}, 1 \mathrm{H}), 7.18(\mathrm{dd}, J=7.6,4.8 \mathrm{~Hz}, 1 \mathrm{H}), 7.10(\mathrm{t}, J=7.6 \mathrm{~Hz}, 1 \mathrm{H}), 6.74(\mathrm{~d}, J=7.8$ $\mathrm{Hz}, 1 \mathrm{H}), 6.28-6.16(\mathrm{~m}, 2 \mathrm{H}), 6.14-6.02(\mathrm{~m}, 1 \mathrm{H}), 3.06(\mathrm{~s}, 3 \mathrm{H}), 3.02-2.94(\mathrm{~m}, 1 \mathrm{H}), 2.71-$ $2.51(\mathrm{~m}, 1 \mathrm{H}) .{ }^{13} \mathrm{C} \mathrm{NMR}\left(101 \mathrm{MHz}, \mathrm{CDCl}_{3}\right) \delta 159.0,156.0,148.4,148.0,145.9,134.0,132.9$, $132.8,130.2,127.5,125.4$ (q, $J=282.0 \mathrm{~Hz}), 123.6,123.5,123.1,120.7,108.8,59.8$ (q, $J=28.4$ $\mathrm{Hz}), 34.1,25.8 .{ }^{19} \mathrm{~F}$ NMR $\left(376 \mathrm{MHz}, \mathrm{CDCl}_{3}\right) \delta-74.48(\mathrm{~d}, J=7.3 \mathrm{~Hz})$. HRMS Calcd. For $\mathrm{C}_{19} \mathrm{H}_{16} \mathrm{~F}_{3} \mathrm{~N}_{3} \mathrm{ONa}\left([\mathrm{M}+\mathrm{Na}]^{+}\right): 382.1138$, found: 382.1138 . The product was analyzed by HPLC to determine the enantiomeric excess: $90 \%$ ee (Chiralpak AS-H, $i$-propanol/hexane $=5 / 95$, flow rate $1.0 \mathrm{~mL} / \mathrm{min}, \lambda=254 \mathrm{~nm}) ; \mathrm{t}_{\mathrm{r}}=26.12$ and $28.65 \mathrm{~min}$.

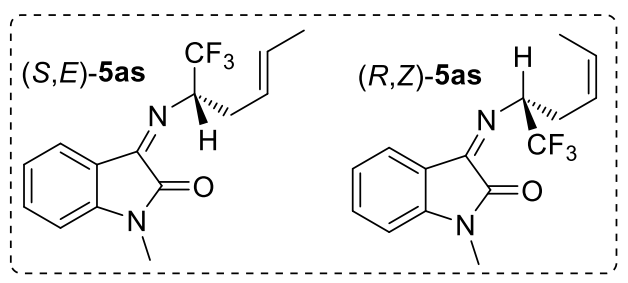

Yellow oil; yield (55.7 mg, 94\%). $[\alpha]^{25} \mathrm{D}=-20.9\left(c 0.11, \mathrm{CH}_{2} \mathrm{Cl}_{2}\right) .{ }^{1} \mathrm{H}$ NMR $\left(400 \mathrm{MHz}, \mathrm{CDCl}_{3}\right)$ $(S, E)$-5as $\delta 7.74-7.64(\mathrm{~m}, 1 \mathrm{H}), 7.49-7.41(\mathrm{~m}, 1 \mathrm{H}), 7.13-7.05(\mathrm{~m}, \mathrm{~Hz}, 1 \mathrm{H}), 6.83-6.69$ (m, $1 \mathrm{H}), 6.05-5.93(\mathrm{~m}, 1 \mathrm{H}), 5.60-5.27(\mathrm{~m}, 2 \mathrm{H}), 3.21(\mathrm{~s}, 3 \mathrm{H}), 2.78-2.53(\mathrm{~m}, 1 \mathrm{H}), 2.47-2.33$ $(\mathrm{m}, 1 \mathrm{H}), 1.56(\mathrm{~d}, J=5.2 \mathrm{~Hz}, 3 \mathrm{H}) .(R, Z)-5 \mathrm{as} \delta 7.74-7.64(\mathrm{~m}, 1 \mathrm{H}), 7.49-7.41(\mathrm{~m}, 1 \mathrm{H}), 7.13$ $7.05(\mathrm{~m}, 1 \mathrm{H}), 6.83-6.69(\mathrm{~m}, 1 \mathrm{H}), 6.15-6.05(\mathrm{~m}, 1 \mathrm{H}), 5.60-5.27(\mathrm{~m}, 2 \mathrm{H}), 3.20(\mathrm{~s}, 3 \mathrm{H}), 2.78$ $-2.53(\mathrm{~m}, 1 \mathrm{H}), 2.47-2.33(\mathrm{~m}, 1 \mathrm{H}), 1.50(\mathrm{~d}, J=6.8 \mathrm{~Hz}, 3 \mathrm{H}) .{ }^{13} \mathrm{C} \mathrm{NMR}\left(101 \mathrm{MHz}, \mathrm{CDCl}_{3}\right)$ $(S, E)-5$ as $\delta 158.88,155.48,145.86,133.65,129.50,125.47$ (q, $J=282.0 \mathrm{~Hz}) 125.20,123.38$, $122.91,120.90,108.60,60.14$ (q, $J=27.3 \mathrm{~Hz}), 33.68,25.78,17.83$. $(R, Z)-5$ as $\delta 158.94,155.45$, 145.87, 133.66, 127.97, 125.20, 125.10 (q, $J=282.0 \mathrm{~Hz}$ ), 124.06, 123.40, 122.86, 120.98, 108.63, $59.94(\mathrm{q}, J=28.3 \mathrm{~Hz}), 27.80,25.82,12.73 .{ }^{19} \mathrm{~F} \mathrm{NMR}\left(376 \mathrm{MHz}, \mathrm{CDCl}_{3}\right)(S, E)-5 \mathbf{a s} \delta$ $74.29(\mathrm{~d}, J=7.4 \mathrm{~Hz}) .(R, Z)-5$ as $\delta-74.50(\mathrm{~d}, J=7.2 \mathrm{~Hz})$. HRMS Calcd. For $\mathrm{C}_{15} \mathrm{H}_{15} \mathrm{~F}_{3} \mathrm{~N}_{2} \mathrm{ONa}$ $\left([\mathrm{M}+\mathrm{Na}]^{+}\right)$: 319.1029 , found: 319.1032 . The product was acidic hydrolyzed followed by protected with $\mathrm{BzCl}$ to provide the corresponding $(S, E)-\mathbf{1 3 a}$ and $(R, Z)-\mathbf{1 3 b}$ (see Page S25-S31 for details), which could be analyzed by HPLC to determine the enantiomeric excess: both $91 \%$ 
ee $($ Chiralcel OD-H + Chiralcel OJ-H, $i$-propanol/hexane $=5 / 95$, flow rate $1.0 \mathrm{~mL} / \mathrm{min}, \lambda=220$ $\mathrm{nm})$; 13a: $\mathrm{t}_{\mathrm{r}}=14.85$ and $17.78 \mathrm{~min}, \mathbf{1 3 b}: \mathrm{t}_{\mathrm{r}}=16.40$ and $20.98 \mathrm{~min}$.

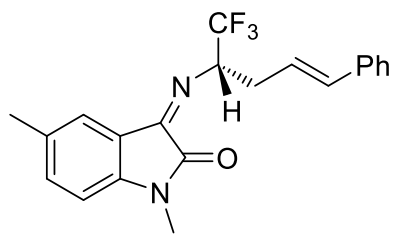

$5 \mathbf{b a}$

(Z)-1,5-dimethyl-3-(((S,E)-1,1,1-trifluoro-5-phenylpent-4-en-2-yl)imino)indolin-2-one:

Yellow oil; yield (67.0 mg, 90\%). $[\alpha]^{25} \mathrm{D}=-126.9\left(c 0.16, \mathrm{CH}_{2} \mathrm{Cl}_{2}\right) .{ }^{1} \mathrm{H} \mathrm{NMR}\left(400 \mathrm{MHz}, \mathrm{CDCl}_{3}\right)$ $\delta 7.54-7.50(\mathrm{~m}, 1 \mathrm{H}), 7.25-7.14(\mathrm{~m}, 6 \mathrm{H}), 6.59(\mathrm{~d}, J=8.0 \mathrm{~Hz}, 1 \mathrm{H}), 6.24(\mathrm{~d}, J=16.0 \mathrm{~Hz}, 1 \mathrm{H})$, $6.18-6.05(\mathrm{~m}, 2 \mathrm{H}), 3.02-2.92(\mathrm{~m}, 4 \mathrm{H}), 2.64-2.50(\mathrm{~m}, 1 \mathrm{H}), 2.34(\mathrm{~s}, 3 \mathrm{H}) .{ }^{13} \mathrm{C}$ NMR $(101$ $\left.\mathrm{MHz}, \mathrm{CDCl}_{3}\right) \delta 159.1,156.2,143.6,137.1,134.0,133.8,133.1,128.4,127.3,126.2,125.5$ (q, $J=282.0 \mathrm{~Hz}), 124.9,123.48,120.7,108.4,59.8(\mathrm{q}, J=28.2 \mathrm{~Hz}), 34.1,25.6,20.9 .{ }^{19} \mathrm{~F}$ NMR $\left(376 \mathrm{MHz}, \mathrm{CDCl}_{3}\right) \delta-74.49(\mathrm{~d}, J=7.3 \mathrm{~Hz})$. HRMS Calcd. For $\mathrm{C}_{21} \mathrm{H}_{19} \mathrm{~F}_{3} \mathrm{~N}_{2} \mathrm{ONa}\left([\mathrm{M}+\mathrm{Na}]^{+}\right)$: 395.1342, found: 395.1342 . The product was analyzed by HPLC to determine the enantiomeric excess: $93 \%$ ee (Chiralpak AS-H, $i$-propanol/hexane $=5 / 95$, flow rate $1.0 \mathrm{~mL} / \mathrm{min}, \lambda=254 \mathrm{~nm}$ ); $\mathrm{t}_{\mathrm{r}}=4.69$ and $5.02 \mathrm{~min}$.

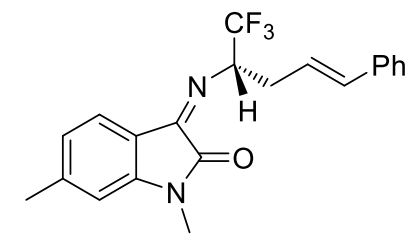

5 ca

(Z)-1,6-dimethyl-3-(((S,E)-1,1,1-trifluoro-5-phenylpent-4-en-2-yl)imino)indolin-2-one:

Yellow oil; yield (73.7 mg, 99\%). $[\alpha]^{25} \mathrm{D}=-83.6\left(c 0.11, \mathrm{CH}_{2} \mathrm{Cl}_{2}\right) .{ }^{1} \mathrm{H} \mathrm{NMR}\left(400 \mathrm{MHz}, \mathrm{CDCl}_{3}\right)$ $\delta 7.57(\mathrm{~d}, J=7.6 \mathrm{~Hz}, 1 \mathrm{H}), 7.28-7.13(\mathrm{~m}, 5 \mathrm{H}), 6.89(\mathrm{~d}, J=7.6 \mathrm{~Hz}, 1 \mathrm{H}), 6.52(\mathrm{~s}, 1 \mathrm{H}), 6.24$ (d, $J=16.0 \mathrm{~Hz}, 1 \mathrm{H}), 6.19-6.03(\mathrm{~m}, 2 \mathrm{H}), 3.03-2.91(\mathrm{~m}, 4 \mathrm{H}), 2.64-2.52(\mathrm{~m}, 1 \mathrm{H}), 2.39(\mathrm{~s}, 3 \mathrm{H})$. ${ }^{13} \mathrm{C} \mathrm{NMR}\left(101 \mathrm{MHz}, \mathrm{CDCl}_{3}\right) \delta 159.4,155.7,146.0,144.9,137.1,133.7,128.4,127.3,126.2$, 125.5 (q, $J=282.0 \mathrm{~Hz}), 124.9,123.9,122.9,118.3,59.7$ (q, $J=28.2 \mathrm{~Hz}), 34.1,25.5,22.5 .{ }^{19} \mathrm{~F}$ NMR (376 MHz, $\left.\mathrm{CDCl}_{3}\right) \delta-74.47(\mathrm{~d}, J=7.3 \mathrm{~Hz})$. HRMS Calcd. For $\mathrm{C}_{21} \mathrm{H}_{19} \mathrm{~F}_{3} \mathrm{~N}_{2} \mathrm{ONa}$ $\left([\mathrm{M}+\mathrm{Na}]^{+}\right): 395.1342$, found: 395.1342 . The product was analyzed by HPLC to determine the enantiomeric excess: 90\% ee (Chiralpak AS-H, $i$-propanol $/$ hexane $=5 / 95$, flow rate $1.0 \mathrm{~mL} / \mathrm{min}$, $\lambda=254 \mathrm{~nm}) ; \mathrm{t}_{\mathrm{r}}=5.02$ and $5.44 \mathrm{~min}$. 


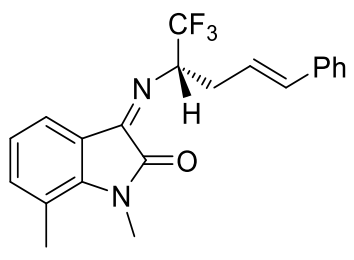

5da

(Z)-1,7-dimethyl-3-(((S,E)-1,1,1-trifluoro-5-phenylpent-4-en-2-yl)imino)indolin-2-one:

Yellow oil; yield (65.5 mg, 88\%). $[\alpha]^{25}{ }_{\mathrm{D}}=-111.3\left(c 0.68, \mathrm{CH}_{2} \mathrm{Cl}_{2}\right) .{ }^{1} \mathrm{H}$ NMR $\left(400 \mathrm{MHz}, \mathrm{CDCl}_{3}\right)$ $\delta 7.56(\mathrm{~d}, J=7.6 \mathrm{~Hz}, 1 \mathrm{H}), 7.26-7.10(\mathrm{~m}, 6 \mathrm{H}), 6.96(\mathrm{t}, J=7.6 \mathrm{~Hz}, 1 \mathrm{H}), 6.19(\mathrm{~d}, J=16.0 \mathrm{~Hz}$, $1 \mathrm{H}), 6.15-6.02(\mathrm{~m}, 2 \mathrm{H}), 3.25(\mathrm{~s}, 3 \mathrm{H}), 3.00-2.90(\mathrm{~m}, 1 \mathrm{H}), 2.61-2.51(\mathrm{~m}, 1 \mathrm{H}), 2.44(\mathrm{~s}, 3 \mathrm{H})$. ${ }^{13} \mathrm{C}$ NMR $\left(101 \mathrm{MHz}, \mathrm{CDCl}_{3}\right) \delta 159.7,156.0,143.4,137.5,137.1,133.9,128.4,127.3,126.2$, $125.5(\mathrm{q}, J=282.0 \mathrm{~Hz}), 125.0,123.3,121.6,121.0,120.3,60.0(\mathrm{q}, J=28.2 \mathrm{~Hz}), 34.0,28.9$, 18.8. ${ }^{19} \mathrm{~F}$ NMR (376 MHz, $\left.\mathrm{CDCl}_{3}\right) \delta-74.52\left(\mathrm{~d}, J=7.3 \mathrm{~Hz}\right.$ ). HRMS Calcd. For $\mathrm{C}_{21} \mathrm{H}_{19} \mathrm{~F}_{3} \mathrm{~N}_{2} \mathrm{ONa}$ $\left([\mathrm{M}+\mathrm{Na}]^{+}\right): 395.1342$, found: 395.1342 . The product was analyzed by HPLC to determine the enantiomeric excess: 94\% ee (Chiralpak AS-H, $i$-propanol $/$ hexane $=5 / 95$, flow rate $1.0 \mathrm{~mL} / \mathrm{min}$, $\lambda=254 \mathrm{~nm}) ; \mathrm{t}_{\mathrm{r}}=4.75$ and $5.00 \mathrm{~min}$.

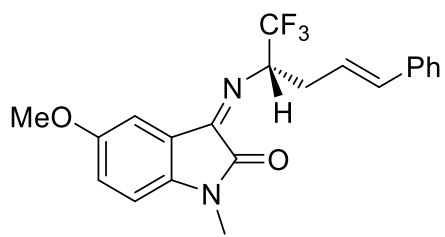

5ea

(Z)-5-methoxy-1-methyl-3-(((S,E)-1,1,1-trifluoro-5-phenylpent-4-en-2-yl)imino)indolin-

2-one:

Yellow solid; yield (71.5 mg, 92\%). m.p. 81-85 ${ }^{\circ} \mathrm{C} ;[\alpha]^{25} \mathrm{D}=-101.0\left(c 0.21, \mathrm{CH}_{2} \mathrm{Cl}_{2}\right) .{ }^{1} \mathrm{H}$ NMR $\left(400 \mathrm{MHz}, \mathrm{CDCl}_{3}\right) \delta 7.26-7.13(\mathrm{~m}, 7 \mathrm{H}), 6.96(\mathrm{dd}, J=8.4,2.8 \mathrm{~Hz}, 1 \mathrm{H}), 6.61(\mathrm{~d}, J=8.4 \mathrm{~Hz}$, $1 \mathrm{H}), 6.23(\mathrm{~d}, J=16.0 \mathrm{~Hz}, 1 \mathrm{H}), 6.16-6.06(\mathrm{~m}, 1 \mathrm{H}), 3.83(\mathrm{~s}, 3 \mathrm{H}), 3.05-2.88(\mathrm{~m}, 4 \mathrm{H}), 2.63-$ $2.52(\mathrm{~m}, 1 \mathrm{H}) .{ }^{13} \mathrm{C} \mathrm{NMR}\left(101 \mathrm{MHz}, \mathrm{CDCl}_{3}\right) \delta 159.1,156.5,156.3,139.6,137.1,133.9,128.4$, $127.4,126.2,125.5(\mathrm{q}, J=282.0 \mathrm{~Hz}), 124.8,121.5,112.0,109.5,107.9,59.9(\mathrm{q}, J=28.2 \mathrm{~Hz})$, 56.1, 34.0, 25.6. ${ }^{19} \mathrm{~F}$ NMR $\left(376 \mathrm{MHz}, \mathrm{CDCl}_{3}\right) \delta-74.45(\mathrm{~d}, J=7.3 \mathrm{~Hz})$. HRMS Calcd. For $\mathrm{C}_{21} \mathrm{H}_{19} \mathrm{~F}_{3} \mathrm{~N}_{2} \mathrm{O}_{2} \mathrm{Na}\left([\mathrm{M}+\mathrm{Na}]^{+}\right): 411.1291$, found: 411.1291 . The product was analyzed by HPLC to determine the enantiomeric excess: $92 \%$ ee (Chiralpak AS-H, $i$-propanol/hexane $=5 / 95$, flow rate $1.0 \mathrm{~mL} / \mathrm{min}, \lambda=254 \mathrm{~nm}) ; \mathrm{t}_{\mathrm{r}}=7.05$ and $7.63 \mathrm{~min}$. 
<smiles>CN1C(=O)/C(=N\C(/C=C/c2ccccc2)C(F)(F)F)c2cc(Br)ccc21</smiles>

\section{5 fa}

(Z)-5-bromo-1-methyl-3-(((S,E)-1,1,1-trifluoro-5-phenylpent-4-en-2-yl)imino)indolin-2one:

Yellow solid; yield (79.6 mg, 91\%). m.p. $120-122{ }^{\circ} \mathrm{C} ;[\alpha]^{25} \mathrm{D}=-70.7\left(c 0.15, \mathrm{CH}_{2} \mathrm{Cl}_{2}\right) .{ }^{1} \mathrm{H}$ NMR $\left(400 \mathrm{MHz}, \mathrm{CDCl}_{3}\right) \delta 7.69(\mathrm{~d}, J=7.2 \mathrm{~Hz}, 1 \mathrm{H}), 7.42(\mathrm{t}, J=7.6 \mathrm{~Hz}, 1 \mathrm{H}), 7.24-7.16(\mathrm{~m}, 2 \mathrm{H})$, $7.15-7.06(\mathrm{~m}, 3 \mathrm{H}), 6.72(\mathrm{~d}, J=7.6 \mathrm{~Hz}, 1 \mathrm{H}), 6.19(\mathrm{~d}, J=16.0 \mathrm{~Hz}, 1 \mathrm{H}), 6.14-5.99(\mathrm{~m}, 2 \mathrm{H})$, $3.04(\mathrm{~s}, 3 \mathrm{H}), 3.00-2.91(\mathrm{~m}, 1 \mathrm{H}), 2.63-2.52(\mathrm{~m}, 1 \mathrm{H}) .{ }^{13} \mathrm{C} \mathrm{NMR}\left(101 \mathrm{MHz}, \mathrm{CDCl}_{3}\right) \delta$ 159.0, $155.9,145.8,135.6,133.8,133.0,132.6,128.6,127.4,125.6,125.5$ (q, $J=282.0 \mathrm{~Hz}), 123.5$, 123.0, 120.8, 108.7, 59.9 (q, $J=28.2 \mathrm{~Hz}), 34.1,25.7 .{ }^{19} \mathrm{~F} \mathrm{NMR}\left(376 \mathrm{MHz}, \mathrm{CDCl}_{3}\right) \delta-74.54(\mathrm{~d}$, $J=7.1 \mathrm{~Hz})$.HRMS Calcd. For $\mathrm{C}_{20} \mathrm{H}_{16} \mathrm{BrF}_{3} \mathrm{~N}_{2} \mathrm{ONa}\left([\mathrm{M}+\mathrm{Na}]^{+}\right)$: 459.0290, found: 459.0290. The product was analyzed by HPLC to determine the enantiomeric excess: 92\% ee (Chiralcel OD$\mathrm{H}, i$-propanol $/$ hexane $=5 / 95$, flow rate $1.0 \mathrm{~mL} / \mathrm{min}, \lambda=254 \mathrm{~nm}) ; \mathrm{t}_{\mathrm{r}}=9.81$ and $10.26 \mathrm{~min}$.<smiles>CN1C(=O)/C(=C\C(/C=C/c2ccccc2)C(F)(F)F)c2cc(Cl)ccc21</smiles>

5ga

(Z)-5-chloro-1-methyl-3-(((S,E)-1,1,1-trifluoro-5-phenylpent-4-en-2-yl)imino)indolin-2one:

Yellow solid; yield (63.6 mg, 81\%). m.p. 87-89 ${ }^{\circ} \mathrm{C} ;[\alpha]^{25} \mathrm{D}=-264.4\left(c 0.18, \mathrm{CH}_{2} \mathrm{Cl}_{2}\right) .{ }^{1} \mathrm{H}$ NMR $\left(400 \mathrm{MHz}, \mathrm{CDCl}_{3}\right) \delta 7.67(\mathrm{~d}, J=1.2 \mathrm{~Hz}, 1 \mathrm{H}), 7.42-7.31(\mathrm{~m}, 1 \mathrm{H}), 7.27-7.14(\mathrm{~m}, 5 \mathrm{H}), 6.62$ $(\mathrm{d}, J=8.4 \mathrm{~Hz}, 1 \mathrm{H}), 6.18(\mathrm{~d}, J=16.0 \mathrm{~Hz}, 1 \mathrm{H}), 6.14-5.97(\mathrm{~m}, 2 \mathrm{H}), 3.04-2.92(\mathrm{~m}, 4 \mathrm{H}), 2.60-$ $2.48(\mathrm{~m}, 1 \mathrm{H}) .{ }^{13} \mathrm{C} \mathrm{NMR}\left(101 \mathrm{MHz}, \mathrm{CDCl}_{3}\right) \delta 158.6,155.0,144.1,136.9,134.1,133.2,129.1$, $128.5,127.5,126.1,125.3(\mathrm{q}, J=282.0 \mathrm{~Hz}), 124.7,123.1,121.9,109.7,60.0$ (q, $J=28.2 \mathrm{~Hz})$, 34.0, 25.7. ${ }^{19} \mathrm{~F}$ NMR $\left(376 \mathrm{MHz}, \mathrm{CDCl}_{3}\right) \delta-74.54(\mathrm{~d}, J=7.2 \mathrm{~Hz})$. HRMS Calcd. For $\mathrm{C}_{20} \mathrm{H}_{16} \mathrm{ClF}_{3} \mathrm{~N}_{2} \mathrm{ONa}\left([\mathrm{M}+\mathrm{Na}]^{+}\right): 415.0795$, found: 415.0795 . The product was analyzed by HPLC to determine the enantiomeric excess: $95 \%$ ee (Chiralpak AS-H, $i$-propanol/hexane $=$ $5 / 95$, flow rate $1.0 \mathrm{~mL} / \mathrm{min}, \lambda=254 \mathrm{~nm}) ; \mathrm{t}_{\mathrm{r}}=8.90$ and $9.80 \mathrm{~min}$. 


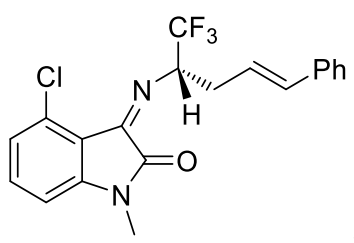

5ha

(Z)-4-chloro-1-methyl-3-(((S,E)-1,1,1-trifluoro-5-phenylpent-4-en-2-yl)imino)indolin-2-

one:

Yellow solid; yield (77.8 mg, 99\%). m.p. $149-151^{\circ} \mathrm{C} ;[\alpha]^{25} \mathrm{D}=-226.4\left(c 0.56, \mathrm{CH}_{2} \mathrm{Cl}_{2}\right) .{ }^{1} \mathrm{H} \mathrm{NMR}$ $\left(400 \mathrm{MHz}, \mathrm{CDCl}_{3}\right) \delta 7.32-7.28(\mathrm{~m}, 1 \mathrm{H}), 7.25-7.12(\mathrm{~m}, 5 \mathrm{H}), 7.06(\mathrm{~d}, J=8.2 \mathrm{~Hz}, 1 \mathrm{H}), 6.60$ $(\mathrm{d}, J=7.7 \mathrm{~Hz}, 1 \mathrm{H}), 6.22(\mathrm{~d}, J=15.9 \mathrm{~Hz}, 1 \mathrm{H}), 6.17-6.03(\mathrm{~m}, 2 \mathrm{H}), 3.18-2.82(\mathrm{~m}, 4 \mathrm{H}), 2.81-$ $2.32(\mathrm{~m}, 1 \mathrm{H}) .{ }^{13} \mathrm{C}$ NMR $\left(101 \mathrm{MHz}, \mathrm{CDCl}_{3}\right) \delta 158.0,154.1,147.0,137.0,133.8,133.5,131.8$, $128.4,127.3,126.1,125.5,125.4(\mathrm{q}, J=281.0 \mathrm{~Hz}), 124.9,116.9,106.9,60.4(\mathrm{q}, J=28.5 \mathrm{~Hz})$, 34.2, 25.7. ${ }^{19} \mathrm{~F} \mathrm{NMR}\left(376 \mathrm{MHz}, \mathrm{CDCl}_{3}\right) \delta-74.58(\mathrm{~d}, J=7.2 \mathrm{~Hz})$. The product was analyzed by HPLC to determine the enantiomeric excess: $89 \%$ ee (Chiralpak AS-H, $i$-propanol/hexane $=$ $5 / 95$, flow rate $1.0 \mathrm{~mL} / \mathrm{min}, \lambda=254 \mathrm{~nm}) ; \mathrm{t}_{\mathrm{r}}=6.06$ and $6.62 \mathrm{~min}$.

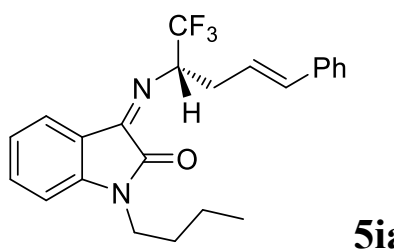

(Z)-1-butyl-3-(((S,E)-1,1,1-trifluoro-5-phenylpent-4-en-2-yl)imino)indolin-2-one: Yellow Solid; yield (79.3 mg, 99\%). m.p. $75-77^{\circ} \mathrm{C} ;[\alpha]^{25} \mathrm{D}=-90.0\left(c \quad 0.13, \mathrm{CH}_{2} \mathrm{Cl}_{2}\right) .{ }^{1} \mathrm{H}$ NMR (400 $\left.\mathrm{MHz}, \mathrm{CDCl}_{3}\right) \delta 7.70(\mathrm{~d}, J=7.6 \mathrm{~Hz}, 1 \mathrm{H}), 7.40(\mathrm{t}, J=7.6 \mathrm{~Hz}, 1 \mathrm{H}), 7.25-7.13(\mathrm{~m}, 5 \mathrm{H}), 7.08(\mathrm{t}$, $J=7.6 \mathrm{~Hz}, 1 \mathrm{H}), 6.73(\mathrm{~d}, J=7.6 \mathrm{~Hz}, 1 \mathrm{H}), 6.25(\mathrm{~d}, J=16.0 \mathrm{~Hz}, 1 \mathrm{H}), 6.18-6.07(\mathrm{~m}, 2 \mathrm{H}), 3.56$ $-3.42(\mathrm{~m}, 2 \mathrm{H}), 3.00-2.92(\mathrm{~m}, 1 \mathrm{H}), 2.66-2.52(\mathrm{~m}, 1 \mathrm{H}), 1.53-1.39(\mathrm{~m}, 2 \mathrm{H}), 1.35-1.22(\mathrm{~m}$, 2H), 0.89 (t, $J=7.2 \mathrm{~Hz}, 3 \mathrm{H}) .{ }^{13} \mathrm{C} \mathrm{NMR}\left(101 \mathrm{MHz}, \mathrm{CDCl}_{3}\right) \delta 158.8,155.9,145.4,137.1,133.8$, 133.6, 128.5, 127.3, 126.1, 125.5 (q, $J=282.0 \mathrm{~Hz}), 124.7,123.1,123.1,120.9,108.9,59.8$ (q, $J=28.2 \mathrm{~Hz}), 39.5,34.0,29.2,20.2,13.8 .{ }^{19} \mathrm{~F} \mathrm{NMR}\left(376 \mathrm{MHz}, \mathrm{CDCl}_{3}\right) \delta-74.54(\mathrm{~d}, J=7.2 \mathrm{~Hz})$. HRMS Calcd. For $\mathrm{C}_{23} \mathrm{H}_{23} \mathrm{~F}_{3} \mathrm{~N}_{2} \mathrm{ONa}\left([\mathrm{M}+\mathrm{Na}]^{+}\right)$: 423.1655, found: 423.1655 . The product was analyzed by HPLC to determine the enantiomeric excess: 93\% ee (Chiralpak AS-H, $i$ propanol $/$ hexane $=5 / 95$, flow rate $1.0 \mathrm{~mL} / \mathrm{min}, \lambda=254 \mathrm{~nm}$ ); $\mathrm{t}_{\mathrm{r}}=5.33$ and $5.64 \mathrm{~min}$. 


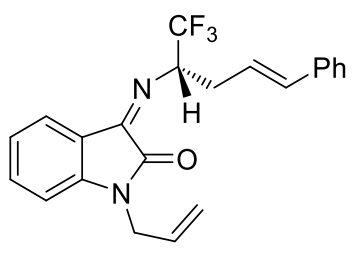

(Z)-1-allyl-3-(((S,E)-1,1,1-trifluoro-5-phenylpent-4-en-2-yl)imino)indolin-2-one: Yellow Solid; yield (64.6 mg, 84\%). m.p. 107-109 ${ }^{\circ} \mathrm{C} ;[\alpha]^{25} \mathrm{D}=-91.4\left(c 0.14, \mathrm{CH}_{2} \mathrm{Cl}_{2}\right) .{ }^{1} \mathrm{H}^{\mathrm{N} M R}(400$ $\left.\mathrm{MHz} \mathrm{CDCl}_{3}\right) \delta 7.71(\mathrm{~d}, J=7.6,1 \mathrm{H}), 7.37(\mathrm{t}, J=7.6,1 \mathrm{H}), 7.25-7.12(\mathrm{~m}, 5 \mathrm{H}), 7.08(\mathrm{t}, J=7.6$, $1 \mathrm{H}), 6.70(\mathrm{~d}, J=8.0 \mathrm{~Hz}, 1 \mathrm{H}), 6.23(\mathrm{~d}, J=16.0 \mathrm{~Hz}, 1 \mathrm{H}), 6.16-6.02(\mathrm{~m}, 2 \mathrm{H}), 5.62-5.50(\mathrm{~m}$, $1 \mathrm{H}), 5.11-5.01(\mathrm{~m}, 2 \mathrm{H}), 4.24-4.04(\mathrm{~m}, 2 \mathrm{H}), 3.08-2.89(\mathrm{~m}, 1 \mathrm{H}), 2.64-2.53(\mathrm{~m}, 1 \mathrm{H}) .{ }^{13} \mathrm{C}$ $\operatorname{NMR}\left(101 \mathrm{MHz}, \mathrm{CDCl}_{3}\right) \delta 158.6,155.6,145.1,137.0,133.9,133.6,130.5,128.5,127.5,126.2$, $125.5(\mathrm{q}, J=282.0 \mathrm{~Hz}), 124.7,123.3,123.0,120.8,118.0,109.5,60.0$ (q, $J=28.2 \mathrm{~Hz}), 41.9$, 34.0. ${ }^{19} \mathrm{~F}$ NMR (376 MHz, $\left.\mathrm{CDCl}_{3}\right) \delta-74.61(\mathrm{~d}, J=7.2 \mathrm{~Hz})$. HRMS Calcd. $\mathrm{For}_{2} \mathrm{C}_{22} \mathrm{H}_{19} \mathrm{~F}_{3} \mathrm{~N}_{2} \mathrm{ONa}^{+}$: 407.1342, found: 407.1342. HRMS Calcd. For $\mathrm{C}_{20} \mathrm{H}_{16} \mathrm{ClF}_{3} \mathrm{~N}_{2} \mathrm{ONa}\left([\mathrm{M}+\mathrm{Na}]^{+}\right)$: 415.0802, found: 415.0795. The product was analyzed by HPLC to determine the enantiomeric excess: $93 \%$ ee (Chiralpak IE, $i$-propanol $/$ hexane $=5 / 95$, flow rate $1.0 \mathrm{~mL} / \mathrm{min}, \lambda=254 \mathrm{~nm}$ ); $\mathrm{t}_{\mathrm{r}}=4.93$ and 5.15 $\min$.

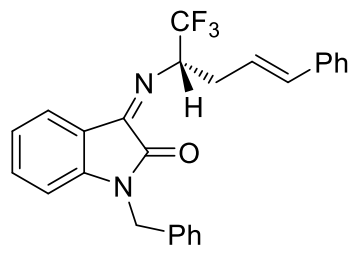

\section{$5 \mathbf{k a}$}

\section{(Z)-1-benzyl-3-(((S,E)-1,1,1-trifluoro-5-phenylpent-4-en-2-yl)imino)indolin-2-one:}

Yellow solid; yield (86.0 mg, 99\%). m.p. $97-99{ }^{\circ} \mathrm{C} ;[\alpha]^{25} \mathrm{D}=-112.9\left(c 0.34, \mathrm{CH}_{2} \mathrm{Cl}_{2}\right) .{ }^{1} \mathrm{H}$ NMR $\left(400 \mathrm{MHz}, \mathrm{CDCl}_{3}\right) \delta 7.70(\mathrm{~d}, J=7.2 \mathrm{~Hz}, 1 \mathrm{H}), 7.32-7.15(\mathrm{~m}, 9 \mathrm{H}), 7.13-7.07(\mathrm{~m}, 2 \mathrm{H}), 7.04$ $(\mathrm{t}, J=7.6 \mathrm{~Hz}, 1 \mathrm{H}), 6.56(\mathrm{~d}, J=8.0 \mathrm{~Hz}, 1 \mathrm{H}), 6.29(\mathrm{~d}, J=16.0 \mathrm{~Hz}, 1 \mathrm{H}), 6.23-6.11(\mathrm{~m}, 2 \mathrm{H})$, $4.77(\mathrm{~d}, J=16.0 \mathrm{~Hz}, 1 \mathrm{H}), 4.67(\mathrm{~d}, J=16.0 \mathrm{~Hz}, 1 \mathrm{H}), 3.05-2.95(\mathrm{~m}, 1 \mathrm{H}), 2.70-2.57(\mathrm{~m}, 1 \mathrm{H})$. ${ }^{13} \mathrm{C} \mathrm{NMR}\left(101 \mathrm{MHz}, \mathrm{CDCl}_{3}\right) \delta 158.9,155.6,145.0,137.0,134.8,133.8,133.6,129.0,128.6$, $127.8,127.4,127.1,126.2,125.5(\mathrm{q}, J=282.0 \mathrm{~Hz}), 124.6,123.4,123.0,120.9,109.7,60.0(\mathrm{q}$, $J=28.2 \mathrm{~Hz}), 43.5,34.0 .{ }^{19} \mathrm{~F}$ NMR $\left(376 \mathrm{MHz}, \mathrm{CDCl}_{3}\right) \delta-74.60(\mathrm{~d}, J=7.3 \mathrm{~Hz})$. HRMS Calcd. For $\mathrm{C}_{26} \mathrm{H}_{21} \mathrm{~F}_{3} \mathrm{~N}_{2} \mathrm{ONa}\left([\mathrm{M}+\mathrm{Na}]^{+}\right): 457.1498$, found: 457.1498 . The product was analyzed by HPLC to determine the enantiomeric excess: $91 \%$ ee (Chiralpak AS-H, $i$-propanol/hexane $=$ $5 / 95$, flow rate $1.0 \mathrm{~mL} / \mathrm{min}, \lambda=254 \mathrm{~nm}) ; \mathrm{t}_{\mathrm{r}}=5.01$ and $5.42 \mathrm{~min}$. 


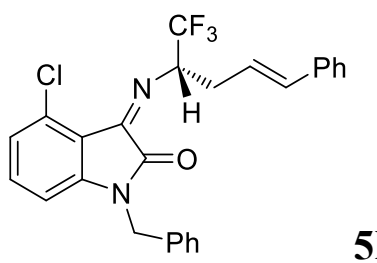

(Z)-1-benzyl-4-chloro-3-(((S,E)-1,1,1-trifluoro-5-phenylpent-4-en-2-yl)imino)indolin-2one:

Yellow solid; yield $(92.8 \mathrm{mg}, 99 \%)$. m.p. $78-80{ }^{\circ} \mathrm{C} ;[\alpha]^{25} \mathrm{D}=-162.6\left(c 0.35, \mathrm{CH}_{2} \mathrm{Cl}_{2}\right) .{ }^{1} \mathrm{H}$ NMR (400 MHz, $\left.\mathrm{CDCl}_{3}\right) \delta 7.27-7.12(\mathrm{~m}, 9 \mathrm{H}), 7.08(\mathrm{~d}, J=6.9 \mathrm{~Hz}, 2 \mathrm{H}), 7.02(\mathrm{~d}, J=8.2 \mathrm{~Hz}, 1 \mathrm{H})$, $6.47(\mathrm{~d}, J=7.8 \mathrm{~Hz}, 1 \mathrm{H}), 6.30$ (d, $J=15.8 \mathrm{~Hz}, 1 \mathrm{H}), 6.25-6.09$ (m, 2H), 4.75 (d, $J=16.0 \mathrm{~Hz}$, 1H), $4.69(\mathrm{~d}, J=16.0 \mathrm{~Hz}, 1 \mathrm{H}), 3.18-2.89(\mathrm{~m}, 1 \mathrm{H}), 2.78-2.52(\mathrm{~m}, 1 \mathrm{H}) .{ }^{13} \mathrm{C} \mathrm{NMR}(101 \mathrm{MHz}$, $\left.\mathrm{CDCl}_{3}\right) \delta 157.9,153.9,146.3,137.0,134.5,133.8,133.5,131.9,129.0,128.7,128.5,127.9$, 127.0, 126.2, 126.0 (q, $J=279.9 \mathrm{~Hz}) 125.6,124.0,117.1,108.0,60.5$ (q, $J=28.6 \mathrm{~Hz}), 43.5$, 34.2. ${ }^{19} \mathrm{~F}$ NMR $\left(376 \mathrm{MHz}, \mathrm{CDCl}_{3}\right) \delta-74.66(\mathrm{~d}, J=7.1 \mathrm{~Hz})$. The product was analyzed by HPLC to determine the enantiomeric excess: $89 \%$ ee (Chiralpak AS-H, $i$-propanol/hexane $=5 / 95$, flow rate $1.0 \mathrm{~mL} / \mathrm{min}, \lambda=254 \mathrm{~nm}$ ); $\mathrm{t}_{\mathrm{r}}=5.81$ and $6.29 \mathrm{~min}$. 


\section{Mechanism investigation}

a)
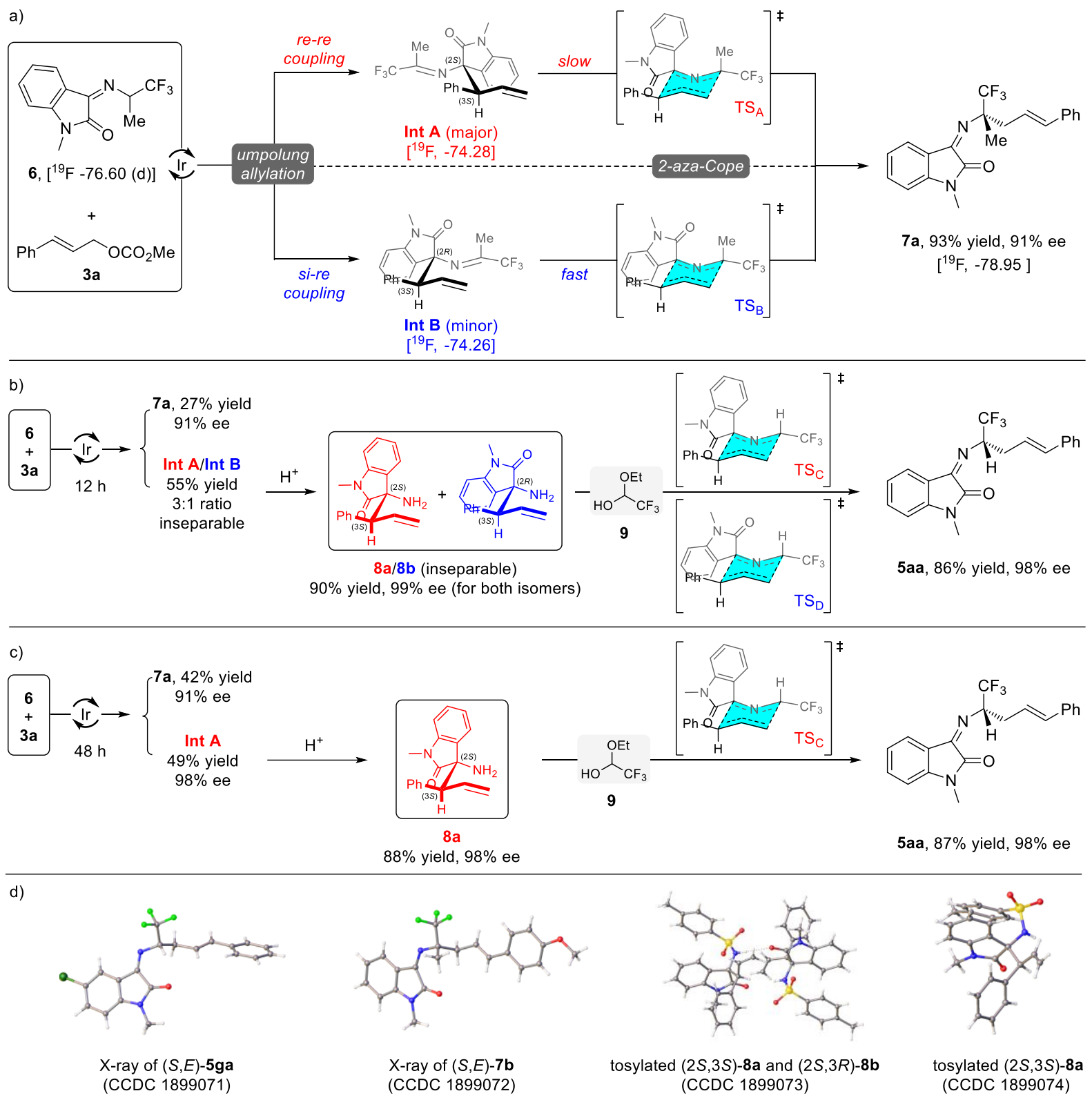

Scheme S1: Mechanism investigation with ${ }^{19} \mathrm{~F} \mathrm{NMR}$, control experiments and X-ray analysis.

\subsection{Synthesis of compound 6}

To a $25 \mathrm{~mL}$ round-bottom flask vial equipped with a stirrer bar were added 3-amino-1methylindolin-2-one hydrochloride (600 mg, $3 \mathrm{mmol})$, 1,1,1-Trifluoroacetone (504 mg, 4.5 mmol), Ti(OEt) $)_{4}(1.37 \mathrm{~g}, 6 \mathrm{mmol}), \mathrm{NEt}_{3}(606 \mathrm{mg}, 6 \mathrm{mmol})$ and dry DCM (10 mL). The mixture was stirred at room temperature for $8 \mathrm{~h}$ and then added dichloromethane $(20 \mathrm{~mL})$ and water $(15$ $\mathrm{mL}$ ). The mixture was stirred for $5 \mathrm{~min}$ and then filtered. The organic layer was separated, dried over anhydrous $\mathrm{Na}_{2} \mathrm{SO}_{4}$, filtered, concentrated, and purified by flash chromatography on silica 
gel (petroleum ether / ethyl acetate $=5: 1)$ to give the product 6 as a yellow solid; yiled (476 mg, $62 \%)$.

Yellow solid; m.p. $128-130{ }^{\circ} \mathrm{C} ;{ }^{1} \mathrm{H}$ NMR (400 MHz, $\left.\mathrm{CDCl}_{3}\right) \delta 7.79-7.61(\mathrm{~m}, 1 \mathrm{H}), 7.45(, J=$ 8.0, 1H), $7.11(\mathrm{t}, J=7.6 \mathrm{~Hz}, 1 \mathrm{H}), 6.82(\mathrm{~d}, J=7.6 \mathrm{~Hz}, 1 \mathrm{H}), 5.89-5.72(\mathrm{~m}, 1 \mathrm{H}), 3.22(\mathrm{~s}, 3 \mathrm{H})$, $1.44(\mathrm{~d}, J=6.8 \mathrm{~Hz}, 3 \mathrm{H}) .{ }^{13} \mathrm{C} \mathrm{NMR}\left(101 \mathrm{MHz}, \mathrm{CDCl}_{3}\right) \delta 158.4,154.8,146.0,133.7,125.9(\mathrm{q}$, $J=282.0 \mathrm{~Hz}), 123.5,123.0,120.9,108.7,56.8(\mathrm{q}, J=29.7 \mathrm{~Hz}), 25.9,14.8,14.8 .{ }^{19} \mathrm{~F} \mathrm{NMR}$ (376 MHz, Tol) $\delta-76.60(\mathrm{~d}, J=7.5 \mathrm{~Hz})$. HRMS Calcd. For $\mathrm{C}_{12} \mathrm{H}_{11} \mathrm{~F}_{3} \mathrm{~N}_{2} \mathrm{ONa}\left([\mathrm{M}+\mathrm{Na}]^{+}\right)$: 279.0716, found: 279.0716 .

5.2 Ir-Catalyzed asymmetric cascade allylation/2-aza-Cope rearrangement of compound 6 In a $25 \mathrm{~mL}$ nitrogen-filled dry Schlenk tube, $[\operatorname{Ir}(\mathrm{COD}) \mathrm{Cl}]_{2}(3.3 \mathrm{mg}, 0.005 \mathrm{mmol})$, phosphoramidite ligand $(S, S, S)$-L2 $(5.6 \mathrm{mg}, 0.01 \mathrm{mmol})$, degassed THF $(0.5 \mathrm{~mL})$ and degassed propylamine $(0.5 \mathrm{~mL})$ were added. After stirring at $50{ }^{\circ} \mathrm{C}$ for $30 \mathrm{mins}$, the reaction was concentrated via rotary evaporation under reduced pressure to give the iridium complex as a pale yellow solid. Then under the nitrogen-refilled dry Schlenk tube, $6(0.2 \mathrm{mmol})$, allylic carbonates 3 (0.22 mmol), DBU (0.2 mmol) and dry PhMe $(2 \mathrm{~mL})$ was added. Once starting material was consumed (monitored by TLC), the reaction mixture was concentrated via rotary evaporation under reduced pressure, and then purified by flash chromatography on silica gel $(\mathrm{PE} / \mathrm{EA}=20: 1)$ to give the product 7 .

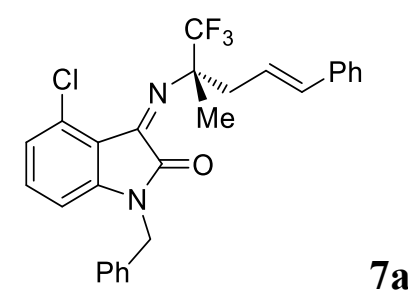

\section{(Z)-1-methyl-3-(((S,E)-1,1,1-trifluoro-2-methyl-5-phenylpent-4-en-2-yl)imino)indolin-2- one:}

Yellow oil; yield (69.3 mg, 93\%). $[\alpha]^{25} \mathrm{D}=-145.9\left(c 0.12, \mathrm{CH}_{2} \mathrm{Cl}_{2}\right) .{ }^{1} \mathrm{H}$ NMR $\left(400 \mathrm{MHz}, \mathrm{CDCl}_{3}\right)$ $\delta 7.63(\mathrm{~d}, J=7.3 \mathrm{~Hz}, 1 \mathrm{H}), 7.41(\mathrm{t}, J=7.6 \mathrm{~Hz}, 1 \mathrm{H}), 7.34-7.23(\mathrm{~m}, 4 \mathrm{H}), 7.18(\mathrm{t}, J=7.1 \mathrm{~Hz}$, 1H), $7.09(\mathrm{t}, J=7.6 \mathrm{~Hz}, 1 \mathrm{H}), 6.78(\mathrm{~d}, J=7.8 \mathrm{~Hz}, 1 \mathrm{H}), 6.44(\mathrm{~d}, J=15.6 \mathrm{~Hz}, 1 \mathrm{H}), 6.23-6.10$ $(\mathrm{m}, 1 \mathrm{H}), 3.34-3.23(\mathrm{~m}, 1 \mathrm{H}), 3.23(\mathrm{~s}, 3 \mathrm{H}), 3.15-3.03(\mathrm{~m}, 1 \mathrm{H}), 1.73(\mathrm{~s}, 3 \mathrm{H}) .{ }^{13} \mathrm{C}$ NMR $(101$ 
$\left.\mathrm{MHz}, \mathrm{CDCl}_{3}\right) \delta 157.4,153.5,145.7,137.5,133.6,133.2,128.5,127.8$ (q, $\left.J=284.8 \mathrm{~Hz}\right), 127.2$, $126.3,124.8,123.5,123.0,122.3,108.4,67.1$ (q, $J=25.3 \mathrm{~Hz}), 36.6,26.2,17.2 .{ }^{19} \mathrm{~F}$ NMR (376 $\left.\mathrm{MHz}, \mathrm{C}_{6} \mathrm{D}_{5} \mathrm{CD}_{3}\right) \delta$-78.95. HRMS Calcd. For $\mathrm{C}_{21} \mathrm{H}_{19} \mathrm{~F}_{3} \mathrm{~N}_{2} \mathrm{ONa}\left([\mathrm{M}+\mathrm{Na}]^{+}\right)$: 395.1342, found: 395.1347. The product was analyzed by HPLC to determine the enantiomeric excess: $91 \%$ ee $($ Chiralpak IA, $i$-propanol $/$ hexane $=10 / 90$, flow rate $1.0 \mathrm{~mL} / \mathrm{min}, \lambda=254 \mathrm{~nm}) ; \mathrm{t}_{\mathrm{r}}=5.27$ and $5.71 \mathrm{~min}$.

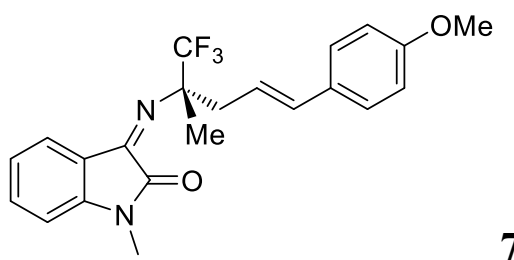

(Z)-1-methyl-3-(((S,E)-1,1,1-trifluoro-5-(4-methoxyphenyl)-2-methylpent-4-en-2-

\section{yl)imino)indolin-2-one:}

Yellow solid; yield (76.5 mg, 95\%). m.p. $110-112{ }^{\circ} \mathrm{C} ;[\alpha]^{25} \mathrm{D}=-95.9\left(c 0.22, \mathrm{CH}_{2} \mathrm{Cl}_{2}\right) .{ }^{1} \mathrm{H}$ NMR $\left(400 \mathrm{MHz}, \mathrm{CDCl}_{3}\right) \delta 7.63(\mathrm{~d}, J=7.6 \mathrm{~Hz}, 1 \mathrm{H}), 7.40(\mathrm{td}, J=8.0,1.2 \mathrm{~Hz}, 1 \mathrm{H}), 7.26-7.20(\mathrm{~m}$, 2H), $7.08(\mathrm{t}, J=7.6 \mathrm{~Hz}, 1 \mathrm{H}), 6.83-6.75(\mathrm{~m}, 3 \mathrm{H}), 6.38(\mathrm{~d}, J=15.6 \mathrm{~Hz}, 1 \mathrm{H}), 6.09-5.86(\mathrm{~m}$, 1H), $3.78(\mathrm{~s}, 3 \mathrm{H}), 3.33-3.17(\mathrm{~m}, 4 \mathrm{H}), 3.10-3.01(\mathrm{~m}, 1 \mathrm{H}), 1.72(\mathrm{~s}, 3 \mathrm{H}) .{ }^{13} \mathrm{C} \mathrm{NMR}(101 \mathrm{MHz}$, $\left.\mathrm{CDCl}_{3}\right) \delta 159.0,157.4,153.4,145.7,133.2,133.0,130.3,127.9$ (q, $\left.J=284.8 \mathrm{~Hz}\right), 127.4,123.4$, $122.9,122.5,122.4,113.9,108.4,67.1$ (q, $J=24.8 \mathrm{~Hz}), 55.3,36.6,26.2,17.2 .{ }^{19} \mathrm{~F}$ NMR $(376$ $\left.\mathrm{MHz}, \mathrm{CDCl}_{3}\right) \delta-79.23$ (s). HRMS Calcd. For $\mathrm{C}_{22} \mathrm{H}_{21} \mathrm{~F}_{3} \mathrm{~N}_{2} \mathrm{O}_{2} \mathrm{Na}\left([\mathrm{M}+\mathrm{Na}]^{+}\right)$: 425.1447, found: 425.1451. The product was analyzed by HPLC to determine the enantiomeric excess: $95 \%$ ee $($ Chiralpak AD-H, $i$-propanol $/$ hexane $=5 / 95$, flow rate $1.0 \mathrm{~mL} / \mathrm{min}, \lambda=254 \mathrm{~nm}) ; \mathrm{t}_{\mathrm{r}}=8.33$ and $9.84 \mathrm{~min}$.

5.3 Mechanism investigation with ${ }^{19} \mathrm{~F}$ NMR analysis and control experiments.

In a $25 \mathrm{~mL}$ nitrogen-filled dry Schlenk tube, $[\operatorname{Ir}(\mathrm{COD}) \mathrm{Cl}]_{2}(3.3 \mathrm{mg}, 0.005 \mathrm{mmol})$, phosphoramidite ligand $(S, S, S)$-L2 $(5.6 \mathrm{mg}, 0.01 \mathrm{mmol})$, degassed THF $(0.5 \mathrm{~mL})$ and degassed propylamine $(0.5 \mathrm{~mL})$ were added. After stirring at $50{ }^{\circ} \mathrm{C}$ for $30 \mathrm{mins}$, the reaction was concentrated via rotary evaporation under reduced pressure to give the iridium complex as a pale yellow solid. Then under the nitrogen-refilled dry Schlenk tube, 6 (51.2 mg, $0.2 \mathrm{mmol}), 3 \mathrm{a}$ 
(0.22 mmol), DBU (30 mg, $0.2 \mathrm{mmol})$ and degassed $\mathrm{C}_{6} \mathrm{D}_{5} \mathrm{CD}_{3}(2 \mathrm{~mL})$ was added. The reaction was monitored by ${ }^{19} \mathrm{~F}$ NMR analysis using $\mathrm{C}_{6} \mathrm{H}_{5} \mathrm{CF}_{3}$ as internal standard.

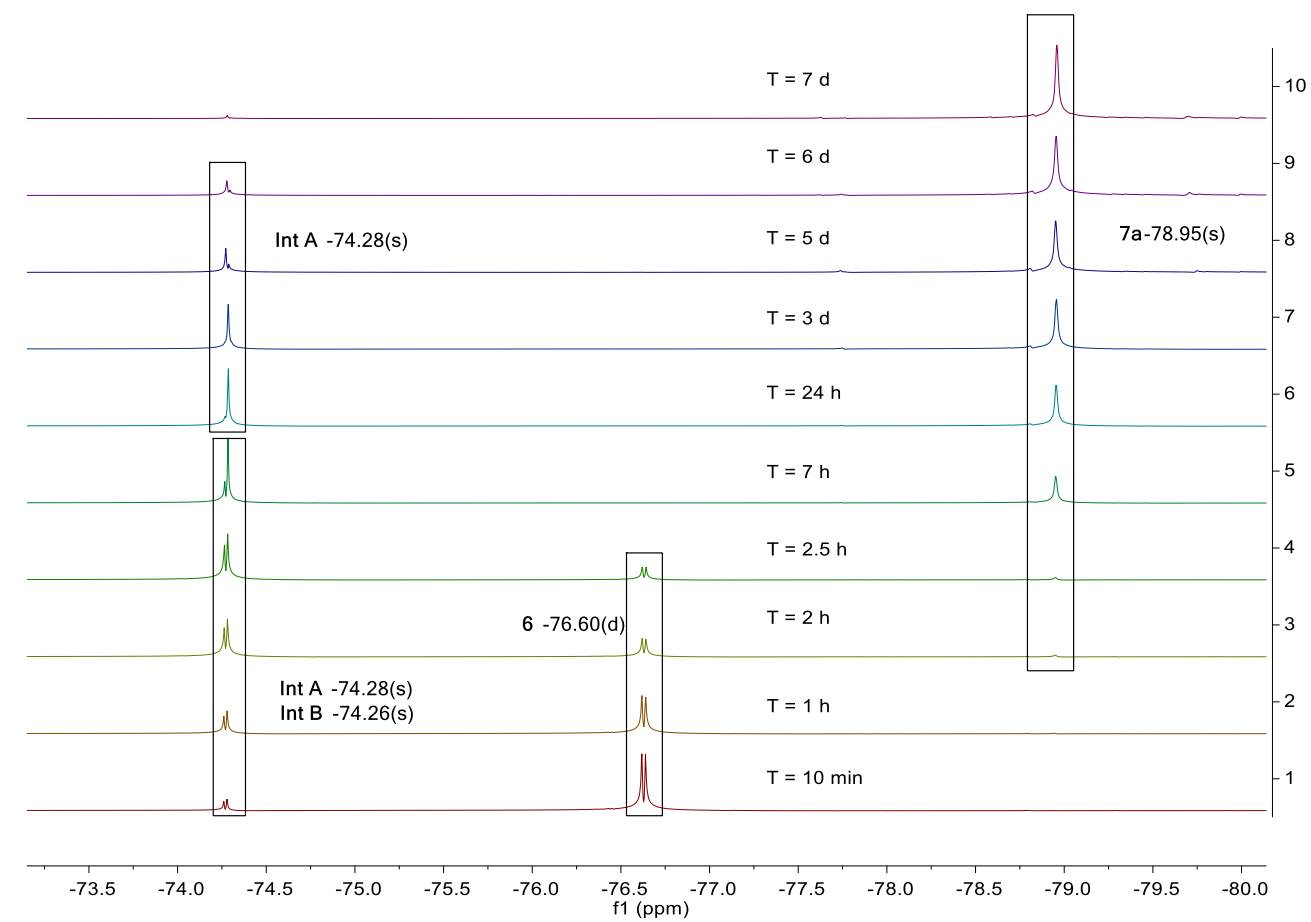

Figure S1. ${ }^{19} \mathrm{~F}$ NMR studies of the reaction intermediates.

After stirring at room temperature for $12 \mathrm{~h}$, the reaction mixture was concentrated via rotary evaporation under reduced pressure, and then purified by flash chromatography on silica gel $(\mathrm{PE} / \mathrm{EA}=20: 1)$ to give $27 \%$ yield of $7 \mathbf{a}$ (which was determined as $91 \%$ ee by HPLC analysis) and 55\% yield of inseparable Int A/Int B. To the mixture of Int A/Int B was added THF ( $1 \mathrm{~mL})$ and $6 \mathrm{~N} \mathrm{HCl}(0.5 \mathrm{~mL})$. After stirring for $5 \mathrm{mins}$, the mixture was concentrated via rotary evaporation under reduced pressure, and $\mathrm{Et}_{3} \mathrm{~N}(1 \mathrm{~mL})$ was added and then concentrated, the residue was directly purified by flash chromatography on silica gel $(\mathrm{PE} / \mathrm{EA}=3: 1)$ to give the inseparable products $8 \mathbf{a}$ and $\mathbf{8 b}$ as a colorless oil $(\mathbf{8 a}: \mathbf{8 b}=3: 1$, yield $(50.1 \mathrm{mg}, 90 \%))$.

Colorless oil; $[\alpha]^{25} \mathrm{D}=-54.7\left(c 0.14, \mathrm{CH}_{2} \mathrm{Cl}_{2}\right) .{ }^{1} \mathrm{H}$ NMR $\left(400 \mathrm{MHz}, \mathrm{CDCl}_{3}\right)$ 8a: $\delta 7.45-7.40(\mathrm{~m}$, 1H), $7.31-7.26(\mathrm{~m}, 1 \mathrm{H}), 7.14-7.07(\mathrm{~m}, 1 \mathrm{H}), 7.08-6.94(\mathrm{~m}, 3 \mathrm{H}), 6.74-6.65(\mathrm{~m}, 2 \mathrm{H}), 6.58$ $-6.52(\mathrm{~m}, 1 \mathrm{H}), 6.38-6.36(\mathrm{~m}, 1 \mathrm{H}), 5.38-5.33(\mathrm{~m}, 1 \mathrm{H}), 5.30-5,22(\mathrm{~m}, 1 \mathrm{H}), 3.71-3.66(\mathrm{~m}$, 1H), 2.73 (s, 3H). 8b: $\delta 7.45-7.40(\mathrm{~m}, 1 \mathrm{H}), 7.26-7.18(\mathrm{~m}, 1 \mathrm{H}), 7.14-7.07$ (m, 1H), 7.08 $6.94(\mathrm{~m}, 3 \mathrm{H}), 6.74-6.65(\mathrm{~m}, 2 \mathrm{H}), 6.58-6.52(\mathrm{~m}, 1 \mathrm{H}), 6.48-6.36(\mathrm{~m}, 1 \mathrm{H}), 5.38-5.33(\mathrm{~m}$, 1H), $5.30-5,22(\mathrm{~m}, 1 \mathrm{H}), 3.71-3.66(\mathrm{~m}, 1 \mathrm{H}), 2.97(\mathrm{~s}, 3 \mathrm{H}) .{ }^{13} \mathrm{C} \mathrm{NMR}\left(101 \mathrm{MHz}, \mathrm{CDCl}_{3}\right) \mathbf{8 a}$ : 
$\delta 178.9,143.7,137.6,135.1,129.9,129.2,128.5,127.6,127.0,124.4,122.4,119.7,108.0,64.6$, 58.7, 25.6. 8a: $\delta 179.2,143.3,138.1,134.5,130.6,129.0,128.8,127.7,127.0,124.2,122.4$, 119.4, 107.8, 64.1, 59.4, 25.8. For $\mathrm{C}_{18} \mathrm{H}_{18} \mathrm{~N}_{2} \mathrm{Ona}\left([\mathrm{M}+\mathrm{Na}]^{+}\right)$: 301.1311 , found: 301.1312 . The product was analyzed by HPLC to determine the enantiomeric excess: 8a: $99 \%$ ee , 8b: $99 \%$ ee $($ Chiralpak IE, $i$-propanol/hexane $=30 / 70$, flow rate $1.0 \mathrm{~mL} / \mathrm{min}, \lambda=254 \mathrm{~nm}) ; 8$ a: $\mathrm{t}_{\mathrm{r}}=11.13$ and $11.60 \mathrm{~min}, \mathbf{8 b}: \mathrm{t}_{\mathrm{r}}=8.38$ and $9.15 \mathrm{~min}$.

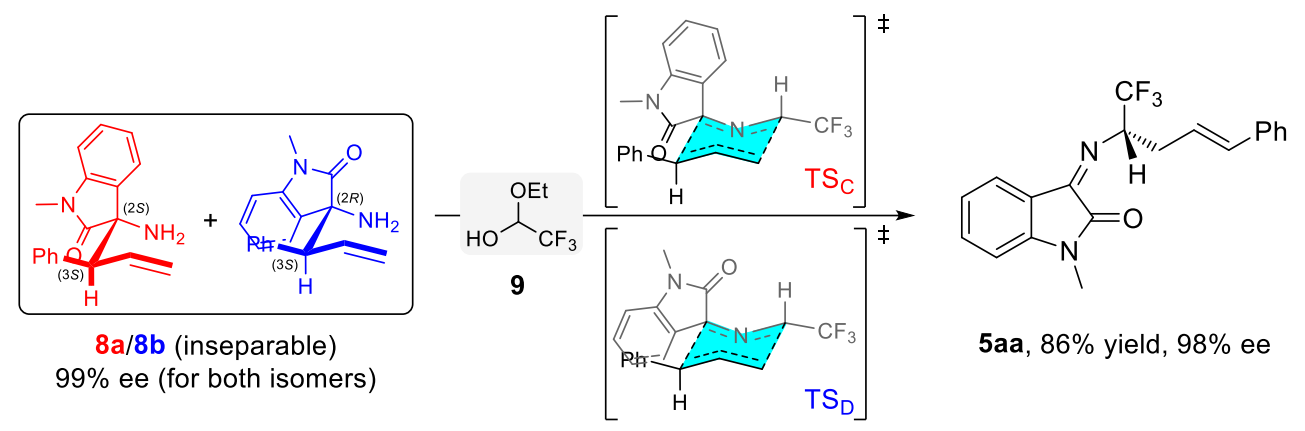

To a 5-mL vial equipped with stirrer bar were added $\mathbf{8 a} / \mathbf{8 b}$ (27.8 mg, $0.1 \mathrm{mmol})$, DCM (1 $\mathrm{mL}$ ) and $\mathbf{9}(23.2 \mathrm{mg}, 0.2 \mathrm{mmol})$. Once starting material was consumed (monitored by TLC), the reaction mixture was concentrated via rotary evaporation under reduced pressure. The mixture was concentrated, and the residue was directly purified by flash chromatography on silica gel $(\mathrm{PE} / \mathrm{EA}=20: 1)$ to give the products 5aa as a yellow oil (yield (30.8 mg, 86\%), 98\% ee).

\subsection{Synthesis of compound Int A}

In a $25 \mathrm{~mL}$ nitrogen-filled dry Schlenk tube, $[\operatorname{Ir}(\mathrm{COD}) \mathrm{Cl}]_{2}(3.3 \mathrm{mg}, 0.005 \mathrm{mmol})$, phosphoramidite ligand $(S, S, S)$-L2 $(5.6 \mathrm{mg}, 0.01 \mathrm{mmol})$, degassed THF $(0.5 \mathrm{~mL})$ and degassed propylamine $(0.5 \mathrm{~mL})$ were added. After stirring at $50{ }^{\circ} \mathrm{C}$ for $30 \mathrm{mins}$, the reaction was concentrated via rotary evaporation under reduced pressure to give the iridium complex as a pale yellow solid. Then under the nitrogen-refilled dry Schlenk tube, 6 (51.2 mg, $0.2 \mathrm{mmol}), \mathbf{3 a}$ (0.22 mmol), DBU (30 mg, $0.2 \mathrm{mmol})$ and degassed $\mathrm{C}_{6} \mathrm{D}_{5} \mathrm{CD}_{3}(2 \mathrm{~mL})$ was added. The reaction was monitored by ${ }^{19} \mathrm{~F}$ NMR analysis using $\mathrm{C}_{6} \mathrm{H}_{5} \mathrm{CF}_{3}$ as internal standard. After stirring at room temperature for $48 \mathrm{~h}$, the reaction mixture was concentrated via rotary evaporation under reduced pressure, and then purified by flash chromatography on silica gel $(\mathrm{PE} / \mathrm{EA}=20: 1)$ to 
give $42 \%$ yield of $7 \mathbf{a}$ (which was determined as $91 \%$ ee by HPLC analysis) and $49 \%$ yield of Int A.

Yellow oil; $[\alpha]^{25} \mathrm{D}=-112.9\left(c 0.15, \mathrm{CH}_{2} \mathrm{Cl}_{2}\right) .{ }^{1} \mathrm{H}$ NMR $\left(400 \mathrm{MHz}, \mathrm{CDCl}_{3}\right) \delta 7.33(\mathrm{t}, J=7.2 \mathrm{~Hz}$, 1H), $7.26-7.18(\mathrm{~m}, 1 \mathrm{H}), 7.15-7.10(\mathrm{~m}, 1 \mathrm{H}), 7.09-6.99(\mathrm{~m}, 3 \mathrm{H}), 6.70(\mathrm{~d}, J=7.2 \mathrm{~Hz}, 2 \mathrm{H})$, $6.65-6.53(\mathrm{~m}, 2 \mathrm{H}), 5.33(\mathrm{~d}, J=10.4 \mathrm{~Hz}, 1 \mathrm{H}), 5.16(\mathrm{~d}, J=17.2 \mathrm{~Hz}, 1 \mathrm{H}), 4.09$ (d, $J=6.8 \mathrm{~Hz}$, 1H), 2.74 (s, 3H), 1.46 (s, 3H). $\left.{ }^{13} \mathrm{C} \mathrm{NMR} \mathrm{(101} \mathrm{MHz,} \mathrm{CDCl}_{3}\right) \delta 174.7,158.9$ (q, $\left.J=34.3 \mathrm{~Hz}\right)$, 143.4, 136.8, 135.4, 129.6, 129.5, 127.9, 127.5, 127.3, 124.8, 122.9, 119.5 (q, $J=280.8 \mathrm{~Hz})$, 119.4, 108.1, 72.5, 58.2, 25.8, 15.7. ${ }^{19} \mathrm{~F}$ NMR (376 MHz, $\left.\mathrm{C}_{6} \mathrm{D}_{5} \mathrm{CD}_{3}\right) \delta$-74.28. HRMS Calcd. For $\mathrm{C}_{21} \mathrm{H}_{19} \mathrm{~F}_{3} \mathrm{~N}_{2} \mathrm{ONa}\left([\mathrm{M}+\mathrm{Na}]^{+}\right)$: 395.1342, found: 395.1342 .

5.5 Synthesis of compound 8a from acidic hydrolysis of Int A

To a 5-mL vial equipped with stirrer bar were added Int A (37.2 mg, $0.1 \mathrm{mmol})$, THF (1 $\mathrm{mL})$ and $6 \mathrm{~N} \mathrm{HCl}(0.5 \mathrm{~mL})$. After stirring for $5 \mathrm{mins}$, the reaction mixture was concentrated via rotary evaporation under reduced pressure, and $\mathrm{Et}_{3} \mathrm{~N}(1 \mathrm{~mL})$ was added and then concentrated, the residue was directly purified by flash chromatography on silica gel $(\mathrm{PE} / \mathrm{EA}=3: 1)$ to give the inseparable product $\mathbf{8 a}$ as a colorless oil; yield $(24.5 \mathrm{mg}, 88 \%)$.

\section{(S)-3-amino-1-methyl-3-((S)-1-phenylallyl)indolin-2-one}

Colorless oil; $[\alpha]^{25} \mathrm{D}=-191.8\left(c 0.11, \mathrm{CH}_{2} \mathrm{Cl}_{2}\right) .{ }^{1} \mathrm{H}$ NMR $\left(400 \mathrm{MHz}, \mathrm{CDCl}_{3}\right) \delta 7.45-7.40(\mathrm{~d}, J$ $=7.2, \mathrm{~Hz}, 1 \mathrm{H}), 7.31-7.26(\mathrm{~m}, 1 \mathrm{H}), 7.11(\mathrm{t}, J=7.6 \mathrm{~Hz}, 1 \mathrm{H}), 7.08-6.96(\mathrm{~m}, 3 \mathrm{H}), 6.74-6.65$ $(\mathrm{m}, 2 \mathrm{H}), 6.55(\mathrm{~d}, J=7.6 \mathrm{~Hz}, 1 \mathrm{H}), 6.48-6.36(\mathrm{~m}, 1 \mathrm{H}), 5.38-5.33(\mathrm{~m}, 1 \mathrm{H}), 5.30-5,22(\mathrm{~m}$, 1H), $3.68(\mathrm{~d}, J=8.8 \mathrm{~Hz}, 1 \mathrm{H}), 2.73(\mathrm{~s}, 3 \mathrm{H}), 1.89$ (s, 2H). ${ }^{13} \mathrm{C} \mathrm{NMR}\left(101 \mathrm{MHz}, \mathrm{CDCl}_{3}\right) \delta 178.9$, 143.7, 137.6, 135.1, 129.9, 129.2, 128.5, 127.6, 127.0, 124.4, 122.4, 119.7, 108.0, 64.6, 58.7, 25.6. For $\mathrm{C}_{18} \mathrm{H}_{18} \mathrm{~N}_{2} \mathrm{Ona}\left([\mathrm{M}+\mathrm{Na}]^{+}\right)$: 301.1311 , found: 301.1312 . The product was analyzed by HPLC to determine the enantiomeric excess: $98 \%$ ee (Chiralpak IE, $i$-propanol/hexane $=30 / 70$, flow rate $1.0 \mathrm{~mL} / \mathrm{min}, \lambda=254 \mathrm{~nm}) ; \mathrm{t}_{\mathrm{r}}=11.21$ and $11.57 \mathrm{~min}$. 
5.6 Synthesis of compound 5aa from 8a

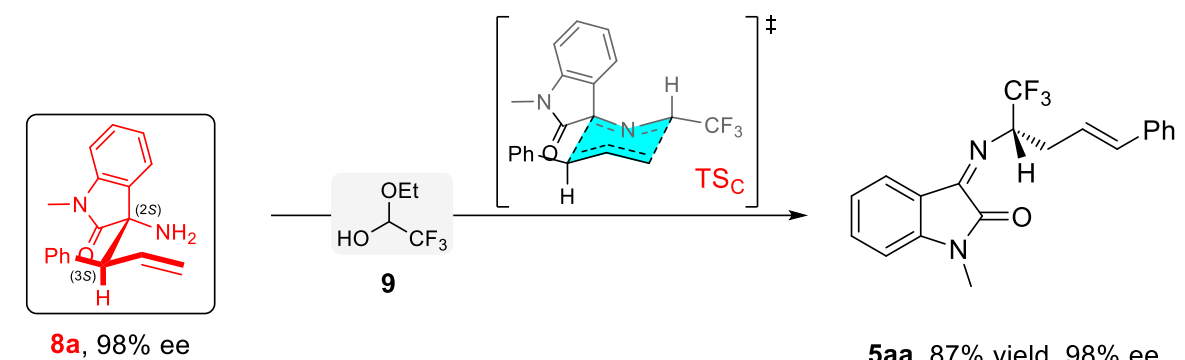

To a 5-mL vial equipped with stirrer bar were added $\mathbf{8 a}(27.8 \mathrm{mg}, 0.1 \mathrm{mmol}), \mathrm{DCM}(1 \mathrm{~mL})$ and $9(23.2 \mathrm{mg}, 0.2 \mathrm{mmol})$. Once starting material was consumed (monitored by TLC), the reaction mixture was concentrated via rotary evaporation under reduced pressure. The mixture was concentrated, and the residue was directly purified by flash chromatography on silica gel $(\mathrm{PE} / \mathrm{EA}=20: 1)$ to give the products 5aa as a yellow oil (yield $(30.8 \mathrm{mg}, 87 \%), 98 \%$ ee).

\subsection{Synthesis of compound tosylated $\mathbf{8 a}$}

To a 5-mL vial equipped with stirrer bar were added compound $8 \mathbf{8}(27.8 \mathrm{mg}, 0.1 \mathrm{mmol})$, p-toluenesulfonyl chloride (28.6 mg, $0.15 \mathrm{mmol})$, pyridine (15.8 $\mathrm{mg}, 0.2 \mathrm{mmol})$ and dry DCM $(1 \mathrm{~mL})$. The mixture was stirred at room temperature, and monitored by TLC until 8a was consumed. The mixture was concentrated, and purified by flash chromatography on silica gel $(\mathrm{PE} / \mathrm{EA}=3: 1)$ to give the products tosylated 8a as a white solid; yield $(35.5 \mathrm{mg}, 82 \%)$.

\section{4-methyl-N-((S)-1-methyl-2-oxo-3-((S)-1-phenylallyl)indolin-3-yl)benzenesulfonamide:}

White solid; m.p. $175-177{ }^{\circ} \mathrm{C} ;[\alpha]^{25} \mathrm{D}=-175.83\left(c\right.$ 0.12, $\left.\mathrm{CH}_{2} \mathrm{Cl}_{2}\right) .{ }^{1} \mathrm{H}$ NMR $\left(400 \mathrm{MHz}, \mathrm{CDCl}_{3}\right)$ $\delta 7.33(\mathrm{~d}, J=8.0 \mathrm{~Hz}, 2 \mathrm{H}), 7.25-7.20(\mathrm{~m}, 1 \mathrm{H}), 7.13-7.03(\mathrm{~m}, 4 \mathrm{H}), 6.98(\mathrm{t}, J=7.6 \mathrm{~Hz}, 2 \mathrm{H})$, $6.92-6.85(\mathrm{~m}, 2 \mathrm{H}), 6.62(\mathrm{~d}, J=7.2 \mathrm{~Hz}, 2 \mathrm{H}), 6.43(\mathrm{~d}, J=7.6 \mathrm{~Hz}, 1 \mathrm{H}), 6.38-6.26(\mathrm{~m}, 1 \mathrm{H})$, $5.40-5.33(\mathrm{~m}, 2 \mathrm{H}), 5.29(\mathrm{~d}, J=16.8 \mathrm{~Hz}, 1 \mathrm{H}), 3.74(\mathrm{~d}, J=9.6 \mathrm{~Hz}, 1 \mathrm{H}), 2.57$ (s, 3H), 2.37 (s, 3H). ${ }^{13} \mathrm{C} \mathrm{NMR}\left(101 \mathrm{MHz}, \mathrm{CDCl}_{3}\right) \delta 174.7,144.2,143.4,137.7,135.1,133.7,129.8,129.1$, $128.9,127.6,127.6,127.6,126.1,124.0,121.9,120.9,108.0,66.1,57.5,25.8,21.6$. For $\mathrm{C}_{25} \mathrm{H}_{24} \mathrm{~N}_{2} \mathrm{O}_{3} \mathrm{SNa}\left([\mathrm{M}+\mathrm{Na}]^{+}\right): 455.1400$, found: 455.1409 . 


\section{Rationale for the experimental results of the reaction of isatin ketamine 1a and methyl}

crotyl carbonate $3 \mathrm{~s}$.

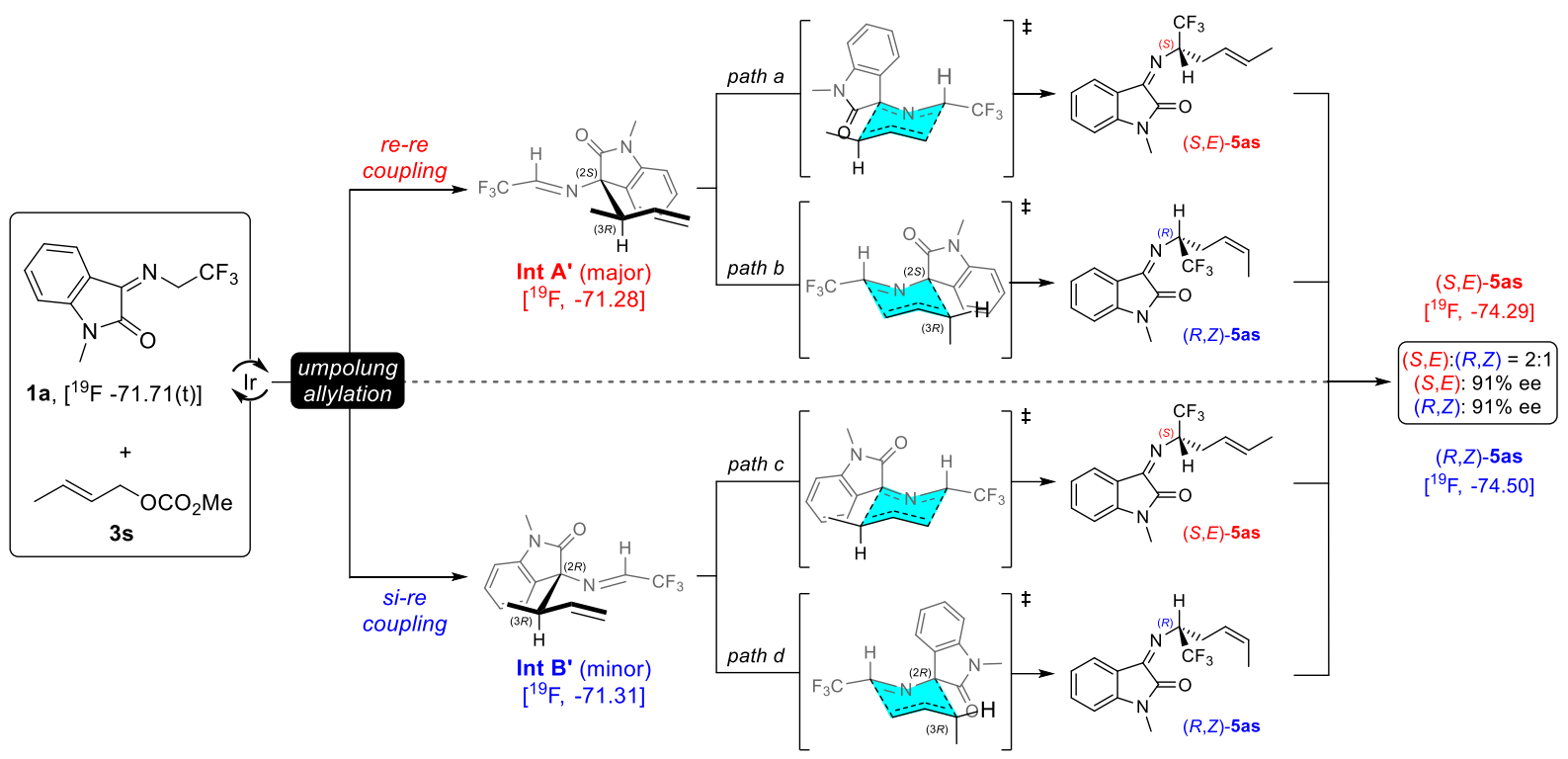

Scheme S2: Mechanism studies: proposed mechanism and the intermediates in the reaction of isatin ketamine 1a and methyl crotyl carbonate $3 \mathbf{s}$.

The Ir-catalyzed cascade allylation/2-aza-Cope rearrangement of isatin ketamine $1 \mathbf{1 a}\left[{ }^{19} \mathrm{~F}\right.$ : $\delta$-71.71(t)] and methyl crotyl carbonate $3 \mathrm{~s}$ in $\mathrm{C}_{6} \mathrm{D}_{5} \mathrm{CD}_{3}$ was continuously monitored by ${ }^{19} \mathrm{~F}$ NMR analysis (with $\mathrm{CF}_{3} \mathrm{C}_{6} \mathrm{H}_{5}$ as internal standard). The initial allylation step is more fast than the subsequent rearrangement step, and almost 3 days were need to reach the full conversion, affording $(S, E)$-5as $[\delta-74.29(\mathrm{~d})]$ and $(R, Z)-5$ as $[\delta-74.50(\mathrm{~s})]$ in $94 \%$ yield as inseparable isomers in 2:1 ratio (Table 2, entry 18; Scheme S2).

Monitoring the reaction mixture by ${ }^{19} \mathrm{~F}$ NMR revealed that two intermediates were initially formed as Int $\mathbf{A}^{\prime}$ [ $\delta$-71.28(d), major isomer] and Int $\mathbf{B}^{\prime}$ [ $\delta$-71.31(d), minor isomer] (Figure S2 and Scheme S3a), which are in line with the intermediates produced by the random approach of $R e$-face and $S i$-face of the nucleophilic aza-allyl anion to the Re-face of in situ formed chiral electrophilic $\pi$-allyl-Ir/ $(S, S, S)$-L2 species. As the starting material 1a was consumed, the intensity of the signal of Int A' and Int B' gradually increases. The signal of the major product $(S, E)$-5as was observed almost immediately $\sim 10 \mathrm{~min}$, while the signal of the minor product $(R, Z)$-5as appeared $\sim 5.5 \mathrm{~h}$. The signals of starting material 1a and minor Int B' almost vanished at the same time $(\sim 21 \mathrm{~h})$. Therefore, it could be concluded that the rearrangement rate of the minor Int $\mathbf{B}^{\prime}$ is faster than that of the major Int $\mathbf{A}^{\prime}$ (Figure S2). Meanwhile, the rearrangement of the minor Int B' prefer delivering the major product $(S, E)-5$ as through $\mathrm{TS}_{\mathrm{c}}$ (pathway c). The 
other rearrangement pathway $\mathrm{d}$, which gernerates the minor product $(R, Z)-\mathbf{5 a s}$ through $\mathrm{TS}_{\mathrm{d}}$, is energy disfavored. In $\mathrm{TS}_{\mathrm{c}}$, the bulky substituent $(\mathrm{Ph})$ in oxindole ring and methyl group reside at the energy-favored equatorial position. In $\mathrm{TS}_{\mathrm{d}}$, both the bulky substituent $(\mathrm{Ph})$ in the oxindole ring and methyl group reside at the energy-disfavored axial position.

When both starting material 1a and minor Int $\mathbf{B}^{\prime}$ vanished $(\sim 21 \mathrm{~h})$, the ratio of major product to minor product is about 5:1, and then the ratio decreases gradually at the expense of the major Int $\mathbf{A}^{\prime}$. The reduced ratio of the products reflects that, for the major $\operatorname{Int} \mathbf{A}^{\prime}$, there is no obvious energy difference between the two rearrangement pathway a (leading to $(S, E)$-5as) and pathway $\mathrm{b}$ (leading to $(R, Z)-5$ as). This conclusion is consistent with the conformational analysis: In $\mathrm{TS}_{\mathrm{a}}$, the bulky substituent $(\mathrm{Ph})$ in the oxindole ring reside at the energy-disfavored axial position while methyl group reside at the energy-favored equatorial position; In $\mathrm{TS}_{\mathrm{b}}$, the bulky substituent $(\mathrm{Ph})$ in the oxindole ring reside at the energy-favored equatorial position while methyl group reside at the energy-disfavored axial position. Compared with the significant conformation difference between $\mathrm{TS}_{\mathrm{c}}$ and $\mathrm{TS}_{\mathrm{d}}$, the reduced energy difference between $\mathrm{TS}_{\mathrm{a}}$ and $\mathrm{TS}_{\mathrm{b}}$ rationalizes the trend of gradually decreased ratio of the products.

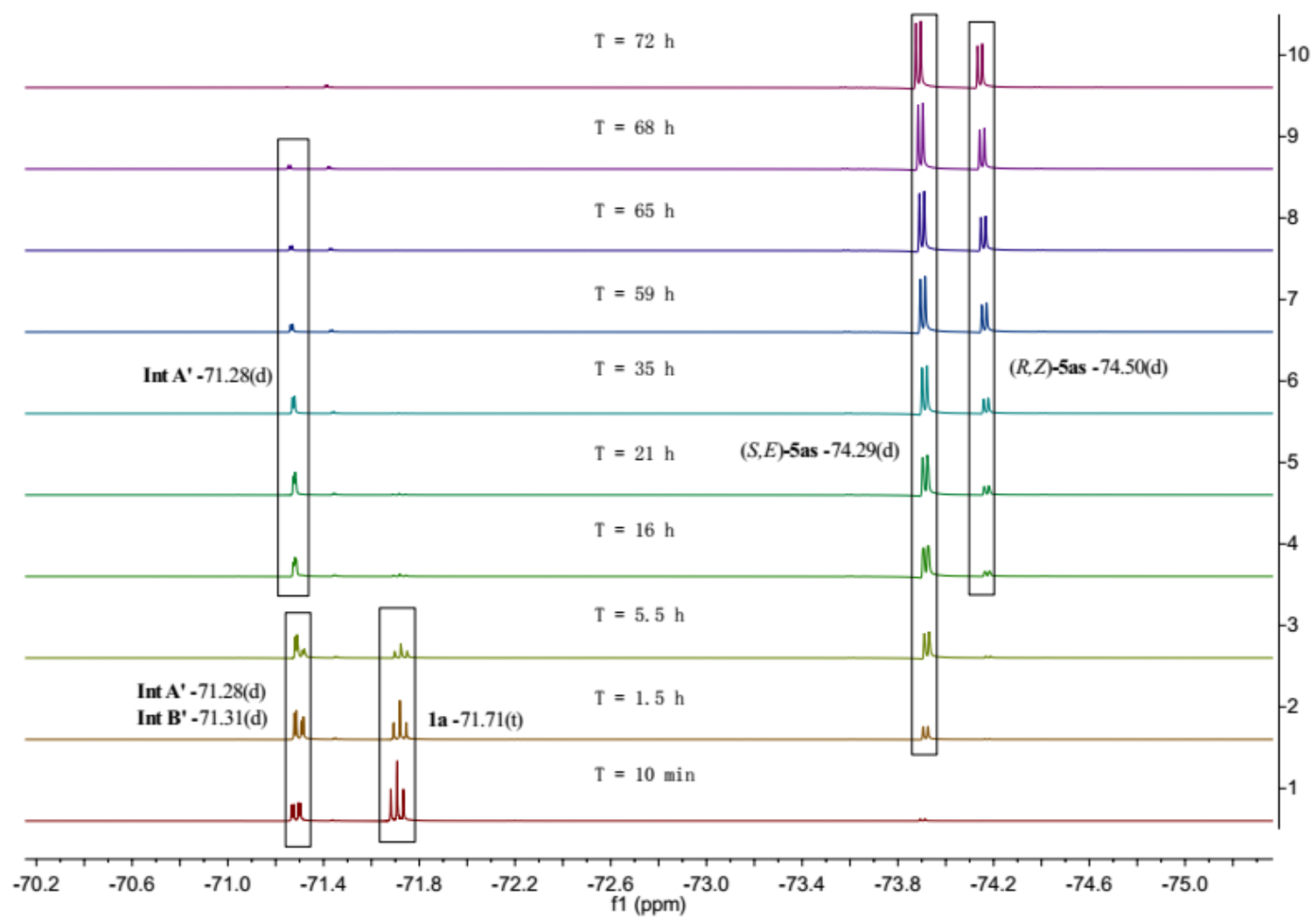

Figure S2. ${ }^{19}$ F NMR studies of the possible intermediates in the reaction of $1 \mathbf{a}$ and $\mathbf{3 s}$. 


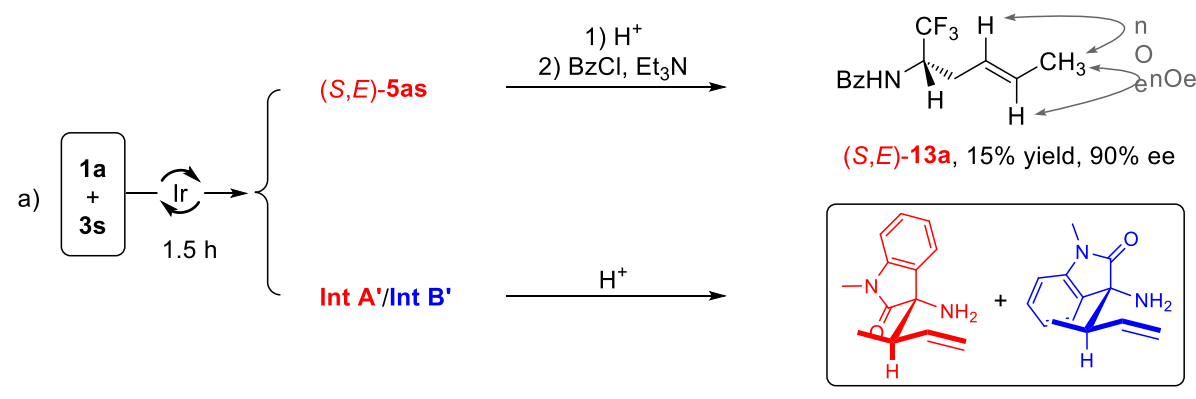

$12 a / 12 b$ (inseparable, 1.1:1) $32 \%$ yield, $91 \%$ ee (for both isomers)

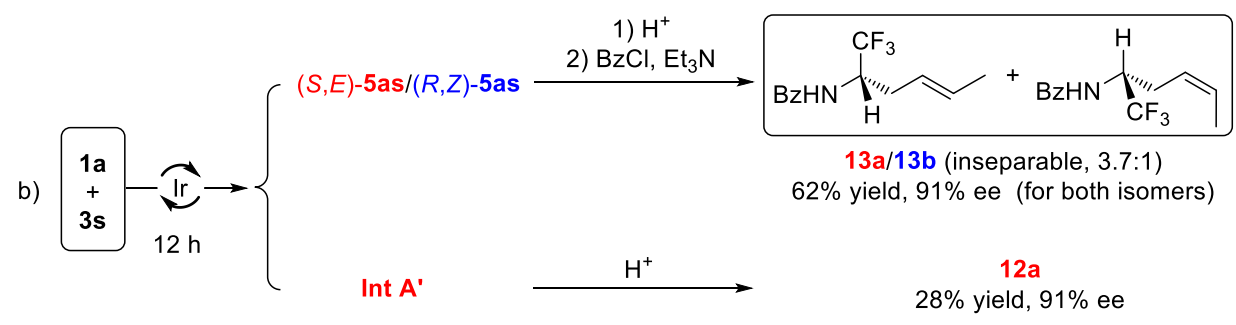

Scheme S3. Reaction mechanism investigation with control experiments.

\subsection{Synthesis of compound $\mathbf{1 2 a} / \mathbf{1 2 b}$ and $\mathbf{1 3 a}$}

In a $25 \mathrm{~mL}$ nitrogen-filled dry Schlenk tube, $[\operatorname{Ir}(\mathrm{COD}) \mathrm{Cl}]_{2}(66 \mathrm{mg}, 0.01 \mathrm{mmol})$, phosphoramidite ligand $(S, S, S)$-L2 (11.2 mg, $0.02 \mathrm{mmol})$, degassed THF (1 mL) and degassed propylamine $(1 \mathrm{~mL})$ were added. After stirring at $50{ }^{\circ} \mathrm{C}$ for $30 \mathrm{mins}$, the reaction was concentrated via rotary evaporation under reduced pressure to give the iridium complex as a pale yellow solid. Then under the nitrogen-refilled dry Schlenk tube, 1a (96.8 mg, $0.4 \mathrm{mmol}$ ), 3s (57.2 $\mathrm{mg}, 0.44 \mathrm{mmol})$ and degassed DCM $(4 \mathrm{~mL})$ was added. After stirring at room temperature for $1.5 \mathrm{~h}$, the reaction mixture was evenly divided into two parts.

For one part, the residue were added THF $(1 \mathrm{~mL})$ and $6 \mathrm{~N} \mathrm{HCl}(0.5 \mathrm{~mL})$. After stirring for 5 mins, the reaction mixture was concentrated via rotary evaporation under reduced pressure, and then $\mathrm{NEt}_{3}(1 \mathrm{~mL})$ was added. After concentrated, the residue was directly purified by flash chromatography on silica gel $(\mathrm{PE} / \mathrm{EA}=3: 1)$ to give the inseparable products $\mathbf{1 2 \mathbf { a }}$ and $\mathbf{1 2 b}$ as a colorless oil (1.1:1 ratio, yield $(13.8 \mathrm{mg}, 32 \%))$.

Yellow oil; $[\alpha]^{25}{ }_{\mathrm{D}}=-134.7\left(c 0.18, \mathrm{CH}_{2} \mathrm{Cl}_{2}\right) .{ }^{1} \mathrm{H} \mathrm{NMR}\left(400 \mathrm{MHz}, \mathrm{CDCl}_{3}\right) \mathbf{1 2 a} \delta 7.38-7.26(\mathrm{~m}$, 2H), $7.11-7.02(\mathrm{~m}, 1 \mathrm{H}), 6.85-6.78(\mathrm{~m}, 1 \mathrm{H}), 6.02-5.91(\mathrm{~m}, 1 \mathrm{H}), 5.27-5.09(\mathrm{~m}, 2 \mathrm{H}), 3.20$ (s, 3H), $2.71-2.61(\mathrm{~m}, 1 \mathrm{H}), 0.74(\mathrm{~d}, J=6.8 \mathrm{~Hz}, 3 \mathrm{H}) . \mathbf{1 2 b} \delta 7.38-7.26(\mathrm{~m}, 2 \mathrm{H}), 7.11-7.02$ $(\mathrm{m}, 1 \mathrm{H}), 6.85-6.78(\mathrm{~m}, 1 \mathrm{H}), 5.74-5.62(\mathrm{~m}, 1 \mathrm{H}), 5.27-5.09(\mathrm{~m}, 1 \mathrm{H}), 5.07-5.01(\mathrm{~m}, 1 \mathrm{H})$, $3.16(\mathrm{~s}, 3 \mathrm{H}), 2.71-2.61(\mathrm{~m}, 1 \mathrm{H}), 0.93(\mathrm{~d}, J=6.8 \mathrm{~Hz}, 3 \mathrm{H}) .{ }^{13} \mathrm{C} \mathrm{NMR}\left(101 \mathrm{MHz}, \mathrm{CDCl}_{3}\right) \mathbf{1 2 a} \delta$ 
$179.88,143.75,137.67,130.30,128.97,124.52,122.66,117.69,108.11,63.51,45.67,26.20$, 14.06. 12b $\delta 180.04,143.72,137.77,130.91,129.04,123.95,122.80,117.51,107.99,63.50$, 47.00, 26.06, 14.58. For $\mathrm{C}_{13} \mathrm{H}_{16} \mathrm{~N}_{2} \mathrm{ONa}^{+}: 239.1155$, found: 239.1156 . The product was analyzed by HPLC to determine the enantiomeric excess: both $91 \%$ ee (Chiralpak IE, $i$-propanol/hexane $=30 / 70$, flow rate $1.0 \mathrm{~mL} / \mathrm{min}, \lambda=254 \mathrm{~nm}) ; \mathbf{1 2 b}: \mathrm{t}_{\mathrm{r}}=5.07$ and $6.12 \mathrm{~min}, \mathbf{1 2} \mathbf{a}: \mathrm{t}_{\mathrm{r}}=12.02$ and $13.04 \mathrm{~min}$.

For another part, the residue was added THF $(1 \mathrm{~mL})$ and $6 \mathrm{~N} \mathrm{HCl}(0.5 \mathrm{~mL})$. After stirring for $5 \mathrm{mins}$, the reaction mixture was concentrated via rotary evaporation under reduced pressure, and then to the residue was added DCM $(5 \mathrm{~mL})$, benzoyl chloride $(28.1 \mathrm{mg}, 0.2 \mathrm{mmol})$ and $\mathrm{NEt}_{3}(1 \mathrm{~mL})$. After stirring for $3 \mathrm{~h}$, the reaction mixture was concentrated, and then directly purified by flash chromatography on silica gel $(\mathrm{PE} / \mathrm{EA}=20: 1)$ to give the products $(S, E)-\mathbf{1 3 a}$ as a white solid; yield (7.7 $\mathrm{mg}, 15 \%)$.

White solid; m.p. $88-90{ }^{\circ} \mathrm{C} ;[\alpha]^{25} \mathrm{D}=-87.5\left(c 0.11, \mathrm{CH}_{2} \mathrm{Cl}_{2}\right) .{ }^{1} \mathrm{H} \mathrm{NMR}\left(400 \mathrm{MHz}, \mathrm{CDCl}_{3}\right) \delta 7.82$ $-7.73(\mathrm{~m}, 2 \mathrm{H}), 7.58-7.51(\mathrm{~m}, 1 \mathrm{H}), 7.50-7.42(\mathrm{~m}, 2 \mathrm{H}), 6.11(\mathrm{~d}, J=9.2 \mathrm{~Hz}, 1 \mathrm{H}), 5.70-5.54$ (m, 1H), $5.47-5.30(\mathrm{~m}, 1 \mathrm{H}), 4.96-4.73(\mathrm{~m}, 1 \mathrm{H}), 2.65-2.51(\mathrm{~m}, 1 \mathrm{H}), 2.44-2.31(\mathrm{~m}, 1 \mathrm{H})$, $1.66(\mathrm{~d}, J=6.4 \mathrm{~Hz}, 3 \mathrm{H}) .{ }^{13} \mathrm{C} \mathrm{NMR}\left(101 \mathrm{MHz}, \mathrm{CDCl}_{3}\right) \delta 167.3,133.7,132.2,130.8,128.9$, 127.1, 125.3 (q, $J=282.8 \mathrm{~Hz}), 123.8,50.2$ (q, $J=30.3 \mathrm{~Hz}), 32.0,18.1 .{ }^{19} \mathrm{~F}$ NMR $(376 \mathrm{MHz}$, $\left.\mathrm{CDCl}_{3}\right) \delta-75.06(\mathrm{~d}, J=7.6 \mathrm{~Hz})$. For $\mathrm{C}_{13} \mathrm{H}_{14} \mathrm{~F}_{3} \mathrm{NONa}^{+}$: 280.0925, found: 280.0925 . The product was analyzed by HPLC to determine the enantiomeric excess: 90\% ee (Chiralcel OD-H + Chiralcel OJ-H, $i$-propanol $/$ hexane $=5 / 95$, flow rate $1.0 \mathrm{~mL} / \mathrm{min}, \lambda=220 \mathrm{~nm}$ ); $\mathrm{t}_{\mathrm{r}}=15.04$ and $17.98 \mathrm{~min}$. 
NOESY spectrum

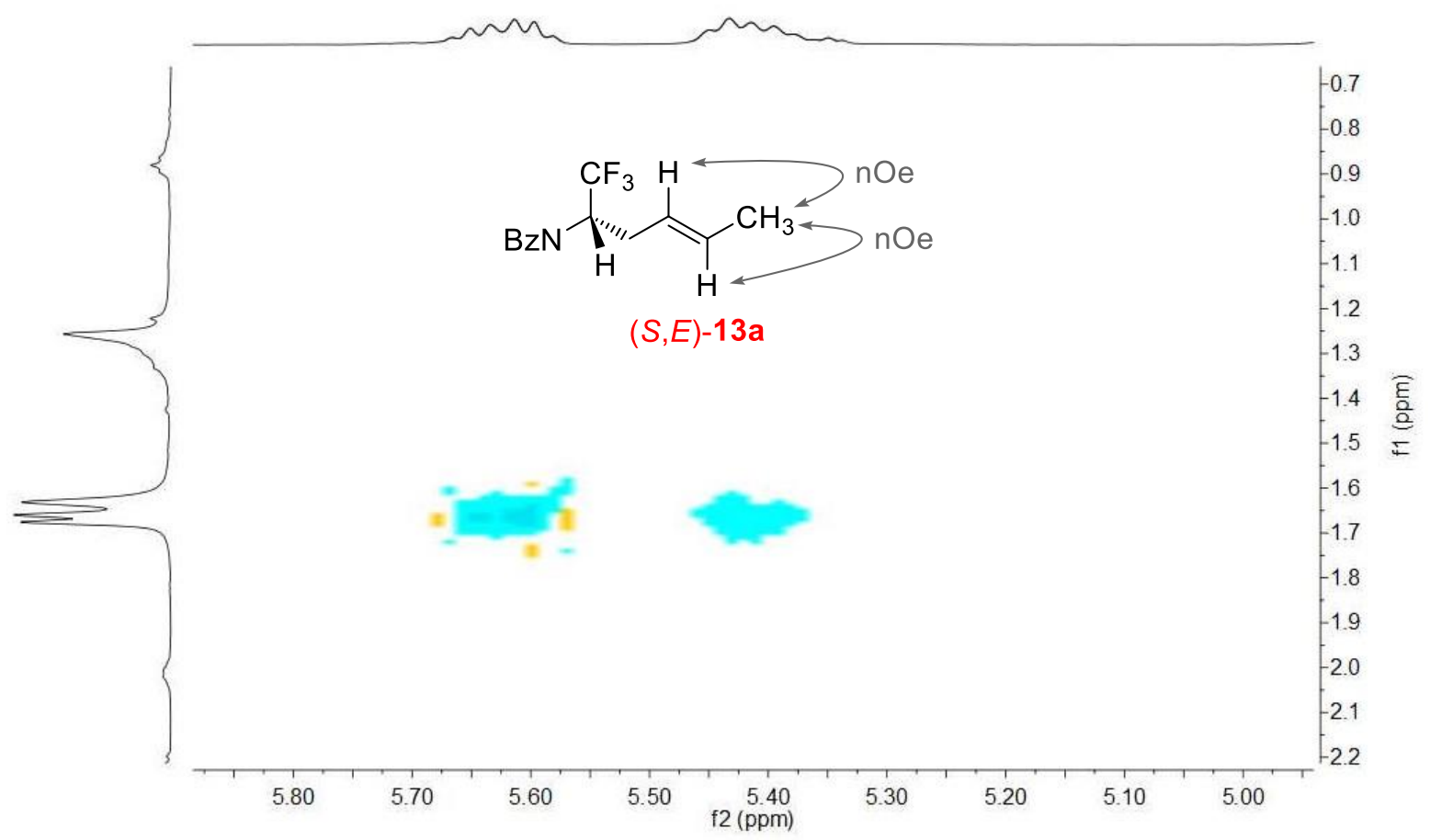

COSY spectrum

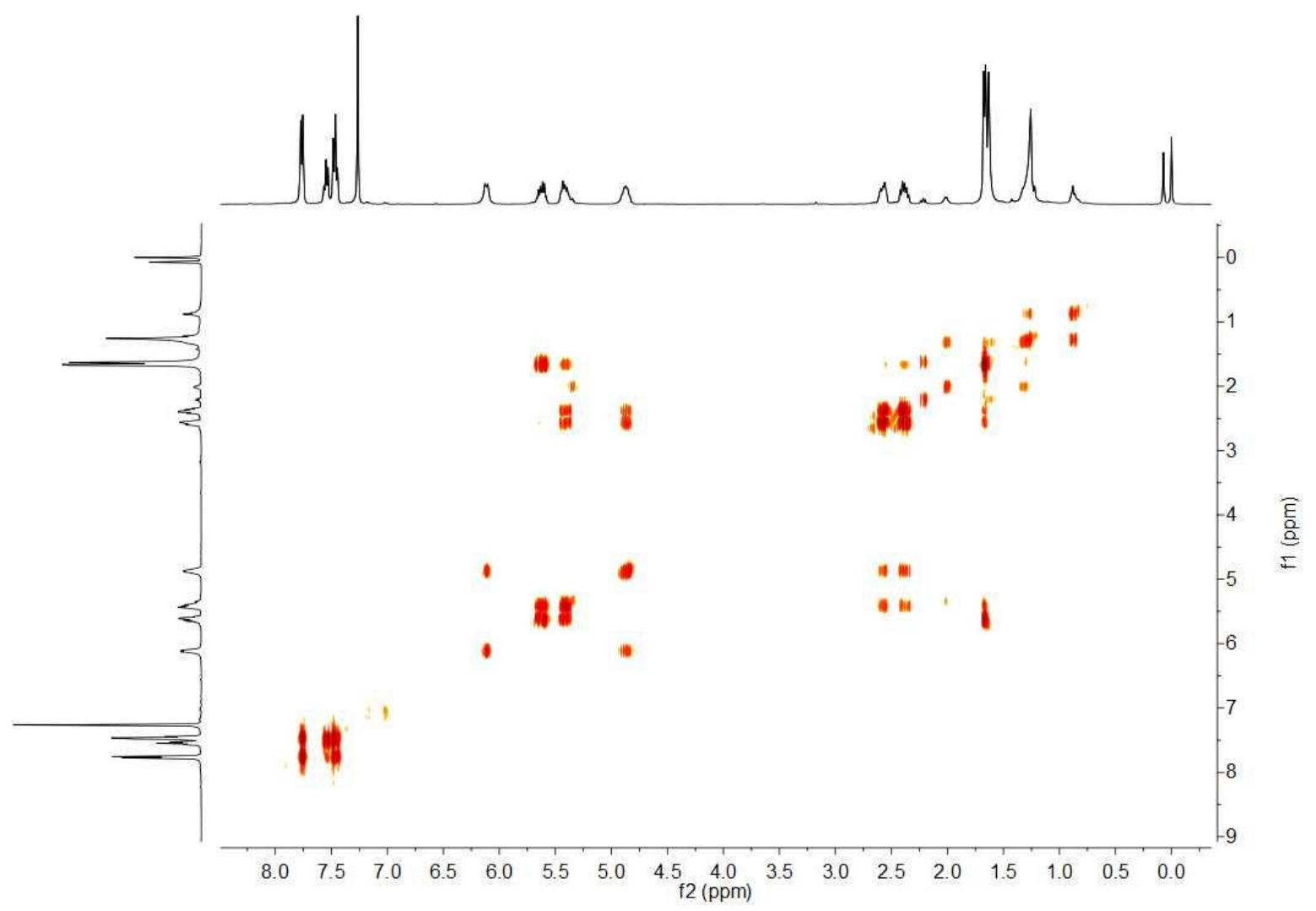




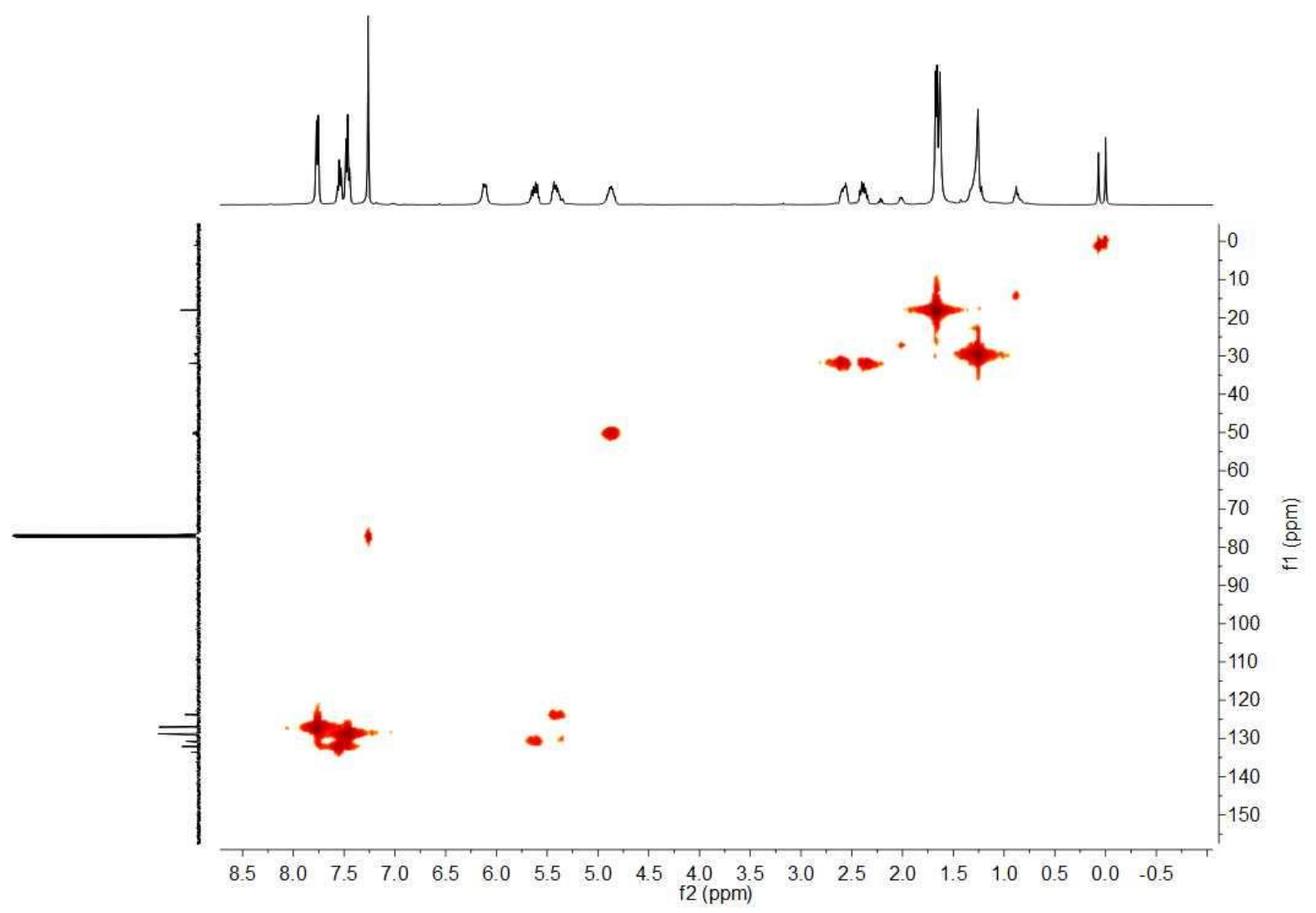

\subsection{Synthesis of compound $\mathbf{1 2 a}$ and $\mathbf{1 3 a} / \mathbf{1 3 b}$}

In a $25 \mathrm{~mL}$ nitrogen-filled dry Schlenk tube, $[\operatorname{Ir}(\mathrm{COD}) \mathrm{Cl}]_{2}(6.6 \mathrm{mg}, 0.01 \mathrm{mmol})$, phosphoramidite ligand $(S, S, S)$-L2 (11.2 $\mathrm{mg}, 0.02 \mathrm{mmol})$, degassed THF $(1 \mathrm{~mL})$ and degassed propylamine $(1 \mathrm{~mL})$ were added. After stirring at $50{ }^{\circ} \mathrm{C}$ for $30 \mathrm{mins}$, the reaction was concentrated via rotary evaporation under reduced pressure to give the iridium complex as a pale yellow solid. Then under the nitrogen-refilled dry Schlenk tube, 1a (96.8 mg, $0.4 \mathrm{mmol}$ ), 3s (57.2 $\mathrm{mg}, 0.44 \mathrm{mmol})$ and degassed DCM (4 mL) was added. After stirring at room temperature for $12 \mathrm{~h}$, the reaction mixture was evenly divided into two parts.

For one part, the reaction mixture was concentrated via rotary evaporation under reduced pressure, and then to the residue were added THF $(1 \mathrm{~mL})$ and $6 \mathrm{~N} \mathrm{HCl}(0.5 \mathrm{~mL})$. After stirring for $5 \mathrm{mins}$, the reaction mixture was concentrated via rotary evaporation under reduced pressure, and then $\mathrm{NEt}_{3}(1 \mathrm{~mL})$ was added. After concentrated, the residue was directly purified by flash chromatography on silica gel $(\mathrm{PE} / \mathrm{EA}=3: 1)$ to give the products 12a as a colorless oil (yield (12.1 mg, 28\%), 91\% ee). 
Yellow oil; $[\alpha]^{25} \mathrm{D}=-134.7\left(c \mathrm{c} 0.18, \mathrm{CH}_{2} \mathrm{Cl}_{2}\right) .{ }^{1} \mathrm{H}$ NMR $\left(400 \mathrm{MHz}, \mathrm{CDCl}_{3}\right) \delta 7.34-7.26(\mathrm{~m}$, 2H), $7.06(\mathrm{t}, J=7.6 \mathrm{~Hz}, 1 \mathrm{H}), 6.84(\mathrm{~d}, J=7.6 \mathrm{~Hz}, 1 \mathrm{H}), 6.02-5.91(\mathrm{~m}, 1 \mathrm{H}), 5.27-5.09(\mathrm{~m}, 2 \mathrm{H})$, $3.20(\mathrm{~s}, 3 \mathrm{H}), 2.71-2.61(\mathrm{~m}, 1 \mathrm{H}), 0.74(\mathrm{~d}, J=6.8 \mathrm{~Hz}, 1 \mathrm{H}) .{ }^{13} \mathrm{C} \mathrm{NMR}\left(101 \mathrm{MHz}, \mathrm{CDCl}_{3}\right) \delta$ $179.9,143.7,137.7,130.3,129.0,124.5,122.7,117.7,108.1,63.5,45.7,26.2,14.1$. For $\mathrm{C}_{13} \mathrm{H}_{16} \mathrm{~N}_{2} \mathrm{ONa}^{+}: 239.1155$, found: 239.1156 .

For another part, the residue was added THF $(1 \mathrm{~mL})$ and $6 \mathrm{~N} \mathrm{HCl}(0.5 \mathrm{~mL})$. After stirring for 5 mins, the reaction mixture was concentrated via rotary evaporation under reduced pressure, and then to the residue was added DCM ( $5 \mathrm{~mL})$, benzoyl chloride $(28.1 \mathrm{mg}, 0.2 \mathrm{mmol})$ and $\mathrm{NEt}_{3}(1 \mathrm{~mL})$. After stirring for $3 \mathrm{~h}$, the reaction mixture was concentrated, and then directly purified by flash chromatography on silica gel $(\mathrm{PE} / \mathrm{EA}=20: 1)$ to give the inseparable products 13a/13b as a white solid (3.7:1 ratio, yield (31.8 $\mathrm{mg}, 62 \%))$.

White solid; m.p. $100-102{ }^{\circ} \mathrm{C} ;[\alpha]^{25} \mathrm{D}=-1.0\left(c 0.10, \mathrm{CH}_{2} \mathrm{Cl}_{2}\right) .{ }^{1} \mathrm{H} \mathrm{NMR}\left(400 \mathrm{MHz}, \mathrm{CDCl}_{3}\right) \mathbf{1 3 a}$ $\delta 7.82-7.73(\mathrm{~m}, 2 \mathrm{H}), 7.58-7.51(\mathrm{~m}, 1 \mathrm{H}), 7.50-7.42(\mathrm{~m}, 2 \mathrm{H}), 6.20-6.05(\mathrm{~m}, 1 \mathrm{H}), 5.66-$ $5.56(\mathrm{~m}, 1 \mathrm{H}), 5.47-5.30(\mathrm{~m}, 1 \mathrm{H}), 4.96-4.73(\mathrm{~m}, 1 \mathrm{H}), 2.62-2.52(\mathrm{~m}, 1 \mathrm{H}), 2.43-2.32(\mathrm{~m}$, 1H), $1.69-1.62(\mathrm{~d}, J=6.4 \mathrm{~Hz}, 3 \mathrm{H}) . \mathbf{1 3 b} \delta 7.82-7.73(\mathrm{~m}, 2 \mathrm{H}), 7.58-7.51(\mathrm{~m}, 1 \mathrm{H}), 7.50-$ $7.42(\mathrm{~m}, 2 \mathrm{H}), 6.20-6.05(\mathrm{~m}, 1 \mathrm{H}), 5.75-5.67(\mathrm{~m}, 1 \mathrm{H}), 5.47-5.30(\mathrm{~m}, 1 \mathrm{H}), 4.96-4.73(\mathrm{~m}$, 1H), $2.72-2.62(\mathrm{~m}, 1 \mathrm{H}), 2.51-2.43(\mathrm{~m}, 1 \mathrm{H}), 1.69-1.62(\mathrm{~d}, J=6.4 \mathrm{~Hz}, 3 \mathrm{H}) .{ }^{19} \mathrm{~F}$ NMR $(376$ $\left.\mathrm{MHz}, \mathrm{CDCl}_{3}\right) \delta-75.07(\mathrm{~d}, J=7.7 \mathrm{~Hz}),-75.17(\mathrm{~d}, J=7.7 \mathrm{~Hz})$.For $\mathrm{C}_{13} \mathrm{H}_{14} \mathrm{~F}_{3} \mathrm{NONa}^{+}: 280.0925$, found: 280.0925. The product was analyzed by HPLC to determine the enantiomeric excess: both $91 \%$ ee $($ Chiralcel OD-H + Chiralcel OJ-H, $i$-propanol/hexane $=5 / 95$, flow rate 1.0 $\mathrm{mL} / \mathrm{min}, \lambda=220 \mathrm{~nm})$; 13a: $\mathrm{t}_{\mathrm{r}}=14.85$ and $17.78 \mathrm{~min}, \mathbf{1 3 b}: \mathrm{t}_{\mathrm{r}}=16.40$ and $20.98 \mathrm{~min}$.

\section{Gram Scale and Synthetic Applications}
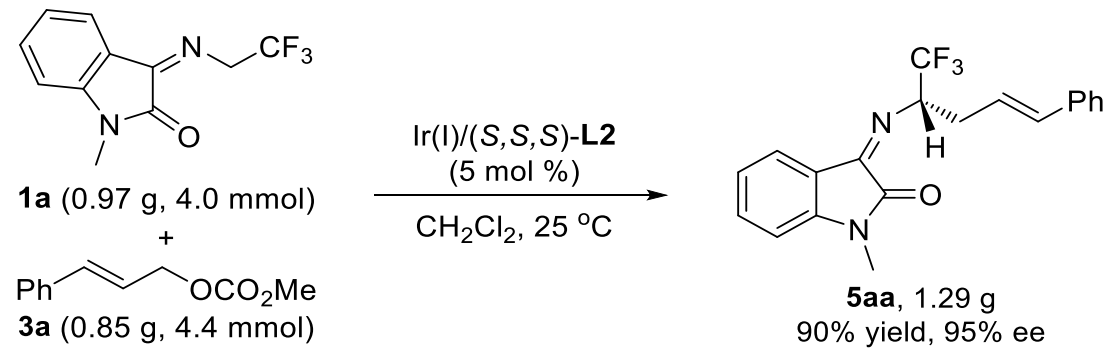
In a $25 \mathrm{~mL}$ nitrogen-filled dry Schlenk tube, $[\operatorname{Ir}(\mathrm{COD}) \mathrm{Cl}]_{2}(66 \mathrm{mg}, 0.1 \mathrm{mmol})$, phosphoramidite ligand $(S, S, S)-\mathbf{L} 2(112 \mathrm{mg}, 0.2 \mathrm{mmol})$, degassed THF (5 mL) and degassed propylamine $(5 \mathrm{~mL})$ were added. After stirring at $50{ }^{\circ} \mathrm{C}$ for $30 \mathrm{mins}$, the reaction was concentrated via rotary evaporation under reduced pressure to give the iridium complex as a pale yellow solid. Then under the nitrogen-refilled dry Schlenk tube, 1a (968 mg, 4 mmol), allylic carbonates 3a (845 mg, $4.4 \mathrm{mmol})$ and dry $\mathrm{CH}_{2} \mathrm{Cl}_{2}(20 \mathrm{~mL})$ was added. After stirring at room temperature for 24 hours, the reaction mixture was concentrated via rotary evaporation under reduced pressure, and purified by flash chromatography on silica gel $(\mathrm{PE} / \mathrm{EA}=20: 1)$ to give the product $\mathbf{5} \mathbf{a a}$ in $90 \%$ yield with $95 \%$ ee.
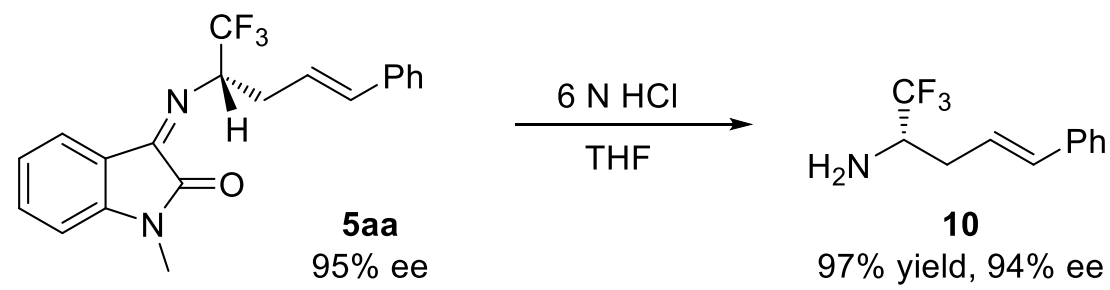

To a 25-mL vial equipped with stirrer bar were added 5aa (716 mg, $2 \mathrm{mmol})$, THF (10 mL) and $6 \mathrm{~N} \mathrm{HCl}(10 \mathrm{~mL})$. After stirring for $5 \mathrm{mins}$, the reaction mixture was concentrated via rotary evaporation under reduced pressure, the residue was added $\mathrm{NEt}_{3}(5 \mathrm{~mL})$. The mixture was concentrated, and the residue was directly purified by flash chromatography on silica gel $(\mathrm{PE} / \mathrm{EA}=5: 1)$ to give the inseparable products $\mathbf{1 0}$ as a yellow solid. yield (417.0 $\mathrm{mg}, 97 \%)$. Meanwhile, isatin was recovered in 90\% yield $(\mathrm{PE} / \mathrm{EA}=3: 1)$.

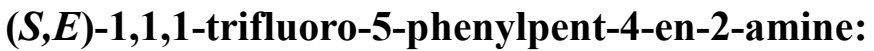

Yellow solid; m.p. $92-93{ }^{\circ} \mathrm{C} ;[\alpha]^{25} \mathrm{D}=-101.4\left(c\right.$ 0.23, $\left.\mathrm{CH}_{2} \mathrm{Cl}_{2}\right) .{ }^{1} \mathrm{H}$ NMR $\left(400 \mathrm{MHz}, \mathrm{CDCl}_{3}\right) \delta$ $7.39-7.27(\mathrm{~m}, 4 \mathrm{H}), 7.26-7.20(\mathrm{~m}, 1 \mathrm{H}), 6.53(\mathrm{~d}, J=15.6 \mathrm{~Hz}, 1 \mathrm{H}), 6.26-6.08(\mathrm{~m}, 1 \mathrm{H}), 3.37$ $-3.35(\mathrm{~m}, 1 \mathrm{H}), 2.68-2.60(\mathrm{~m}, 1 \mathrm{H}), 2.45-2.27(\mathrm{~m}, 1 \mathrm{H}), 1.40(\mathrm{~s}, 2 \mathrm{H}) .{ }^{13} \mathrm{C}$ NMR $(101 \mathrm{MHz}$, $\left.\mathrm{CDCl}_{3}\right) \delta 136.8,134.0,128.6,127.6,126.2(\mathrm{q}, J=282.0 \mathrm{~Hz}), 126.3,124.2,53.5(\mathrm{q}, J=28.5$ $\mathrm{Hz})$, 33.7. ${ }^{19} \mathrm{~F}$ NMR $\left(376 \mathrm{MHz}, \mathrm{CDCl}_{3}\right) \delta-78.18(\mathrm{~d}, J=7.3 \mathrm{~Hz})$. For $\mathrm{C}_{11} \mathrm{H}_{13} \mathrm{~F}_{3} \mathrm{~N}^{+}: 215.0922$, found: 215.0924. The product was analyzed by HPLC to determine the enantiomeric excess: 
$95 \%$ ee $($ Chiralpak IA, $i$-propanol $/$ hexane $=10 / 90$, flow rate $1.0 \mathrm{~mL} / \mathrm{min}, \lambda=254 \mathrm{~nm}) ; \mathrm{t}_{\mathrm{r}}=7.52$ and $8.18 \mathrm{~min}$.

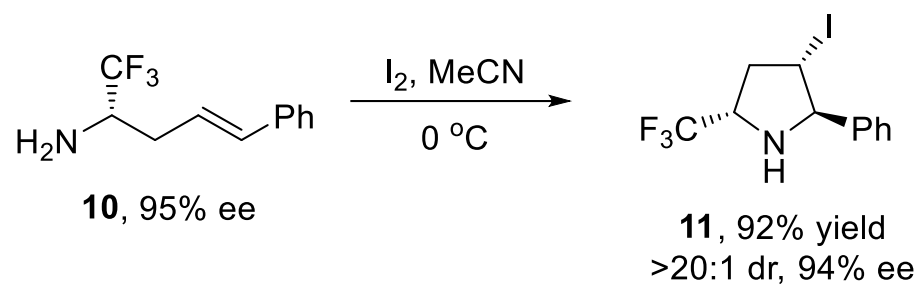

To a 5-mL vial equipped with stirrer bar were added 10 (43 mg, $0.2 \mathrm{mmol}), \mathrm{I}_{2}$ (76 mg, 0.6 mmol) and $\mathrm{CH}_{3} \mathrm{CN}(1 \mathrm{~mL})$. The mixture was stirred at room temperature for $4 \mathrm{~h}$, and TLC showed that 10a was disappeared. The mixture was stirred for $10 \mathrm{~min}$ before quenched by addition of $\mathrm{CH}_{2} \mathrm{Cl}_{2}(5 \mathrm{~mL})$ and saturated $\mathrm{Na}_{2} \mathrm{~S}_{2} \mathrm{O}_{3}(5 \mathrm{~mL})$, and the aqueous layer was extracted with additional portions of $\mathrm{CH}_{2} \mathrm{Cl}_{2}$. The combined organic layers were combined, concentrated, purified by flash chromatography on silica gel $(\mathrm{PE} / \mathrm{EA}=5: 1)$ to give the inseparable products 11 as a colorless oil; yield (62.7 mg, 92\%).

\section{(2R,3S,5S)-3-iodo-2-phenyl-5-(trifluoromethyl)pyrrolidine:}

Colorless oil; $[\alpha]^{25} \mathrm{D}=-137.1\left(c\right.$ 0.1.2, $\left.\mathrm{CH}_{2} \mathrm{Cl}_{2}\right) .{ }^{1} \mathrm{H}$ NMR $\left(400 \mathrm{MHz}, \mathrm{CDCl}_{3}\right) \delta 7.44-7.30(\mathrm{~m}$, 5H), $4.34(\mathrm{~d}, J=10.0 \mathrm{~Hz}, 1 \mathrm{H}), 3.99-3.79(\mathrm{~m}, 2 \mathrm{H}), 2.95-2.82(\mathrm{~m}, 1 \mathrm{H}), 2.48-2.36(\mathrm{~m}, 1 \mathrm{H})$, $2.24(\mathrm{~s}, 1 \mathrm{H}) .{ }^{13} \mathrm{C} \mathrm{NMR}\left(100 \mathrm{MHz}, \mathrm{CDCl}_{3}\right) \delta 138.0,128.9,128.8,127.2,126.1$ (q, $\left.J=282.0 \mathrm{~Hz}\right)$, $58.6(\mathrm{q}, J=30.9 \mathrm{~Hz}), 71.9,38.6,38.6,25.1 .{ }^{19} \mathrm{~F} \mathrm{NMR}\left(376 \mathrm{MHz}, \mathrm{CDCl}_{3}\right) \delta-77.17(\mathrm{~d}, J=7.8$ $\mathrm{Hz}$ ). For $\mathrm{C}_{11} \mathrm{H}_{12} \mathrm{~F}_{3} \mathrm{IN}^{+}:$341.9957, found: 341.9961 . The product was analyzed by HPLC to determine the enantiomeric excess: $94 \%$ ee (Chiralcel OD-H, $i$-propanol/hexane $=10 / 90$, flow rate $1.0 \mathrm{~mL} / \mathrm{min}, \lambda=254 \mathrm{~nm}) ; \mathrm{t}_{\mathrm{r}}=6.02$ and $7.00 \mathrm{~min}$.

\section{References}

[1] a) L. M. Stanley, J. F. Hartwig, J. Am. Chem. Soc. 2009, 131, 8971. b) L. Wei, Q. Zhu, S.M. Xu, X. Chang, C.-J. Wang, J. Am. Chem. Soc. 2018, 140, 1508. 
9. NMR spectra

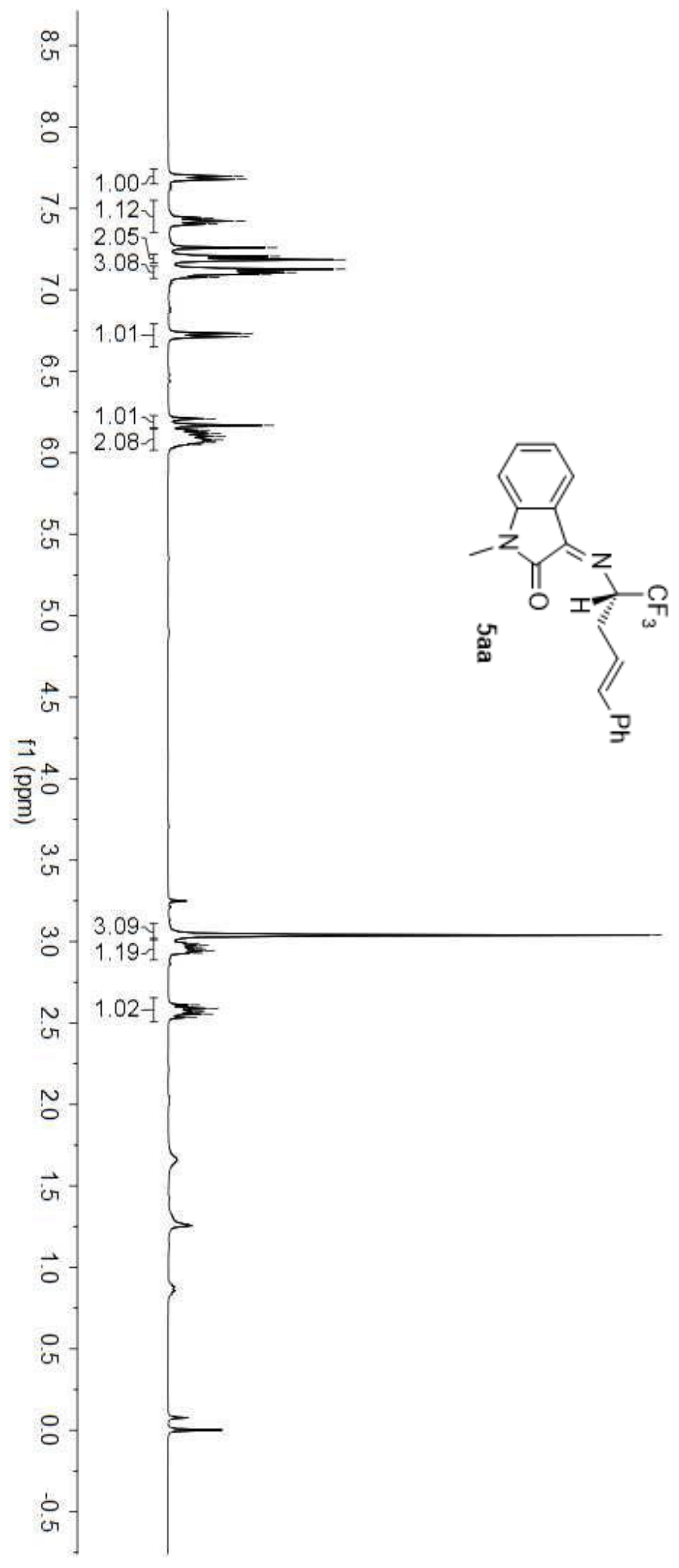

$-2.533$ 


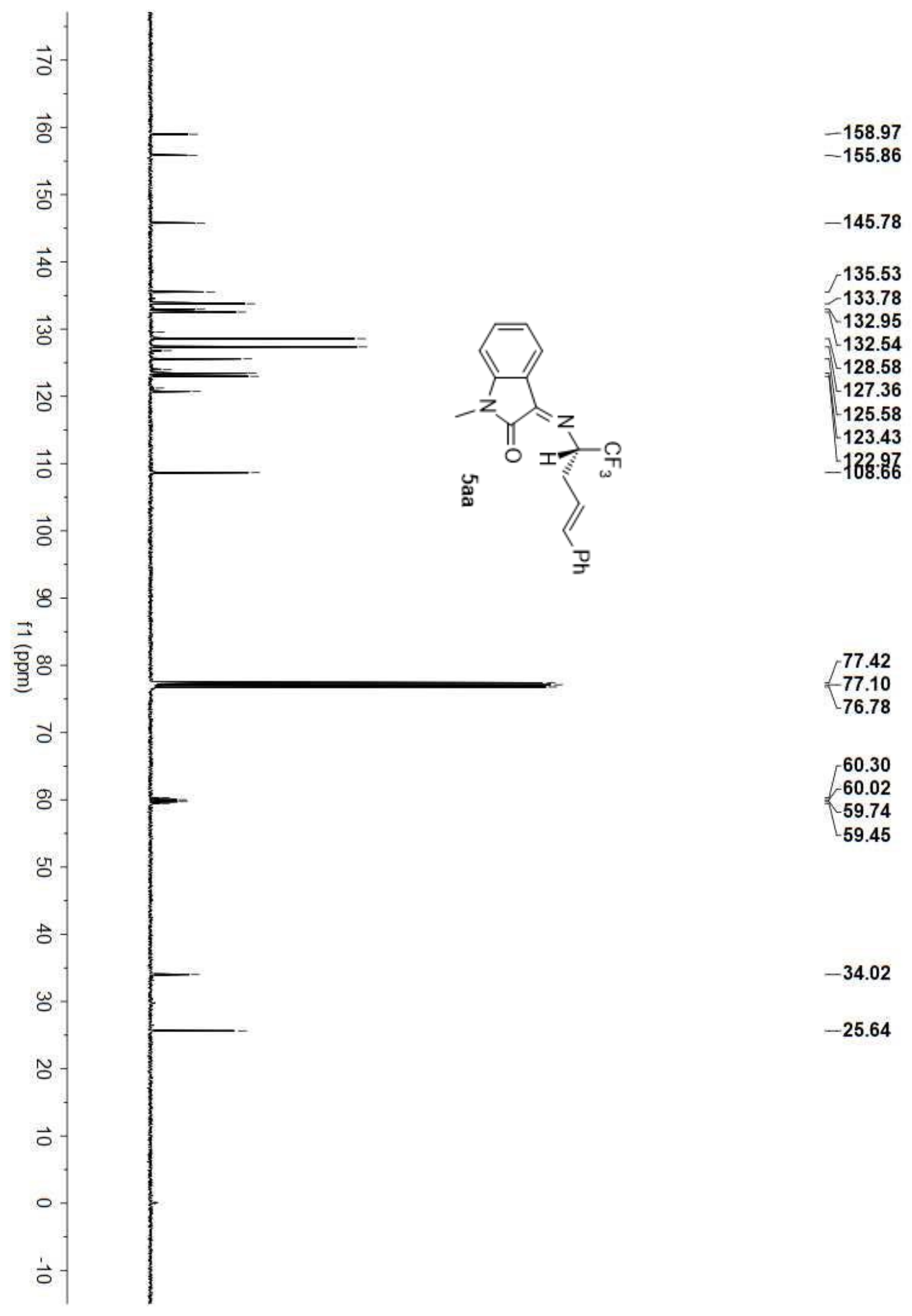



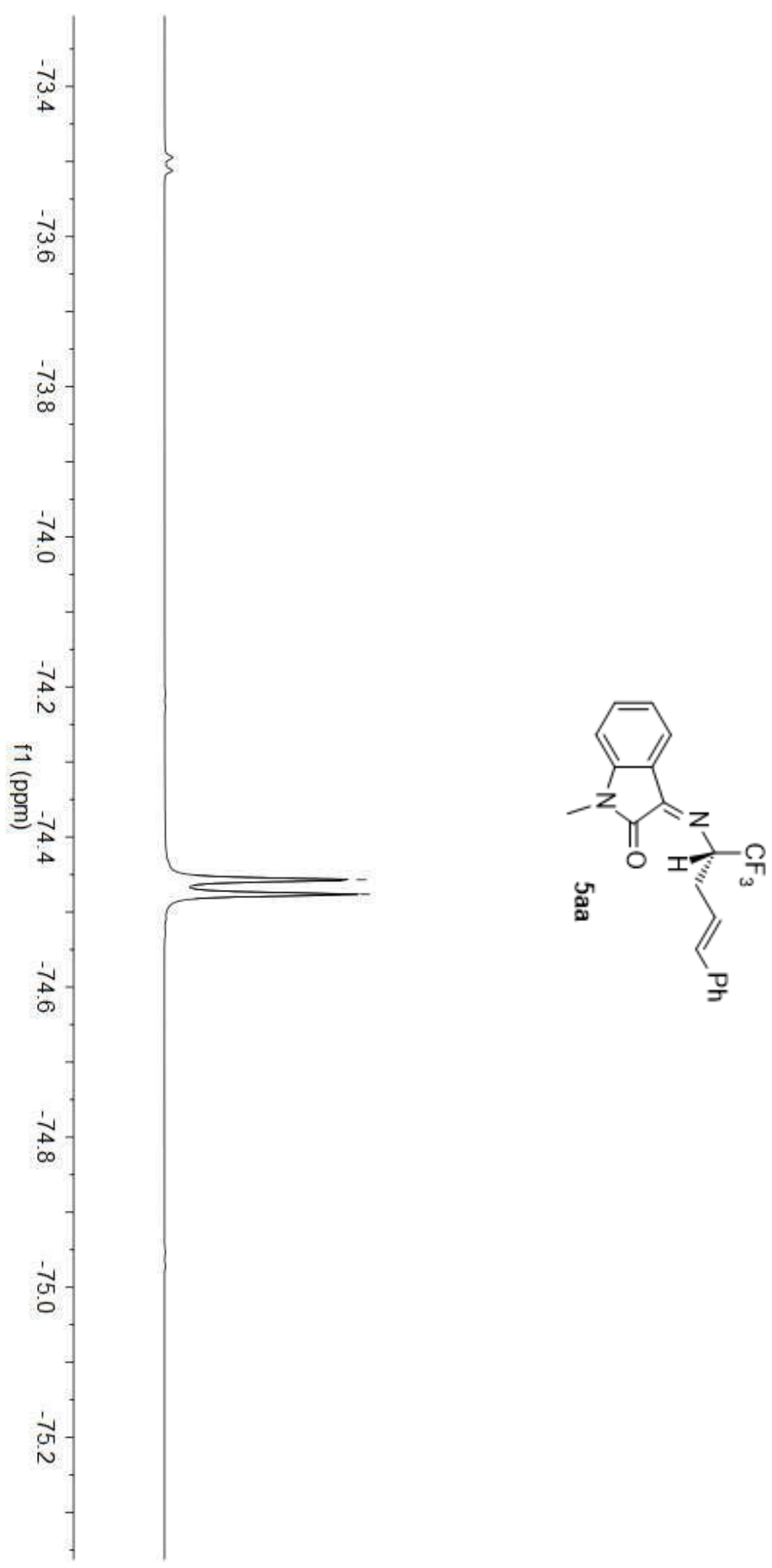

-74.457
--74.476

S38 


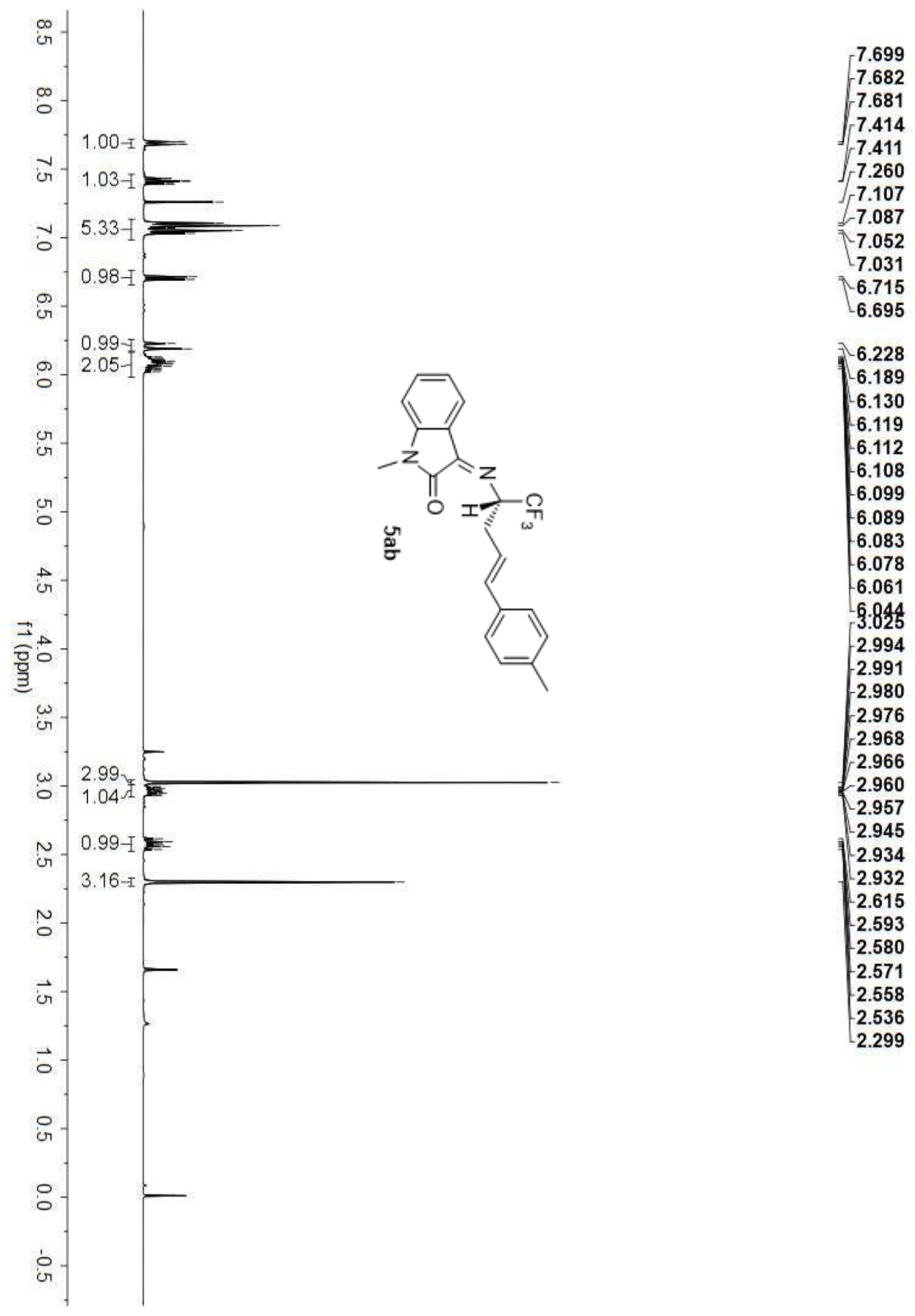




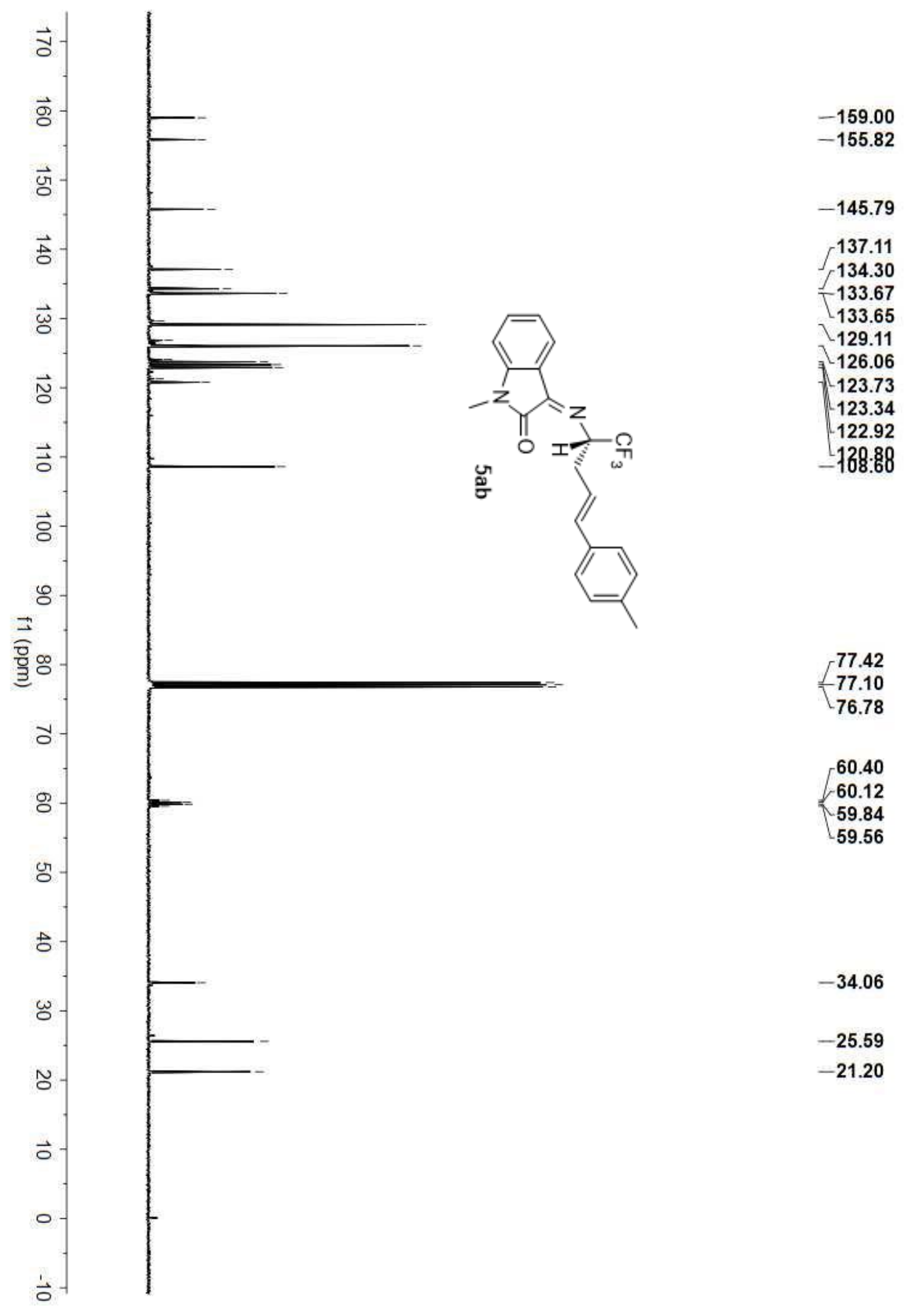



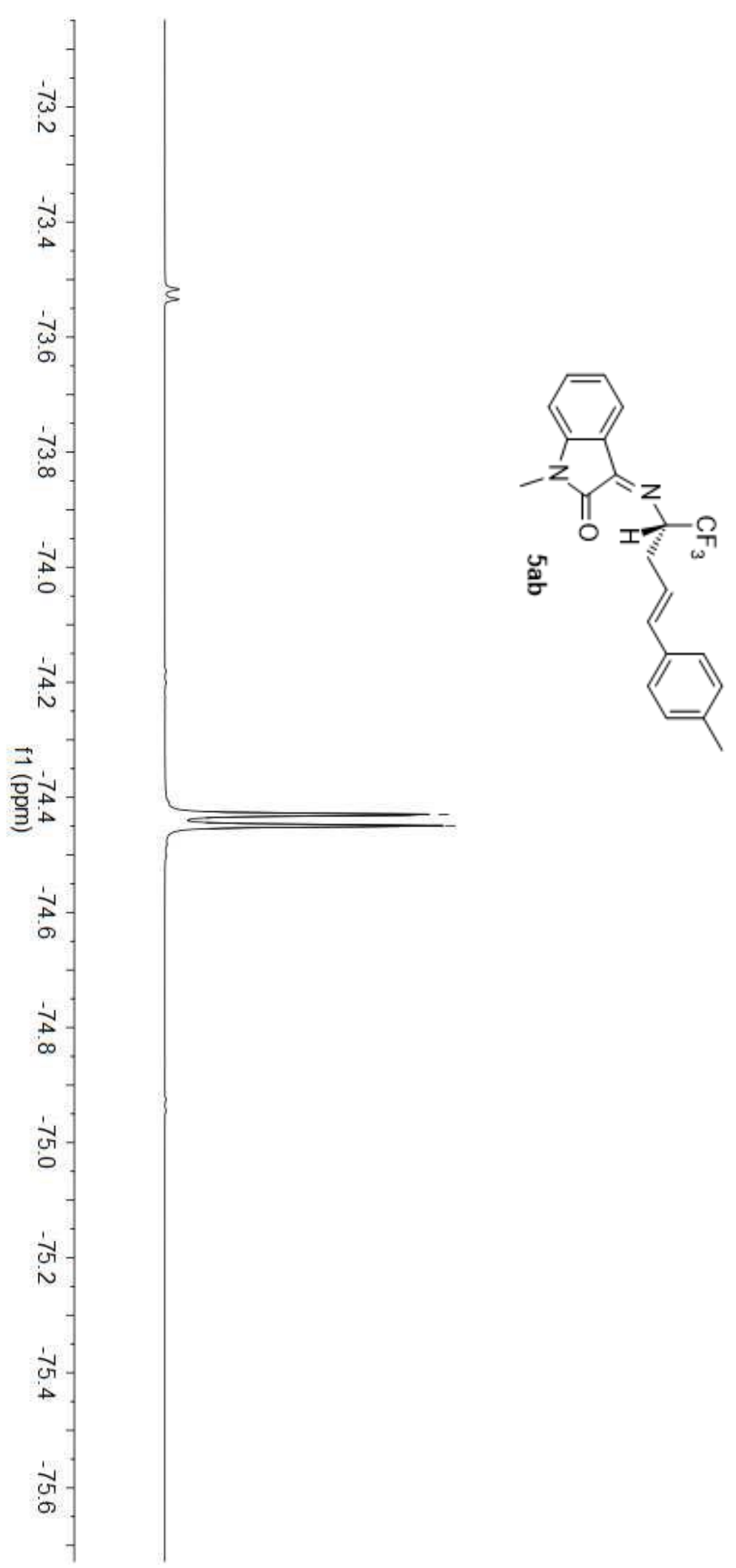

$$
\begin{array}{r}
-74.430 \\
-74.449
\end{array}
$$

S41 


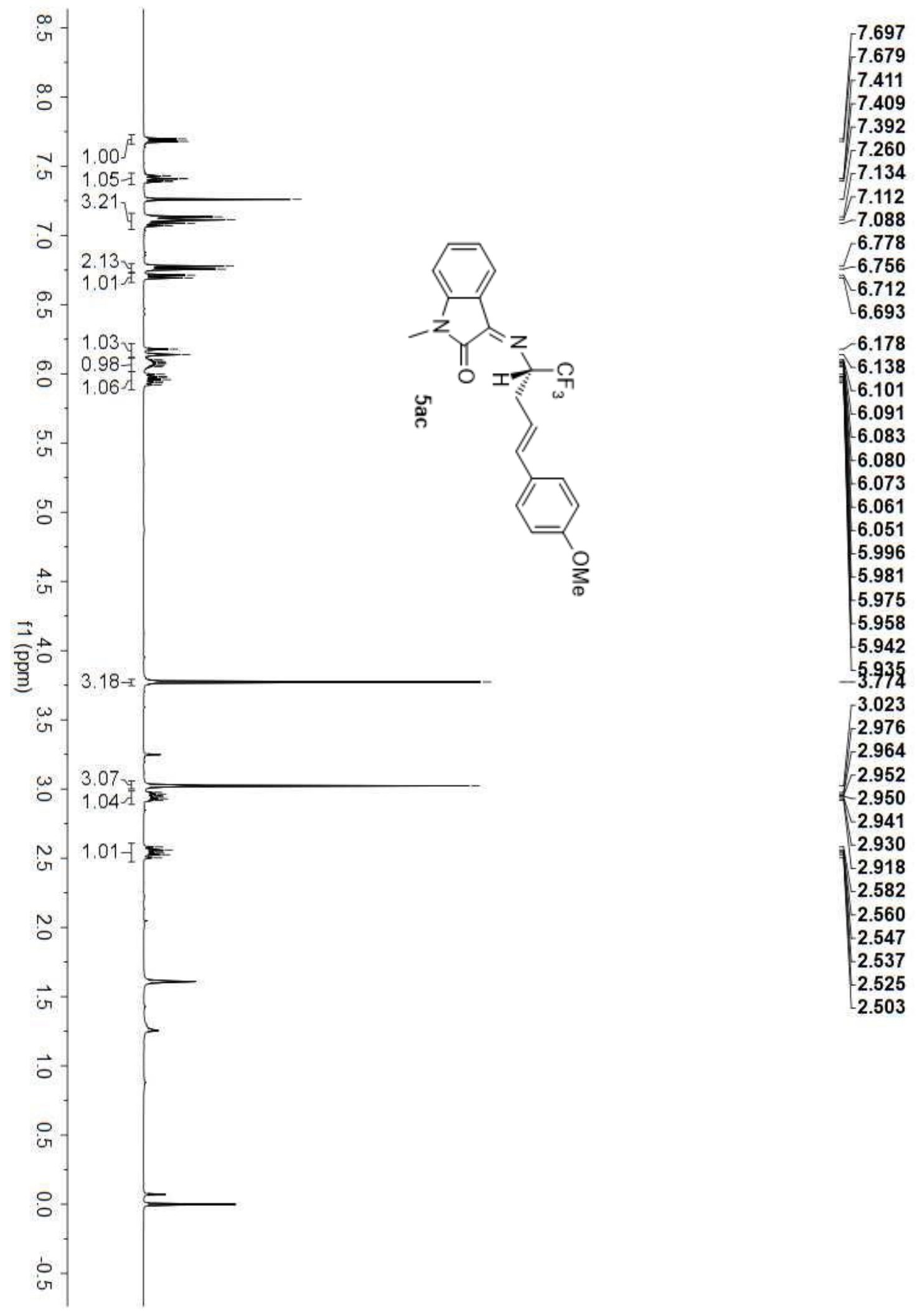




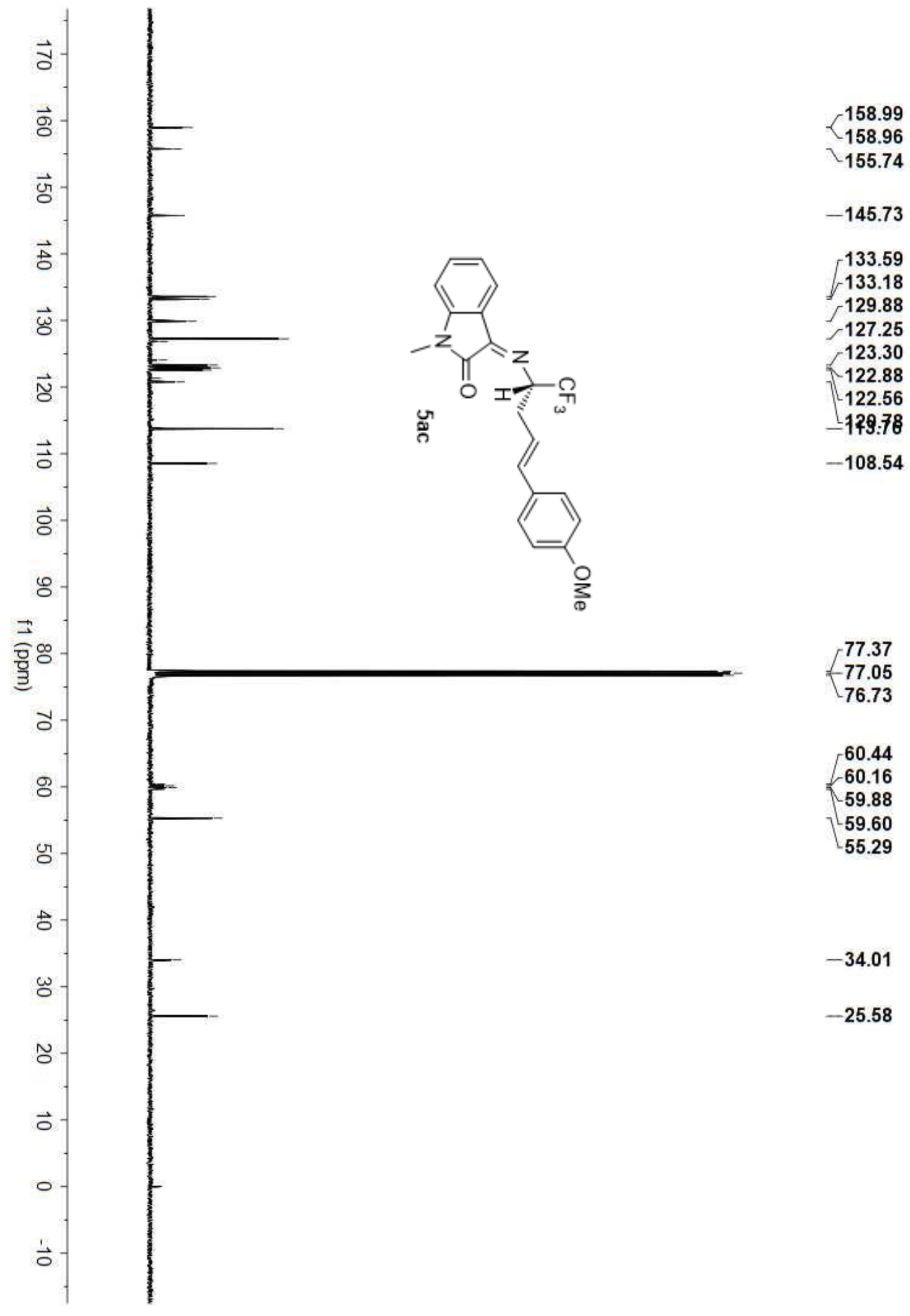



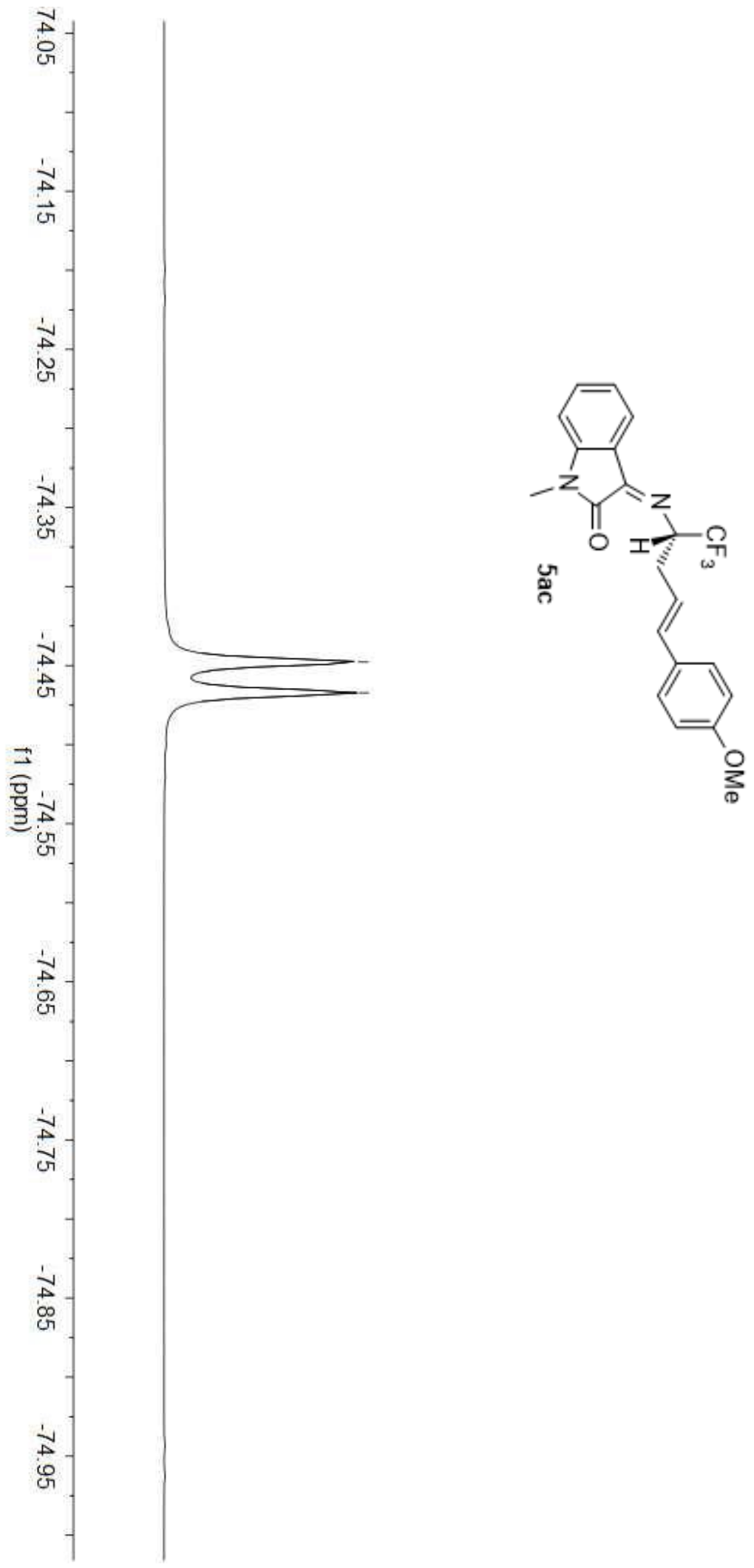

-.74 .448
--74.467

S44 


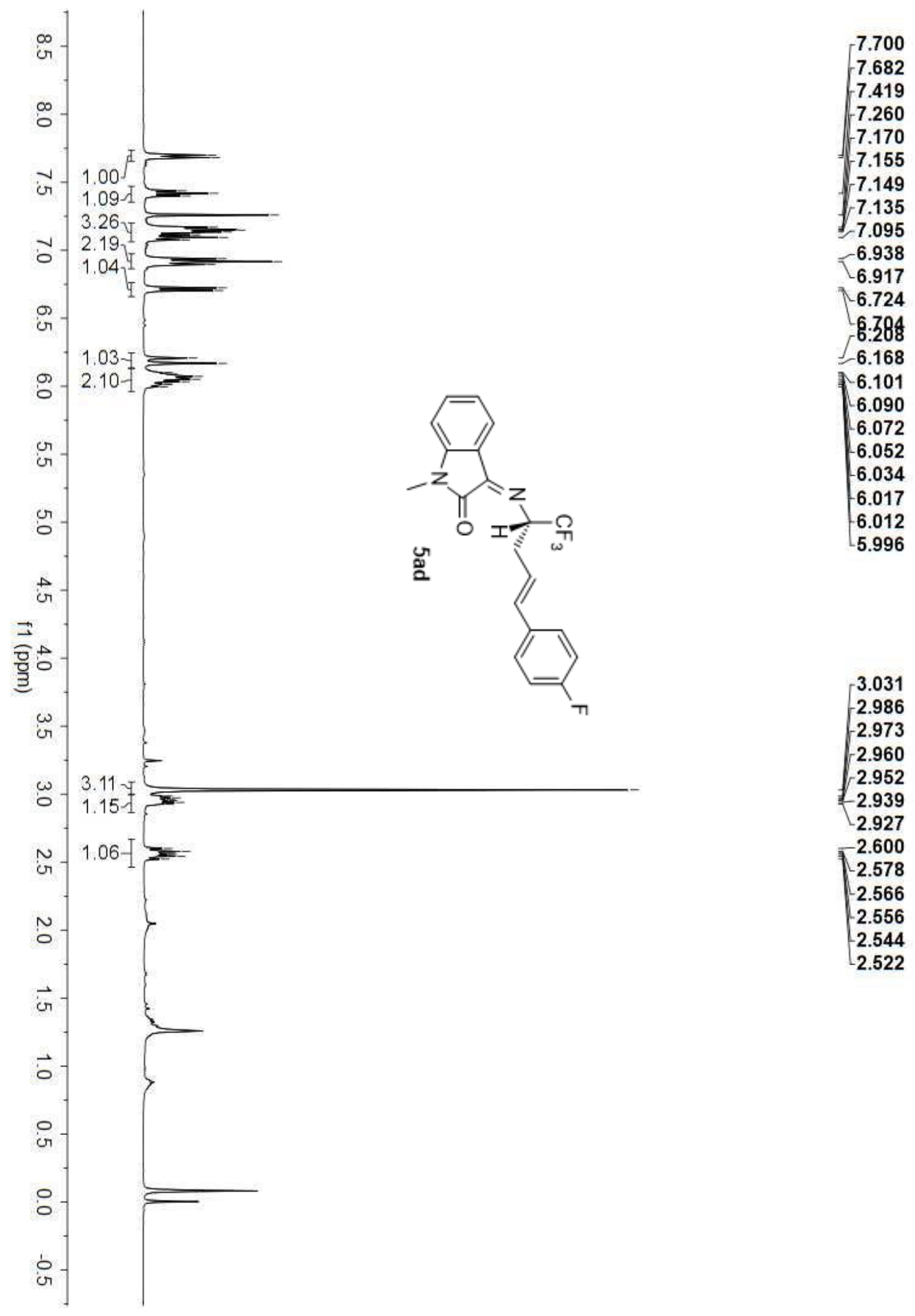




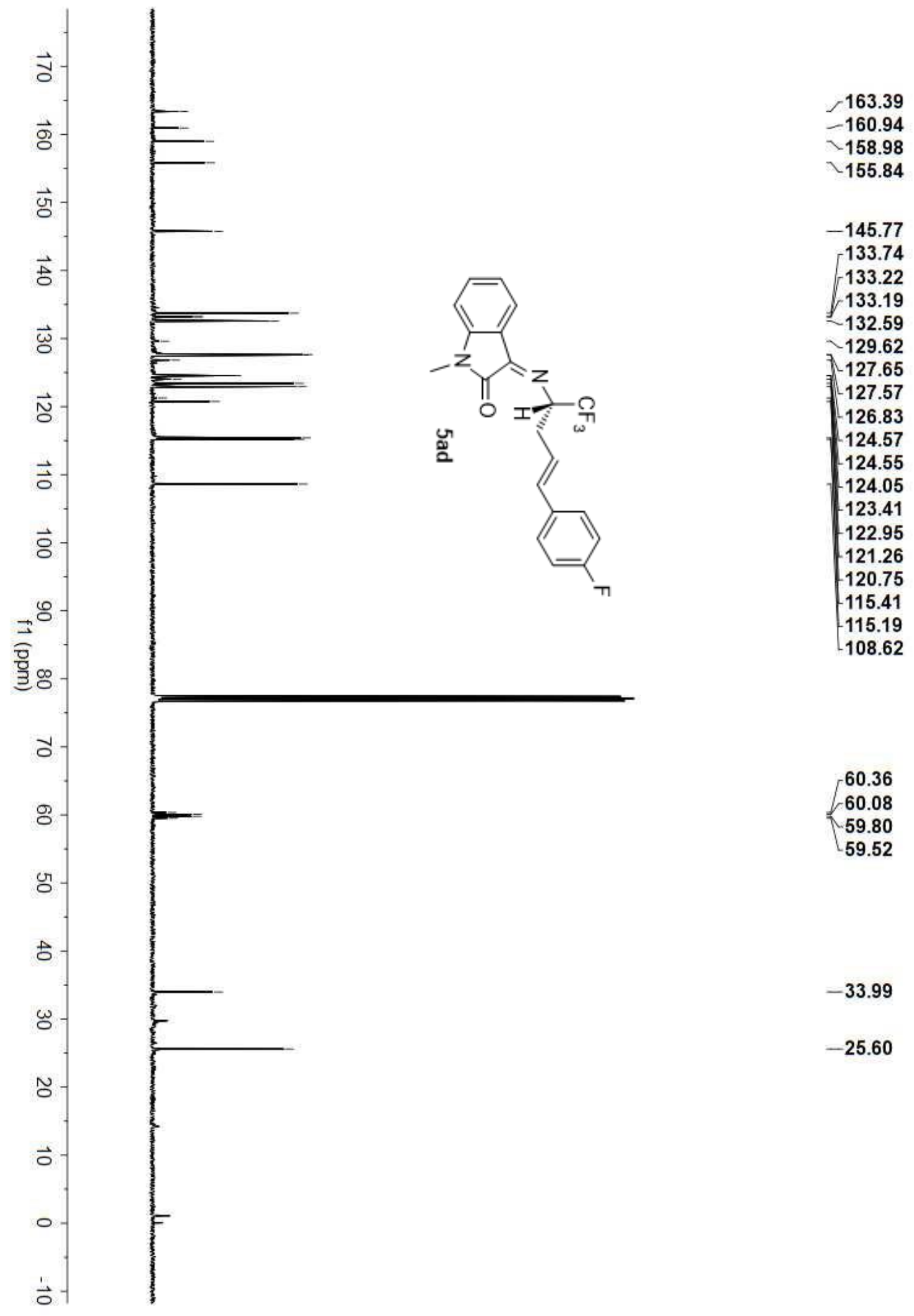




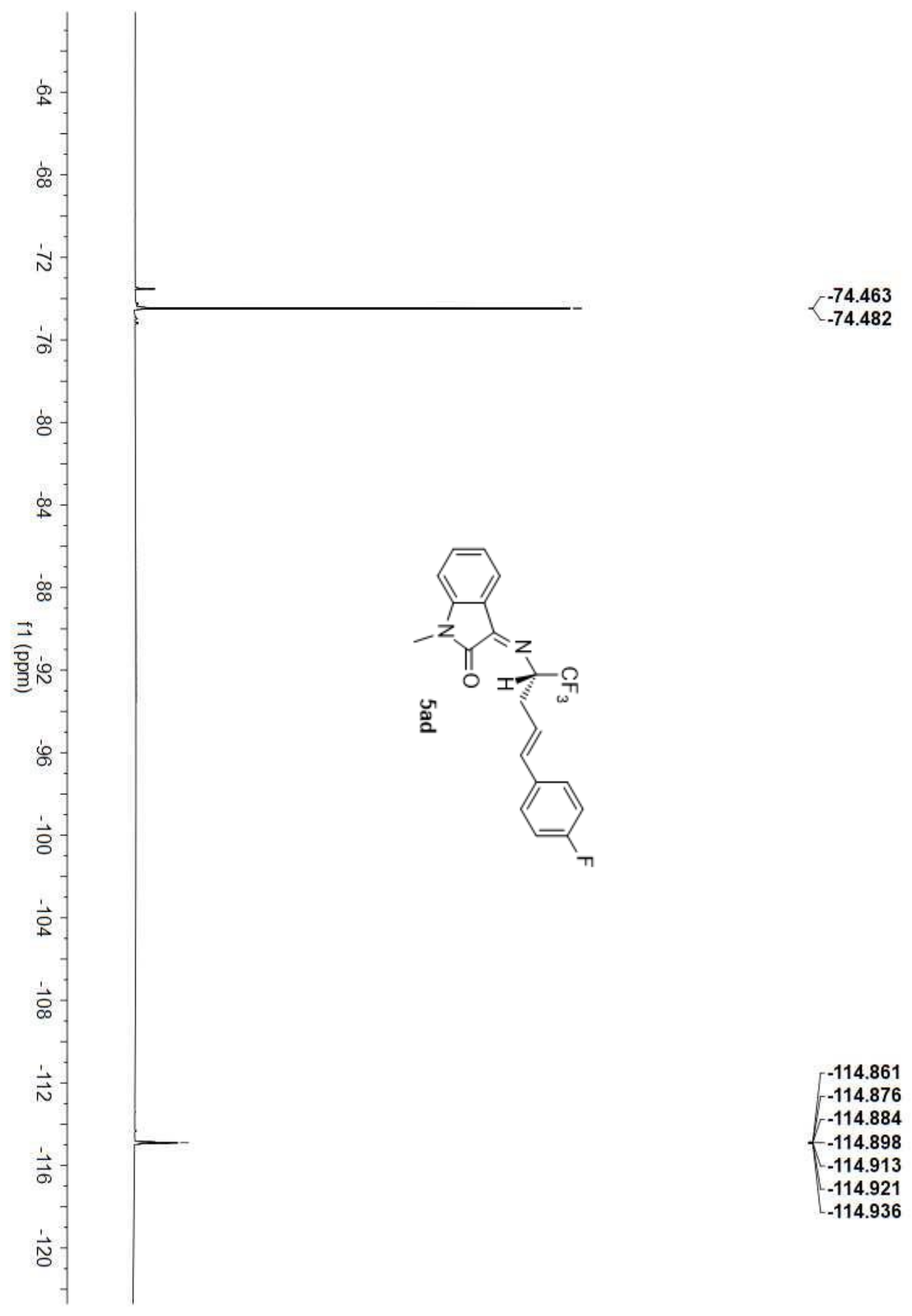




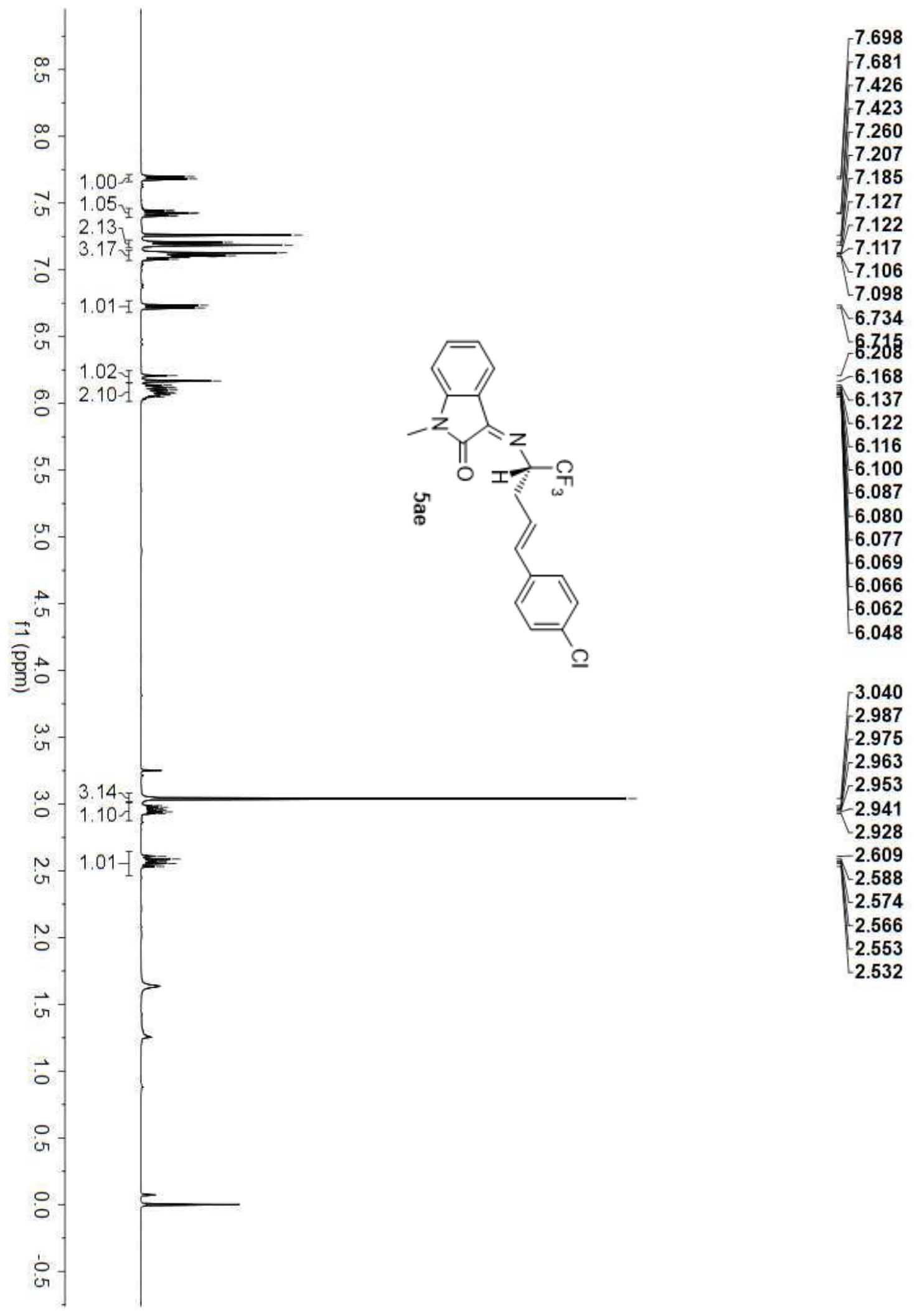




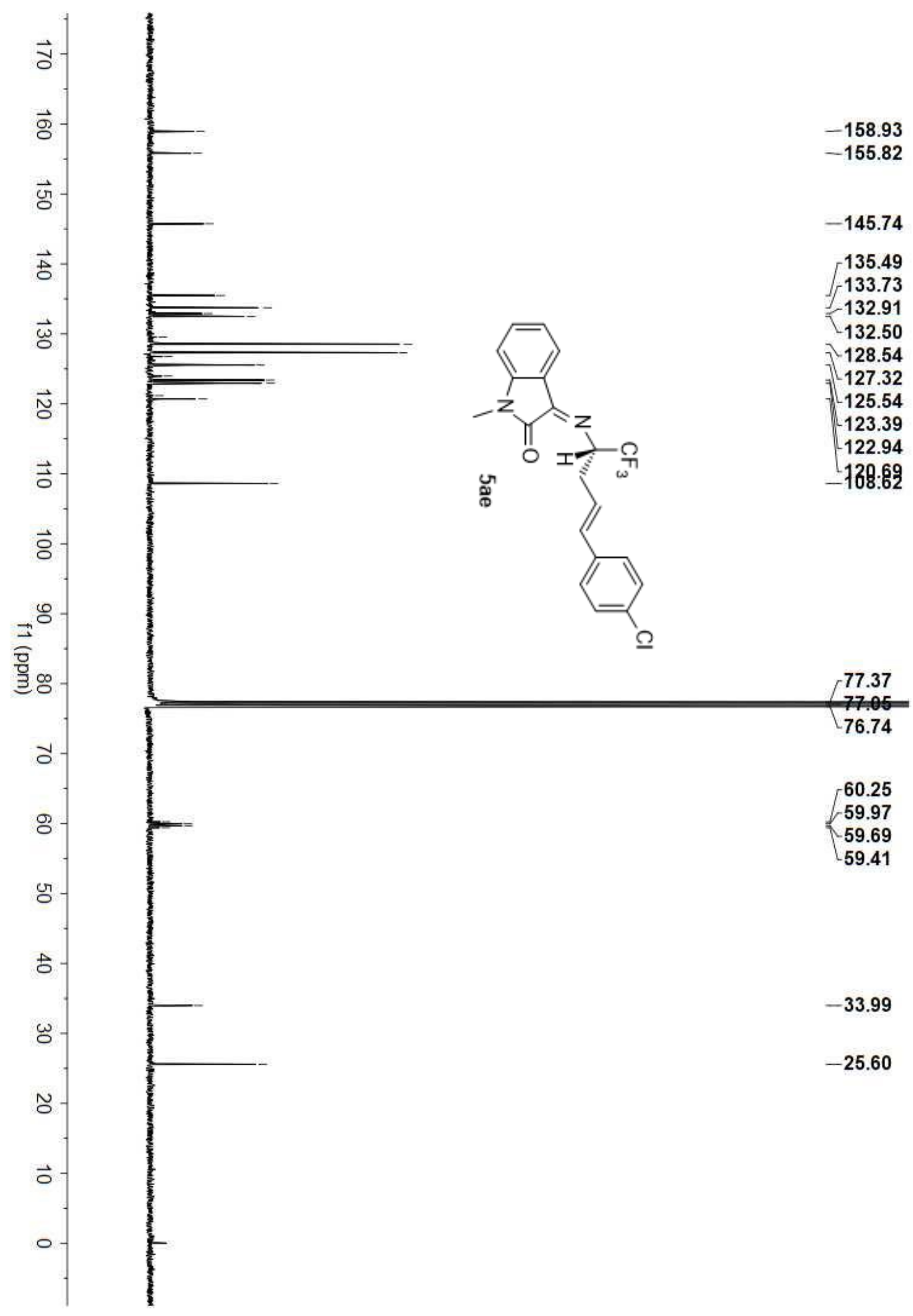




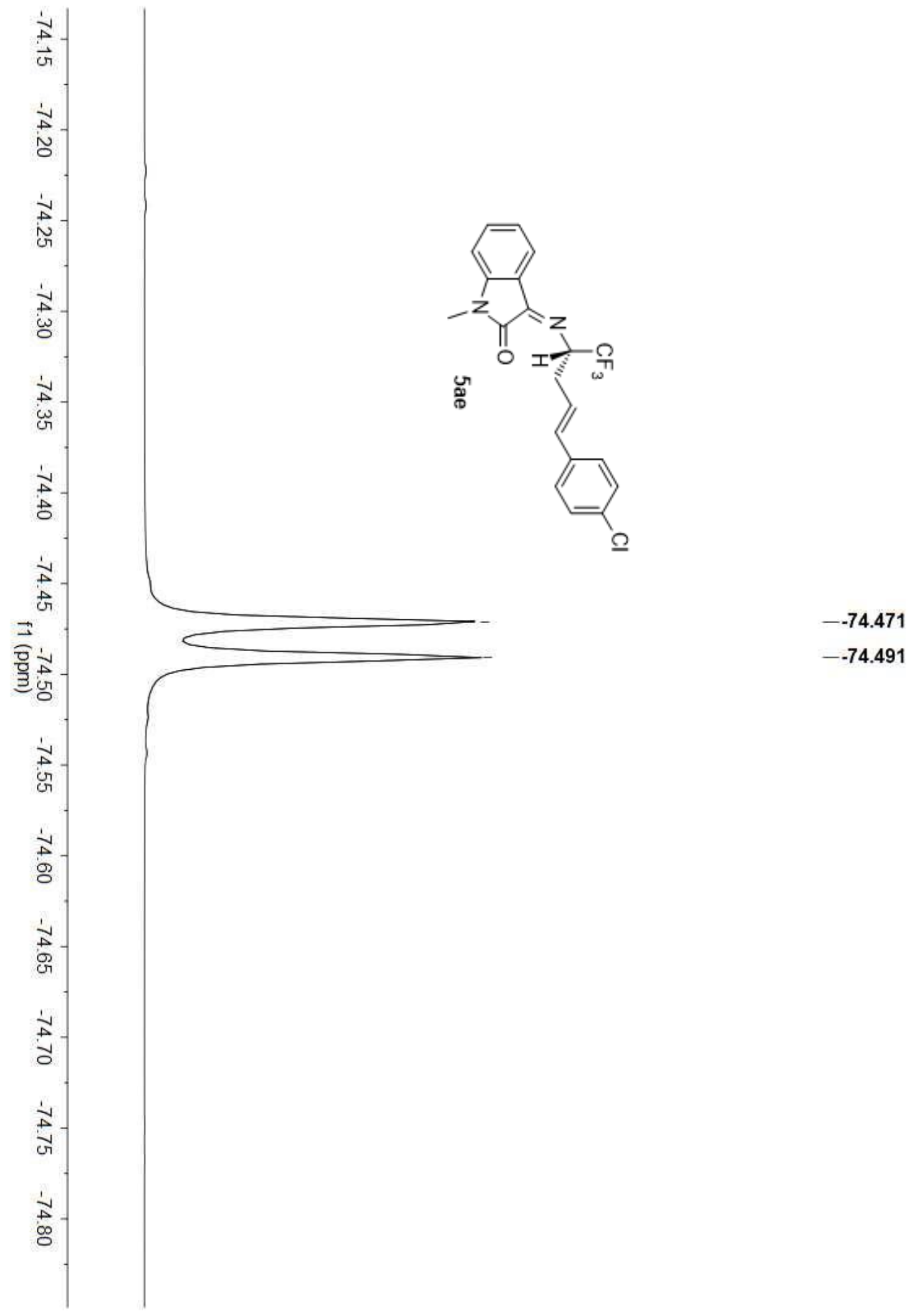




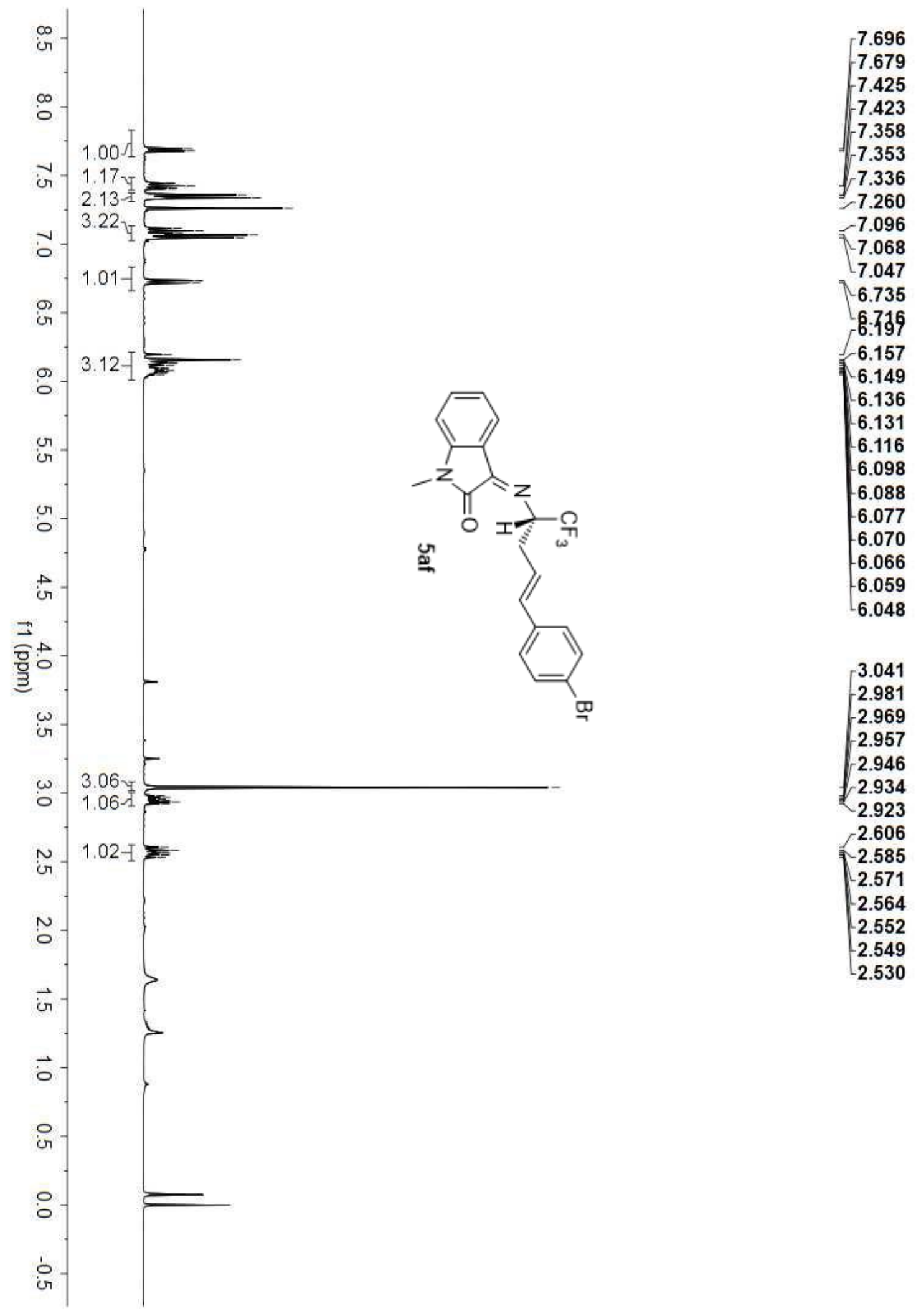




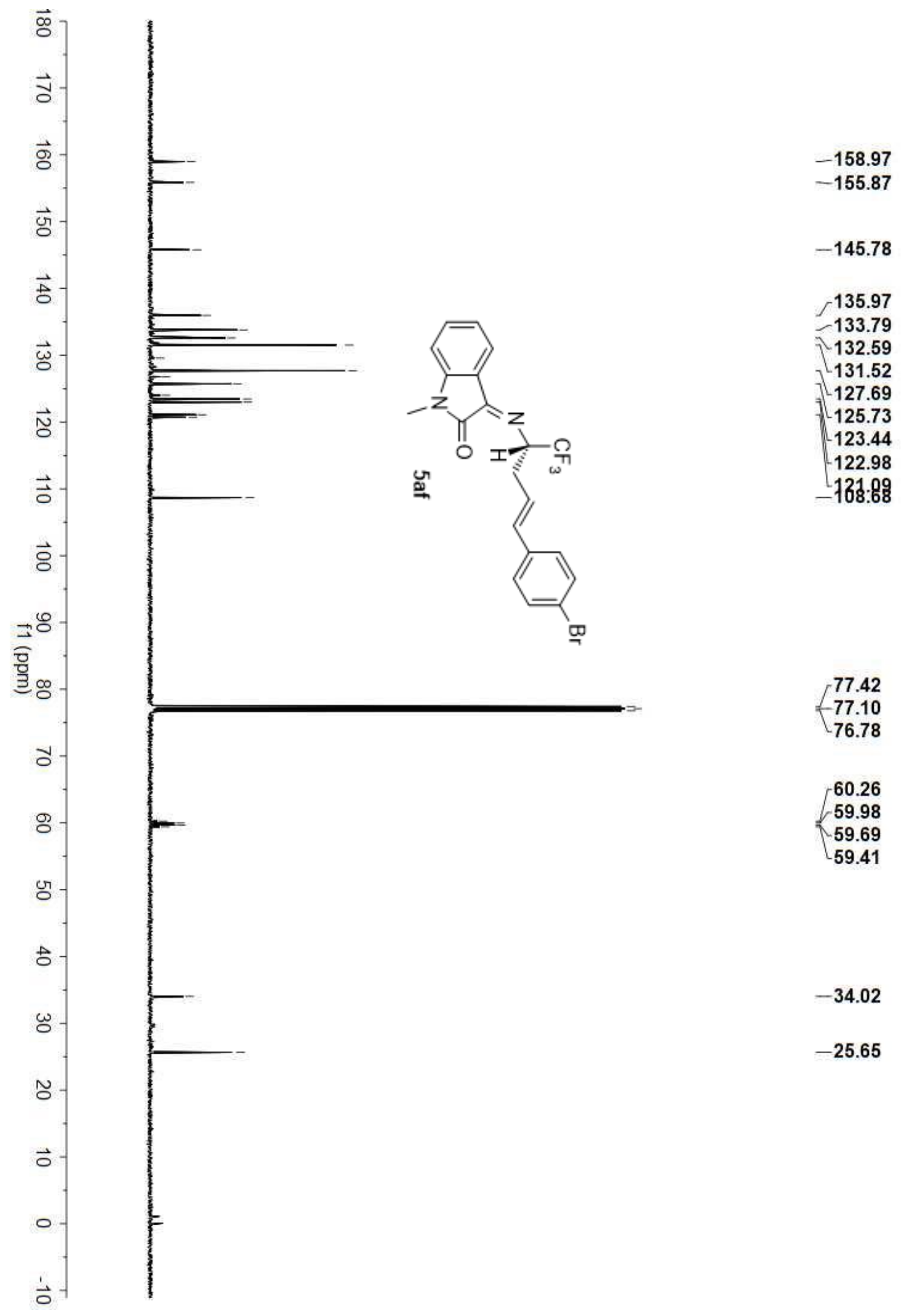




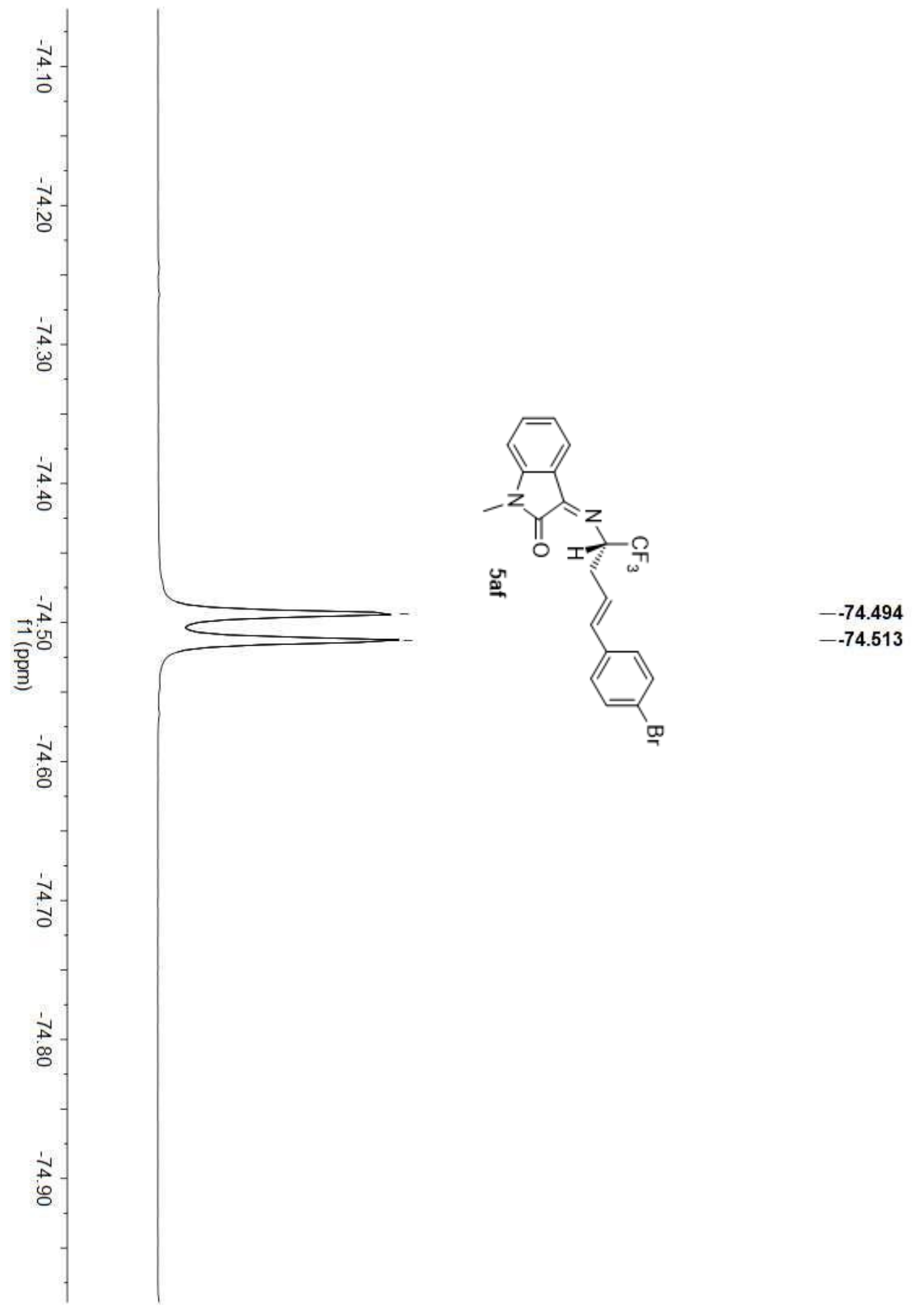




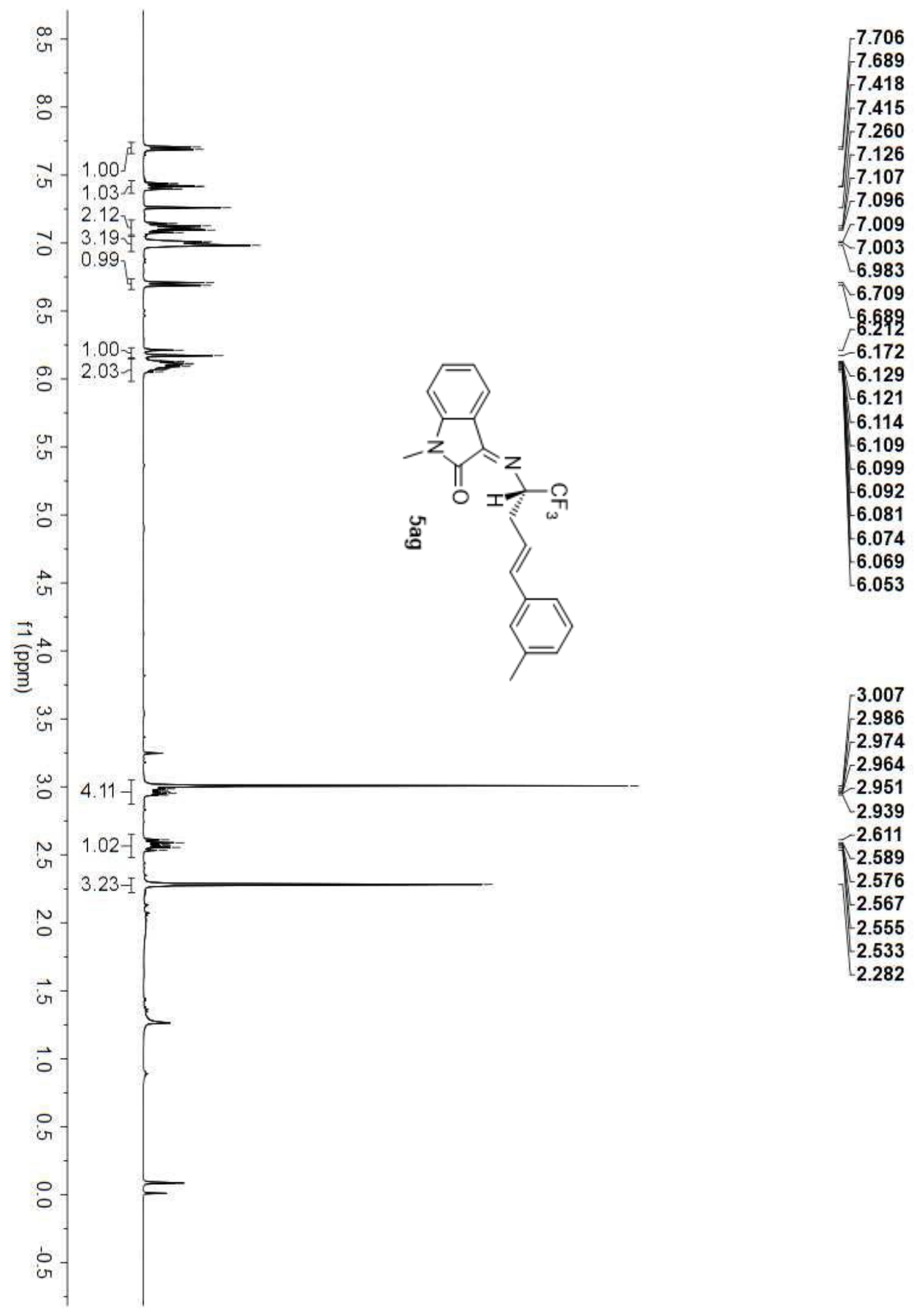




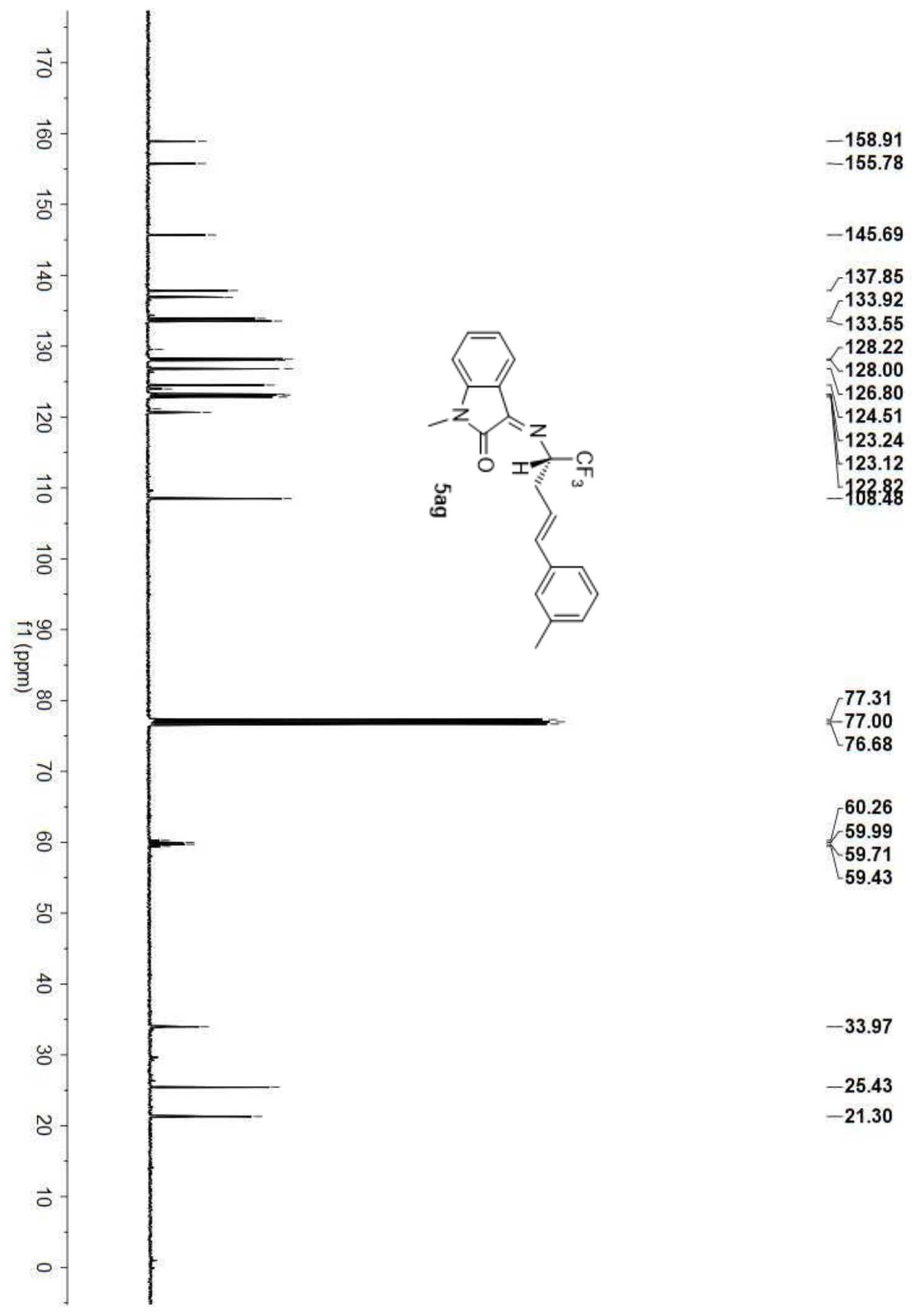



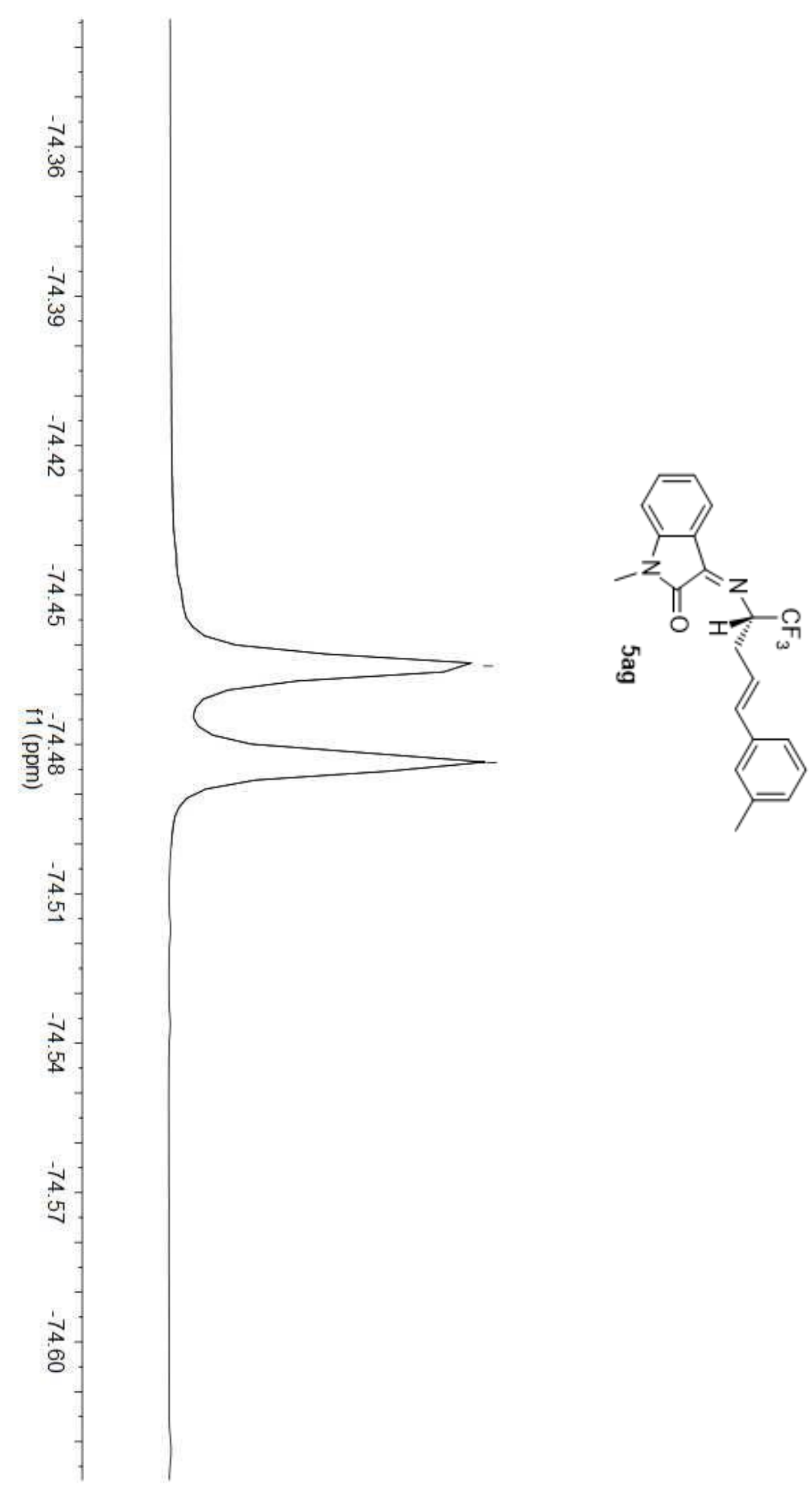

-.74 .464
--74.484

S56 


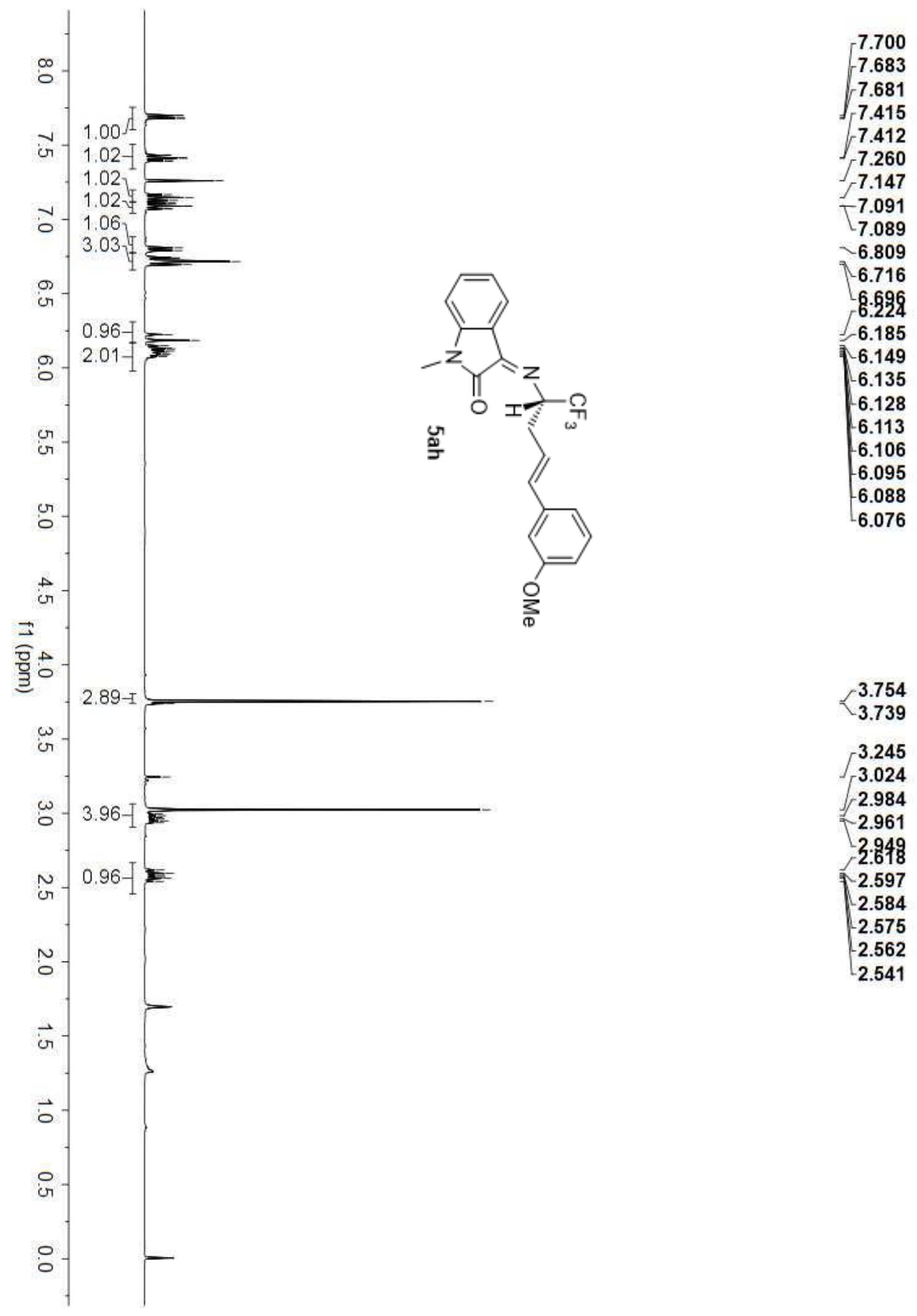




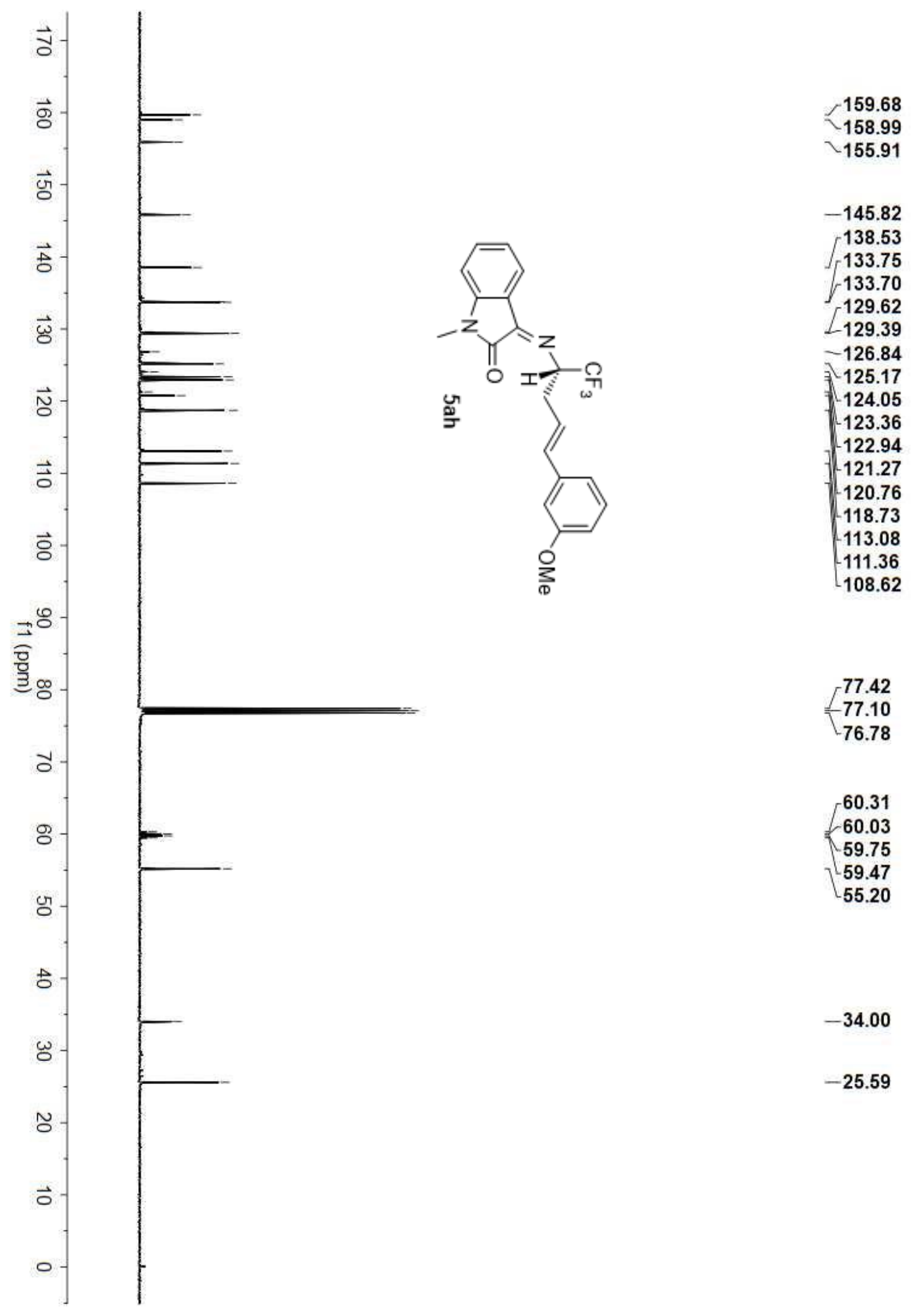




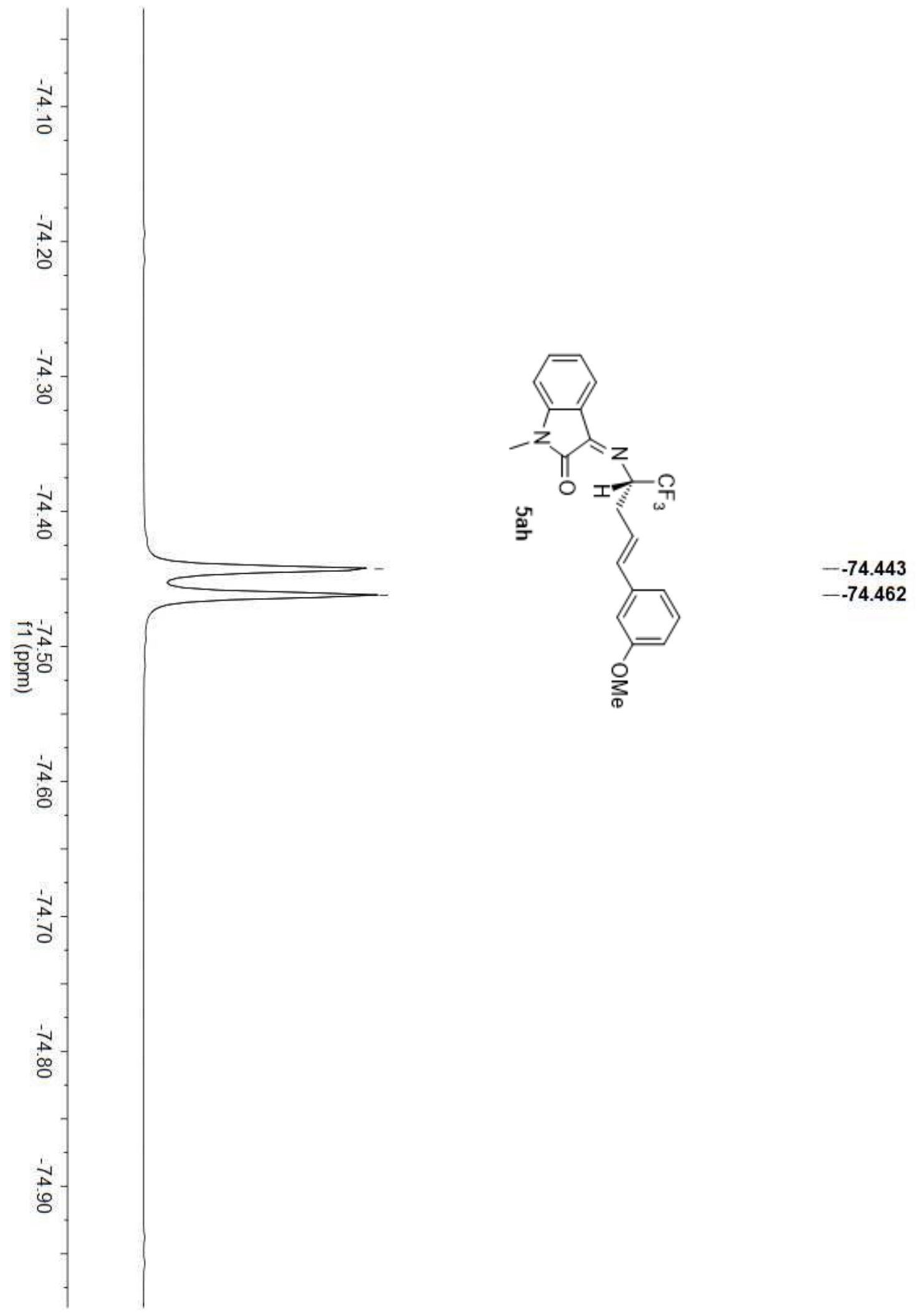




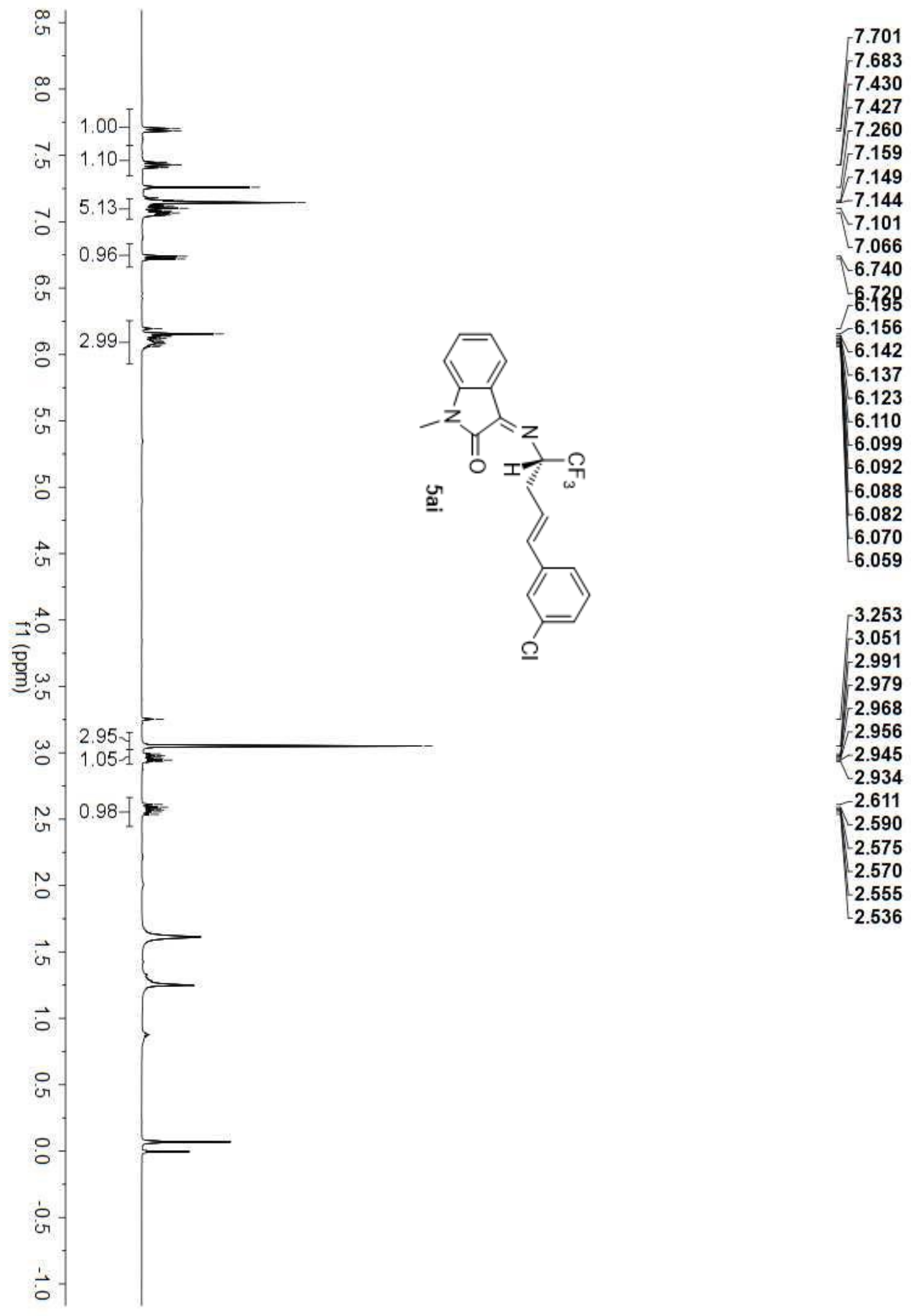




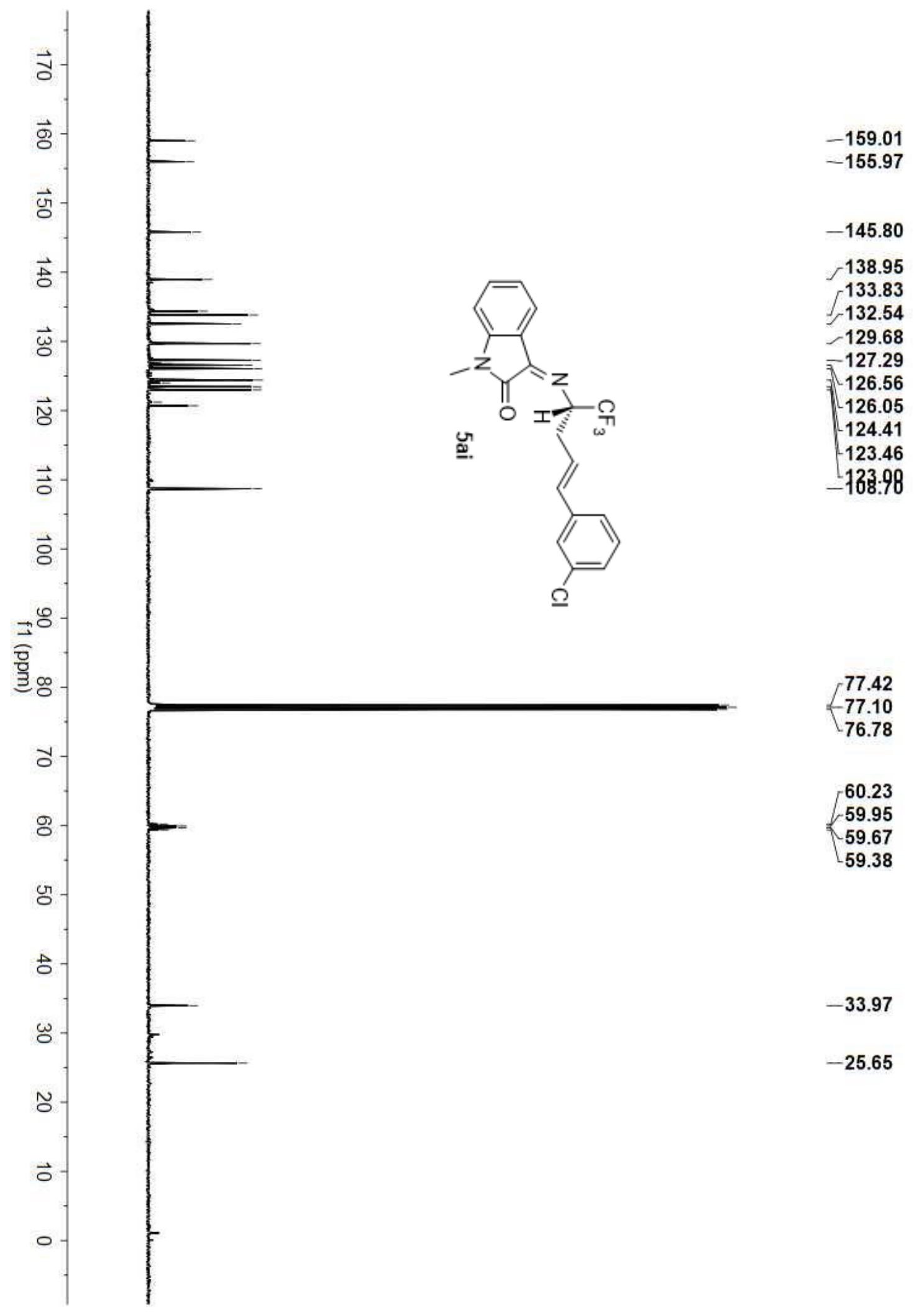




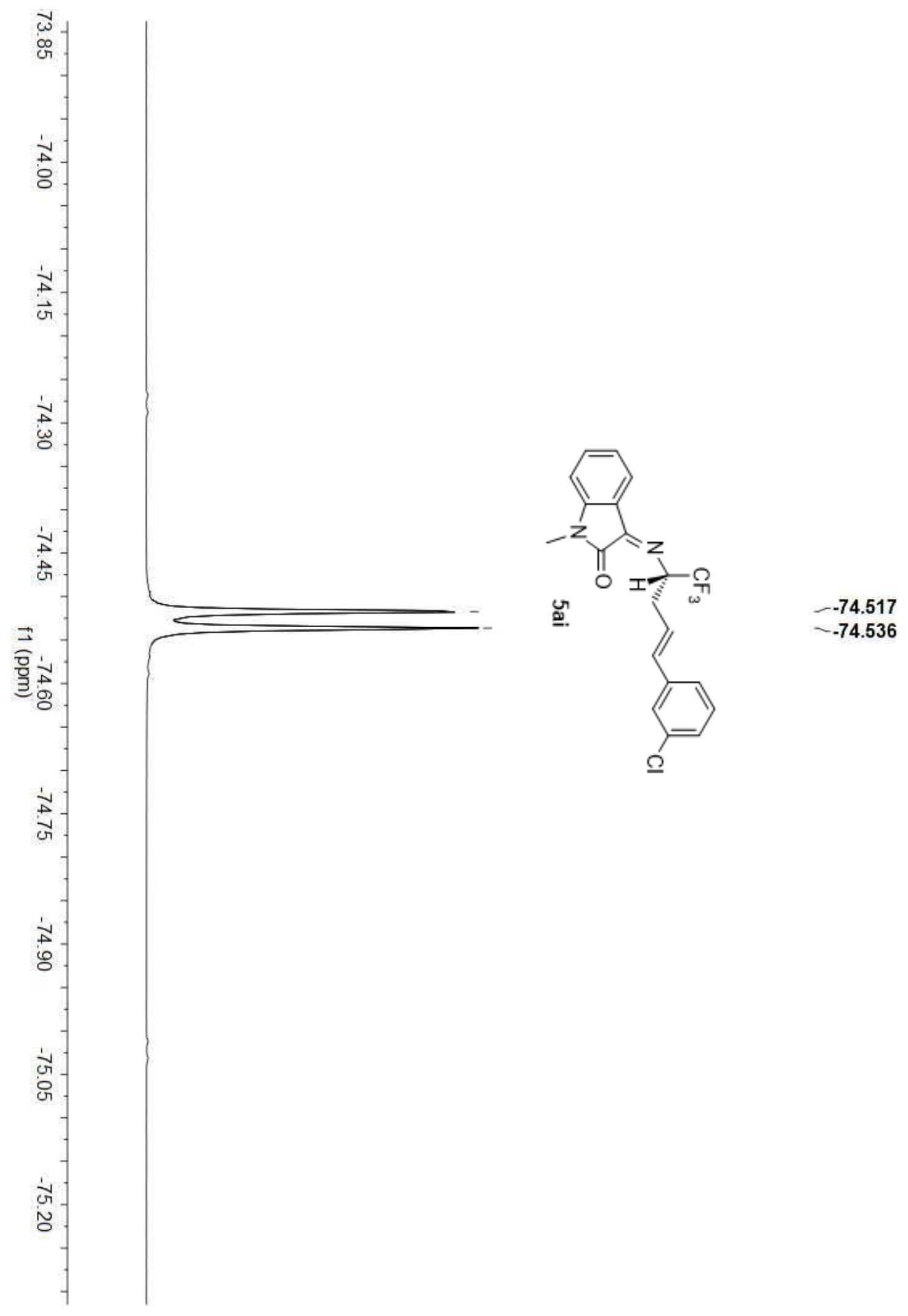




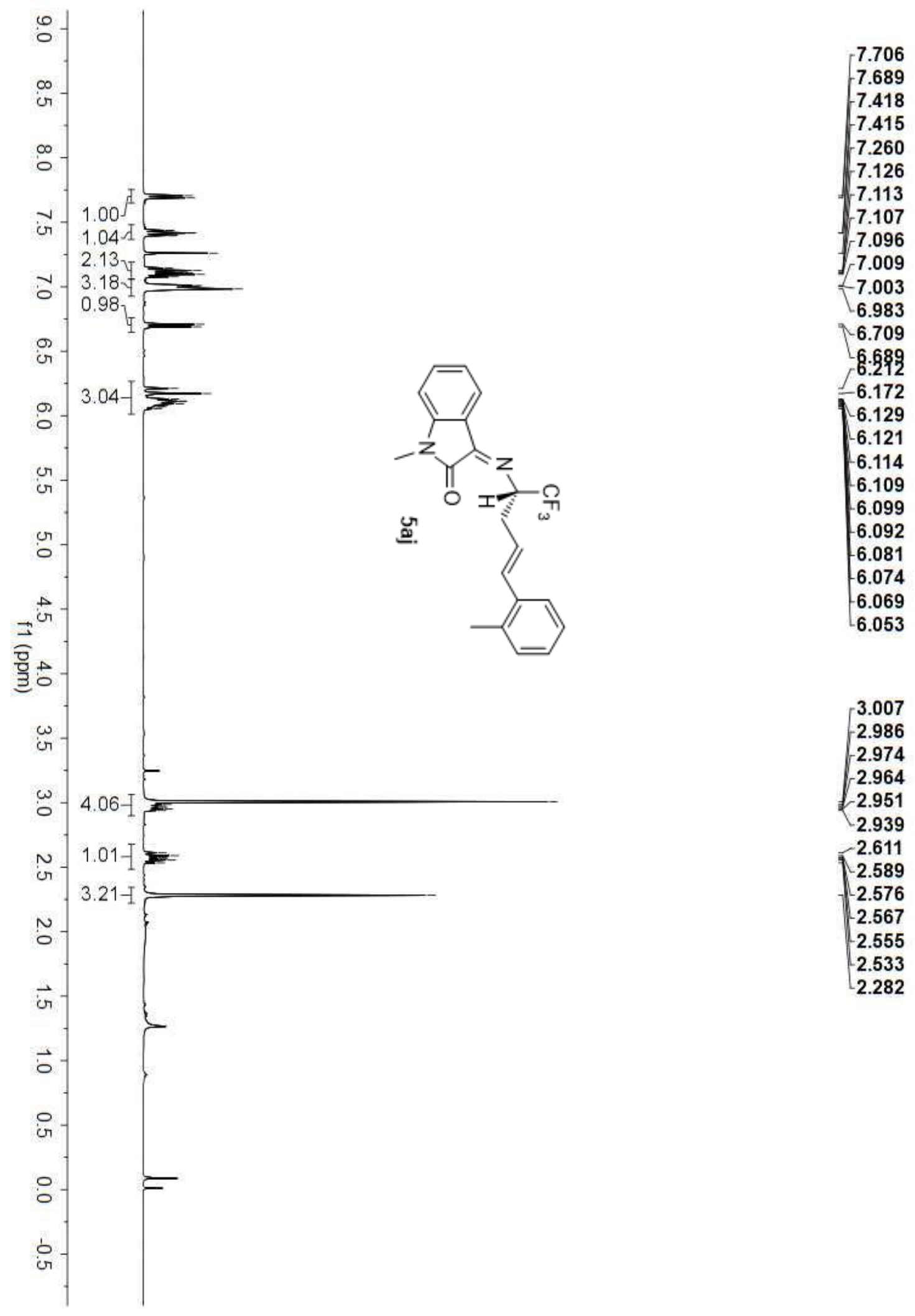




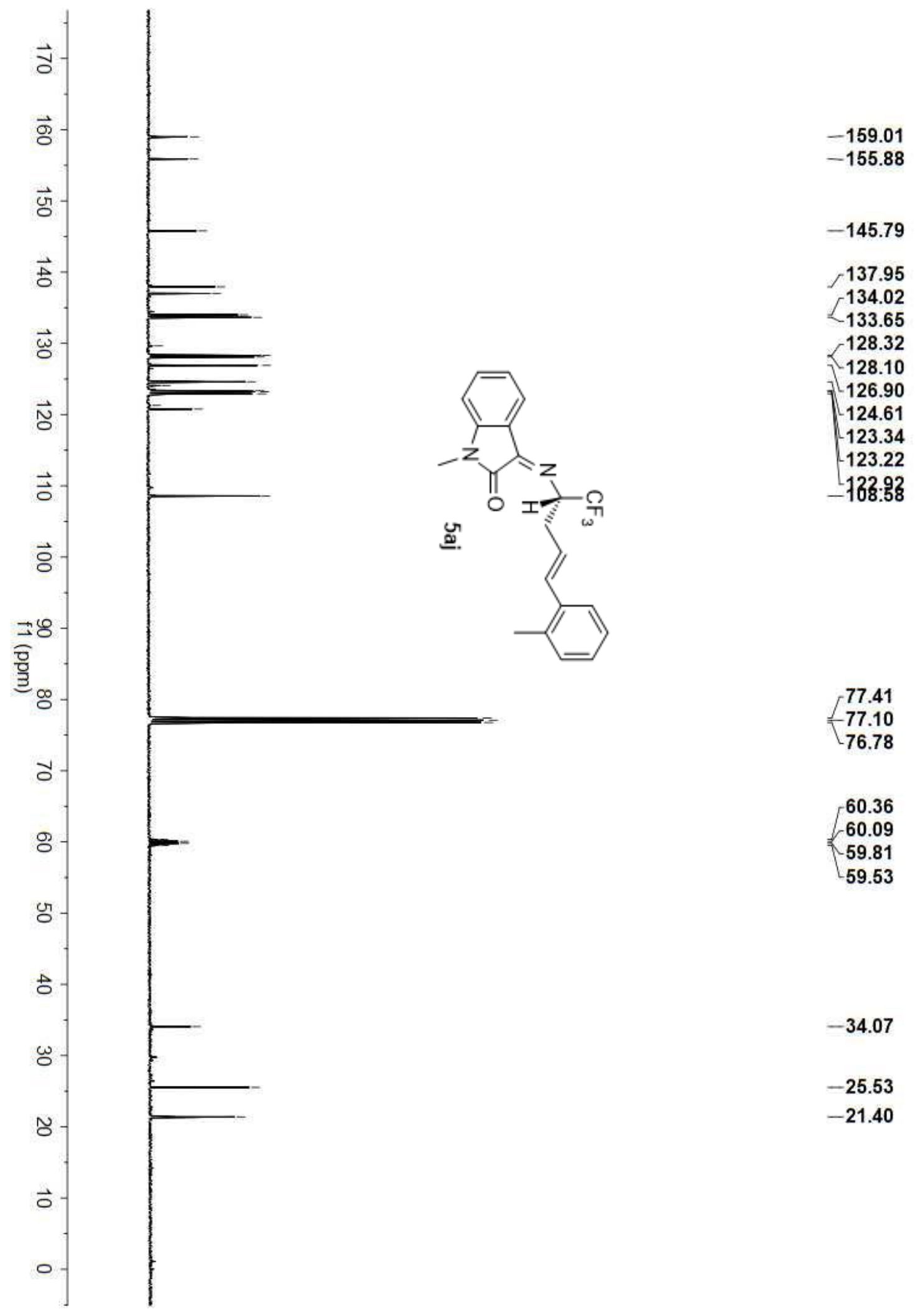



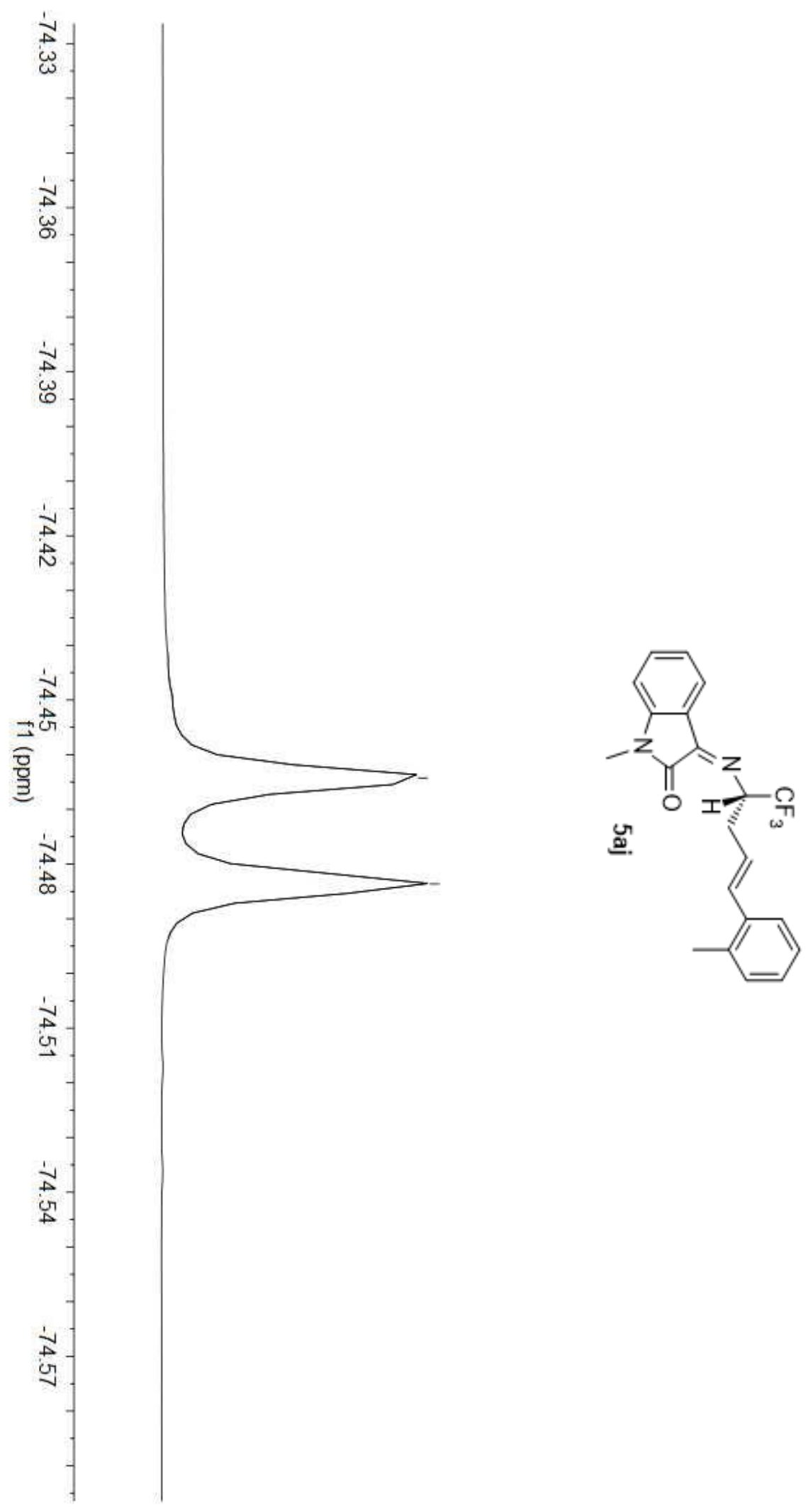

-.74 .464
-.74 .484

S65 


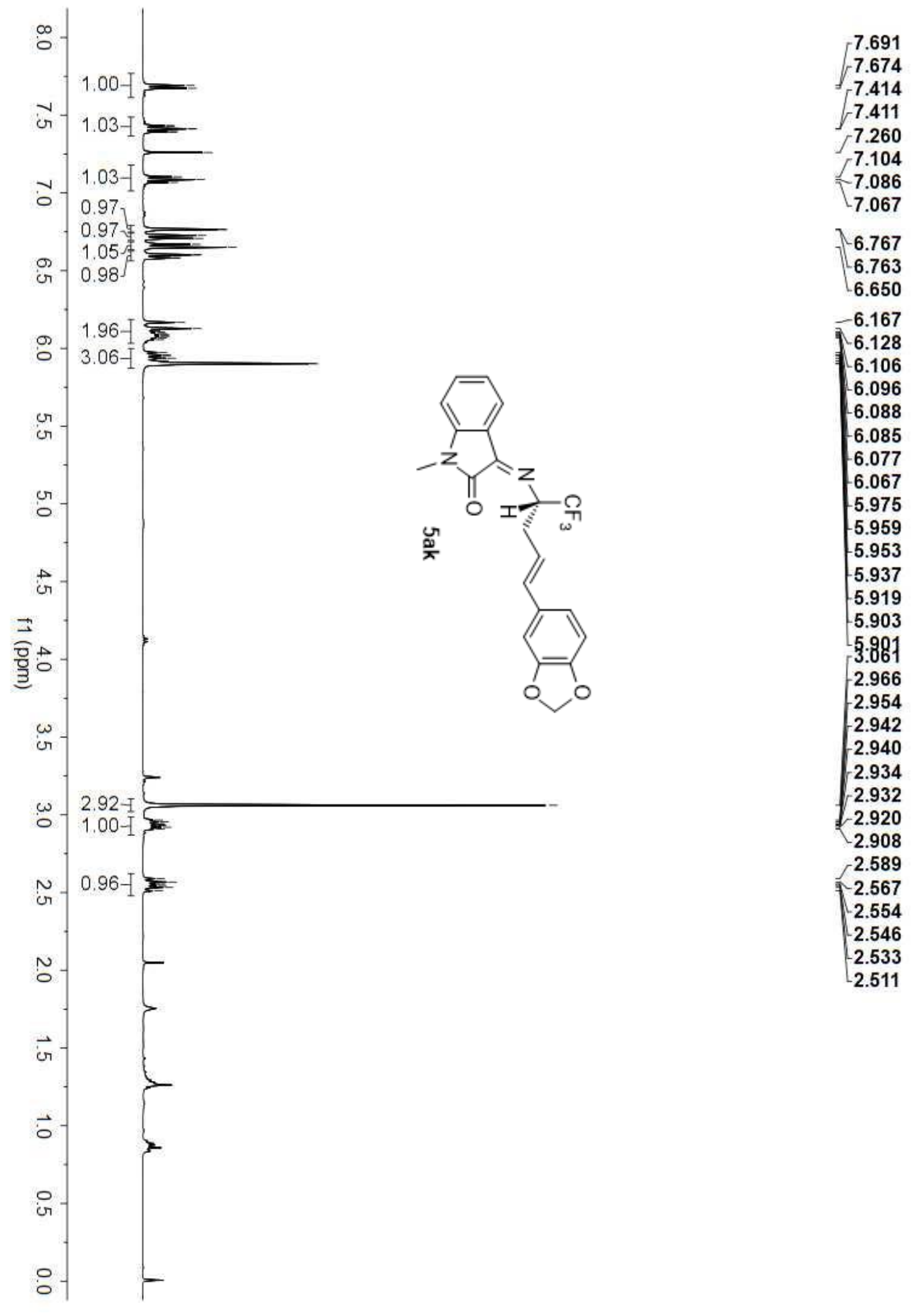




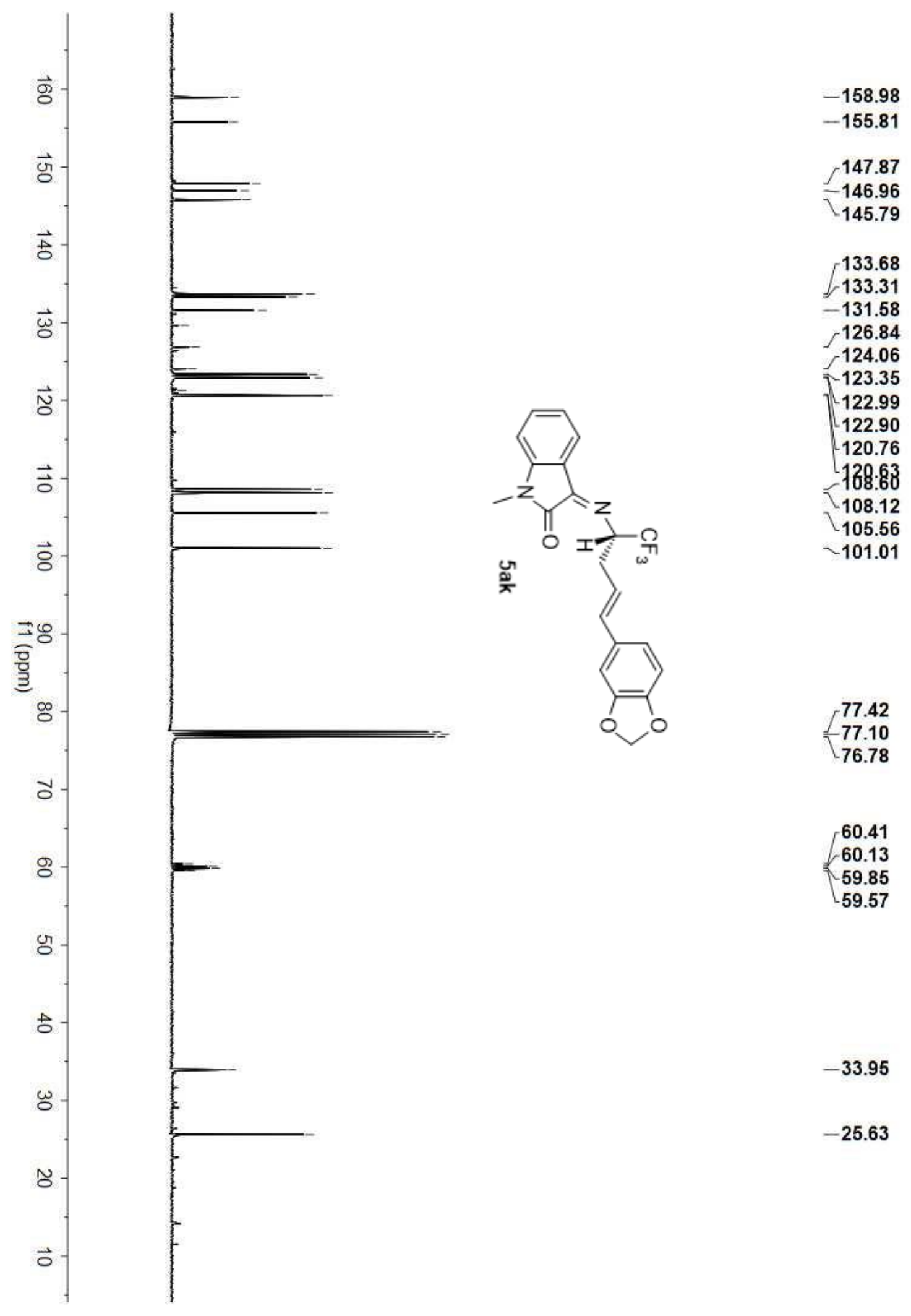



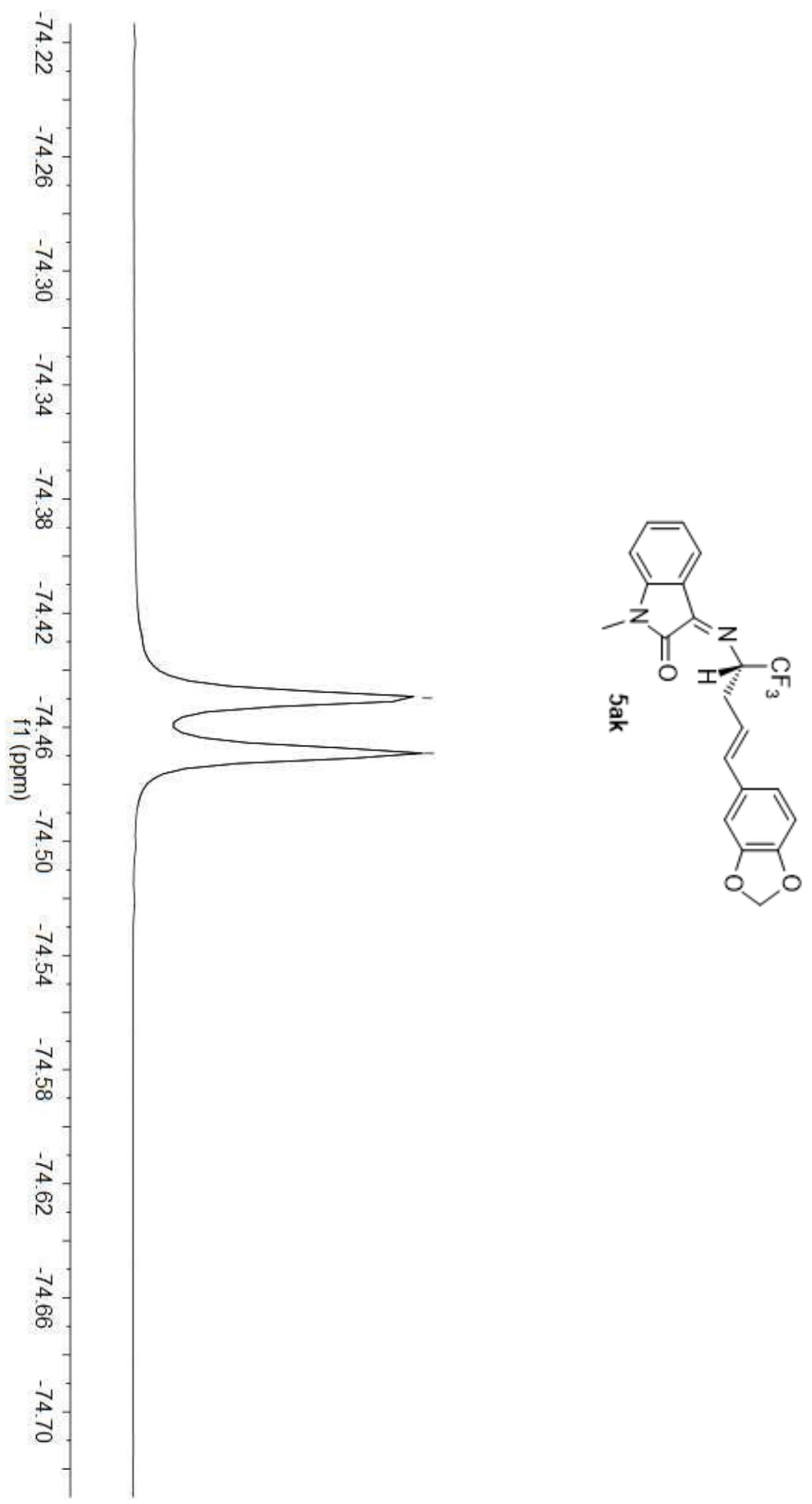

$--74.450$

$-.74 .469$

S68 


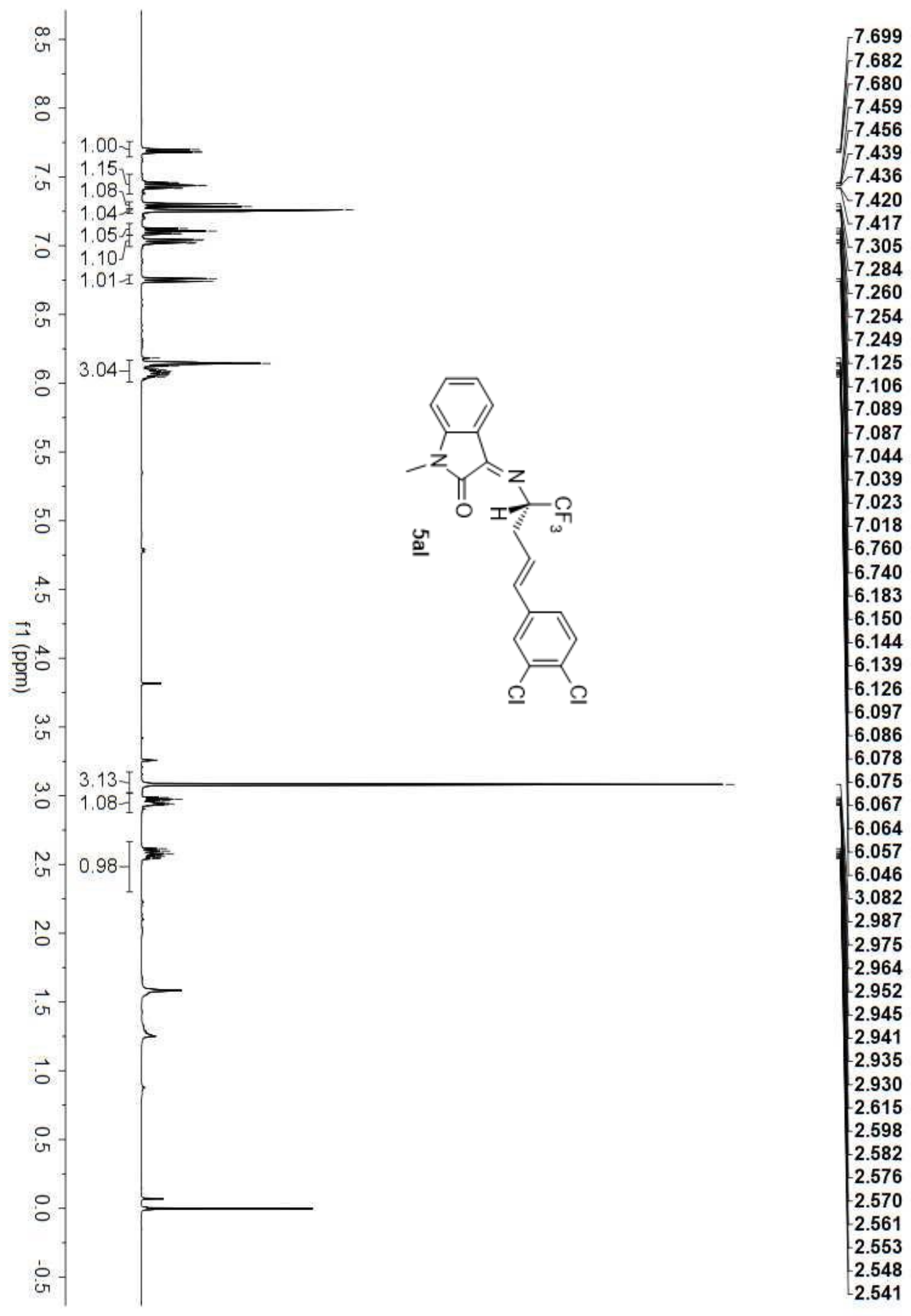




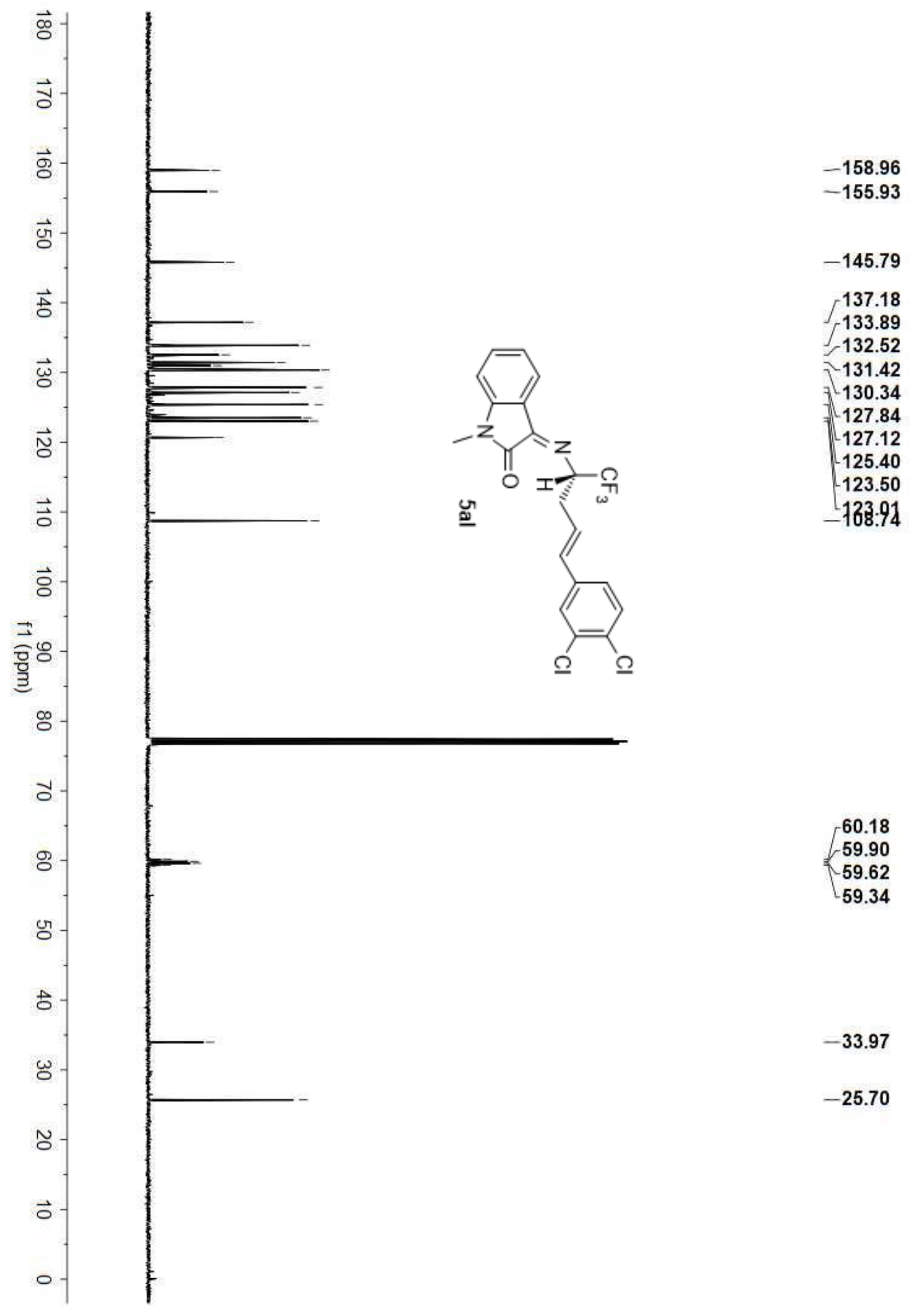



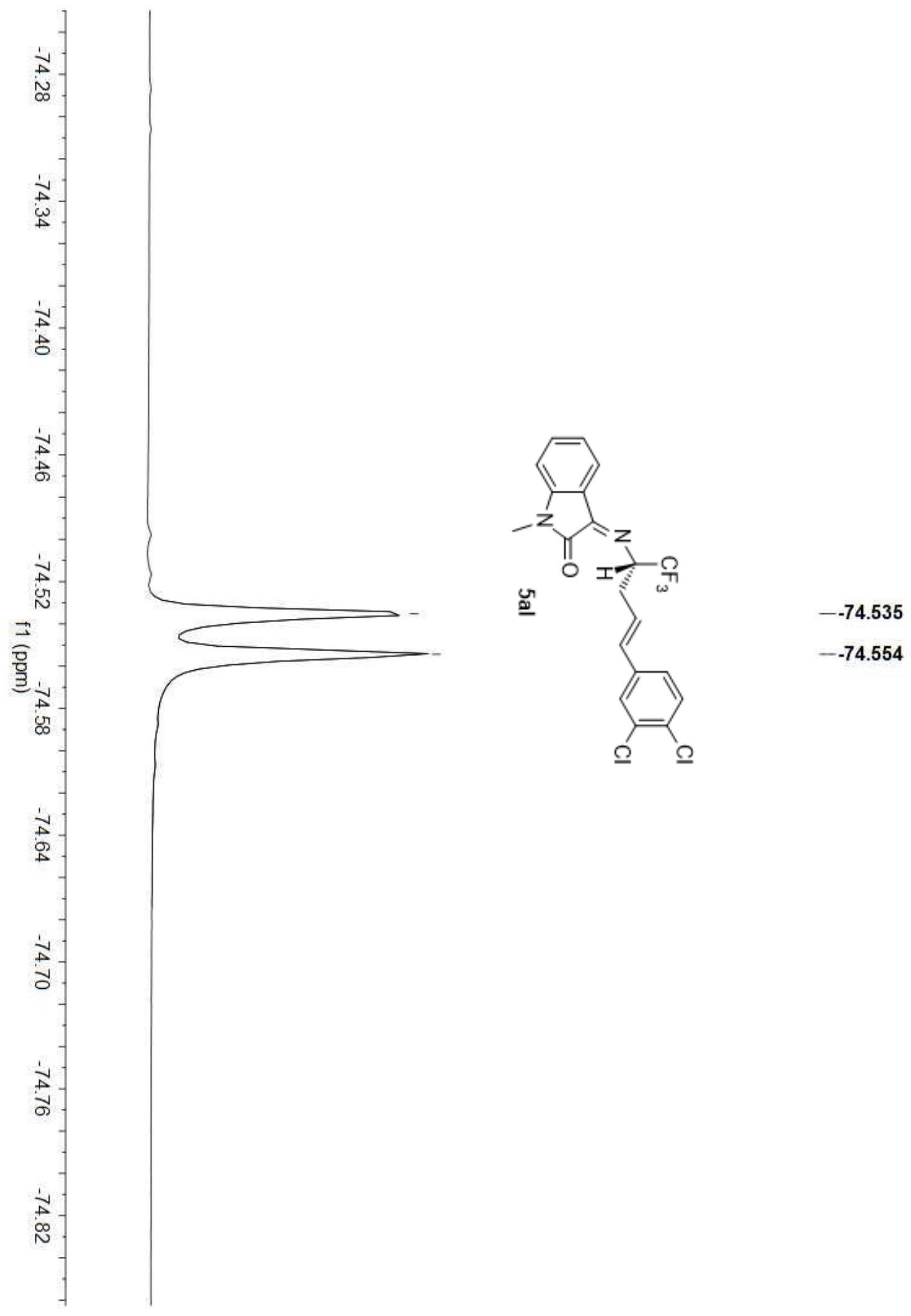


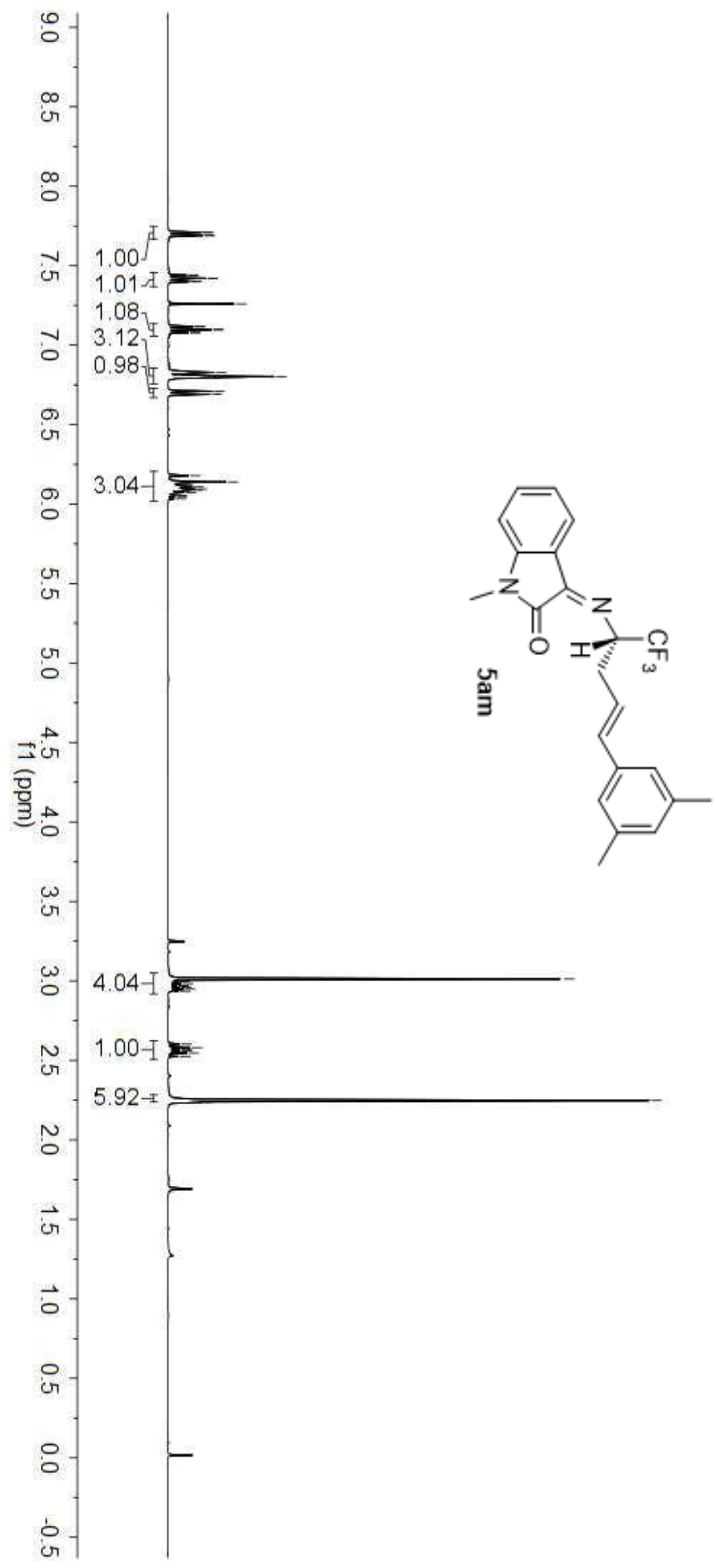




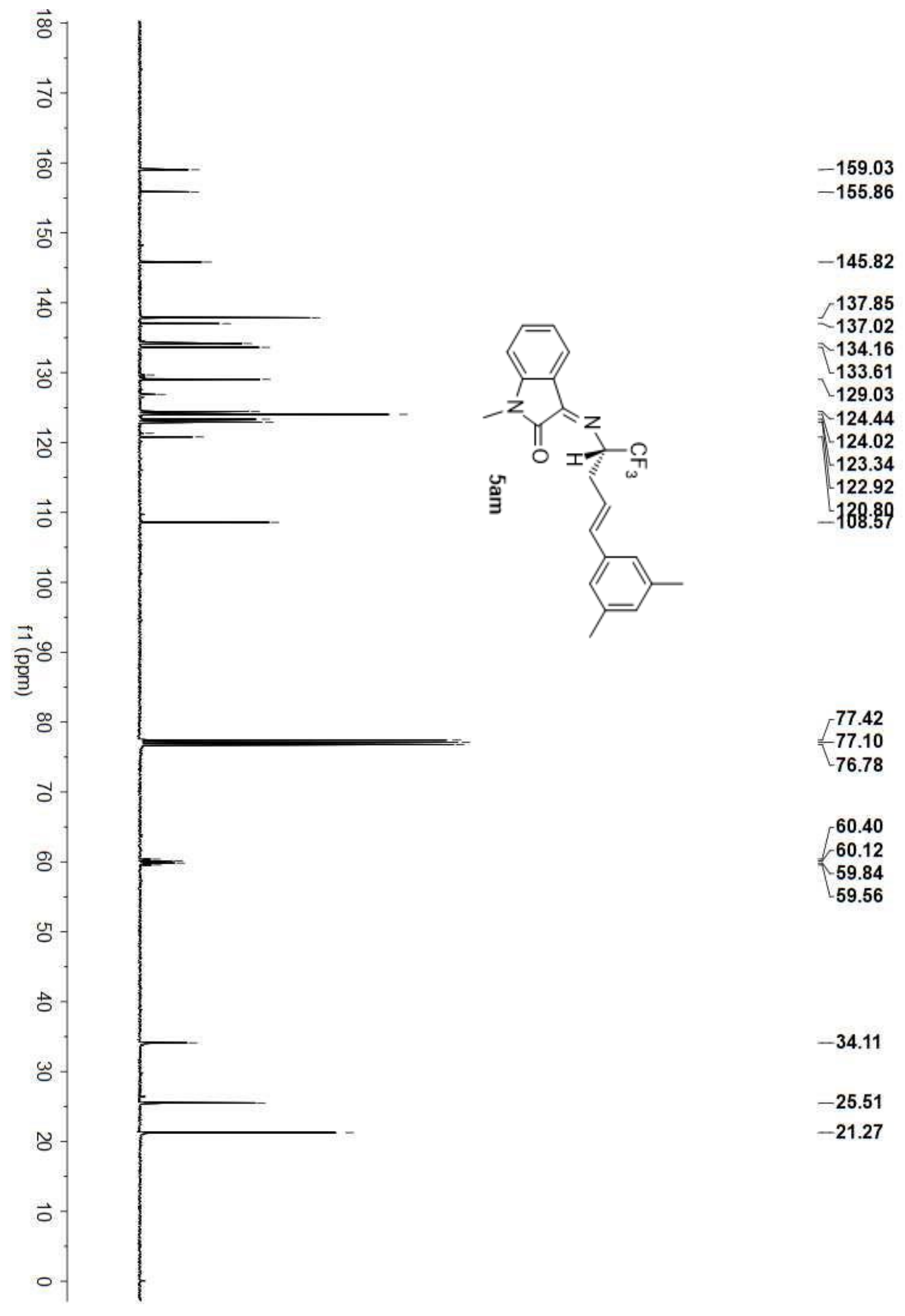




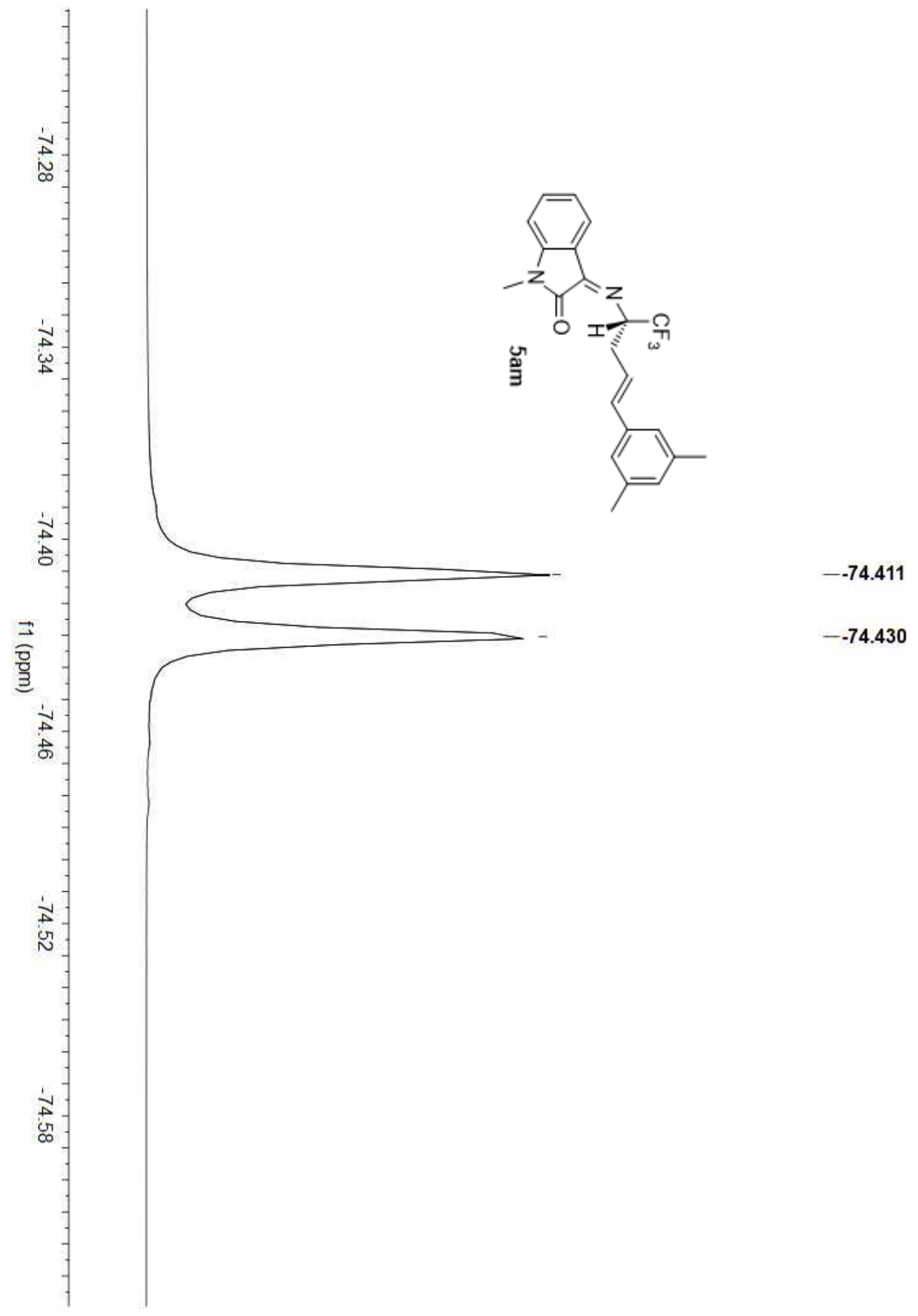




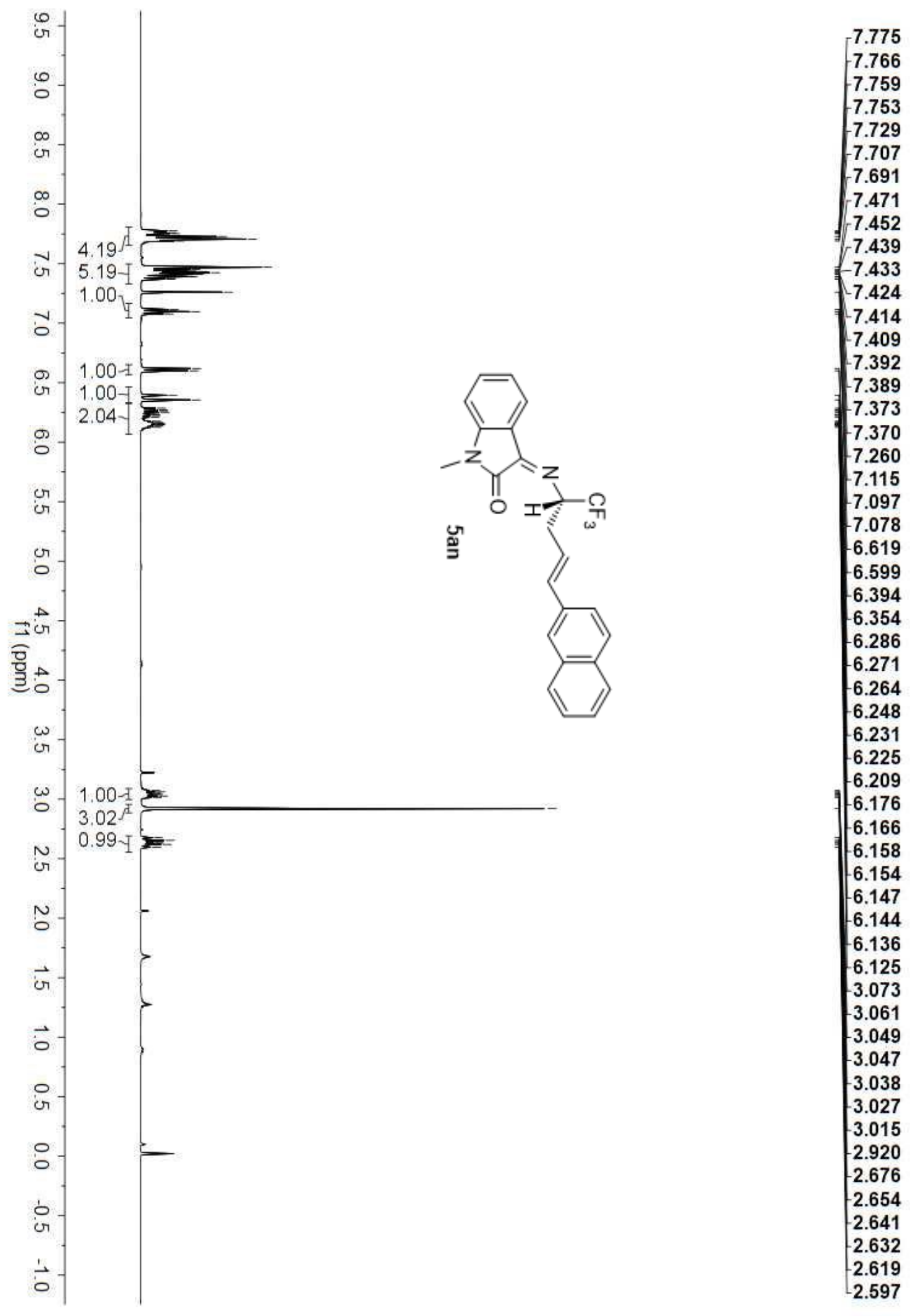




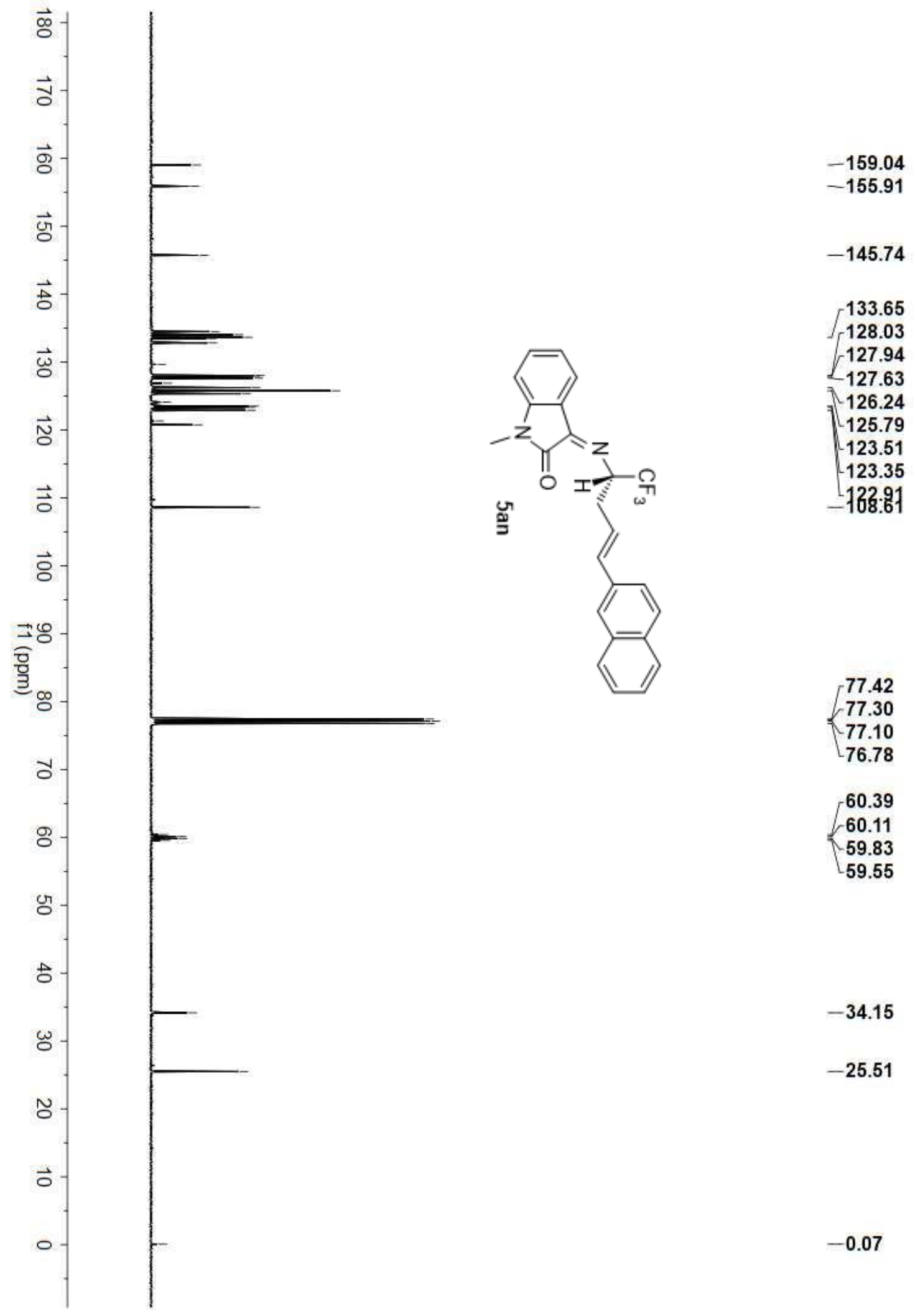



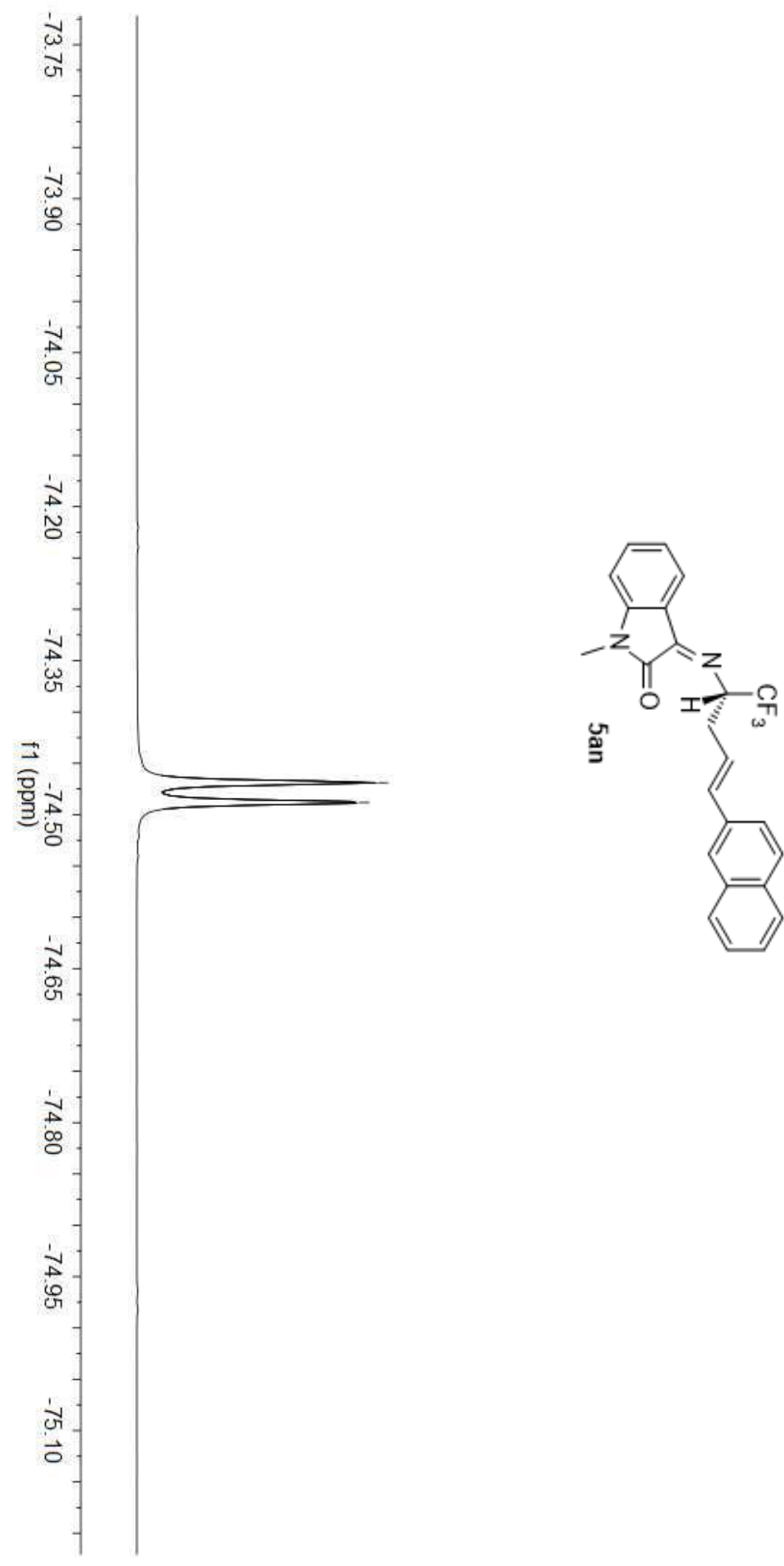

-74.469
--74.488 


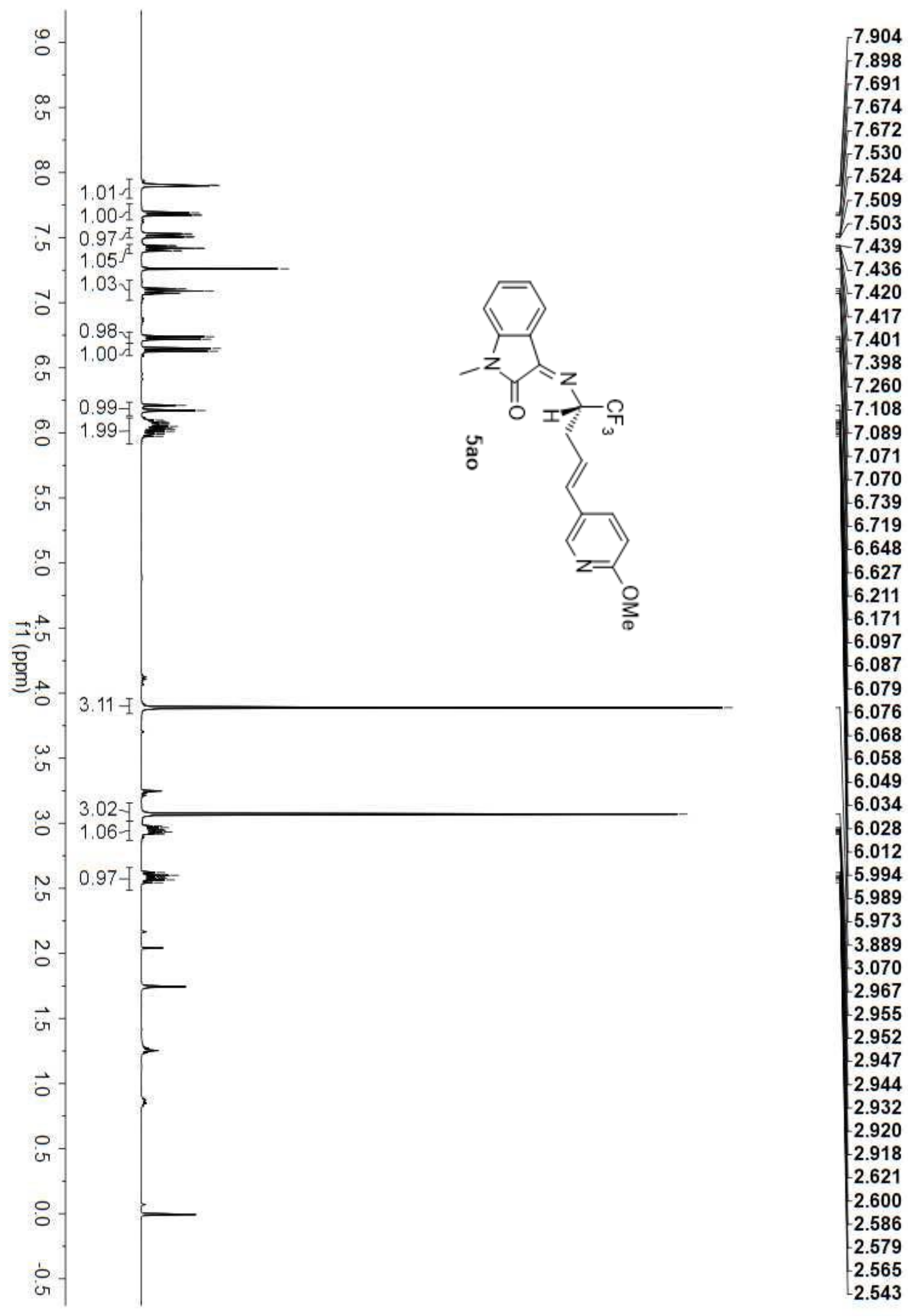




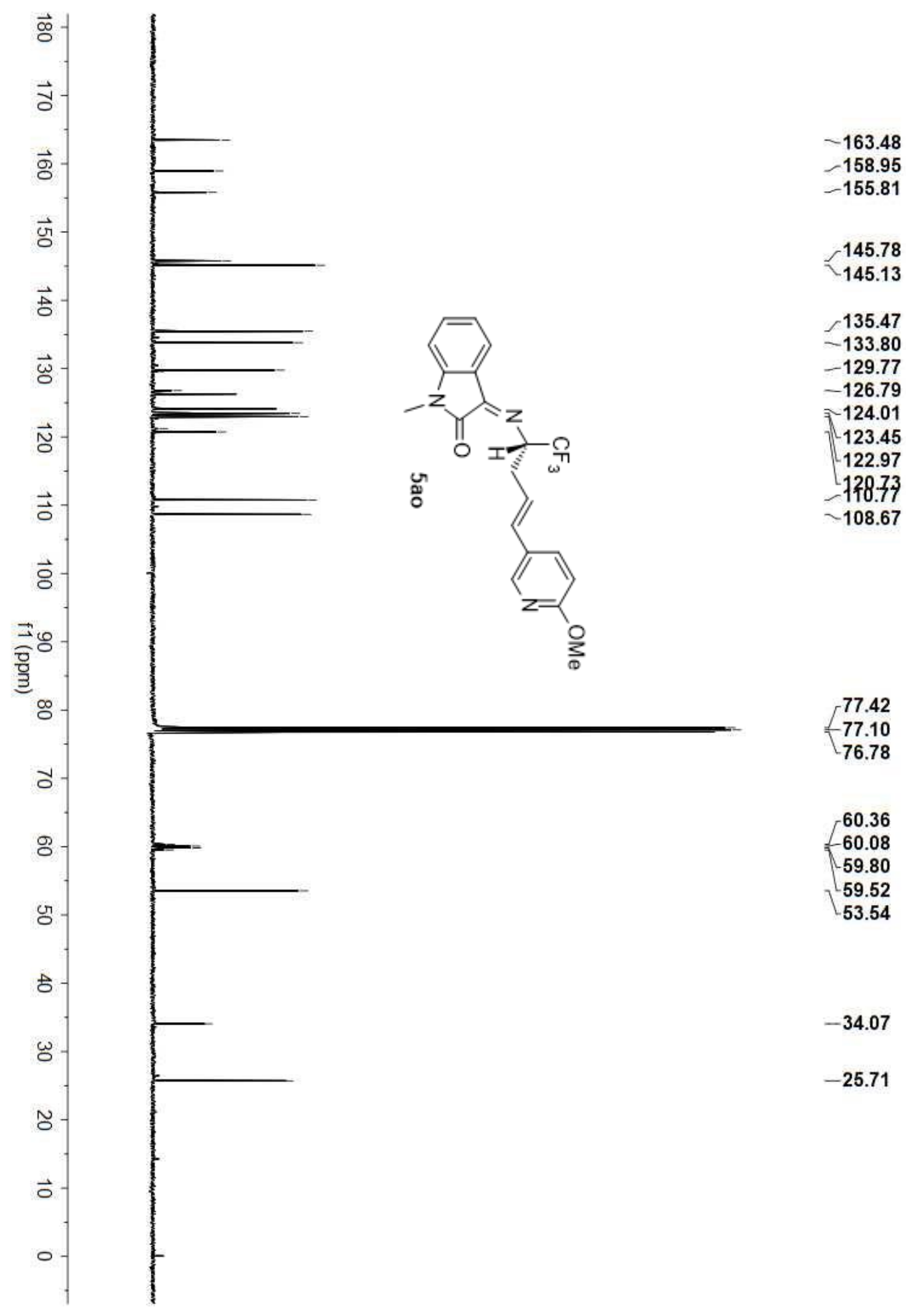




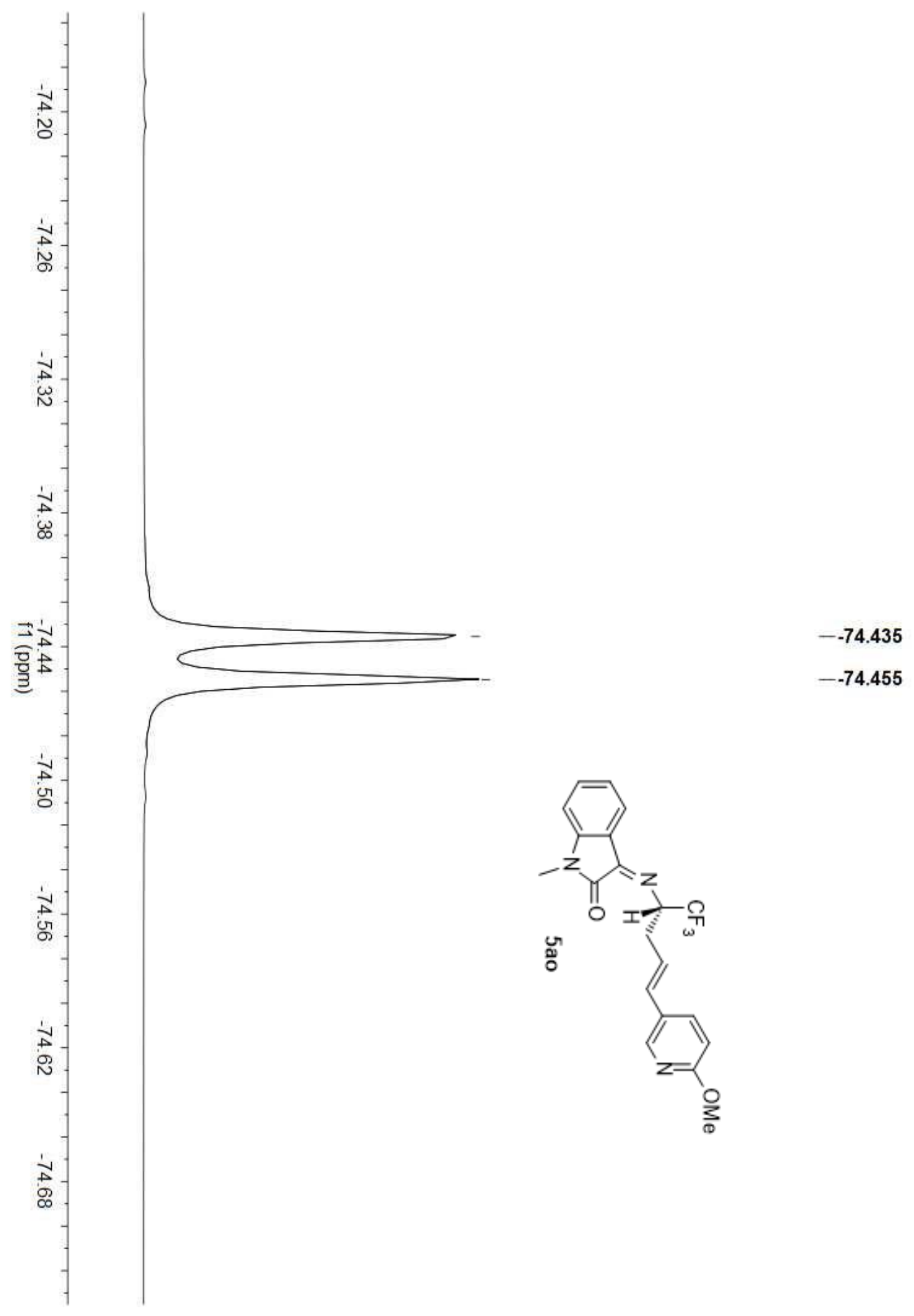




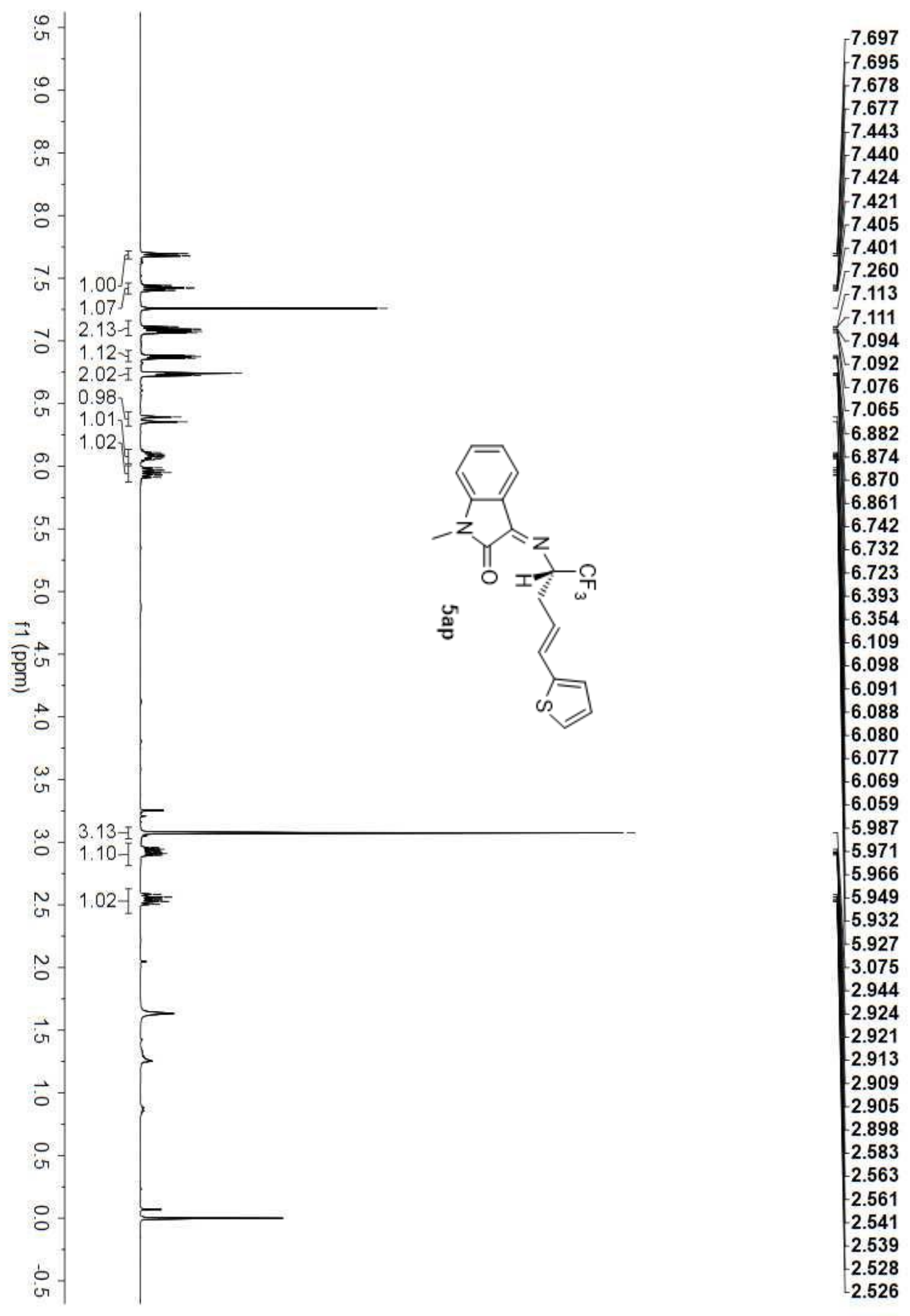




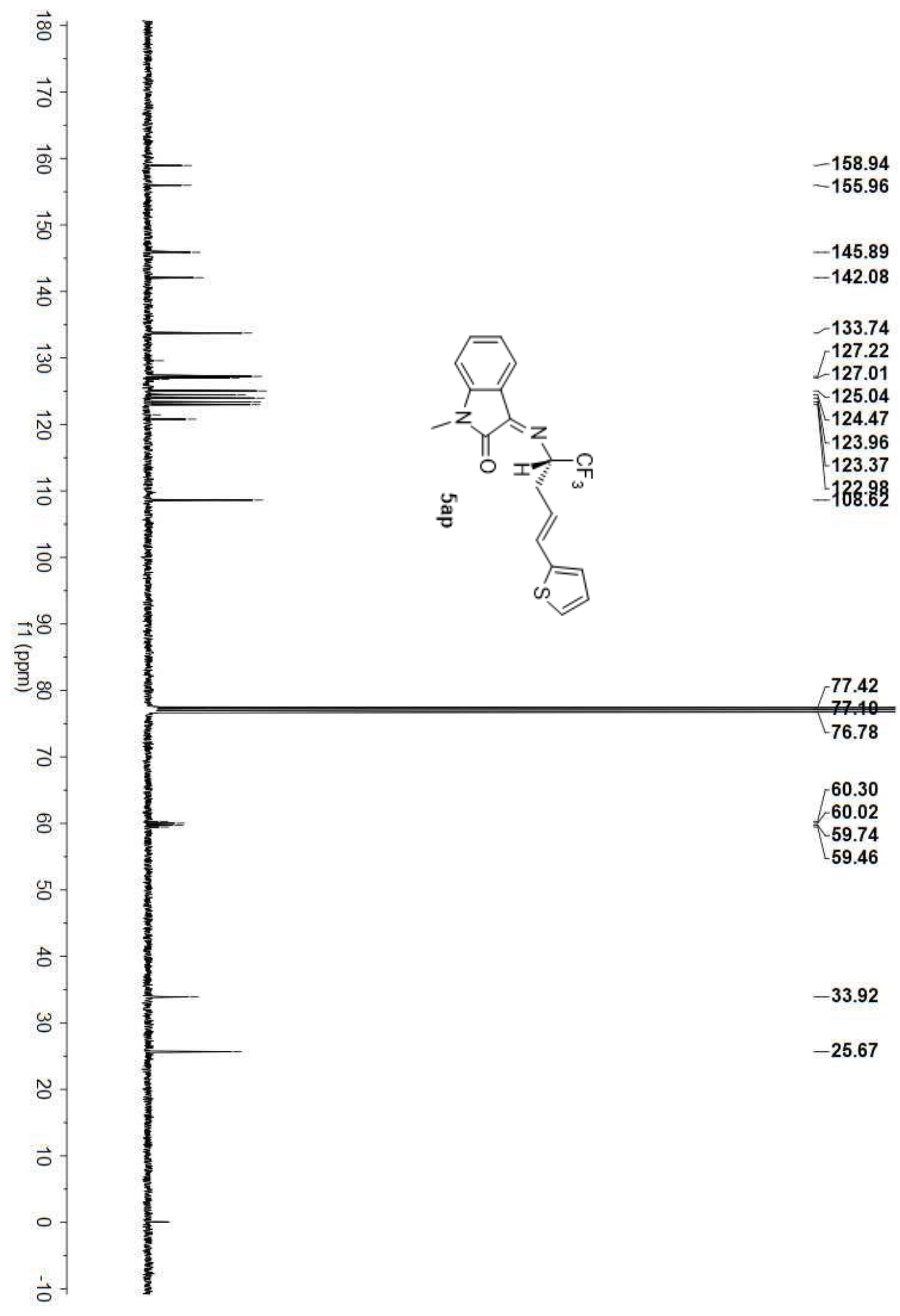




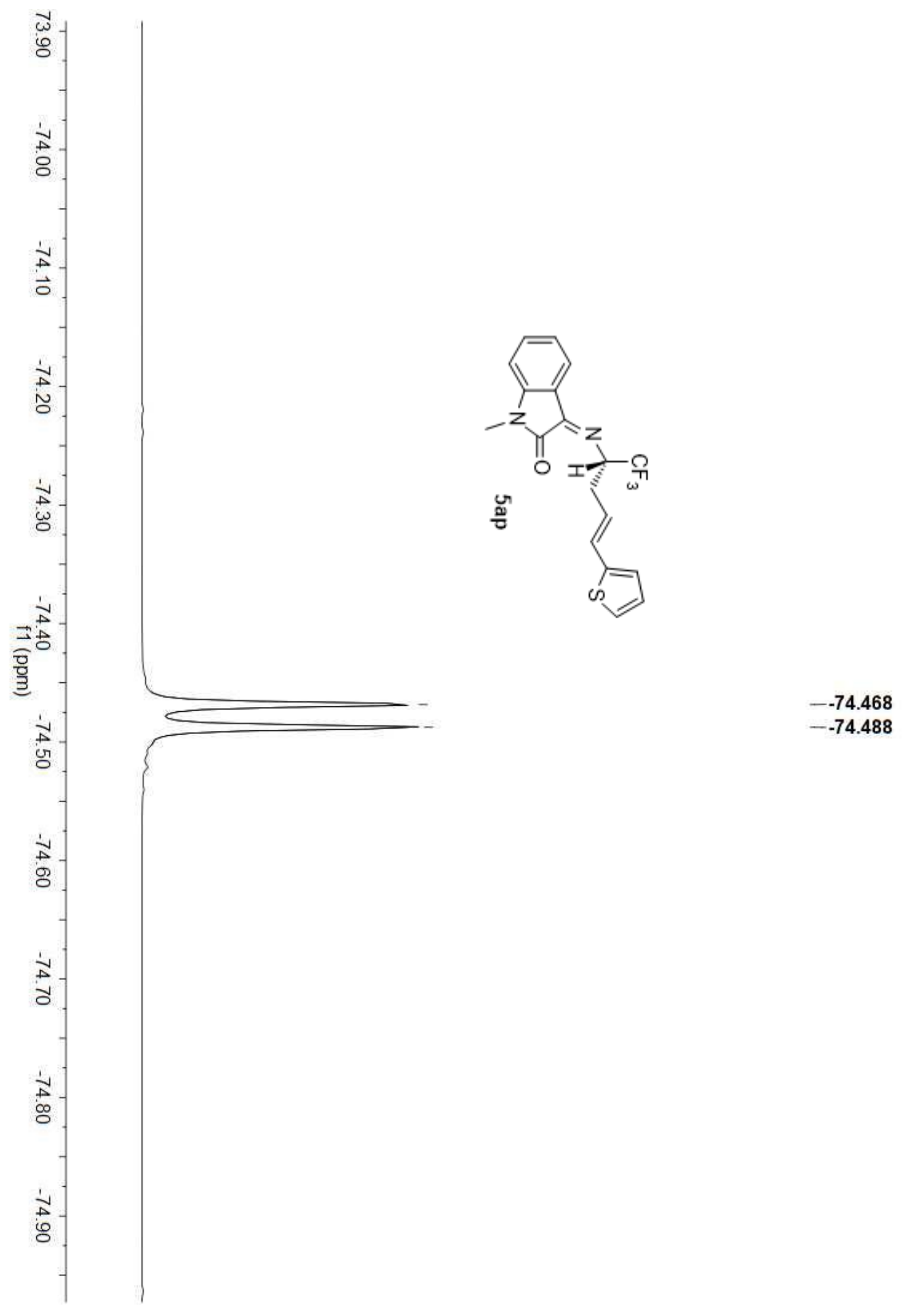




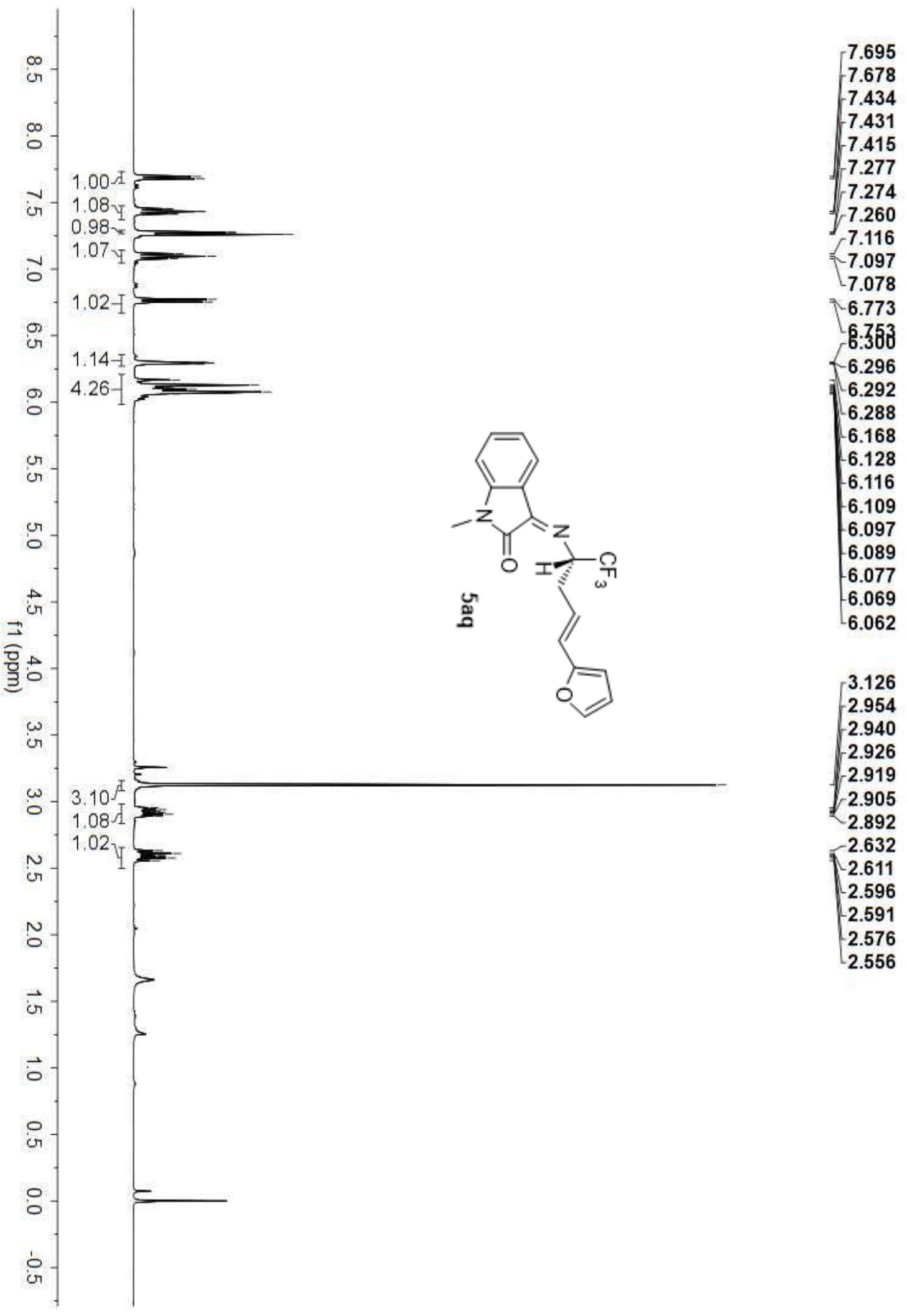




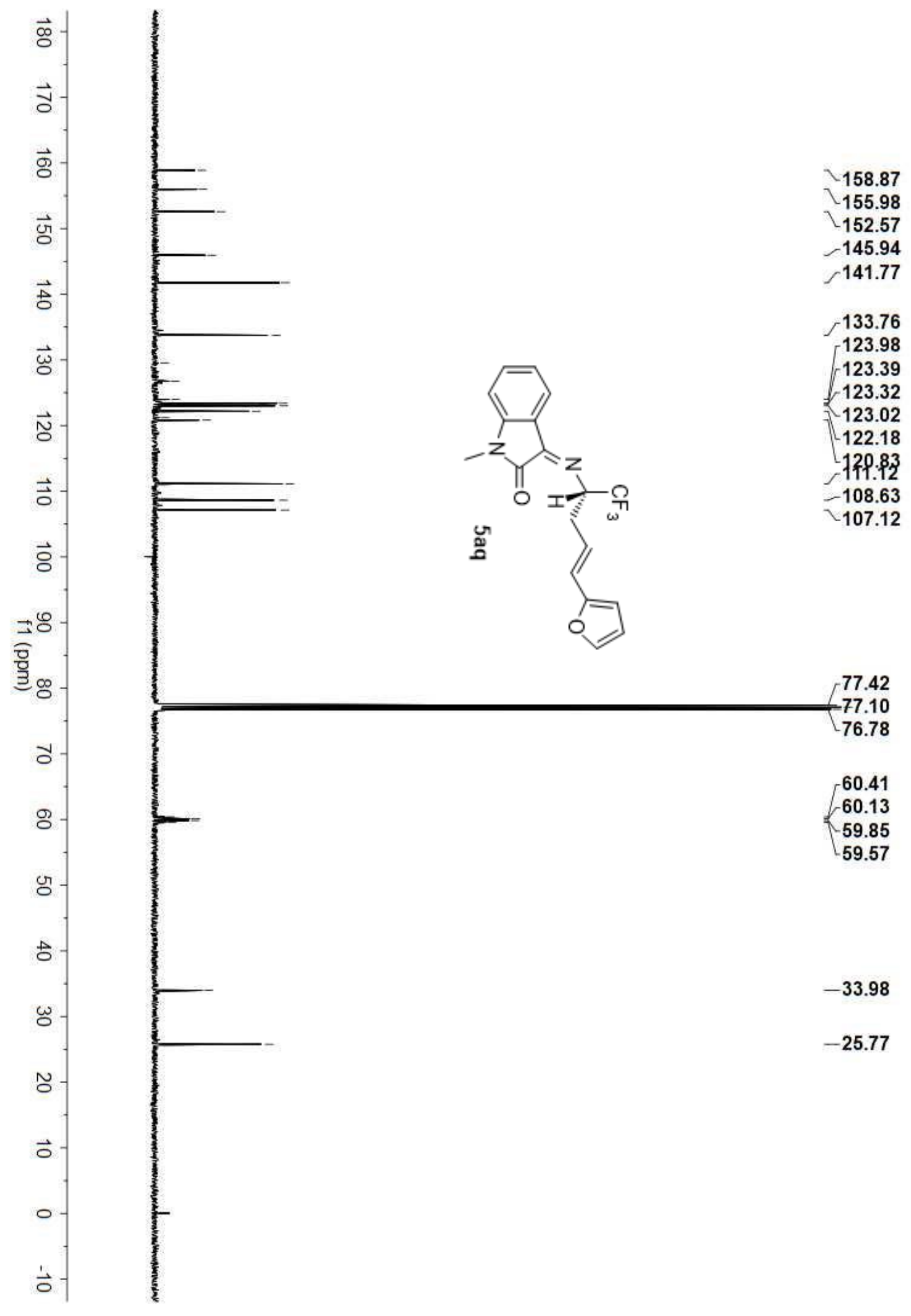




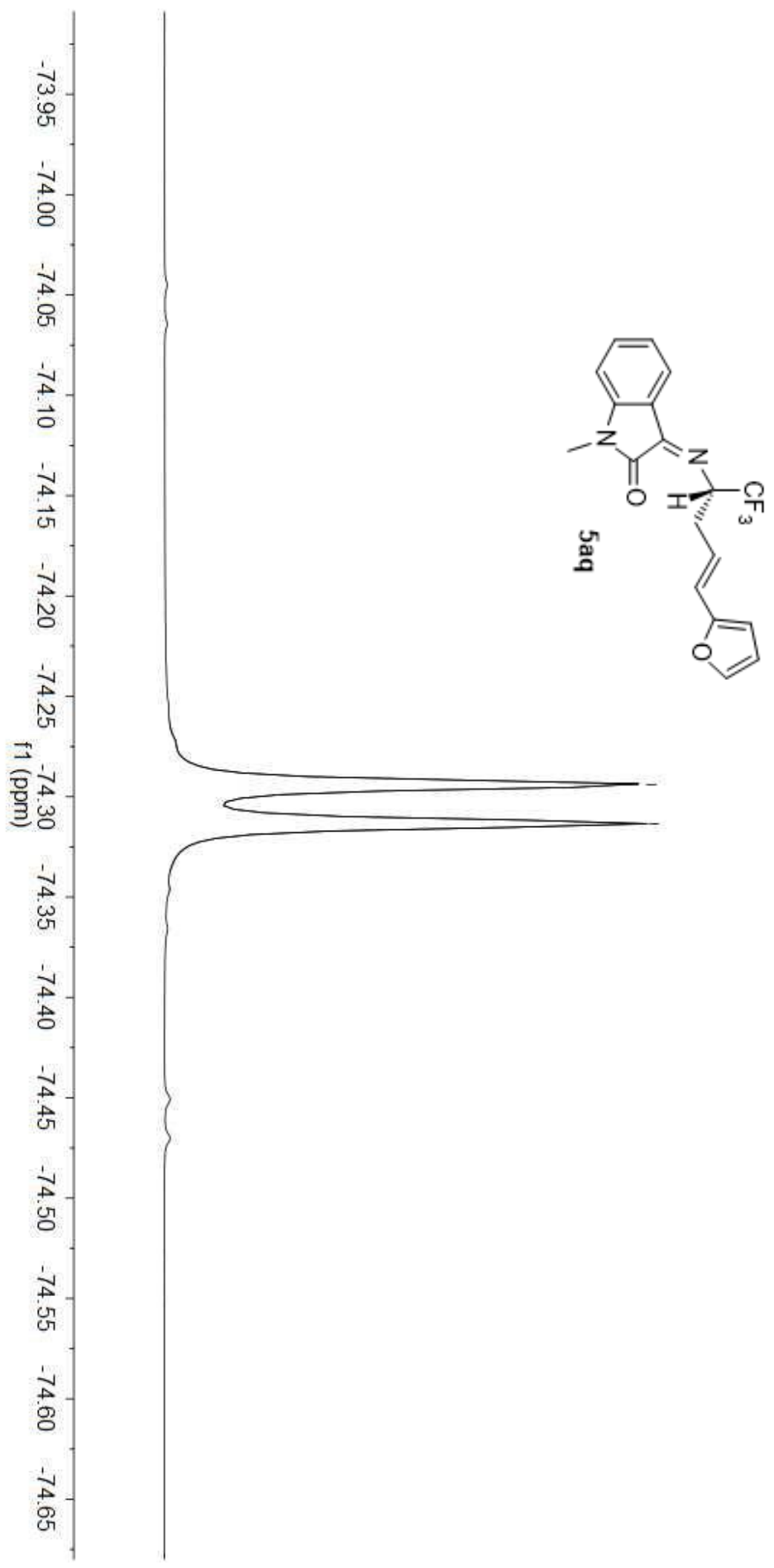

$--74.294$

$-.74 .313$

S86 


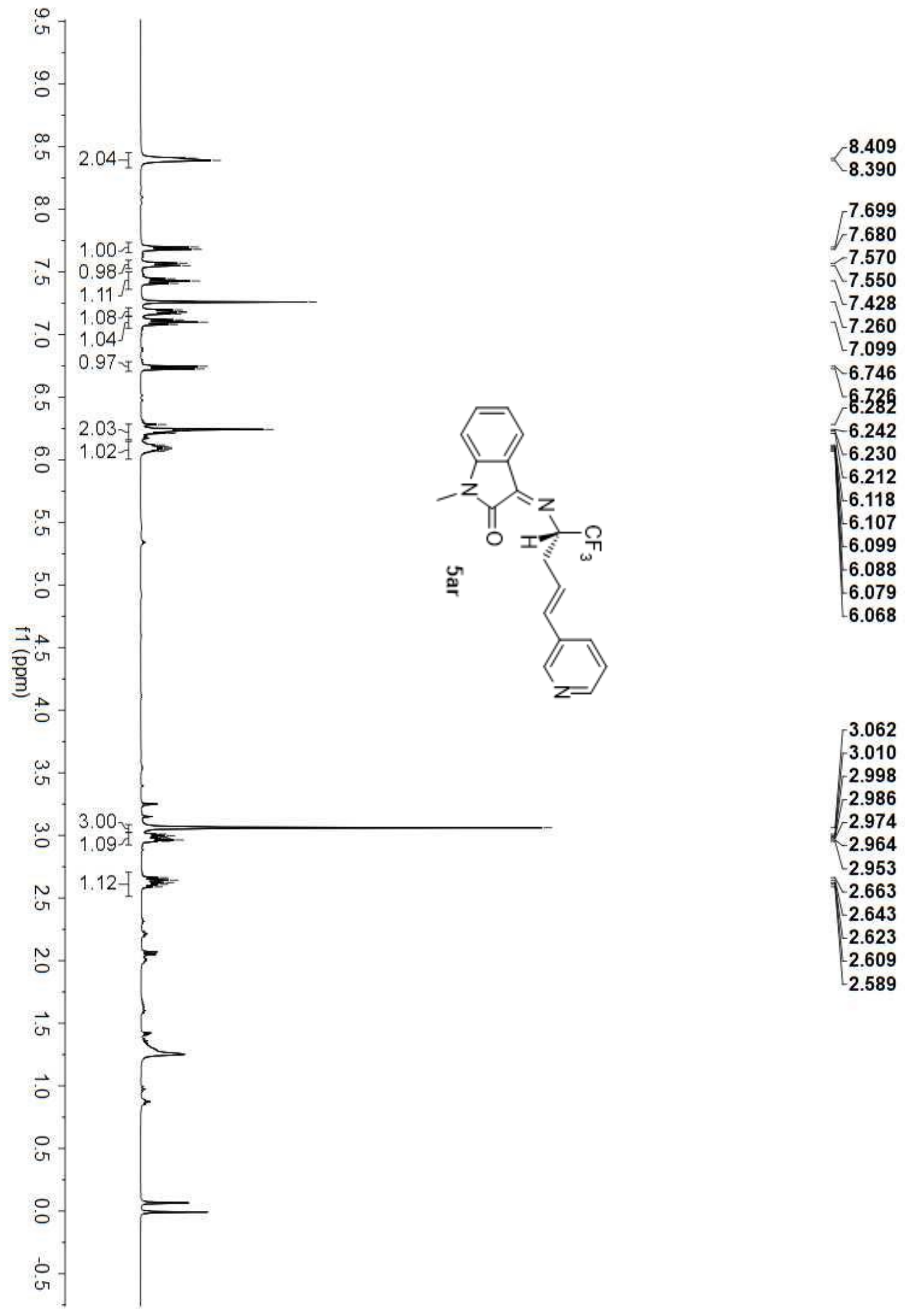




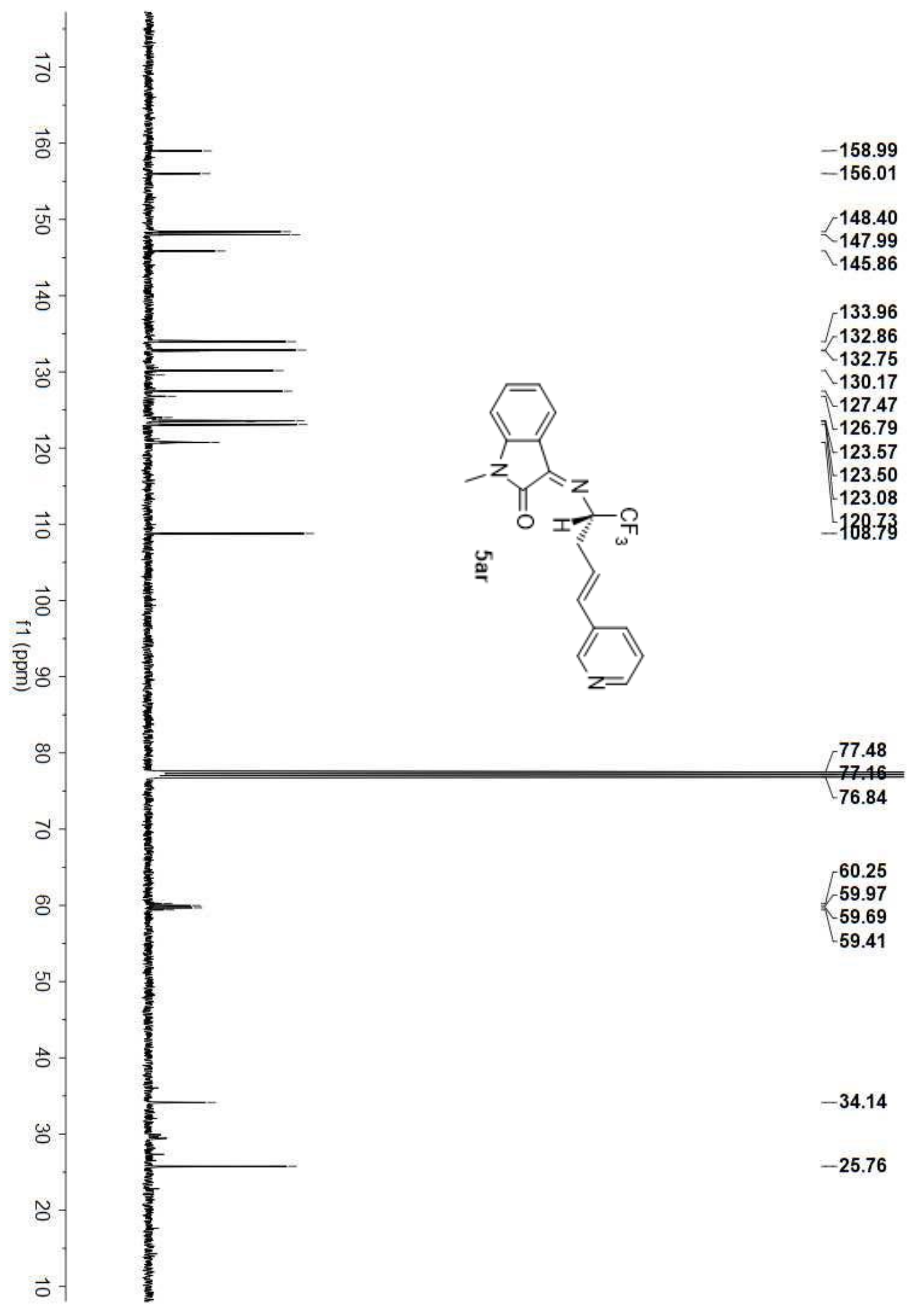



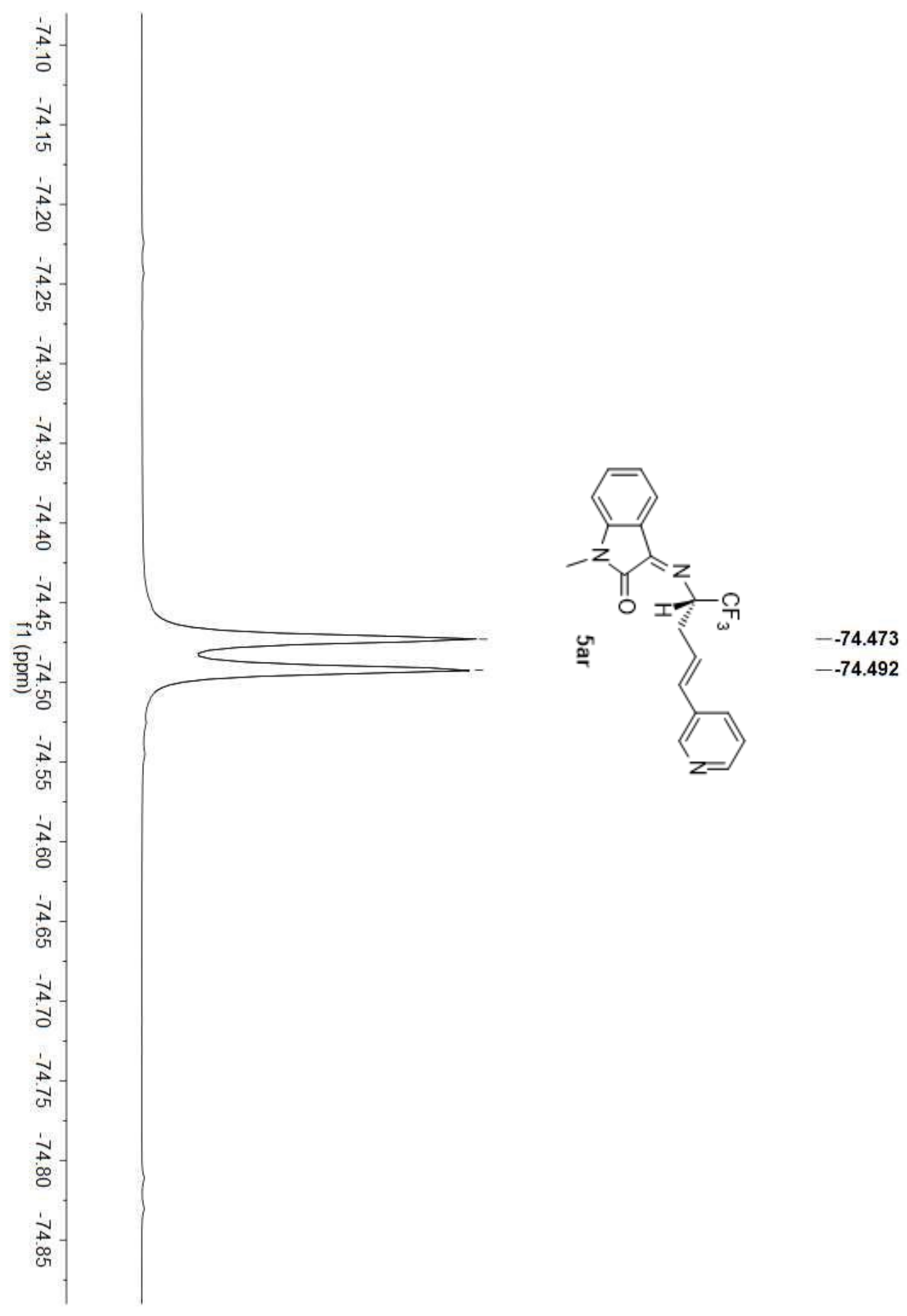


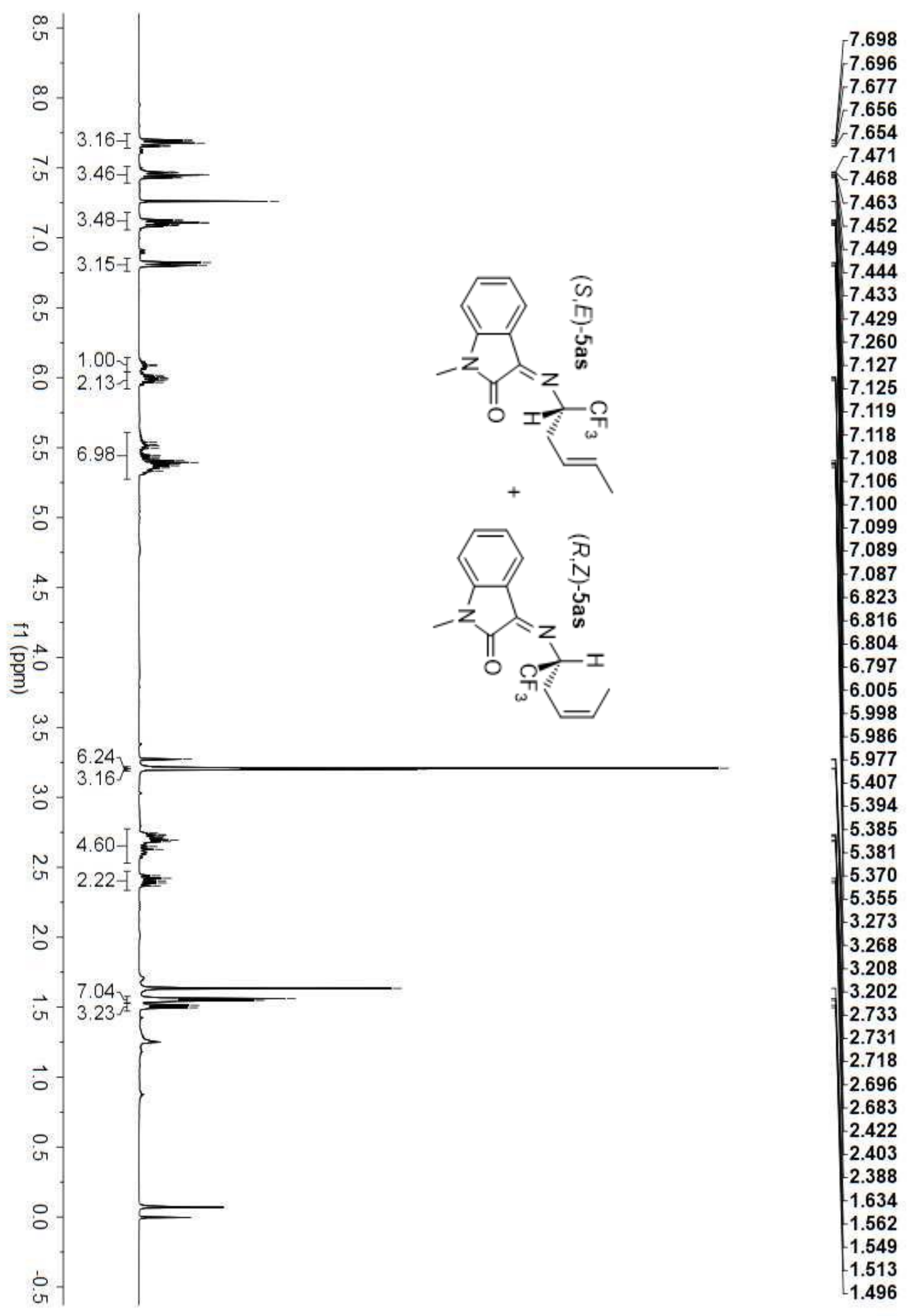




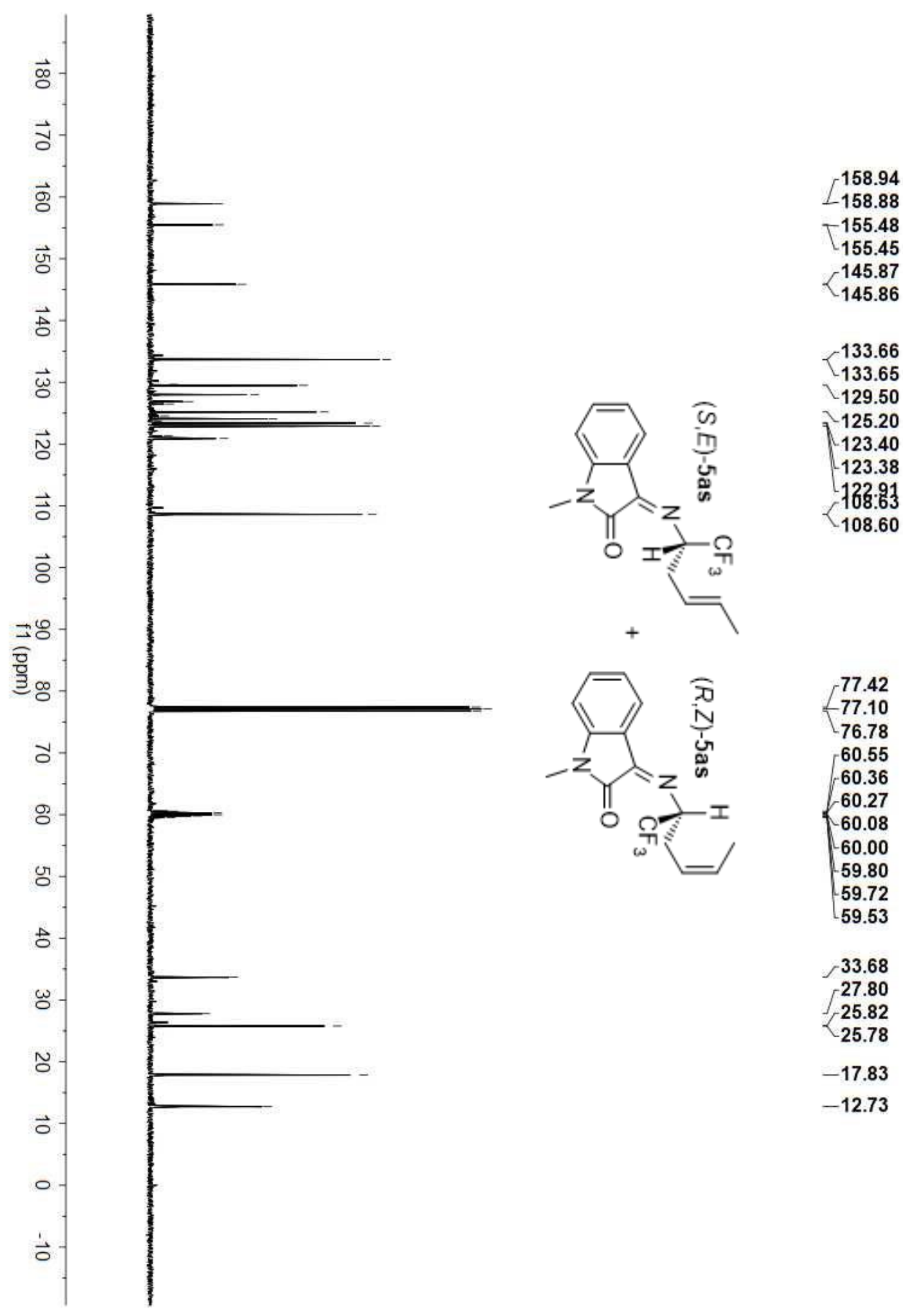



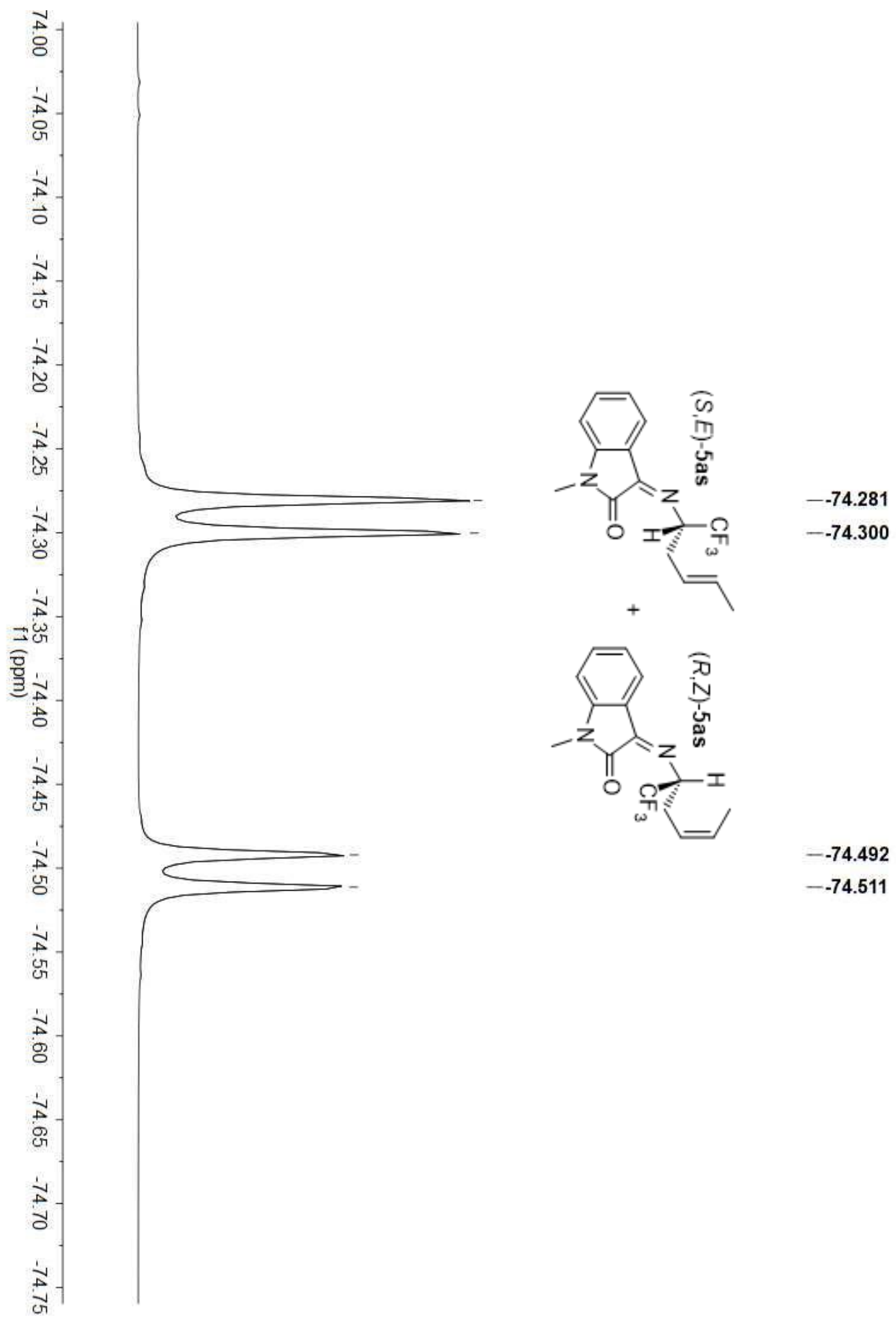


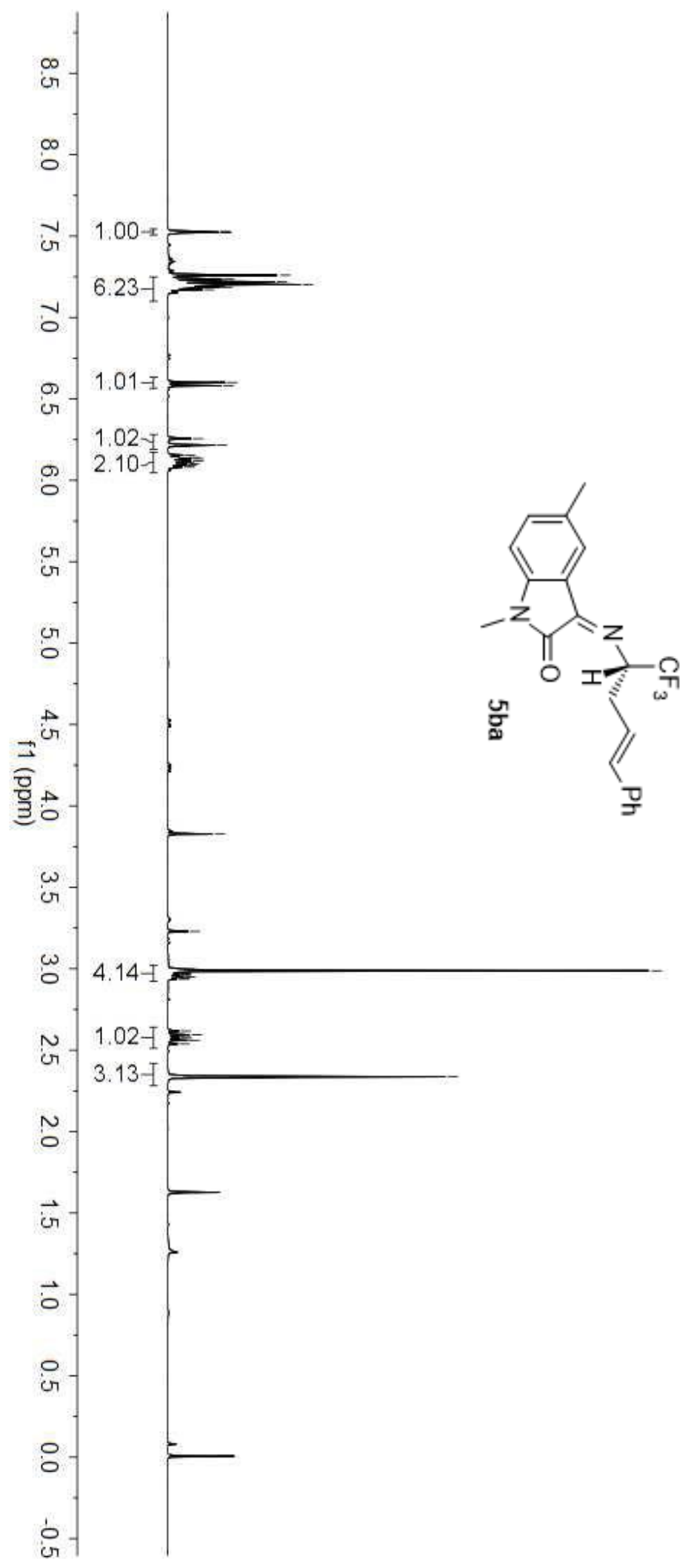




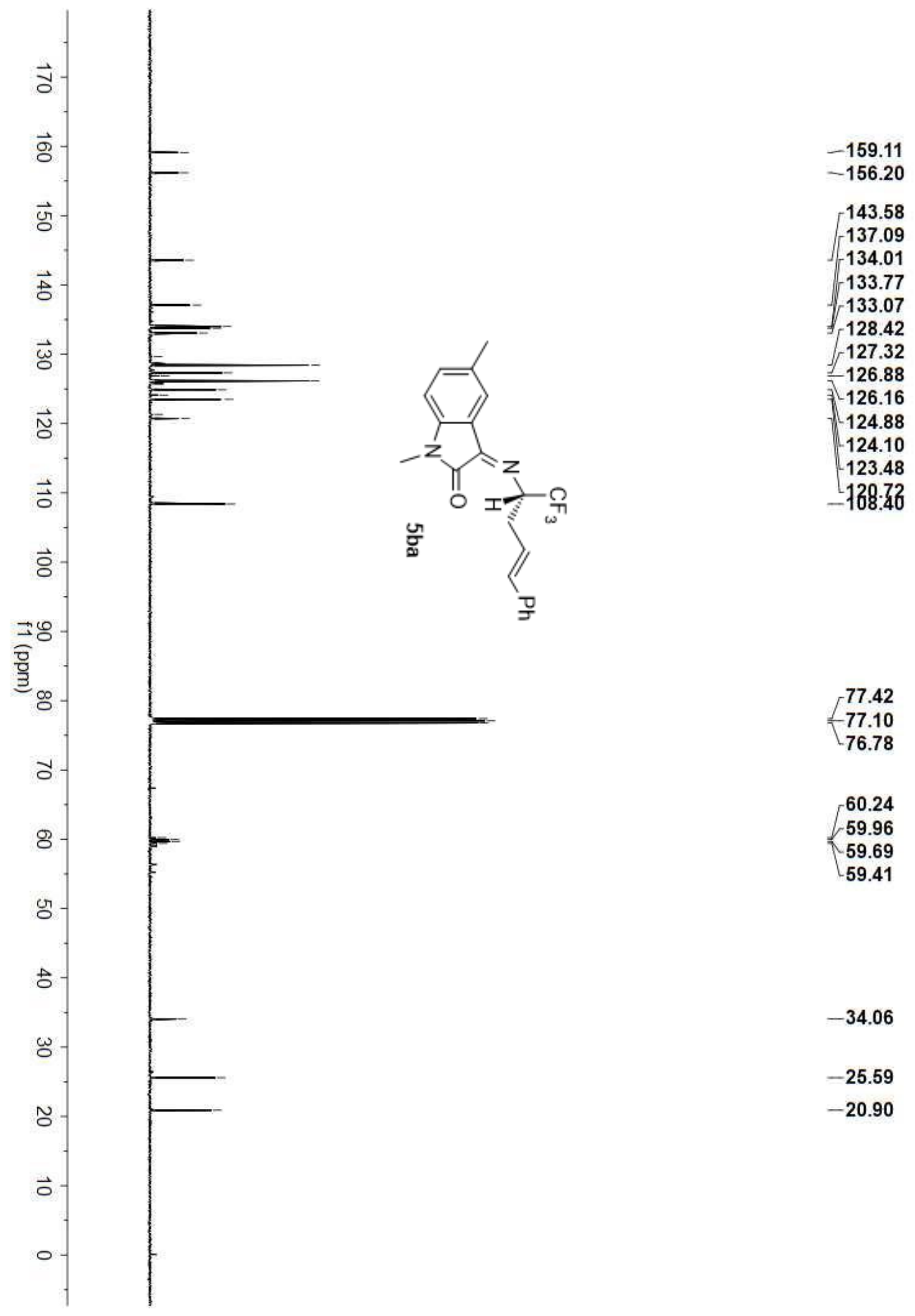




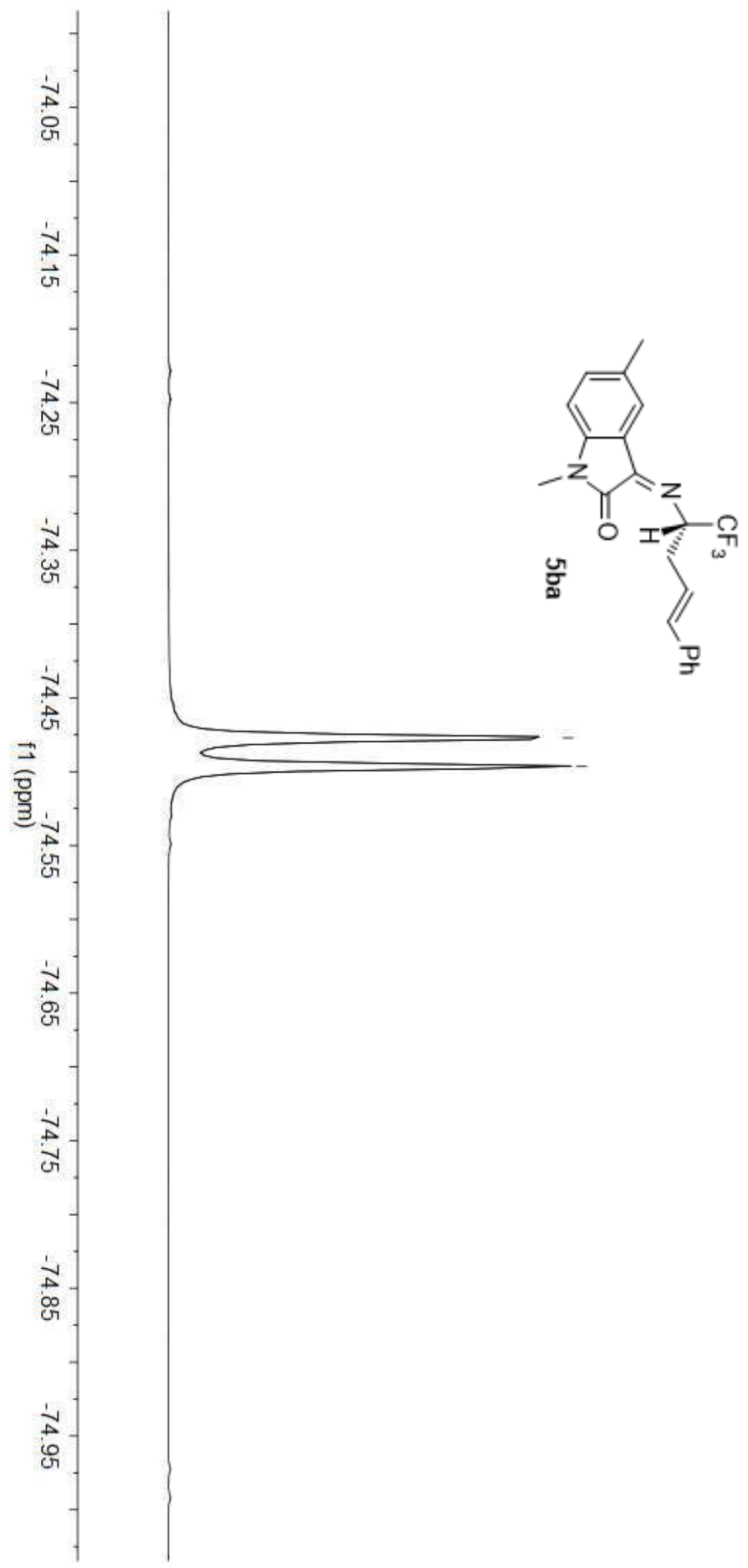




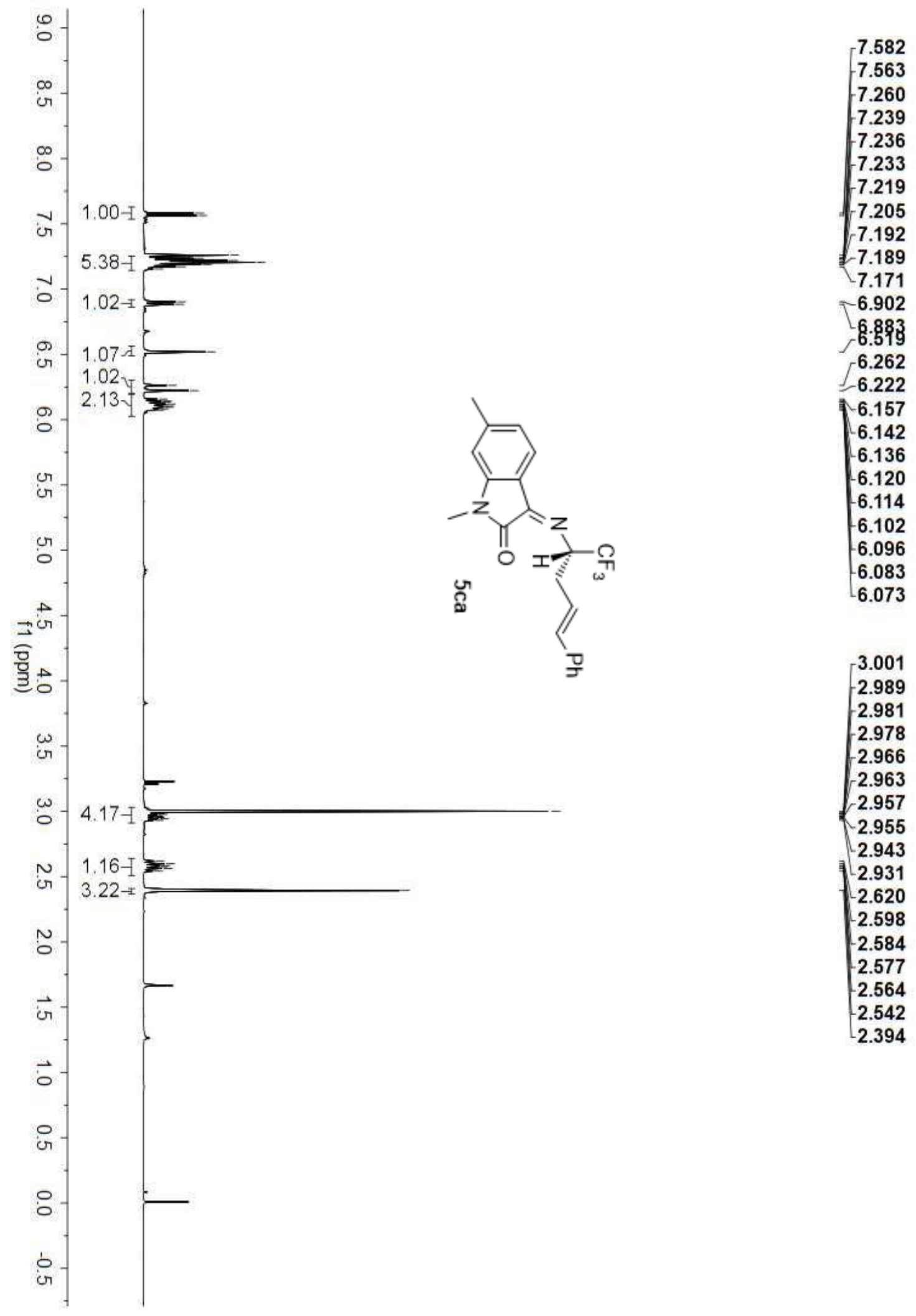




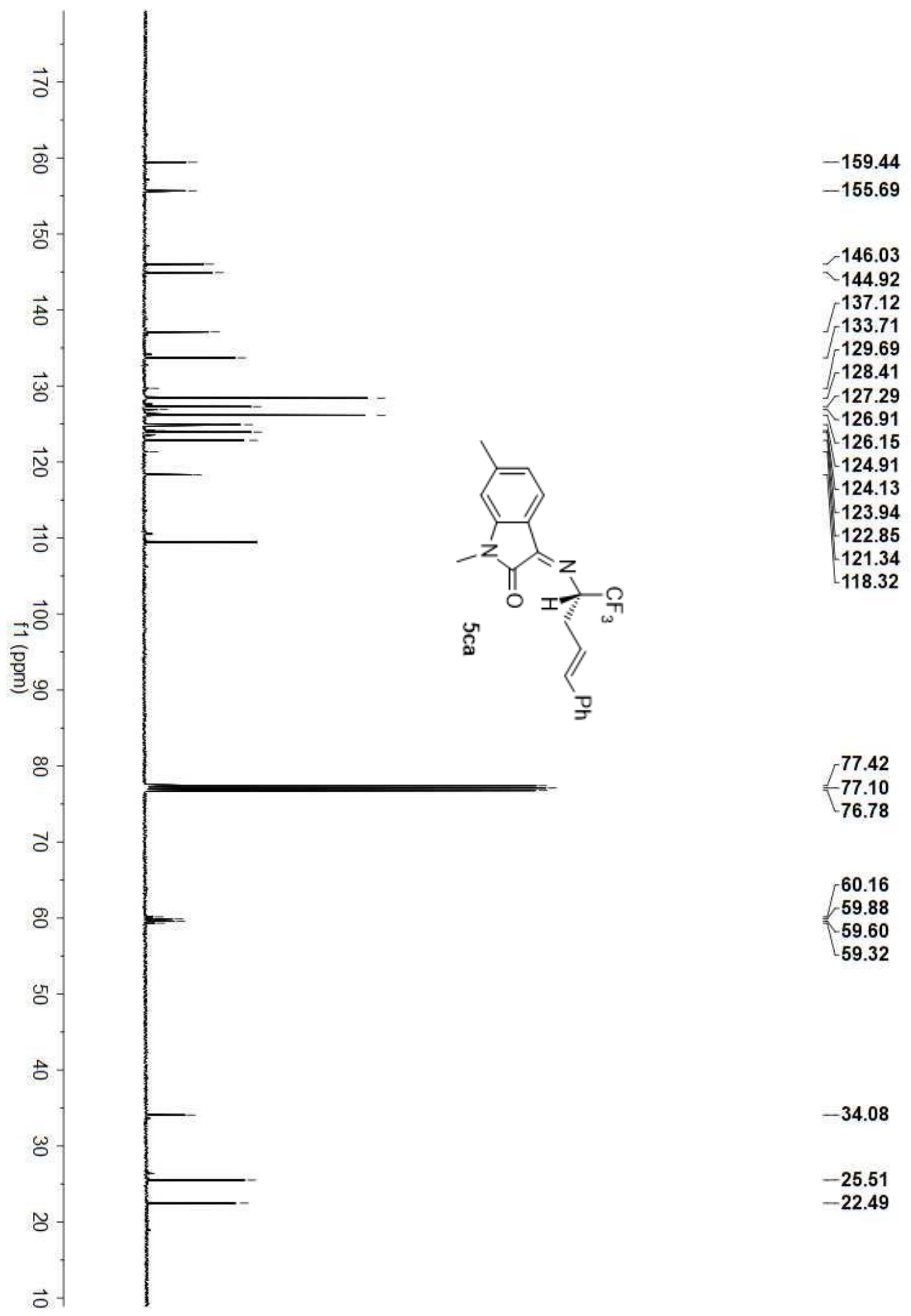




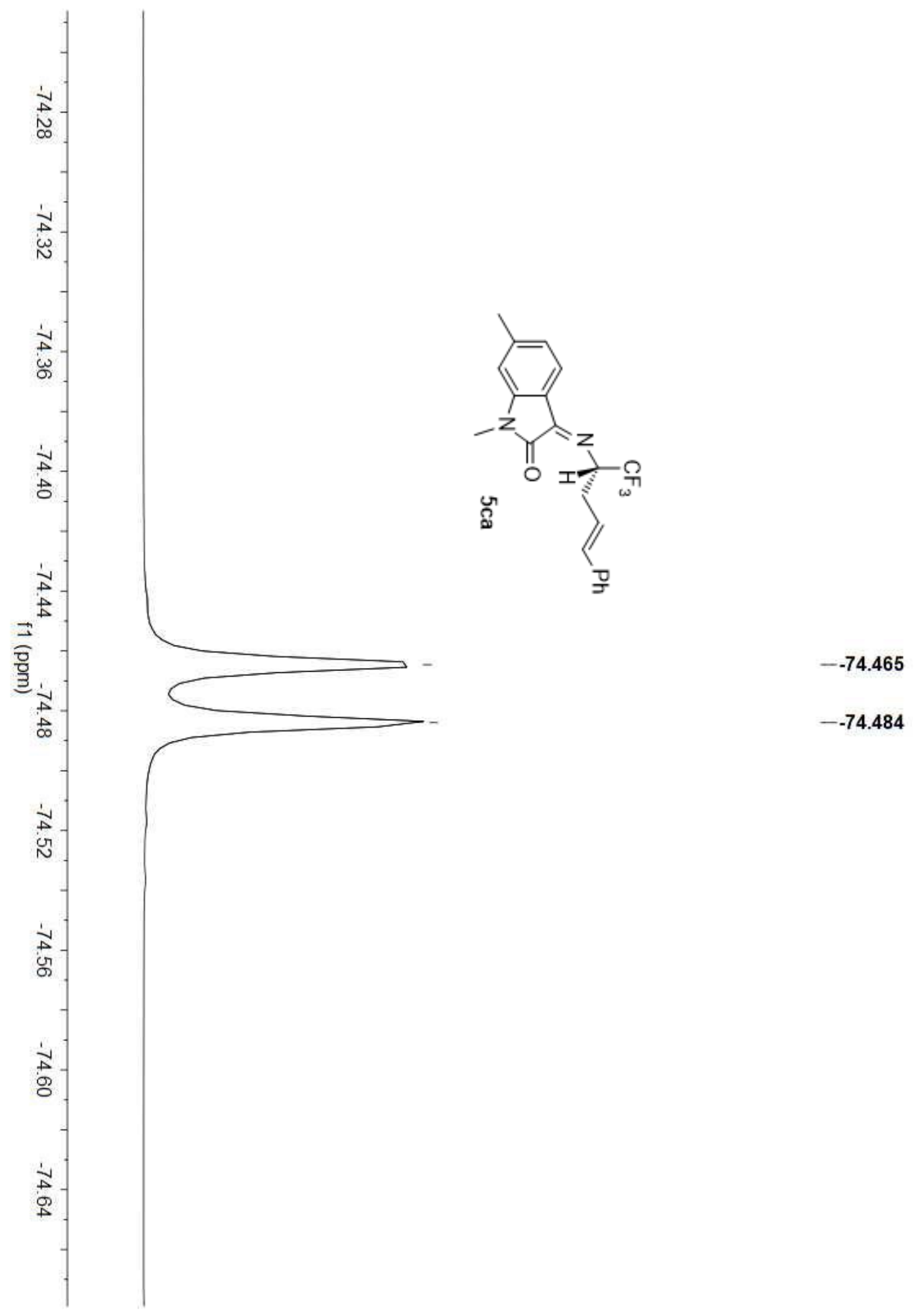




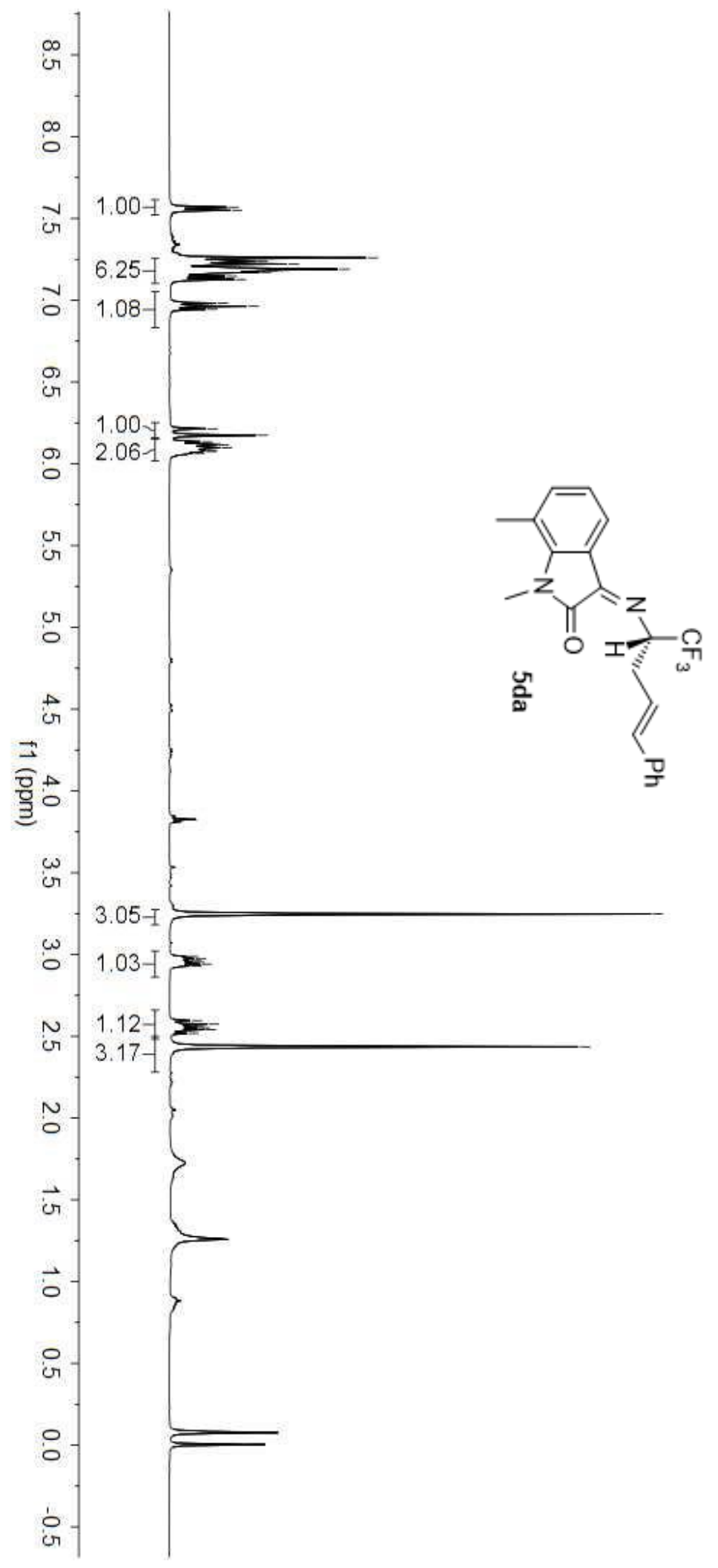

$\left[\begin{array}{r}7.569 \\ 7.550 \\ 7.260 \\ 7.239 \\ 7.222 \\ 7.189 \\ 7.182 \\ 7.171 \\ 7.146 \\ 7.127 \\ 6.982 \\ 6.294\end{array}\right.$

6.963

6.174

$-6.135$

6.120

$-6.115$

$-6.098$

$-6.082$

$-6.075$

6.065

3.247

$-2.987$

$-2.975$

$-2.963$

$-2.953$

2.941

$-2.929$

2.596

$-2.574$

$-2.561$

$-2.552$

$-2.540$

$-2.518$

2.436 


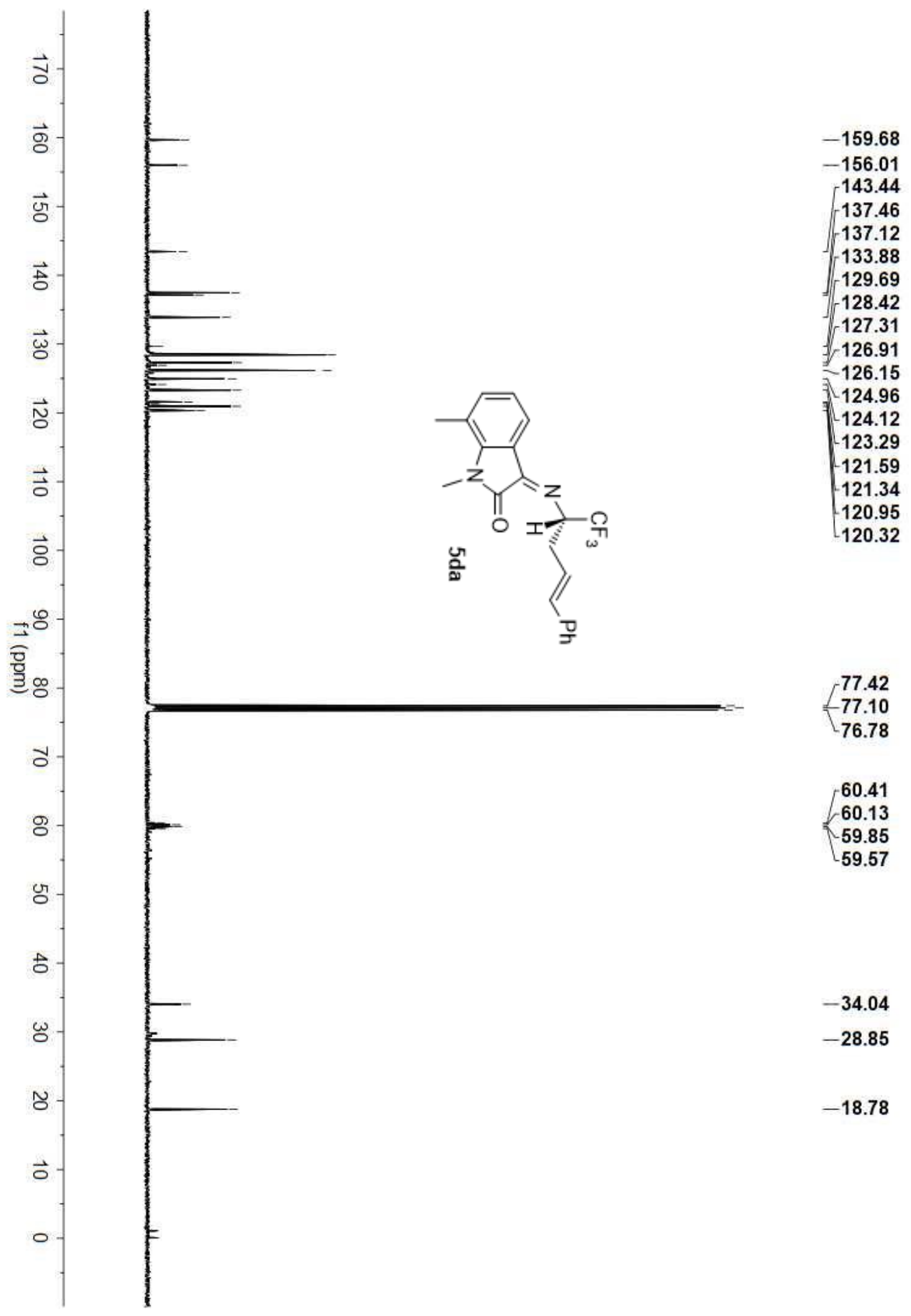




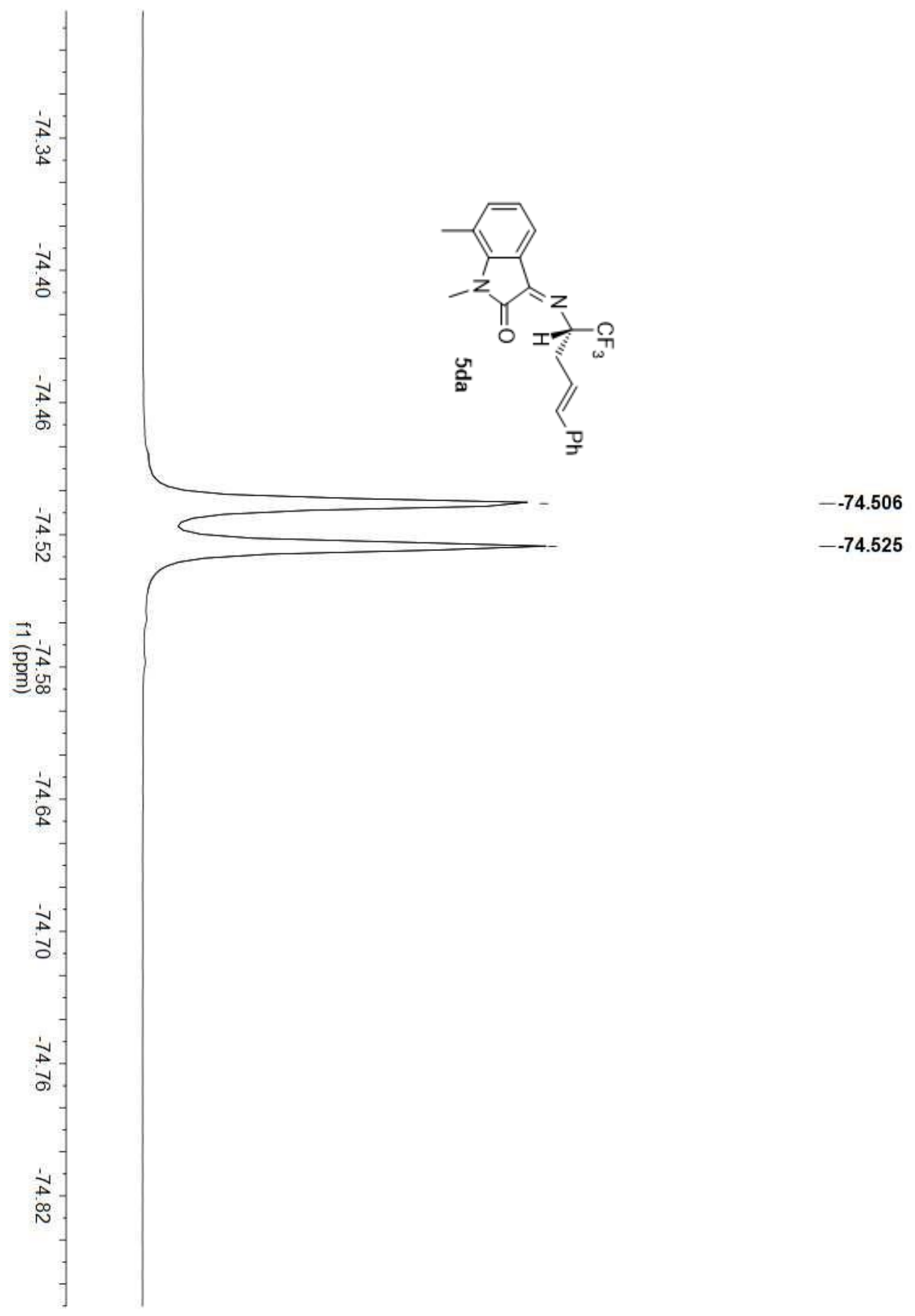




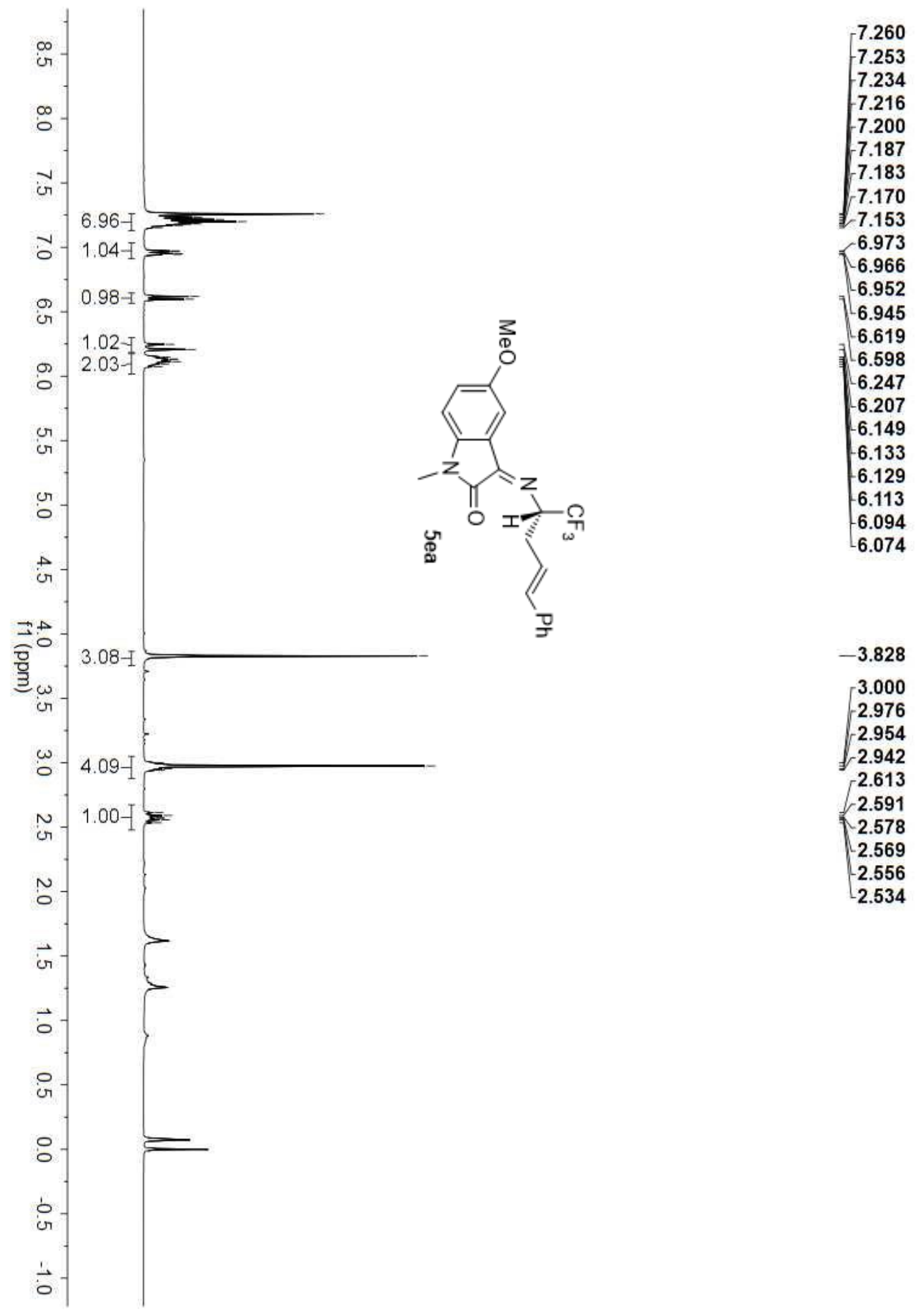




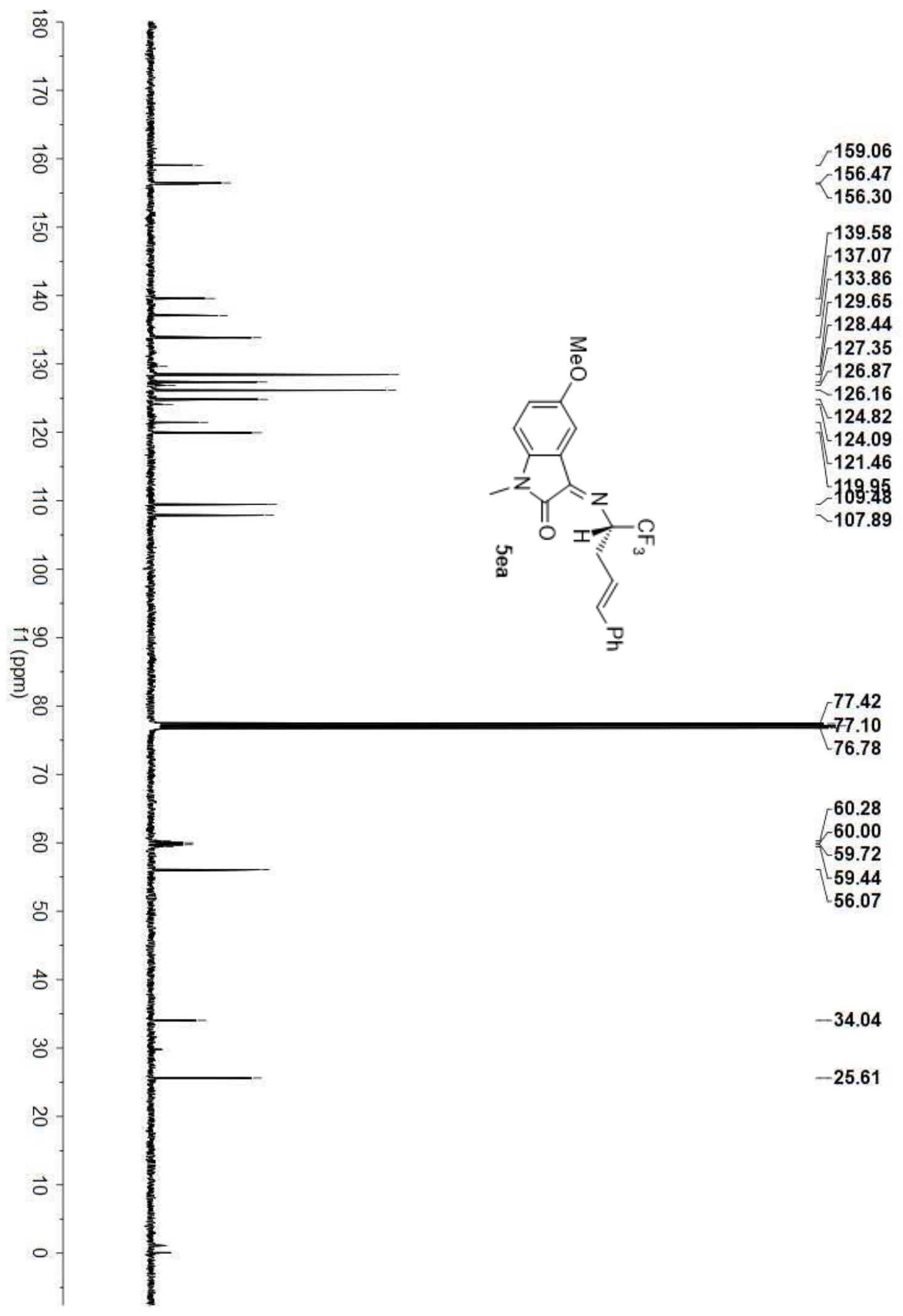




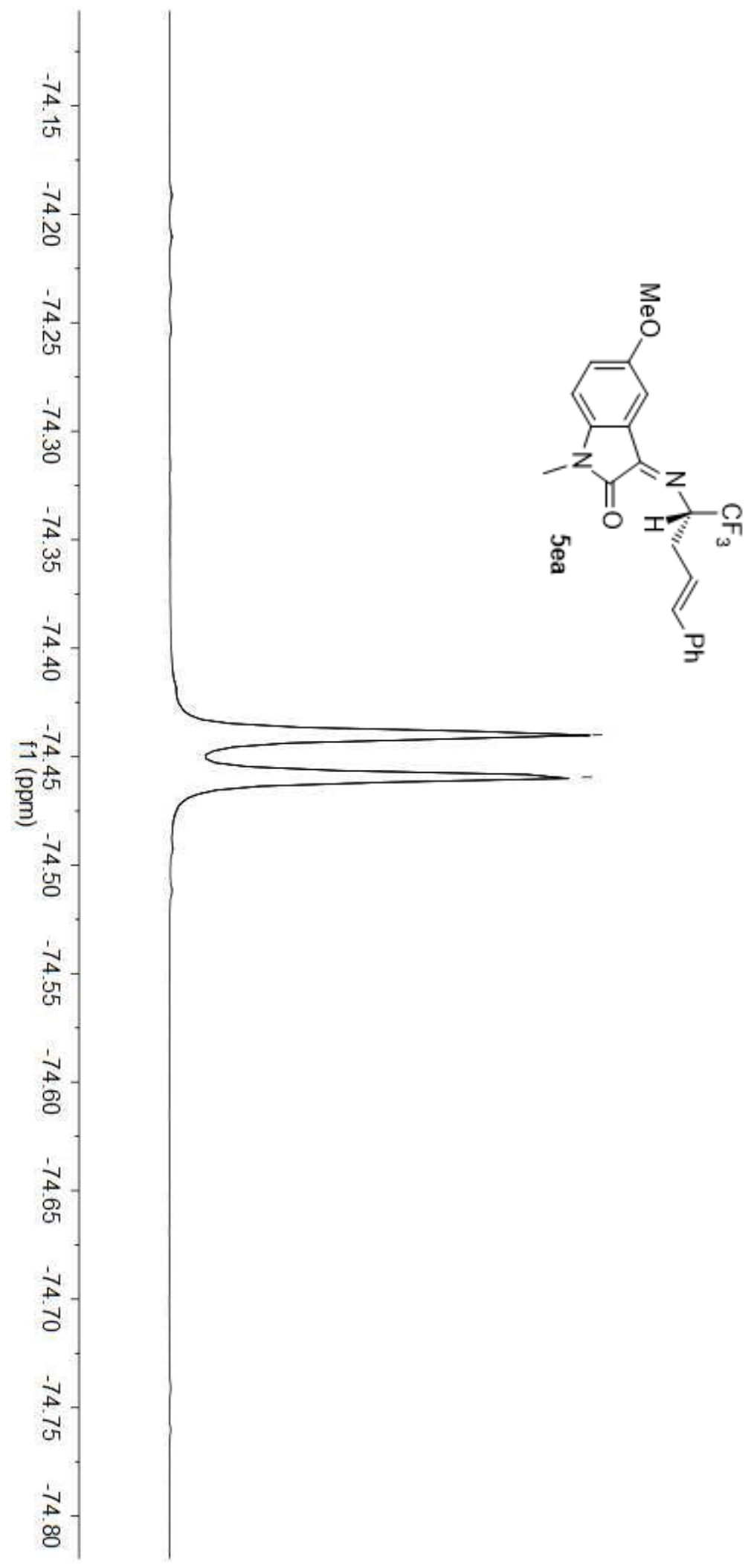

$--74.440$

$-.74 .459$ 


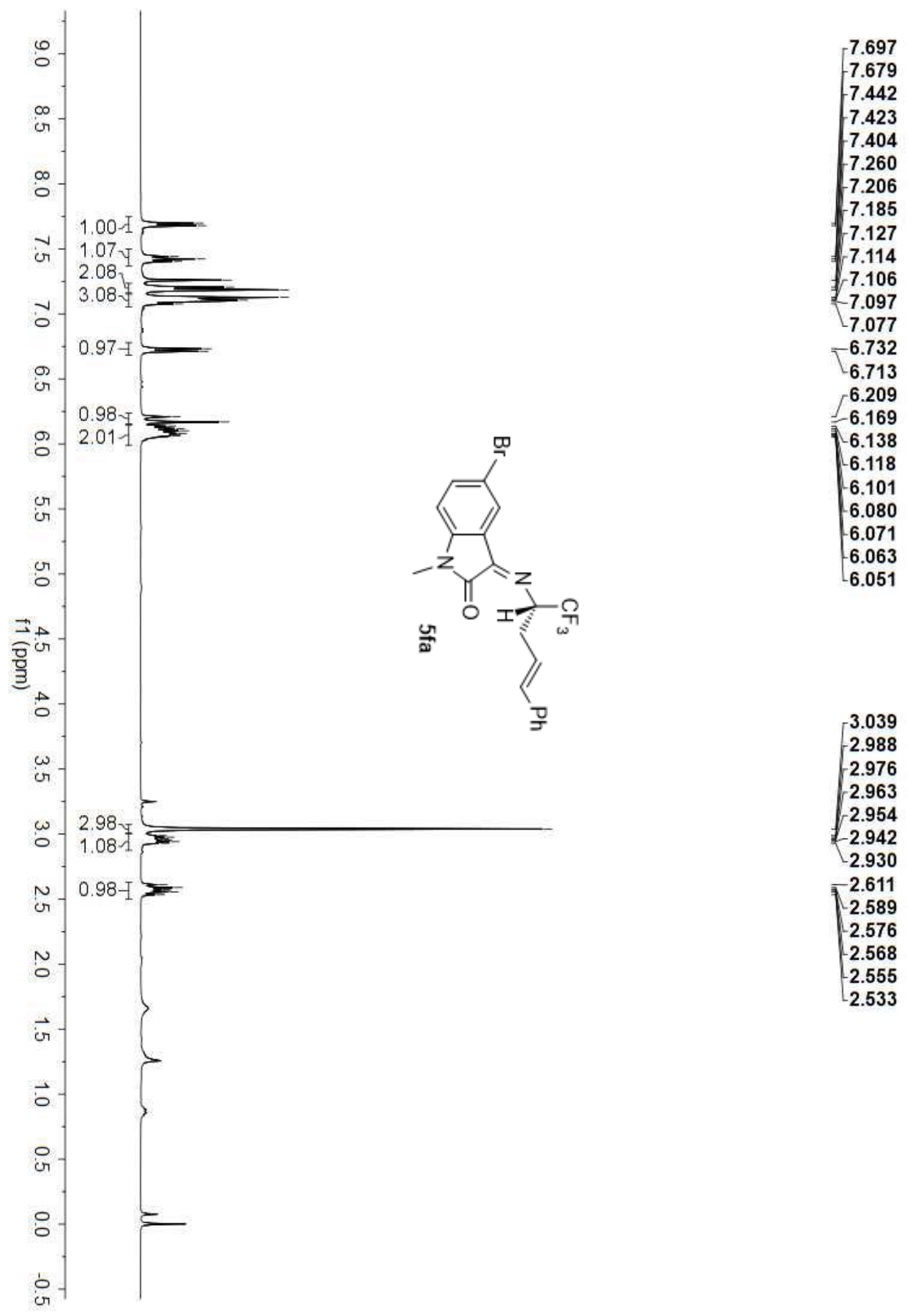




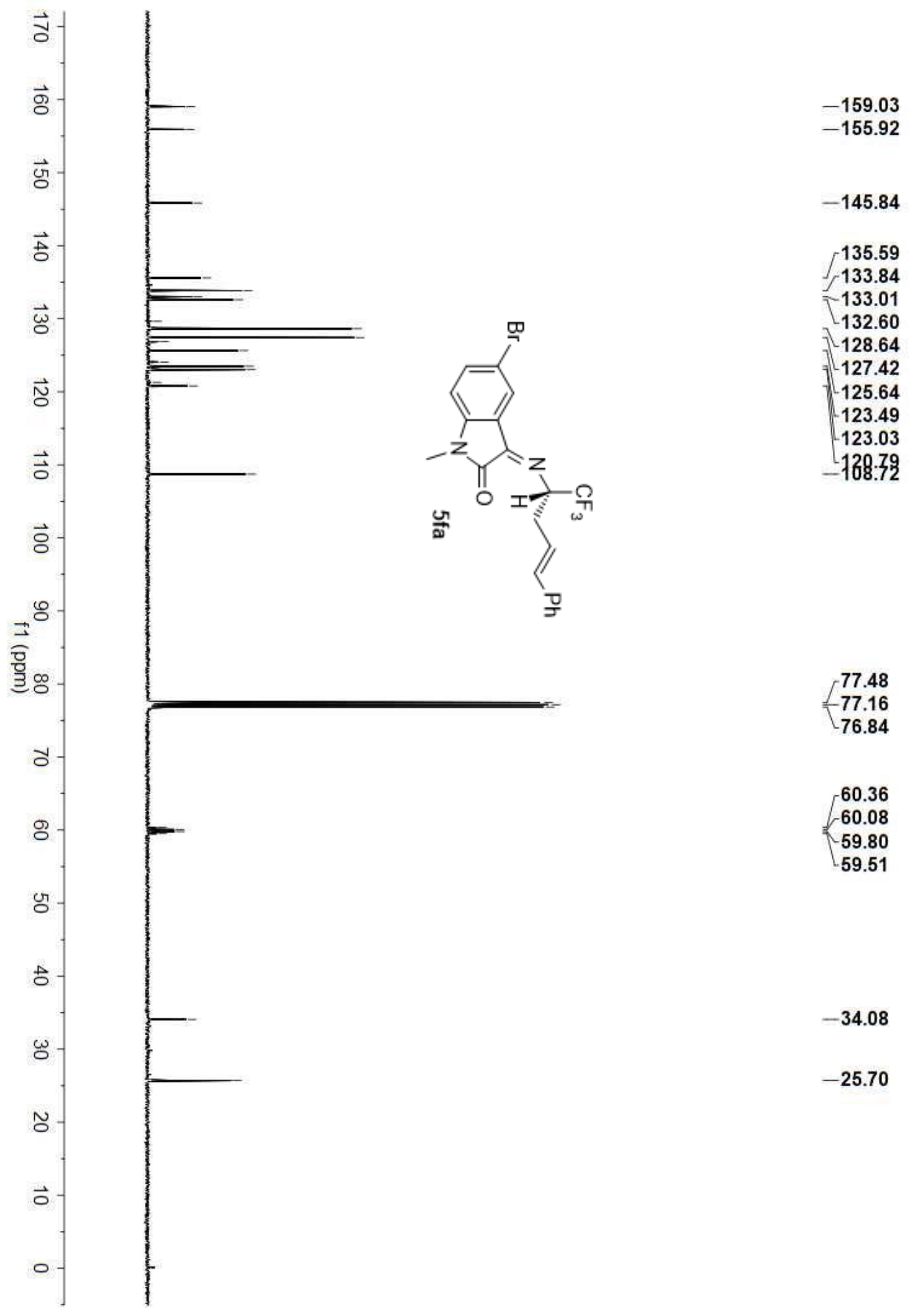




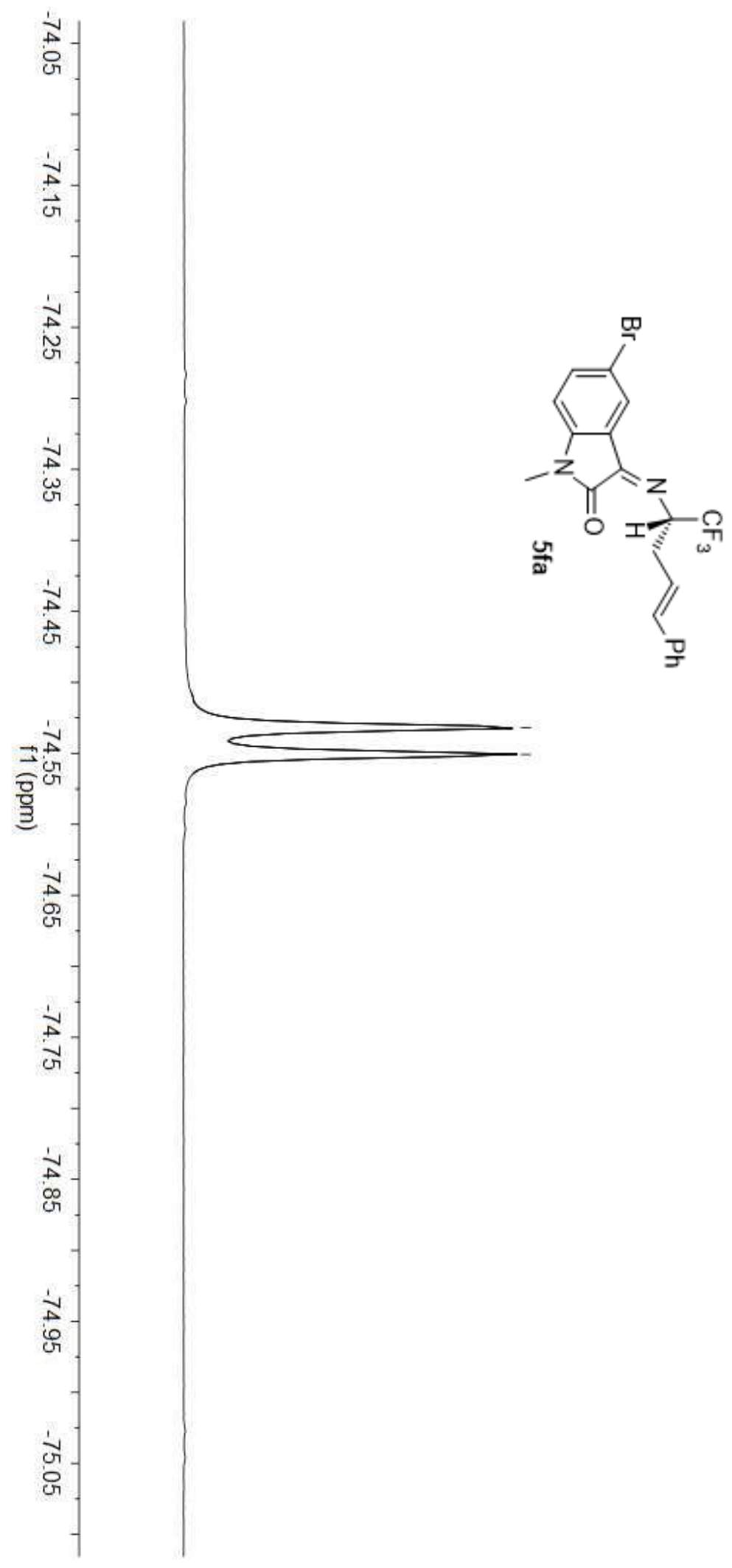

$-.74 .532$

$--74.551$ 


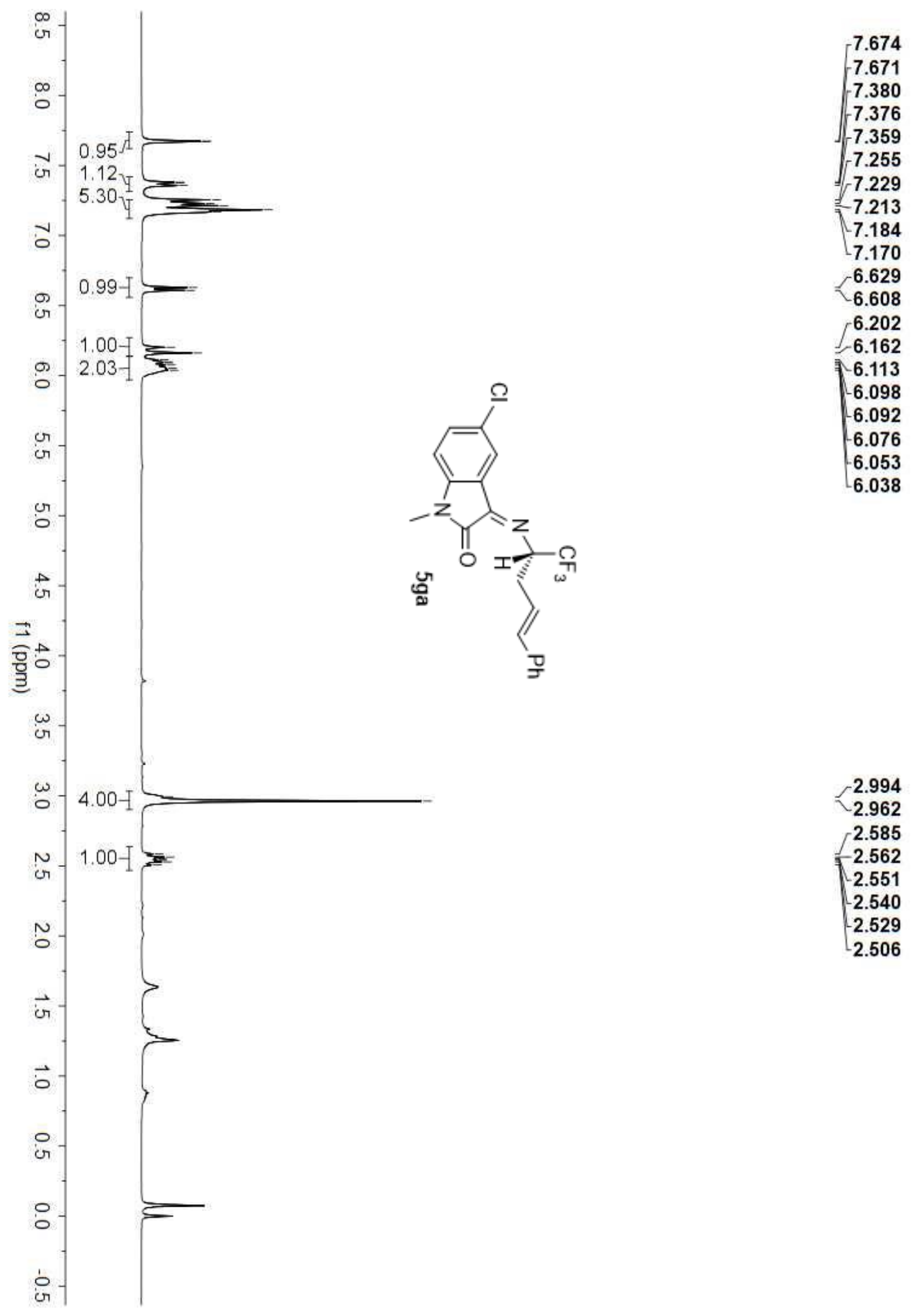




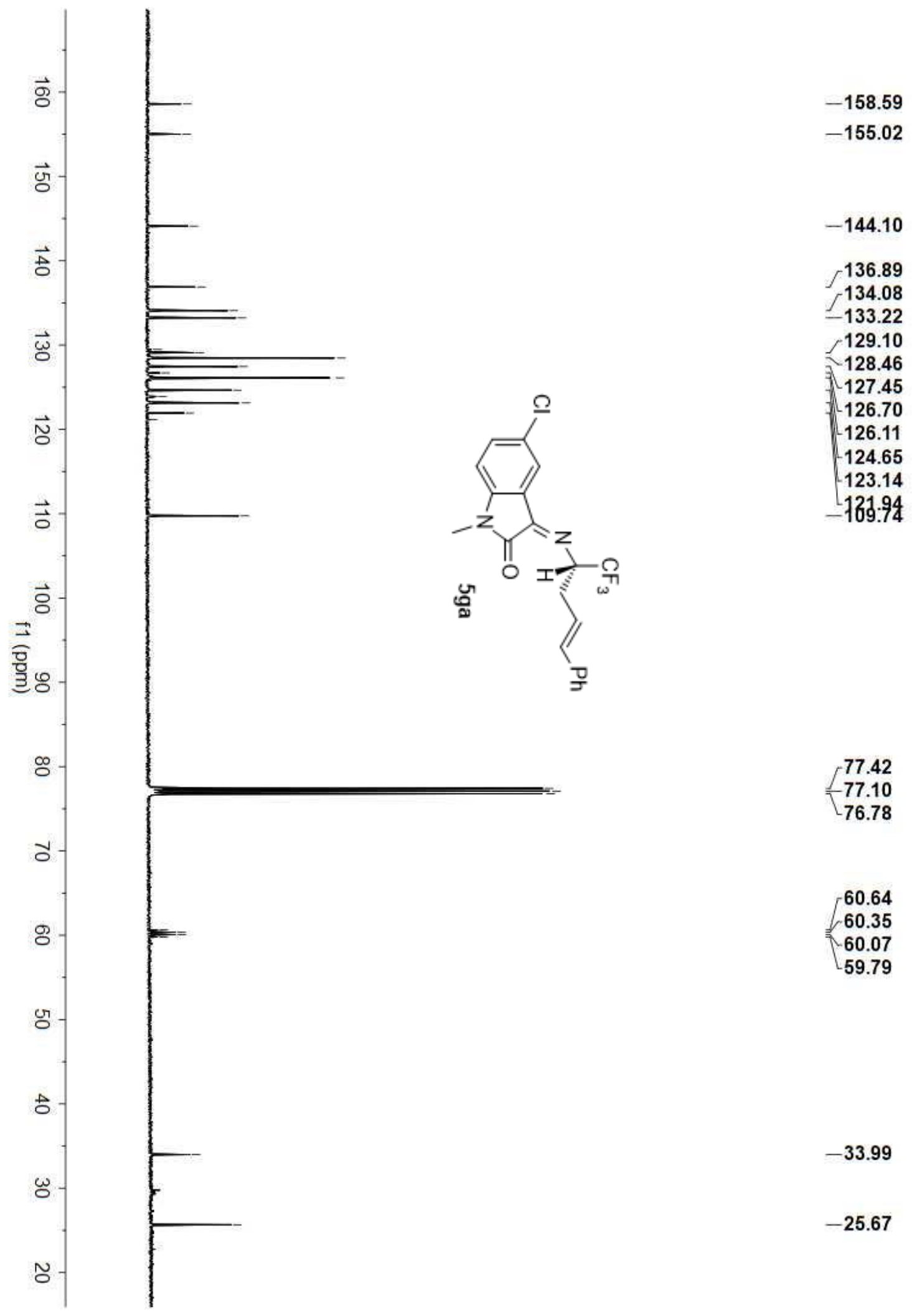




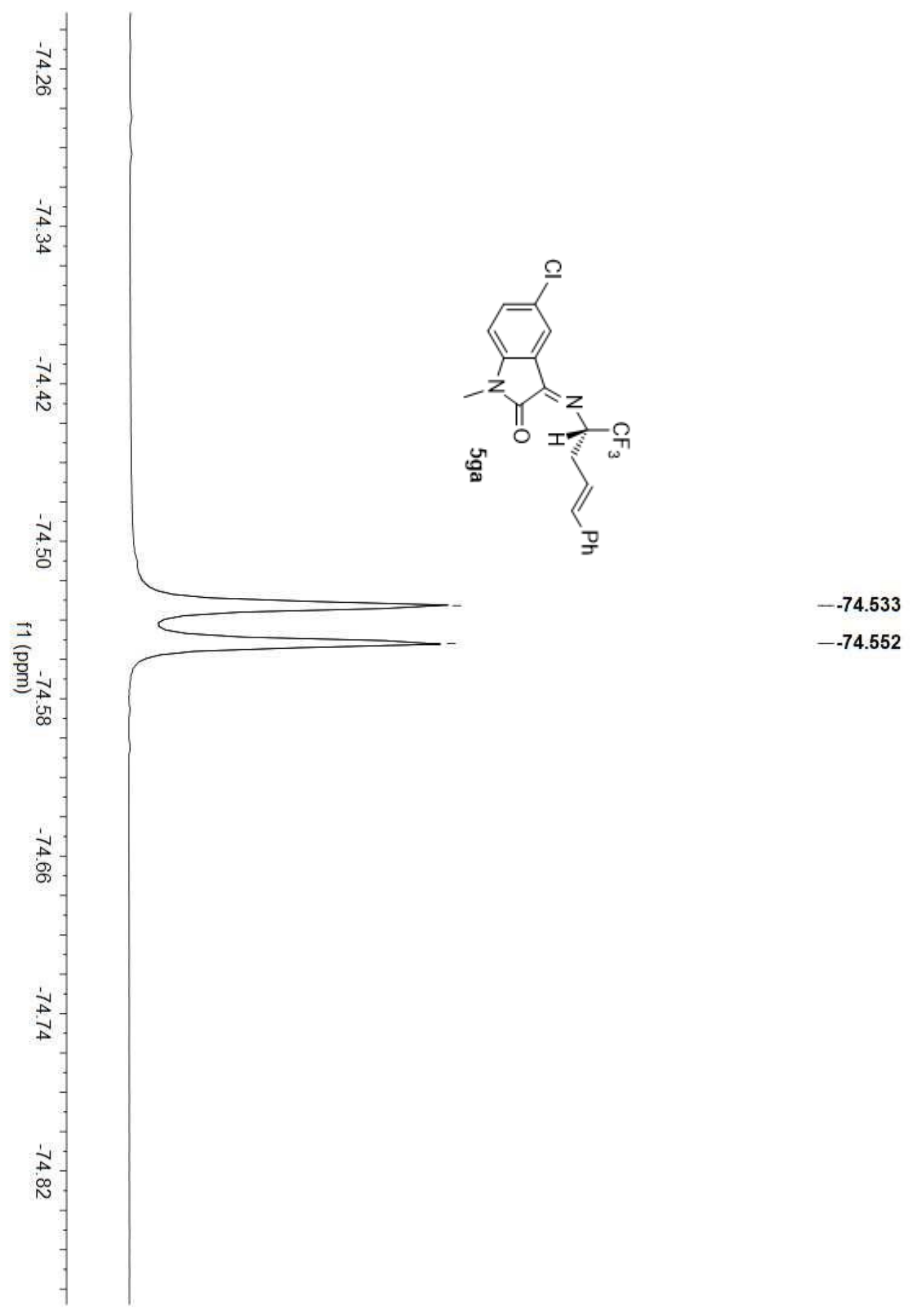




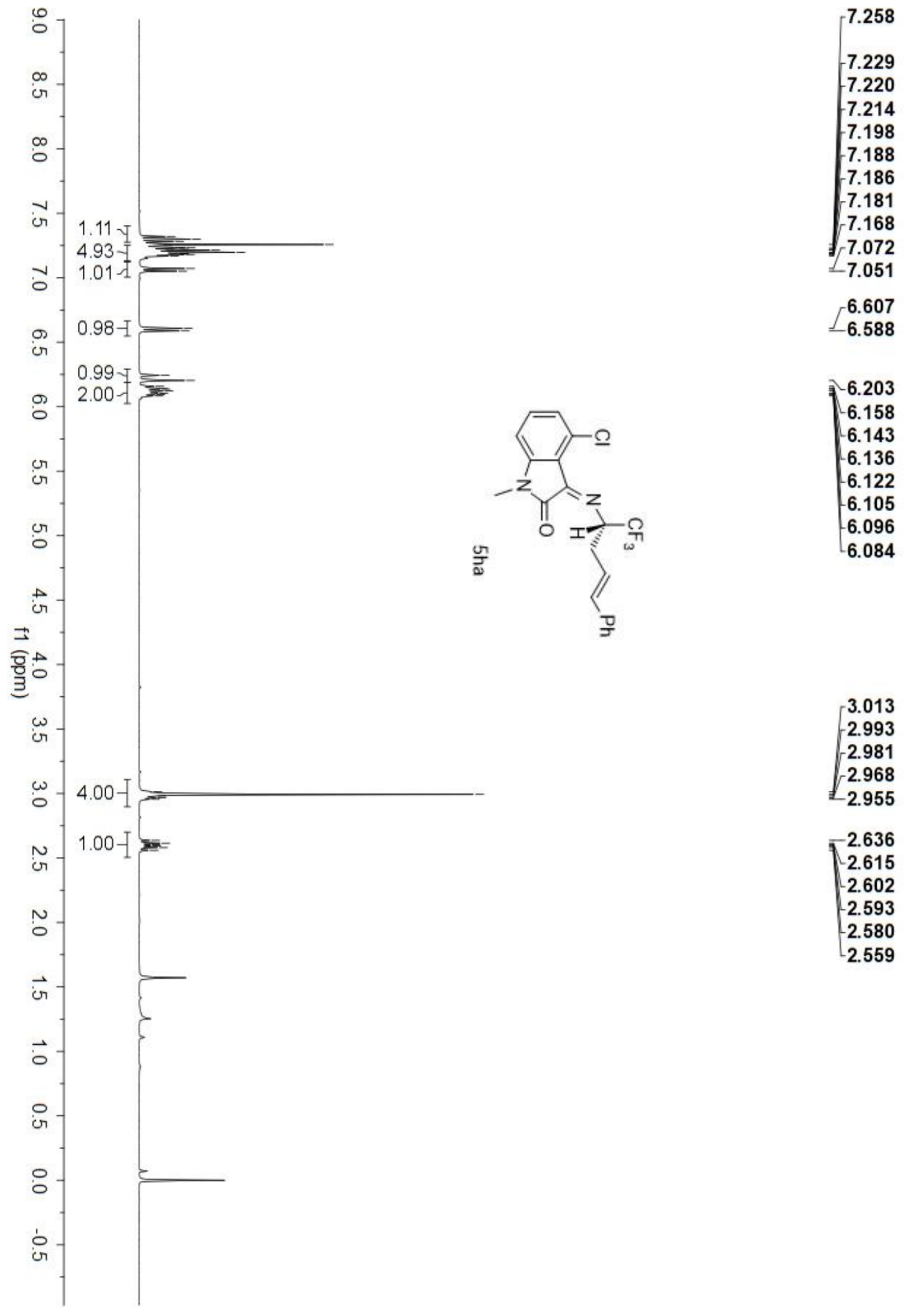




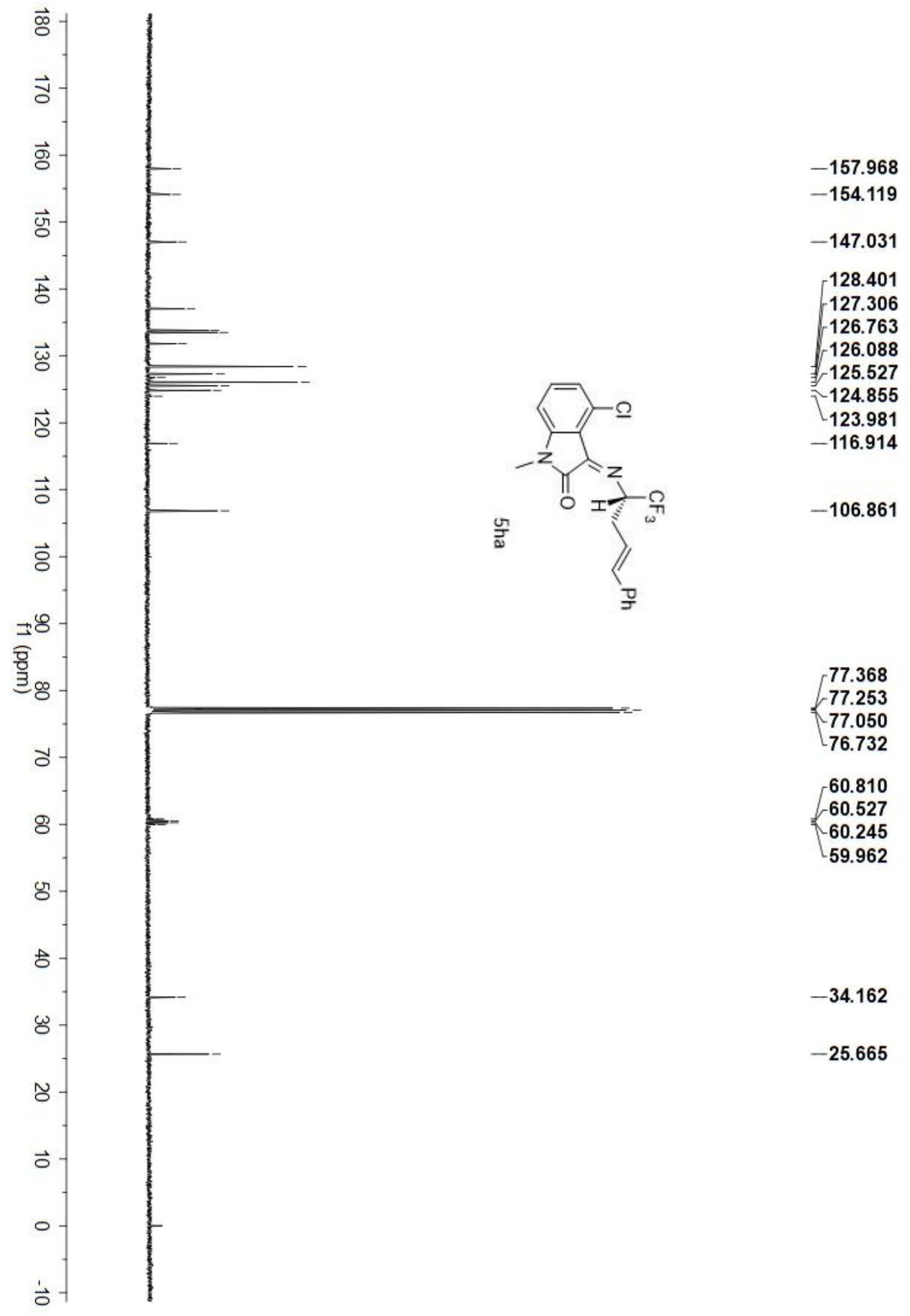




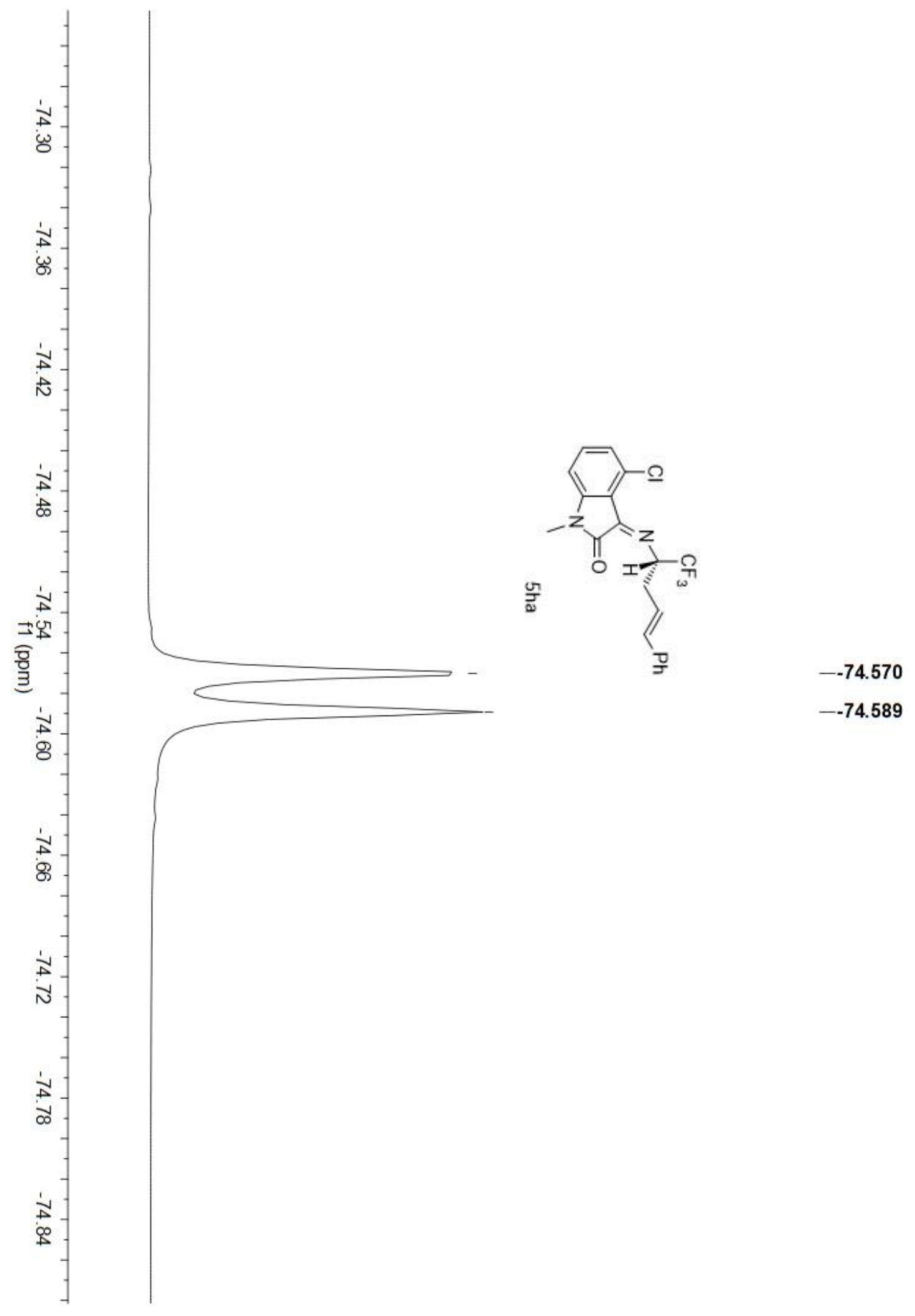




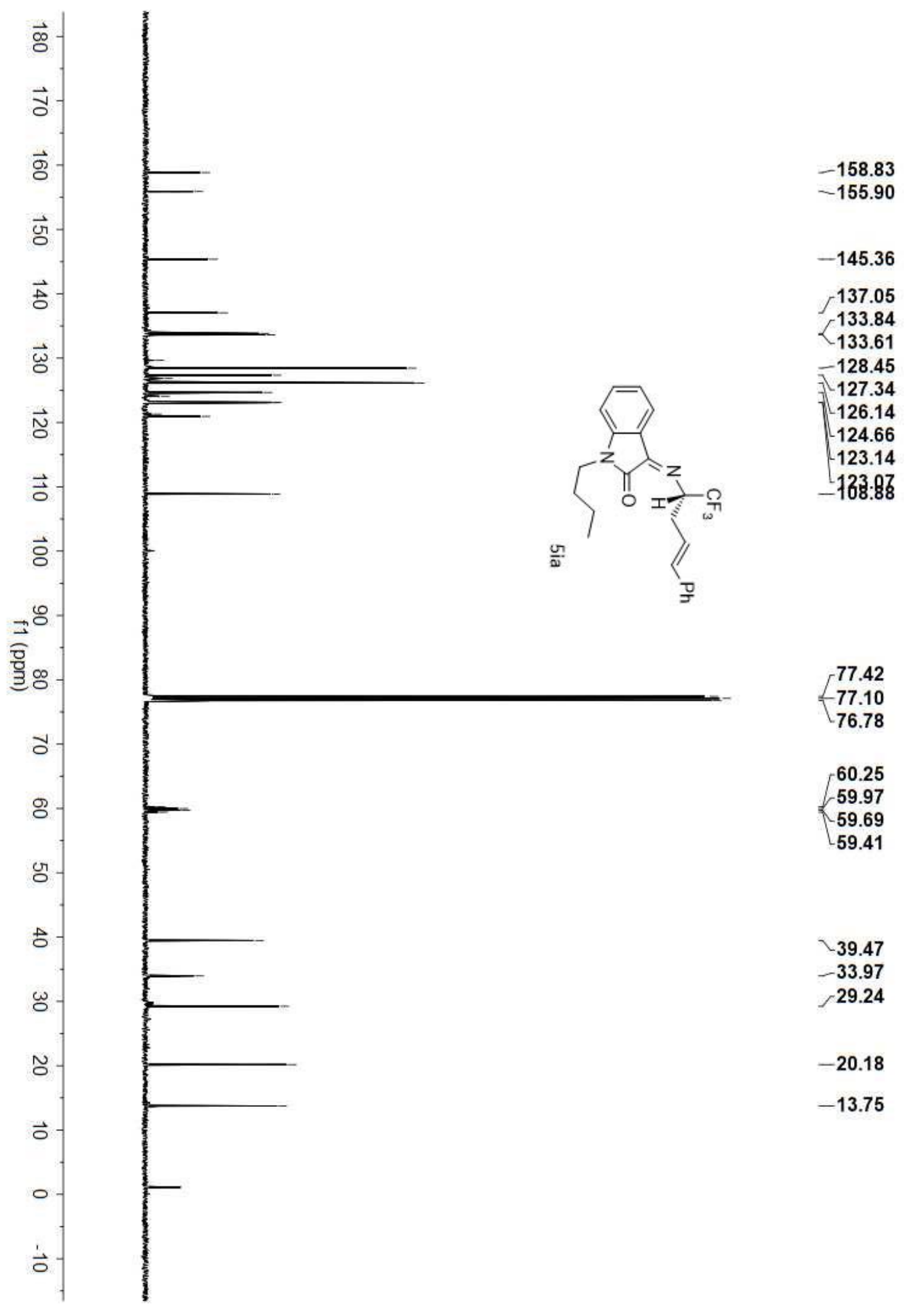



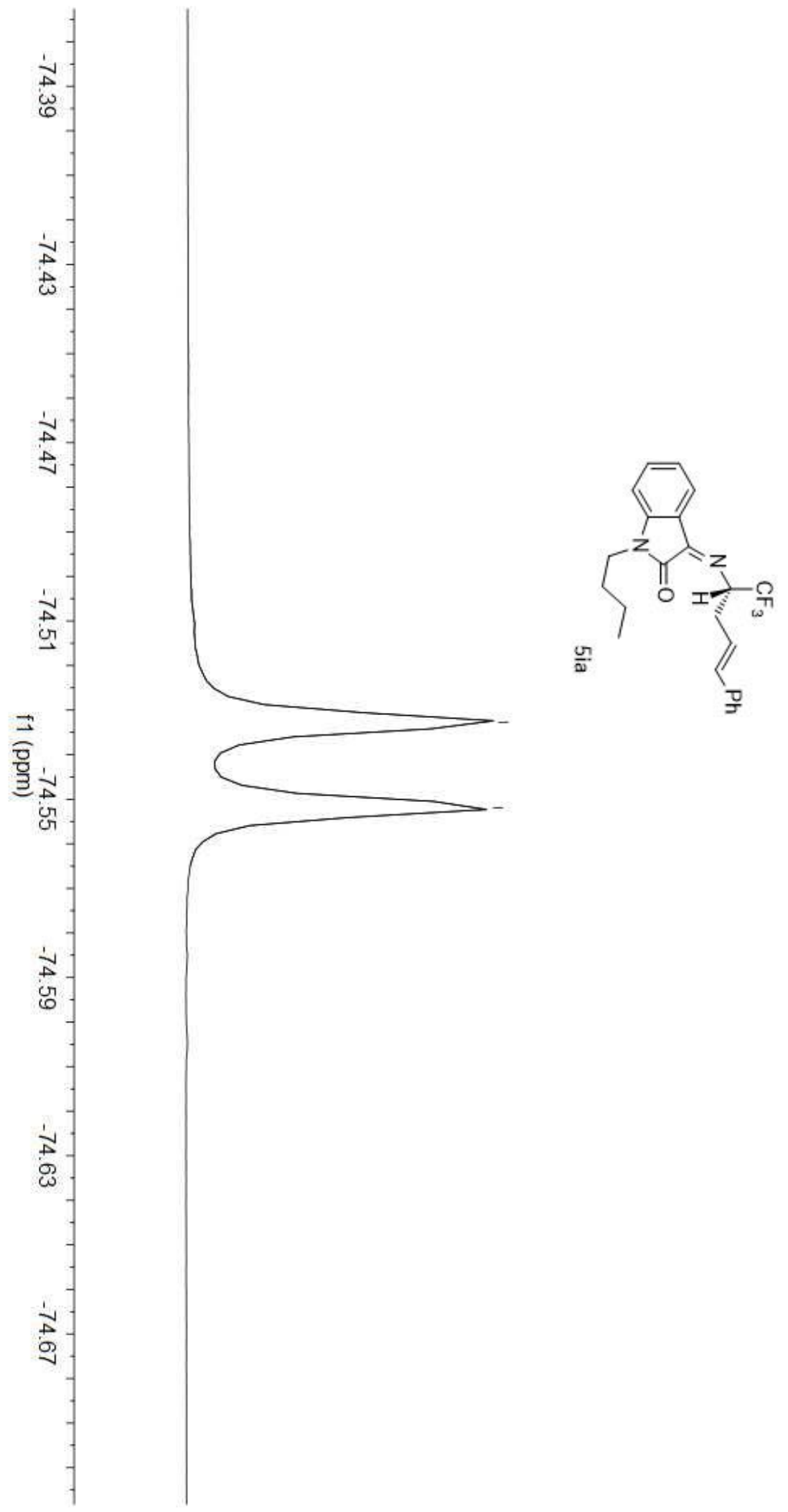

$-.74 .533$

$-.74 .552$ 


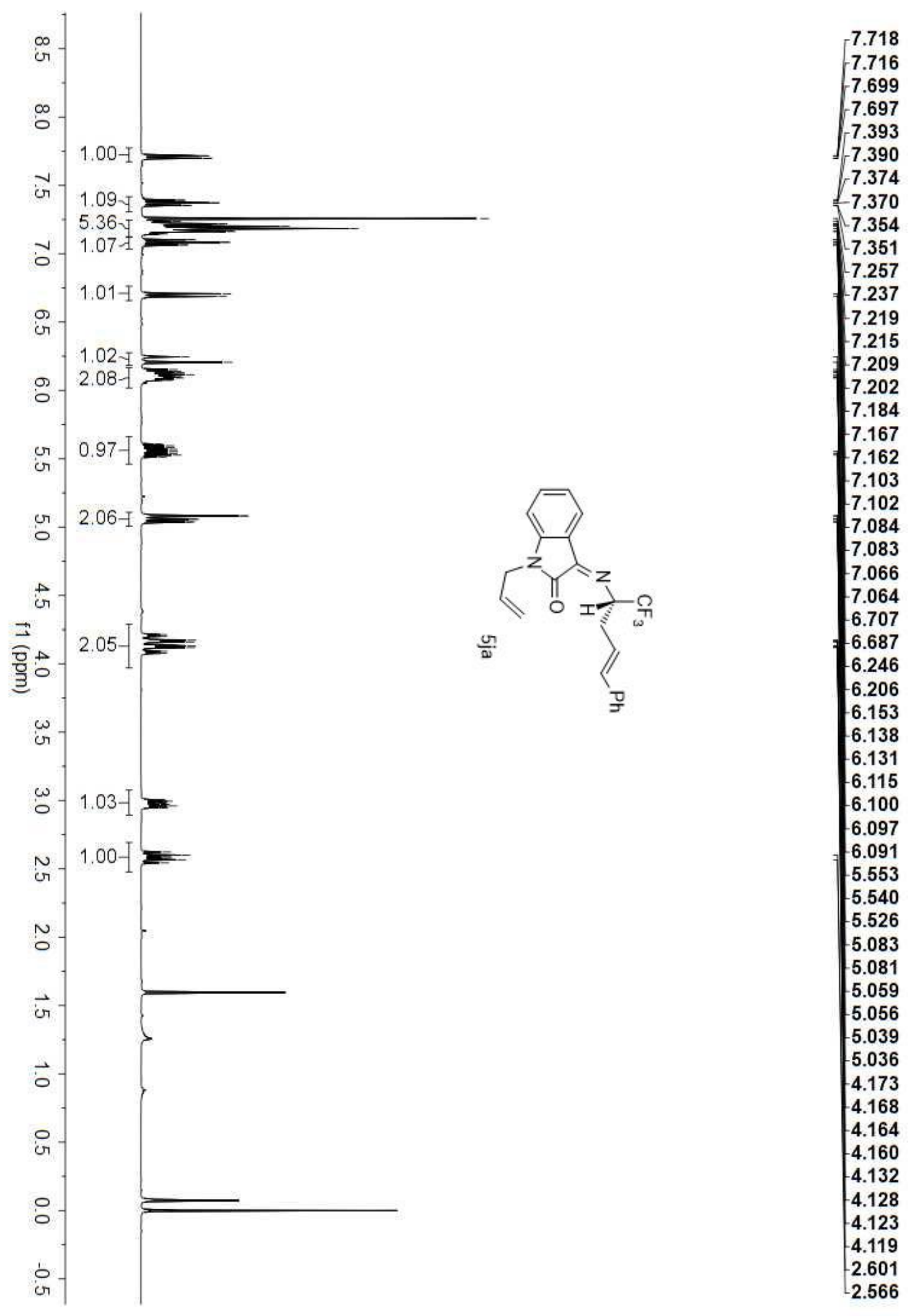




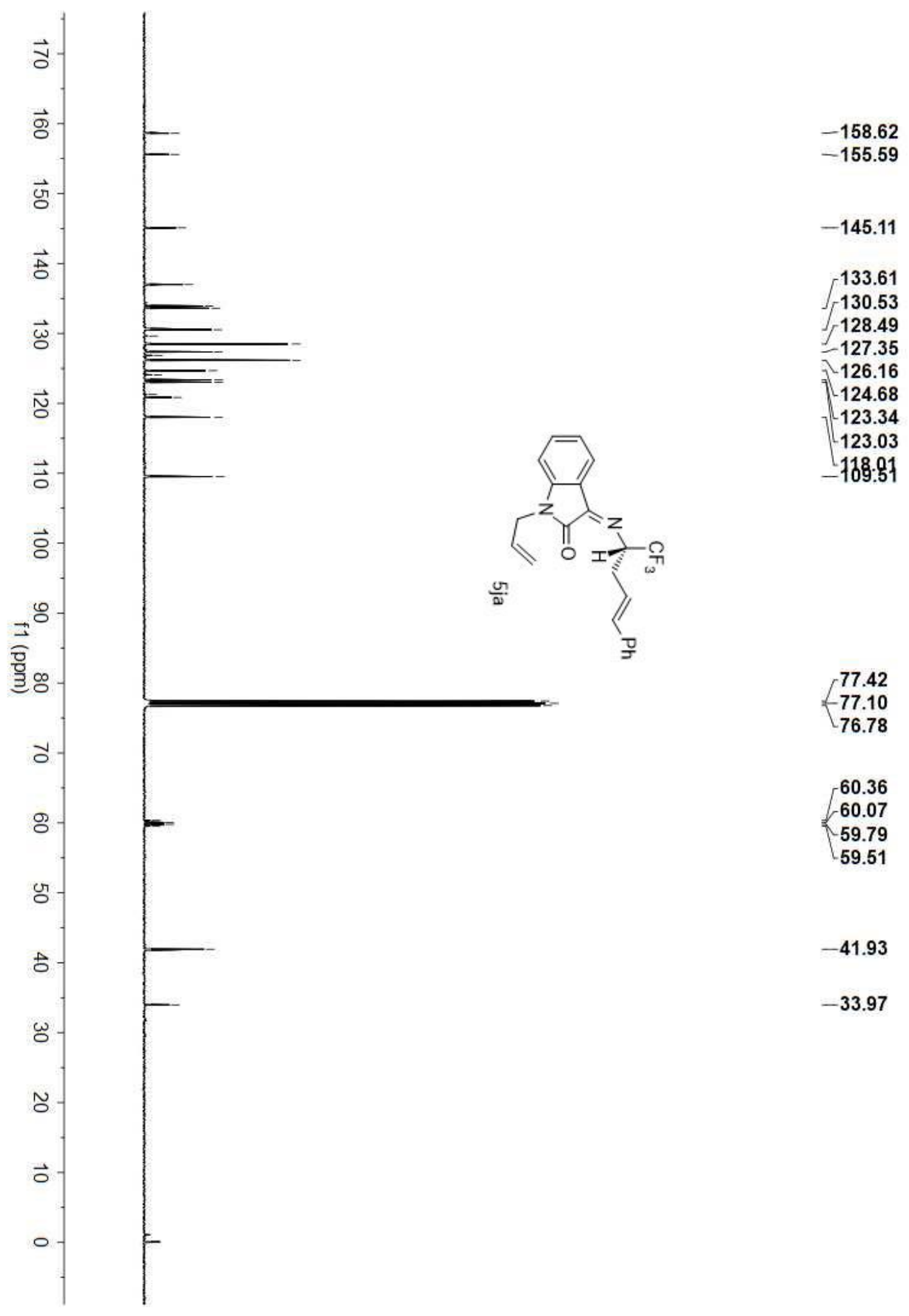




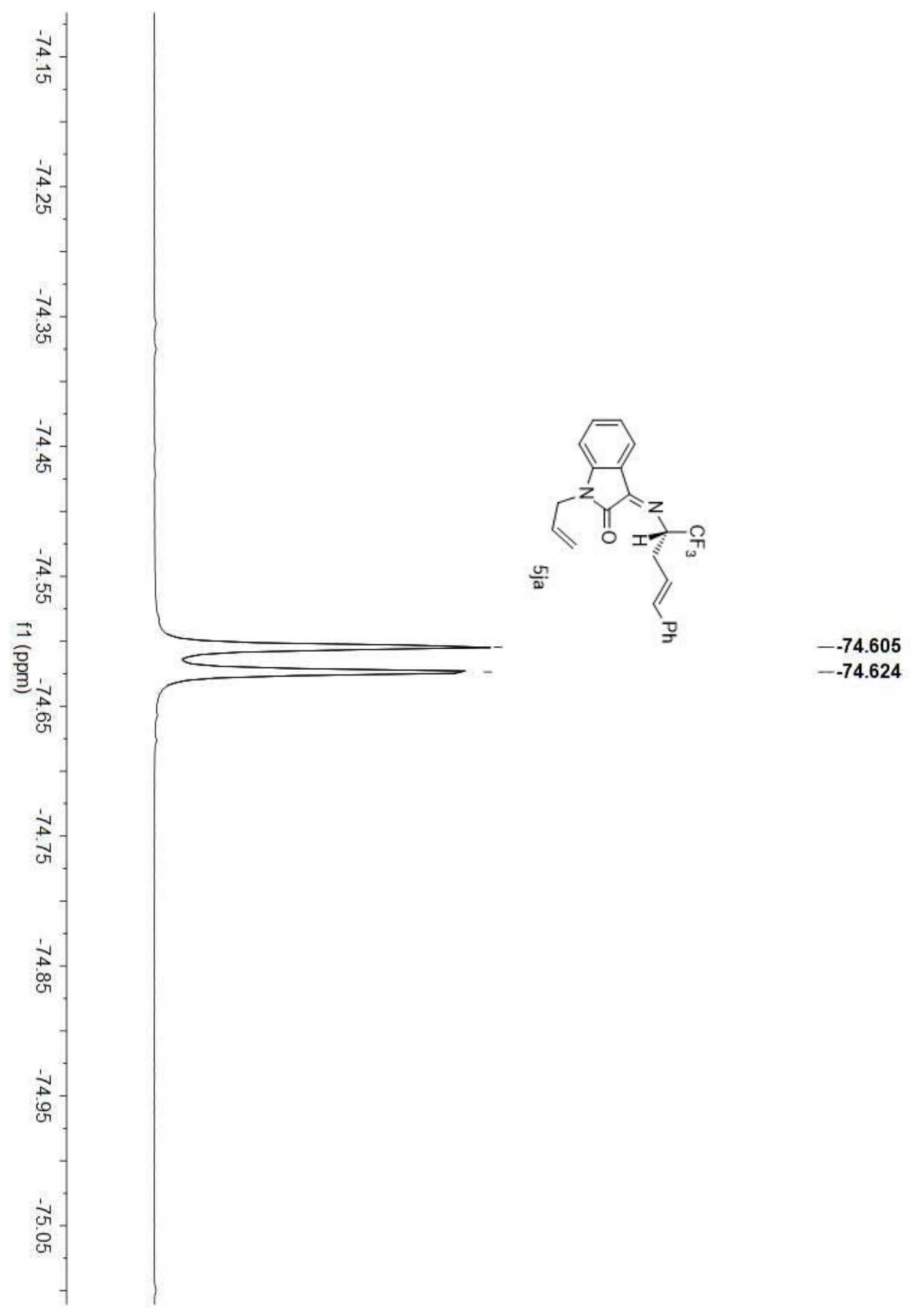




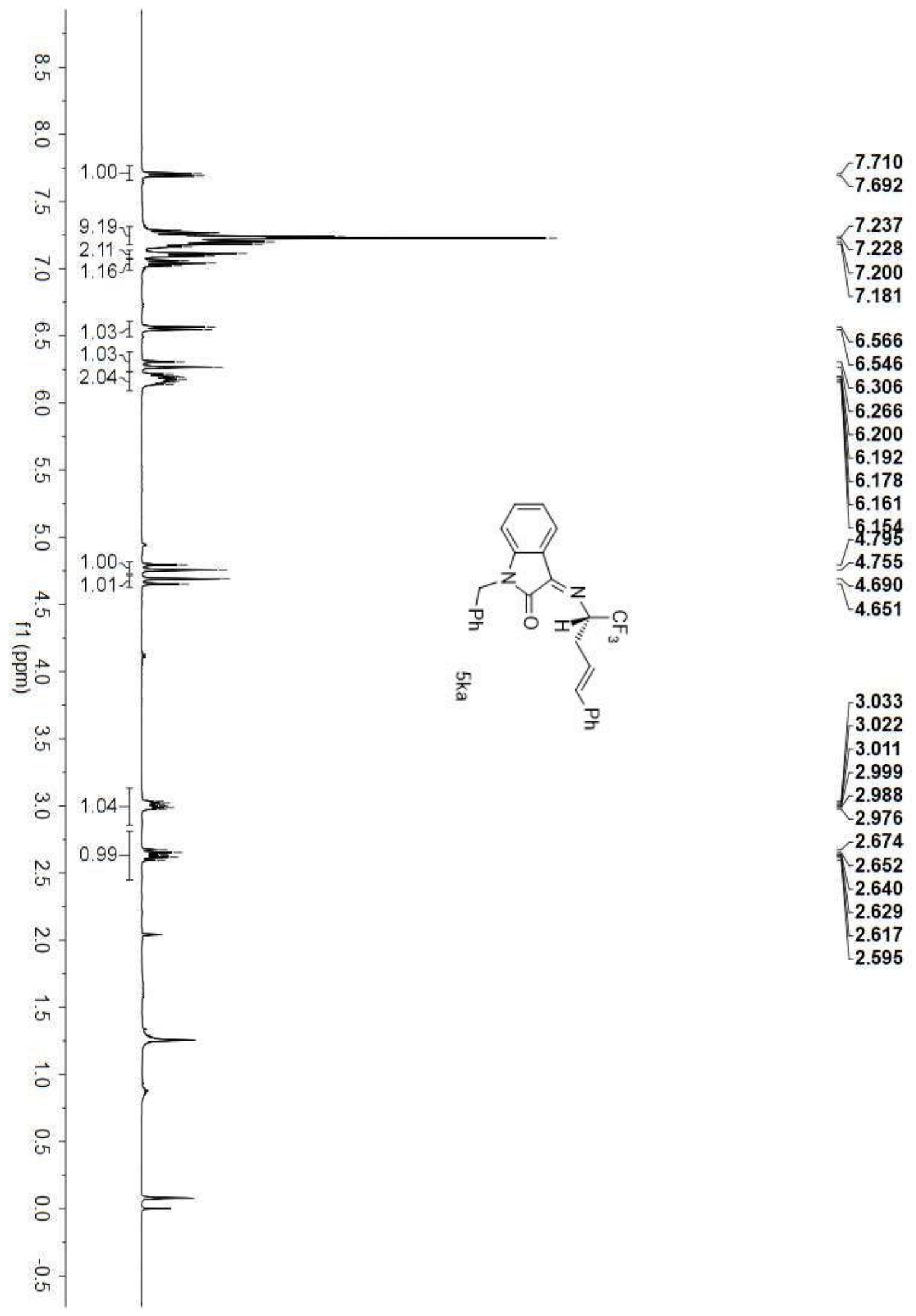




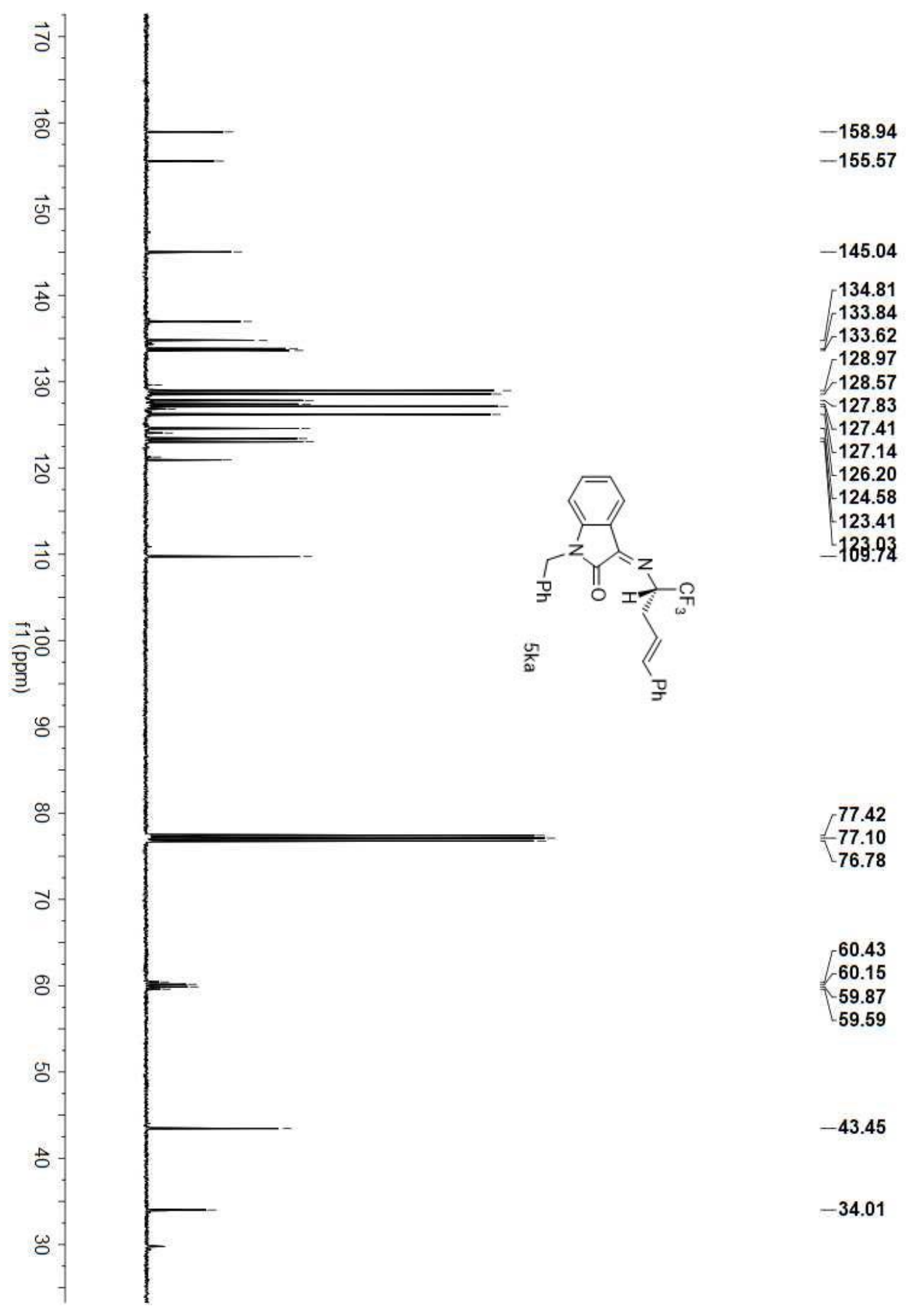




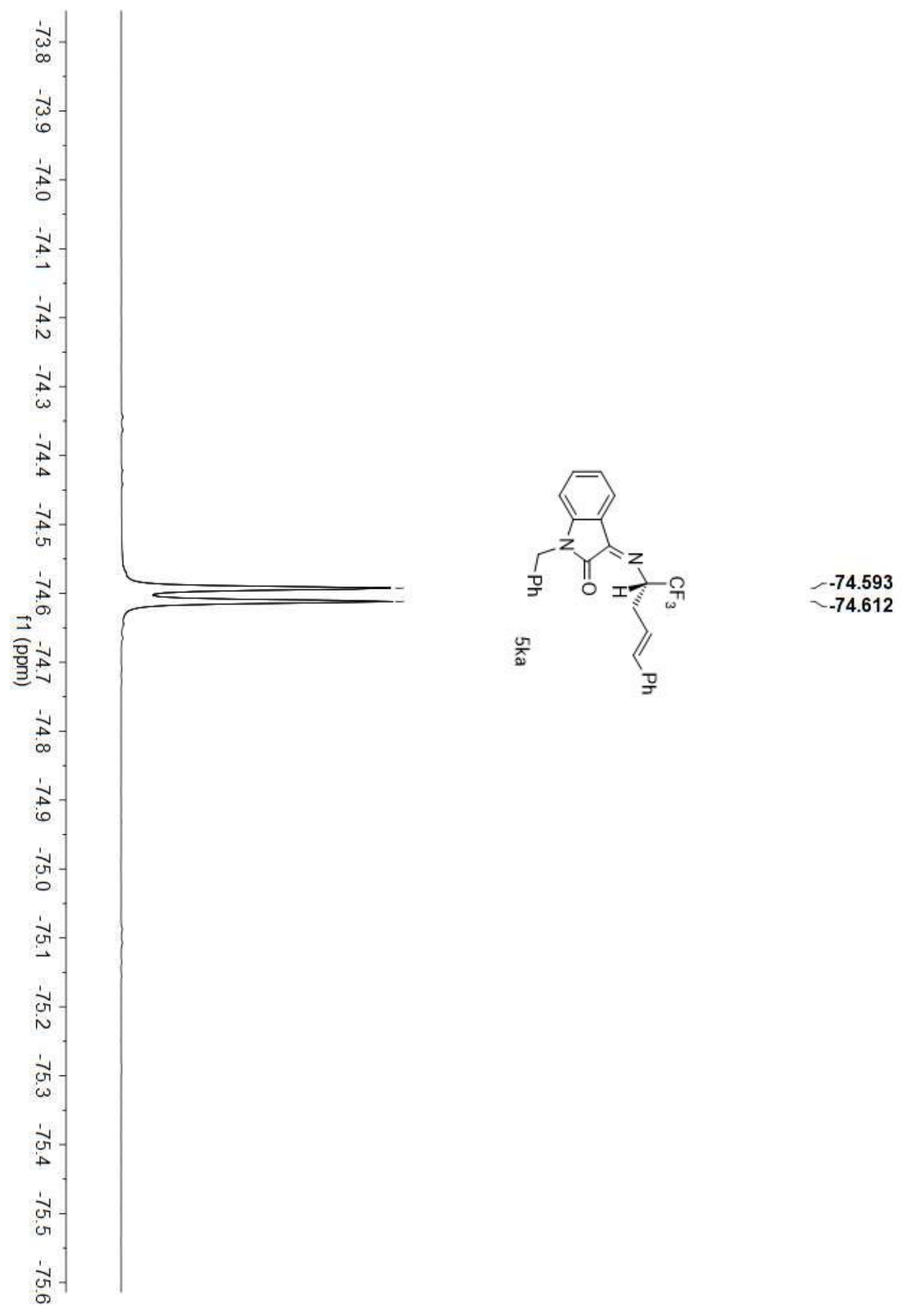




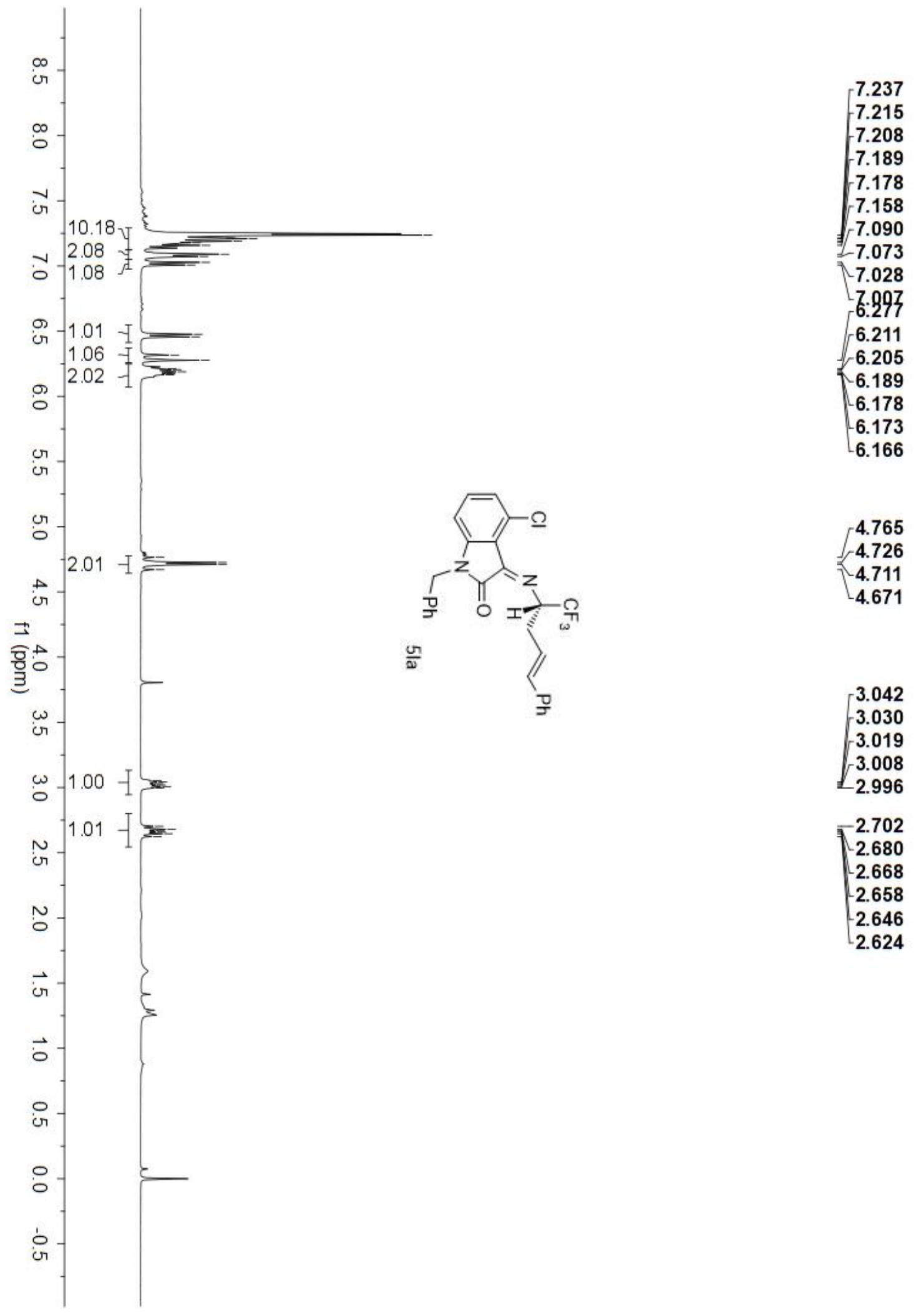




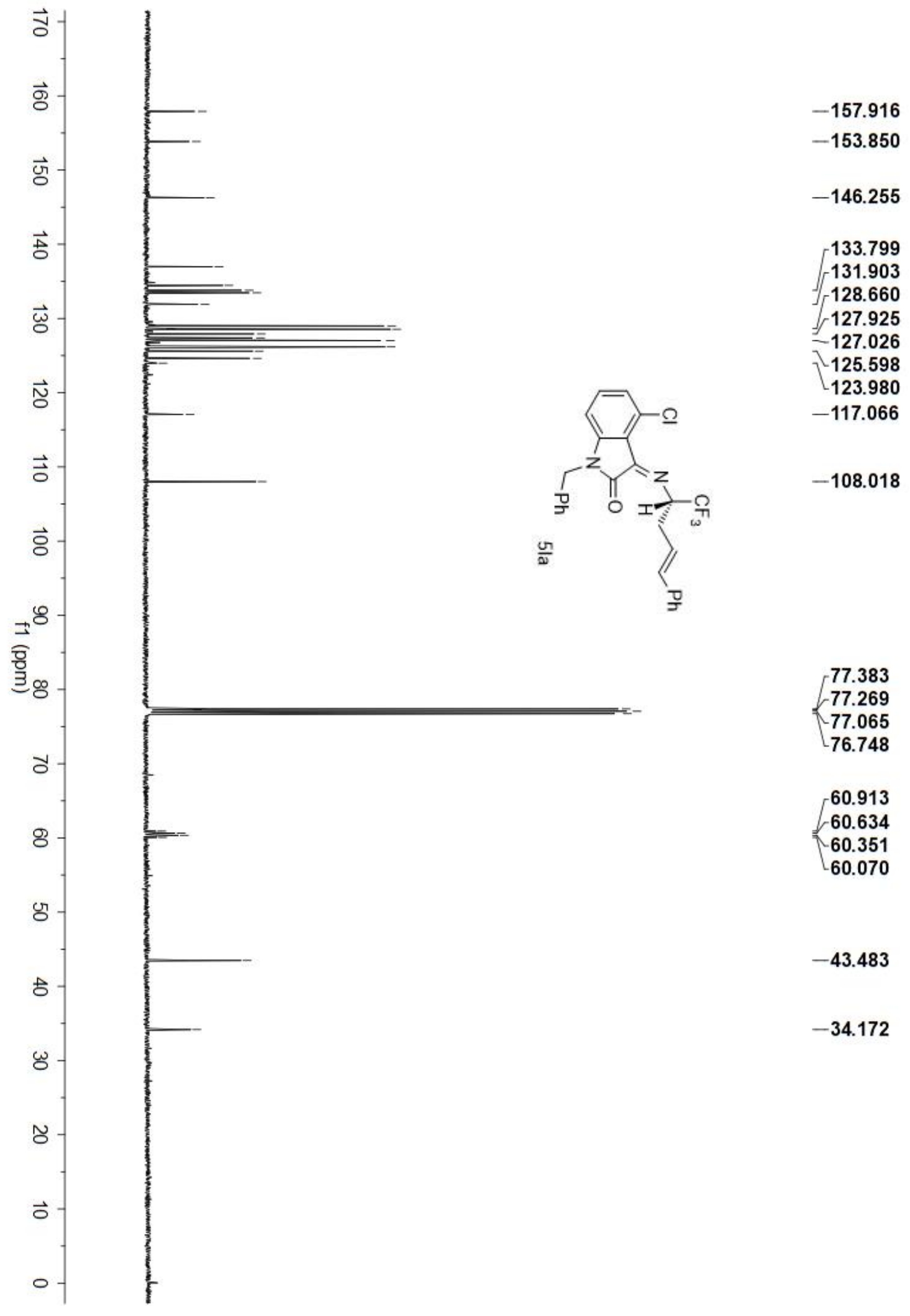



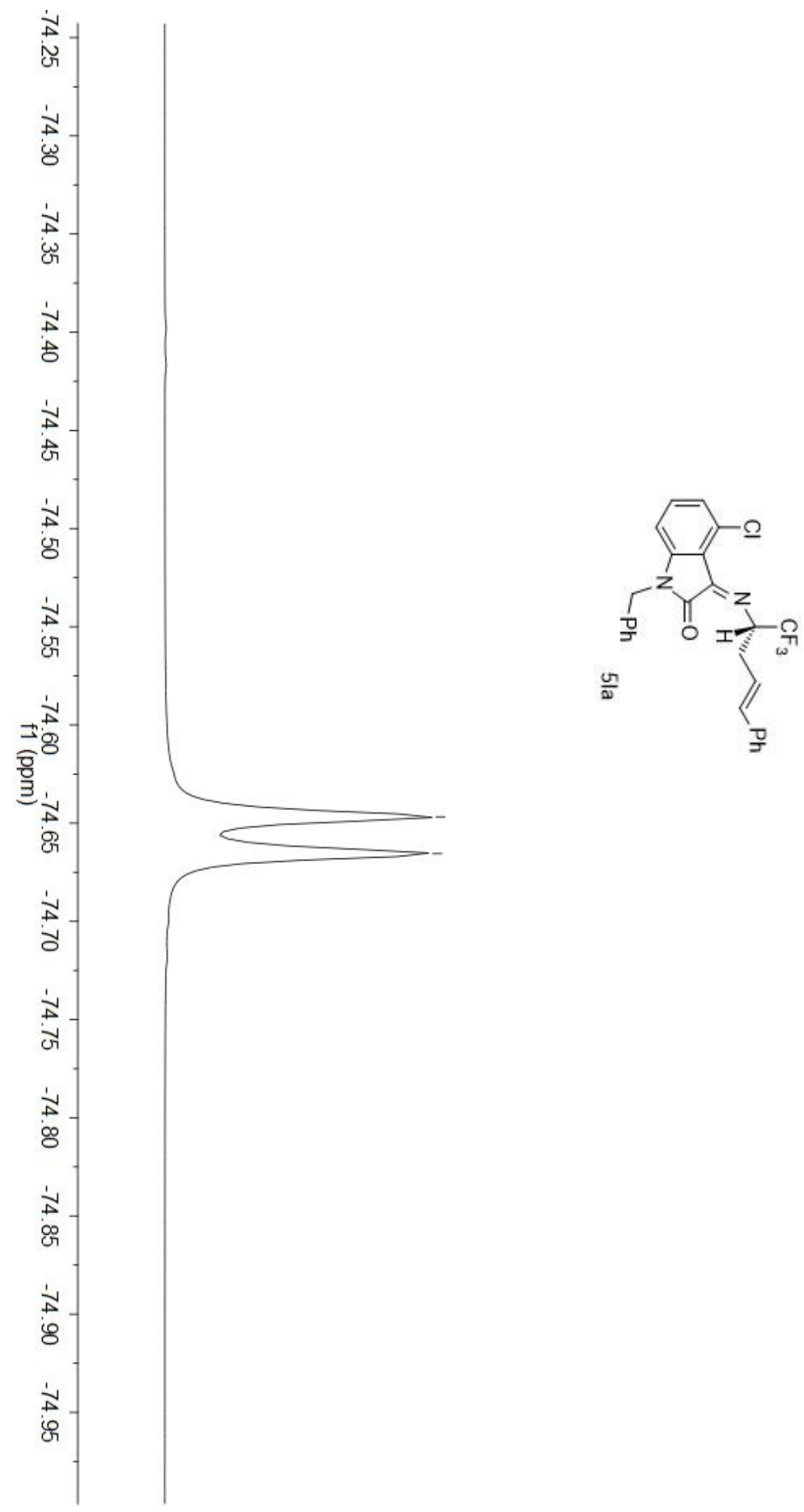

$--74.647$

$-.74 .666$ 


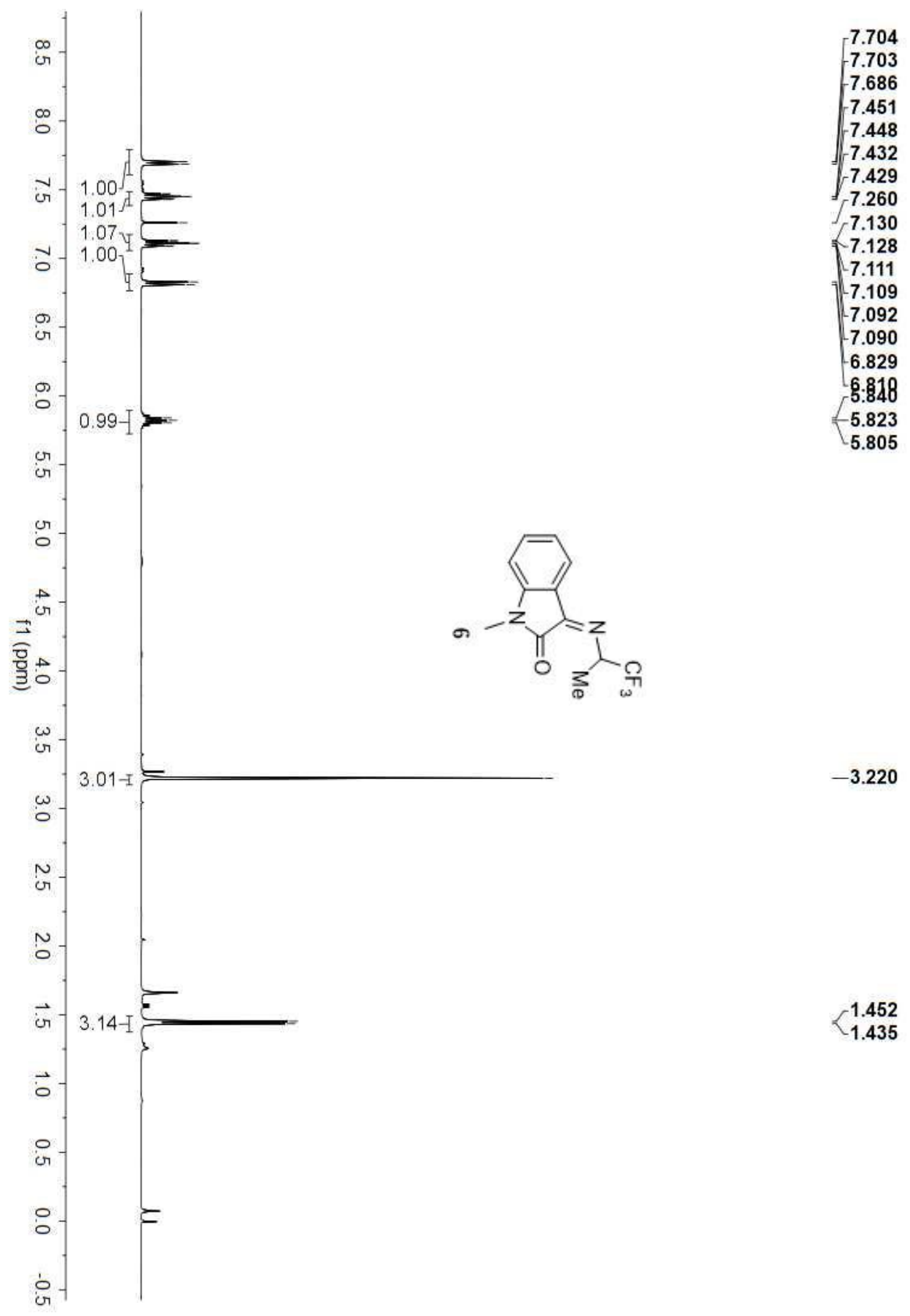




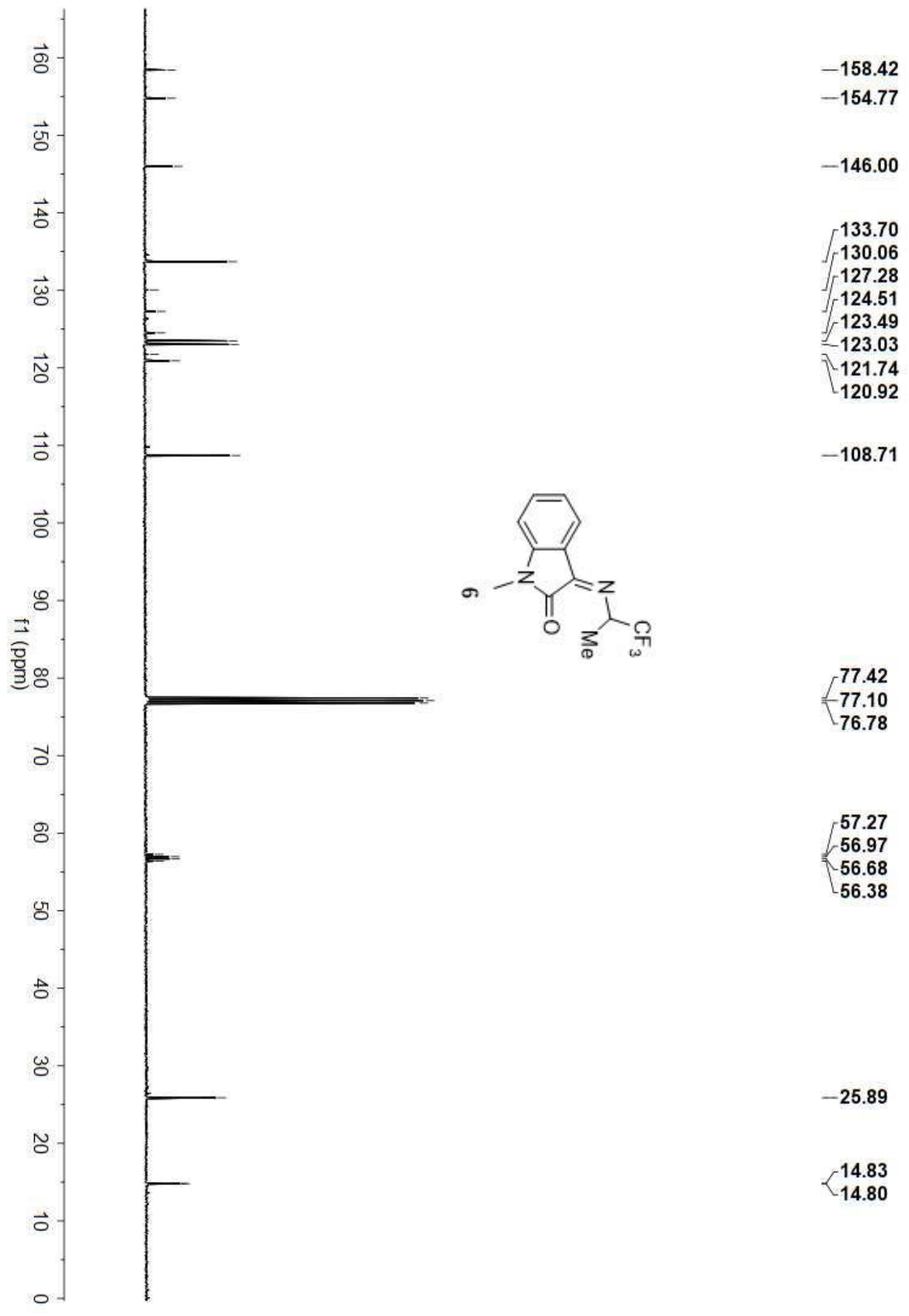



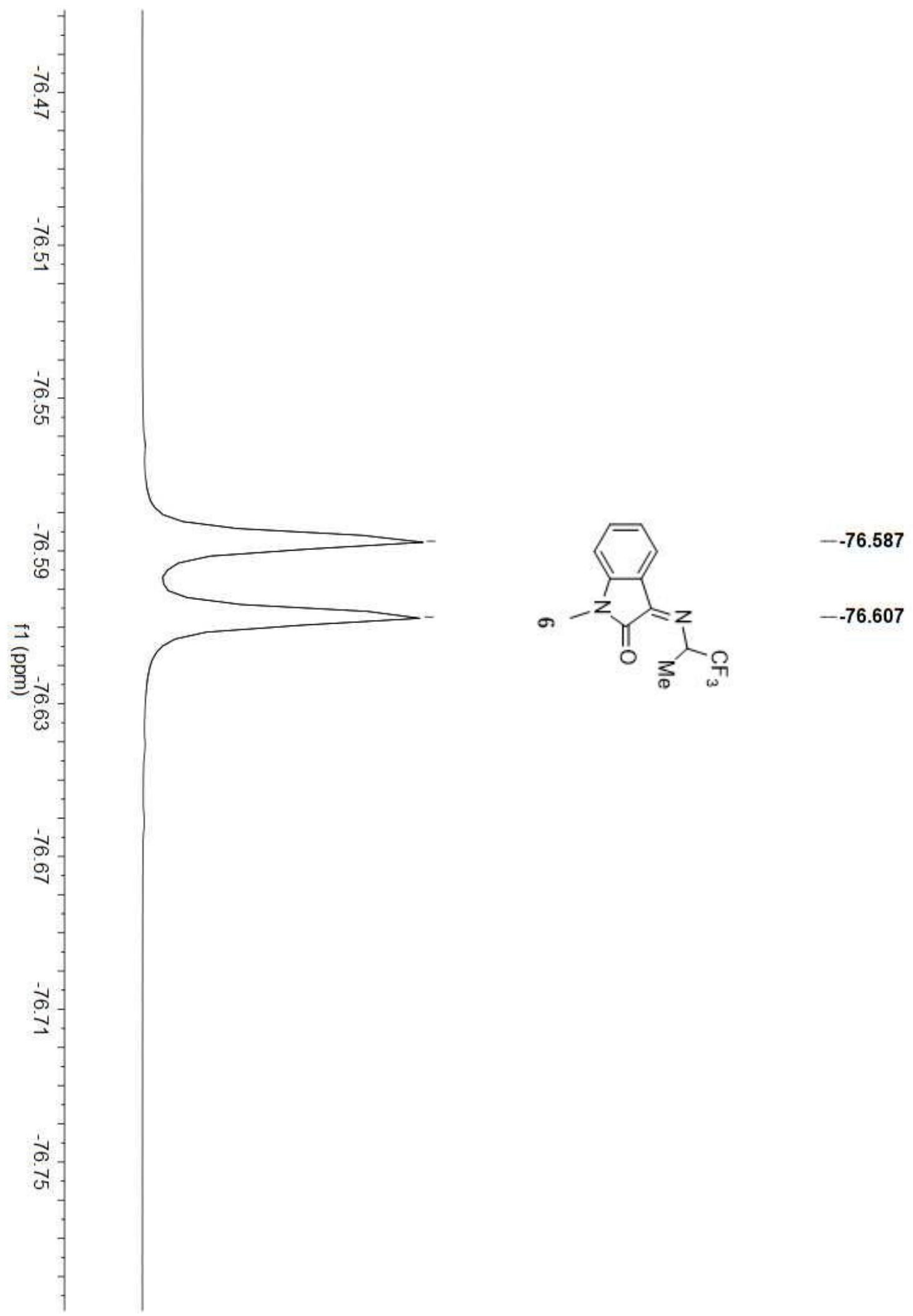


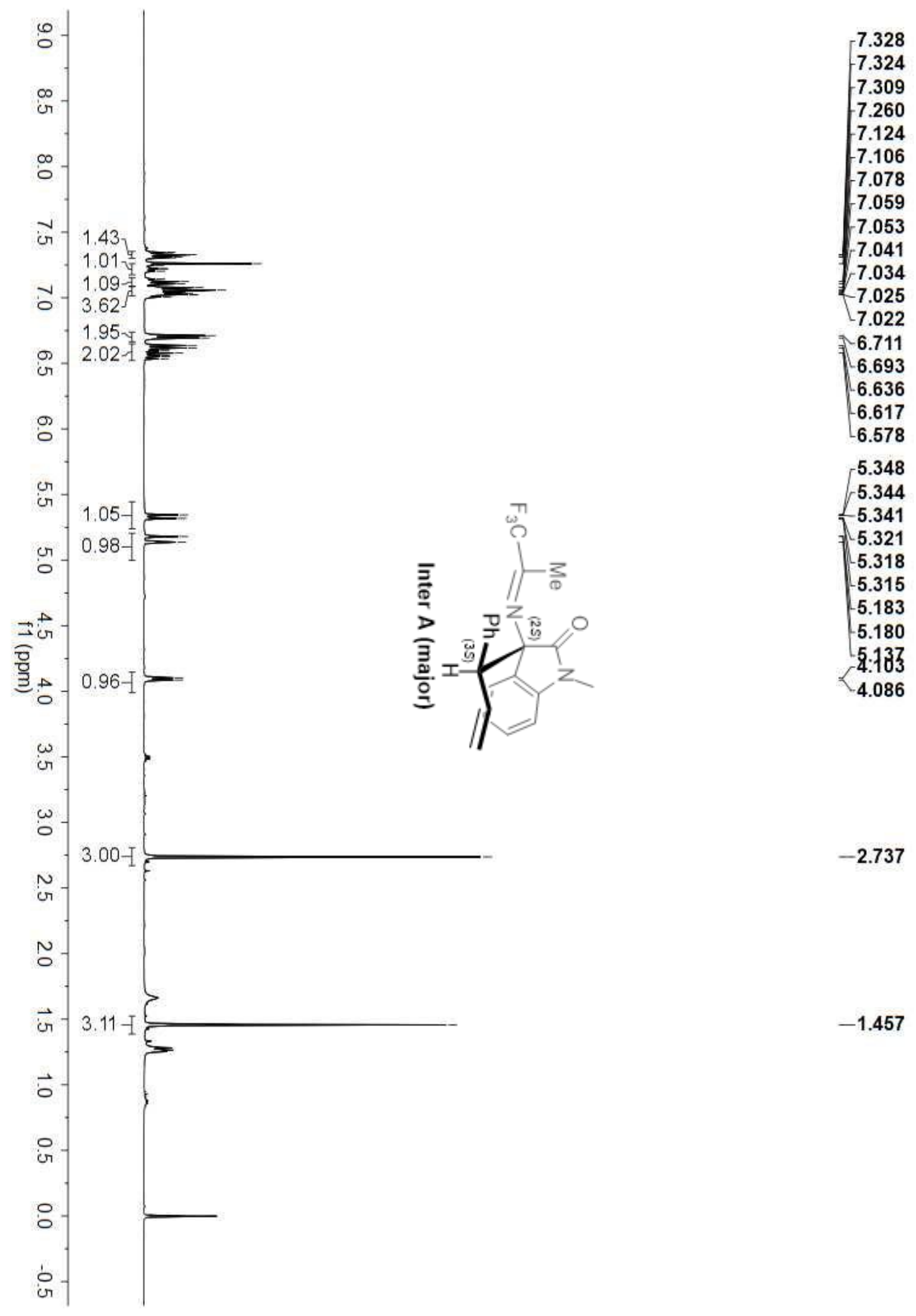




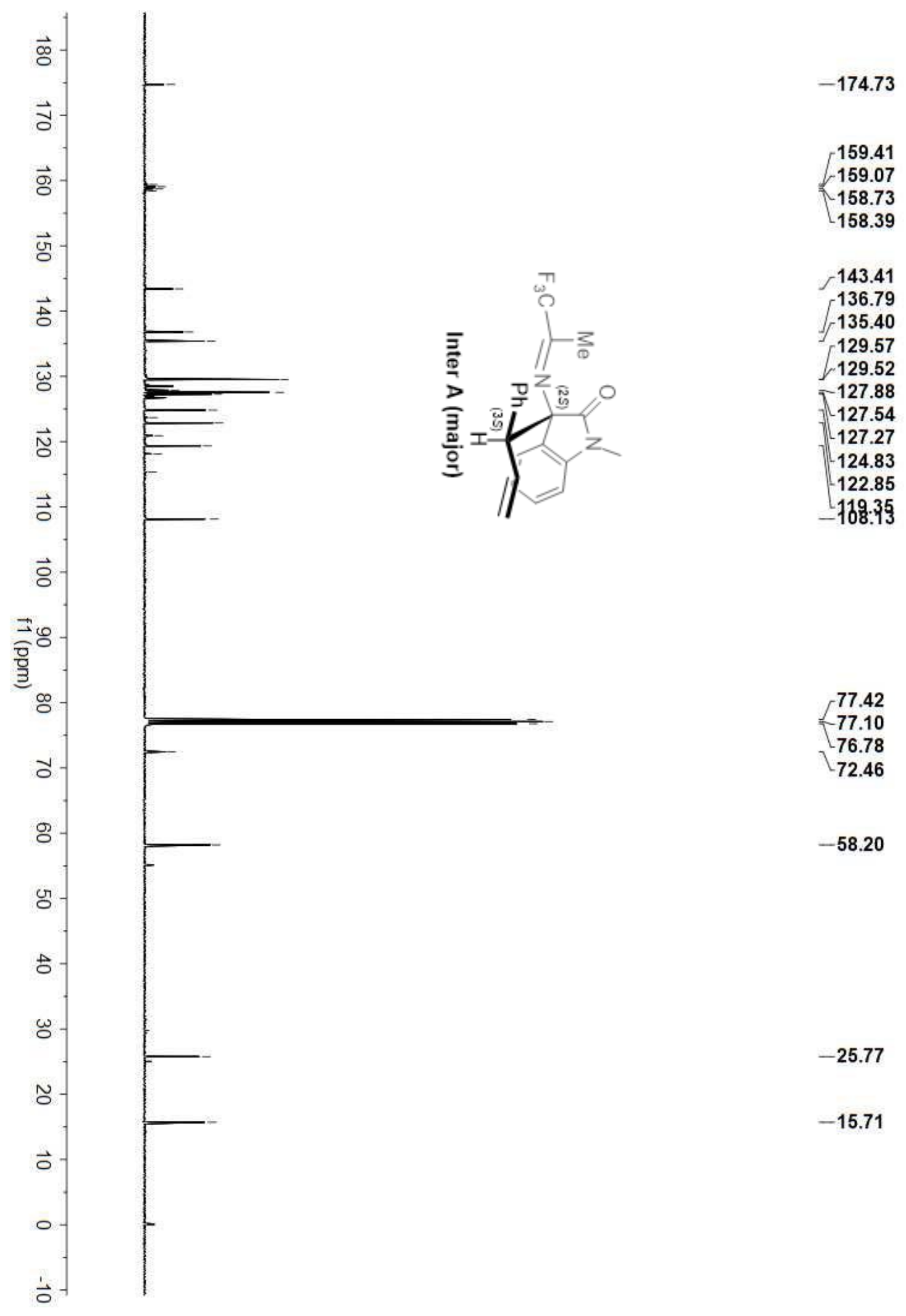




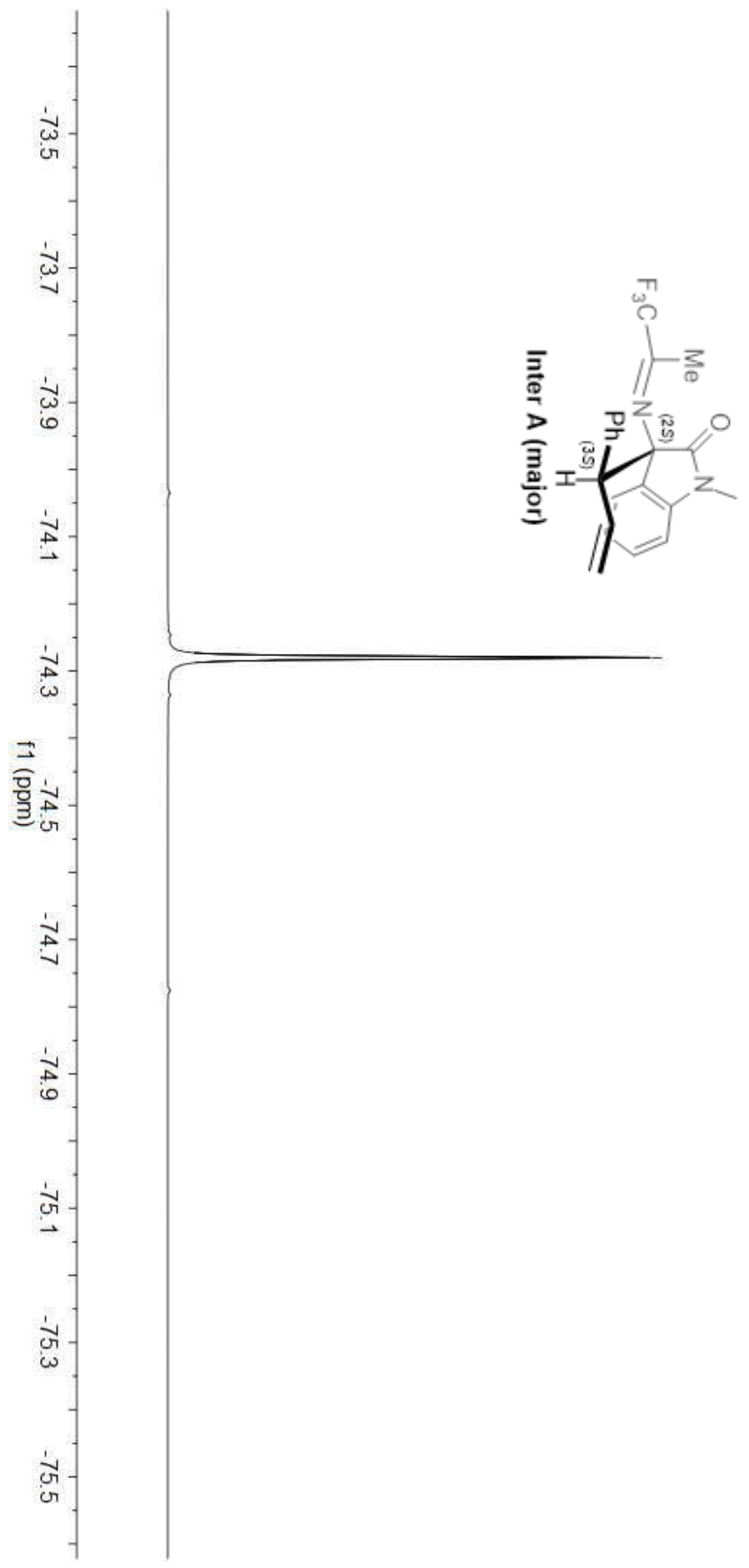




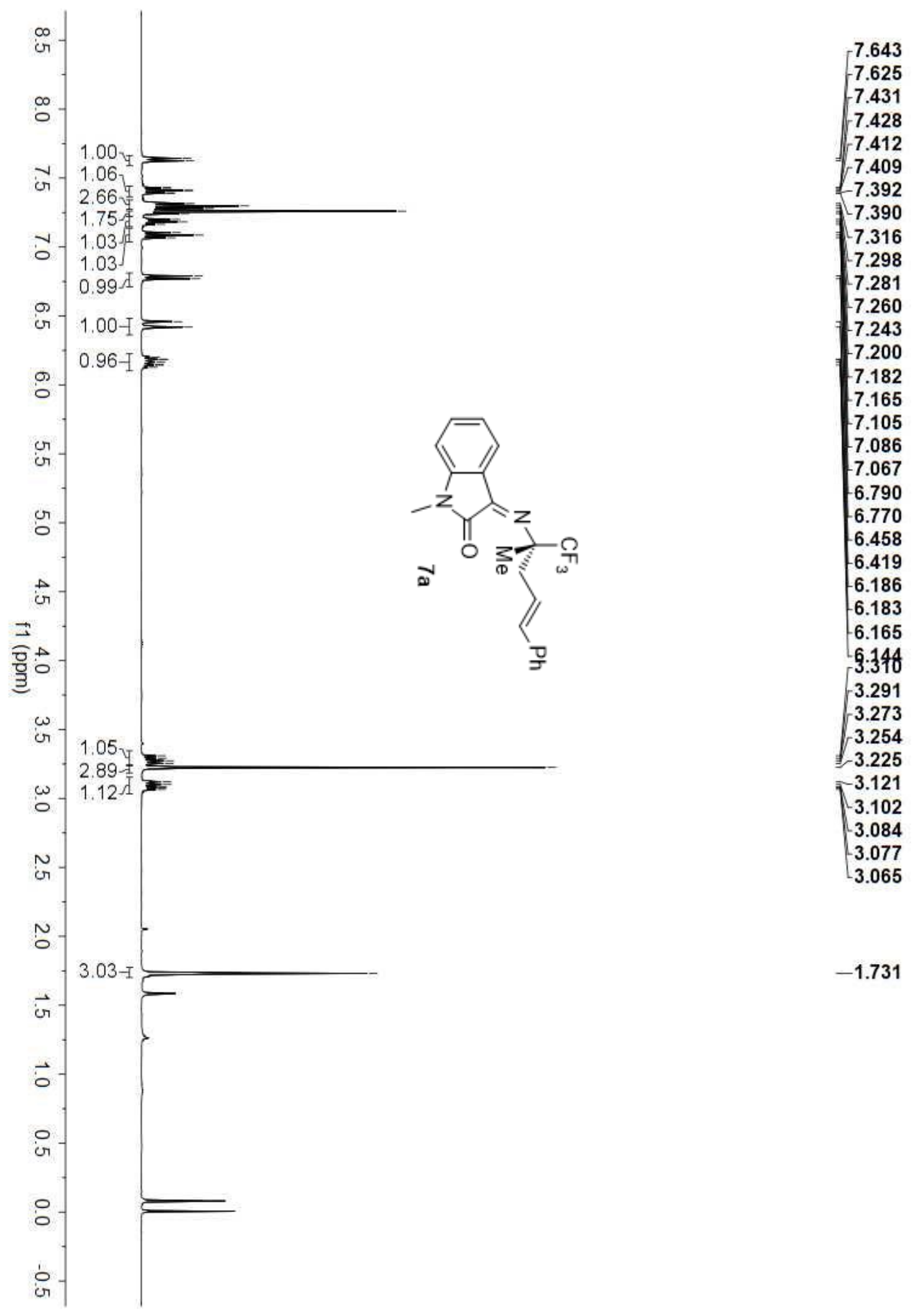




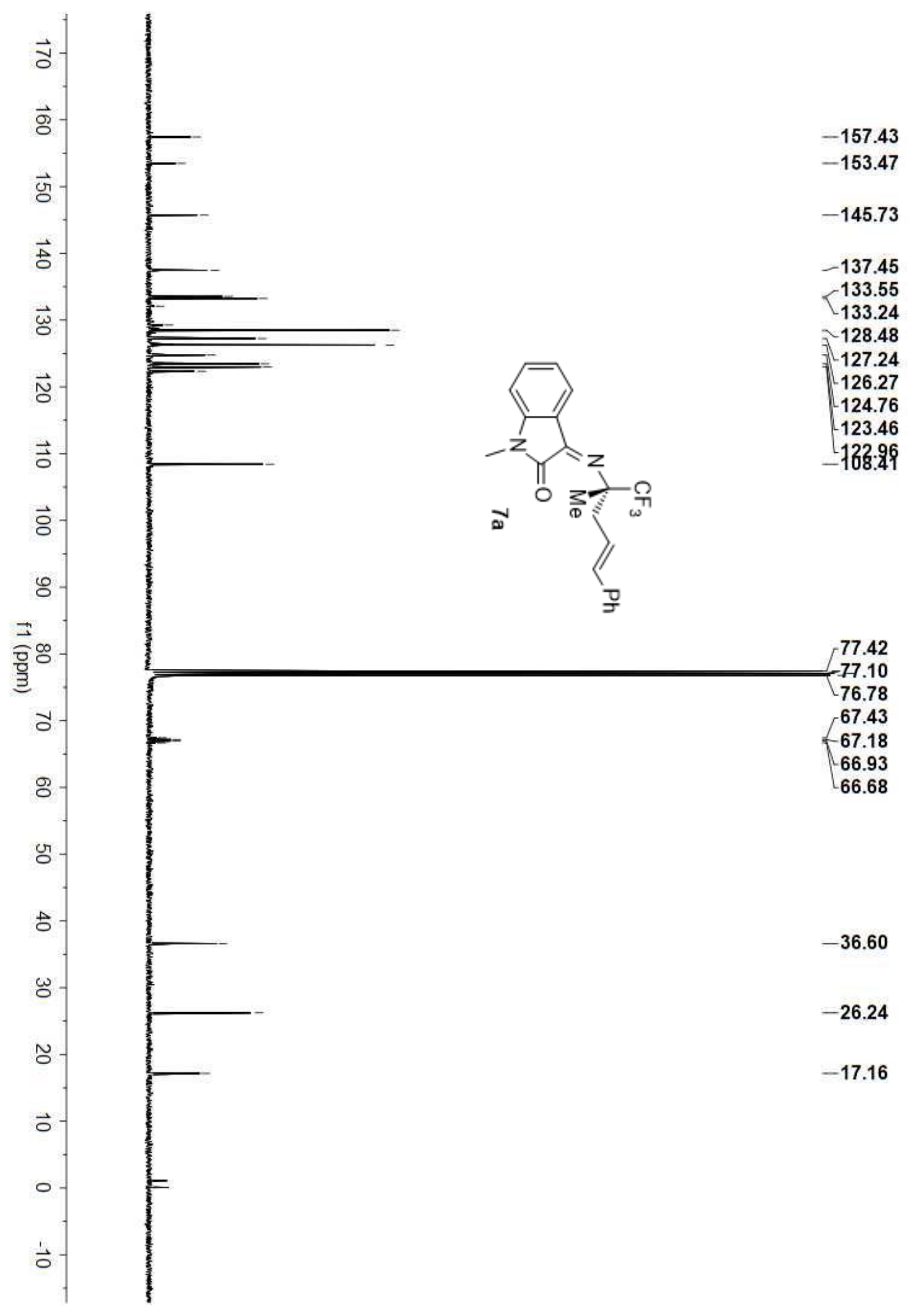



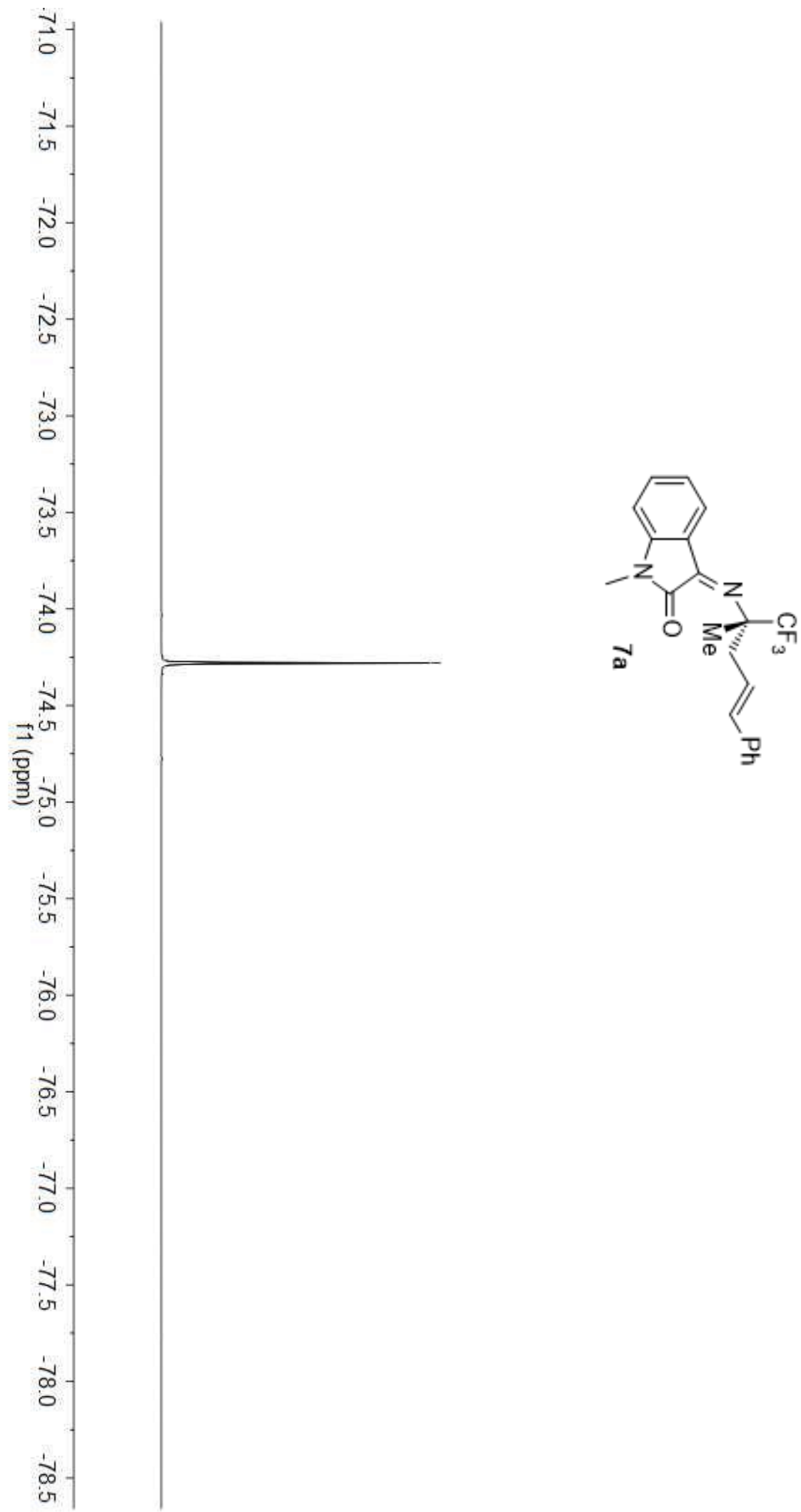


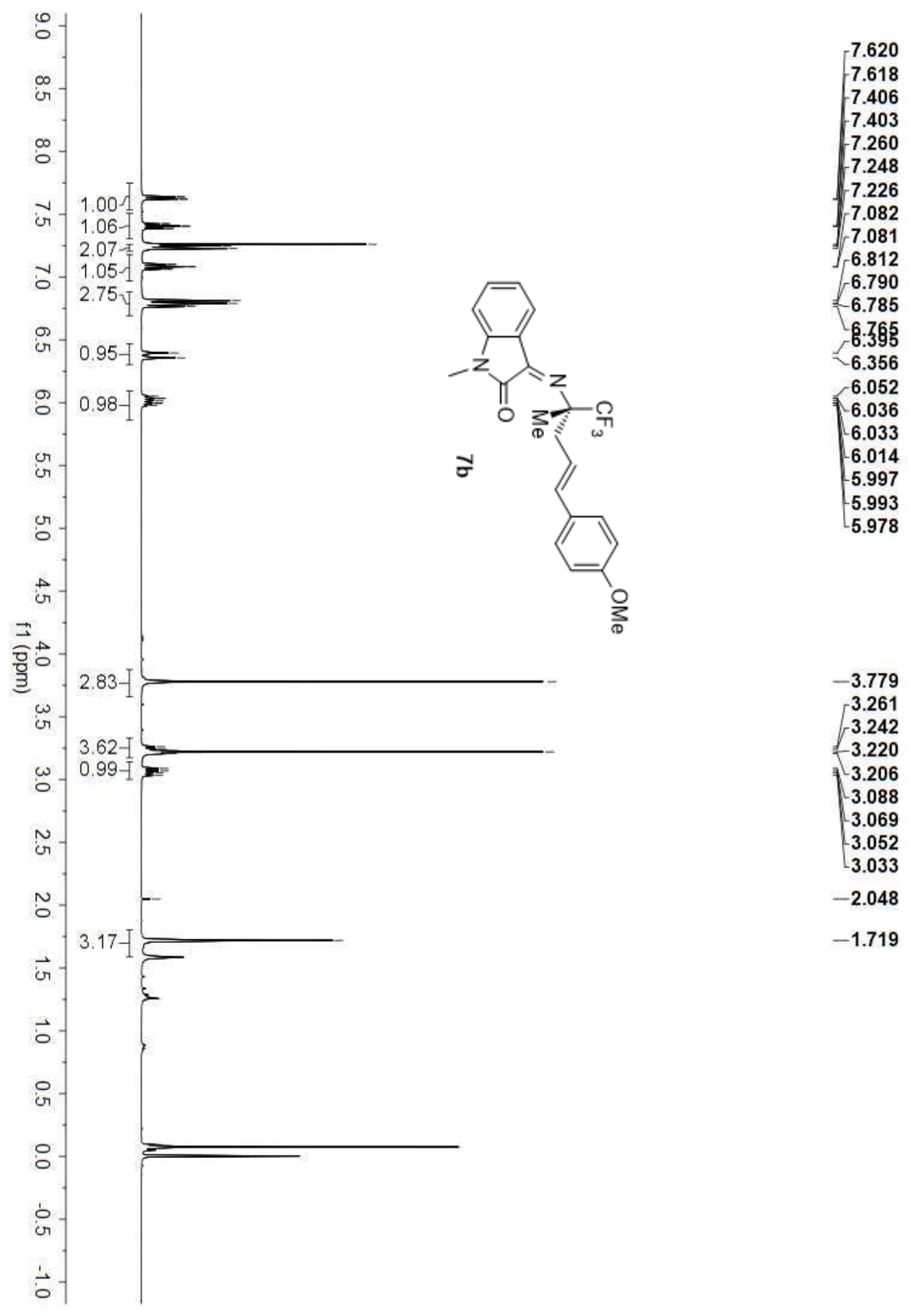




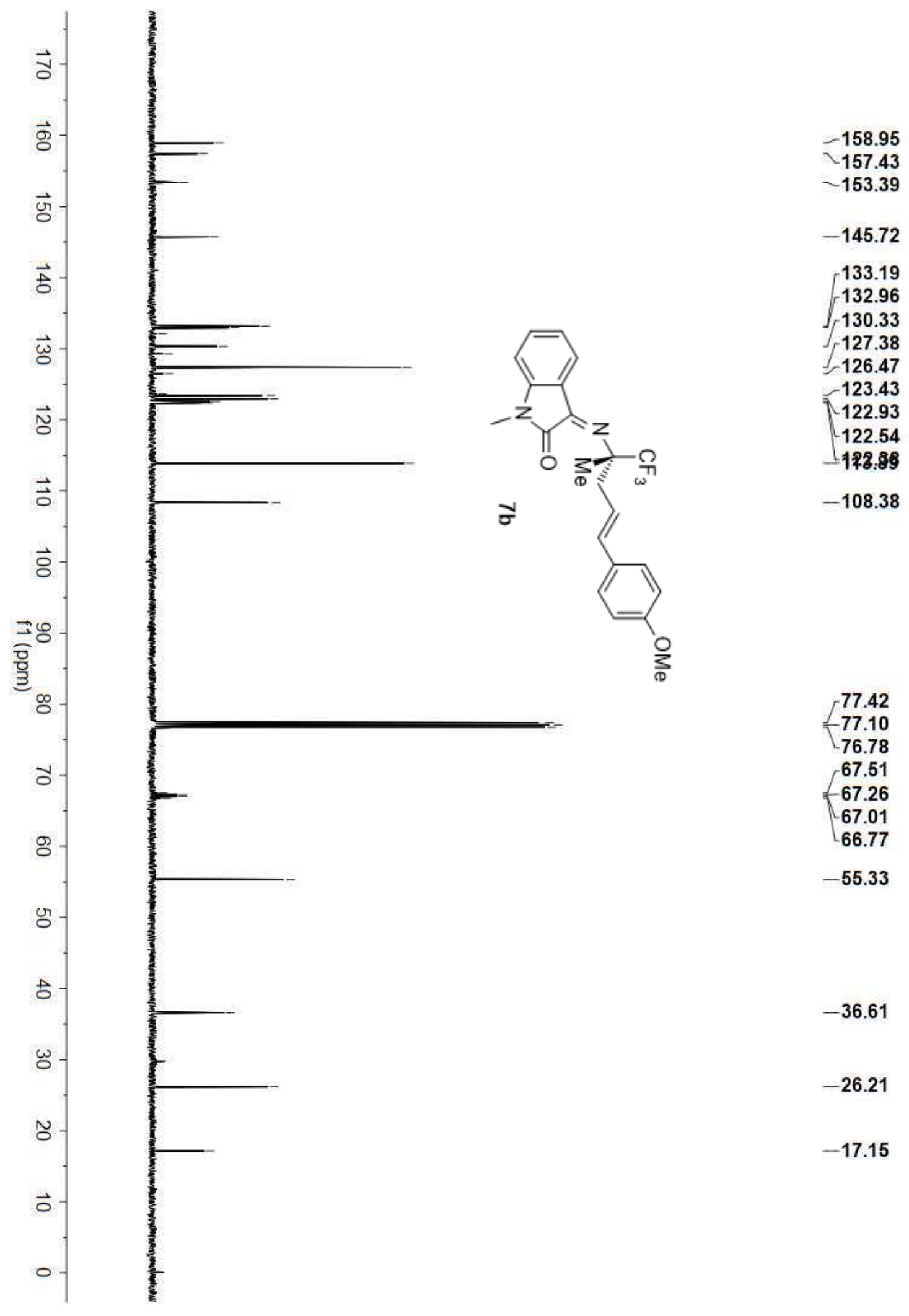




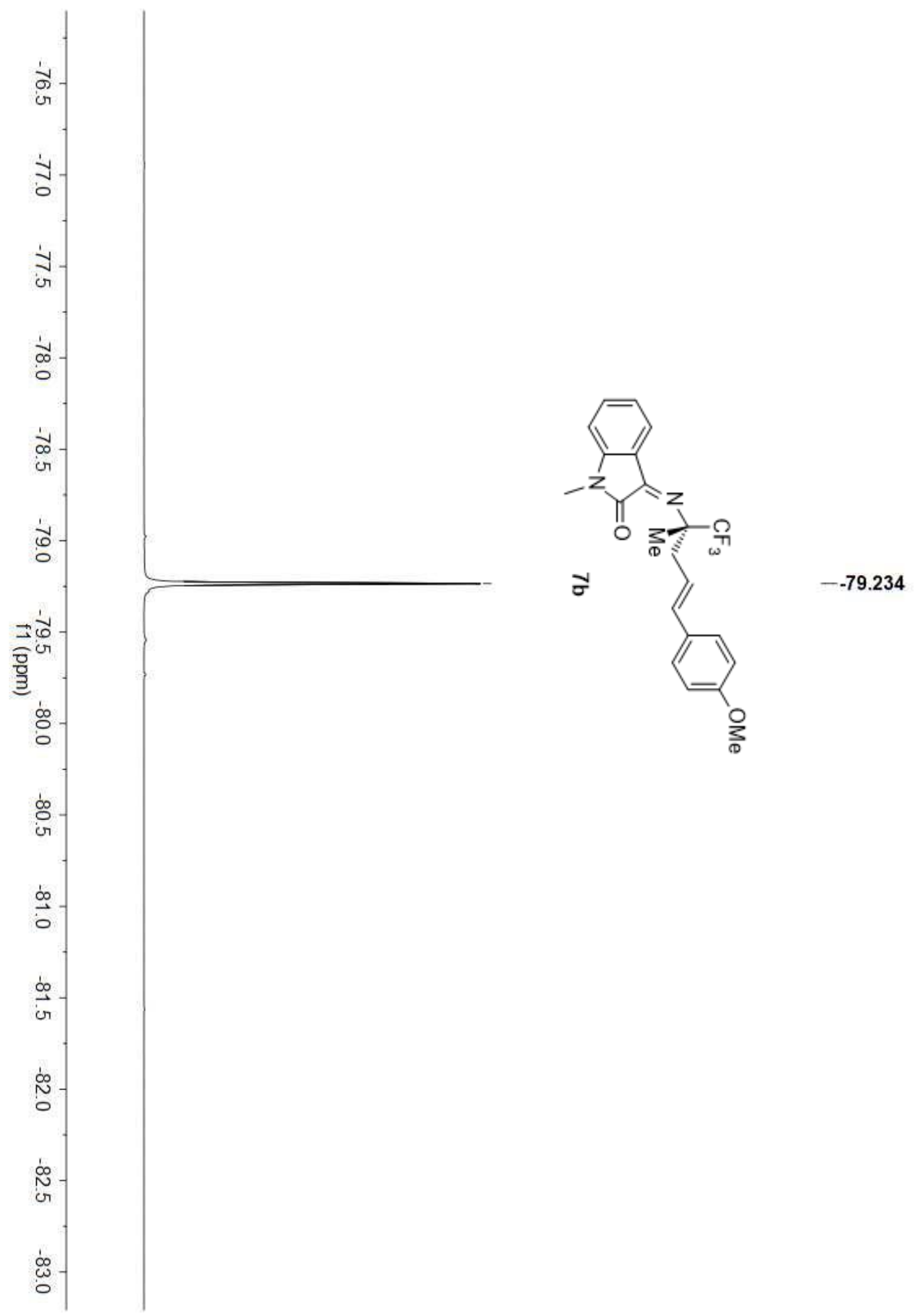




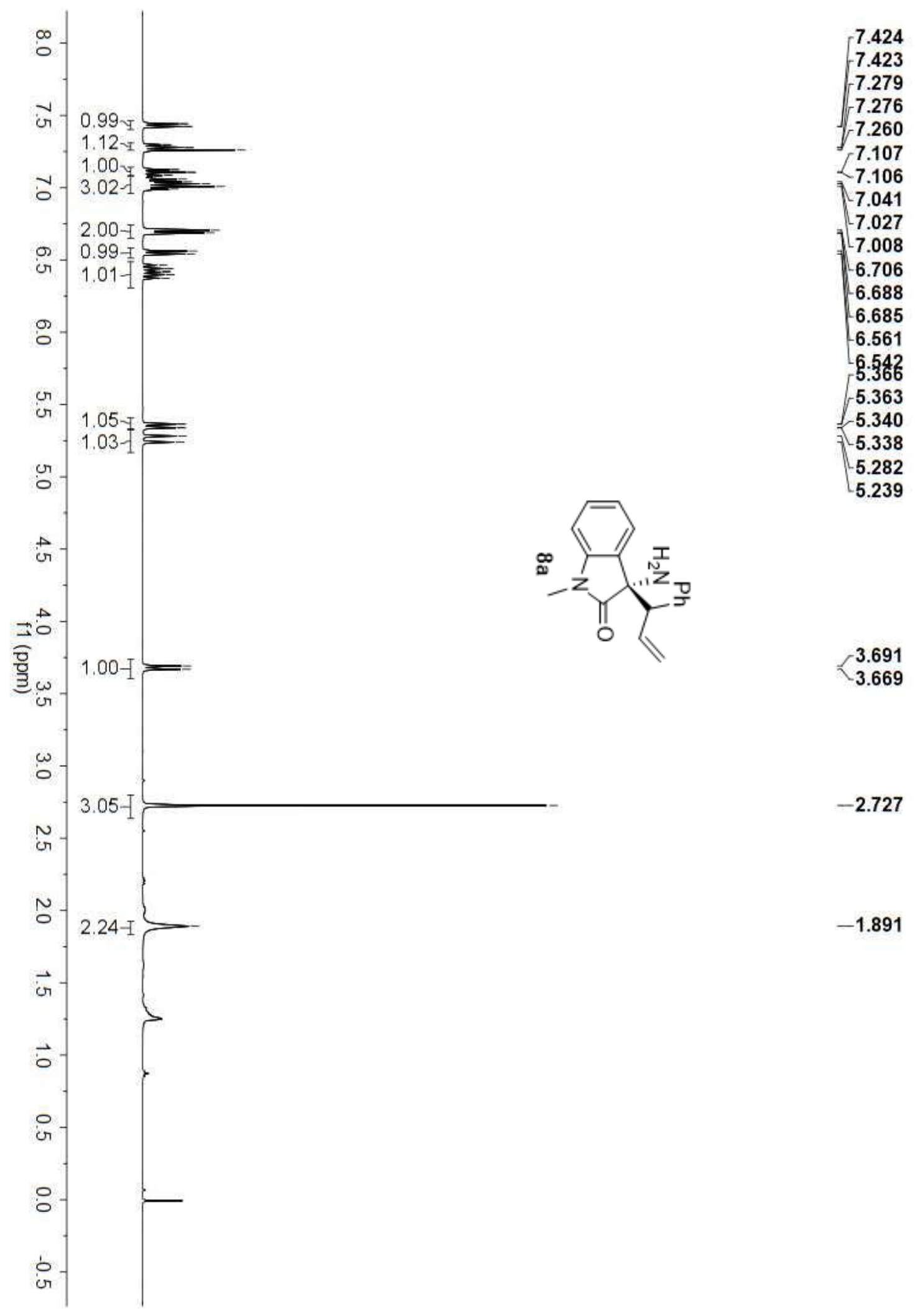




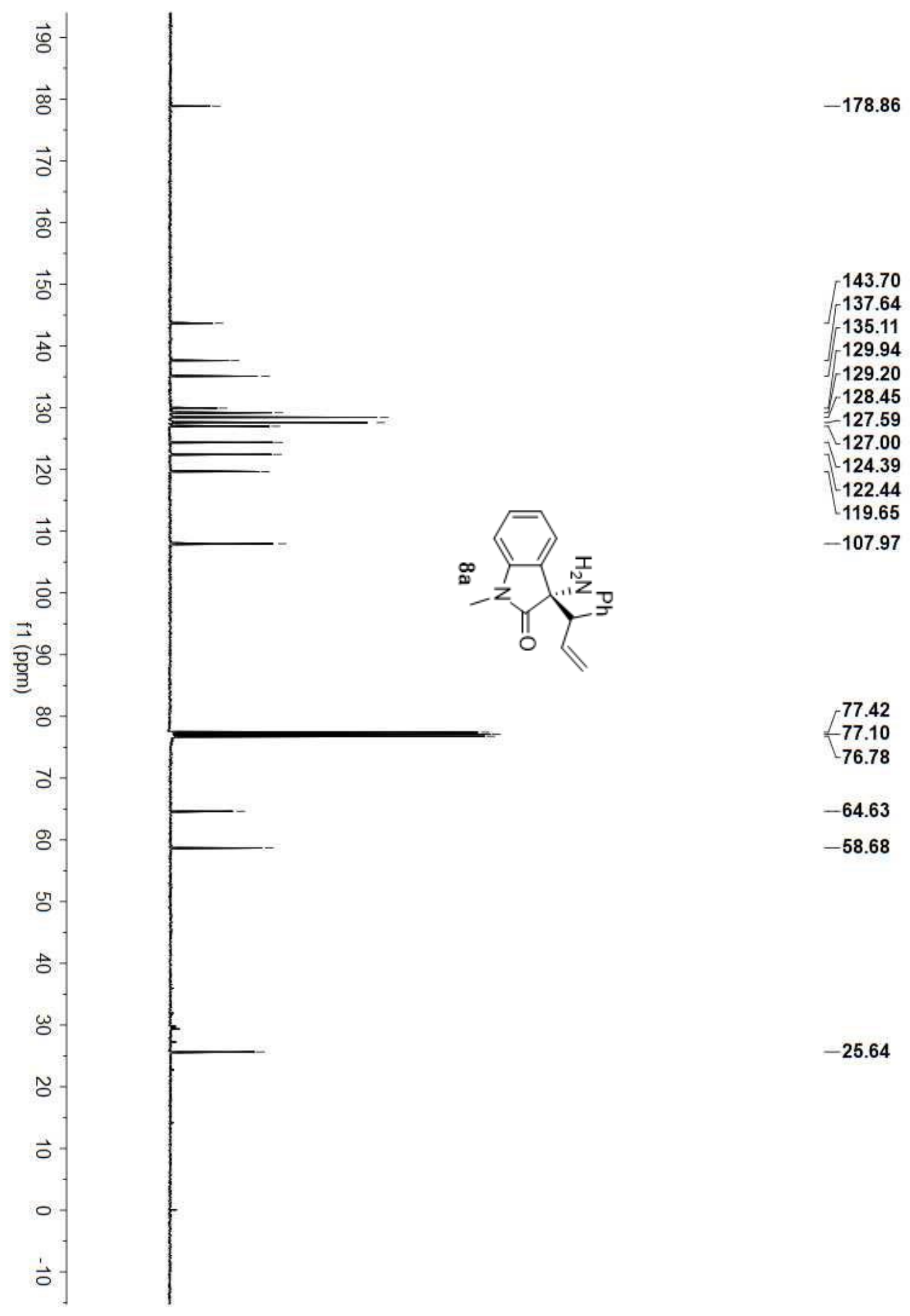




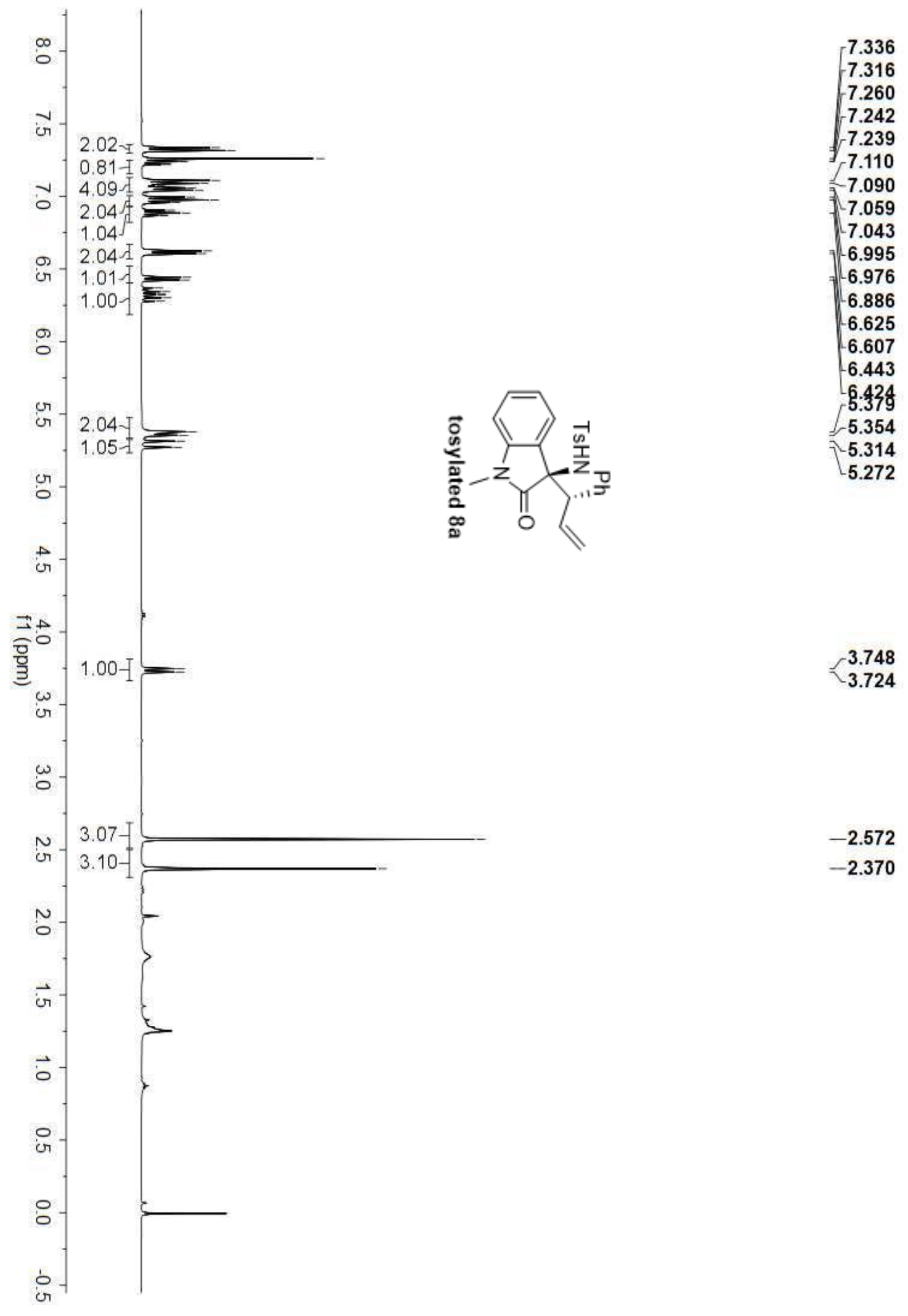




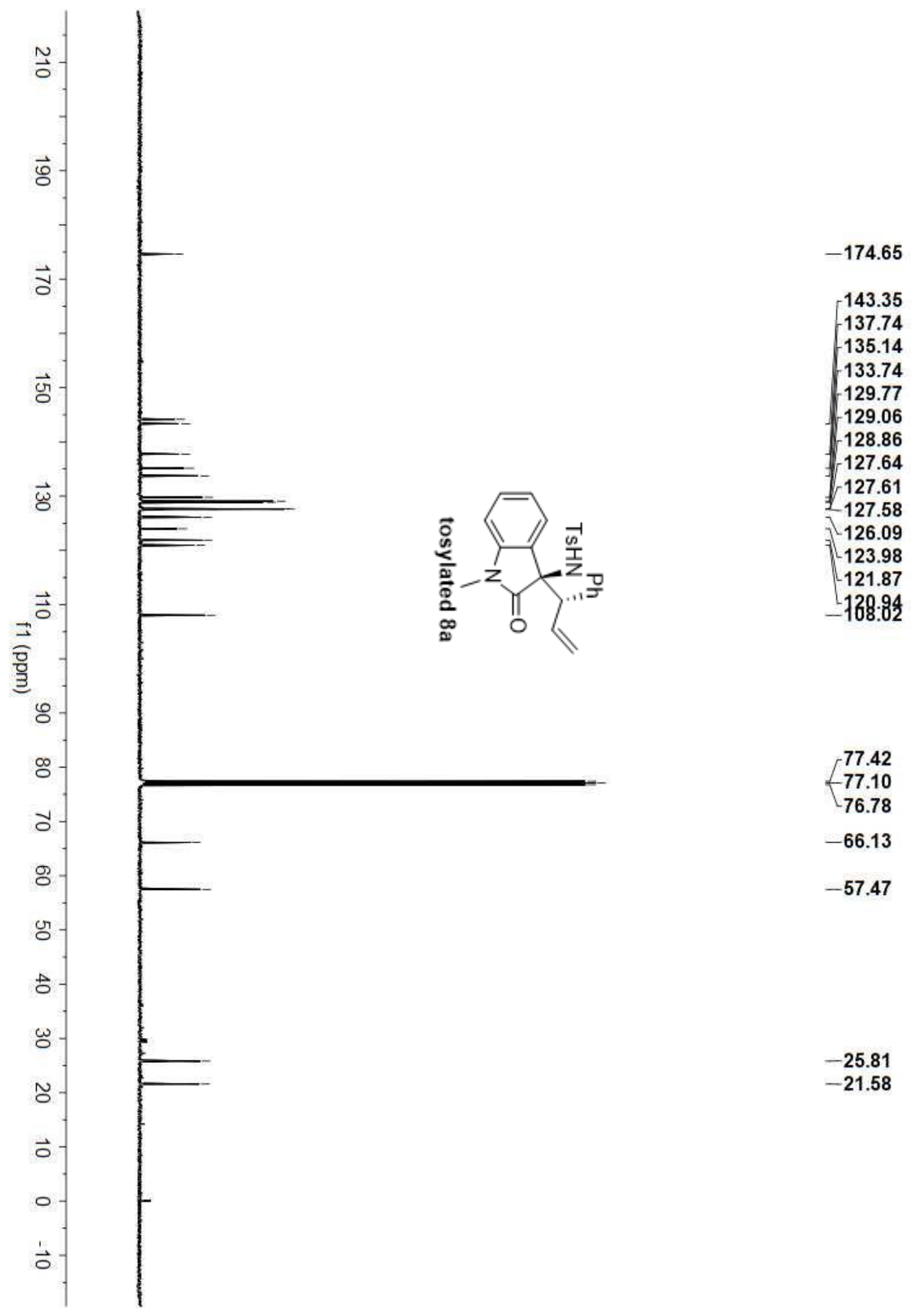




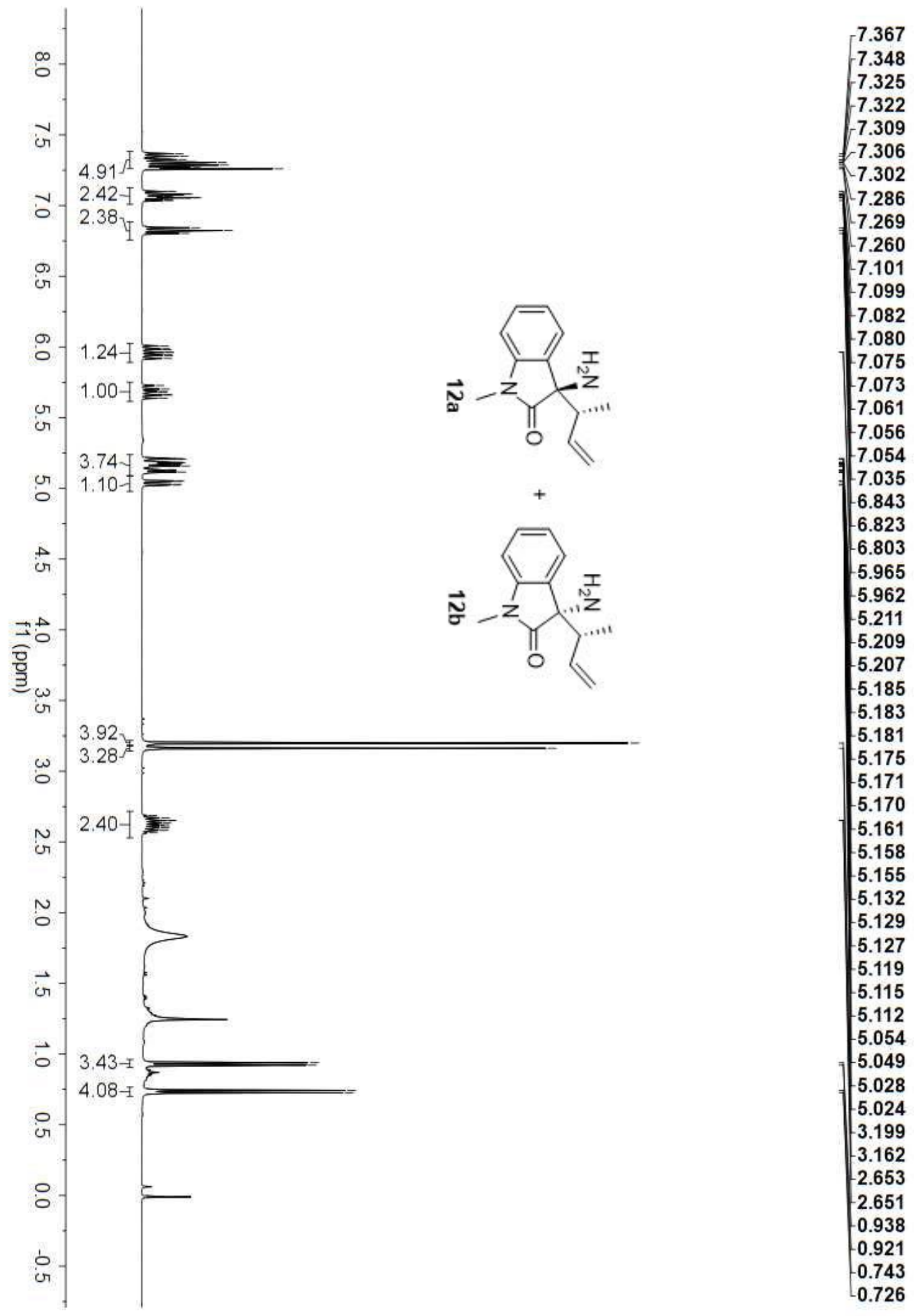




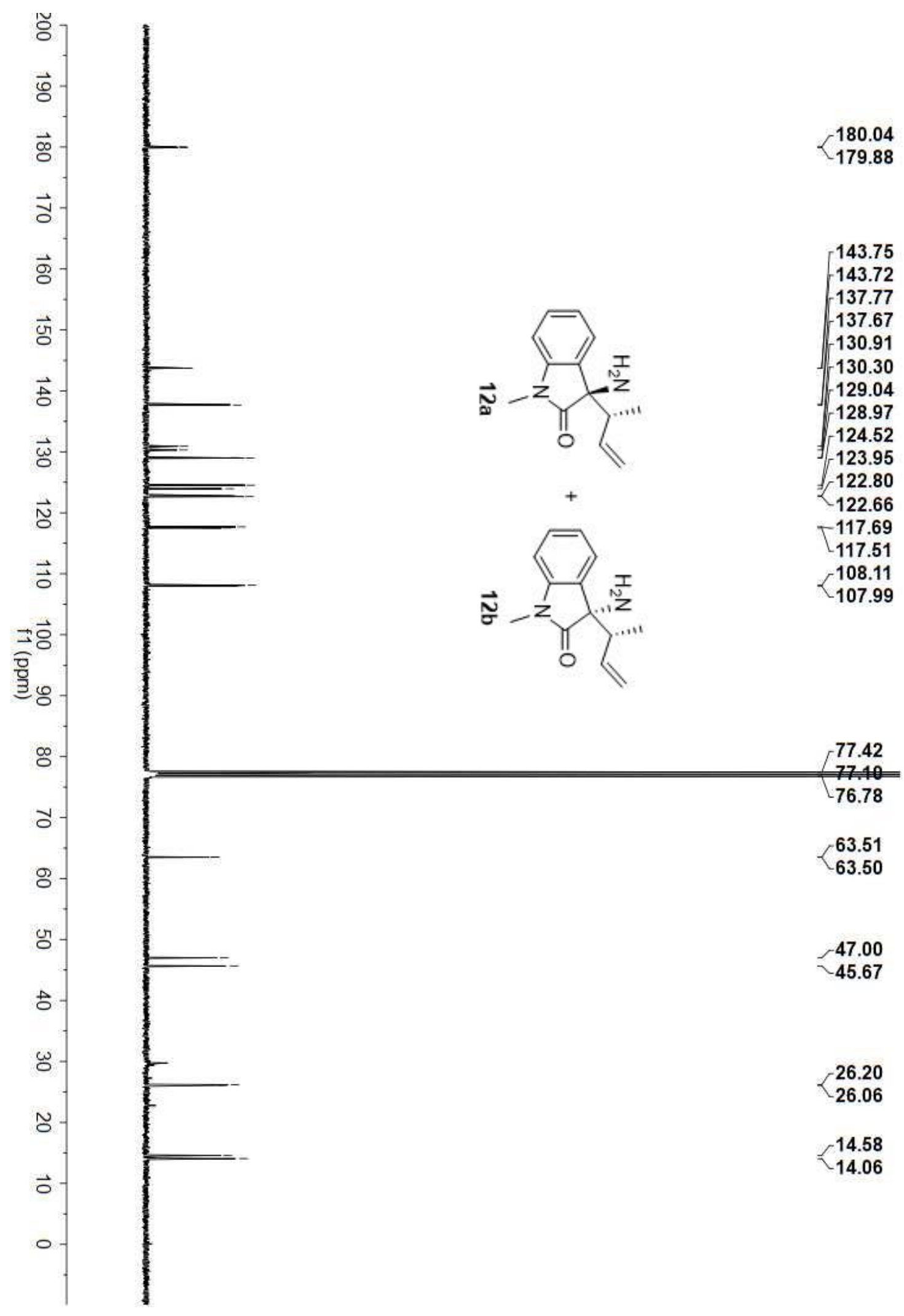




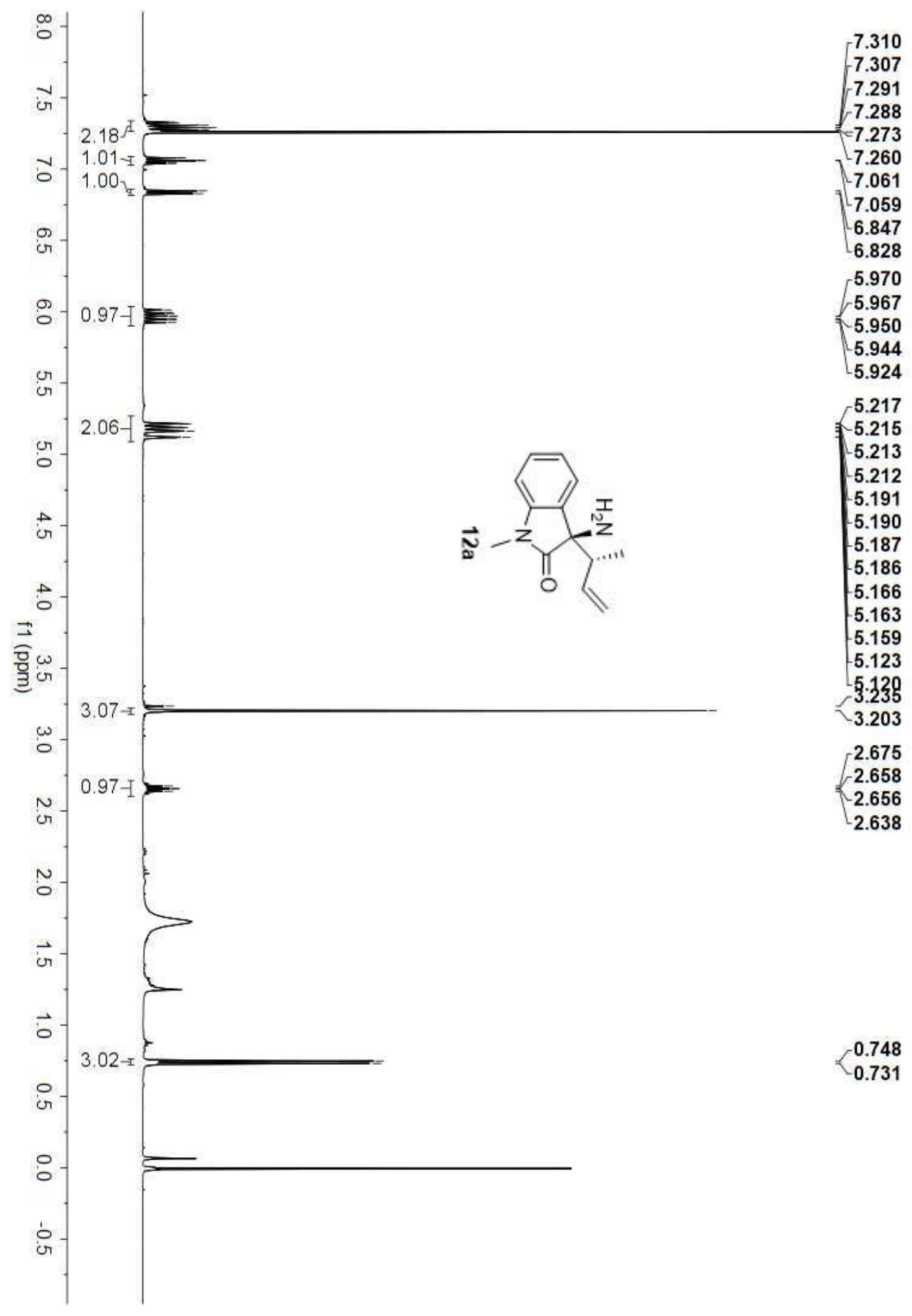




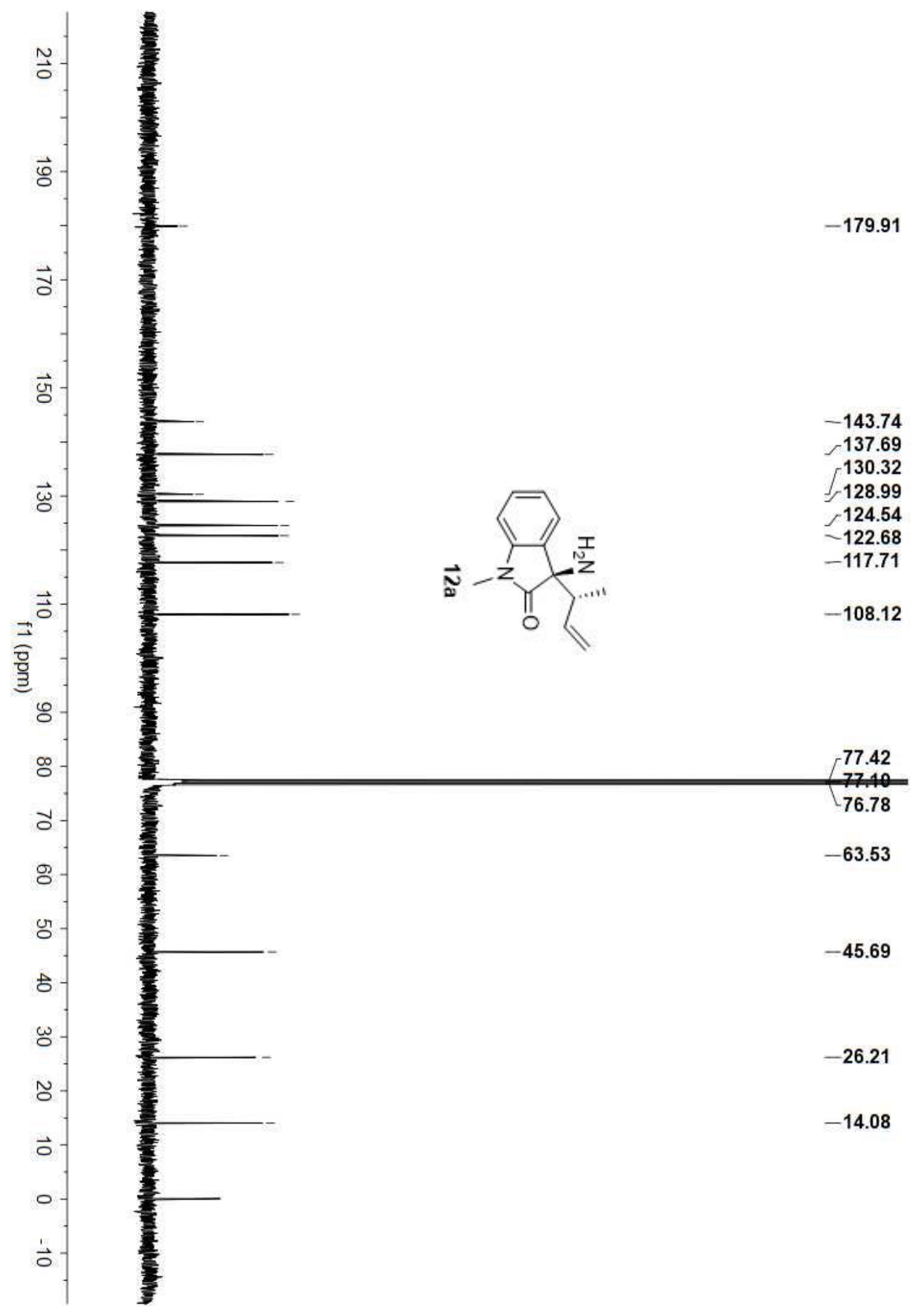




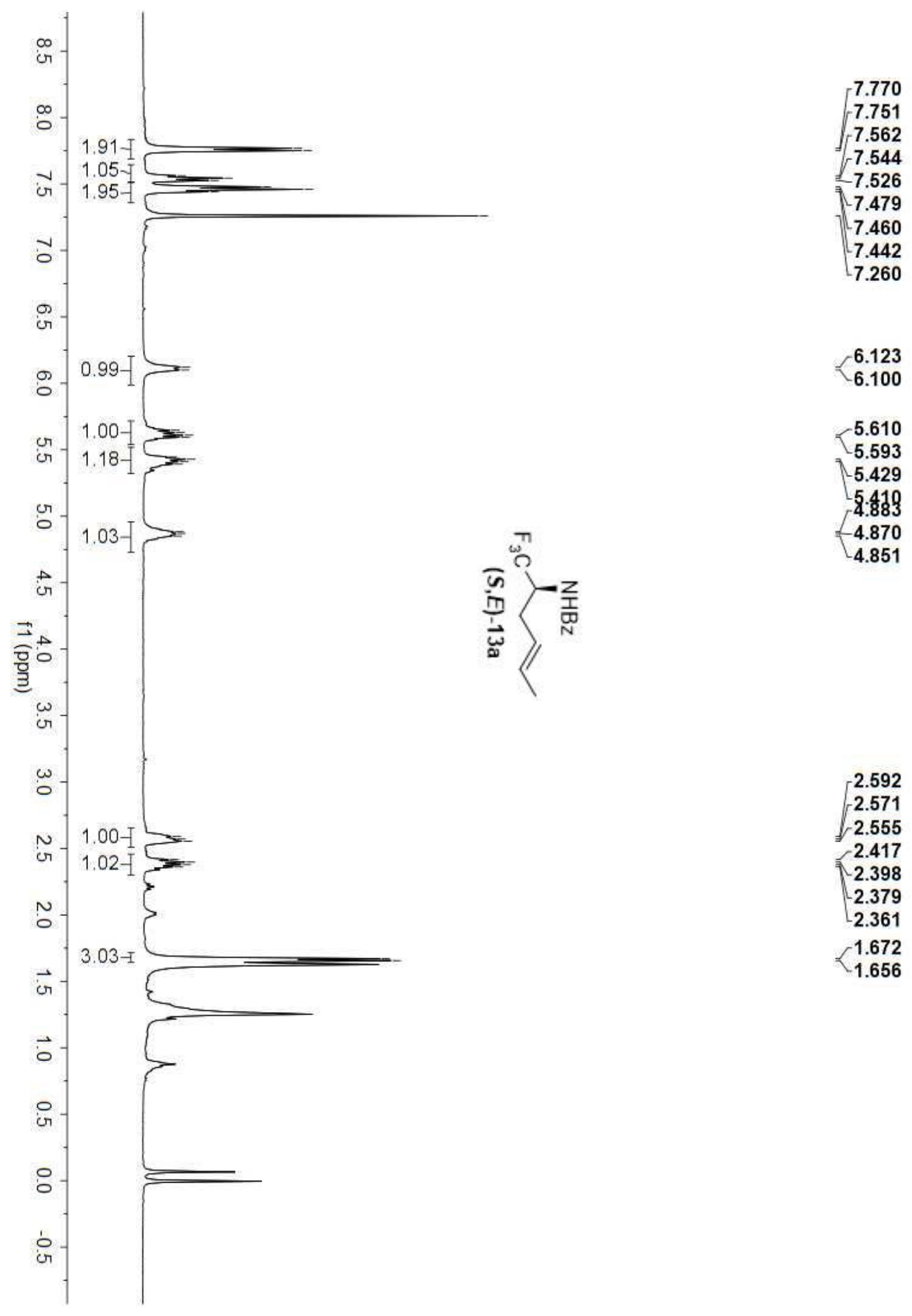




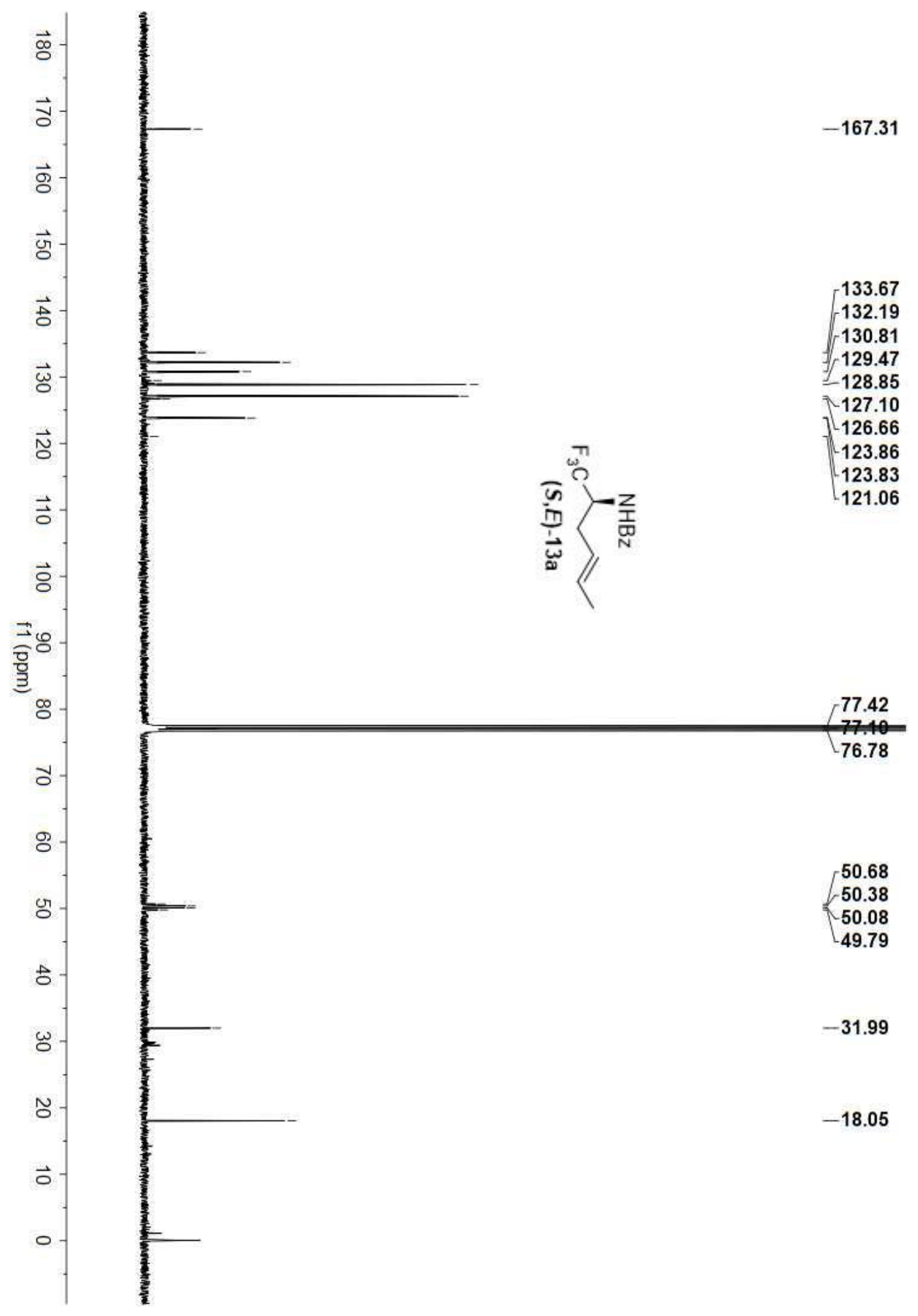



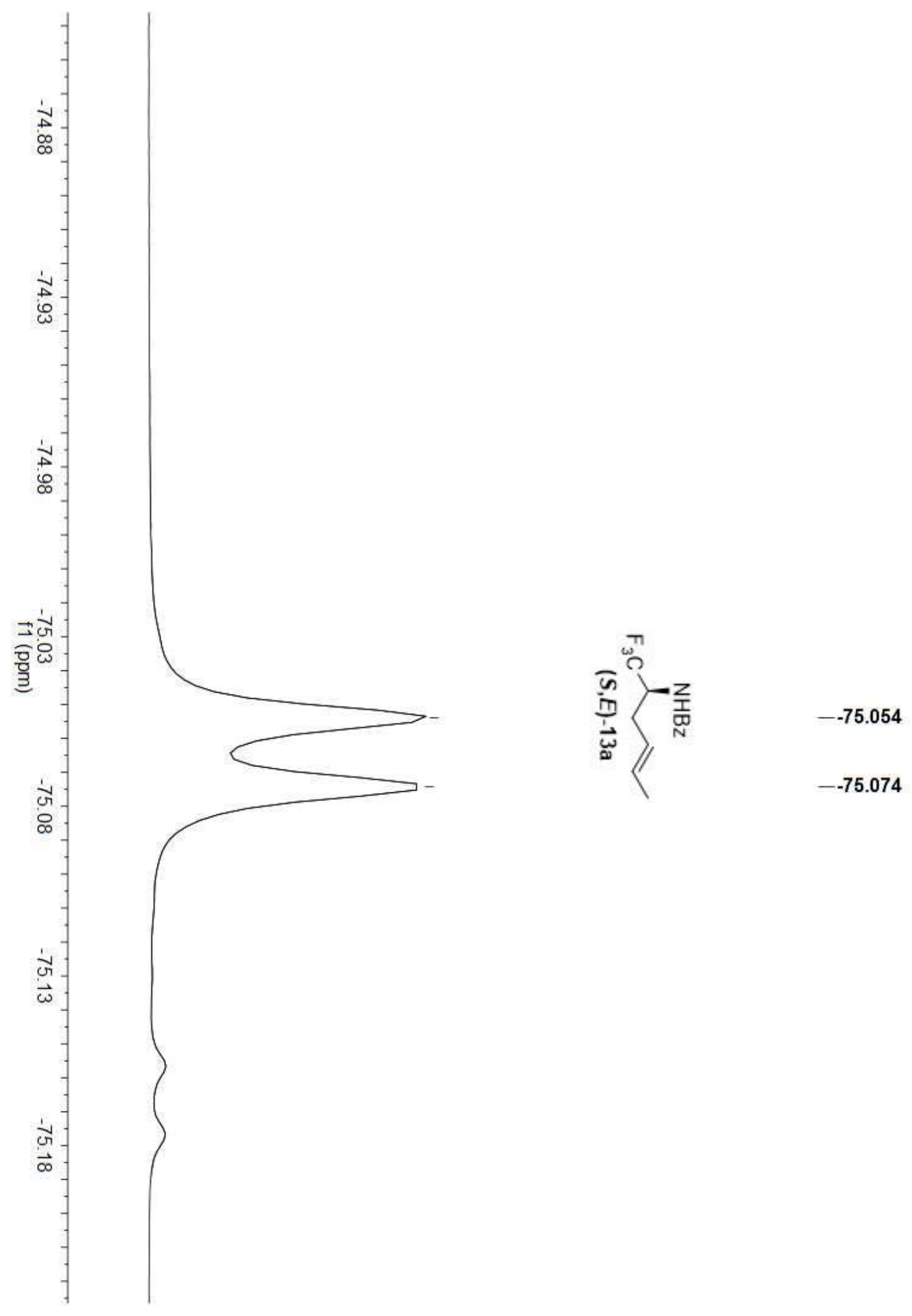


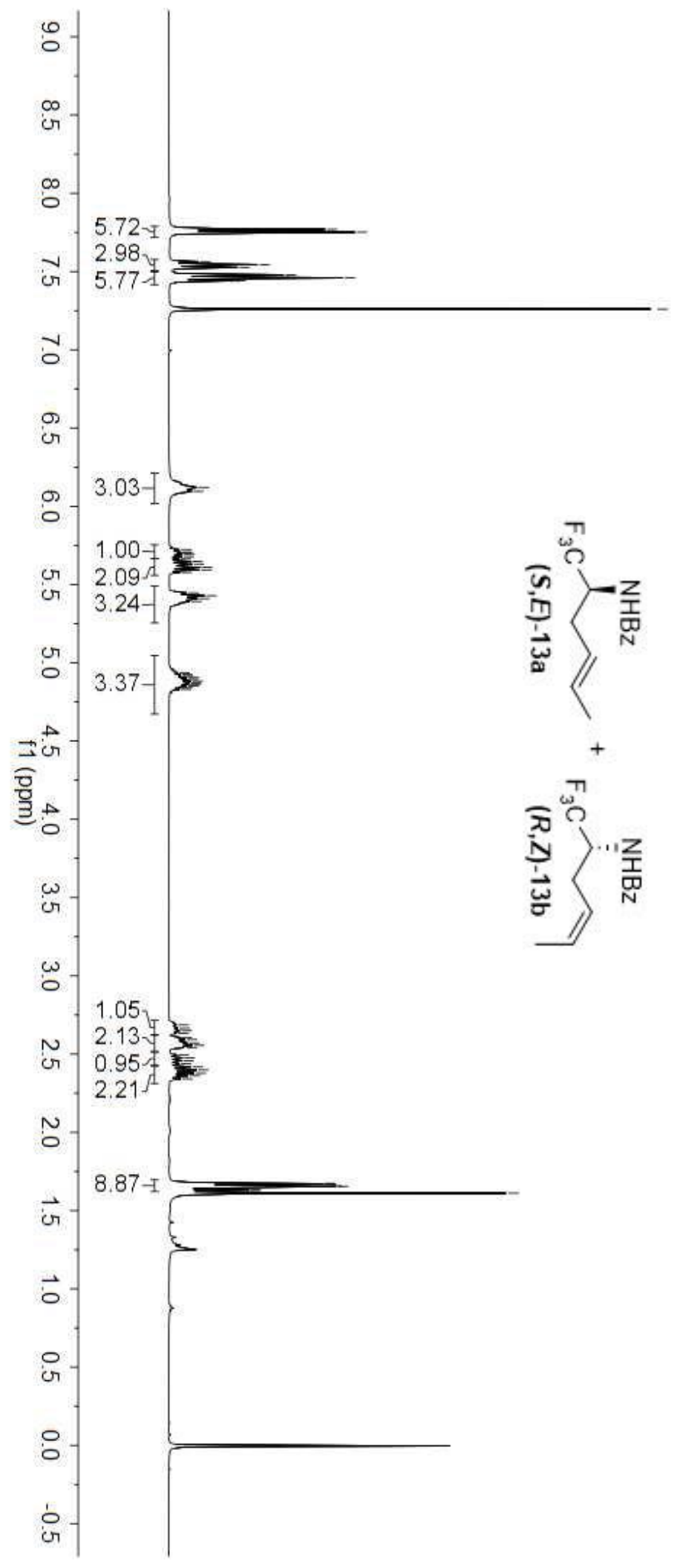




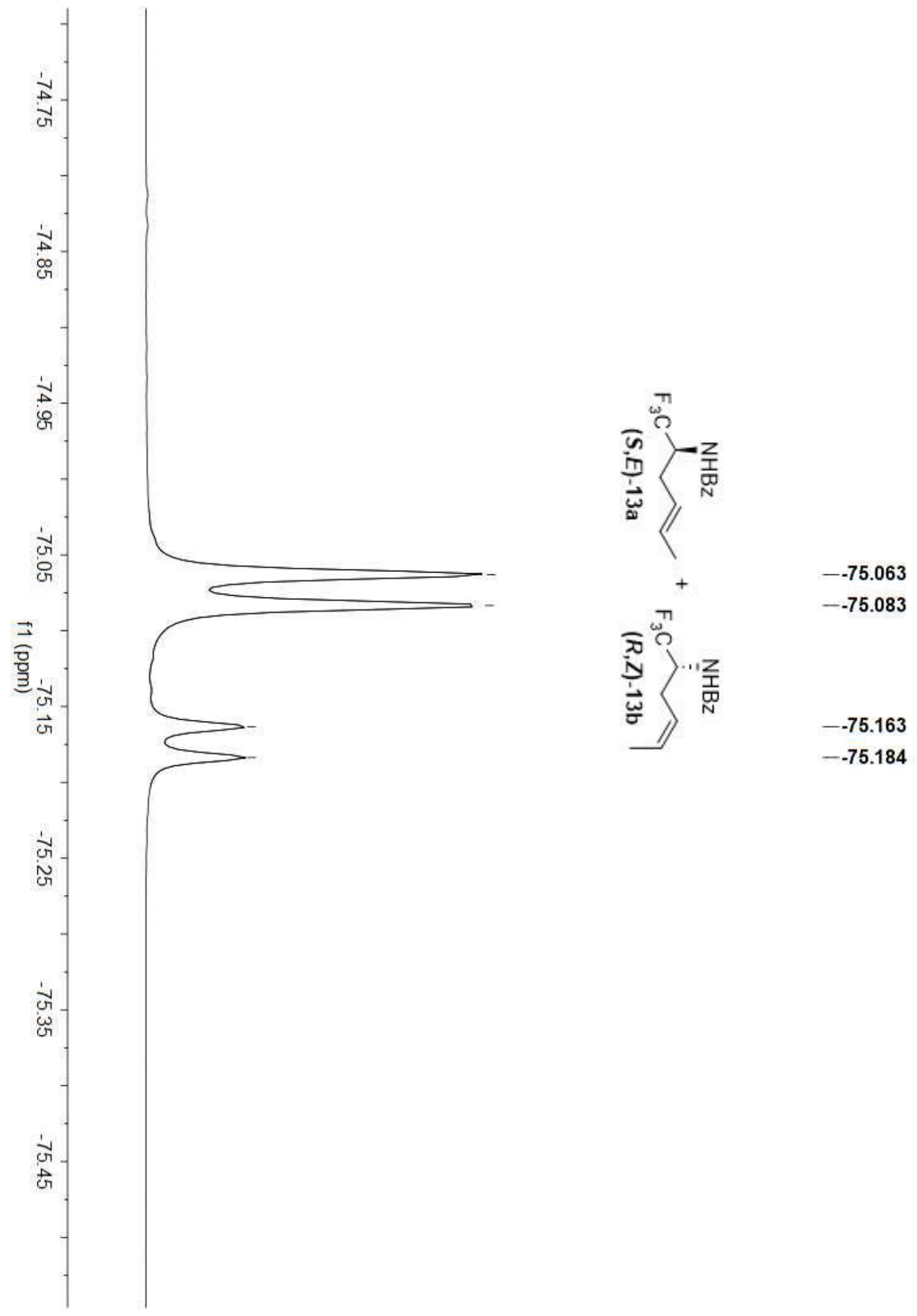




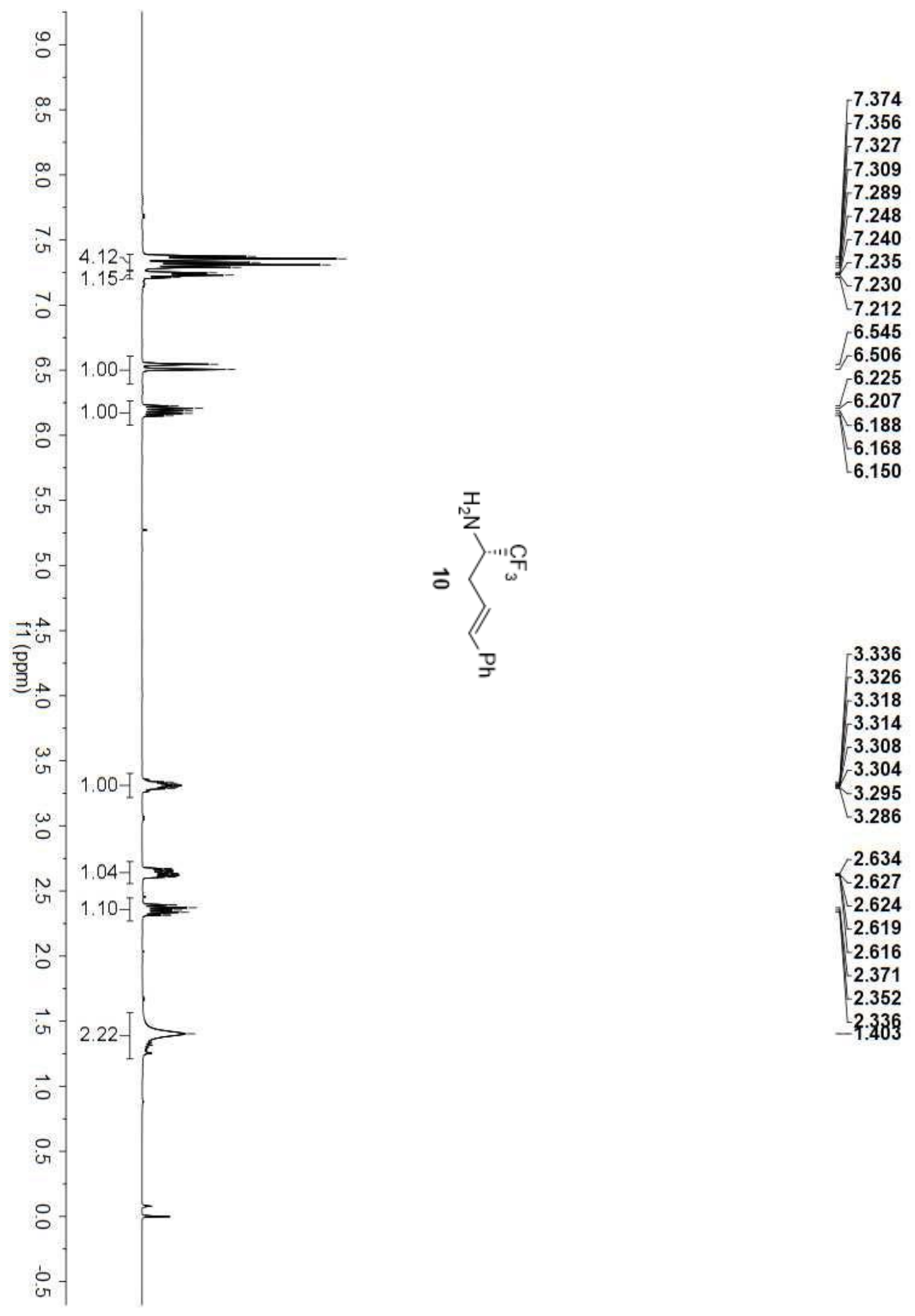




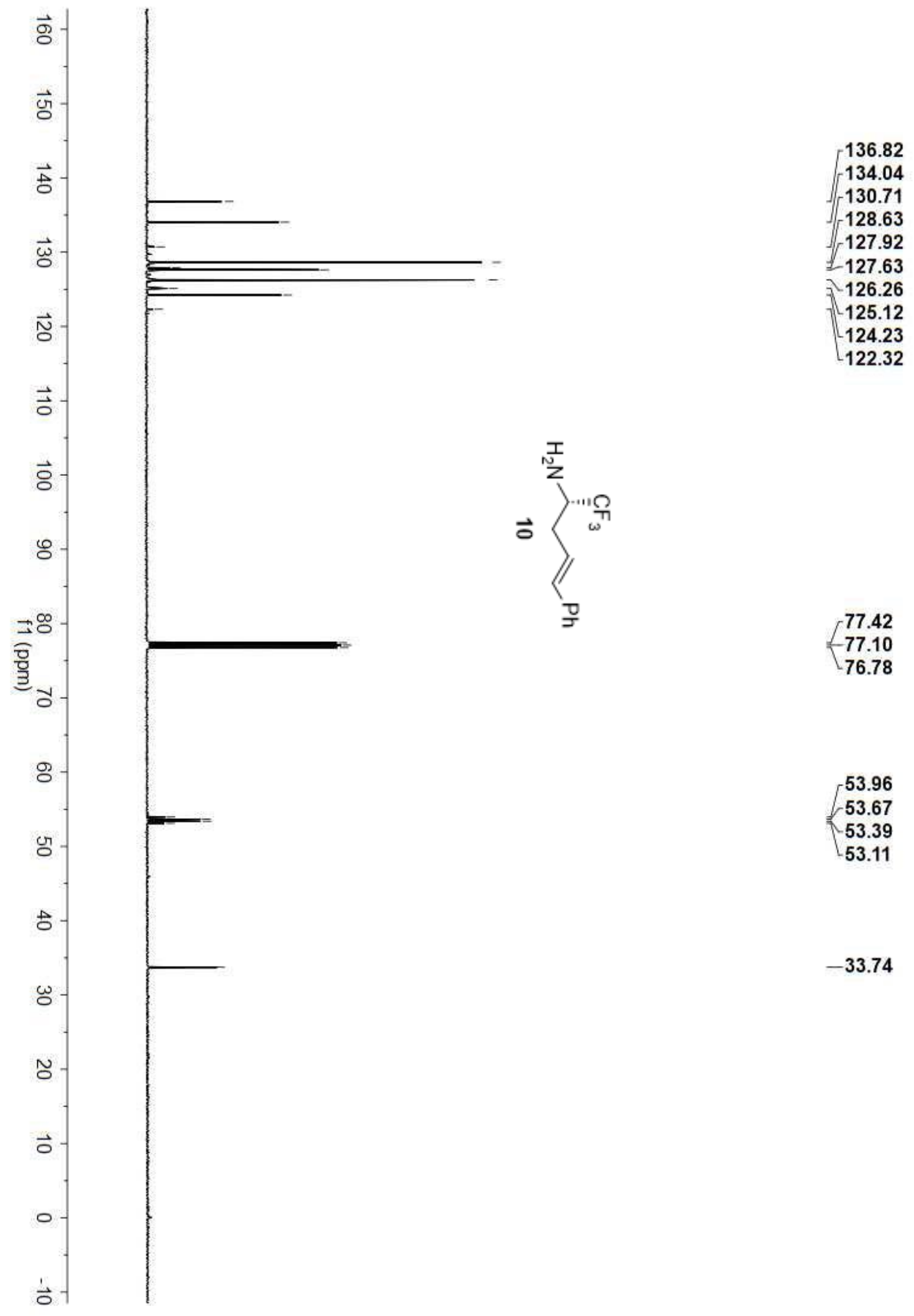



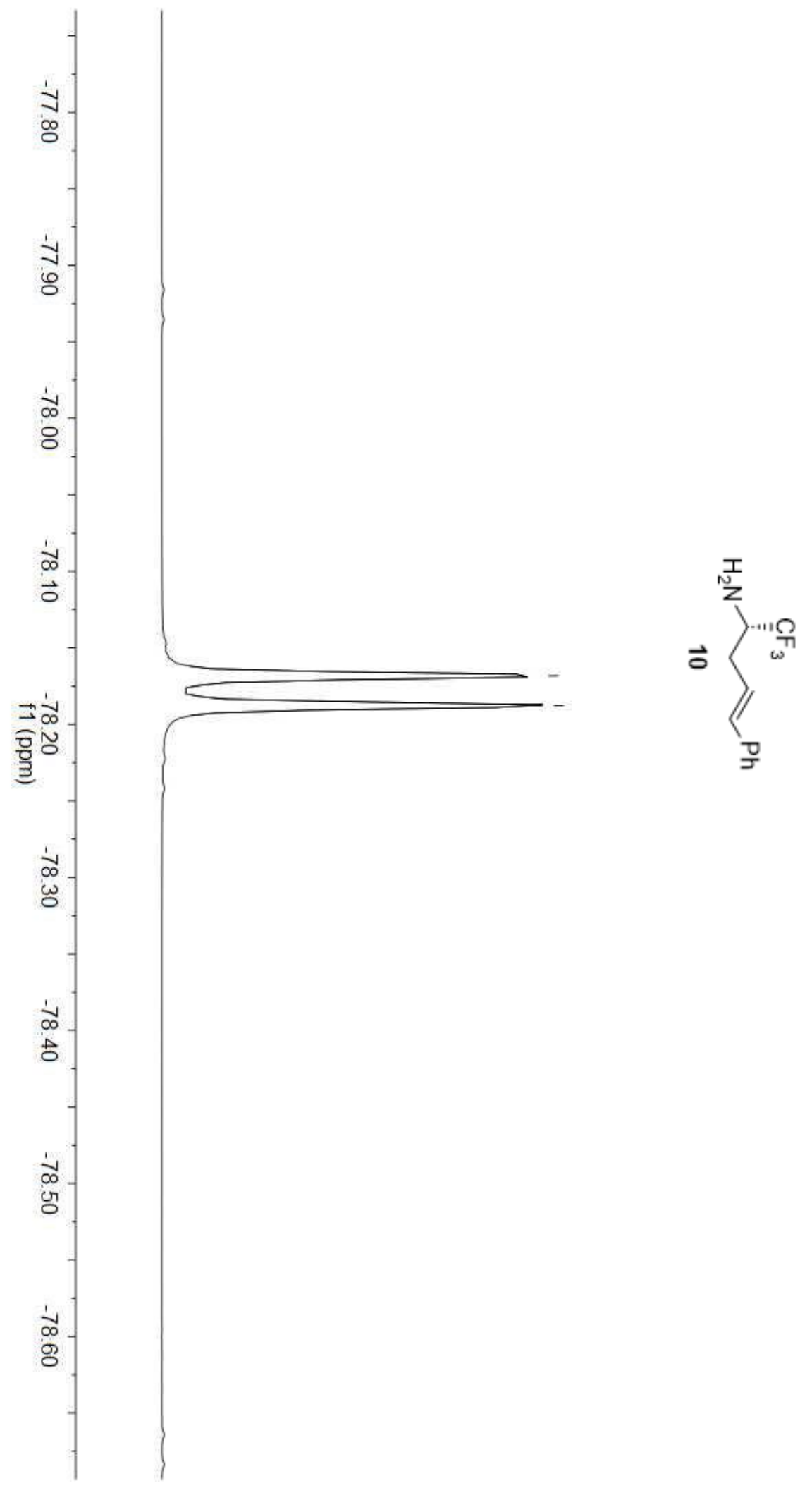

--78.168
--78.188 


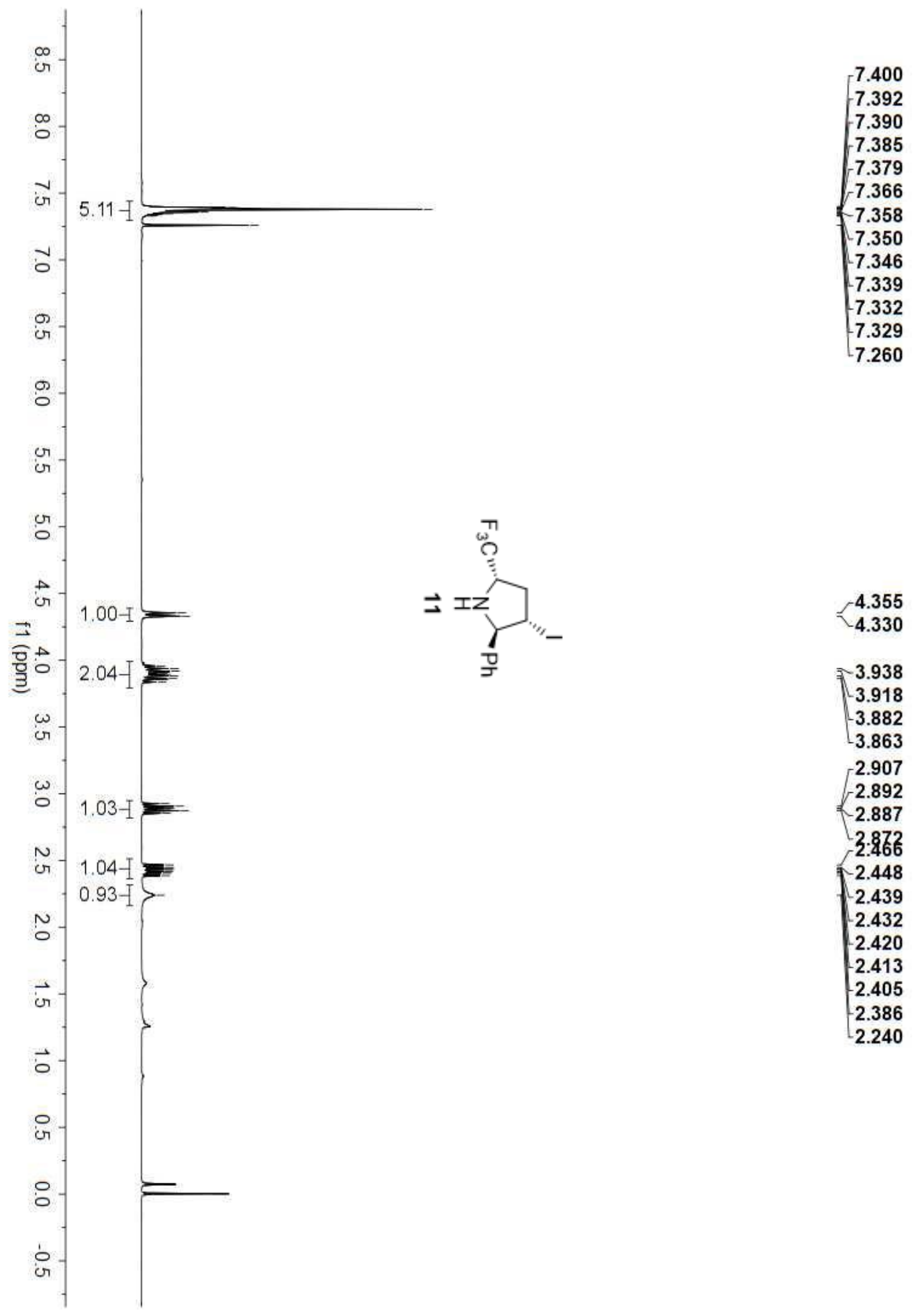




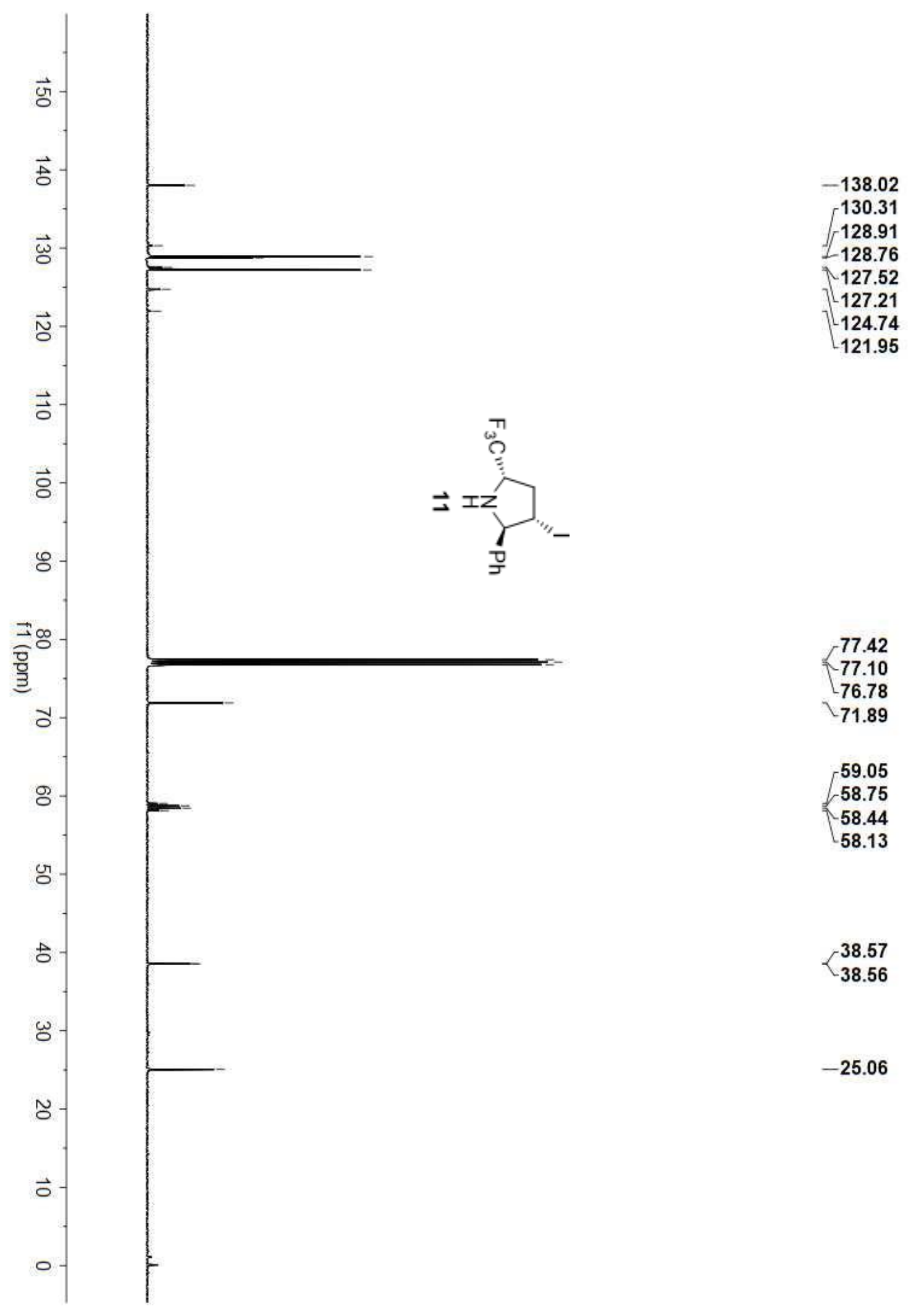



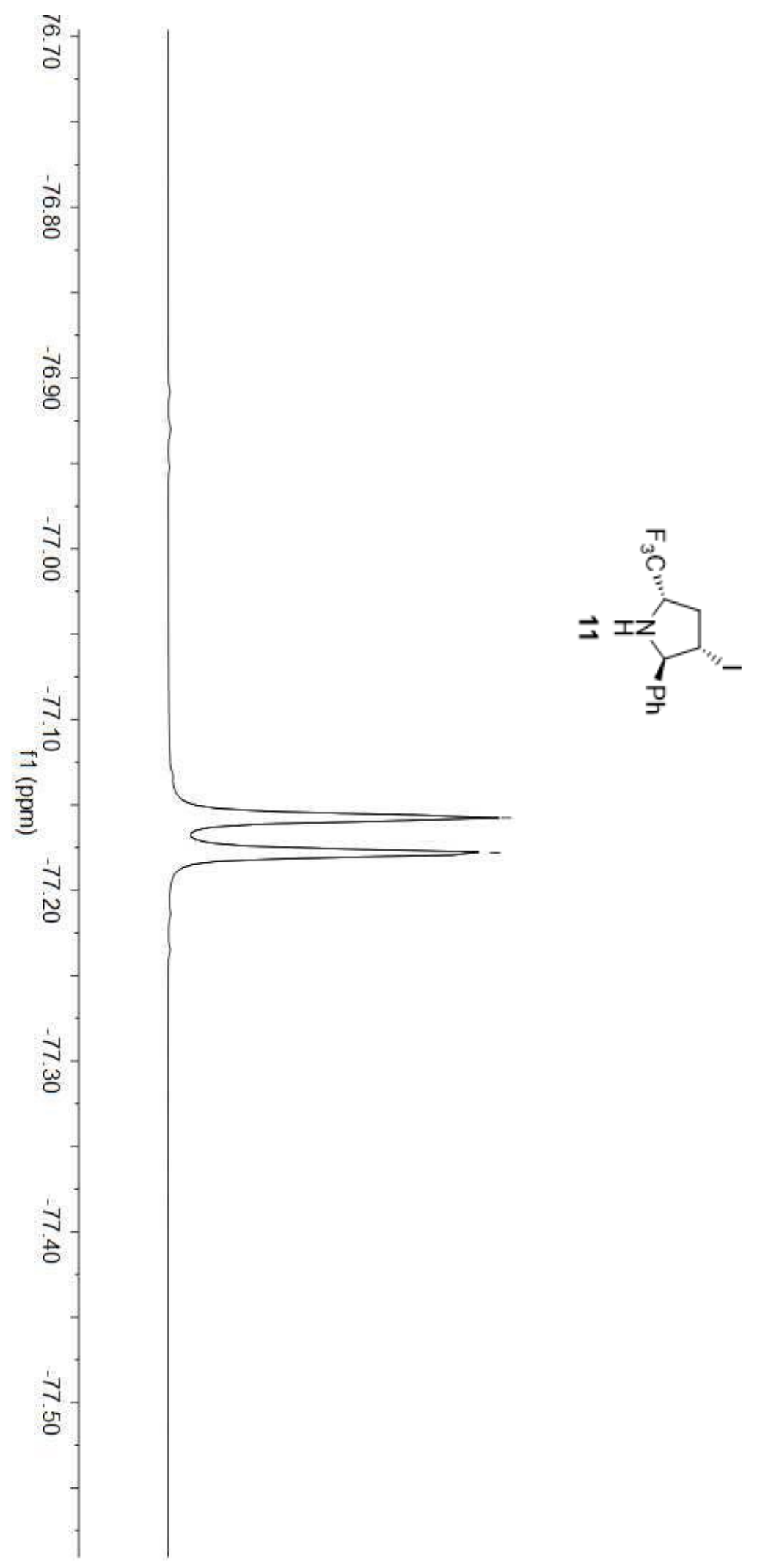


\section{HPLC spectra}<smiles>CN1C(=O)/C(=N\C(/C=C/c2ccccc2)C(F)(F)F)c2ccccc21</smiles>

Data File E: \DATA SLM SLM-6-09 SLM-6-09 2017-07-03 11-35-13\SLM-6-093.D Sample Name: SLM-6-09-Cu-rac

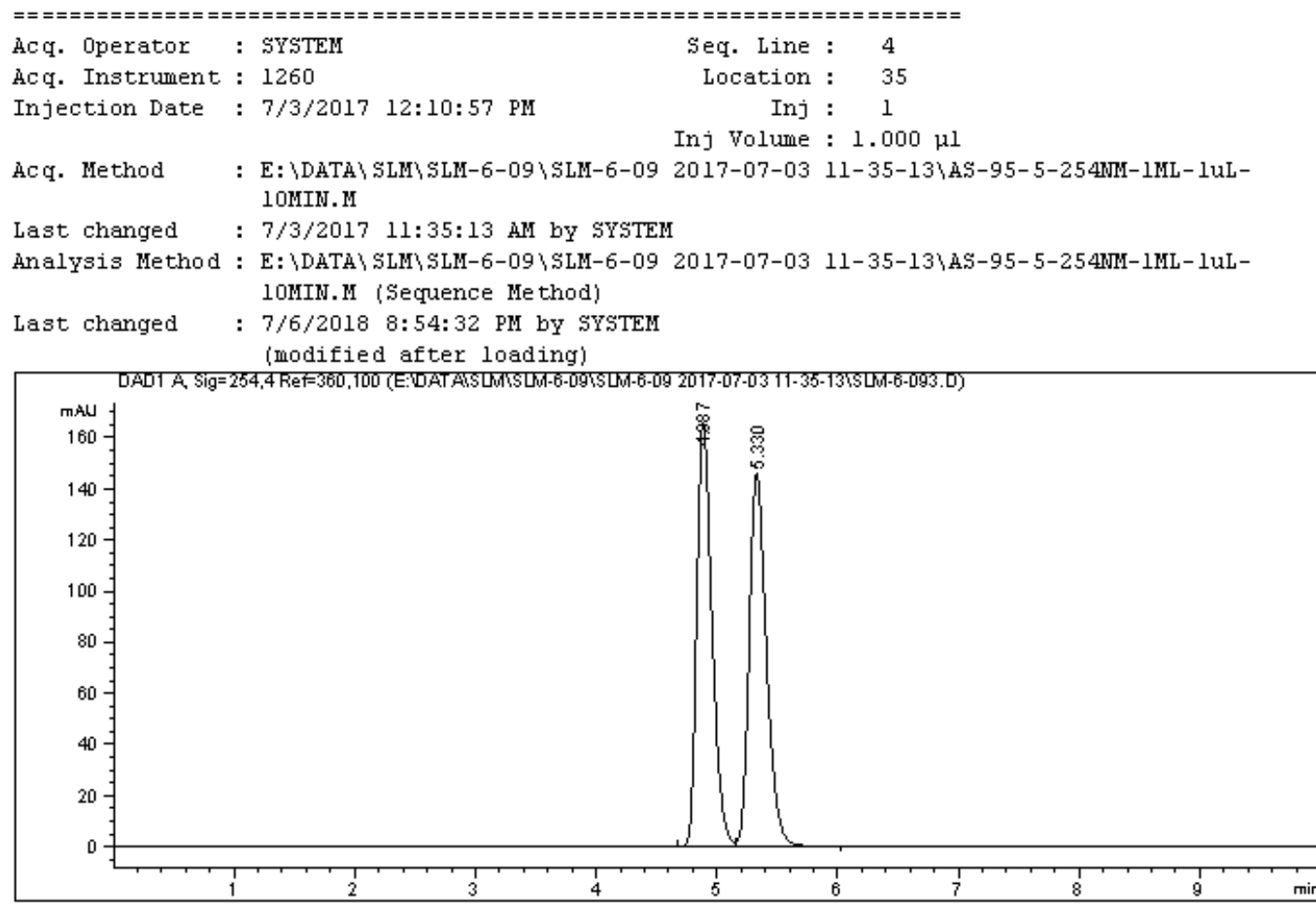

Area Percent Report

\begin{tabular}{|c|c|c|c|c|}
\hline Sorted BY & : & \multicolumn{2}{|l|}{ Signal } & \\
\hline Multiplier & : & \multicolumn{2}{|l|}{1.0000} & \\
\hline Dilution & : & \multicolumn{2}{|l|}{1.0000} & \\
\hline \multicolumn{5}{|c|}{ Do not use Multiplier \& Dilution Factor with ISTDs } \\
\hline \multicolumn{5}{|c|}{ Signal 1: DADl A, Sig $=254,4$ Ref $=360,100$} \\
\hline $\begin{array}{l}\text { Peak RetTime Type } \\
\# \quad \text { [min] }\end{array}$ & $\begin{array}{l}\text { Width } \\
\text { [min] }\end{array}$ & $\begin{array}{c}\text { Area } \\
{\left[\mathrm{mAU} U^{*} \mathrm{~S}\right]}\end{array}$ & $\begin{array}{l}\text { Height } \\
\text { [mAU] }\end{array}$ & $\underset{\stackrel{A}{A} \text { Area }}{\stackrel{5}{*}}$ \\
\hline \multicolumn{5}{|c|}{$----|-------|----|-------|---------|---------|--------\mid$} \\
\hline $4.887 \mathrm{BV}$ & 0.1328 & 1443.65149 & 165.46519 & 49.8919 \\
\hline $5.330 \mathrm{VB}$ & 0.1533 & 1449.90454 & 145.46928 & 50.1081 \\
\hline Totals : & & 2893.55603 & 310.93448 & \\
\hline
\end{tabular}

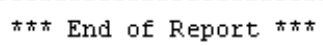


<smiles>CN1C(=O)/C(=N\C(/C=C/c2ccccc2)C(F)(F)F)c2ccccc21</smiles>

Data File E: $\backslash$ DATA $\backslash$ SLM $\backslash$ SLM-7-78\SLM-7-78 2017-11-17 10-23-43\SLM-7-78.D Sample Name: SLM-7-78-ceshi
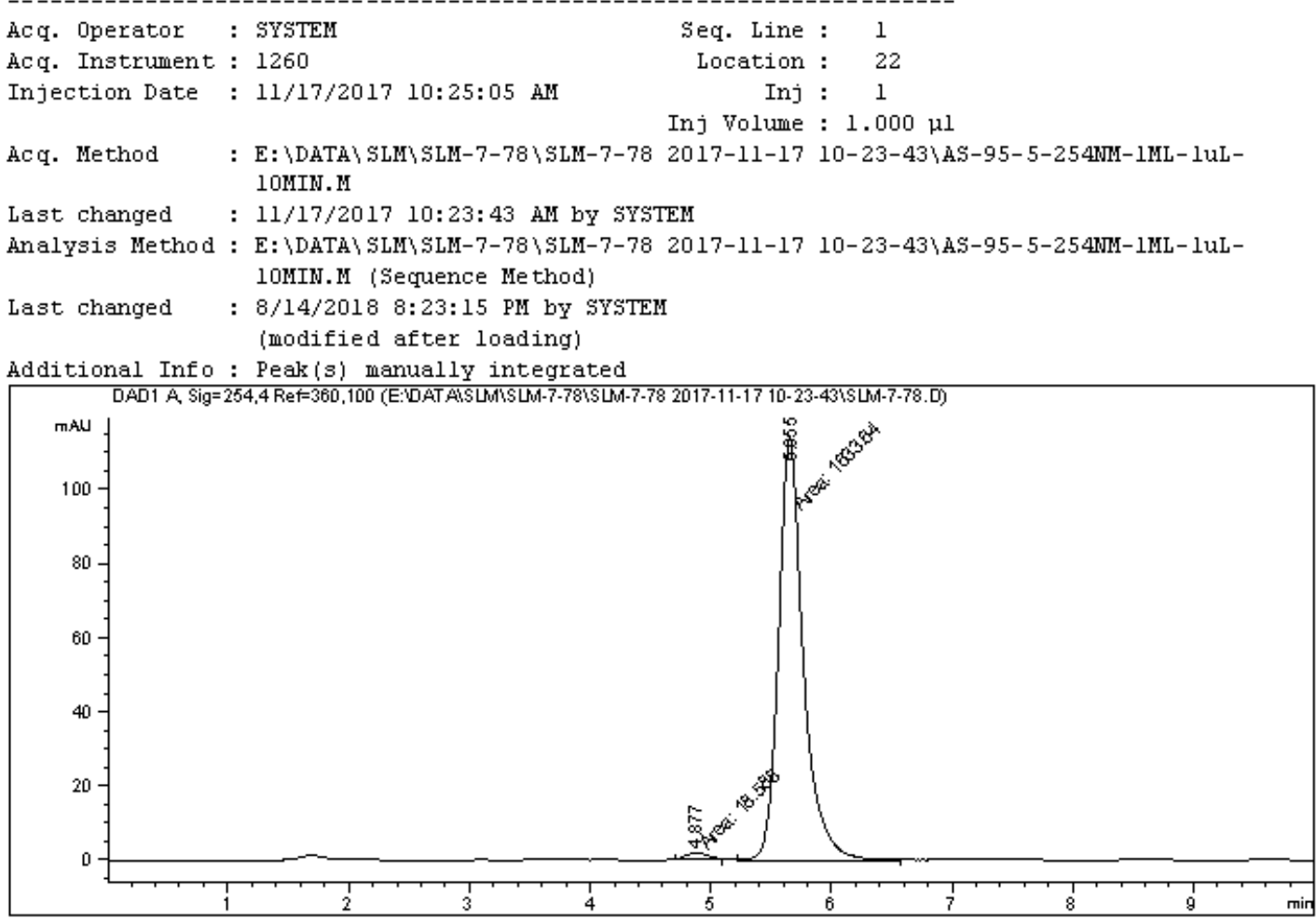

Area Percent Report

\begin{tabular}{|c|c|c|}
\hline Sorted By & : & Signal \\
\hline Multiplier & : & 1.0000 \\
\hline Dilution & : & 1.0000 \\
\hline
\end{tabular}

Do not use Multiplier \& Dilution Factor with ISTDs

Signal 1: DADl A, Sig=254, 4 Ref $=360,100$

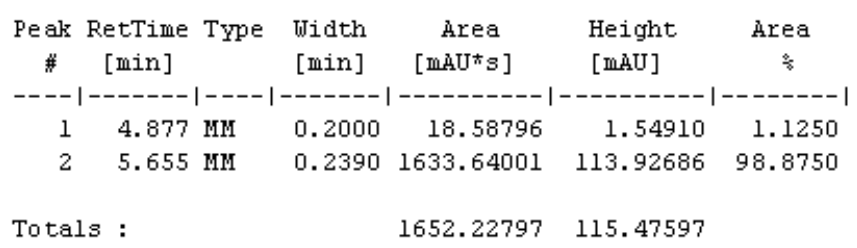


<smiles>Cc1ccc(/C=C/C=C(N=C2C(=O)N(C)c3ccccc32)C(F)(F)F)cc1</smiles>

Data File D: $\backslash$ LC $\backslash$ DATA $\backslash$ SLM SLM-9-90\SLM-9-90 2018-07-08 16-02-46\041-0101.D Sample Name: SLM-9-90-P-Me-RaC

\begin{tabular}{|c|c|}
\hline $\begin{array}{l}\text { Acq. Operator : LHC } \\
\text { Acq. Inst rument : Instrument } 1\end{array}$ & $\begin{array}{l}\text { Seq. Line : } 1 \\
\text { Location : Vial } 41\end{array}$ \\
\hline Injection Date : 7/8/2018 4:04:05 PM & 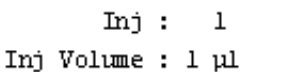 \\
\hline
\end{tabular}

Acq. Method : D: $\backslash$ LC $\backslash$ DATA $\backslash$ SLM SLM-9-90\SLM-9-90 2018-07-08 16-02-46 $\backslash$ ASH-95-5-254MM-1ULIOMDN.M

Last changed : 9/21/2017 11:55:29 $\mathrm{MM}$ by LHC

Analysis Method : D: $\backslash$ LC \DATA SLM SLM-9-90\SLM-9-90 2018-07-08 16-02-46\041-0101.D\DA.M । ASH-95-5-254NM-1UL-10MПN. M)

Last changed : 7/8/2018 4:24:43 PM by LHC

(modi fied after loading)

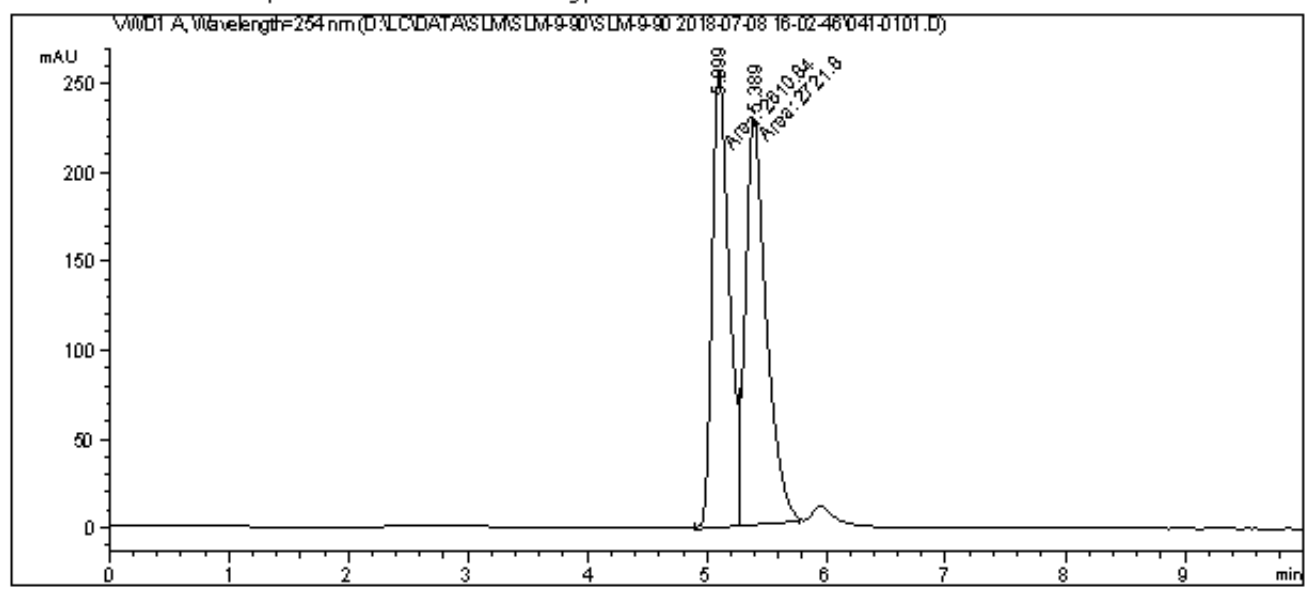

Area Percent Report

\begin{tabular}{|c|c|}
\hline Sorted By & : \\
\hline Multiplier & : \\
\hline Dilution & : \\
\hline
\end{tabular}

Use Multiplier \& Dilution Factor with IsTDs

Signal 1: VTD $1 \mathrm{~A}$, Wavelength $=254 \mathrm{rm}$

\begin{tabular}{|c|c|c|c|c|c|}
\hline Peak & RetTime Type & Width & Area & Height & Area \\
\hline$\#$ & [min] & [min] & m.MUJ & [midU ] & 몹 \\
\hline--1 & $----1-$ & ------- & |----------| & ---------- | & --------| \\
\hline 1 & $5.099 \mathrm{MF}$ & 0.1687 & 2610.84399 & 257.97610 & 48.9596 \\
\hline 2 & $5.389 \mathrm{FM}$ & 0.1979 & 2721.80176 & 229.23329 & 51.0404 \\
\hline otal & & & 5332.64575 & 487.20940 & \\
\hline
\end{tabular}


<smiles>Cc1ccc(/C=C/C=C/N=C2C(=O)N(C)c3ccccc32)cc1</smiles>

Data File D: \LC\DATA \LM SLM-9-90\SLM-9-90 2018-07-08 16-02-46\042-0201.D Sample Name: SLM-9-90-P-Me-CHIRAL

\begin{tabular}{|c|c|c|}
\hline Acq. Operator & : LHC & Seq. Line : \\
\hline Acq. Inst rument & : Instrument 1 & Location : Vial 42 \\
\hline Injection Date & : 7/8/2018 4:15:21 PM & $\begin{array}{rlc}\text { Inj } & : & 1 \\
\text { Inj Volume } & : 1 \mu l\end{array}$ \\
\hline
\end{tabular}

Acq. Method : D: \LC \DATA SLM SLM-9-90\SLM-9-90 2018-07-08 16-02-46\ASH-95-5-254MM-1UL1 OMDI.M

Last changed : 9/21/2017 11:55:29 AM by LHC

Analysis Method : D: LC\DATA SLM SLM-9-90\SLM-9-90 2018-07-08 16-02-46\042-0201.D\DA.M । ASH-95-5-254NM-1UL-10MIN. M

Last changed : 7/8/2018 4:26:03 PM by LHC

(modi fied after loading)

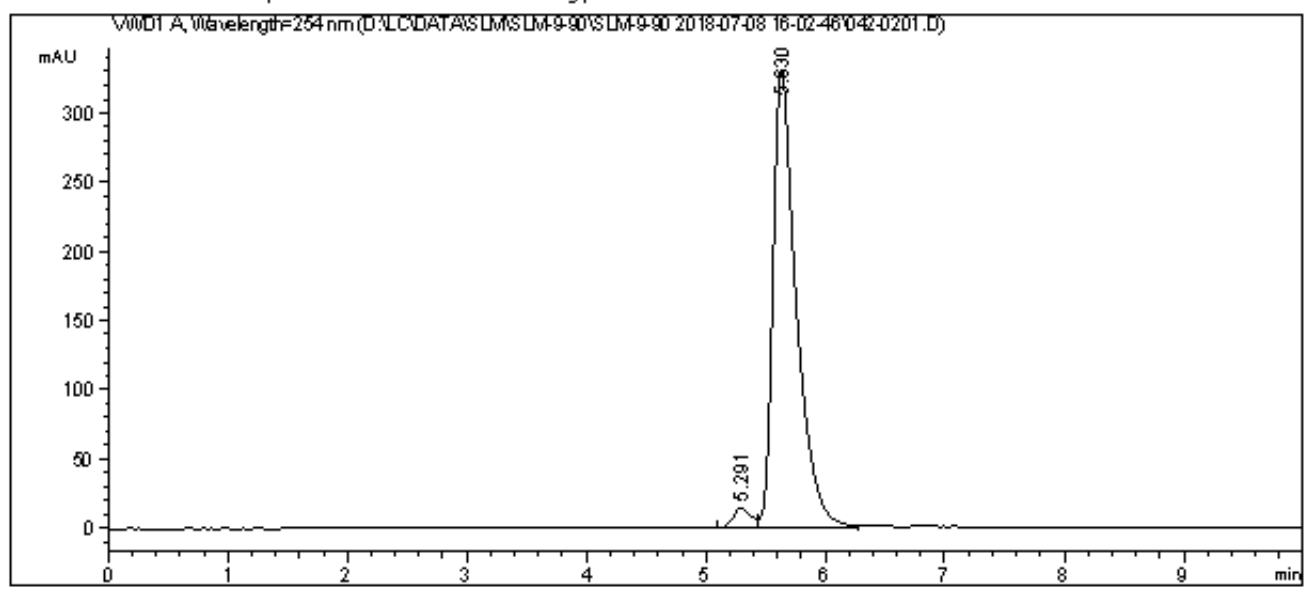

Area Percent Report

\begin{tabular}{|c|c|}
\hline Sorted By & : \\
\hline Multiplier & : \\
\hline Dilution & : \\
\hline
\end{tabular}

Use Multiplier \& Dilution Factor with ISTDs

Signal 1: VWD 1 , Wavelength=254 nm

\begin{tabular}{|c|c|c|c|c|c|}
\hline Peak & RetTime Type & Width & Area & Height & Area \\
\hline$\#$ & [min] & [min] & $\mathrm{m} \mathrm{BJJ}$ & [m.3U & 믑 \\
\hline- & ---1 & -- & |---------- & ---------- & -------1 \\
\hline 1 & $5.291 \mathrm{~W}$ & 0.1668 & 167.31635 & 15.13759 & 3.5511 \\
\hline 2 & $5.630 \mathrm{~W}$ & 0.2004 & 4544.37988 & 332.03140 & 96.4489 \\
\hline Tota & & & 4711.69623 & 347.16899 & \\
\hline
\end{tabular}


<smiles>COc1ccc(/C=C/C=C(N=C2C(=O)N(C)c3ccccc32)C(F)(F)F)cc1</smiles>

Data File D: \LC\DATA $\backslash$ SLM SXS-3-65\SXS-3-65 2017-09-14 16-16-01\024-0101.D Sample Name: SXs-3-65

\begin{tabular}{|c|c|c|}
\hline Acq. Operator & : $5 \times 5-3-60$ & Seq. Line : \\
\hline Acq. Inst rument & : Instrument 1 & Location : Vial 24 \\
\hline Injection Date & : 9/14/2017 4:17:45 PM & $\operatorname{Inj}:$ \\
\hline
\end{tabular}

Acq. Method : D: \LC \DATA $\backslash$ SLM SXS-3-65 \SXS-3-65 2017-09-14 16-16-01\ASH-95-5-254NM-1UL$10 \mathrm{MDN} . \mathrm{M}$

Last changed : 9/14/2017 4:29:25 PM by SXs-3-60 (modi fied after loading)

Analysis Method : D: \LC\DATA SLM SXS-3-65\SXS-3-65 2017-09-14 16-16-01\024-0101.D DA.M । ASH-9.5-5-254NM-1UL-10MIN. M)

Last changed : 7/6/2018 4:57:37 PM by LHC (modi fied after loading)

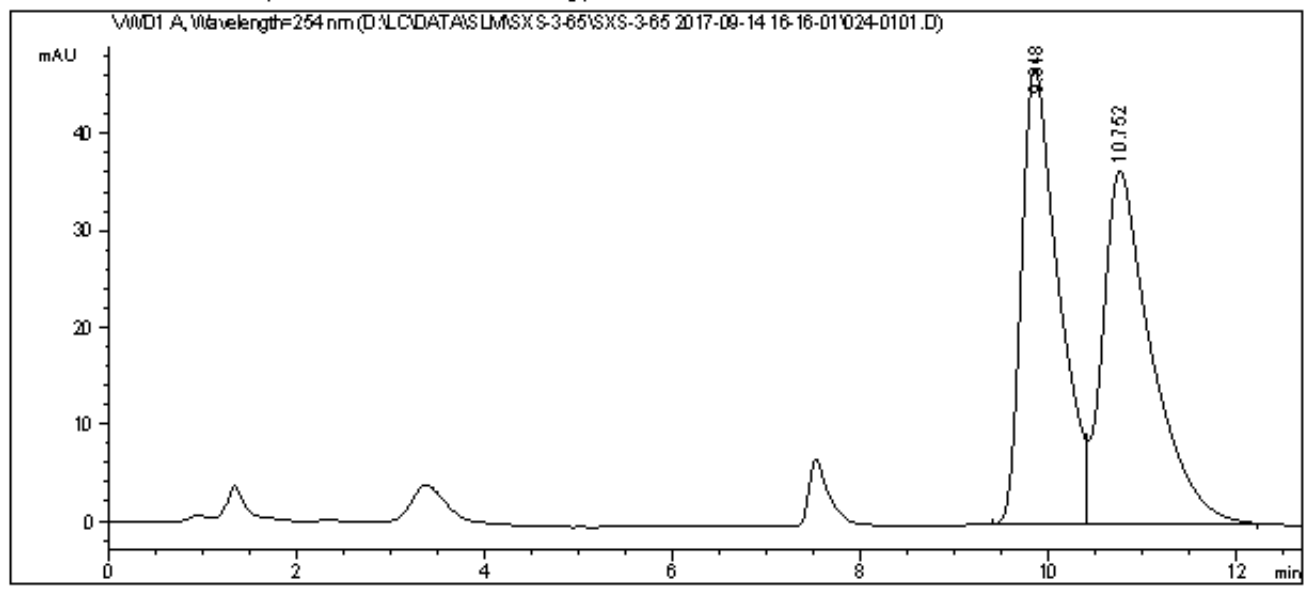

Area Percent Report

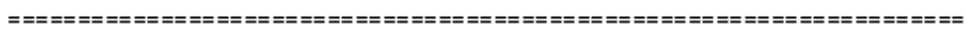

$\begin{array}{lll}\text { Sorted By } & : & \text { Signal } \\ \text { Multiplier } & : & 1.0000 \\ \text { Dilution } & : & 1.0000\end{array}$

Use Multiplier \& Dilution Factor with IsTDs

Signal l: VWD $\mathrm{A}$, Wavelength=254 nm

\begin{tabular}{|c|c|c|c|c|c|}
\hline \multirow{2}{*}{$\begin{array}{c}\text { Pealz } \\
\#\end{array}$} & \multirow{2}{*}{$\begin{array}{l}\text { RetTime Type } \\
\text { [min] }\end{array}$} & \multirow{2}{*}{$\begin{array}{l}\text { Width } \\
\text { [min] }\end{array}$} & Area & Height & \multirow{2}{*}{$\begin{array}{c}\text { Area } \\
\text { 믑 }\end{array}$} \\
\hline & & & $\mathrm{m} \cdot \mathrm{BJ}$ & {$[\mathrm{m} \mathrm{mUJ}$} & \\
\hline & -- & -1 & ------- & ---- & ------1 \\
\hline 1 & $9.848 \mathrm{BV}$ & 0.4006 & 1299.63611 & 47.29989 & 49.6695 \\
\hline 2 & 10.752 VB & 0.5063 & 1316.93286 & 36.67751 & 50.3305 \\
\hline
\end{tabular}

Totals : $\quad 2616.56897 \quad 83.97741$ 
<smiles>COc1ccc(/C=C/C=C(N=C2C(=O)N(C)c3ccccc32)C(F)(F)F)cc1</smiles>

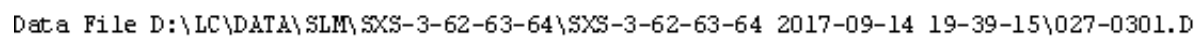
Sample Name: Sxs-3-64

\begin{tabular}{|c|c|c|}
\hline Acq. Operator & : $5 \times 5-3-62-63-64$ & Seq. Line : \\
\hline Acq. Inst rument & : Instrument 1 & Location : Vial 27 \\
\hline Injection Date & : 9/14/2017 8:04:16 PM & $\operatorname{Inj}:$ \\
\hline
\end{tabular}

Acq. Method : D: \LCDATA SLM SXs-3-62-63-64\SXS-3-62-63-64 2017-09-14 19-39-15\ASH-95$5-254 \mathrm{MM}-1 \mathrm{UL}-1 \mathrm{MMDN} . \mathrm{M}$

Last changed : 9/14/2017 8:05:19 PM by 5Xs-3-62-63-64

(modified after loading)

Analysis Method : D: \LC \DATA SLM SXs-3-62-63-64 \5XS-3-62-63-64 2017-09-14 19-39-15\0270301.D\DA.M (ASH-95-5-254M-1UL-1OMDN.M)

Last changed : 7/6/2018 4:56:48 PM by LHC (modified after loading)

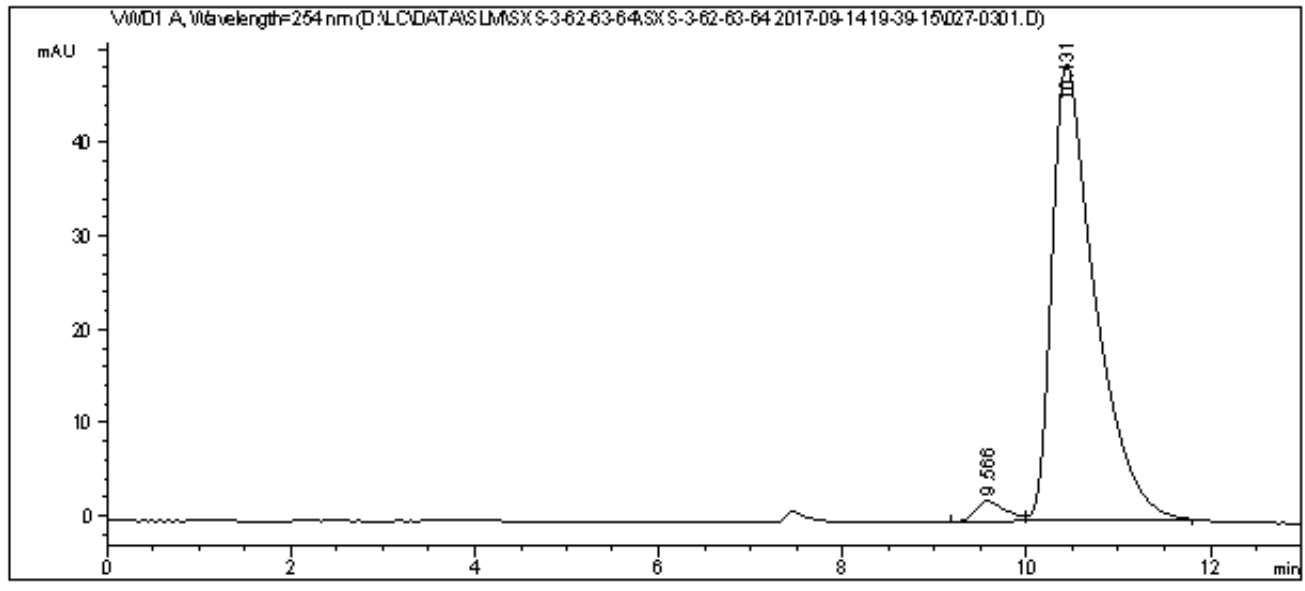

area Percent Report

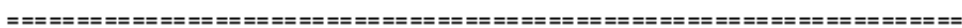

$\begin{array}{lll}\text { Sorted By } & : & \text { Signal } \\ \text { Multiplier } & : & 1.0000 \\ \text { Dilution } & : & 1.0000\end{array}$

Use Multiplier \& Dilution Factor with IsTDs

Signal 1: VoD 1 , Wavelength=254 nm

\begin{tabular}{|c|c|c|c|c|c|}
\hline Peak & RetTime Type & width & Area & Height & Area \\
\hline$\#$ & [min] & [min] & misU & [m.SU & 믑 \\
\hline-1 & --- & ---- & |-------- & --------- | & -------1 \\
\hline 1 & $9.566 \mathrm{BV}$ & 0.3357 & 52.72862 & 2.21729 & 3.1895 \\
\hline 2 & $10.431 \mathrm{VB}$ & 0.4722 & 1600.44617 & 49.07691 & 96.8105 \\
\hline
\end{tabular}

Totals : $\quad 1653.17479 \quad 51.29420$ 
<smiles>CN1C(=O)/C(=N\[C@H](/C=C/c2ccc(F)cc2)C(F)(F)F)c2ccccc21</smiles>

Data File D: $\backslash$ LC $\backslash 5 X S \backslash 5 X 5-4-1-2 \backslash 5 X 5-4-1-2 \quad 2017-10-10 \quad 20-27-52 \backslash 066-0101 . D$ Sample Name: sXs-4-1

\begin{tabular}{|c|c|}
\hline $\begin{array}{l}\text { Acq. Operator : sXs } \\
\text { Acq. Inst rument : Instrument } 1\end{array}$ & $\begin{array}{l}\text { Seq. Line : } 1 \\
\text { Location : Vial } 66\end{array}$ \\
\hline Injection Date : 10/10/2017 8:29:03 PM & 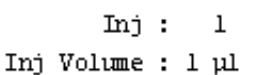 \\
\hline
\end{tabular}

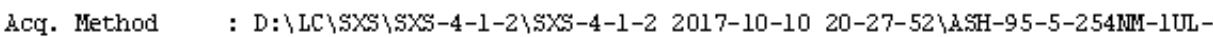
IOMDN.M

Last changed : 9/15/2017 9:40:05 AM by SX5-3-62-63-64

Analysis Method : D: $\backslash$ LC \SXS\SXS-4-1-2\SXS-4-1-2 2017-10-10 20-27-52\066-0101.D \D.M (A.SH95-5-254NM-1UL-10MПN. M)

Last changed : 7/6/2018 3:48:18 PM by LHC

(modi fied after loading)

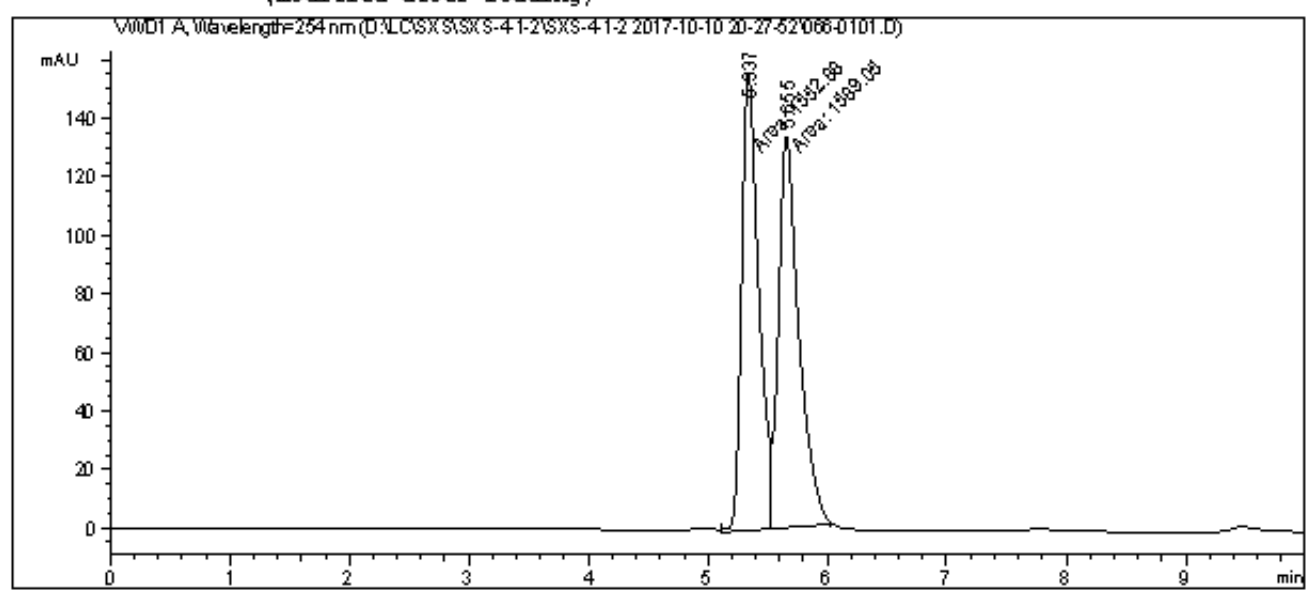

Area Percent Report

\begin{tabular}{|c|c|}
\hline Sorted By & : \\
\hline Multiplier & : \\
\hline Dilution & : \\
\hline
\end{tabular}

Use Multiplier \& Dilution Factor with ISTDs

Signal 1: VWD $1 \mathrm{~A}$, Wavelength $=254 \mathrm{rm}$

\begin{tabular}{|c|c|c|c|c|c|}
\hline Peak & RetTime Type & Width & Area & Height & Area \\
\hline$\#$ & [min] & [min] & m.MUJ & {$[\mathrm{m} \mathrm{mUJ}$} & 몹 \\
\hline--1 & $----1-$ & ------- & |----------| & ---------- | & --------| \\
\hline 1 & $5.337 \mathrm{MF}$ & 0.1653 & 1552.88208 & 156.58736 & 49.4244 \\
\hline 2 & $5.655 \mathrm{FM}$ & 0.1976 & 1589.05420 & 134.05367 & 50.5756 \\
\hline otal & & & 3141.93628 & 290.64102 & \\
\hline
\end{tabular}


<smiles>CN1C(=O)/C(=N\[C@H](/C=C/c2ccc(F)cc2)C(F)(F)F)c2ccccc21</smiles>

Data File D: $\backslash$ LC $\backslash 5 X S \backslash 5 X 5-4-1-2 \backslash 5 X 5-4-1-2 \quad 2017-10-10 \quad 20-27-52 \backslash 067-0201 . D$ Sample Name: sXs-4-2

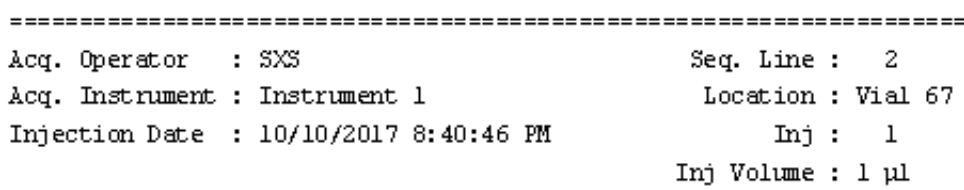

Acq. Method : D: $\backslash$ LC $\backslash 5 \times S \backslash 5 X 5-4-1-2 \backslash 5 X 5-4-1-2 \quad 2017-10-10 \quad 20-27-52 \backslash 4$ SH-95-5-254MM-1UL1 IOMNN.M

Last changed : 9/15/2017 9:40:05 AM by SX5-3-62-63-64

Analysis Method : D: $\backslash$ LC \SXS\SXS-4-1-2\SXS-4-1-2 2017-10-10 20-27-52\067-0201.D \D.M (A.SH95-5-254MM-1UL-10MПN. M)

Last changed : 7/6/2018 3:50:35 PM by LHC

(modi fied after loading)

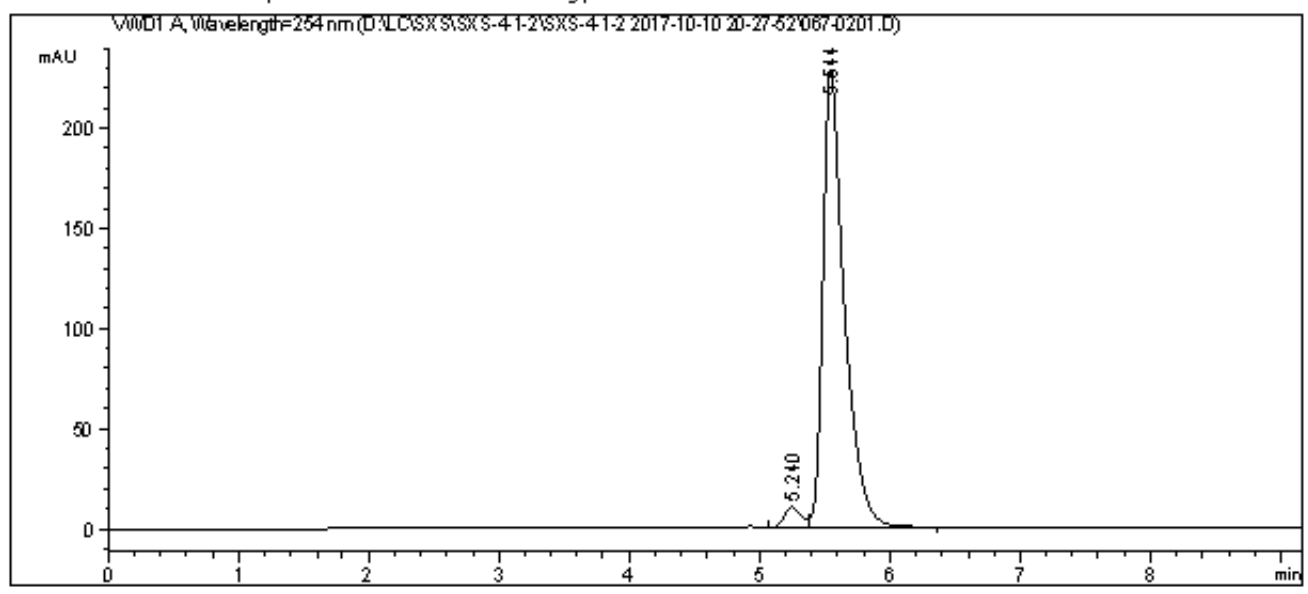

Area Percent Report

\begin{tabular}{|c|c|}
\hline Sorted By & : \\
\hline Multiplier & : \\
\hline Dilution & : \\
\hline
\end{tabular}

Use Multiplier \& Dilution Factor with ISTDs

Signal l: VID $1 \mathrm{~A}$, Wavelength $=254 \mathrm{rm}$

\begin{tabular}{|c|c|c|c|c|c|}
\hline Peak & RetTime Type & width & Area & Height & Area \\
\hline$\#$ & [min] & [min] & $\mathrm{m}$ 当J & {$[\mathrm{m}$ BJU } & 몸 \\
\hline & ----1-- & ------- & |----------| & ---------- | & --------1 \\
\hline 1 & $5.240 \mathrm{~W}$ & 0.1364 & 92.13062 & 10.16025 & 3.3978 \\
\hline 2 & $5.544 \mathrm{VB}$ & 0.1656 & 2619.38574 & 228.86935 & 96.6022 \\
\hline Total & & & 2711.51636 & 239.02961 & \\
\hline
\end{tabular}


<smiles>CN1C(=O)/C(=N\[C@H](/C=C/c2ccc(Cl)cc2)C(F)(F)F)c2ccccc21</smiles>

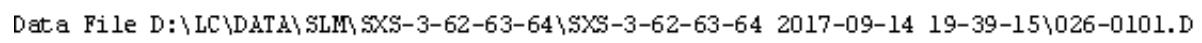
Sample Name: Sxs-3-63

\begin{tabular}{|c|c|c|}
\hline Acq. Operator & : $5 \times 5-3-62-63-64$ & Seq. Line : \\
\hline Acq. Inst rument & : Instrument 1 & Location : Vial 26 \\
\hline Injection Date & : 9/14/2017 7:40:40 PM & $\begin{array}{rlc}\text { Inj } & : & 1 \\
\text { Inj Volume } & 1 & 1\end{array}$ \\
\hline
\end{tabular}

Acq. Method : D: \LC \DATA SLM SXS-3-62-63-64\SXS-3-62-63-64 2017-09-14 19-39-15\ASH-955-254M-1UL-10MПN.M

Last changed : 9/14/2017 7:50: $13 \mathrm{PM}$ by $5 \times 5-3-62-63-64$

(modified after loading)

Analysis Method : D: \LC\DATA SLM SXs-3-62-63-64\5XS-3-62-63-64 2017-09-14 19-39-15\0260101.D\DA.M (ASH-95-5-254M-1UL-1OMDN.M)

Last changed : 7/6/2018 4:53:48 PM by LHC (modified after loading)

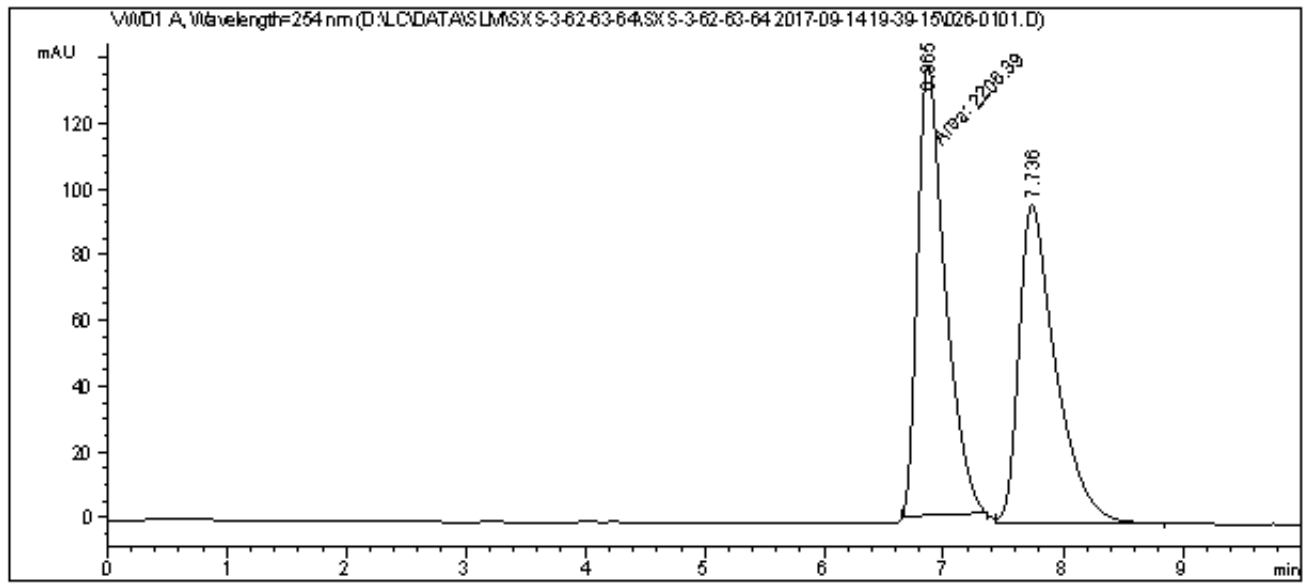

Area Percent Report

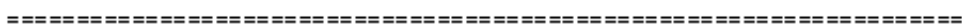

$\begin{array}{lll}\text { Sorted By } & : & \text { Signal } \\ \text { Multiplier } & : & 1.0000 \\ \text { Dilution } & : & 1.0000\end{array}$

Use Multiplier \& Dilution Factor with IsTDs

Signal l: VTDl $\mathrm{A}$, Wavelength=254 nm

\begin{tabular}{|c|c|c|c|c|c|}
\hline Peak & RetTime Type & Width & Area & Height & Area \\
\hline$\#$ & [min] & [min] & misU & [m.2JJ & 믑 \\
\hline--1 & $-0---0$ & - & --------1 & -------- & -- \\
\hline 1 & $6.865 \mathrm{MM}$ & 0.2679 & 2206.39258 & 137.24699 & 51.5075 \\
\hline 2 & $7.736 \mathrm{VB}$ & 0.3103 & 2077.23975 & 97.28675 & 48.4925 \\
\hline
\end{tabular}

Totals : $\quad 4283.63232 \quad 234.53374$ 
<smiles>CN1C(=O)/C(=N\[C@H](/C=C/c2ccc(Cl)cc2)C(F)(F)F)c2ccccc21</smiles>

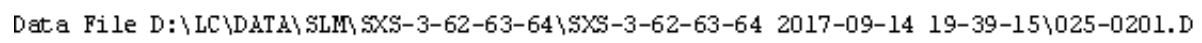
Sample Name: Sxs-3-62

\begin{tabular}{|c|c|c|}
\hline Acq. Operator & : $5 \times 5-3-62-63-64$ & Seq. Line : \\
\hline Acq. Inst rument & : Instrument 1 & Location : Vial 25 \\
\hline Injection Date & : 9/14/2017 7:51:57 PM & $\operatorname{Inj}:$ \\
\hline
\end{tabular}

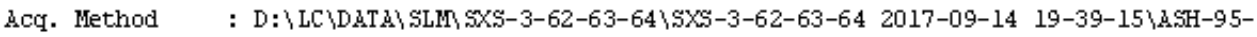
5-254M-1UL-10MПN.M

Last changed : 9/14/2017 7:50:49 PM by 5Xs-3-62-63-64

(modi fied after loading)

Analysis Method : D: \LC \DATA SLM SXs-3-62-63-64\5XS-3-62-63-64 2017-09-14 19-39-15\0250201.D\DA.M (ASH-95-5-254M-1UL-1OMDN.M)

Last changed : 7/6/2018 4:55:51 PM by LHC (modified after loading)

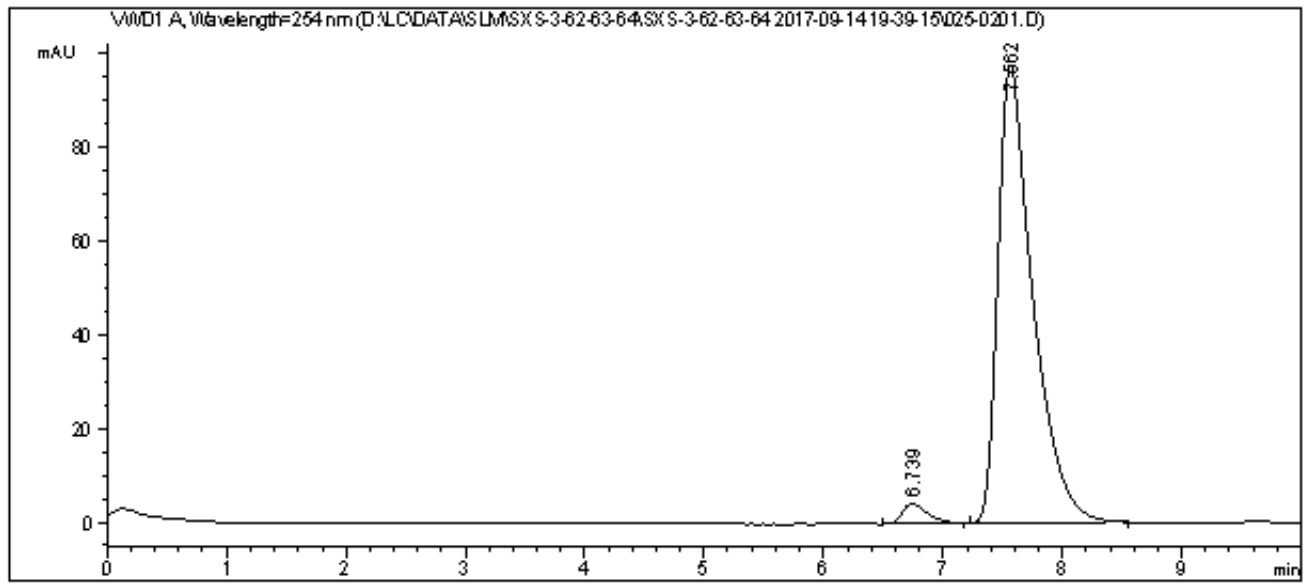

Area Percent Report

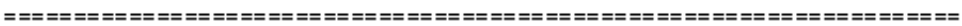

$\begin{array}{lll}\text { Sorted BV } & : & \text { Sigmal } \\ \text { Multiplier } & : & 1.0000 \\ \text { Dilution } & : & 1.0000\end{array}$

Use Multiplier \& Dilution Factor with IsTDs

Signal l: VTDl $\mathrm{A}$, Wavelength=254 nm

\begin{tabular}{|c|c|c|c|c|c|}
\hline Peak & RetTime Type & Width & Area & Height & Area \\
\hline$\#$ & [min] & [min] & misJ & [m.2JJ & 몹 \\
\hline--1 & ------- & -- & ------ & -------- | & ------1 \\
\hline 1 & $6.739 \mathrm{BB}$ & 0.2217 & 65.99398 & 4.39759 & 3.2118 \\
\hline 2 & 7. $562 \mathrm{BB}$ & 0.2954 & 1988.71362 & 97.82352 & 96.7882 \\
\hline
\end{tabular}

Totals : $\quad 2054.70760102 .22111$ 
<smiles>CN1C(=O)/C(=N\[C@H](/C=C/c2ccc(Br)cc2)C(F)(F)F)c2ccccc21</smiles>

Data File D: \LC\5XS\5XS-4-3-4-5-6-7\5XS-4-3-4-5-6-7 2017-10-12 12-49-36\046-0101.D Sample Name: SXs-4-3

\begin{tabular}{|c|c|c|}
\hline Acq. Operator & $: \operatorname{sXs}$ & seq. Line : \\
\hline Acq. Inst rument & : Instrument 1 & Location : Vial 46 \\
\hline Injection Date & : 10/12/2017 12:50:45 PM & $\operatorname{Inj}:$ \\
\hline
\end{tabular}

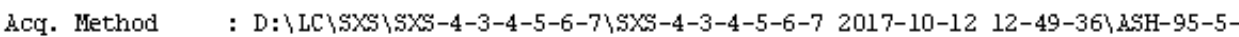
254M-1UL-1OMDN.M

Last changed : 9/15/2017 9:40:05 AM by SXs-3-62-63-64

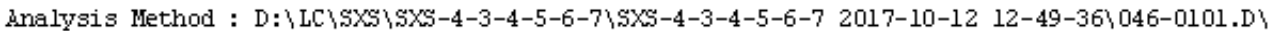
DA.M (ASH-95-5-254MM-1UL-10NாN. M)

Last changed : 7/6/2018 3:55:44 PM by LHC

(modified after loading)

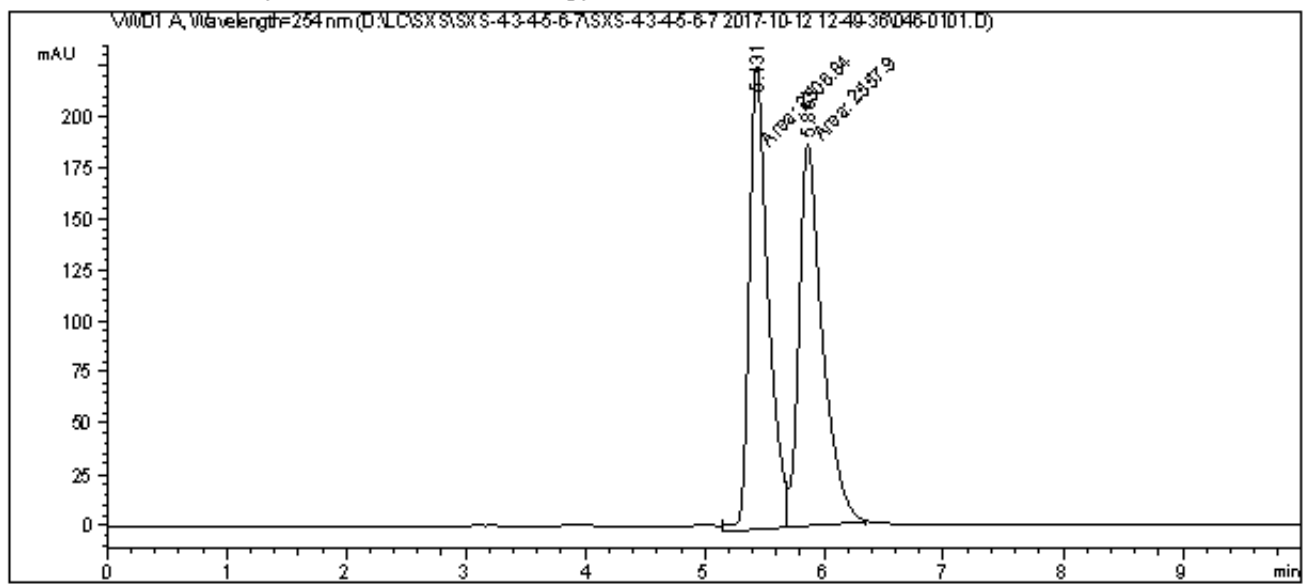

Area Percent Report

\begin{tabular}{|c|c|}
\hline Sorted By & : \\
\hline Multiplier & : \\
\hline Dilution & : \\
\hline
\end{tabular}

Use Multiplier \& Dilution Factor with IsTDs

Signal 1: VTD $\mathrm{A}$, Wavelength=254 nm

\begin{tabular}{|c|c|c|c|c|c|}
\hline \multirow{2}{*}{$\begin{array}{c}\text { Peak } \\
\#\end{array}$} & \multirow{2}{*}{$\begin{array}{l}\text { RetTime Type } \\
\text { [min] }\end{array}$} & \multirow{2}{*}{$\begin{array}{l}\text { Width } \\
\text { [min] }\end{array}$} & Area & Height & \multirow{2}{*}{$\begin{array}{c}\text { Area } \\
\text { 맙 }\end{array}$} \\
\hline & & & $\mathrm{m} \mathrm{BJ}$ & [m.2JJ & \\
\hline---- & -----||$--$ & ------- & |----------| & ---------- & -------1 \\
\hline 1 & $5.431 \mathrm{MF}$ & 0.1841 & 2506.83716 & 226.89919 & 49.4959 \\
\hline 2 & $5.861 \mathrm{FM}$ & 0.2277 & 2557.89526 & 187.22313 & 50.5041 \\
\hline Tota & & & 5064.73242 & 414.12231 & \\
\hline
\end{tabular}


<smiles>CN1C(=O)/C(=N\[C@H](/C=C/c2ccc(Br)cc2)C(F)(F)F)c2ccccc21</smiles>

Data File D: \LC\5XS\5XS-4-3-4-5-6-7\5XS-4-3-4-5-6-7 2017-10-12 12-49-36\047-0201.D Sample Name: SXs-4-4

\begin{tabular}{|c|c|c|}
\hline $\begin{array}{l}\text { Acq. Operator } \\
\text { Acq. Inst rument }\end{array}$ & $\begin{array}{l}\text { : sXs } \\
: \text { Instrument } 1\end{array}$ & $\begin{array}{l}\text { seq. Line : } 2 \\
\text { Location : Vial } 47\end{array}$ \\
\hline Injection Date & : 10/12/2017 1:02:12 PM & $\operatorname{Inj}:$ \\
\hline
\end{tabular}

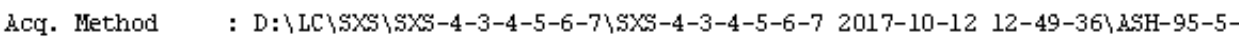
254M-1UL-1OMDN.M

Last changed : 9/15/2017 9:40:05 AM by SXs-3-62-63-64

Analysis Method : D: \L \SXS\SXS-4-3-4-5-6-7\SXS-4-3-4-5-6-7 2017-10-12 12-49-36\047-0201.D \ DA.M (ASH-95-5-254NM-1UL-10MN.M)

Last changed : 7/6/2018 3:56:50 PM by LHC

(modi fied after loading)

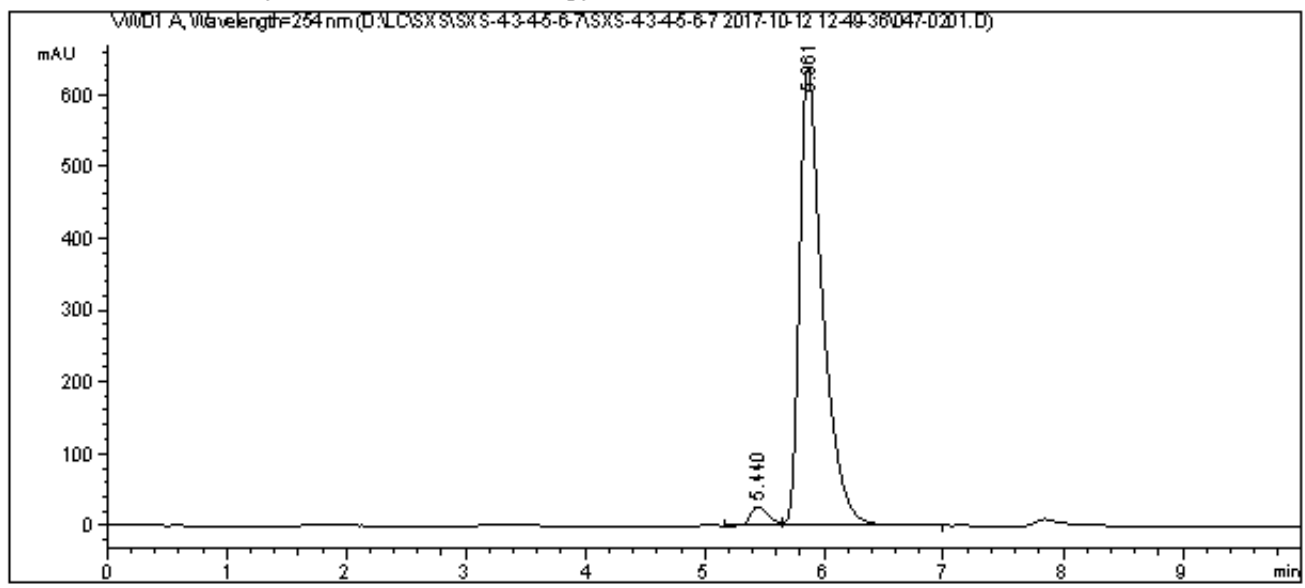

Area Percent Report

\begin{tabular}{|c|c|}
\hline Sorted By & : \\
\hline Multiplier & : \\
\hline Dilution & : \\
\hline
\end{tabular}

Use Multiplier \& Dilution Factor with IsTDs

Signal 1: VTD $\mathrm{A}$, Wavelength=254 nm

\begin{tabular}{|c|c|c|c|c|c|}
\hline \multirow{2}{*}{$\begin{array}{c}\text { Peak } \\
\#\end{array}$} & \multirow{2}{*}{$\begin{array}{l}\text { RetTime Type } \\
\text { [min] }\end{array}$} & \multirow{2}{*}{$\begin{array}{l}\text { Width } \\
\text { [min] }\end{array}$} & Area & Height & \multirow{2}{*}{$\begin{array}{c}\text { Area } \\
\text { 몹 }\end{array}$} \\
\hline & & & misu & [m.3J & \\
\hline & |-------|---- & 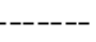 & |------- & --------- & -------1 \\
\hline 1 & $5.440 \mathrm{WV}$ & 0.1576 & 288.86844 & 27.14773 & 3.2527 \\
\hline 2 & $5.861 \mathrm{VB}$ & 0.1960 & 8591.91992 & 639.94031 & 96.7473 \\
\hline
\end{tabular}

Totals :

$8880.78836 \quad 667.08804$ 
<smiles>Cc1cccc(/C=C/C=C/[C@@H](N=C2C(=O)N(C)c3ccccc32)C(F)(F)F)c1</smiles>

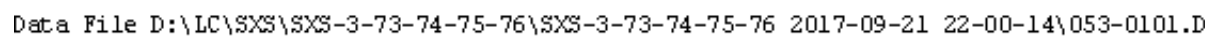
Sample Name: Sxs-3-73

\begin{tabular}{|c|c|c|}
\hline Acq. Operator & : $\mathbf{s X s}$ & Seq. Line : \\
\hline Acq. Inst rument & : Instrument 1 & Location : Vial 53 \\
\hline Injection Date & : 9/21/2017 10:01:37 PM & Inj : \\
\hline
\end{tabular}

Acq. Method : D : $\backslash$ LC $\backslash 5 \times 5 \backslash 5 \times 5-3-73-74-75-76 \backslash 5 \times 5-3-73-74-75-76 \quad 2017-09-2122-00-14 \backslash$ ASH-95$5-254 \mathrm{MM}-1 \mathrm{UL}-1 \mathrm{MM} \mathrm{N} . \mathrm{M}$

Last changed : 9/15/2017 9:40:05 AM by SXs-3-62-63-64

Analysis Method : D: $\backslash$ LC \SXS\SXS-3-73-74-75-76\5XS-3-73-74-75-76 2017-09-21 22-00-14\0530101.D DA.M (ASH-95-5-254M-1UL-1OMDN.M)

Last changed : 7/6/2018 4:46:42 PM by LHC

(modified after loading)

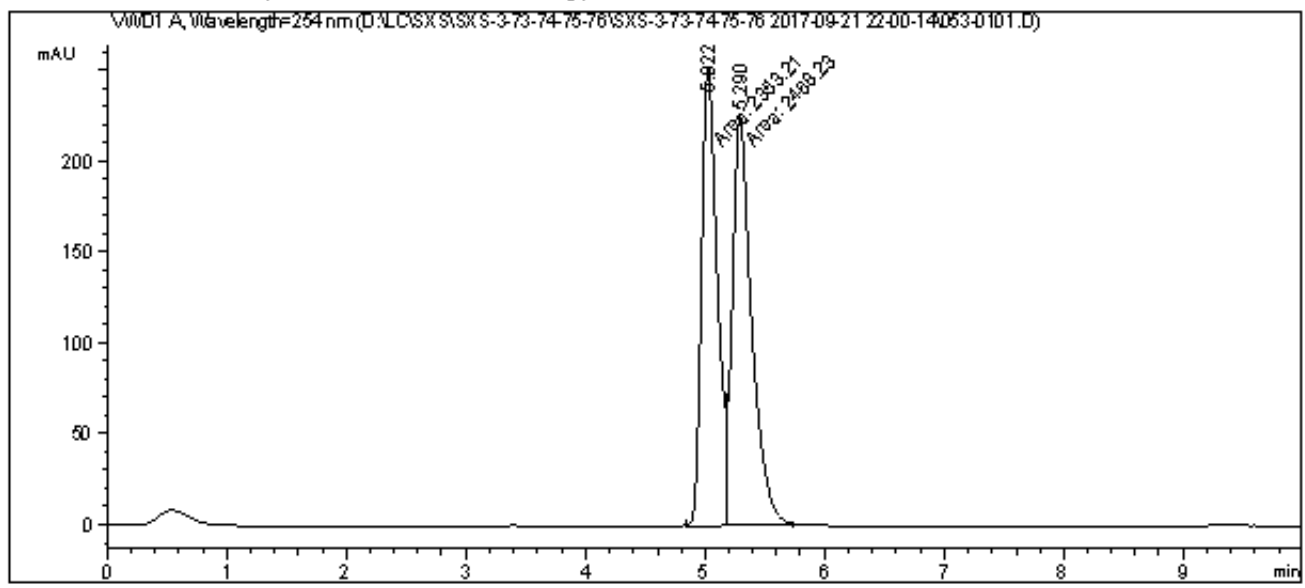

Area Percent Report

\begin{tabular}{|c|c|}
\hline Sorted By & : \\
\hline Multiplier & : \\
\hline Dilution & : \\
\hline
\end{tabular}

Use Multiplier \& Dilution Factor with IsTDs

Signal 1: VIDl A, Wavelength=254 nm

\begin{tabular}{|c|c|c|c|c|c|}
\hline Peak & RetTime Type & Width & Area & Height & Area \\
\hline$\#$ & [min] & [min] & misJ & [m-3UJ ] & 몹 \\
\hline----1 & $------\mid---$ & ------- & |----------| & ----------। & -------1 \\
\hline 1 & $5.022 \mathrm{MF}$ & 0.1554 & 2353.21216 & 252.32886 & 48.8073 \\
\hline 2 & $5.290 \mathrm{FM}$ & 0.1833 & 2468.22583 & 224.44679 & 51.1927 \\
\hline Total & : & & 4821.43799 & 476.77565 & \\
\hline
\end{tabular}


<smiles>Cc1cccc(/C=C/C=C/[C@@H](N=C2C(=O)N(C)c3ccccc32)C(F)(F)F)c1</smiles>

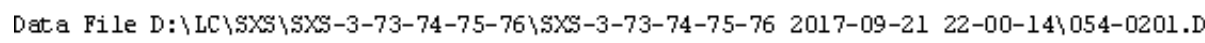
Sample Name: Sxs-3-74

\begin{tabular}{|c|c|c|}
\hline Acq. Operator & : $\mathbf{s X 5}$ & Seq. Line : \\
\hline Acq. Inst rument & : Instrument 1 & Location : Vial 54 \\
\hline Injection Date & : 9/21/2017 10:12:59 PM & Inj : \\
\hline
\end{tabular}

Acq. Method : D : $\backslash$ LC $\backslash 5 \times S \backslash S X 5-3-73-74-75-76 \backslash 5 \times 5-3-73-74-75-76 \quad 2017-09-21 \quad 22-00-14 \backslash$ ASH-95$5-254 \mathrm{MM}-1 \mathrm{UL}-1 \mathrm{MM} \mathrm{N} . \mathrm{M}$

Last changed : 9/15/2017 9:40:05 AM by 5Xs-3-62-63-64

Analysis Method : D: \LC \SXS\SXS-3-73-74-75-76\5X5-3-73-74-75-76 2017-09-21 22-00-14\0540201.D DA.M (ASH-95-5-254M-1UL-1OMDN.M)

Last changed : 7/6/2018 4:47:32 PM by LHC

(modified after loading)

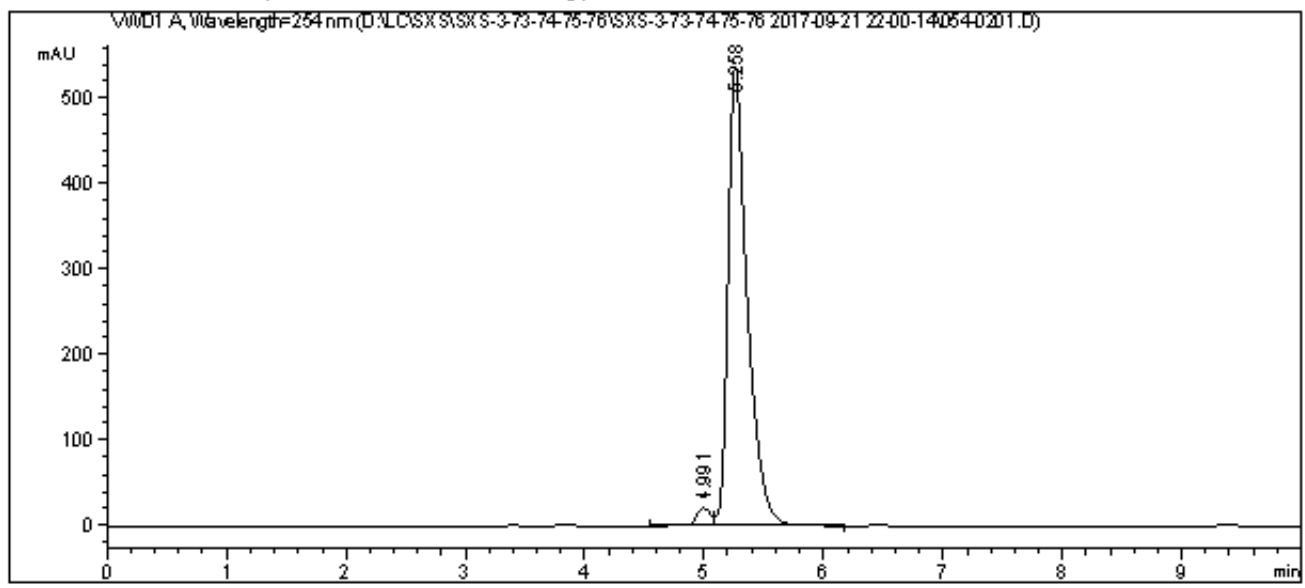

Area Percent Report

\begin{tabular}{|c|c|}
\hline Sorted By & : \\
\hline Multiplier & : \\
\hline Dilution & : \\
\hline
\end{tabular}

Use Multiplier \& Dilution Factor with ISTDs

Signal 1: VTD 1 , Wavelength=254 nm

\begin{tabular}{|c|c|c|c|c|c|c|c|}
\hline Peak & RetTime Type & Width & Ar & ea & $\mathrm{He}$ & ght & Area \\
\hline$\#$ & [min] & [min] & minJ & ${ }^{*} 3$ & [m.2JJ & ] & 몹 \\
\hline & - & -1 & $\mid---$ & ---1 & $1--$ & ---1 & --------1 \\
\hline 1 & $4.991 \mathrm{BV}$ & 1327 & 186 & 0230 & & 32617 & 3.0054 \\
\hline 2 & $5.258 \mathrm{VB}$ & 42 & 6025. & 46045 & 537 & 30426 & 946 \\
\hline
\end{tabular}

Totals : $\quad 6212.16275 \quad 559.13043$ 
<smiles>COc1cccc(/C=C/C=C/[C@H](N=C2C(=O)N(C)c3ccccc32)C(F)(F)F)c1</smiles>

Data File D: $\backslash$ LC $\backslash$ DATA $\backslash$ SLM SLM-9-08\SLM-9-08 2018-06-12 12-03-53\004-0101.D Sample Name: SLM-9-08-m-Me0-RAC

\begin{tabular}{|c|c|c|}
\hline $\begin{array}{l}\text { Acq. Oper ator } \\
\text { Acq. Inst rument }\end{array}$ & $\begin{array}{l}\text { : LHC } \\
: \text { Instrument } 1\end{array}$ & $\begin{array}{r}\text { Seq. Line : } \\
\text { Location : Vial } 4\end{array}$ \\
\hline Injection Date & : 6/12/2018 12:05:00 PM & $\begin{array}{rlc}\text { Inj } & : & 1 \\
\text { Inj Volume } & : & 1\end{array}$ \\
\hline
\end{tabular}

Acq. Method : D $\backslash$ LC $\backslash$ DATA $\backslash$ SLM, SLM-9-08 \SLM-9-08 2018-06-12 $12-03-53 \backslash$ ASH-95-5-254NM-1ULIOMDN.M

Last changed : 9/21/2017 11:55:29 $\mathrm{MM}$ by LHC

Analysis Method : D: $\backslash$ LC \DATA SLM SLM-9-08\SLM-9-08 2018-06-12 12-03-53\004-0101.D\DA.M । ASH-95-5-254MM-1UL-10M世N. M)

Last changed : 7/6/2018 5:10:48 PM by LHC

(modi fied after loading)

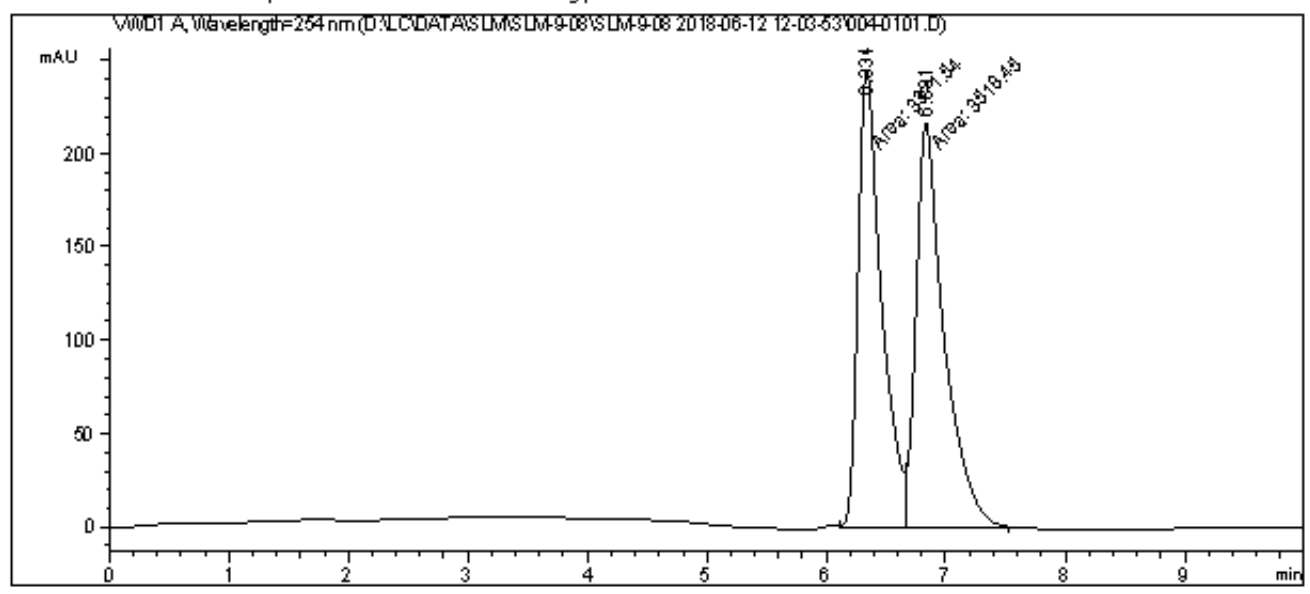

Area Percent Report

\begin{tabular}{|c|c|}
\hline Sorted By & : \\
\hline Multiplier & : \\
\hline Dilution & : \\
\hline
\end{tabular}

Use Multiplier \& Dilution Factor with IsTDs

Signal 1: VTD 1 , Wavelength $=254 \mathrm{rm}$

\begin{tabular}{|c|c|c|c|c|c|}
\hline Peak & RetTime Type & width & Area & Height & Area \\
\hline$\#$ & [min] & [min] & maUJ & [mBSU & $\frac{\mathrm{a}}{\mathrm{b}}$ \\
\hline--1 & ------1-- & ------- & |----------| & |---------- & -------- I \\
\hline 1 & $6.334 \mathrm{MF}$ & 0.2291 & 3371.53979 & 245.28752 & 48.9339 \\
\hline 2 & $6.831 \mathrm{FM}$ & 0.2710 & 3518.45020 & 216.38625 & 51.0661 \\
\hline $\mathrm{t} a$ & & & 6889.98999 & 461.67377 & \\
\hline
\end{tabular}


<smiles>COc1cccc(/C=C/C=C/[C@H](N=C2C(=O)N(C)c3ccccc32)C(F)(F)F)c1</smiles>

Data File D: \LC\DATA \LM SLM-9-08\SLM-9-08 2018-06-08 11-40-25 082-0201.D Sample Name: SLM-9-08-M-Me0-CHIRaL

\begin{tabular}{|c|c|c|}
\hline Acq. Operator & : $\mathrm{LHC}$ & Seq. Line : \\
\hline Acq. Inst rument & : Instrument 1 & Location : Vial 82 \\
\hline Injection Date & : 6/8/2018 11:53:04 $\mathrm{AM}$ & $\begin{array}{rll}\text { Inj } & : & 1 \\
\text { Inj Volume } & : 1 \mu l\end{array}$ \\
\hline
\end{tabular}

Acq. Method : D : \L \DATA SLM SLM-9-08\SLM-9-08 2018-06-08 11-40-25 ASH-95-5-254MM-1UL1 OMDI.M

Last changed : 9/21/2017 11:55:29 AM by LHC

Analysis Method : D: LC\DATA SLM SLM-9-08\SLM-9-08 2018-06-08 11-40-25\082-0201.D\DA.M ؛ ASH-95-5-254NM-1UL-10MIN. M

Last changed : 7/6/2018 5:09:26 PM by LHC

(modi fied after loading)

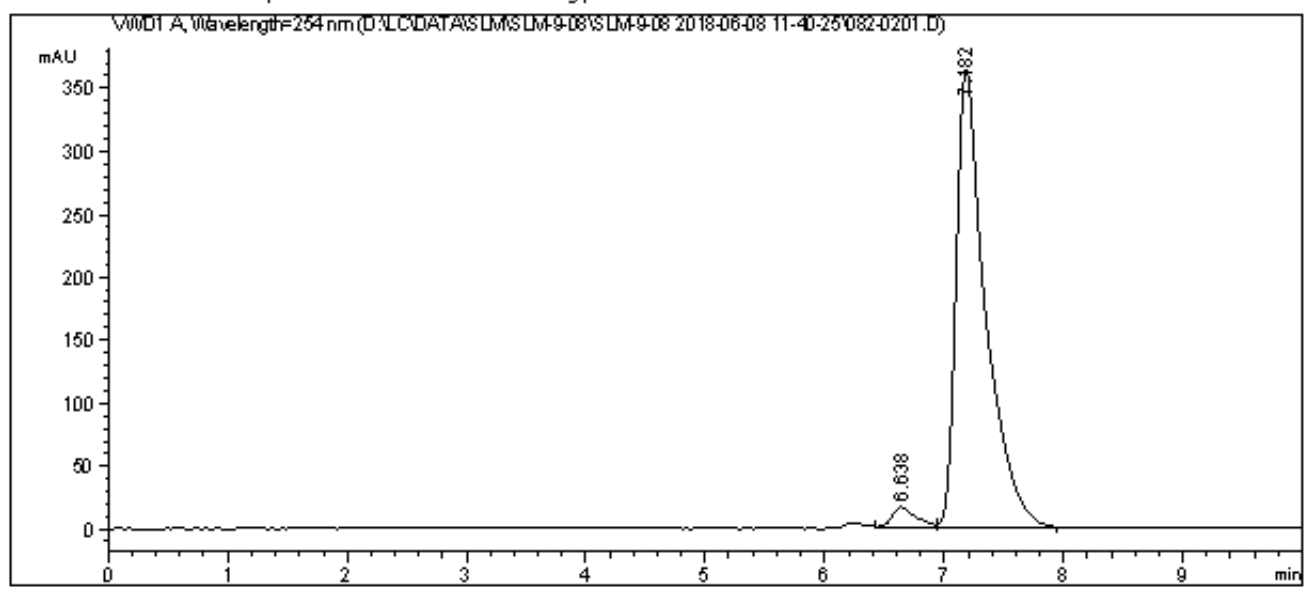

Area Percent Report

\begin{tabular}{|c|c|}
\hline Sorted By & : \\
\hline Multiplier & : \\
\hline Dilution & : \\
\hline
\end{tabular}

Use Multiplier \& Dilution Factor with ISTDs

Signal 1: VWDl A, Wavelength=254 nm

\begin{tabular}{|c|c|c|c|c|c|}
\hline Peak & RetTime Type & width & Area & Height & Area \\
\hline$\#$ & [min] & [min] & $\mathrm{m} \mathrm{BJU}$ & {$[\mathrm{m} \mathrm{mUJ}$} & 믑 \\
\hline---1 & -------|-- & ------- & |---------- & ---------- & -------1 \\
\hline 1 & $6.638 \mathrm{~W}$ & 0.2196 & 270.01974 & 17.47399 & 4.1024 \\
\hline 2 & $7.182 \mathrm{~W}$ & 0.2467 & 6311.99023 & 365.34564 & 95.8976 \\
\hline Total & : & & 6582.00998 & 382.81963 & \\
\hline
\end{tabular}


<smiles>CN1C(=O)/C(=N\C(/C=C/c2cccc(Cl)c2)C(F)(F)F)c2ccccc21</smiles>

Data File E: \DATA $\backslash$ SX...29-35-36-37 2017-08-24 15-50-38\5Xs-3-23-25-26-27-28-29-35-36-374.D Sample Name: SXs-3-27

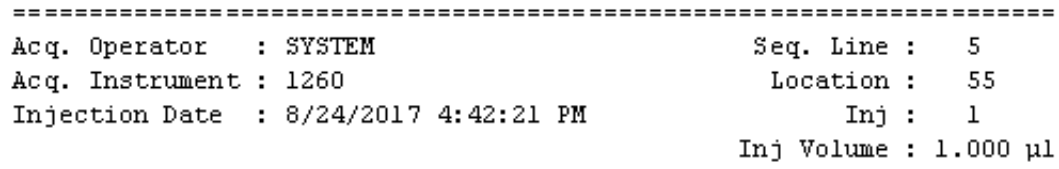

Acq. Method : E: \DATA \SXS\SXS-3-23-25-26-27-28-29-35-36-37 2017-08-24 15-50-38\ASH-95-5ALLMM-1. OML-1UL-10MIN.M

Last changed : 8/24/2017 3:50:38 PM by SYSTEM

Analysis Method : E: \DATA SXS\SXS-3-23-25-26-27-28-29-35-36-37 2017-08-24 15-50-38\ASH-95-5ALLMM-1. OML-1UL-10MIN.M (Sequence Method)

Last changed : 7/6/2018 5:13:56 PM by SYSTEM

(modified after loading)

Additional Info: Peak (s) manually integrated

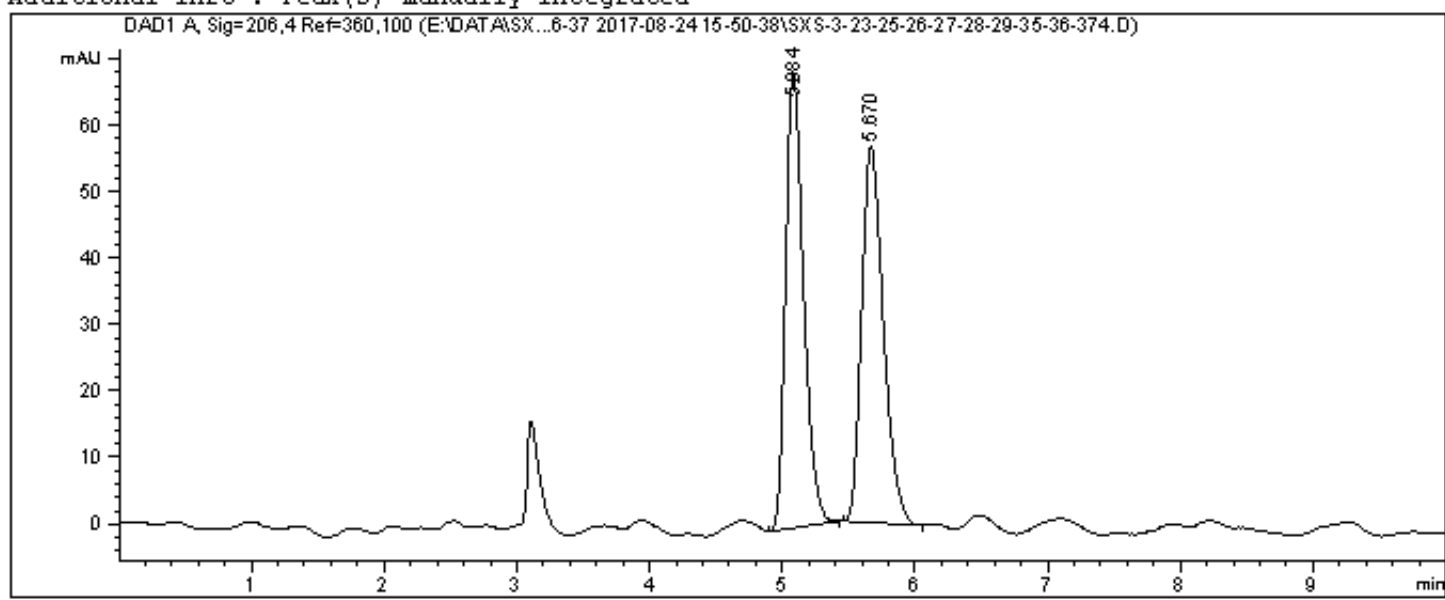

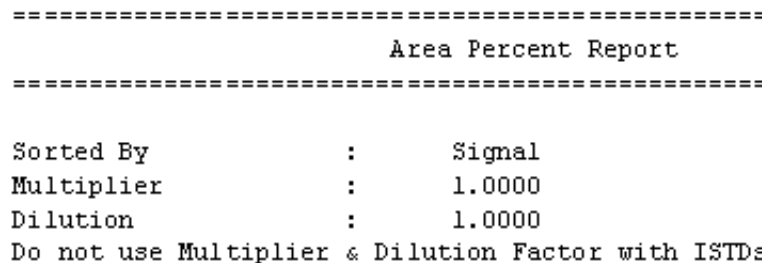

Signal 1: DADl A, Sig=206, 4 Ref $=360,100$

\begin{tabular}{|c|c|c|c|c|c|c|}
\hline $\begin{array}{c}\text { Peak } \\
\#\end{array}$ & $\begin{array}{c}\text { RetTime } \\
\text { [min] }\end{array}$ & Type & $\begin{array}{l}\text { Width } \\
\text { [min] }\end{array}$ & $\begin{array}{c}\text { Area } \\
{\left[\mathrm{m}_{\mathrm{A} \mathrm{U}^{*} \mathrm{~S}}\right]}\end{array}$ & $\begin{array}{l}\text { Height } \\
\text { [miU] }\end{array}$ & $\begin{array}{c}\text { Area } \\
\frac{s}{5}\end{array}$ \\
\hline 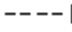 & -1 & & -- & -------- & ------- & --------1 \\
\hline 1 & 5.0 & B & 0.1428 & 647.00500 & 68.73624 & 50.0795 \\
\hline 2 & 5.670 & $\mathrm{BB}$ & 0.1738 & 644.95038 & 56.63884 & 49.9205 \\
\hline
\end{tabular}

Totals :

$1291.95538 \quad 125.37508$

ネネー End of Report ネネ 
<smiles>CN1C(=O)/C(=N\[C@H](/C=C/c2cccc(Cl)c2)C(F)(F)F)c2ccccc21</smiles>

Data File D: $\backslash$ LC $\backslash$ DATA $\backslash$ SLM SLM-9-01 \SLM-9-01 2018-06-02 11-04-27\071-0101.D Sample Name: SLM-9-01-P-Cl

\begin{tabular}{|c|c|}
\hline $\begin{array}{l}\text { Acq. Operator : LHC } \\
\text { Acq. Inst rument : Instrument } 1\end{array}$ & $\begin{aligned} & \text { Seq. Line : } 1 \\
& \text { Location : Vial } 71\end{aligned}$ \\
\hline Injection Date : 6/2/2018 11:06:02 $\mathrm{hM}$ & 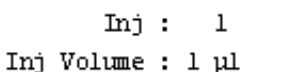 \\
\hline
\end{tabular}

Acq. Method : D: $\backslash$ LC $\backslash$ DATA $\backslash$ SLM SLM-9-01 \SLM-9-01 2018-06-02 11-04-27 \ASH-95-5-254MM-1ULIOMDN.M

Last changed : 9/21/2017 11:55:29 AM by LHC

Analysis Method : D: $\backslash C \backslash D A T A \backslash S L M$, SLM-9-01 \SLM-9-01 2018-06-02 11-04-27\071-0101.D\DA.M । ASH-95-5-254MM-1UL-10MIN. M)

Last changed : 7/7/2018 12:33:15 AM by LHC

(modi fied after loading)

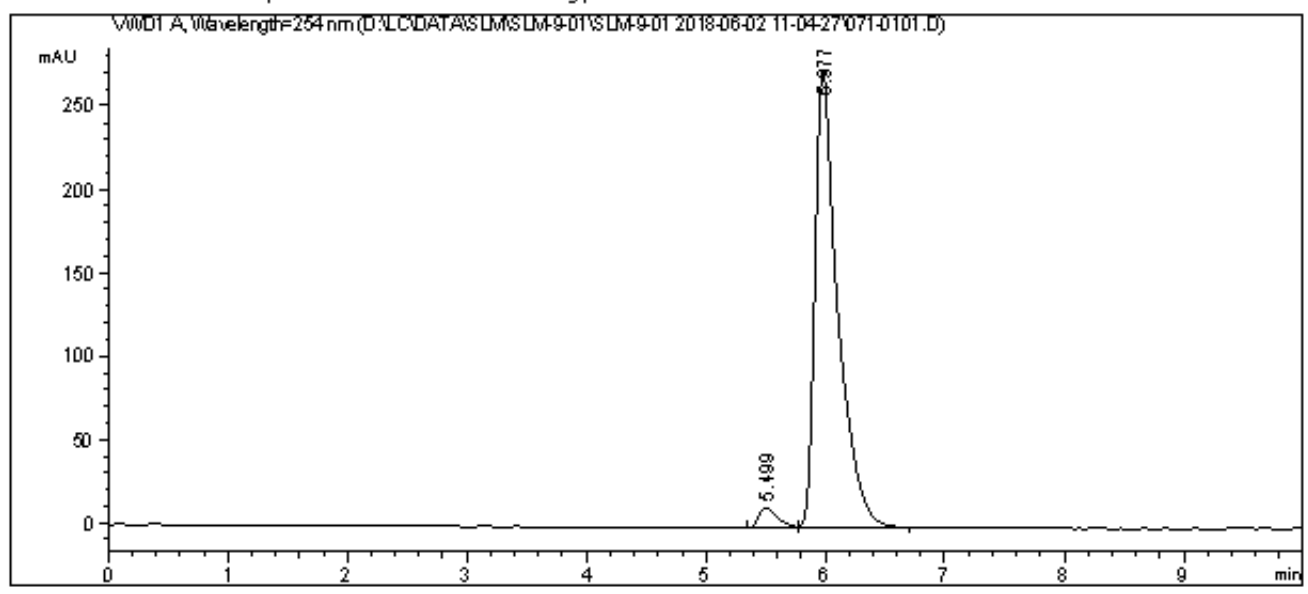

Area Percent Report

\begin{tabular}{|c|c|}
\hline Sorted By & : \\
\hline Multiplier & : \\
\hline Dilution & : \\
\hline
\end{tabular}

Use Multiplier s Dilution Factor with ISTDs

Signal 1: VTD $1 \mathrm{~A}$, Wavelength=254 nm

\begin{tabular}{|c|c|c|c|c|c|c|c|}
\hline Peak & RetTime Type & Width & & rea & Hei & & Area \\
\hline \# & {$[\min ]$} & [min] & misJ & $*^{3}$ & {$[\mathrm{~m}$ hUJ } & ] & 읍 \\
\hline & & & - & - & -- & - & ------1 \\
\hline 1 & $5.499 \mathrm{~W}$ & 0.1582 & 139. & .44186 & 12. & 50747 & 3.6551 \\
\hline 2 & $5.977 \mathrm{~W}$ & 0.1907 & 3675 & .51807 & 275. & 23471 & 96.3449 \\
\hline tal & & & 3814 & 95993 & 287. & 34219 & \\
\hline
\end{tabular}


<smiles>Cc1ccccc1/C=C/C=N/C(=O)C1C(=O)N(C)c2ccccc21</smiles>

Data File D: $\backslash$ LC $\backslash$ DATA $\backslash$ SLM SLM-7-58\SLM-7-58-2 2017-10-31 15-05-58\002-0101.D Sample Name: SLM-7-58-RAC

$\begin{array}{lr}\text { Acq. Operator }: \text { sXs } & \text { Seq. Line : } 1 \\ \text { Acq. Inst rument : Instrument 1 } & \text { Location : Vial } 2 \\ \text { Injection Date : 10/31/2017 3:07:14 PM } & \text { Inj : } 1 \\ & \text { Inj Volume : } 1 \mu l\end{array}$

Acq. Method : D: \LC \DATA SLM SLM-7-58\SLM-7-58-2 2017-10-31 15-05-58\ASH-95-5-254MM$1 \mathrm{UL}-10 \mathrm{MDN}$.M

Last changed : 9/21/2017 11:55:29 AM by LHC

Analysis Method : D: $\backslash$ LC \DATA SLM SLM-7-58\SLM-7-58-2 2017-10-31 15-05-58\002-0101.D\DA.M ( ASH-95-5-254NM-1UL-10NMN. M)

Last changed : 8/14/2018 10:00:41 PM by LHC (modified after loading)

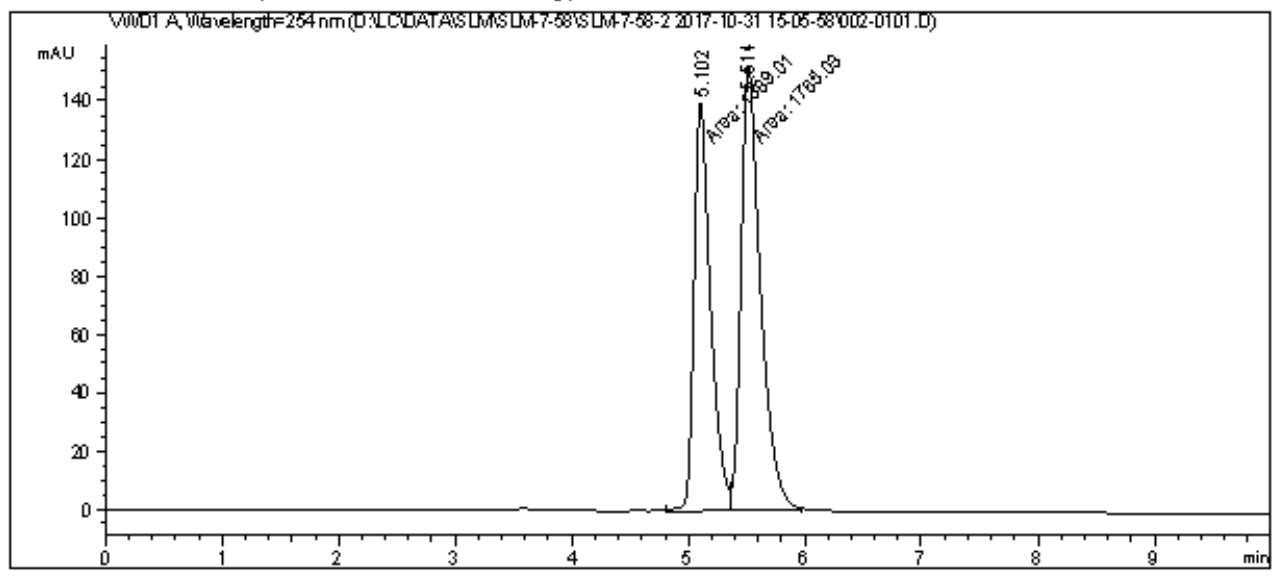

area Percent Report

$\begin{array}{lll}\text { Sorted By } & : & \text { Signal } \\ \text { Multiplier } & : & 1.0000 \\ \text { Dilution } & : & 1.0000\end{array}$

Use Multiplier a Dilution Factor with IsTDs

Signal 1: VTD 1 , Wavelength=254 nm

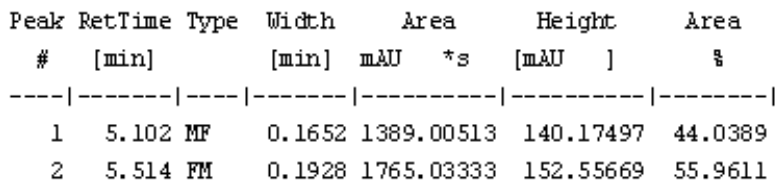

Totals :

$3154.03845 \quad 292.73166$ 
<smiles>Cc1ccccc1/C=C/C=C/[C@H](N=C1C(=O)N(C)c2ccccc21)C(F)(F)F</smiles>

Data File D: $\backslash$ LC $\backslash$ DATA $\backslash$ SLM SLM-7-60\SLM-7-60 2017-11-01 15-52-21\001-0101.D Sample Name: SLM-7-60-1

\begin{tabular}{|c|c|c|}
\hline Acq. Operator : & : SXS & seq. Line : 1 \\
\hline Acq. Inst rument : & : Instrument 1 & Location : Vial 1 \\
\hline Injection Date & $: 11 / 1 / 20173: 53: 28$ PM & $\begin{array}{rlc}\text { Inj } & : & 1 \\
\text { Inj Volume } & \text { : } & 1\end{array}$ \\
\hline
\end{tabular}

Acq. Method : D: $\backslash$ LC $\backslash$ DATA $\backslash$ SLM SLM-7-60 \SLM-7-60 2017-11-01 15-52-21 \ASH-95-5-254MM-1ULIOMDN.M

Last changed : 10/17/2017 4:06:22 PM by SXS

Analysis Method : D: $\backslash$ LC \DATA SLM SLM-7-60\SLM-7-60 2017-11-01 15-52-21\001-0101.D\DA.M । ASH-95-5-254MM-1UL-10MIN. M

Last changed : 7/6/2018 8:57:45 PM by LHC

(modi fied after loading)

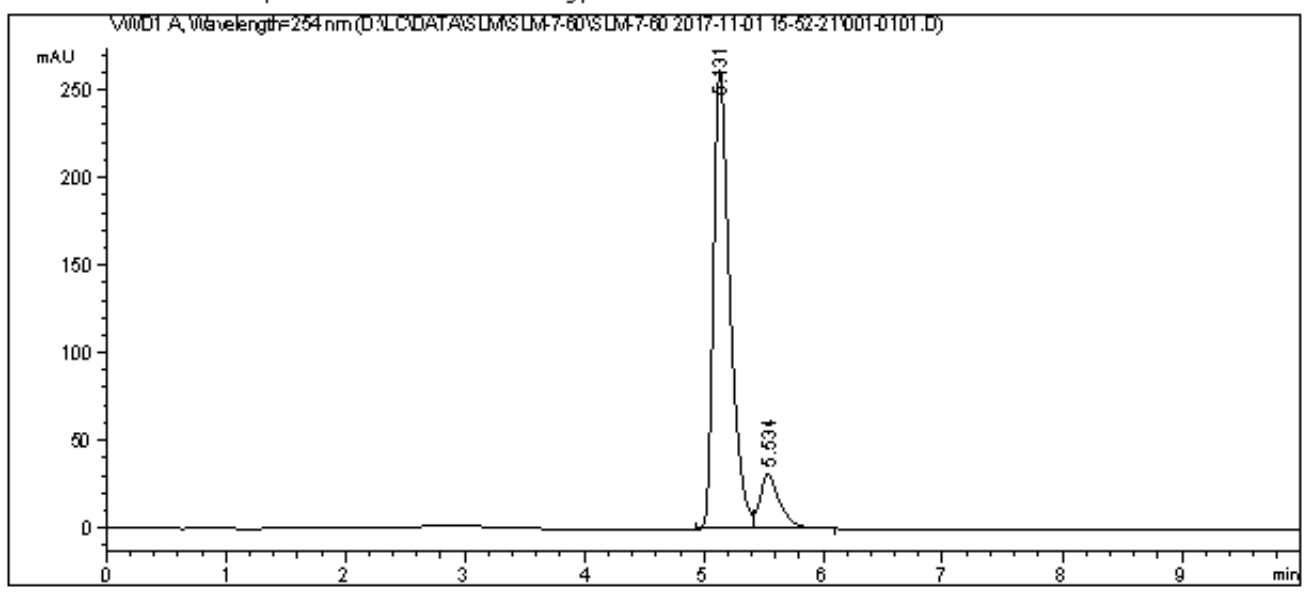

Area Percent Report

\begin{tabular}{|c|c|}
\hline Sorted By & : \\
\hline Multiplier & : \\
\hline bilution & : \\
\hline
\end{tabular}

Use Multiplier a Dilution Factor with ISTDs

Signal 1: VID $1 \mathrm{~A}$, Wavelength $=254 \mathrm{rm}$

\begin{tabular}{|c|c|c|c|c|c|c|}
\hline Peak & RetTime Type & Width & & fea & Height & Area \\
\hline \# & [min] & [min] & misJ & $*^{3}$ & [ [mBSU ] & 읍 \\
\hline & & & -1 & - & ------ & ------1 \\
\hline 1 & $5.131 \mathrm{~W}$ & 0.1422 & 2509 & 15552 & 262.21558 & 87.3160 \\
\hline 2 & $5.534 \mathrm{VB}$ & 0.1689 & 364 & 49310 & 31.40347 & 12.6840 \\
\hline ta & & & 2873. & 64862 & 293.61905 & \\
\hline
\end{tabular}


<smiles>CN1C(=O)/C(=N\[C@H](/C=C/c2ccc3c(c2)OCO3)C(F)(F)F)c2ccccc21</smiles>

Data File E: \DATA $\backslash$ SLM-9-13\SLM-9-13 2018-06-11 12-14-50\SLM-9-132. D Sample Name: SLM-9-HJQ-11

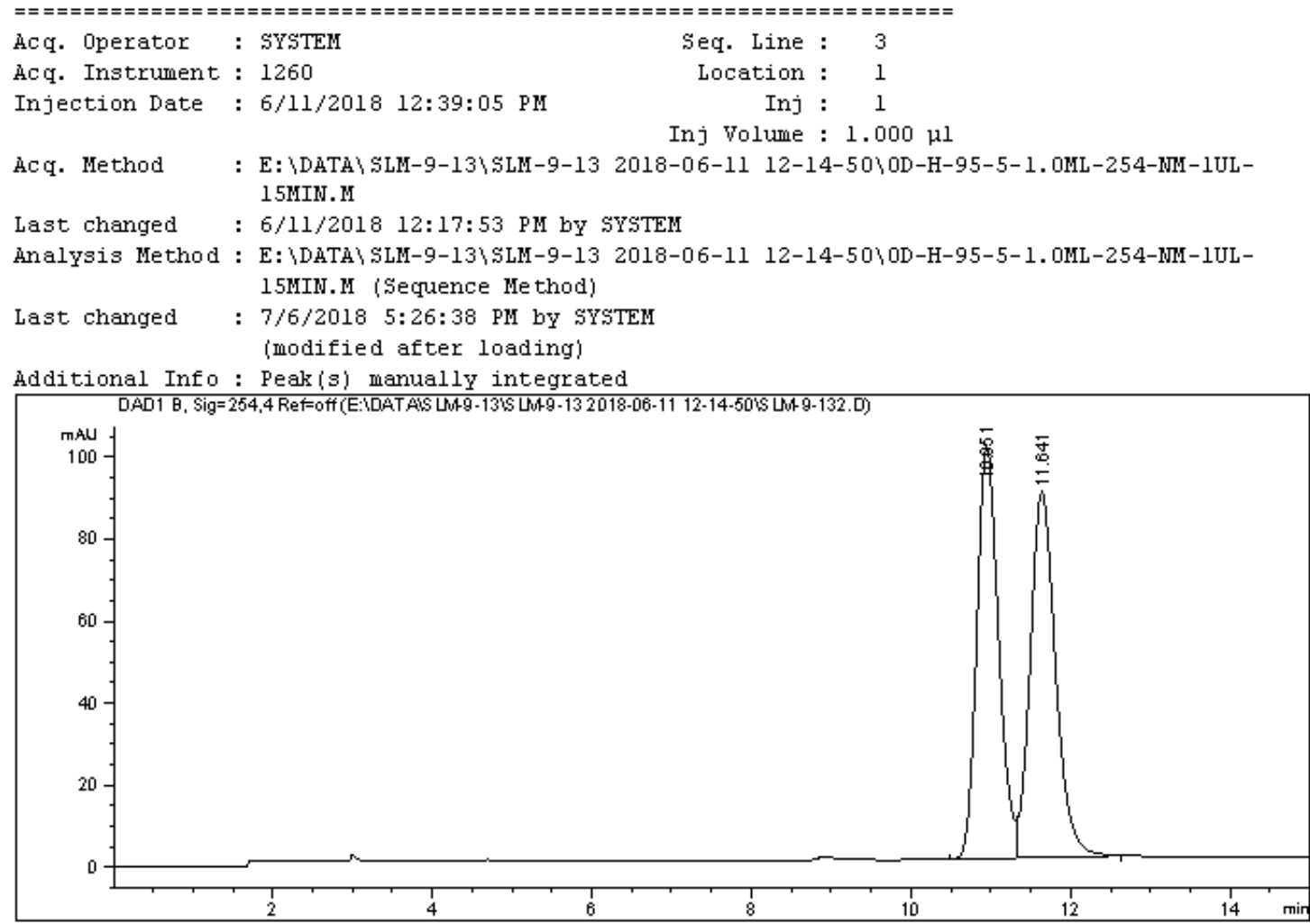

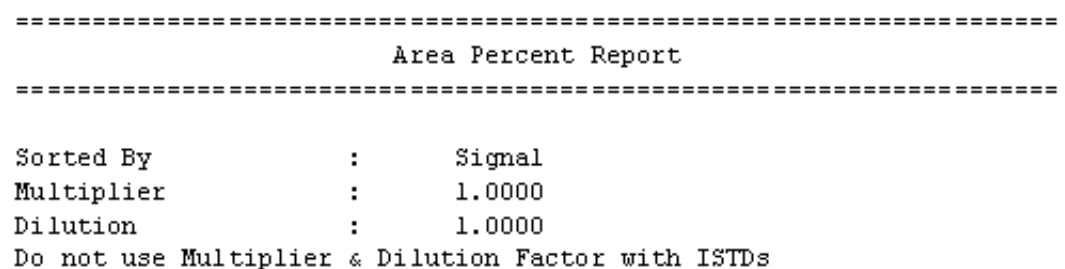

Do not use Multiplier \& Dilution Factor with ISTDs

Signal 1: DADl B, Sig=254, 4 Ref=off

\begin{tabular}{|c|c|c|c|c|c|c|}
\hline $\begin{array}{c}\text { Peak } \\
\#\end{array}$ & $\begin{array}{c}\text { RetTime } \\
\text { [min] }\end{array}$ & Type & $\begin{array}{l}\text { Width } \\
\text { [min] }\end{array}$ & $\begin{array}{c}\text { Area } \\
{\left[\mathrm{mAU} U^{*} \mathrm{~s}\right]}\end{array}$ & $\begin{array}{l}\text { Height } \\
\text { [miU] }\end{array}$ & $\begin{array}{c}\text { Area } \\
\frac{s}{5}\end{array}$ \\
\hline & & & ---1 & ---------- & $---------\mid$ & --------1 \\
\hline 1 & 10.9 & $\mathrm{~V}$ & 0.2908 & 1900.94910 & 100.46324 & 49.0996 \\
\hline 2 & 11.641 & VB & 0.3368 & 1970.66626 & 89.17263 & 50.9004 \\
\hline
\end{tabular}

Totals :

$3871.61536 \quad 189.63587$

ネネー End of Report *ネ 
<smiles>CN1C(=O)/C(=N\[C@H](/C=C/c2ccc3c(c2)OCO3)C(F)(F)F)c2ccccc21</smiles>

Data File E: \DATA \SLM $\backslash$ SLM-9-13 2018-06-11 20-21-24\SLM-9-hjq-11.D Sample Name: sLM-9-hjq-chiral-11

\begin{tabular}{|c|c|c|c|}
\hline Ácq. Operator & : SYSTEM & seq. Line : & 1 \\
\hline Ac q. Instrument & : 1260 & Location : & 2 \\
\hline Injection Date & : 6/11/2018 8:22:46 PM & Inj : & 1 \\
\hline
\end{tabular}

Acq. Method : E: \DATA SLM SLM-9-13 2018-06-11 20-21-24\0D-H-95-5-1. 0ML-254-MM-1UL-15MIN.M Last changed : 6/11/2018 8:21:25 PM by SYSTEM

Analysis Method : E: \DATA SLM SLM-9-13 2018-06-11 20-21-24\0D-H-95-5-1. 0ML-254-MM-1UL-15MIN. M (Sequence Method)

Last changed : 7/6/2018 5:22:35 PM by SYSTEM (modified after loading)

Additional Info : Peak (s) manually integrated

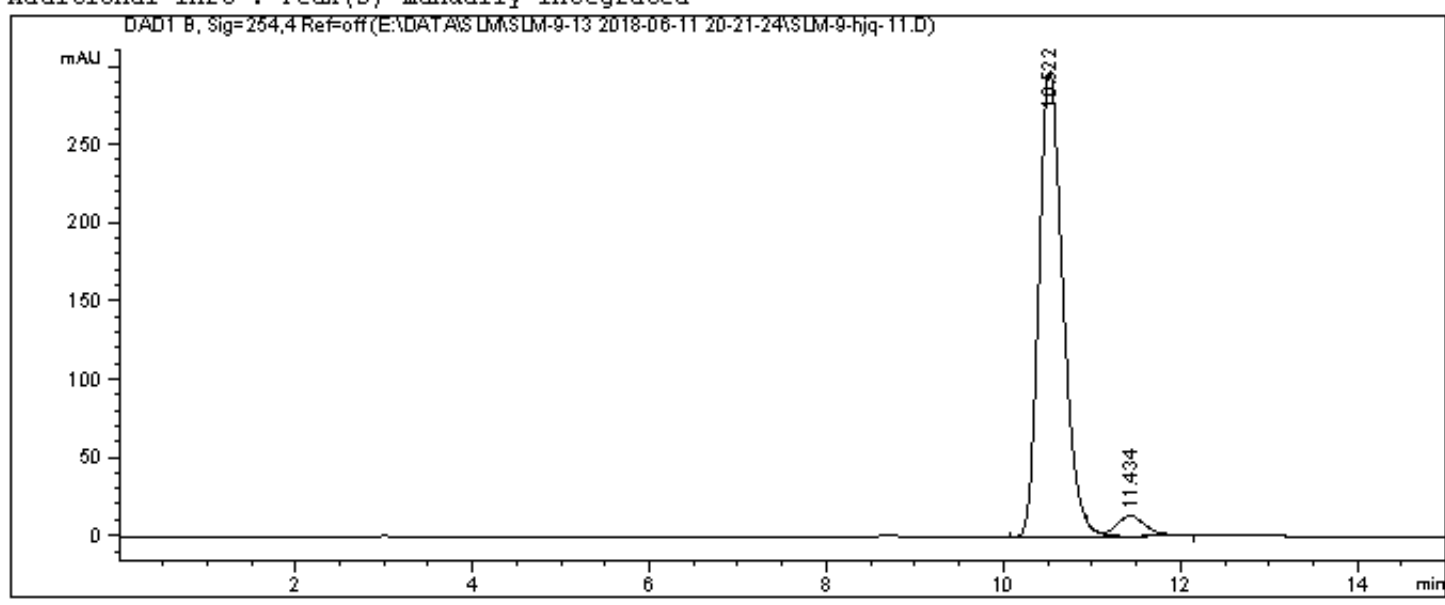

Area Percent Report

\begin{tabular}{|c|c|c|}
\hline Sorted BY & : & Signal \\
\hline Multiplier & : & 1.0000 \\
\hline Dilution & : & 1.0000 \\
\hline
\end{tabular}

Do not use Multiplier \& Dilution Factor with IsTDs

Signal 1: DẢDl B, Sig=254, 4 Ref=off

\begin{tabular}{|c|c|c|c|c|c|}
\hline $\begin{array}{c}\text { Peak } \\
\#\end{array}$ & $\begin{array}{l}\text { RetTime Type } \\
\text { [min] }\end{array}$ & $\begin{array}{l}\text { Width } \\
\text { [min] }\end{array}$ & $\begin{array}{c}\text { Area } \\
{\left[\mathrm{maU}^{*} \mathrm{~s}\right]}\end{array}$ & $\begin{array}{l}\text { Height } \\
\text { [mAU] }\end{array}$ & $\begin{array}{c}\text { Area } \\
\stackrel{s}{*}\end{array}$ \\
\hline- & 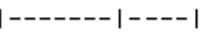 & 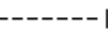 & $----------\mid$ & $---------\mid$ & -------- \\
\hline 1 & $10.522 \mathrm{BV} \mathrm{R}$ & 0.2920 & 5609.56299 & 297.48694 & 94.9480 \\
\hline 2 & $11.434 \mathrm{VB} E$ & 0.3353 & 298.47668 & 13.12346 & 5.0520 \\
\hline \multicolumn{3}{|c|}{ Totals : } & 5908.03967 & 310.61040 & \\
\hline
\end{tabular}

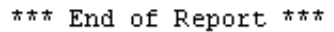


<smiles>CN1C(=O)/C(=N\[C@H](/C=C/c2ccc(Cl)c(Cl)c2)C(F)(F)F)c2ccccc21</smiles>

Data File D: $\backslash$ LC $\backslash$ DATA $\backslash$ SLM SLM-6-102\SLM-6-102-1 2017-09-21 12-21-54\003-0101.D Sample Name: SLM-6-102-RaC

\begin{tabular}{|c|c|c|}
\hline Acq. Operator & : LHC & Seq. Line : 1 \\
\hline Acq. Inst rument & : Instrument 1 & Location : Vial 3 \\
\hline Injection Date & : 9/21/2017 12:23:04 PM & $\operatorname{Inj}: 1$ \\
\hline
\end{tabular}

Acq. Method : D: \LC \DATA SLM SLM-6-102\SLM-6-102-1 2017-09-21 12-21-54 \ASH-95-5-254NM1UL-7MIN. M

Last changed : 9/21/2017 12:20:56 PM by LHC

Analysis Method : D: LC DATA SLM SLM-6-102\SLM-6-102-1 2017-09-21 12-21-54 003-0101.D DA.M (ASH-95-5-254M-1UL-7MாN. M)

Last changed : 7/6/2018 5:06:12 PM by LHC

(modi fied after loading)

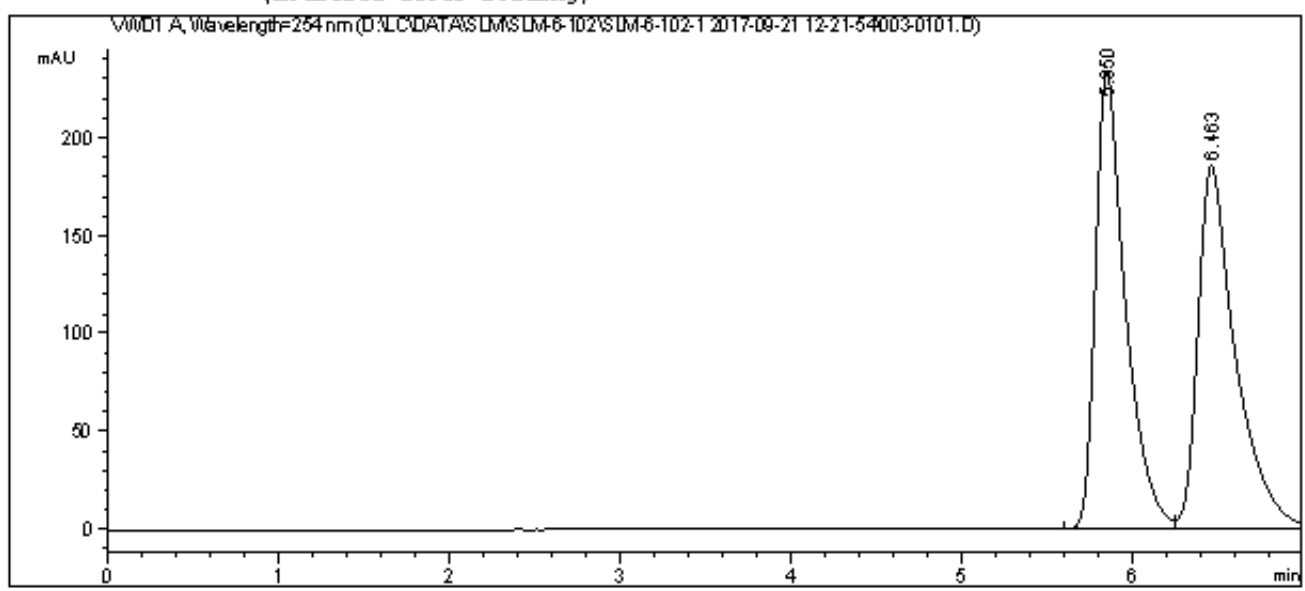

Area Percent Report

\begin{tabular}{|c|c|c|}
\hline Sorted By & : & Sign \\
\hline Multiplier & : & 1.00 \\
\hline Dilution & : & 1.00 \\
\hline
\end{tabular}

Use Multiplier \& Dilution Factor with IsTDs

Signal 1: VWDl A, Wavelength=254 nm

\begin{tabular}{|c|c|c|c|c|c|c|c|}
\hline Peak & etTime & Type & Width & & ea & Height & Area \\
\hline$\#$ & [min] & & [min] & midU & $*_{3}$ & {$[\mathrm{~m} 3 \mathrm{BU}$} & 몹 \\
\hline 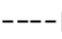 & - & 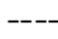 & --- & $\mid---$ & ----- & ---------- & $-------\mid$ \\
\hline 1 & 5.850 & WV & 0.1783 & 284 & 49780 & 233.94556 & 50.1631 \\
\hline 2 & 6.463 & VBA & 0.2218 & 282 & 99927 & 185.12585 & 49.8369 \\
\hline Tota & : & & & 5670 & 49707 & 419.07141 & \\
\hline
\end{tabular}


<smiles>CN1C(=O)/C(=N\[C@H](/C=C/c2ccc(Cl)c(Cl)c2)C(F)(F)F)c2ccccc21</smiles>

Data File D: $\backslash$ LC $\backslash D A T A \backslash S L M \backslash$ SLM-6-102\SLM-6-102-1 2017-09-21 12-21-54\004-0301.D Sample Name: SLM-6-102-CHIRAL

\begin{tabular}{|c|c|c|}
\hline Acq. Operator & : LHC & Seq. Line : \\
\hline Acq. Inst rument & : Instrument 1 & Location: Vial 4 \\
\hline Injection Date & : 9/21/2017 12:39:21 PM & $\begin{array}{rlc}\text { Inj } & \text { : } & 1 \\
\text { Inj Volume } & 1 \text { l }\end{array}$ \\
\hline
\end{tabular}

Acq. Method : D: \LC\DATA SLM SLM-6-102\SLM-6-102-1 2017-09-21 12-21-54 \ASH-95-5-254MM1UL-7MIN. M

Last changed : 9/21/2017 12:20:56 PM by LHC

Analysis Method : D: LC DATA SLM SLM-6-102\SLM-6-102-1 2017-09-21 12-21-54 004-0301.D DA.M (BSH-95-5-254M-1UL-7M-N. M)

Last changed : 7/6/2018 5:07:52 PM by LHC

(modi fied after loading)

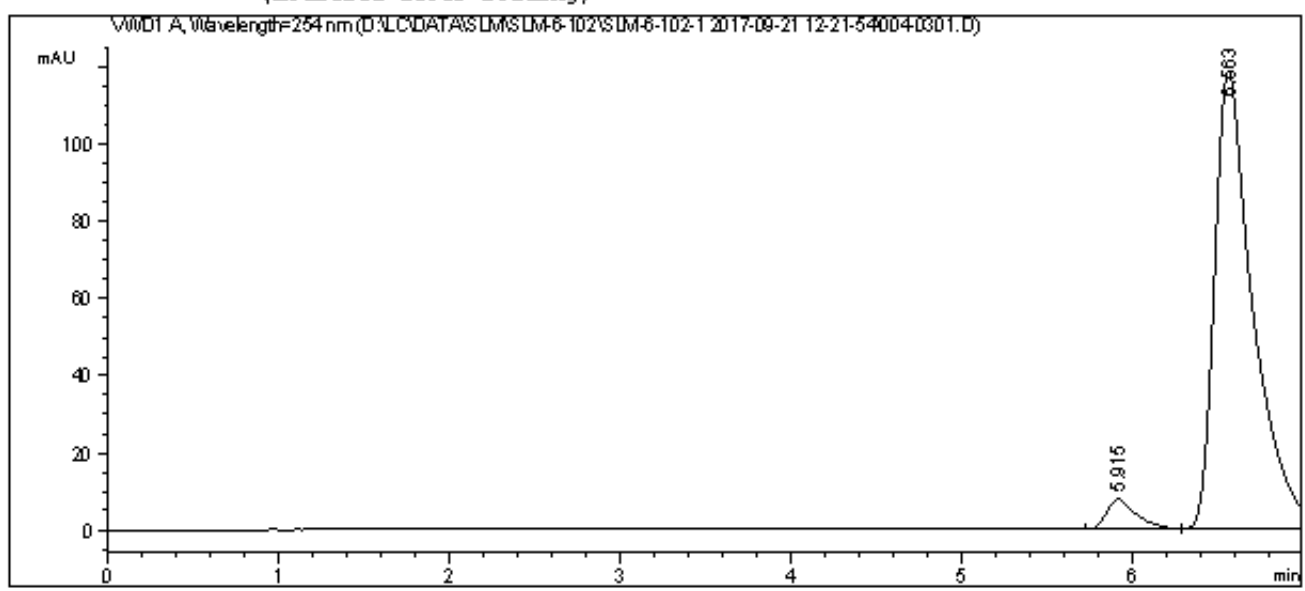

Area Percent Report

$\begin{array}{lll}============================= \\ \text { Sorted BY } & : & \text { Signal } \\ \text { Multiplier } & : & 1.0000 \\ \text { Dilution } & : & 1.0000\end{array}$

Use Multiplier \& Dilution Factor with IsTDs

Signal 1: VoD 1 , Wavelength=254 nm

\begin{tabular}{|c|c|c|c|c|c|}
\hline Peak & RetTime Type & Width & area & Height & Area \\
\hline$\#$ & [min] & [min] & $\mathrm{m} 3 \mathrm{SU}$ & [mbU ］ & 믑 \\
\hline----1 & $|-------|----$ & ------- & |----------| & ---------- | & -------1 \\
\hline 1 & $5.915 \mathrm{BV}$ & 0.1811 & 96.68581 & 7.79450 & 4.9992 \\
\hline 2 & $6.563 \mathrm{VBA}$ & 0.2253 & 1837.34119 & 118.98087 & 95.0008 \\
\hline Total & Ls: & & 1934.02700 & 126.77537 & \\
\hline
\end{tabular}


<smiles>Cc1cc(C)cc(/C=C/C=C/C(=O)NC2C(=O)N(C)c3ccccc32)c1</smiles>

Data File E: \DATA $\backslash$ SLM $\backslash$ SLM-9-17 \SLM-9-17 2018-06-13 15-42-16 SLM-9-17-RAC.D Sample Name: SLM-9-17-RAC

\begin{tabular}{|c|c|c|c|}
\hline Acq. Operator & : SYSTEM & Seq. Line : & 1 \\
\hline Ac q. Instrument & $: 1260$ & Location : & 31 \\
\hline Injection Date & : $6 / 13 / 2018 \quad 3: 43: 43 \mathrm{PM}$ & $\begin{array}{r}\text { Inj : } \\
\text { Inj Volume : }\end{array}$ & $\begin{array}{l}1 \\
.000 \mu l\end{array}$ \\
\hline
\end{tabular}

ACq. Method : E: \DÁTA \SLM SLM-9-17 \SLM-9-17 2018-06-13 15-42-16 0D-H-95-5-1. 0ML-254-MMIUL-1OMIN.M

Last changed : 6/13/2018 3:42:16 PM by SYSTEM

Analysis Method : E: \DATA SLM SLM-9-17 SLM-9-17 2018-06-13 15-42-16 0D-H-95-5-1. 0ML-254-MMIUL-1OMIN.M (Sequence Method)

Last changed : 7/6/2018 5:23:46 PM by SYSTEM (modified after loading)

Additional Info : Peak (s) manually integrated

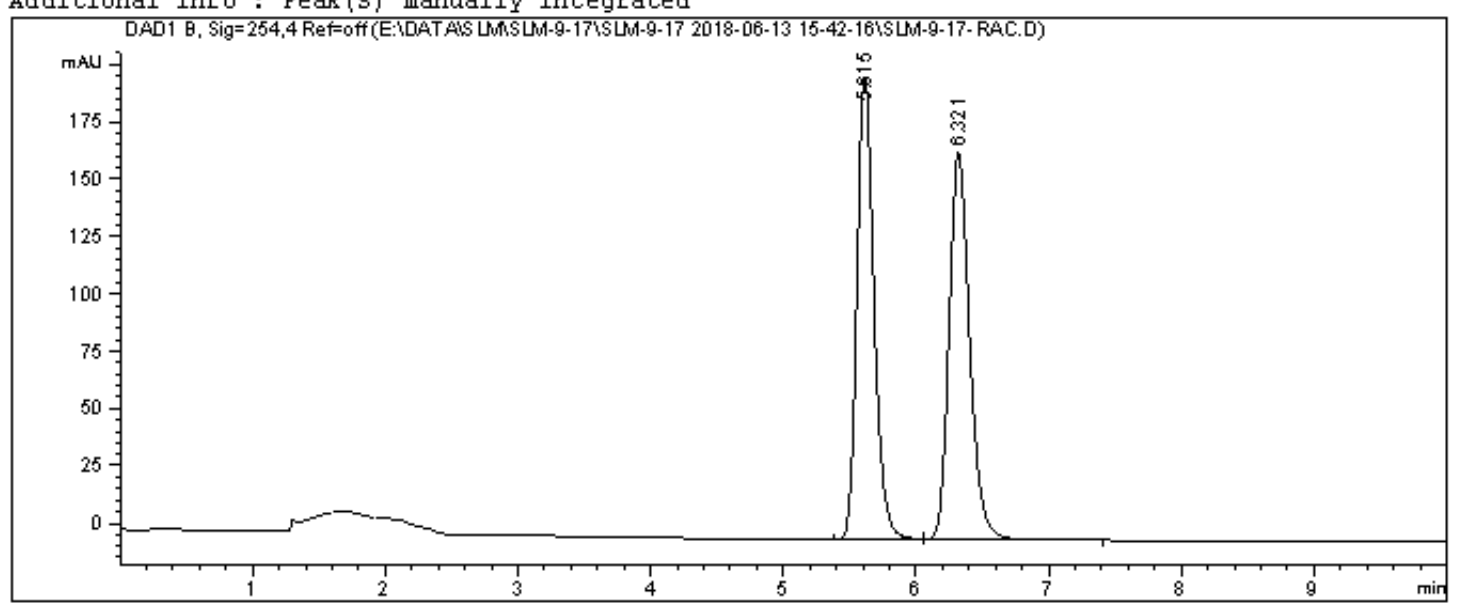

Area Percent Report

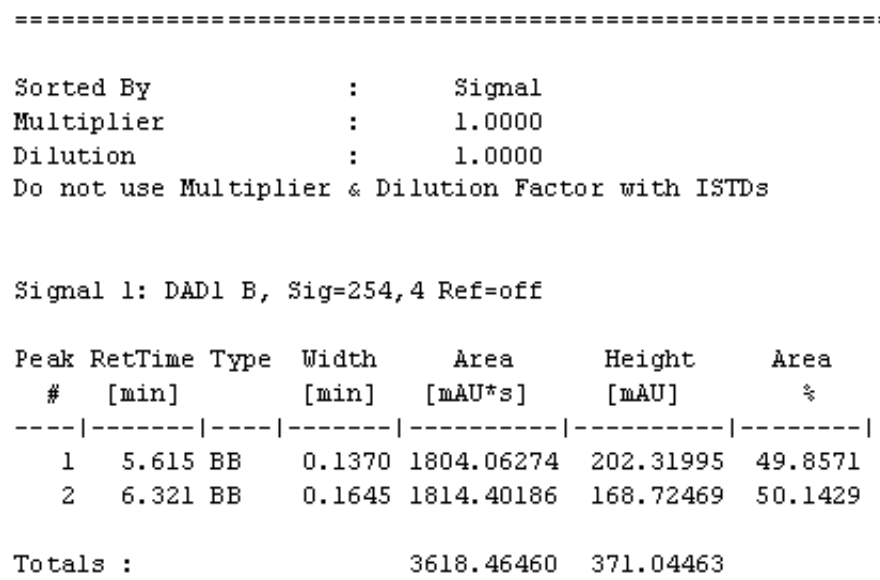

ホネホ End of Report ネネ゙ 
<smiles>Cc1cc(C)cc(/C=C/C=C/N=C2C(=O)N(C)c3ccccc32)c1</smiles>

Data File E: \DATA \LLM SLM-9-17 \SLM-9-17 2018-06-13 15-42-16 SLM-9-17-RAC1.D Sample Name: SLM-9-17-CHIRAL-3-5-Me

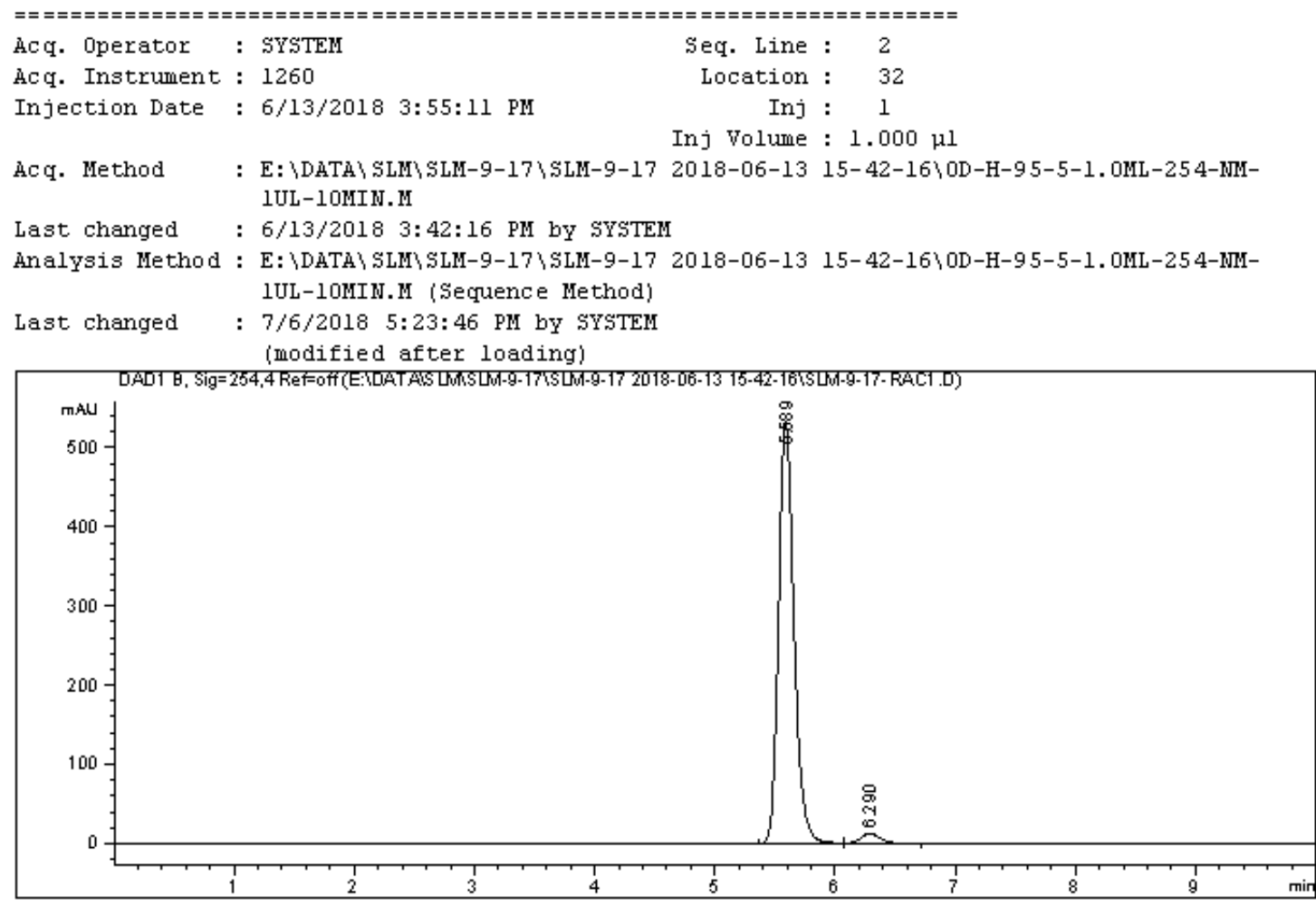

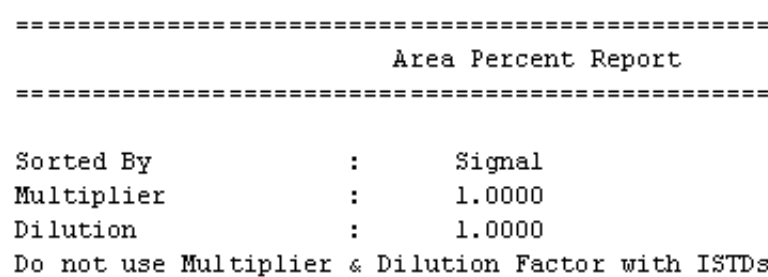

Signal 1: DADl B, Sig=254, 4 Ref=off

\begin{tabular}{|c|c|c|c|c|c|c|}
\hline $\begin{array}{c}\text { Peak } \\
\#\end{array}$ & $\begin{array}{c}\text { RetTime } \\
\text { [min] }\end{array}$ & Type & $\begin{array}{l}\text { Width } \\
\text { [min] }\end{array}$ & $\begin{array}{c}\text { Area } \\
{\left[\mathrm{mAU} \mathbf{U}^{*} \mathrm{~S}\right]}\end{array}$ & $\begin{array}{l}\text { Height } \\
\text { [mAU] }\end{array}$ & $\begin{array}{c}\text { Area } \\
\frac{*}{*}\end{array}$ \\
\hline & & & & $----------\mid$ & $----------\mid$ & $------1-$ \\
\hline 1 & & & & 4758.94971 & 533.45453 & 97.3309 \\
\hline 2 & 6.290 & $\mathrm{BB}$ & 0.1647 & 130.50436 & 12.31005 & 2.6691 \\
\hline
\end{tabular}

Totals : $4889.45407 \quad 545.76458$ 
<smiles>CN1C(=O)/C(=N\C(C/C=C/c2ccc3ccccc3c2)C(F)(F)F)c2ccccc21</smiles>

Data File E: \DATA $\backslash$ SXS $\backslash$ SXS-7-2 2018-08-29 15-46-23\SXS-7-2-3-53.D

Sample Name: SXs-7-2

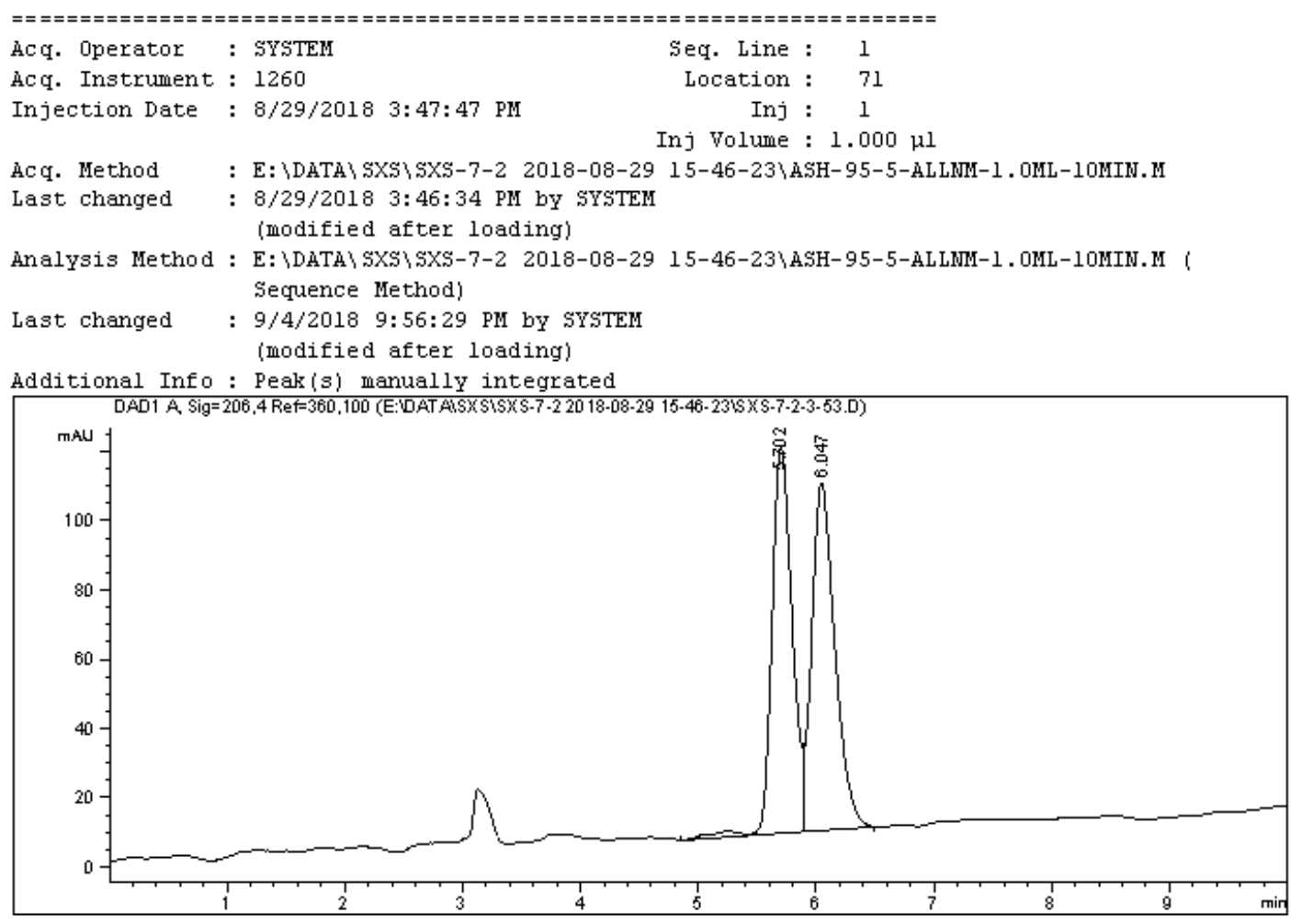

Area Percent Report

\begin{tabular}{|c|c|c|}
\hline Sorted By & : & Signal \\
\hline Multiplier & : & 1.0000 \\
\hline Dilution & : & 1.0000 \\
\hline
\end{tabular}

Do not use Multiplier \& Dilution Factor with ISTDs

Signal 1: DADl A, Sig=206, 4 Ref $=360,100$

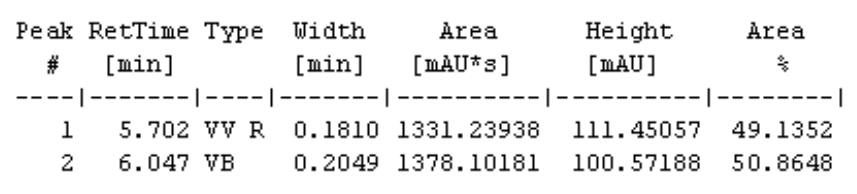

Totals : $\quad 2709.34119 \quad 212.02245$ 
<smiles>CN1C(=O)/C(=N\C(Cc2ccccc2)C(F)(F)F)c2ccccc21</smiles>

Data File E: $\backslash$ DATA $\backslash$ SXS $\backslash$ SXS-7-2 2018-08-29 15-46-23\5XS-7-2-3-531.D Sample Name: sXs-3-53

\begin{tabular}{|c|c|c|}
\hline Acq. Operator & : SYSTEM & seq. Line : \\
\hline Acq. Instrument & : 1260 & Location : \\
\hline Injection Date & : 8/29/2018 3:59:10 PM & $\begin{array}{r}\text { Inj : } \\
\text { Inj Volume : }\end{array}$ \\
\hline
\end{tabular}

Ac q. Method : E: \DATA SXS SXS-7-2 2018-08-29 15-46-23\ASH-95-5-ALLMM-1. OML-10MIN. M Last changed : 8/29/2018 3:46:34 PM by SYSTEM

Analysis Method : E: \DATA SXS\SXS-7-2 2018-08-29 15-46-23\ASH-95-5-ALLMM-1.0ML-10MIN.M ( Sequence Method)

Last changed : 11/4/2018 6:07:34 PM by SYSTEM (modified after loading)

Additional Info : Peak (s) manually integrated

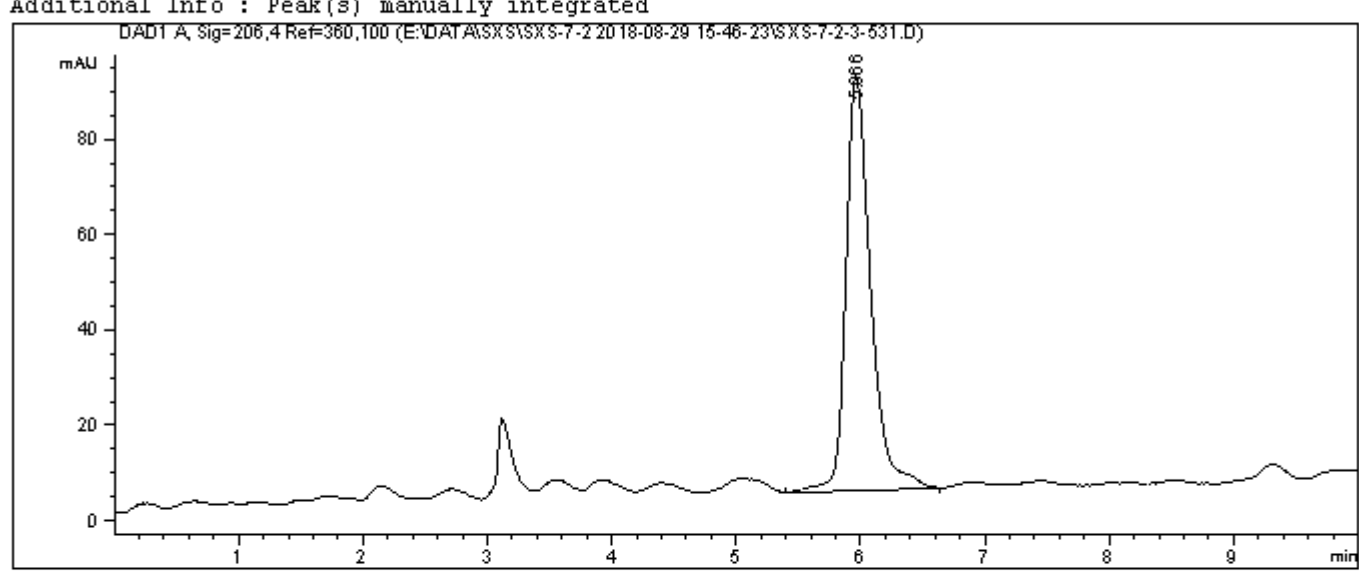

Area Percent Report

\begin{tabular}{|c|c|c|}
\hline Sorted By & $:$ & Signal \\
\hline Multiplier & : & 1.0000 \\
\hline Dilution & : & 1.0000 \\
\hline
\end{tabular}

Do not use Multiplier \& Dilution Factor with ISTDs

Signal 1: DADl À, Sig $=206,4$ Ref $=360,100$

\begin{tabular}{|c|c|c|c|c|c|}
\hline $\begin{array}{c}\mathrm{Peak} \\
\#\end{array}$ & $\begin{array}{l}\text { RetTime Type } \\
\text { [min] }\end{array}$ & $\begin{array}{l}\text { Width } \\
\text { [min] }\end{array}$ & $\begin{array}{c}\text { Area } \\
\text { [mAUt's] }\end{array}$ & $\begin{array}{l}\text { Height } \\
\text { [mAU] }\end{array}$ & $\begin{array}{c}\text { Area } \\
\stackrel{5}{*}\end{array}$ \\
\hline--1 & $|-------|-$ & ------ & ---------- & ------ & -------1 \\
\hline 1 & $5.966 \mathrm{BB}$ & 0.2074 & 1203.83557 & 86.99982 & 100.0000 \\
\hline $\mathrm{ta}$ & : & & 1203.83557 & 86.99982 & \\
\hline
\end{tabular}

ネネー End of Report ネネ 
<smiles>COc1ccc(/C=C/C=C(N=C2C(=O)N(C)c3ccccc32)C(F)(F)F)cn1</smiles>

Data File D: $\backslash \mathrm{LC} \backslash 5 \mathrm{SXS} \backslash 5 \mathrm{SX}-4-30-31-33-34 \backslash 5 X 5-4-30-31-33-34 \quad 2017-10-28 \quad 16-47-32 \backslash 019-0201 . \mathrm{D}$ Sample Name: Sxs-4-33

\begin{tabular}{|c|c|c|}
\hline Acq. Operator & $: \operatorname{sXs}$ & Seq. Line : \\
\hline Acq. Inst rument & : Instrument 1 & Location : Vial 19 \\
\hline Injection Date & : 10/28/2017 5:00:18 PM & $\operatorname{Inj}:$ \\
\hline
\end{tabular}

Acq. Method : D : \LC \SXS\SX5-4-30-31-33-34\5X5-4-30-31-33-34 2017-10-28 16-47-32\25H-95$5-254 \mathrm{MM}-1 \mathrm{UL}-10 \mathrm{MDN} . \mathrm{M}$

Last changed : 10/28/2017 5:12:30 PM by SXS (modified after loading)

Analysis Method : D: \LC \SXS\SX5-4-30-31-33-34 \5X5-4-30-31-33-34 2017-10-28 16-47-32 0190201.D DA.M (ASH-95-5-254MM-1UL-10MDN.M)

Last changed : 7/6/2018 4:17:24 PM by LHC (modified after loading)

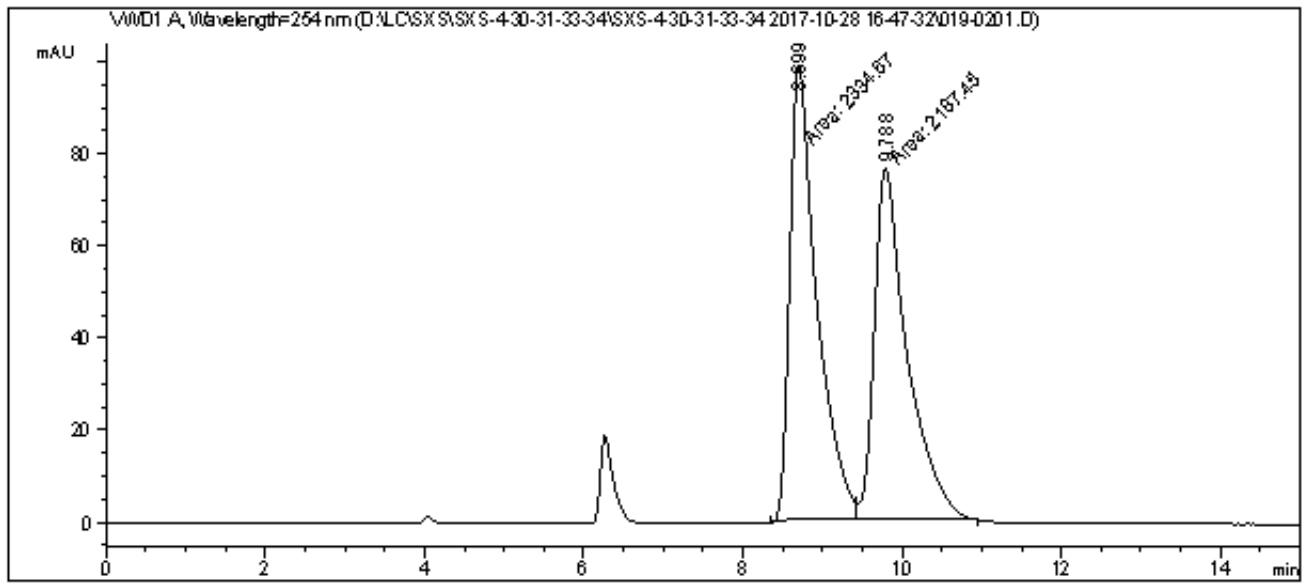

area Percent Report

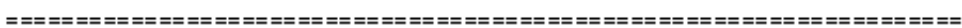

$\begin{array}{lll}\text { Sorted By } & : & \text { Signal } \\ \text { Multiplier } & : & 1.0000 \\ \text { Dilution } & : & 1.0000\end{array}$

Use Multiplier \& Dilution Factor with IsTDs

Signal 1: VoD 1 , Wavelength=254 nm

\begin{tabular}{|c|c|c|c|c|c|c|}
\hline \multirow{2}{*}{$\begin{array}{c}\text { Peak } \\
\quad \#\end{array}$} & \multirow{2}{*}{$\begin{array}{c}\text { RetTime } \\
\text { [min] }\end{array}$} & \multirow{2}{*}{ Type } & \multirow{2}{*}{$\begin{array}{l}\text { Width } \\
\text { [min] }\end{array}$} & Area & Height & \multirow{2}{*}{$\begin{array}{c}\text { Area } \\
\text { 믑 }\end{array}$} \\
\hline & & & & $\mathrm{m} 3 \mathrm{BJ}$ & [m.3J & \\
\hline & 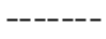 & & $-1-0-1$ & - & --- & -1 \\
\hline 1 & 8. & MF & 0. & 57017 & 98.89878 & 278 \\
\hline 2 & 9.788 & FM & 0.4789 & 2187.44800 & 76.13137 & 48.3722 \\
\hline
\end{tabular}

Totals : $\quad 4522.11816 \quad 175.03015$ 
<smiles>COc1ccc(/C=C/C=C(N=C2C(=O)N(C)c3ccccc32)C(F)(F)F)cn1</smiles>

Data File D: $\backslash \mathrm{LC} \backslash \mathrm{SXS} \backslash \mathrm{SXS}-4-30-31-33-34 \backslash \mathrm{SXS}-4-30-31-33-34 \quad 2017-10-28 \quad 16-47-32 \backslash 020-0301 . \mathrm{D}$ Sample Name: SXs-4-34

\begin{tabular}{|c|c|c|}
\hline Acq. Operator & : $\mathbf{S X 5}$ & Seq. Line : \\
\hline Acq. Inst rument & : Instrument 1 & Location : Vial 20 \\
\hline Injection Date & : 10/28/2017 5:17:35 PM & $\operatorname{Inj}: 1$ \\
\hline
\end{tabular}

Acq. Method : D : \LC \SXS\SX5-4-30-31-33-34\5X5-4-30-31-33-34 2017-10-28 16-47-32\25H-95$5-254 \mathrm{MM}-1 \mathrm{UL}-10 \mathrm{MDN} . \mathrm{M}$

Last changed : 10/28/2017 5:15:30 PM by SXS (modified after loading)

Analysis Method : D: \LC \SXS\SX5-4-30-31-33-34 \5X5-4-30-31-33-34 2017-10-28 16-47-32\0200301.D DA.M (ASH-95-5-254M-1UL-1OMDN.M)

Last changed : 7/6/2018 4:18:11 PM by LHC (modified after loading)

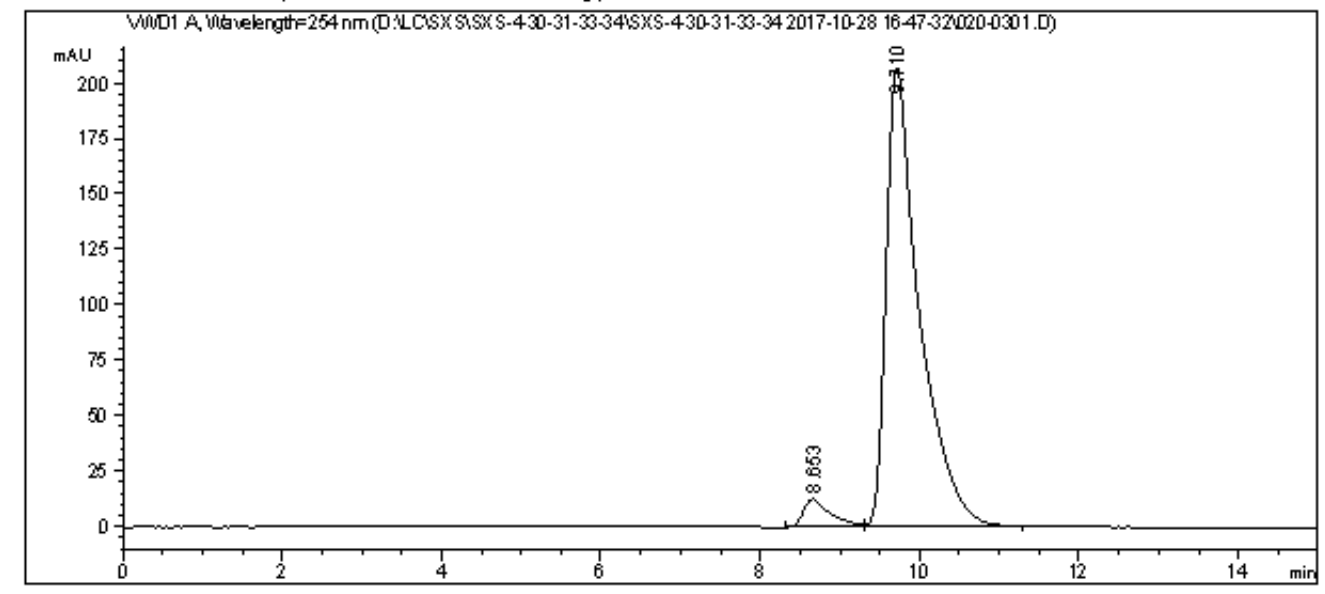

Area Percent Report

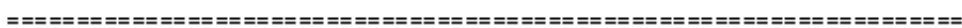

$\begin{array}{lll}\text { Sorted By } & : & \text { Signal } \\ \text { Multiplier } & : & 1.0000 \\ \text { Dilution } & : & 1.0000\end{array}$

Use Multiplier \& Dilution Factor with IsTDs

Signal l: VoDl h, Wavelength=254 nm

\begin{tabular}{|c|c|c|c|c|c|c|}
\hline \multirow{2}{*}{$\begin{array}{c}\text { Pealz } \\
\#\end{array}$} & \multirow{2}{*}{$\begin{array}{c}\text { RetTime } \\
\text { [min] }\end{array}$} & \multirow{2}{*}{ Type } & \multirow{2}{*}{$\begin{array}{l}\text { Width } \\
\text { [min] }\end{array}$} & Area & Height & \multirow{2}{*}{$\begin{array}{c}\text { Area } \\
\text { 몹 }\end{array}$} \\
\hline & & & & $\mathrm{m} 3 \mathrm{SJ}$ & [midU & \\
\hline----1 & |------ & $\mid--$ & ------- & |--------- & ---------- & --------1 \\
\hline 1 & 8.653 & BV & 0.3373 & 300.26483 & 12.68425 & 4.7617 \\
\hline 2 & 9.710 & VB & 0.4144 & 6005.60889 & 206.88347 & 95.2383 \\
\hline Tots & : & & & 6305.87372 & 219.56772 & \\
\hline
\end{tabular}


<smiles>CN1C(=O)/C(=N\C(/C=C/c2cccs2)C(F)(F)F)c2ccccc21</smiles>

Data File D: $\backslash$ LC \SXS\SXS-4-38-39-40-41\5XS-4-38-39-40-41 2017-11-01 16-25-20 057-0101.D Sample Name: Sxs-4-38

\begin{tabular}{|c|c|c|}
\hline Acq. Operator & : $\operatorname{sXs}$ & Seq. Line : \\
\hline Acq. Inst rument & : Instrument 1 & Location : Vial 57 \\
\hline Injection Date & : 11/1/2017 4:27:04 PM & Inj : \\
\hline
\end{tabular}

Acq. Method : D : $\backslash$ LC \SXS \SXS-4-38-39-40-41 \5X5-4-38-39-40-41 2017-11-01 16-25-20 ASH-95$5-254 \mathrm{MM}-1 \mathrm{UL}-1 \mathrm{MMDN} . \mathrm{M}$

Last changed : 10/17/2017 4:06:22 PM by SXS

Analysis Method : D: LC \SXS\SXS-4-38-39-40-41 SXS-4-38-39-40-41 2017-11-01 16-25-20 0570101.D DA.M (ASH-95-5-254M-1UL-1OMDN.M)

Last changed : 7/6/2018 4:19:07 PM by LHC

(modified after loading)

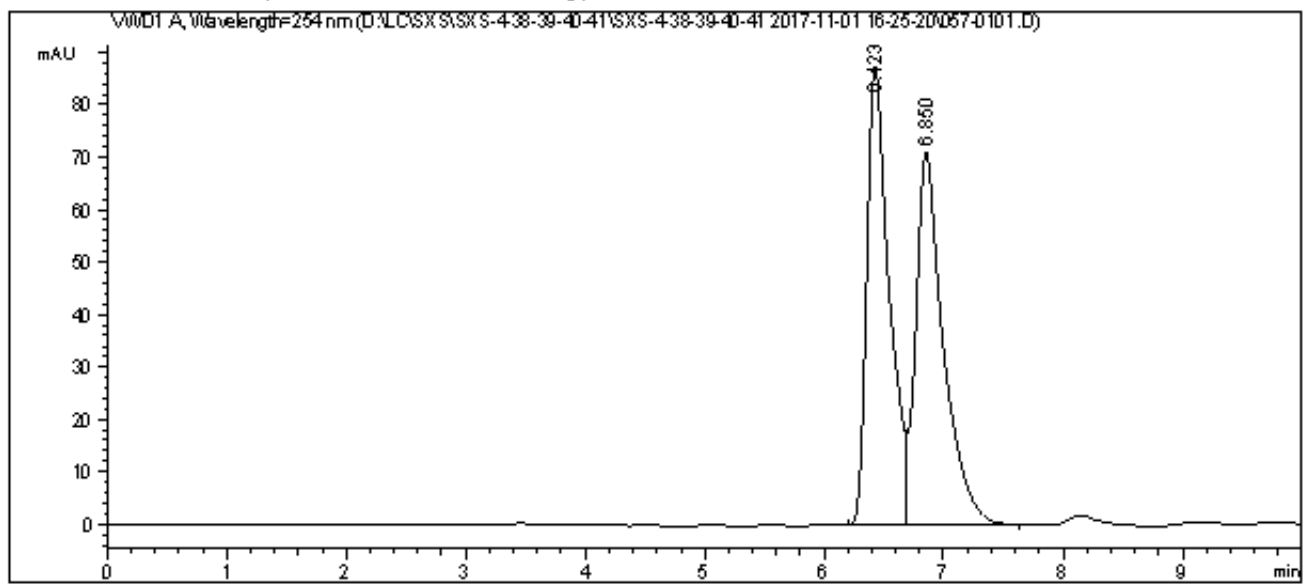

Area Percent Report

\begin{tabular}{|c|c|}
\hline Sorted By & : \\
\hline Multiplier & : \\
\hline Dilution & : \\
\hline
\end{tabular}

Use Multiplier \& Dilution Factor with IsTDs

Signal 1: VWDl A, Wavelength=254 nm

\begin{tabular}{|c|c|c|c|c|c|}
\hline Peak & RetTime Type & Width & Area & Height & Area \\
\hline$\#$ & [min] & [min] & $\mathrm{m} \mathrm{BU}$ & [ming ] & 몹 \\
\hline----1 & $------\mid----$ & ------- & |---------- | & ----------- & --------1 \\
\hline 1 & $6.423 \mathrm{BV}$ & 0.1899 & 1142.51660 & 87.64913 & 49.9917 \\
\hline 2 & $6.850 \mathrm{VB}$ & 0.2294 & 1142.89807 & 71.23038 & 50.0083 \\
\hline Total & : & & 2285.41467 & 158.87951 & \\
\hline
\end{tabular}


<smiles>CN1C(=O)/C(=N\C(/C=C/c2cccs2)C(F)(F)F)c2ccccc21</smiles>

Data File D: $\backslash$ LC \SXS \SXS-4-38-39-40-41\5XS-4-38-39-40-41 2017-11-01 16-25-20 058-0201.D Sample Name: Sxs-4-39

\begin{tabular}{|c|c|c|}
\hline Acq. Operator & : $\operatorname{sXs}$ & Seq. Line : \\
\hline Acq. Inst rument & : Instrument 1 & Location : Vial 58 \\
\hline Injection Date & : $11 / 1 / 20174: 38: 38 \mathrm{PM}$ & Inj : \\
\hline
\end{tabular}

Acq. Method : D : $\backslash$ LC \SXS \SXS-4-38-39-40-41 \5X5-4-38-39-40-41 2017-11-01 16-25-20 ASH-95$5-254 \mathrm{MM}-1 \mathrm{UL}-1 \mathrm{MMDN} . \mathrm{M}$

Last changed : 10/17/2017 4:06:22 PM by SXS

Analysis Method : D: \LC \SXS\SXS-4-38-39-40-41 \5X5-4-38-39-40-41 2017-11-01 16-25-20 0580201.D DA.M (ASH-95-5-254M-1UL-10MnN.M)

Last changed : 7/6/2018 4:19:55 PM by LHC

(modi fied after loading)

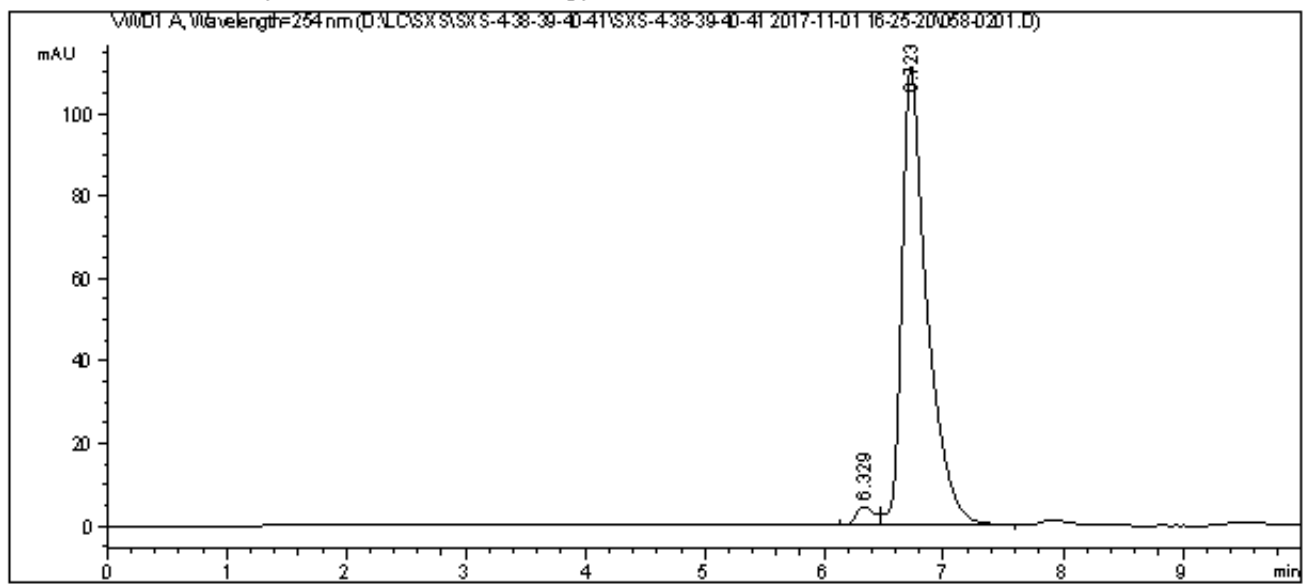

Area Percent Report

\begin{tabular}{|c|c|}
\hline Sorted By & : \\
\hline Multiplier & : \\
\hline Dilution & : \\
\hline
\end{tabular}

Use Multiplier \& Dilution Factor with IsTDs

Signal 1: VWDl A, Wavelength=254 nm

\begin{tabular}{|c|c|c|c|c|c|}
\hline Peak & RetTime Type & Width & Area & Height & Area \\
\hline$\#$ & [min] & [min] & misu & [m.2JJ & 몹 \\
\hline- & -1 & - & ------ & $-------\mid$ & -------1 \\
\hline 1 & $6.329 \mathrm{WV}$ & 609 & 48.89839 & 4.47870 & 2.9192 \\
\hline 2 & $6.723 \mathrm{VB}$ & 0.2099 & 1626.18115 & 111.20063 & 97.0808 \\
\hline
\end{tabular}

Totals :

$1675.07954 \quad 115.67933$ 
<smiles>CN1C(=O)/C(=N\[C@H](/C=C/c2ccco2)C(F)(F)F)c2ccccc21</smiles>

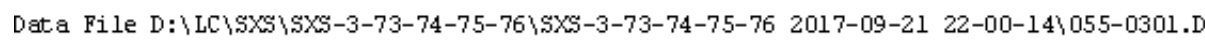
Sample Name: sXs-3-75

\begin{tabular}{|c|c|c|}
\hline Acq. Operator & : $5 \times 5$ & Seq. Line : \\
\hline Acq. Inst rument & : Instrument 1 & Location : Vial 55 \\
\hline Injection Date & : 9/21/2017 10:24:20 PM & $\begin{array}{rll}\operatorname{Inj} & : & 1 \\
\text { Inj Volume } & 1 \mu l\end{array}$ \\
\hline
\end{tabular}

Acq. Method : D : $\backslash$ LC $\backslash S \times S \backslash S \times 5-3-73-74-75-76 \backslash 5 \times 5-3-73-74-75-76 \quad 2017-09-21 \quad 22-00-14 \backslash 25 H-95-$ $5-254 \mathrm{MM}-1 \mathrm{UL}-1 \mathrm{MM} \mathrm{N} . \mathrm{M}$

Last changed : 9/15/2017 9:40:05 AM by SXs-3-62-63-64

Analysis Method : D: $\backslash$ LC \SXS\SXS-3-73-74-75-76\SX5-3-73-74-75-76 2017-09-21 22-00-14\0550301.D DA.M (ASH-95-5-254M-1UL-1OMDN.M)

Last changed : 7/6/2018 4:59:43 PM by LHC

(modified after loading)

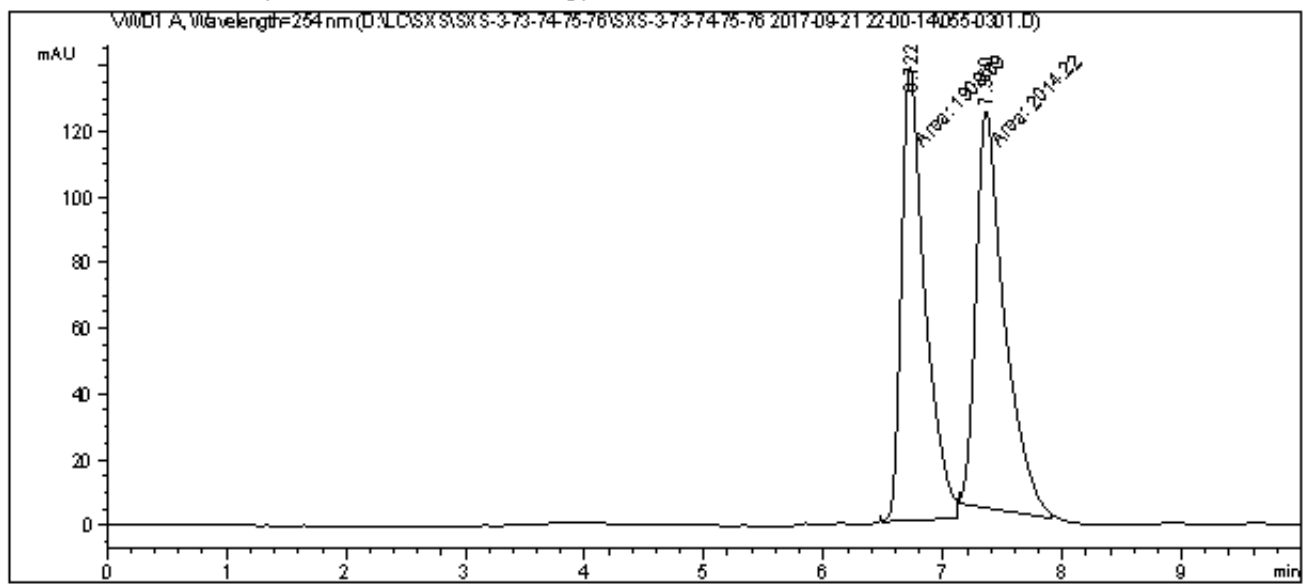

Area Percent Report

\begin{tabular}{|c|c|}
\hline Sorted By & : \\
\hline Multiplier & : \\
\hline Dilution & : \\
\hline
\end{tabular}

Use Multiplier \& Dilution Factor with IsTDs

Signal 1: VIDl A, Wavelength=254 nm

\begin{tabular}{|c|c|c|c|c|c|}
\hline Peak & RetTime Type & Width & Area & Height & Area \\
\hline$\#$ & [min] & [min] & misJ & [m-3UJ ] & 몹 \\
\hline----1 & ------|--- & ------- & |----------| & ----------। & -------1 \\
\hline 1 & $6.722 \mathrm{MM}$ & 0.2296 & 1909.69336 & 138.60258 & 48.6681 \\
\hline 2 & $7.360 \mathrm{MM}$ & 0.2774 & 2014.21692 & 121.00085 & 51.3319 \\
\hline Total & : & & 3923.91028 & 259.60344 & \\
\hline
\end{tabular}


<smiles>CN1C(=O)/C(=N\C(/C=C/c2ccco2)C(F)(F)F)c2ccccc21</smiles>

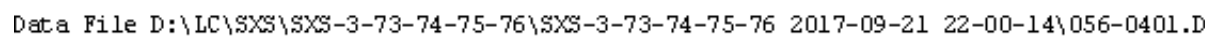
Sample Name: sXs-3-76

\begin{tabular}{|c|c|c|}
\hline Acq. Operator & : SXS & Seq. Line : \\
\hline Acq. Inst rument & : Instrument 1 & Location : Vial 56 \\
\hline Injection Date & : 9/21/2017 10:35:53 PM & Inj : \\
\hline
\end{tabular}

Acq. Method : D : $\backslash$ LC $\backslash S \times S \backslash S \times 5-3-73-74-75-76 \backslash 5 \times 5-3-73-74-75-76 \quad 2017-09-21 \quad 22-00-14 \backslash 25 H-95-$ $5-254 \mathrm{MM}-1 \mathrm{UL}-1 \mathrm{MM} \mathrm{N} . \mathrm{M}$

Last changed : 9/15/2017 9:40:05 AM by SXs-3-62-63-64

Analysis Method : D: $\backslash$ LC \SXS\SXS-3-73-74-75-76\SX5-3-73-74-75-76 2017-09-21 22-00-14\0560401.D DA.M (ASH-95-5-254M-1UL-1OMDN.M)

Last changed : 7/6/2018 5:00:48 PM by LHC

(modi fied after loading)

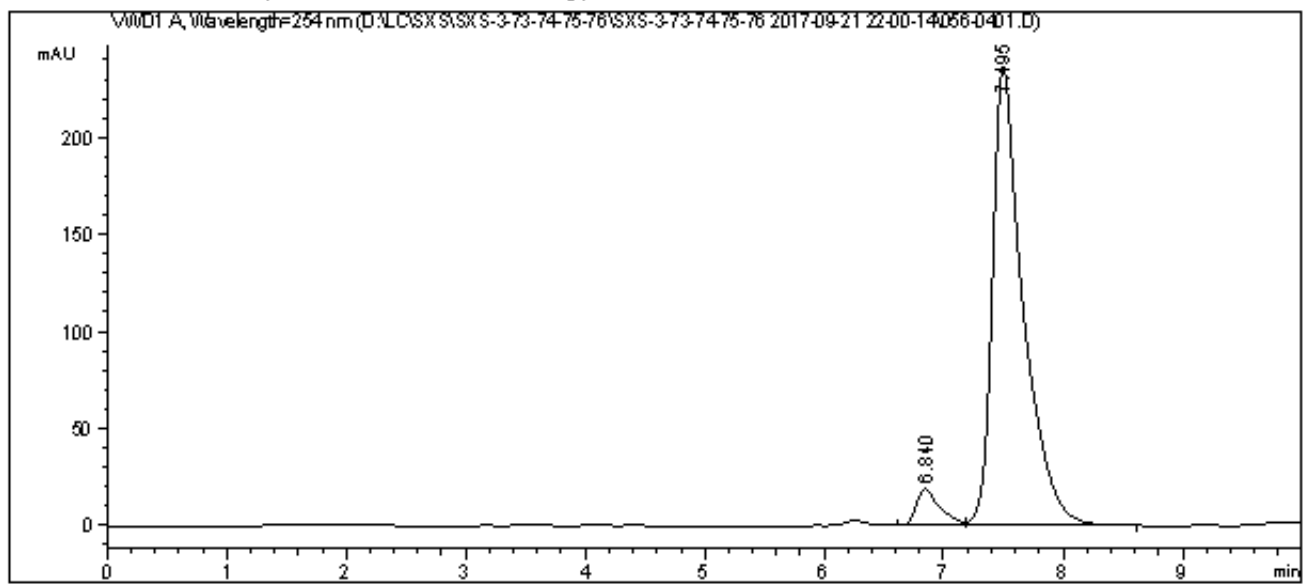

Area Percent Report

\begin{tabular}{|c|c|}
\hline Sorted By & : \\
\hline Multiplier & : \\
\hline Dilution & : \\
\hline
\end{tabular}

Use Multiplier \& Dilution Factor with IsTDs

Signal 1: VWDl A, Wavelength=254 nm

\begin{tabular}{|c|c|c|c|c|c|}
\hline Peak & RetTime Type & Width & area & Height & Area \\
\hline$\#$ & [min] & [min] & $\mathrm{m} 3 \mathrm{SU}$ & [mbU ］ & 믑 \\
\hline----1 & |-------| |--- & ------- & |----------| & ---------- | & -------1 \\
\hline 1 & $6.840 \mathrm{~W}$ & 0.2057 & 268.01178 & 18.96216 & 5.9341 \\
\hline 2 & $7.495 \mathrm{VB}$ & 0.2556 & 4248.47656 & 237.12898 & 94.0659 \\
\hline Total & 1s: & & 4516.48834 & 256.09114 & \\
\hline
\end{tabular}


<smiles>CN1C(=O)/C(=N\C(/C=C/c2cccnc2)C(F)(F)F)c2ccccc21</smiles>

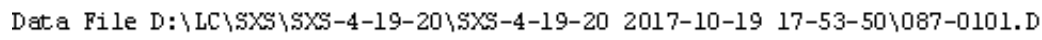
Sample Name: SXs-4-19

\begin{tabular}{|c|c|c|}
\hline Acq. Operator & : sXs & Seq. Line : \\
\hline Acq. Inst rument & : Instrument 1 & Location : Vial 87 \\
\hline Injection Date & : 10/19/2017 5:55:22 PM & Inj : 1 \\
\hline
\end{tabular}

Acq. Method : D: \LC \SXS\SXS-4-19-20\5XS-4-19-20 2017-10-19 17-53-50\AsH-95-5-254MM-5UL$10 M D$ M

Last changed : 10/19/2017 5:54:27 PM by SXs (modified after loading)

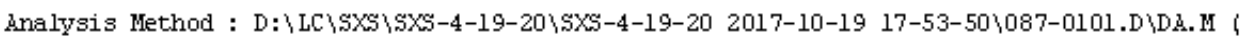
ASH-9.5-5-254NM-5UL-10MIN. M)

Last changed : 7/6/2018 4:09:52 PM by LHC (modified after loading)

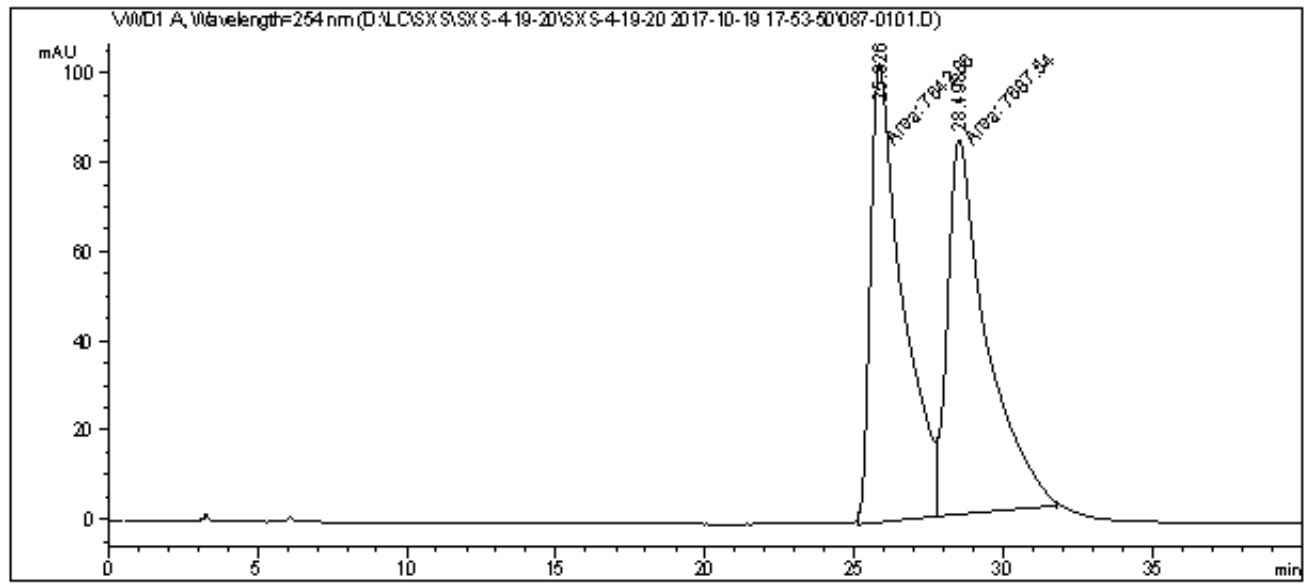

Area Percent Report

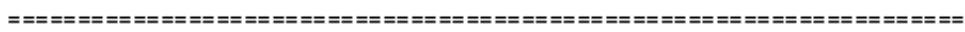

$\begin{array}{lll}\text { Sorted By } & : & \text { Signal } \\ \text { Multiplier } & : & 1.0000 \\ \text { Dilution } & : & 1.0000\end{array}$

Use Multiplier \& Dilution Factor with IsTDs

Signal l: VWD $\mathrm{A}$, Wavelength=254 nm

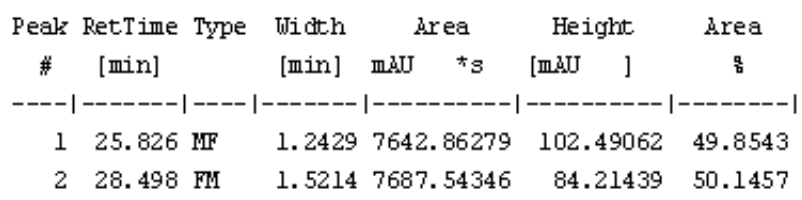

Totals : $\quad 1.53304 \mathrm{e} 4 \quad 186.70500$ 
<smiles>CN1C(=O)/C(=N\C(/C=C/c2cccnc2)C(F)(F)F)c2ccccc21</smiles>

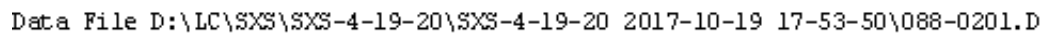
Sample Name: SXs-4-20

\begin{tabular}{|c|c|c|}
\hline Acq. Operator & : $\mathrm{sXs}$ & Seq. Line : \\
\hline Acq. Inst rument & : Instrument 1 & Location : Vial 88 \\
\hline Injection Date & : 10/19/2017 6:37:05 PM & $\begin{array}{rlc}\text { Inj } & : & 1 \\
\text { Inj Volume } & : 5 \mu l\end{array}$ \\
\hline
\end{tabular}

Acq. Method : D : \LC \SXS\SXS-4-19-20\SXS-4-19-20 2017-10-19 17-53-50 \2SH-95-5-254M-5UL$10 M D$ M

Last changed : 10/19/2017 6:35:46 PM by SXs (modi fied after loading)

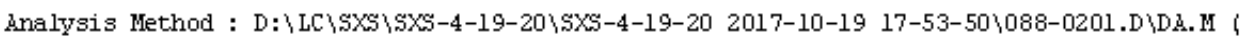
ASH-95-5-254NM-5UL-10MIN. M)

Last changed : 7/6/2018 4:10:55 PM by LHC (modified after loading)

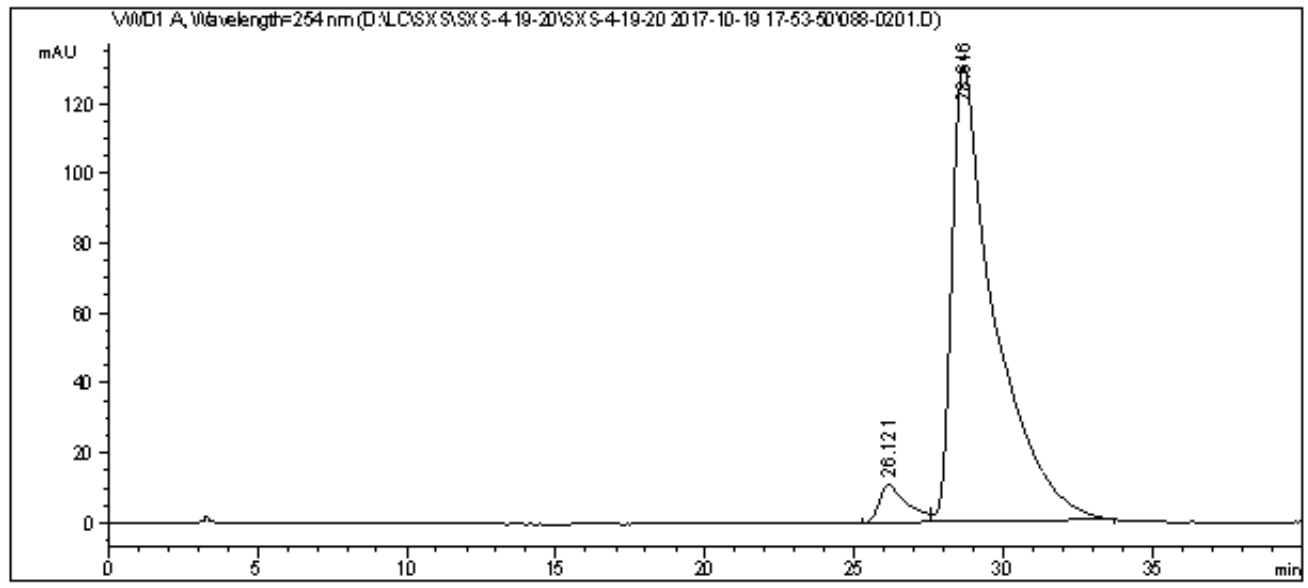

Area Percent Report

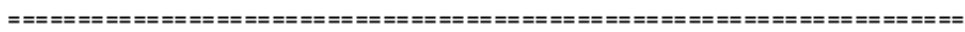

$\begin{array}{lll}\text { Sorted By } & : & \text { Signal } \\ \text { Multiplier } & : & 1.0000 \\ \text { Dilution } & : & 1.0000\end{array}$

Use Multiplier \& Dilution Factor with IsTDs

Signal l: VWD $\mathrm{A}$, Wavelength=254 nm

\begin{tabular}{|c|c|c|c|c|c|}
\hline \multirow{2}{*}{$\begin{array}{c}\text { Peak } \\
\#\end{array}$} & \multirow{2}{*}{$\begin{array}{l}\text { RetTime Type } \\
\text { [min] }\end{array}$} & \multirow{2}{*}{$\begin{array}{l}\text { Width } \\
\text { [min] }\end{array}$} & Area & Height & \multirow{2}{*}{$\begin{array}{c}\text { Area } \\
\text { 믑 }\end{array}$} \\
\hline & & & misu & [misJ & \\
\hline & & - & --- & ---- & -------1 \\
\hline 1 & $26.121 \mathrm{BV}$ & 0.8859 & 708.01086 & 10.81690 & 5.1602 \\
\hline 2 & $28.646 \mathrm{VB}$ & 1. 3662 & $1.30125 \mathrm{e} 4$ & 130.93097 & 94.8398 \\
\hline
\end{tabular}

Totals : $\quad 1.37205 \mathrm{e} 4 \quad 141.74786$ 
<smiles>Cc1ccc2c(c1)C(=NC(C=Cc1ccccc1)(C(F)(F)F)C(F)(F)F)C(=O)N2C</smiles>

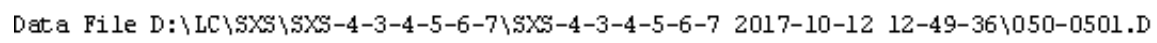
Sample Name: SXs-4-7

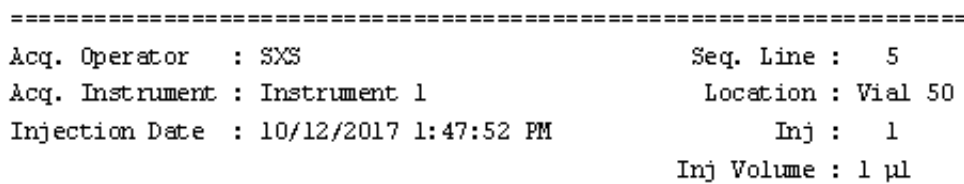

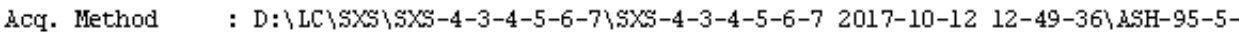
254MM-1UL-1OMDN.M

Last changed : 10/12/2017 1:57:32 PM by SXs

(modi fied after loading)

Analysis Method : D: \LC \SXS\SXS-4-3-4-5-6-7\5X5-4-3-4-5-6-7 2017-10-12 12-49-36\050-0501.D DA.M (A.SH-95-5-254MM-1UL-10MIN. M)

Last changed : 7/6/2018 3:58:16 PM by LHC

(modi fied after loading)

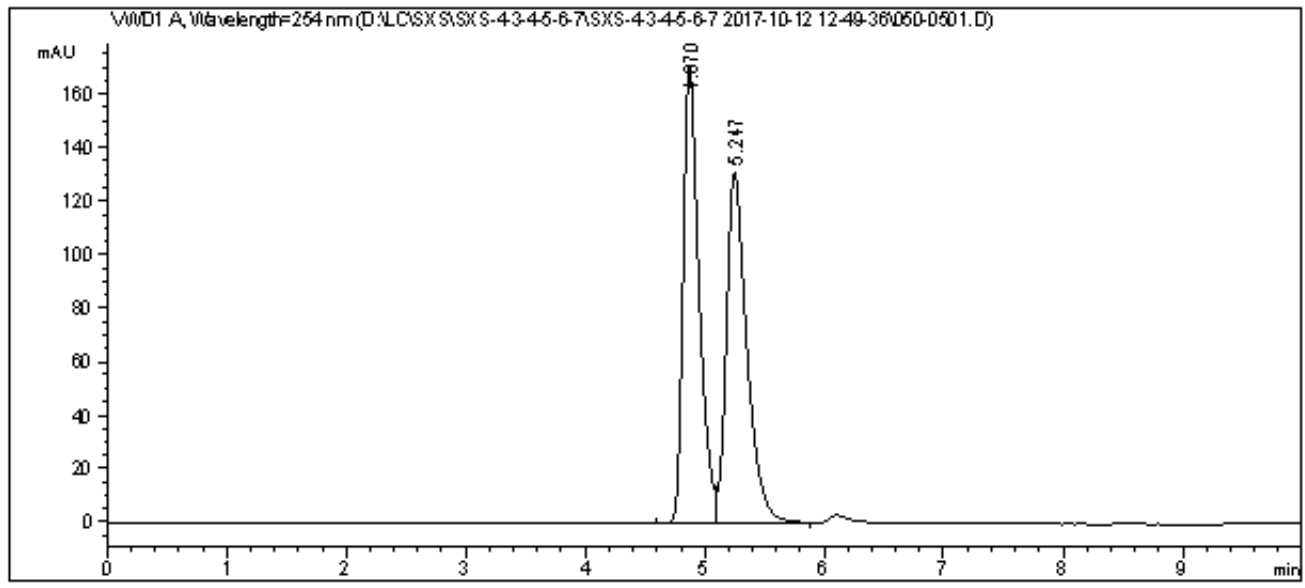

Area Percent Report

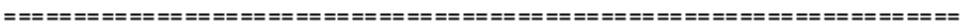

$\begin{array}{lll}\text { Sorted By } & : & \text { Signal } \\ \text { Multiplier } & : & 1.0000 \\ \text { Dilution } & : & 1.0000\end{array}$

Use Multiplier \& Dilution Factor with IsTDs

Signal l: VoDl h, Wavelength=254 nm

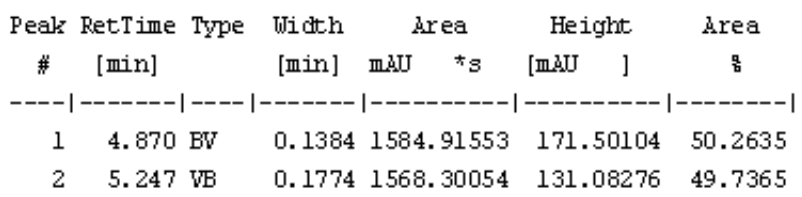

Totals : $\quad 3153.21606 \quad 302.58380$ 
<smiles>Cc1ccc2c(c1)C(=NC(C=Cc1ccccc1)C(F)(F)F)C(=O)N2C</smiles>

Data File D: \LC\5XS\5XS-4-8-9-10\5X5-4-8-9-10 2017-10-13 14-54-13\074-0101.D Sample Name: SXs-4-8

\begin{tabular}{|c|c|c|}
\hline Acq. Operator & : $\operatorname{sXs}$ & seq. Line : 1 \\
\hline Acq. Inst rument & : Instrument 1 & Location : Vial 74 \\
\hline Injection Date & : 10/13/2017 2:55:37 PM & $\begin{array}{rll}\text { Inj } & : & 1 \\
\text { Inj Volume } & 1 \mu l\end{array}$ \\
\hline
\end{tabular}

Acq. Method : D: LC \SXS\SXS-4-8-9-10 SXS-4-8-9-10 2017-10-13 14-54-13 25H-95-5-254MM1UL-1OMDN.M

Last changed : 9/15/2017 9:40:05 AM by SXS-3-62-63-64

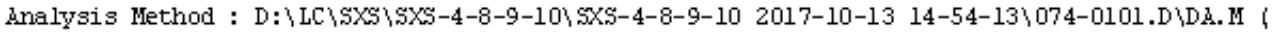
ASH-9 5-5-25 4MM-1UL-10M-N. M)

Last changed : 7/6/2018 3:59:11 PM by LHC

(modi fied after loading)

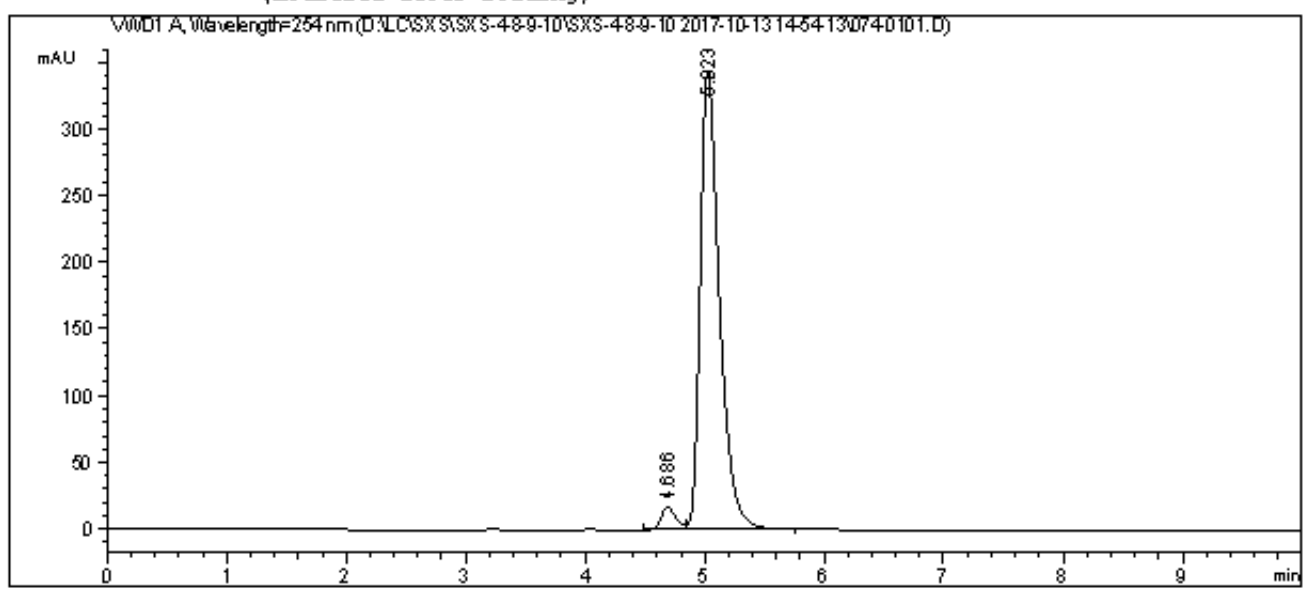

Area Percent Report

\begin{tabular}{|c|c|}
\hline Sorted By & : \\
\hline Multiplier & : \\
\hline Dilution & : \\
\hline
\end{tabular}

Use Multiplier \& Dilution Factor with ISTDs

Signal 1: VIDl A, Wavelength=254 nm

\begin{tabular}{|c|c|c|c|c|c|}
\hline Peak & RetTime Type & Width & Area & Height & Area \\
\hline$\#$ & [min] & [min] & misJ & [m-3UJ ] & 몹 \\
\hline----1 & ------|--- & ------- & |----------| & ---------- | & $--------\mid$ \\
\hline 1 & $4.686 \mathrm{BV}$ & 0.1283 & 144.47014 & 16.99958 & 3.6132 \\
\hline 2 & $5.023 \mathrm{VB}$ & 0.1667 & 3853.89624 & 345.12515 & 96.3868 \\
\hline Total & s: & & 3998.36638 & 362.12473 & \\
\hline
\end{tabular}


<smiles>Cc1ccc2c(c1)N(C)C(=O)/C2=N\C(=O)c1ccccc1</smiles>

Data File D: $\backslash$ LC \SXS \SXS-4-38-39-40-41\5XS-4-38-39-40-41 2017-11-01 16-25-20 059-0301.D Sample Name: Sxs-4-40

\begin{tabular}{|c|c|c|}
\hline Acq. Operator & : $\mathbf{S X 5}$ & Seq. Line : \\
\hline Acq. Inst rument & : Instrument 1 & Location : Vial 59 \\
\hline Injection Date & : 11/1/2017 4:50:08 PM & $\operatorname{Inj}: 1$ \\
\hline
\end{tabular}

Acq. Method : D : $\backslash$ LC $\backslash S \times S \backslash S \times 5-4-38-39-40-41 \backslash 5 \times 5-4-38-39-40-41 \quad 2017-11-01 \quad 16-25-20 \backslash 45 H-95-$ $5-254 \mathrm{MM}-1 \mathrm{UL}-1 \mathrm{MMDN} . \mathrm{M}$

Last changed : 10/17/2017 4:06:22 PM by SXS

Analysis Method : D: \LC\SXS\SXS-4-38-39-40-41 \SXS-4-38-39-40-41 2017-11-01 16-25-20\0590301.D DA.M (ASH-95-5-254M-1UL-10MDN.M)

Last changed : 7/6/2018 4:20:42 PM by LHC

(modified after loading)

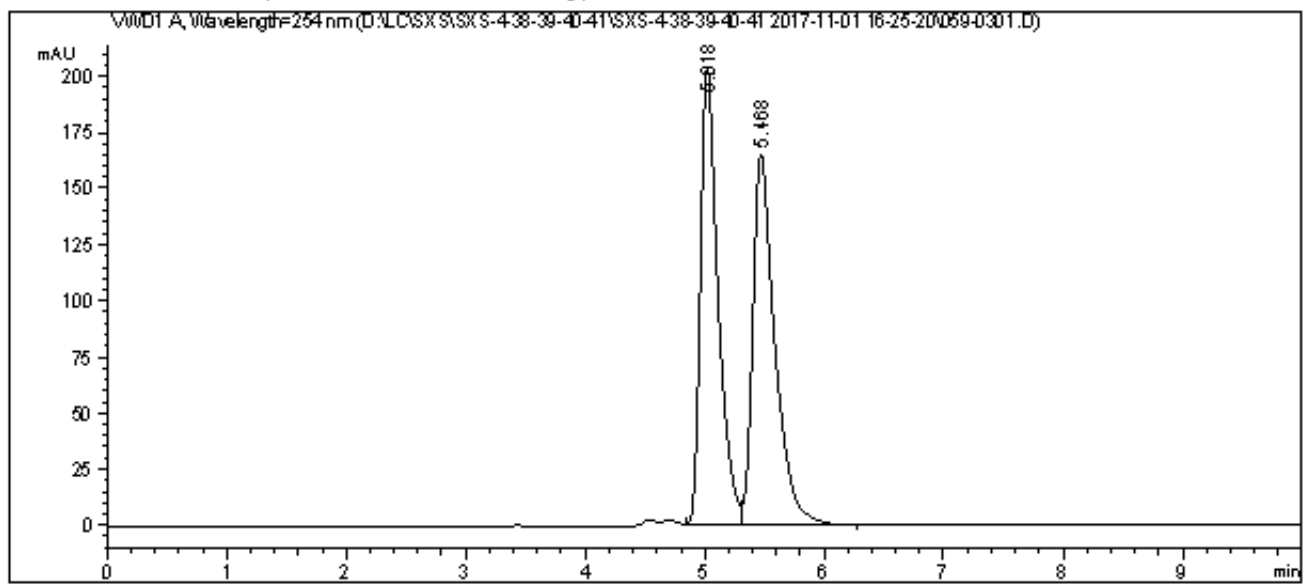

Area Percent Report

\begin{tabular}{|c|c|}
\hline Sorted By & : \\
\hline Multiplier & : \\
\hline Dilution & : \\
\hline
\end{tabular}

Use Multiplier \& Dilution Factor with ISTDs

Signal 1: VIDl A, Wavelength=254 nm

\begin{tabular}{|c|c|c|c|c|c|}
\hline Peak & RetTime Type & Width & Area & Height & Area \\
\hline$\#$ & [min] & [min] & minJ & [m-3UJ ] & 몹 \\
\hline----1 & -------| |--- & ------- & |----------| & ----------। & -------1 \\
\hline 1 & $5.018 \mathrm{WV}$ & 0.1518 & 2097.97974 & 204.41037 & 49.5566 \\
\hline 2 & $5.468 \mathrm{VB}$ & 0.1870 & 2135.52344 & 165.38759 & 50.4434 \\
\hline Total & : & & 4233.50317 & 369.79796 & \\
\hline
\end{tabular}


<smiles>Cc1ccc2c(c1)N(C)C(=O)/C2=N\C(=O)c1ccccc1</smiles>

Data File D: $\backslash$ LC \SXS \SXS-4-38-39-40-41\5XS-4-38-39-40-41 2017-11-01 16-25-20 060-0401.D Sample Name: SXs-4-41

\begin{tabular}{|c|c|c|}
\hline Acq. Operator & : $\operatorname{sXs}$ & Seq. Line : \\
\hline Acq. Inst rument & : Instrument 1 & Location : Vial 60 \\
\hline Injection Date & : 11/1/2017 5:01:40 PM & Inj : \\
\hline
\end{tabular}

Acq. Method : D : $\backslash$ LC \SXS \SXS-4-38-39-40-41 \5X5-4-38-39-40-41 2017-11-01 16-25-20 ASH-95$5-254 \mathrm{MM}-1 \mathrm{UL}-1 \mathrm{MMDN} . \mathrm{M}$

Last changed : 10/17/2017 4:06:22 PM by SXS

Analysis Method : D: \LC\SXS\SXS-4-38-39-40-41 \SXS-4-38-39-40-41 2017-11-01 16-25-20\0600401.D DA.M (ASH-95-5-254M-1UL-1OMDN.M)

Last changed : 7/6/2018 4:21:24 PM by LHC

(modi fied after loading)

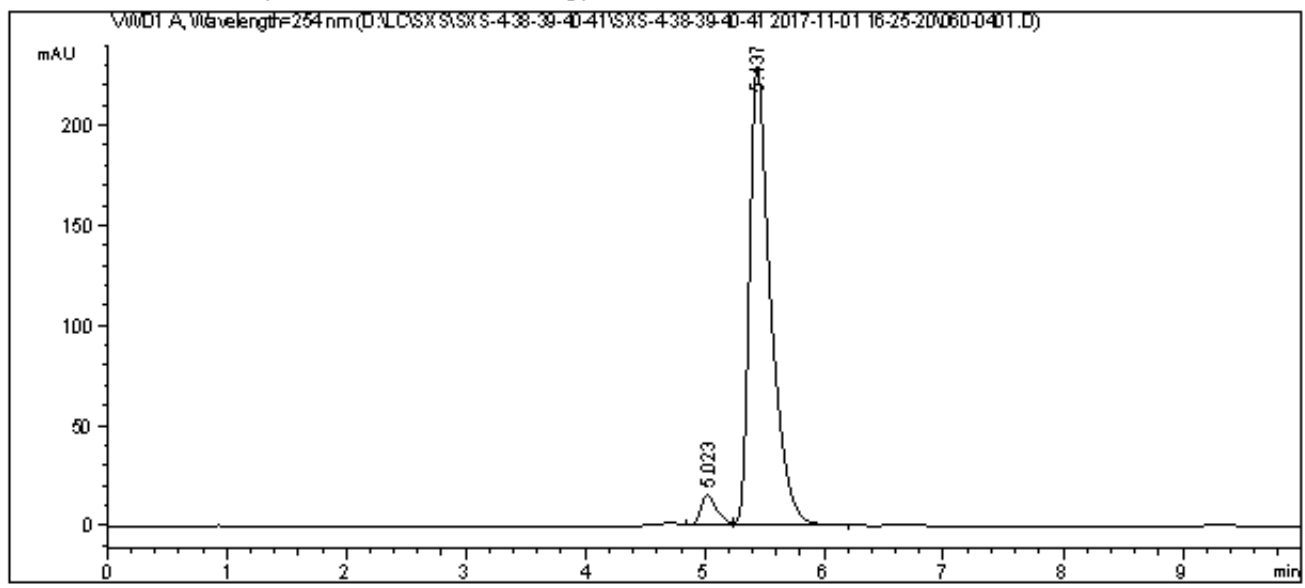

Area Percent Report

\begin{tabular}{|c|c|}
\hline Sorted By & : \\
\hline Multiplier & : \\
\hline Dilution & : \\
\hline
\end{tabular}

Use Multiplier \& Dilution Factor with ISTDs

Signal l: VWD 1 , Wavelength $=254 \mathrm{~nm}$

\begin{tabular}{|c|c|c|c|c|c|c|c|c|}
\hline \multirow{2}{*}{$\begin{array}{c}\text { Peak } \\
\#\end{array}$} & \multirow{2}{*}{\multicolumn{2}{|c|}{$\begin{array}{l}\text { RetTime Type } \\
\text { [min] }\end{array}$}} & \multirow{2}{*}{$\begin{array}{l}\text { Width } \\
\text { [min] }\end{array}$} & \multicolumn{2}{|c|}{ Area } & \multicolumn{2}{|c|}{ Height } & \multirow{2}{*}{$\begin{array}{c}\text { Area } \\
\text { 믑 }\end{array}$} \\
\hline & & & & m.3U & $*_{3}$ & {$[\mathrm{~m} 2 \mathrm{SJ}$} & ] & \\
\hline & & & & $1-$ & & - & & \\
\hline 1 & & & 0 & 152 & 8831 & & 861 & 897 \\
\hline 2 & 5. & 7 & 22 & 283 & 4428 & 23 & 083 & 103 \\
\hline
\end{tabular}

Totals :

$2987.17259 \quad 245.59945$ 
<smiles>Cc1cccc2c1N(C)C(=O)/C2=N\C(/C=C/c1ccccc1)C(F)(F)F</smiles>

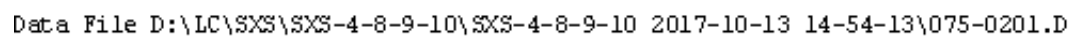
Sample Name: SXs-4-9

\begin{tabular}{|c|c|c|}
\hline Acq. Operat or & : $\mathbf{s X S}$ & Seq. Line : \\
\hline Acq. Inst rument & : Instrument 1 & Location : Vial 75 \\
\hline Injection Date & : 10/13/2017 3:07:22 PM & $\operatorname{Inj}:$ \\
\hline
\end{tabular}

Acq. Method : D: LC \SXS\SXS-4-8-9-10 SXS-4-8-9-10 2017-10-13 14-54-13 25H-95-5-254MMLUL-1OMDN.M

Last changed : 9/15/2017 9:40:05 AM by SXS-3-62-63-64

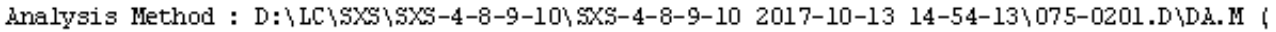
ASH-95-5-254MM-1UL-10NपN. M)

Last changed : 7/6/2018 4:00:30 PM by LHC

(modi fied after loading)

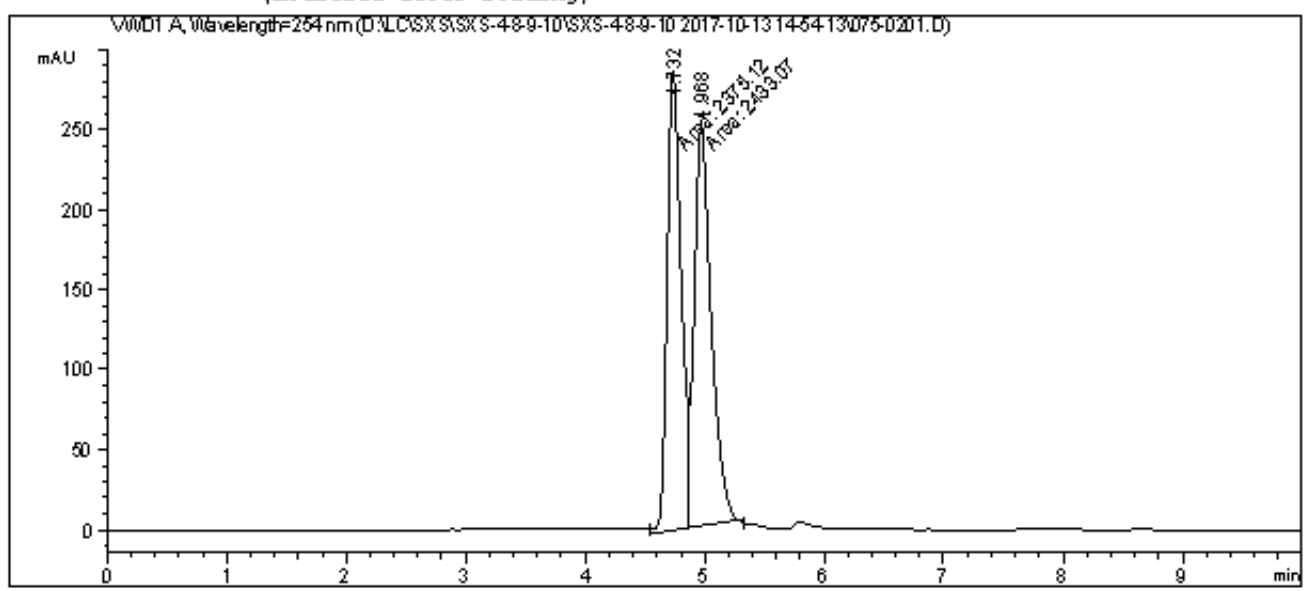

Area Percent Report

\begin{tabular}{|c|c|c|}
\hline Sorted By & : & Sign \\
\hline Multiplier & : & 1.00 \\
\hline Dilution & : & 1.00 \\
\hline
\end{tabular}

Use Multiplier \& Dilution Factor with ISTDs

Signal 1: VIDl A, Wavelength=254 nm

\begin{tabular}{|c|c|c|c|c|c|}
\hline Peak & RetTime Type & Width & Area & Height & Area \\
\hline$\#$ & [min] & [min] & misu & [m.2JJ & 몹 \\
\hline--1 & - & - & --------1 & --------- & ------- \\
\hline 1 & $4.732 \mathrm{MF}$ & 78 & 12036 & 287.28479 & 49.3974 \\
\hline 2 & 4. $968 \mathrm{FM}$ & 0.1621 & 2433.06738 & 250.20598 & 50.6026 \\
\hline
\end{tabular}

Totals :

$4808.18774 \quad 537.49077$ 
<smiles>Cc1cccc2c1N(C)C(=O)/C2=N\C(/C=C/c1ccccc1)C(F)(F)F</smiles>

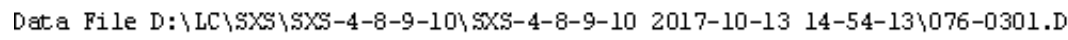
Sample Name: Sxs-4-10

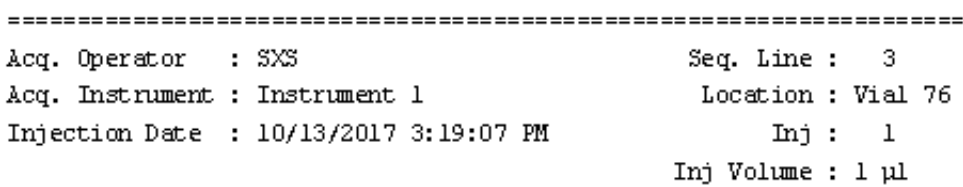

Acq. Method : D: LC \SXS\SXS-4-8-9-10 SXS-4-8-9-10 2017-10-13 14-54-13 25H-95-5-254MM1UL-1OMDN.M

Last changed : 9/15/2017 9:40:05 AM by SXS-3-62-63-64

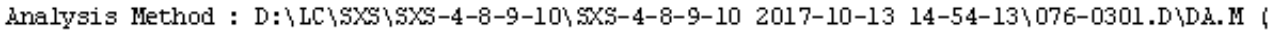
ASH-95-5-254MM-1UL-10NपN. M)

Last changed : 7/6/2018 4:01:34 PM by LHC (modi fied after loading)

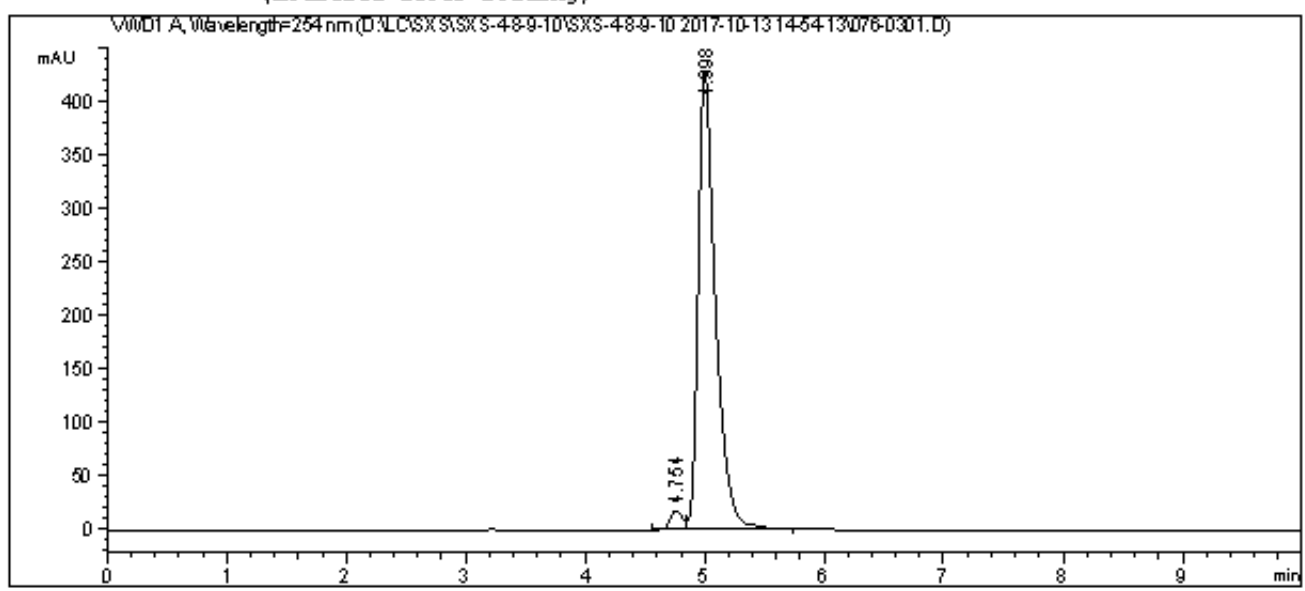

Area Percent Report

\begin{tabular}{|c|c|}
\hline Sorted By & : \\
\hline Multiplier & : \\
\hline Dilution & : \\
\hline
\end{tabular}

Use Multiplier \& Dilution Factor with ISTDs

Signal 1: VIDl A, Wavelength=254 nm

\begin{tabular}{|c|c|c|c|c|c|}
\hline Peak & RetTime Type & Width & Area & Height & Area \\
\hline$\#$ & [min] & [min] & misu & [m.2JJ & 몹 \\
\hline-1 & --- & - & ------ & --------- & -------1 \\
\hline 1 & 4. $754 \mathrm{BV}$ & 143 & 131.67329 & 17.73956 & 2.9399 \\
\hline 2 & $4.998 \mathrm{WV}$ & 0.1486 & 4347.18408 & 429.61780 & 97.0601 \\
\hline
\end{tabular}

Totals :

$4478.85738 \quad 447.35736$ 
<smiles>COc1ccc2c(c1)C(=NC(C=Cc1ccccc1)C(F)(F)F)C(=O)N2C</smiles>

Data File D: $\backslash \mathrm{LC} \backslash 5 X 5 \backslash 5 \times 5-4-11-12 \backslash 5 X 5-4-11-12 \quad 2017-10-14 \quad 20-57-02 \backslash 077-0101 . \mathrm{D}$ Sample Name: SXs-4-11

\begin{tabular}{|c|c|c|}
\hline Acq. Operator & : $\operatorname{s\times s}$ & Seq. Line : \\
\hline Acq. Inst rument & : Instrument 1 & Location : Vial 77 \\
\hline Injection Date & : 10/14/2017 8:58:27 PM & 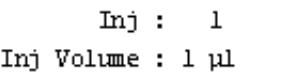 \\
\hline
\end{tabular}

Acq. Method : D : $\backslash$ LC \SXS\SXS-4-11-12 SXS-4-11-12 2017-10-14 20-57-02 \25H-95-5-254MM-1UL$10 M D$ M

Last changed : 9/15/2017 9:40:05 AM by SXs-3-62-63-64

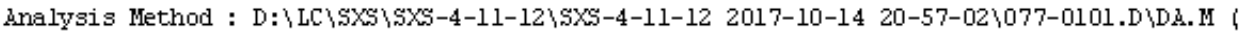
ASH-95-5-254NM-1UL-10N世N. M)

Last changed : 7/6/2018 4:03:12 PM by LHC

(modi fied after loading)

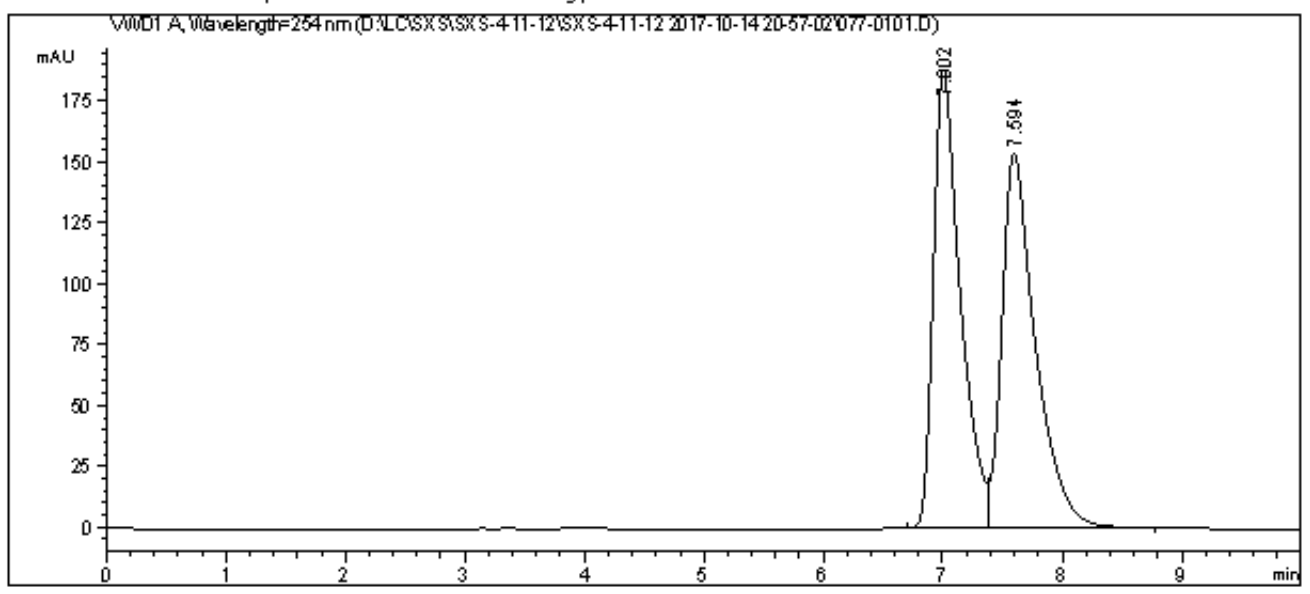

Area Percent Report

\begin{tabular}{|c|c|}
\hline Sorted By & : \\
\hline Multiplier & : \\
\hline Dilution & : \\
\hline
\end{tabular}

Use Multiplier \& Dilution Factor with ISTDs

Signal 1: VWDl A, Wavelength=254 nm

\begin{tabular}{|c|c|c|c|c|c|c|}
\hline Peak & RetTime Tvpe & Width & & ea & Height & Area \\
\hline$\#$ & [min] & [min] & $\mathrm{m} \mathrm{BUJ}$ & $\pi_{S}$ & [m.3U & 믑 \\
\hline--1 & $---1-$ & ---- & $\mid---$ & ---- & ---------- & $-------\mid$ \\
\hline 1 & $7.002 \mathrm{VV}$ & 0.2308 & 295 & 62109 & 188.64980 & 49.3793 \\
\hline 2 & $7.594 \mathrm{VB}$ & 0.2844 & 3028 & 90430 & 154.27087 & 50.6207 \\
\hline Total & $s$ : & & 5983 & 52539 & 342.92067 & \\
\hline
\end{tabular}


<smiles>COc1ccc2c(c1)C(=NC(C=Cc1ccccc1)C(F)(F)F)C(=O)N2C</smiles>

Data File D: $\backslash \mathrm{LC} \backslash 5 X 5 \backslash 5 \times 5-4-11-12 \backslash 5 X 5-4-11-12 \quad 2017-10-14 \quad 20-57-02 \backslash 078-0201 . \mathrm{D}$ Sample Name: SXs-4-12

\begin{tabular}{|c|c|c|}
\hline Acq. Operator & : $\mathrm{sXs}$ & Seq. Line : \\
\hline Acq. Inst rument & : Instrument 1 & Location : Vial 78 \\
\hline Injection Date & : 10/14/2017 9:09:55 PM & $\begin{array}{rlc}\operatorname{Inj} & : & 1 \\
\text { Inj Volume } & 1 & 1\end{array}$ \\
\hline
\end{tabular}

Acq. Method : D : $\backslash$ LC \SXS\SXS-4-11-12 SXS-4-11-12 2017-10-14 20-57-02 \25H-95-5-254MM-1UL$10 M D$ M

Last changed : 9/15/2017 9:40:05 AM by SXs-3-62-63-64

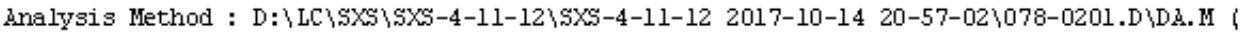
ASH-95-5-254NM-1UL-10MIN. M)

Last changed : 7/6/2018 4:03:57 PM by LHC

(modi fied after loading)

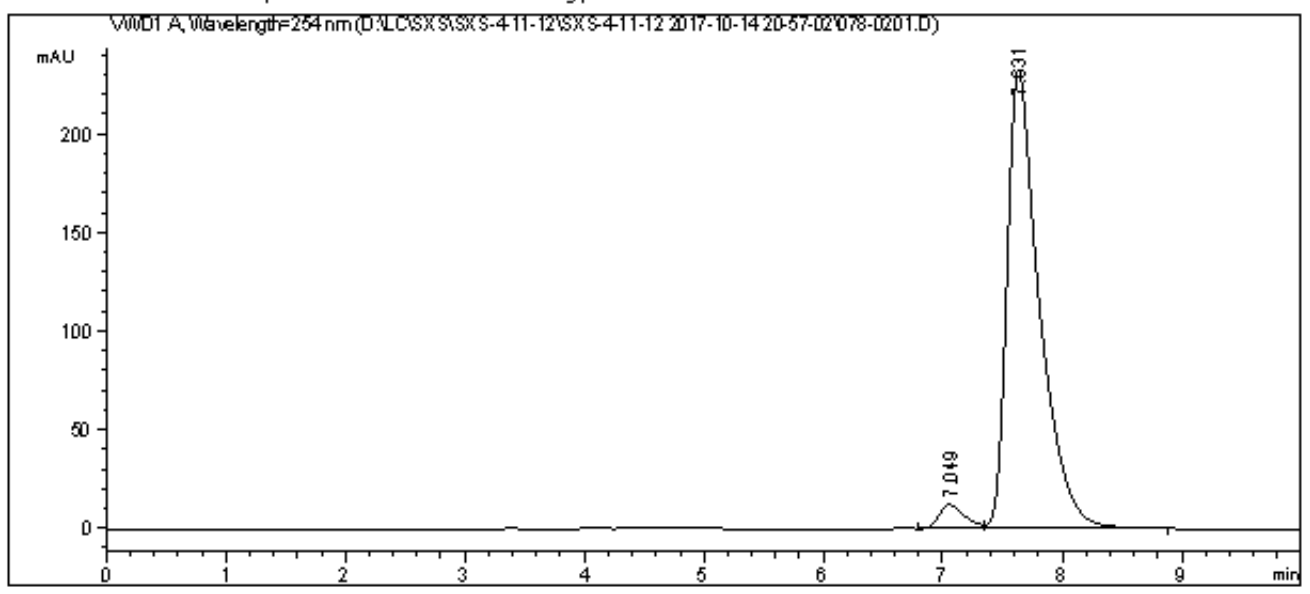

Area Percent Report

$\begin{array}{lll}\text { === }========================= \\ \text { Sorted BV } & : & \text { Signal } \\ \text { Multiplier } & : & 1.0000 \\ \text { Dilution } & : & 1.0000\end{array}$

Use Multiplier \& Dilution Factor with IsTDs

Signal 1: VWDl A, Wavelength=254 nm

\begin{tabular}{|c|c|c|c|c|c|}
\hline Peak & RetTime Type & Width & area & Height & Area \\
\hline$\#$ & [min] & [min] & $\mathrm{m}$ 能 & [mbU ] & 믑 \\
\hline----1 & -------ー|--- & ------- & |----------- | & ---------- | & $--------\mid$ \\
\hline 1 & $7.049 \mathrm{~W}$ & 0.2229 & 184.77116 & 12.23006 & 4.0373 \\
\hline 2 & $7.631 \mathrm{VB}$ & 0.2739 & 4391.88135 & 232.87416 & 95.9627 \\
\hline Total & : & & 4576.65251 & 245.10423 & \\
\hline
\end{tabular}


<smiles>CN1C(=O)/C(=N\C(/C=C/c2ccccc2)C(F)(F)F)c2cc(Br)ccc21</smiles>

Data File E: \DATA \SLM SLM-7-80\SLM-7-80 2017-11-16 19-35-41\SLM-7-80.D Sample Name: SLM-7-80-rac

\begin{tabular}{|c|c|c|}
\hline Acq. Operator & : SYSTEM & Seq. Line \\
\hline Acq. Instrument & $: 1260$ & Location \\
\hline Injection Date & : 11/16/2017 7:37:02 PM & $\begin{array}{r}\text { Inj } \\
\text { Inj Volume }\end{array}$ \\
\hline
\end{tabular}

ACq. Method : E: \DATA \SLM \LM-7-80 \SLM-7-80 2017-11-16 19-35-41 \0D-H-9 5-5-1. OML-25 4-MM5UL-15MIN.M

Last changed : 11/16/2017 7:35:42 PM by SYSTEM

Analysis Method : E: \DATA SLM SLM-7-80 SLM-7-80 2017-11-16 19-35-41 0D-H-95-5-1.0ML-254-MM5UL-15MIN.M (Sequence Method)

Last changed : 7/6/2018 4:25:26 PM by 5YsTEM (modified after loading)

Additional Info: Peak (s) manually integrated

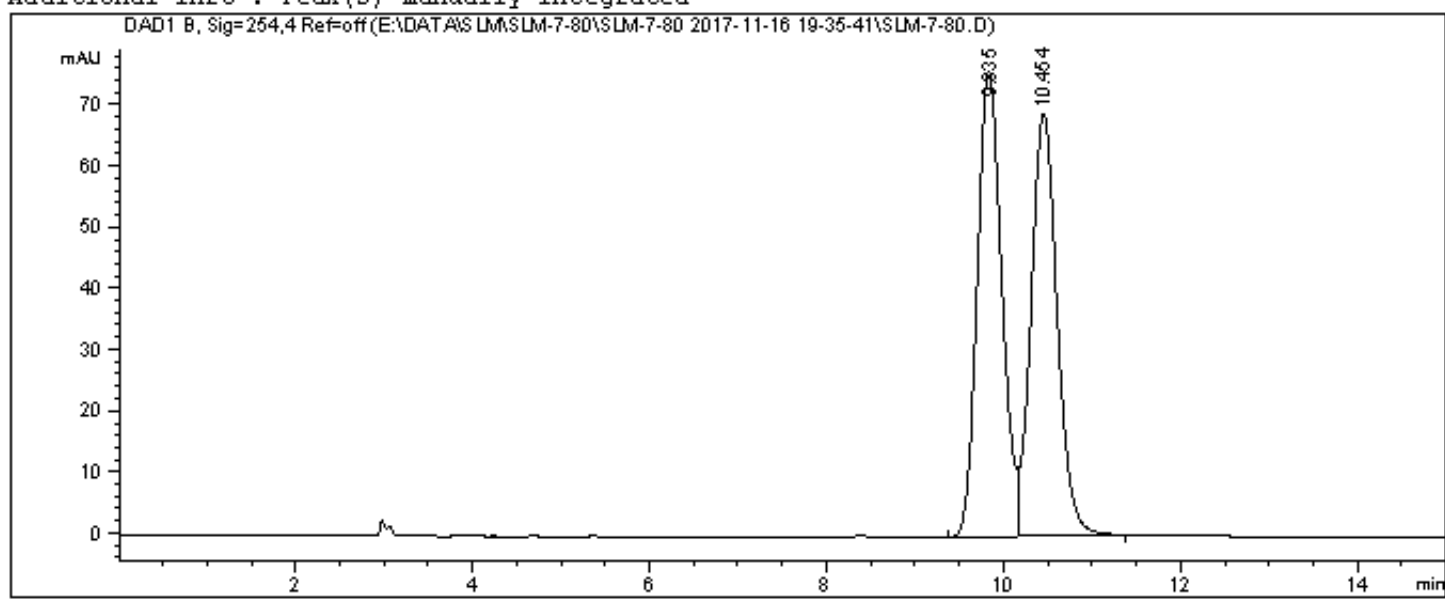

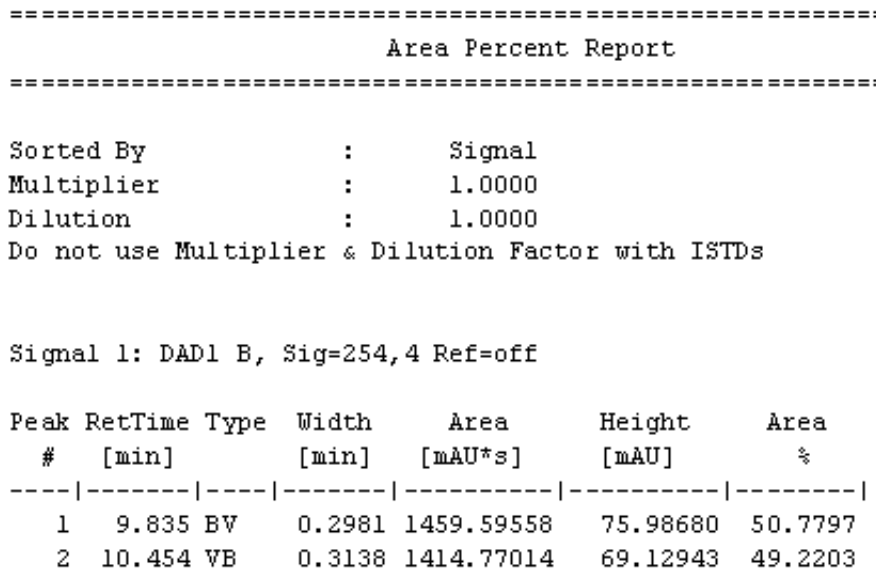

Totals :

$2874.36572 \quad 145.11623$

ホネホ End of Report *ネ 
<smiles>CN1C(=O)/C(=N\C(/C=C/c2ccccc2)C(F)(F)F)c2cc(Br)ccc21</smiles>

Data File E: \DATA $\backslash$ SLM SLM-7-80\SLM-7-80 2017-11-16 19-35-41\SLM-7-801.D Sample Name: SLM-7-80-chiral

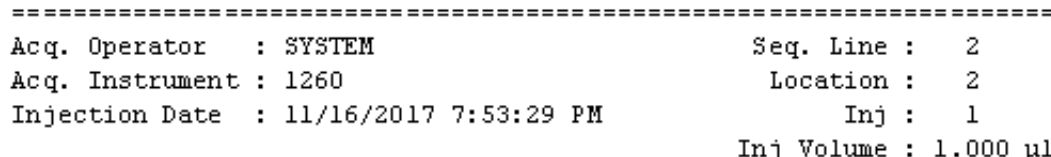

Acq. Method : E: \DATA \SLM SLM-7-80 SLM-7-80 2017-11-16 19-35-41 0D-H-95-5-1. 0ML-254-MM1UL-15MIN.M

Last changed : 11/16/2017 7:35:42 PM by SYsTEM

Analysis Method : E: \DATA SLM SLM-7-80 SLM-7-80 2017-11-16 19-35-41 0D-H-95-5-1.0ML-254-MM1UL-15MIN.M (Sequence Method)

Last changed : 7/6/2018 4:27:18 PM by SYSTEM

(modified after loading)

Additional Info: Peak (s) manually integrated

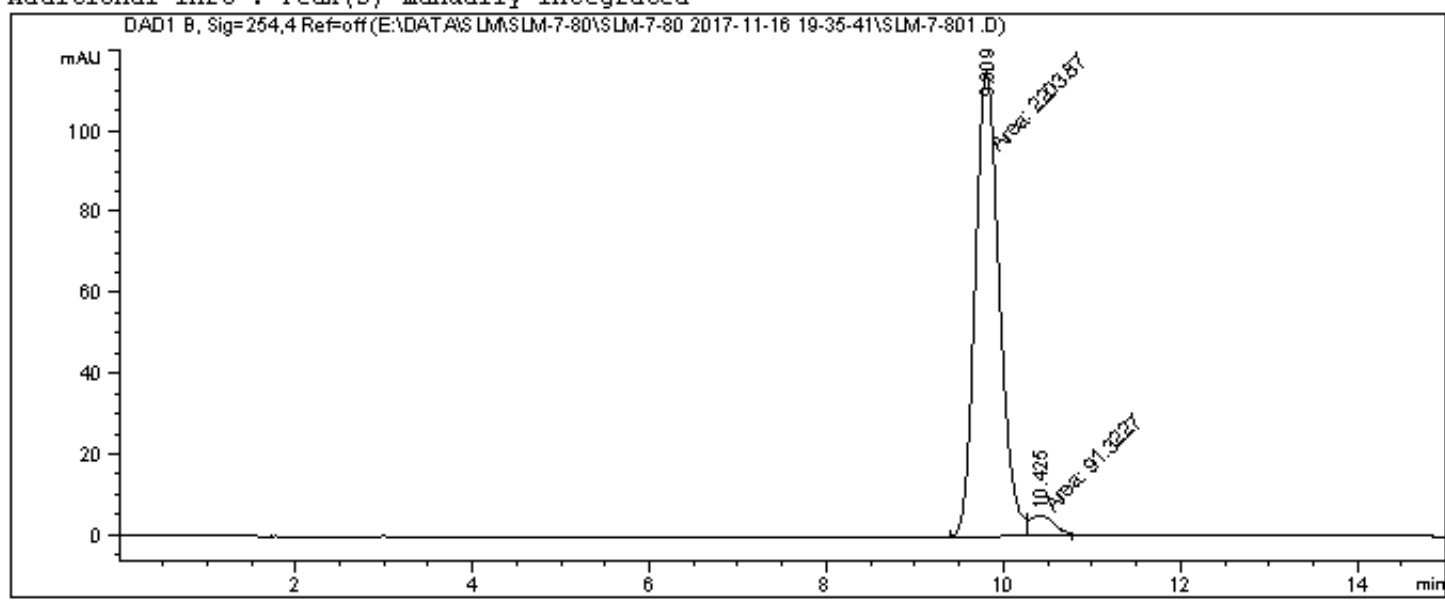

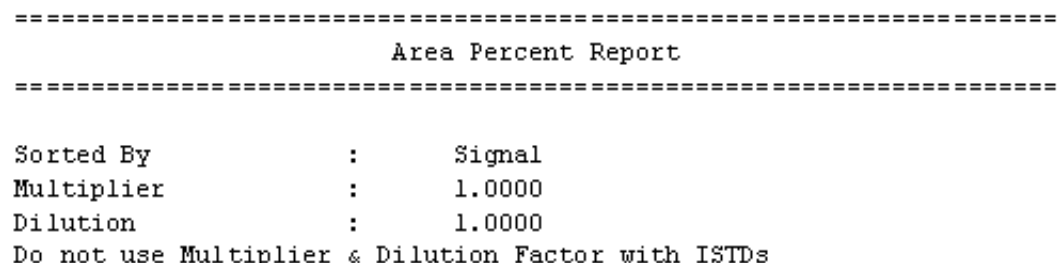

Do not use Multiplier \& Dilution Factor with IsTDs

Signal 1: DADl B, Sig=254, 4 Ref=off

\begin{tabular}{|c|c|c|c|c|c|c|}
\hline $\begin{array}{c}\text { Peak } \\
\#\end{array}$ & $\begin{array}{c}\text { RetTime } \\
\text { [min] }\end{array}$ & Type & $\begin{array}{l}\text { Width } \\
\text { [min] }\end{array}$ & $\begin{array}{c}\text { Area } \\
{\left[\mathrm{m}^{\mathrm{A} U^{*} \mathrm{~s}}\right]}\end{array}$ & $\begin{array}{l}\text { Height } \\
\text { [miU] }\end{array}$ & $\begin{array}{c}\text { Area } \\
\frac{s}{5}\end{array}$ \\
\hline & & & - & ---------- & $---------\mid$ & --------1 \\
\hline 1 & 9.809 & MF & 0.3188 & 2203.86694 & 115.23344 & 96.0211 \\
\hline 2 & 10.425 & FM & 0.3031 & 91.32268 & 5.02187 & 3.9789 \\
\hline
\end{tabular}

Totals :

$2295.18962 \quad 120.25531$

ホネホ End of Report ホホ 
<smiles>CN1C(=O)/C(=N\C(/C=C/c2ccccc2)C(F)(F)F)c2cc(Cl)ccc21</smiles>

Data File D: \LC\5XS\SXS-4-16-17\SXS-4-16-17 2017-10-17 16-54-13\084-0101.D Sample Name: Sxs-4-16

\begin{tabular}{|c|c|c|}
\hline Acq. Operator & : $\operatorname{sXs}$ & Seq. Line : \\
\hline Acq. Inst rument & : Instrument 1 & Location : Vial 84 \\
\hline Injection Date & : $10 / 17 / 20174: 55: 48 \mathrm{PM}$ & 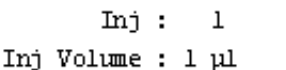 \\
\hline
\end{tabular}

Acq. Method : D : \LC \SXS\SXS-4-16-17\SXS-4-16-17 2017-10-17 16-54-13\4SH-97-3-254M-1UL$10 M D$ M

Last changed : 10/17/2017 5:04:26 PM by SXs (modi fied after loading)

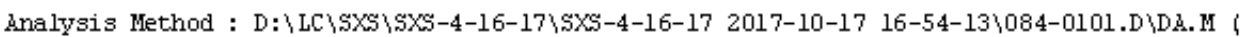
ASH-97-3-254NM-1UL-10M-N. M)

Last changed : 7/6/2018 4:05:05 PM by LHC (modi fied after loading)

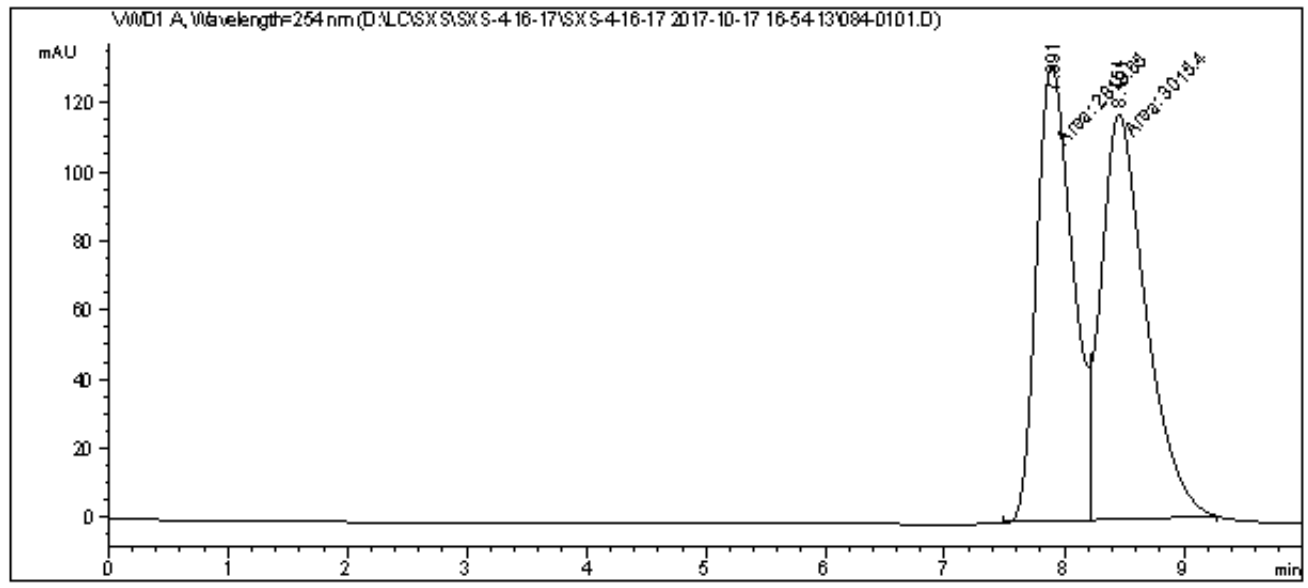

Area Percent Report

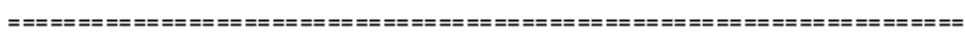

$\begin{array}{lll}\text { Sorted By } & : & \text { Signal } \\ \text { Multiplier } & : & 1.0000 \\ \text { Dilution } & : & 1.0000\end{array}$

Use Multiplier \& Dilution Factor with IsTDs

Signal l: VWD $\mathrm{A}$, Wavelength=254 nm

\begin{tabular}{|c|c|c|c|c|c|}
\hline Peak & RetTime Type & Width & Area & Height & Area \\
\hline$\#$ & [min] & [min] & misJ & [m.2JJ & 믑 \\
\hline 1 & 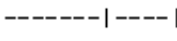 & -- & $---------\mid$ & --------1 & ---1 \\
\hline 1 & $7.891 \mathrm{MF}$ & 0.3551 & 2818.64795 & 132.29872 & 48.3137 \\
\hline 2 & 8.454 FM & 0.4276 & 3015.40283 & 117.54398 & 51.6863 \\
\hline
\end{tabular}

Totals : $\quad 5834.05078 \quad 249.84270$ 
<smiles>CN1C(=O)/C(=N\[C@H](/C=C/c2ccccc2)C(F)(F)F)c2cc(Cl)ccc21</smiles>

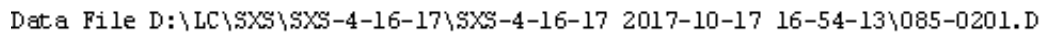
Sample Name: sXs-4-17

Acq. Operator : $\mathrm{s \times s}$

Acq. Inst rument : Instrument

Injection Date : 10/17/2017 5:07:44 PM

Inj Volume : $1 \mu$

Acq. Method : D: $\backslash$ LC \SXS\SXS-4-16-17\SXS-4-16-17 2017-10-17 16-54-13\ASH-97-3-254MM-1UL$10 M D$ M.M

Last changed : 10/17/2017 5:19:16 PM by sXs

(modi fied after loading)

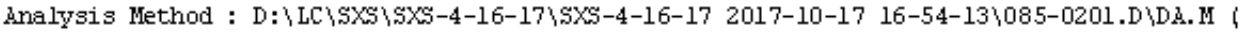
ASH-97-3-254NM-1UL-10NIN. M)

Last changed : 7/6/2018 4:07:14 PM by LHC

(modi fied after loading)

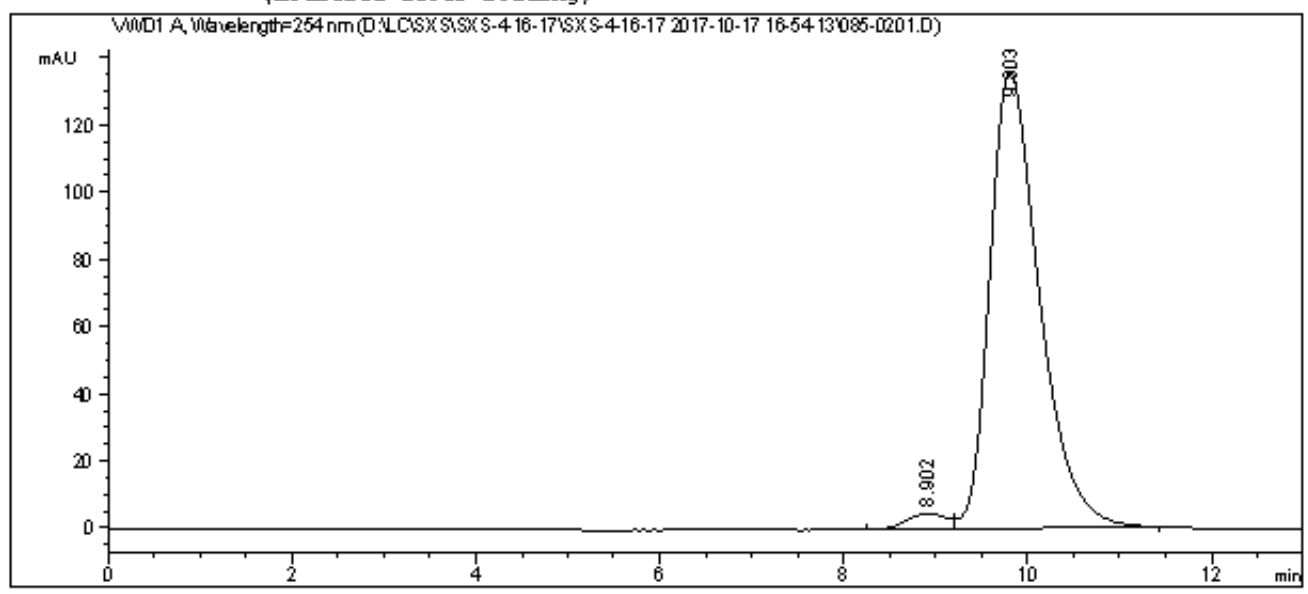

area Percent Report

\begin{tabular}{|c|c|}
\hline Sorted By & : \\
\hline Multiplier & : \\
\hline Dilution & : \\
\hline
\end{tabular}

Use Multiplier \& Dilution Factor with IsTDs

Signal 1: VWDl A, Wavelength=254 nm

\begin{tabular}{|c|c|c|c|c|c|}
\hline Peak & RetTime Type & Width & area & Height & Area \\
\hline$\#$ & [min] & [min] & m m & [madJ & 음 \\
\hline----1 & |-------|--- & ------- & |---------- & $|---------|$ & $-------\mid$ \\
\hline 1 & 8. $902 \mathrm{BV}$ & 0.3962 & 143.67114 & 4.62069 & 2.7375 \\
\hline 2 & $9.803 \mathrm{VB}$ & 0.5697 & 5104.68359 & 136.22063 & 97.2625 \\
\hline Total & ls: & & 5248.35474 & 140.84132 & \\
\hline
\end{tabular}


<smiles>CN1C(=O)/C(=N\C(/C=C/c2ccccc2)C(F)(F)F)c2c(Cl)cccc21</smiles>

5ha

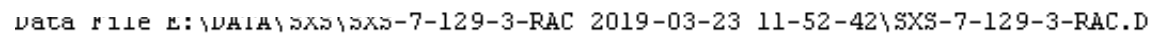
Sample Name: sXs-7-129-3-RAC

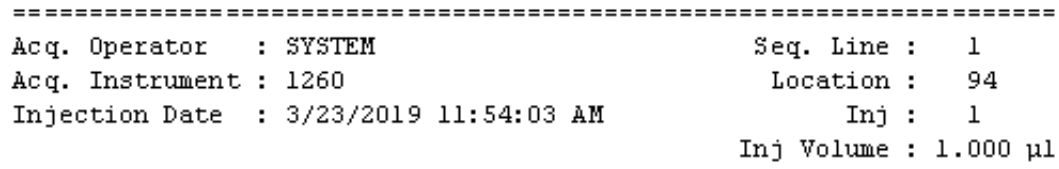

Á q. Method : E: \DATA \SXS\SXS-7-129-3-RAC 2019-03-23 11-52-42\ASH-95-5-ALLMM-1. OML-3ULIOMIN.M

Last changed : 3/23/2019 11:52:42 AM by SYSTEM

Analysis Method : E: \DATA SXS\SXS-7-129-3-RAC 2019-03-23 11-52-42 ASH-95-5-ALLMM-1. OML-3ULIOMIN.M (Sequence Me thod)

Last changed : 3/26/2019 12:29:42 AM by SYSTEN (modified after loading)

Additional Info: Peak (s) manually integrated

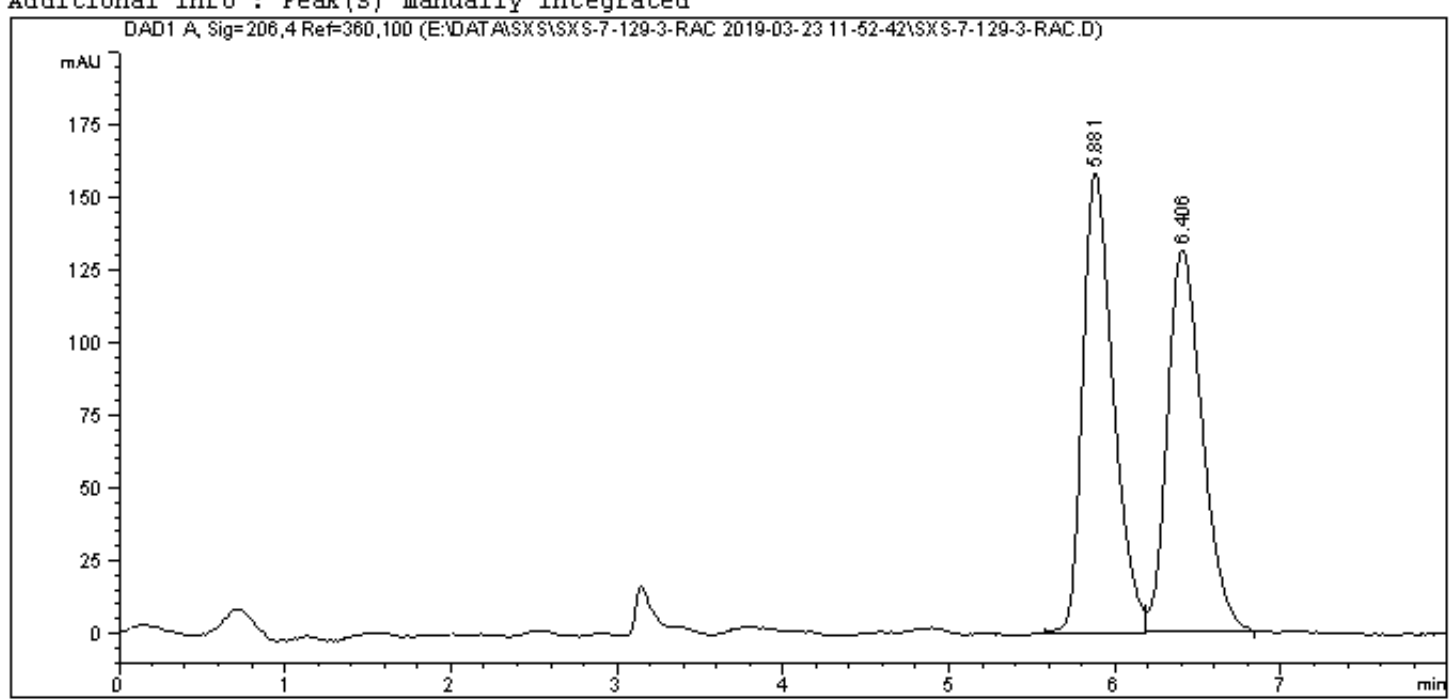

\begin{tabular}{|c|c|c|}
\hline Sorted By & : & Signal \\
\hline Multiplier & : & 1.0000 \\
\hline Dilution & : & 1.0000 \\
\hline
\end{tabular}

Do not use Multiplier \& Dilution Factor with ISTDs

Signal 1: DADl A, Sig=206, 4 Ref $=360,100$

\begin{tabular}{|c|c|c|c|c|c|c|}
\hline $\begin{array}{c}\text { Peak } \\
\#\end{array}$ & $\begin{array}{c}\text { RetTime } \\
\text { [min] }\end{array}$ & Type & $\begin{array}{l}\text { Width } \\
\text { [min] }\end{array}$ & 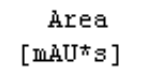 & $\begin{array}{l}\text { Height } \\
\text { [mid] }\end{array}$ & $\begin{array}{c}\text { Àrea } \\
\stackrel{5}{\circ}\end{array}$ \\
\hline & & & & ----ー-ー--- & ----------1 & --------1 \\
\hline 1 & 5.88 & $\mathrm{~V}$ & 0.1877 & 2029.08826 & 158.15875 & 51.2901 \\
\hline 2 & 6.406 & $\mathrm{VV} \mathrm{R}$ & 0.2115 & 1927.01538 & 131.89452 & 48.7099 \\
\hline
\end{tabular}

Totals :

$3956.10364 \quad 290.05327$

ホネー End of Report ネー 
<smiles>CN1C(=O)/C(=N\C(CC=Cc2ccccc2)C(F)(F)F)c2c(Cl)cccc21</smiles>

\section{5ha}

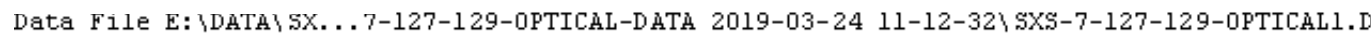
Sample Name: sXs-7-129

\begin{tabular}{|c|c|c|c|}
\hline Acq. Operator & : SYSTEM & Seq. Line : & 2 \\
\hline Acq. Instrument & : 1260 & Location : & 56 \\
\hline Injection Date & : 3/24/2019 11:25:32 AM & $\begin{array}{r}\text { Inj : } \\
\text { Inj Volume : }\end{array}$ & 1 \\
\hline
\end{tabular}
OML-3UL-10MIN. $\mathrm{N}$

Last changed : 3/24/2019 11:34:15 AM bY SYSTEM (modified after loading)

Analysis Method : E: \DATA SXS\SXS-7-127-129-0PTICAL-DATA 2019-03-24 11-12-32\ASH-95-5-ALLMM-1 . OML-3UL-10MIN.M (Sequence Method)

Last changed : 3/24/2019 3:45:36 PM by SYSTEM (modified after loading)

Additional Info: Peak (s) manually integrated

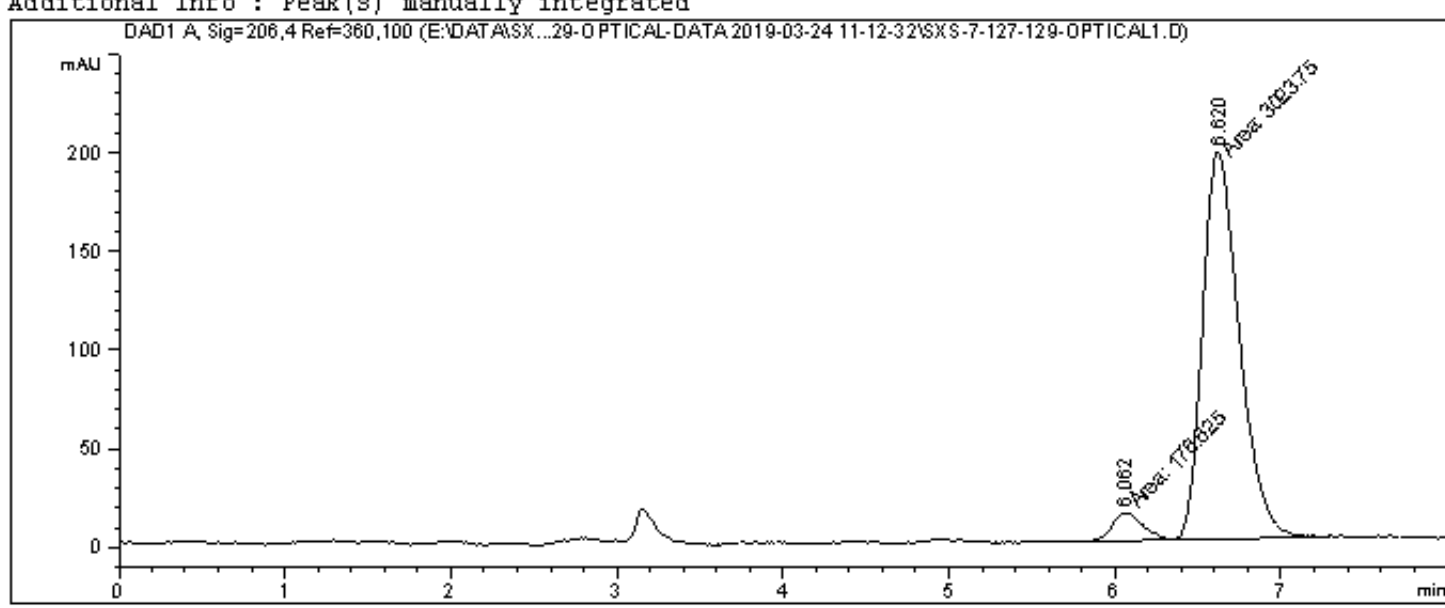

Area Percent Report

\begin{tabular}{|c|c|c|}
\hline Sorted By & $:$ & Signal \\
\hline Multiplier & : & 1.0000 \\
\hline Dilution & : & 1.0000 \\
\hline
\end{tabular}

Do not use Multiplier \& Dilution Factor with ISTDs

Signal 1: DADl A, Sig=206, 4 Ref $=360,100$

\begin{tabular}{|c|c|c|c|c|c|c|}
\hline $\begin{array}{c}\text { Peak } \\
\#\end{array}$ & $\begin{array}{c}\text { RetTime } \\
\text { [min] }\end{array}$ & Type & $\begin{array}{l}\text { Width } \\
\text { [min] }\end{array}$ & 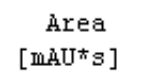 & $\begin{array}{l}\text { Height } \\
\text { [MAU] }\end{array}$ & $\begin{array}{c}\text { Area } \\
\stackrel{4}{*}\end{array}$ \\
\hline & & & & 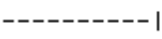 & & \\
\hline 1 & 6.06 & $\Gamma$ & 0.2101 & 176.62521 & 14.01060 & 5.5189 \\
\hline 2 & 6.620 & FM & 0.2568 & 3023.74805 & 196.26003 & 94.4811 \\
\hline
\end{tabular}

Totals :

$3200.37326 \quad 210.27063$ 
<smiles>CCCCN1C(=O)/C(=N\C(/C=C/c2ccccc2)C(F)(F)F)c2ccccc21</smiles>

5 ia

Data File E: \DATA $\backslash$ SXS $\$ SXS-4-30-31 2017-10-30 14-35-53 SXS-4-30-31. D Sample Name: sXs-4-30

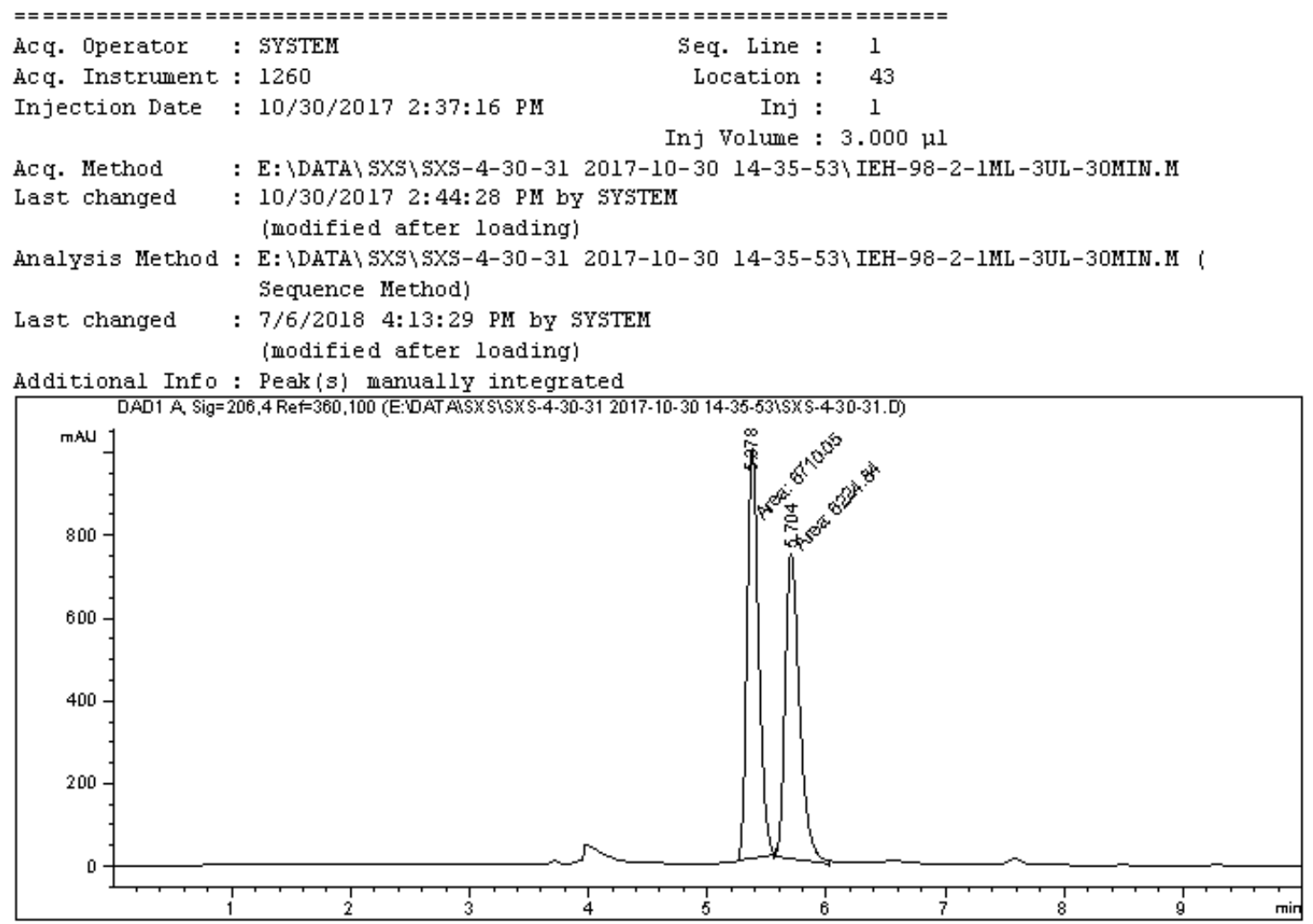

\section{Area Percent Report}

\begin{tabular}{|c|c|c|}
\hline Sorted By & : & Signal \\
\hline Multiplier & : & 1.0000 \\
\hline Dilution & : & 1.0000 \\
\hline
\end{tabular}

Do not use Multiplier \& Dilution Factor with ISTDs

Signal 1: DADl A, Sig=206, 4 Ref $=360,100$

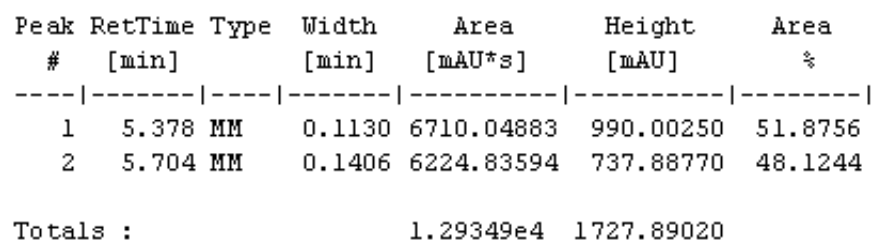

ホネ゙ End of Report ネネ 
<smiles>CCCCN1C(=O)/C(=N\C(/C=C/c2ccccc2)C(F)(F)F)c2ccccc21</smiles>

5 ia

Data File E: \DATA $\backslash$ SXS $5 X 5-4-30-31$ 2017-10-30 14-35-53 SXS-4-30-311.D Sample Name: sXs-4-31

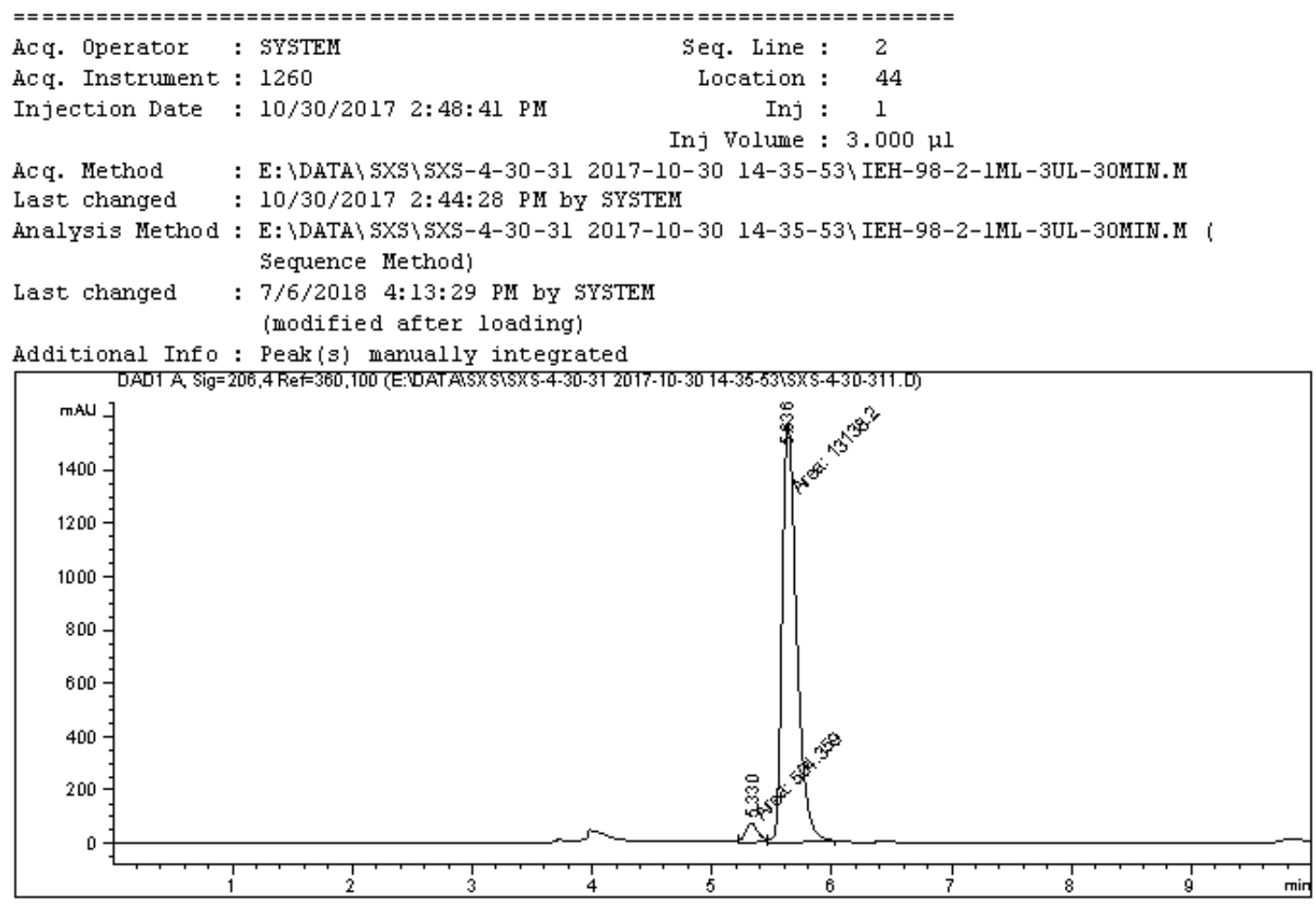

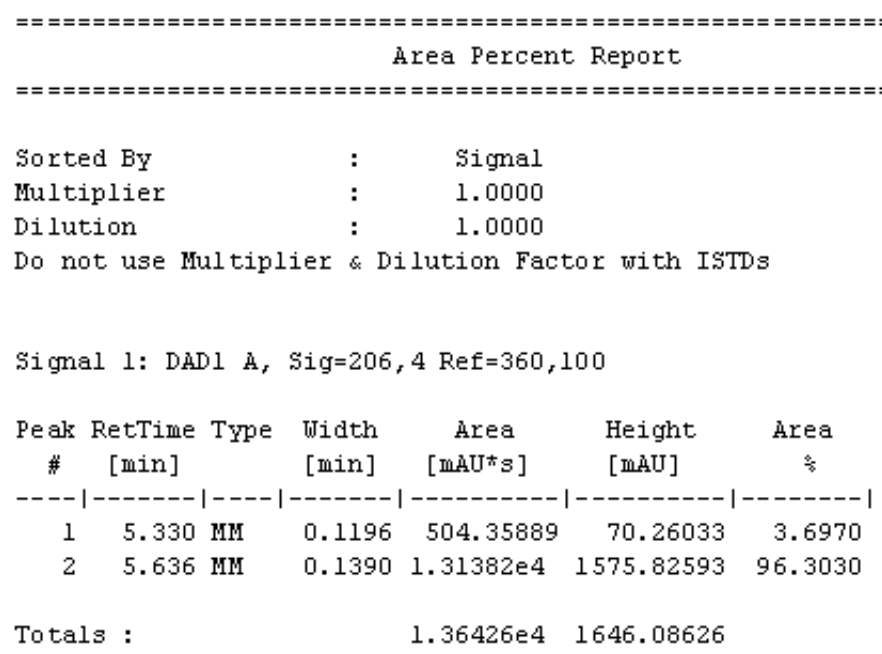


<smiles>C=CCN1C(=O)/C(=N\C(=C/C=C/c2ccccc2)C(F)(F)F)c2ccccc21</smiles>

Data File E: \DATA SLM SLM-6-93\SLM-6-93-4 2017-09-14 17-55-06\SLM-6-93.D Sample Name: SLM-6-93-RAC

\begin{tabular}{|c|c|c|c|}
\hline Acq. Operator & : SYSTEM & Seq. Line : & 1 \\
\hline Acq. Instrument & : 1260 & Location : & 34 \\
\hline Injection Date & : 9/14/2017 5:56:27 PM & $\begin{array}{r}\text { Inj : } \\
\text { Inj Volume : }\end{array}$ & $\begin{array}{l}1 \\
.000 \mu l\end{array}$ \\
\hline
\end{tabular}

Acq. Method : E: \DATA \SLM SLM-6-93\SLM-6-93-4 2017-09-14 17-55-06 IE-98-2-254NM-1ML1UL$10 \mathrm{MIN}-\mathrm{TD}-4 . \mathrm{M}$

Last changed : 9/14/2017 5:55:06 PM by SYSTEM

Analysis Method : E: \DATA SLM SLM-6-93 SLM-6-93-4 2017-09-14 17-55-06 IE-98-2-254MM-1ML1uL10MIN-TD-4.M (Sequence Method)

Last changed : 7/6/2018 4:32:23 PM by SYSTEM (modified after loading)

Additional Info : Peak (s) manually integrated

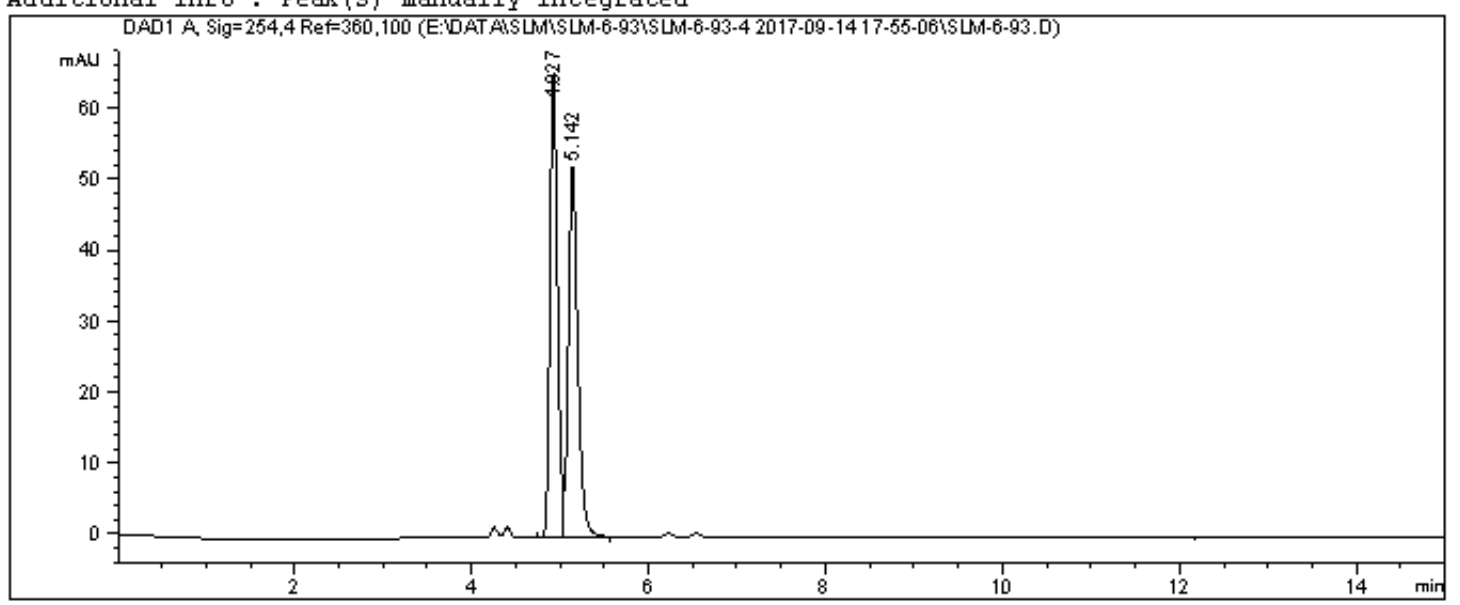

Area Percent Report

\begin{tabular}{|c|c|c|}
\hline Sorted By & : & Signal \\
\hline Multiplier & : & 1.0000 \\
\hline Dilution & : & 1.0000 \\
\hline
\end{tabular}

Do not use Multiplier \& Dilution Factor with IsTDs

Signal 1: DADl Aे, Sig=254, 4 Ref $=360,100$

\begin{tabular}{|c|c|c|c|c|c|c|}
\hline $\begin{array}{c}\text { Peak } \\
\#\end{array}$ & $\begin{array}{c}\text { RetTime } \\
\text { [min] }\end{array}$ & Type & $\begin{array}{l}\text { Width } \\
\text { [min] }\end{array}$ & $\begin{array}{c}\text { Area } \\
{\left[\mathrm{m}^{2} \mathrm{U}^{*} \mathrm{~S}\right]}\end{array}$ & $\begin{array}{l}\text { Height } \\
\text { [mAU] }\end{array}$ & $\begin{array}{c}\text { Area } \\
\stackrel{8}{*}\end{array}$ \\
\hline-- & ---- & & & $----------\mid$ & --- & -1 \\
\hline 1 & 4.92 & $\mathrm{y}$ & 0.0893 & 382.49924 & 65.37911 & 382 \\
\hline 2 & 5.142 & VB & 0.1113 & 386.52570 & 52.27330 & 50.2618 \\
\hline
\end{tabular}

Totals : $\quad 769.02493 \quad 117.65241$ 
<smiles>C=CCN1C(=O)/C(=N\C(C=Cc2ccccc2)C(F)(F)F)c2ccccc21</smiles>

Data File E: \DATA SLM SLM-6-93 SLM-6-93-4 2017-09-14 17-55-06 SLM-6-931.D Sample Name: SLM-6-93-CHIRAL

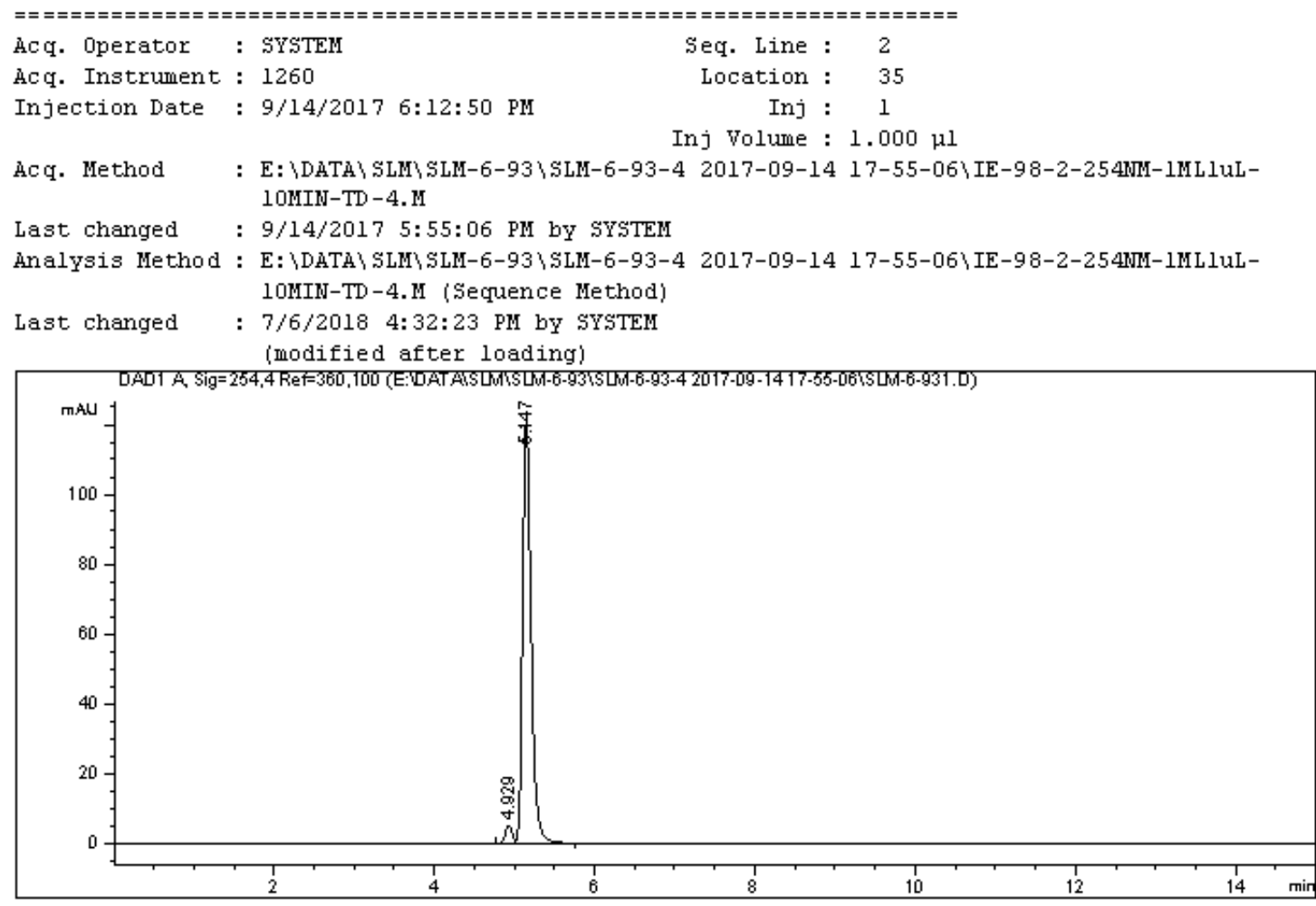

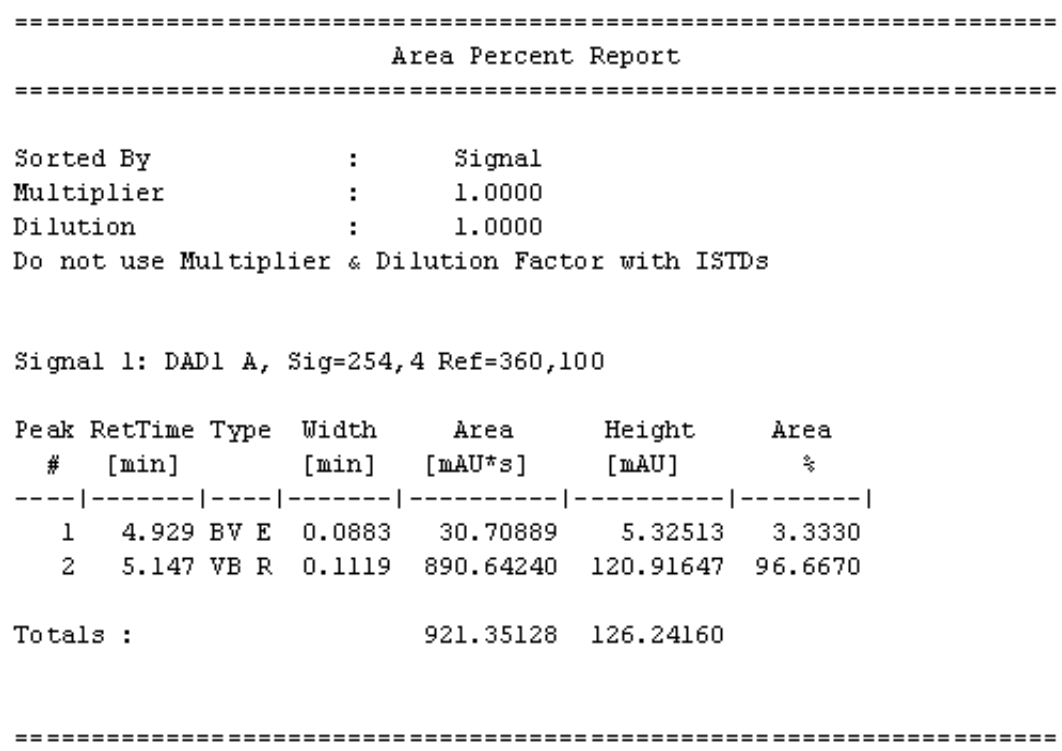


<smiles>O=C1/C(=N\C(/C=C/c2ccccc2)C(F)(F)F)c2ccccc2N1Cc1ccccc1</smiles>

Data File E: \DATA SXs\5Xs-7-6 2018-09-06 15-37-57 5Xs-7-6.D Sample Name: SXs-7-6-RAC

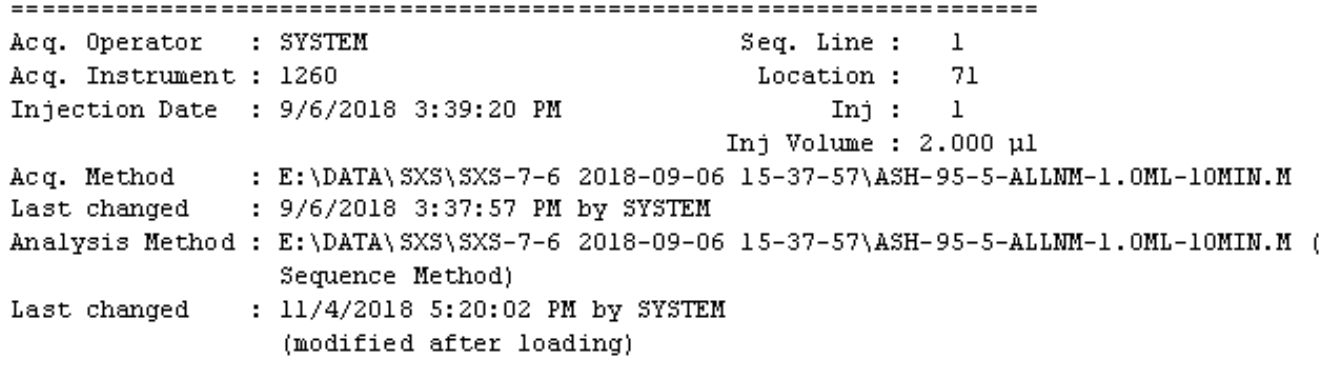

Additional Info: Peak (s) manually integrated
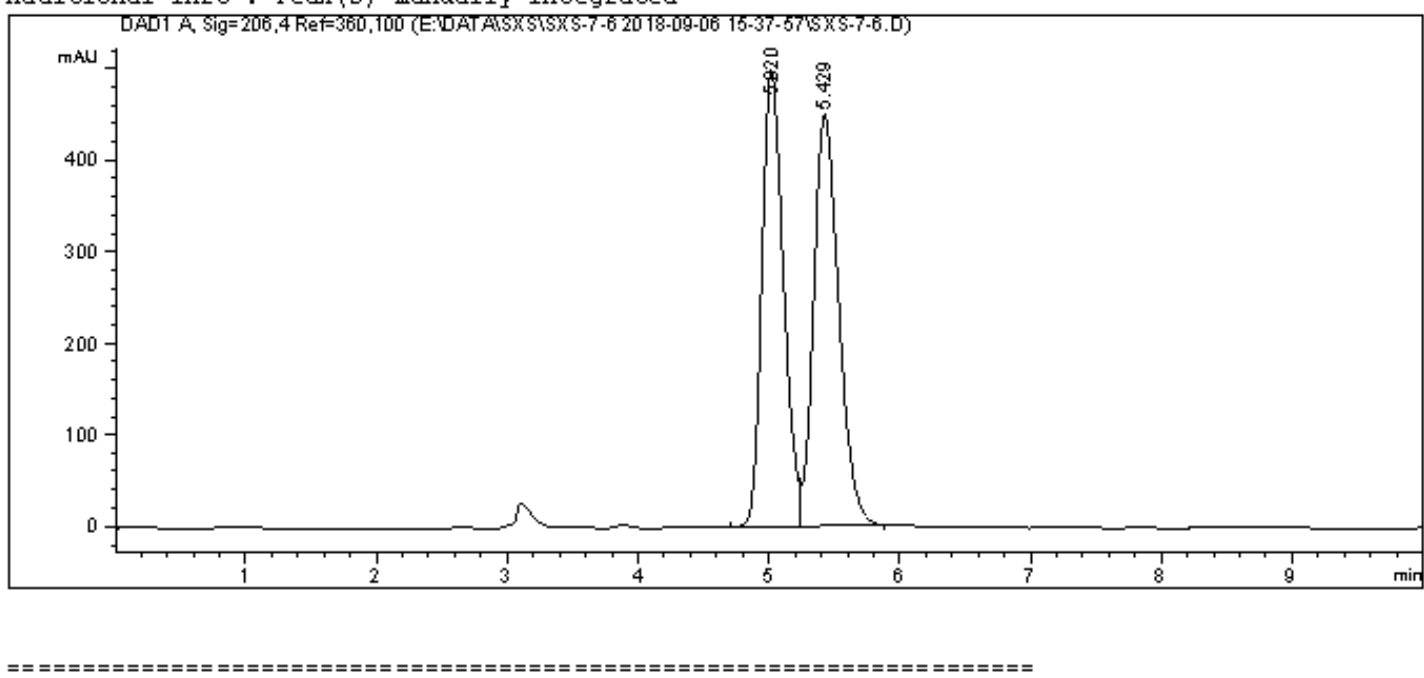

Area Percent Report

\begin{tabular}{|c|c|c|}
\hline Sorted By & : & Signal \\
\hline Multiplier & : & 1.0000 \\
\hline Dilution & : & 1.0000 \\
\hline
\end{tabular}

Do not use Multiplier \& Dilution Factor with IsTDs

Signal 1: DADl A, Sig $=206,4$ Ref $=360,100$

\begin{tabular}{|c|c|c|c|c|c|c|}
\hline $\begin{array}{c}\text { Peak } \\
\#\end{array}$ & $\begin{array}{c}\text { RetTime } \\
\text { [min] }\end{array}$ & Type & $\begin{array}{l}\text { Width } \\
\text { [min] }\end{array}$ & $\begin{array}{c}\text { Area } \\
{\left[\mathrm{maU}^{*} \mathrm{~s}\right]}\end{array}$ & $\begin{array}{l}\text { Height } \\
\text { [mBU] }\end{array}$ & $\begin{array}{c}\text { Area } \\
\stackrel{5}{*}\end{array}$ \\
\hline & & & $-0-1$ & -- & . & 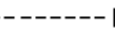 \\
\hline 1 & 5 & & 0.177 & 5733. & 498 & 606 \\
\hline 2 & 5.429 & & .2024 & 5977.07080 & 448.84769 & 51.0394 \\
\hline
\end{tabular}

Totals : $\quad 1.17107 \mathrm{e} 4947.55991$ 
<smiles>O=C1/C(=N\C(/C=C/c2ccccc2)C(F)(F)F)c2ccccc2N1Cc1ccccc1</smiles>

Data File E: \DATA $\backslash$ SXS\SXS-7-6 2018-09-06 15-37-57\SXS-7-61.D Sample Name: SXS-3-10

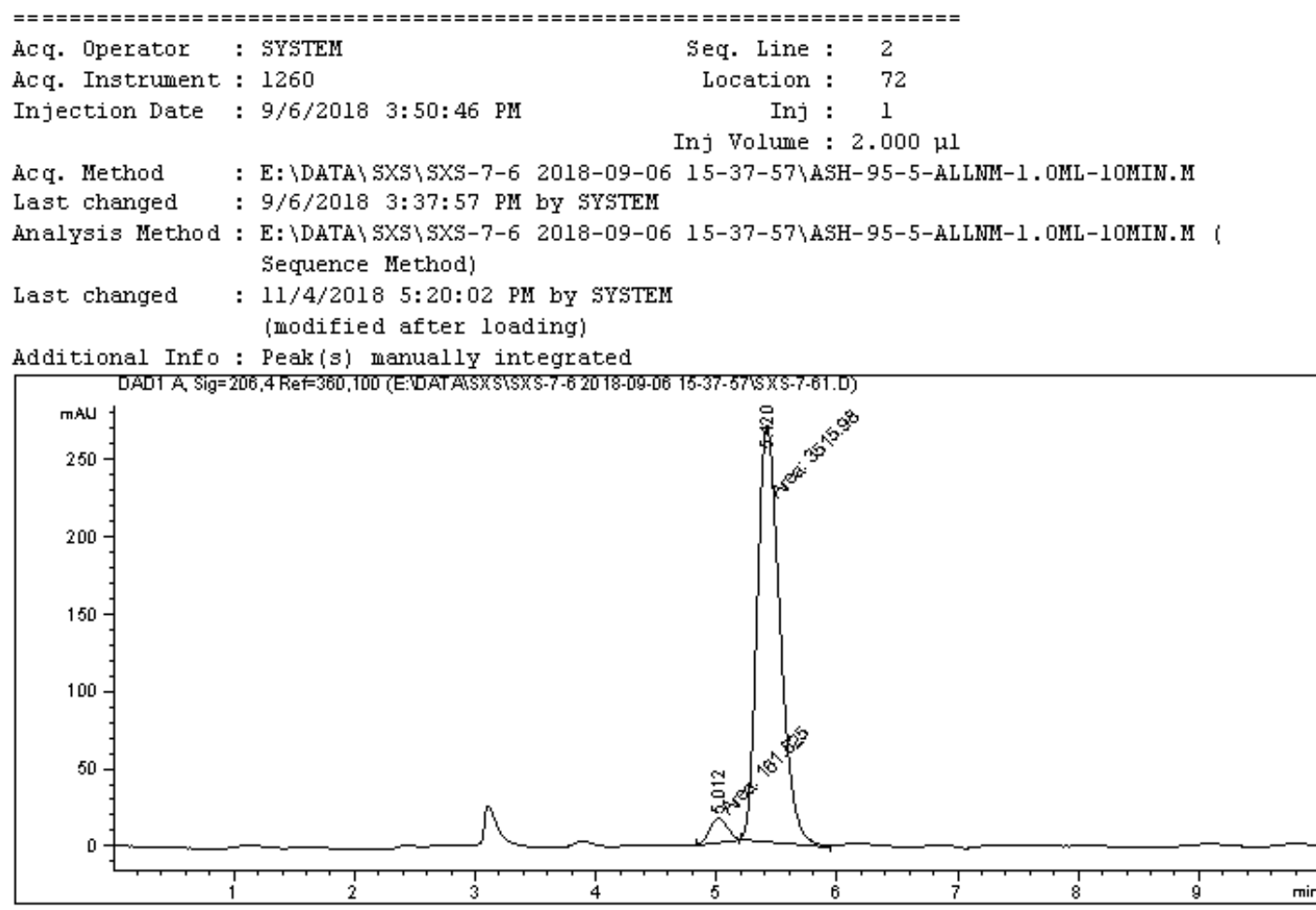

Area Percent Report

\begin{tabular}{|c|c|c|}
\hline Sorted BY & : & Signal \\
\hline Multiplier & : & 1.0000 \\
\hline Dilution & : & 1.0000 \\
\hline
\end{tabular}

Do not use Multiplier \& Dilution Factor with ISTDs

Signal 1: DADl À, Sig $=206,4$ Ref $=360,100$

\begin{tabular}{|c|c|c|c|c|c|c|}
\hline $\begin{array}{c}\text { Peak } \\
\#\end{array}$ & $\begin{array}{c}\text { RetTime } \\
\text { [min] }\end{array}$ & Type & $\begin{array}{l}\text { Width } \\
\text { [min] }\end{array}$ & 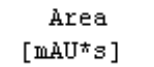 & $\begin{array}{l}\text { Height } \\
\text { [mAU] }\end{array}$ & $\begin{array}{c}\text { Àrea } \\
\stackrel{4}{8}\end{array}$ \\
\hline & & & ---- & ---------- & 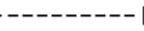 & $-------\mid$ \\
\hline 1 & 5.012 & MM & 0.1704 & 161.82481 & 15.82592 & 4. 4000 \\
\hline 2 & 5.420 & MM & 0.2182 & 3515.98193 & 268.60703 & 95.6000 \\
\hline Tota. & Ls: & & & 3677.80675 & 284.43294 & \\
\hline
\end{tabular}

ネネ゙ End of Report ネネ 
<smiles>O=C1/C(=N\C(/C=C/c2ccccc2)C(F)(F)F)c2c(Cl)cccc2N1Cc1ccccc1</smiles>

Data File E: \DATA \XS\SXS-7-127-129-1-RAC 2019-03-23 11-26-52 \XS-7-127-129-1-RAC.D Sample Name: SXS-7-127-1-RAC

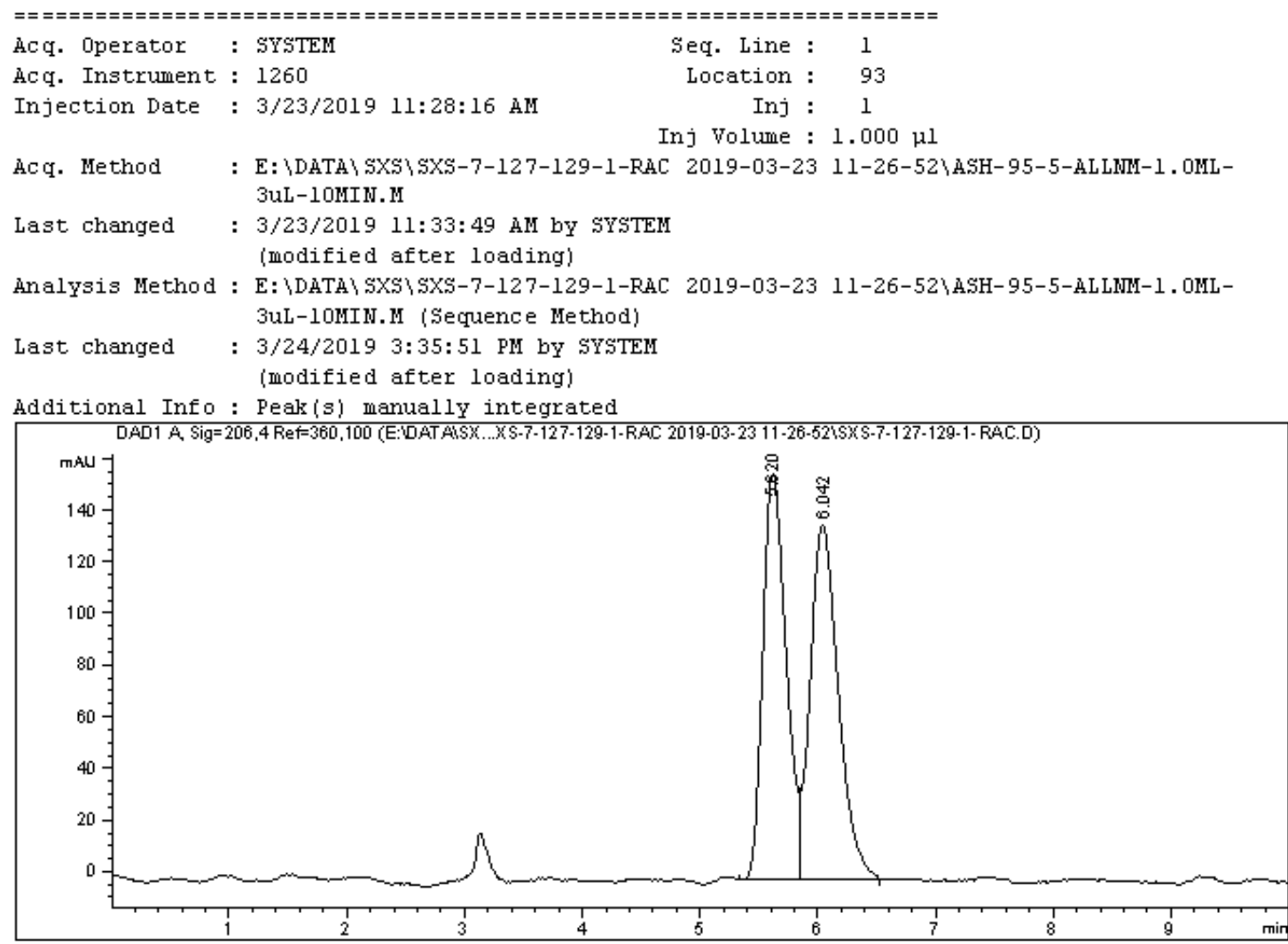

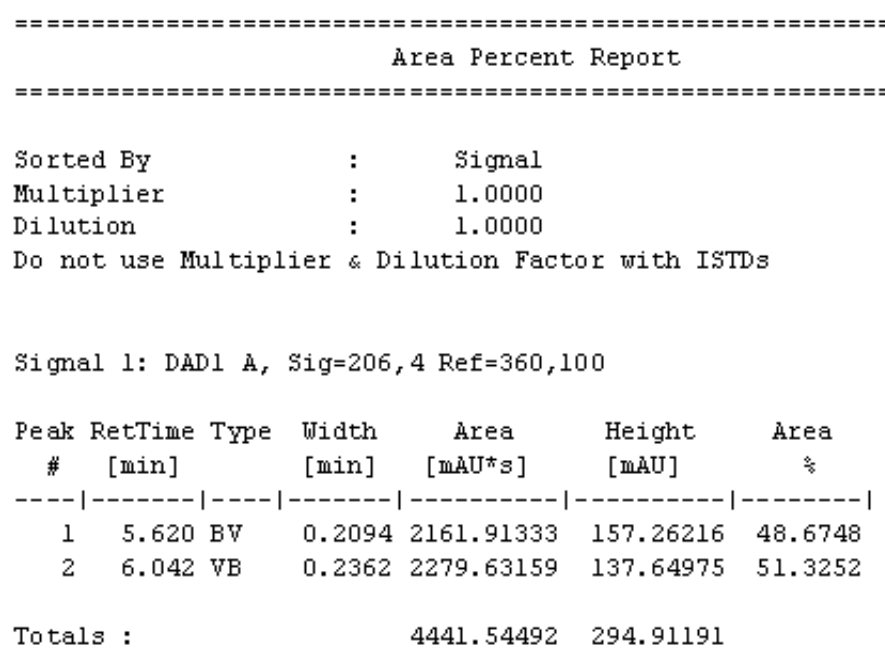


<smiles>O=C1/C(=N\C(/C=C/c2ccccc2)C(F)(F)F)c2c(Cl)cccc2N1Cc1ccccc1</smiles>

Data File E: \DATA $\backslash$ SX...7-127-129-0PTICAL-DATẢ 2019-03-24 11-12-32〉 5X5-7-127-129-0PTICAL2.D sample Name: $5 \times 5-7-127$

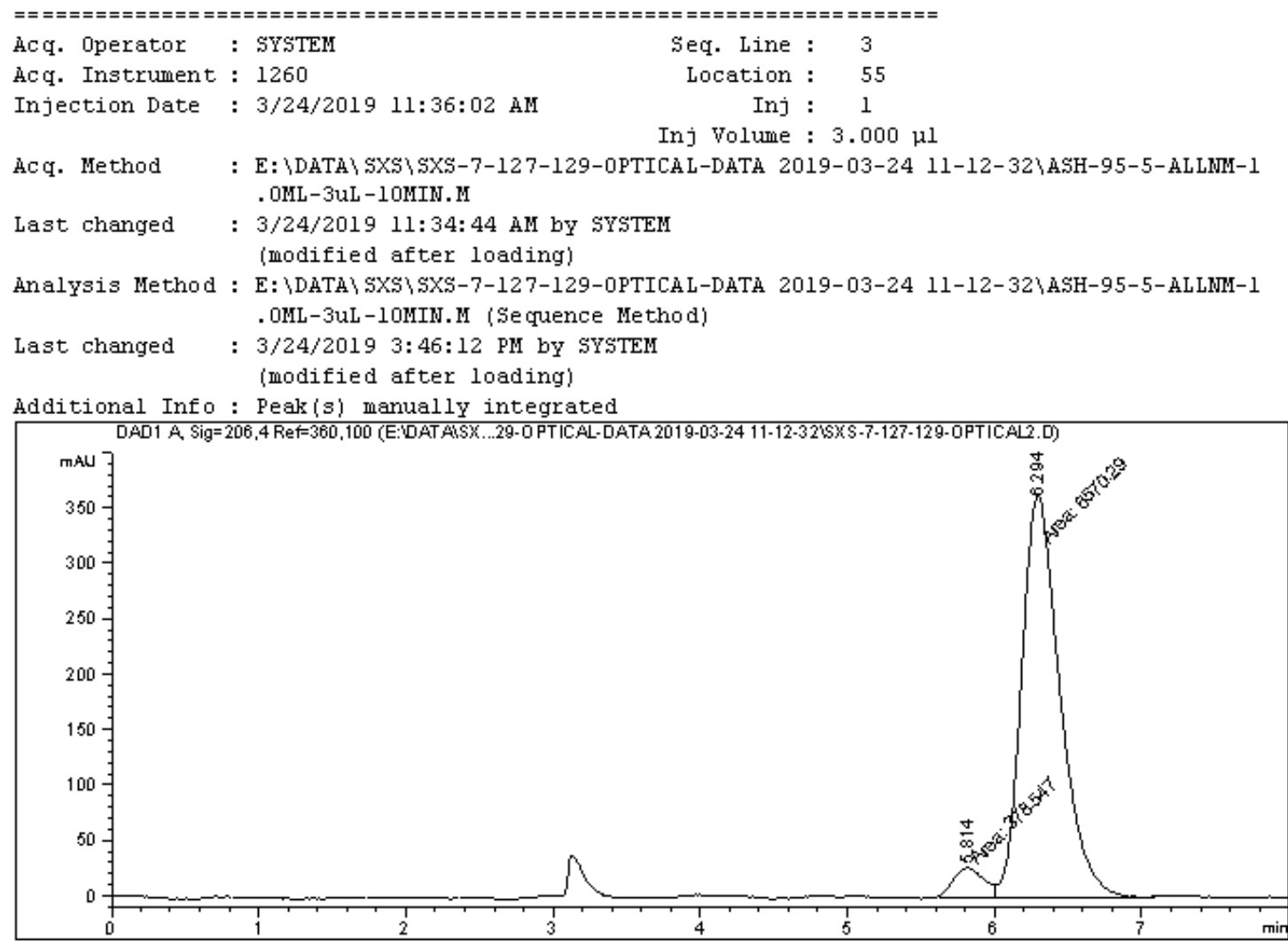

\section{Area Percent Report}

\begin{tabular}{|c|c|c|c|c|}
\hline Sorted BY & : & \multicolumn{2}{|l|}{ Signal } & \\
\hline Multiplier & : & \multicolumn{2}{|l|}{1.0000} & \\
\hline Dilution & : & \multicolumn{2}{|l|}{1.0000} & \\
\hline \multicolumn{5}{|c|}{ Do not use Multiplier \& Dilution Factor with ISTDs } \\
\hline \multicolumn{5}{|c|}{ Signal 1: DADl A, Sig $=206,4$ Ref $=360,100$} \\
\hline Peak RetTime Type & Width & Area & Height & Area \\
\hline$\# \quad[$ min $]$ & [min] & {$\left[\mathrm{m} A U^{*} s\right]$} & [ [mAUU] & $\stackrel{8}{8}$ \\
\hline \multicolumn{5}{|c|}{$----|-------|----|-------|---------||---------||-------\mid$} \\
\hline $5.814 \mathrm{MF}$ & 0.2383 & 378.54688 & 26.47249 & 5.4476 \\
\hline $6.294 \mathrm{FM}$ & 0.3020 & 6570.28906 & 362.61853 & 94.5524 \\
\hline Totals : & & 6948.83594 & 389.09102 & \\
\hline
\end{tabular}


<smiles>CN1C(=O)/C(=N\C(C)(/C=C/c2ccccc2)C(F)(F)F)c2ccccc21</smiles>

Data File E: \DATA $\backslash$ SLM $\backslash$ SLM-7-72-1 2017-11-13 12-21-16\SLM-7-72.D

Sample Name: SLM-7-72-RAC

\begin{tabular}{|c|c|c|c|}
\hline Acq. Operator & : SYSTEM & seq. Line : & 1 \\
\hline Ac q. Instrument & : 1260 & Location : & 21 \\
\hline Injection Date & $: 11 / 13 / 2017$ 12:22:38 PM & $\begin{array}{r}\text { Inj : } \\
\text { Inj Volume : }\end{array}$ & $\begin{array}{l}1 \\
.000\end{array}$ \\
\hline
\end{tabular}

Ac q. Method : E: \DATA \SLM SLM-7-72-1 2017-11-13 12-21-16\AD-95-5-254MM-1ML-1UL-10M IN-TD-2 .$M$

Last changed : 11/13/2017 12:21:16 PM by SYSTEM

Analysis Method : E: \DATA SLM SLM-7-72-1 2017-11-13 12-21-16 ADD-95-5-254MM-1ML-1UL-10M IN-TD-2 .M (Sequence Method)

Last changed : 7/6/2018 9:42:35 PM by SYSTEM

(modified after loading)

Additional Info: Peak (s) manually integrated

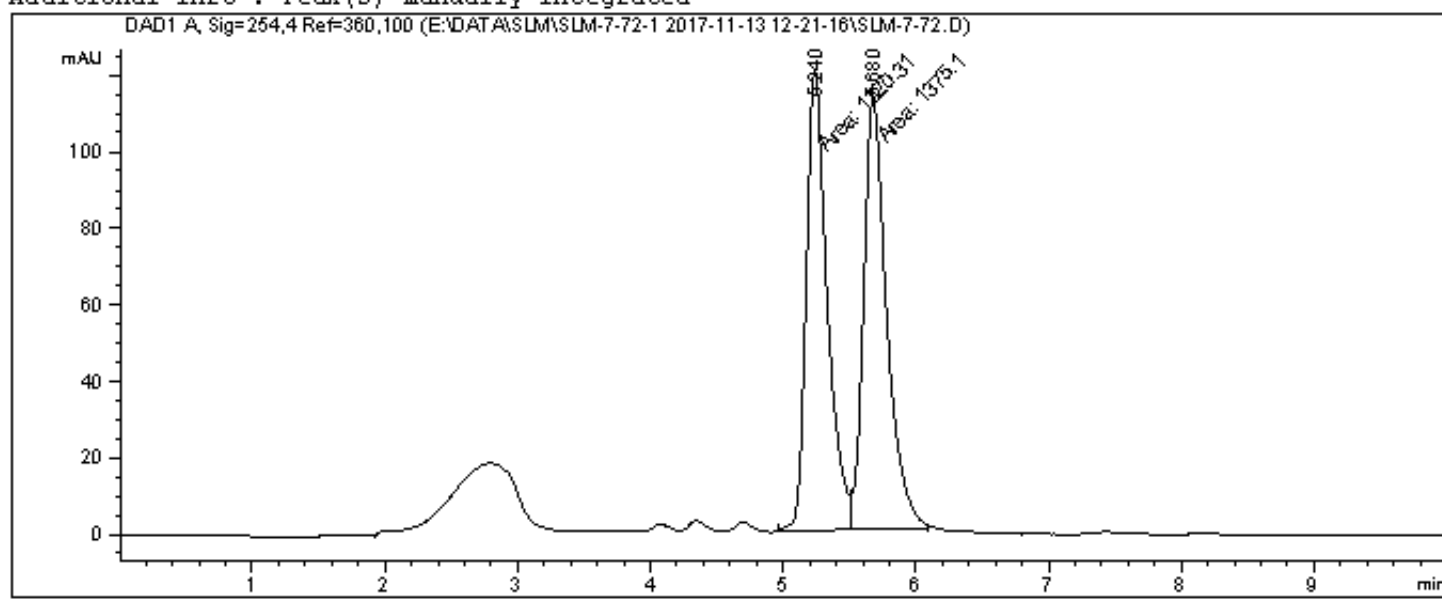

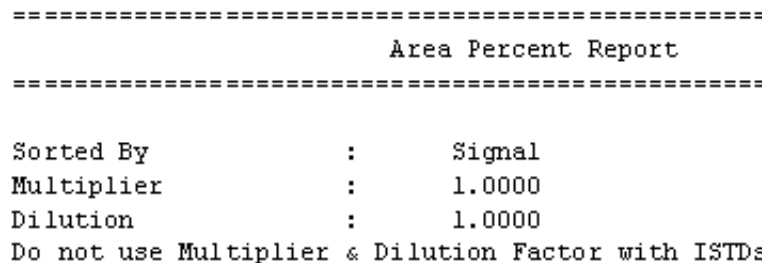

Signal 1: DADl A, sig $=254,4$ Ref $=360,100$

\begin{tabular}{|c|c|c|c|c|c|c|}
\hline $\begin{array}{c}\text { Peak } \\
\#\end{array}$ & $\begin{array}{c}\text { RetTime } \\
\text { [min] }\end{array}$ & Type & $\begin{array}{l}\text { Width } \\
\text { [min] }\end{array}$ & $\begin{array}{c}\text { Area } \\
{\left[\mathrm{mAU}^{*} \mathrm{~s}\right]}\end{array}$ & $\begin{array}{l}\text { Height } \\
\text { [mAU] }\end{array}$ & $\begin{array}{c}\text { Area } \\
\stackrel{8}{8}\end{array}$ \\
\hline-- & ---- & & ------- & |--------- & ---------1 & -------1 \\
\hline 1 & 5.240 & $M F$ & 0.1835 & 1320.31079 & 119.94832 & 48.9836 \\
\hline 2 & 5.680 & FM & 0.2025 & 1375.10339 & 113.16945 & 51.0164 \\
\hline Tot & : & & & 2695.41418 & 233.11777 & \\
\hline
\end{tabular}

ホネホ End of Report ホネ 
<smiles>CN1C(=O)/C(=N\C(C)(/C=C/c2ccccc2)C(F)(F)F)c2ccccc21</smiles>

Data File E: \DATA \LM \LM-8-80\SLM-8-80 2018-04-24 18-06-49\SLM-8-80.D Sample Name: SLM-8-80-cf3+ch3

\begin{tabular}{|c|c|c|c|}
\hline Acq. Operator & : SYSTEM & seq. Line : & 1 \\
\hline Ac q. Instrument & : 1260 & Location : & 30 \\
\hline Injection Date & : 4/24/2018 6:08:17 PM & $\begin{array}{r}\text { Inj : } \\
\text { Inj Volume : }\end{array}$ & $\begin{array}{l}1 \\
.000\end{array}$ \\
\hline
\end{tabular}

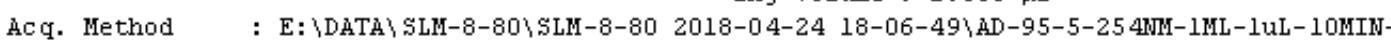
$\mathrm{TD}-2 . \mathrm{M}$

Last changed : 4/24/2018 6:06:49 PM by SYSTEM

Analysis Method : E: \DATA SLM SLM-8-80 SLM-8-80 2018-04-24 18-06-49 AAD-95-5-254MM-1ML-1uL10MIN-TD-2.M (Sequence Method)

Last changed : 7/6/2018 9:46:56 PM by SYSTEM (modified after loading)

Additional Info : Peak (s) manually integrated

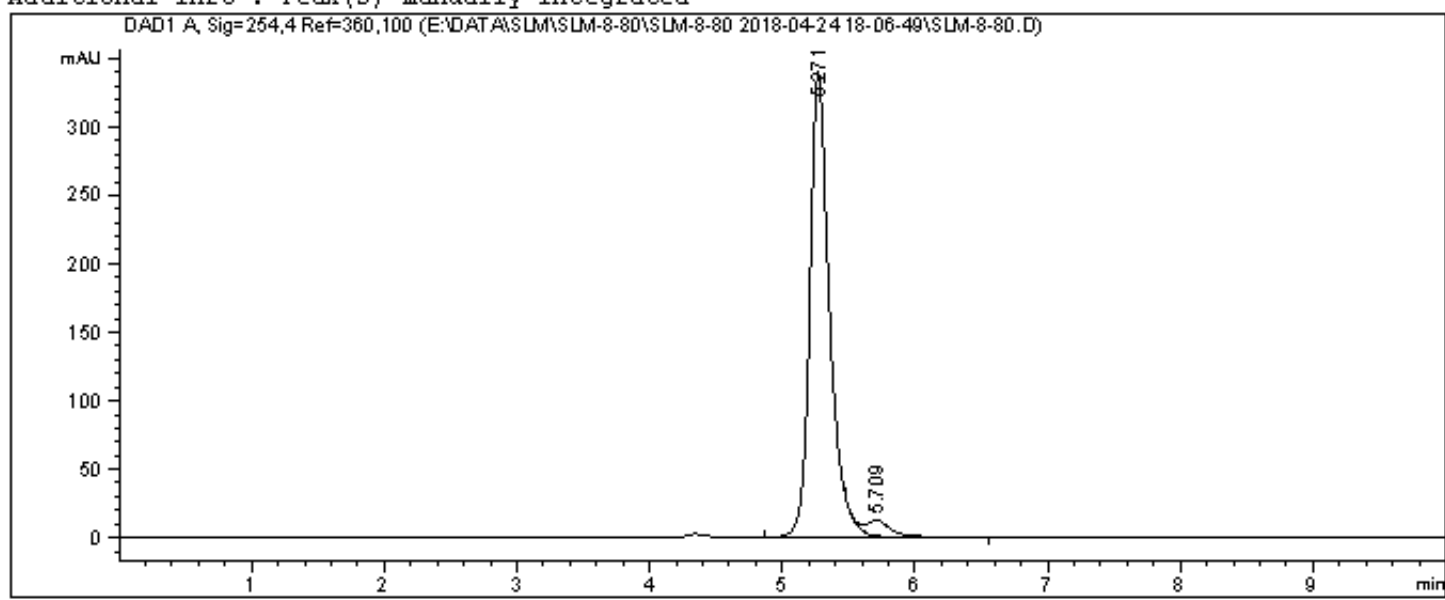

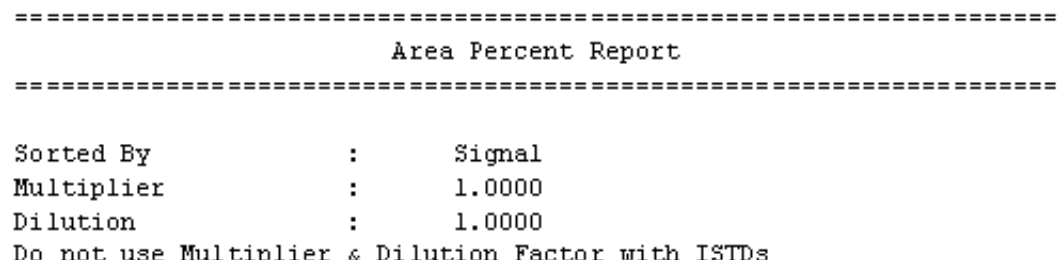

Do not use Multiplier \& Dilution Factor with IsTDs

Signal 1: DADl A, sig $=254,4$ Ref $=360,100$

\begin{tabular}{|c|c|c|c|c|c|c|}
\hline $\begin{array}{c}\text { Peak } \\
\#\end{array}$ & $\begin{array}{c}\text { RetTime } \\
\text { [min] }\end{array}$ & Type & $\begin{array}{l}\text { Width } \\
\text { [min] }\end{array}$ & $\begin{array}{c}\text { Area } \\
{\left[\mathrm{mAH}^{*} \mathrm{~B}\right]}\end{array}$ & $\begin{array}{l}\text { Height } \\
\text { [miU] }\end{array}$ & $\begin{array}{c}\text { Area } \\
\stackrel{s}{\hat{s}}\end{array}$ \\
\hline & & & & --------- & $--------\mid$ & -------1 \\
\hline 1 & 5.27 & $\mathrm{~V} R$ & 0.1530 & 3526.50391 & 340.05945 & 95.6422 \\
\hline 2 & 5.709 & VB E & 0.1914 & 160.68079 & 11.75967 & 4.3578 \\
\hline
\end{tabular}

Totals :

$3687.18469 \quad 351.81912$

ホネホ End of Report ホネ 
<smiles></smiles>

Data File E: \DATA $\backslash$ SLM $\backslash$ SLM-9-23\SLM-9-23 2018-07-05 15-25-09\SLM-9-23.D Sample Name: SLM-9-23-RAC
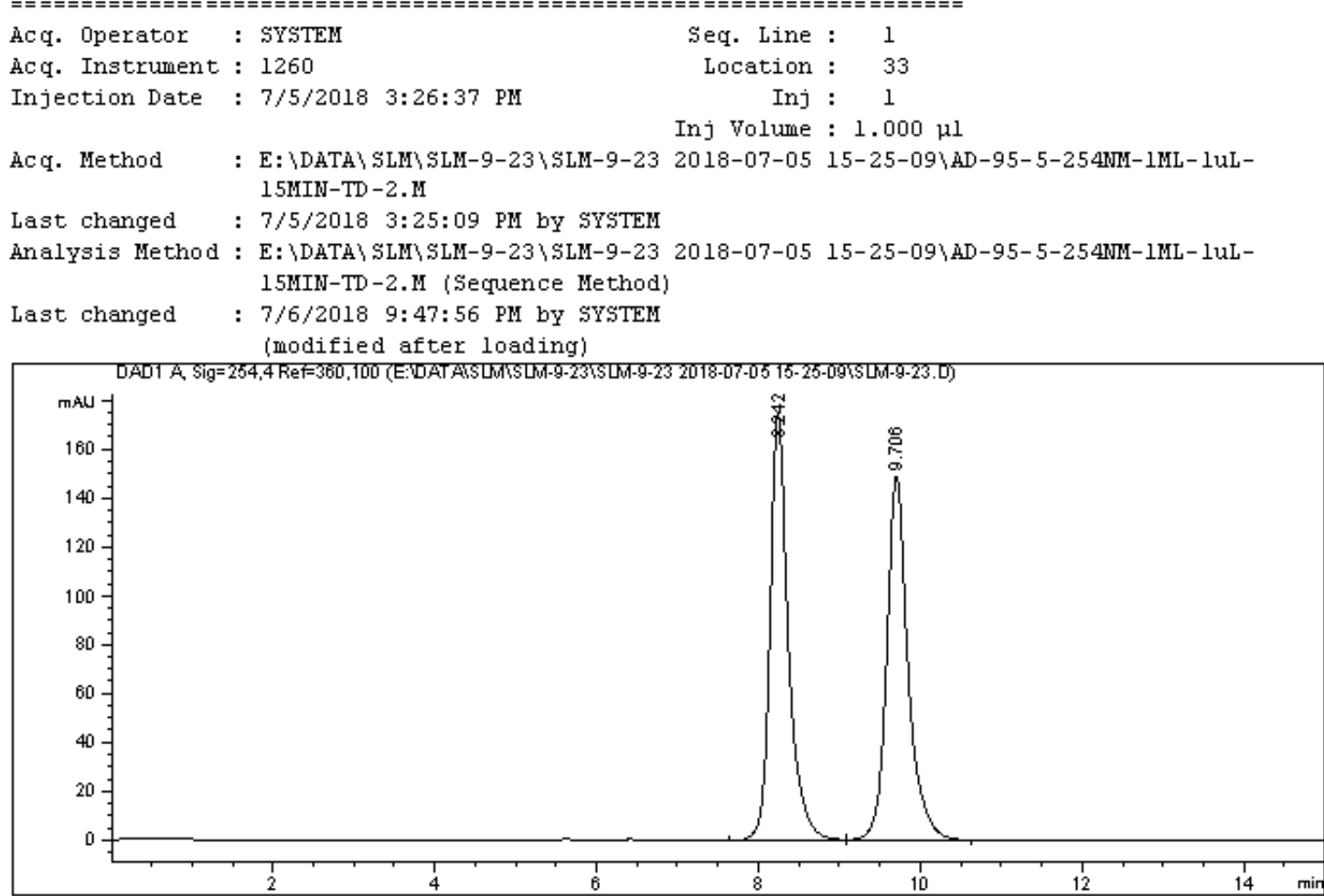

Area Percent Report

\begin{tabular}{|c|c|c|}
\hline Sorted By & : & Signal \\
\hline Multiplier & : & 1.0000 \\
\hline Dilution & : & 1.0000 \\
\hline
\end{tabular}

Do not use Multiplier \& Dilution Factor with IsTDs

Signal 1: DADl A, Sig $=254,4$ Ref $=360,100$

\begin{tabular}{|c|c|c|c|c|c|c|}
\hline $\begin{array}{c}\text { Peak } \\
\#\end{array}$ & $\begin{array}{c}\text { RetTime } \\
\text { [min] }\end{array}$ & Type & $\begin{array}{l}\text { Width } \\
\text { [min] }\end{array}$ & $\begin{array}{c}\text { Area } \\
\left.\text { [m } \mathrm{m} \mathrm{U}^{*} \mathrm{~s}\right]\end{array}$ & $\begin{array}{l}\text { Height } \\
\text { [MAU] }\end{array}$ & $\begin{array}{c}\text { Area } \\
\stackrel{5}{*}\end{array}$ \\
\hline \multicolumn{7}{|c|}{ 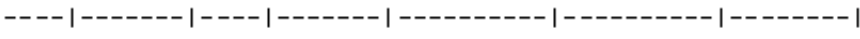 } \\
\hline 1 & 8.242 & $\mathrm{BB}$ & 0.2325 & 2740.66846 & 174.28999 & 50.0614 \\
\hline 2 & 9.706 & $\mathrm{BB}$ & 0.2734 & 2733.94312 & 148.77861 & 49.9386 \\
\hline $\mathrm{ota}$ & & & & 5474.61157 & 323.06860 & \\
\hline
\end{tabular}

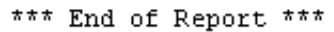


<smiles></smiles>

Data File E: \DATA $\backslash$ SLM $\backslash$ SLM-9-23 2018-07-04 21-22-41 \SLM-9-23.D Sample Name: SLM-9-23-CHIRAL

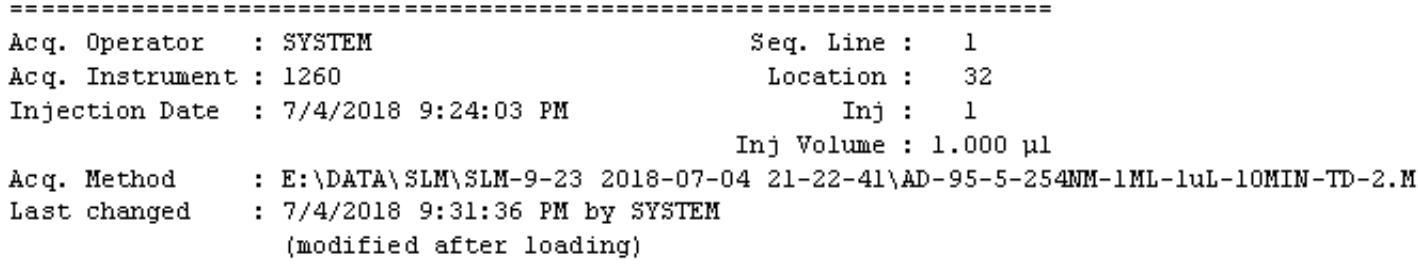

Analysis Method : E: \DATA SLM SLM-9-23 2018-07-04 21-22-41 (Sequence Method)

Last changed : 7/6/2018 9:48:46 PM by SYSTEM

(modified after loading)

Additional Info: Peak (s) manually integrated

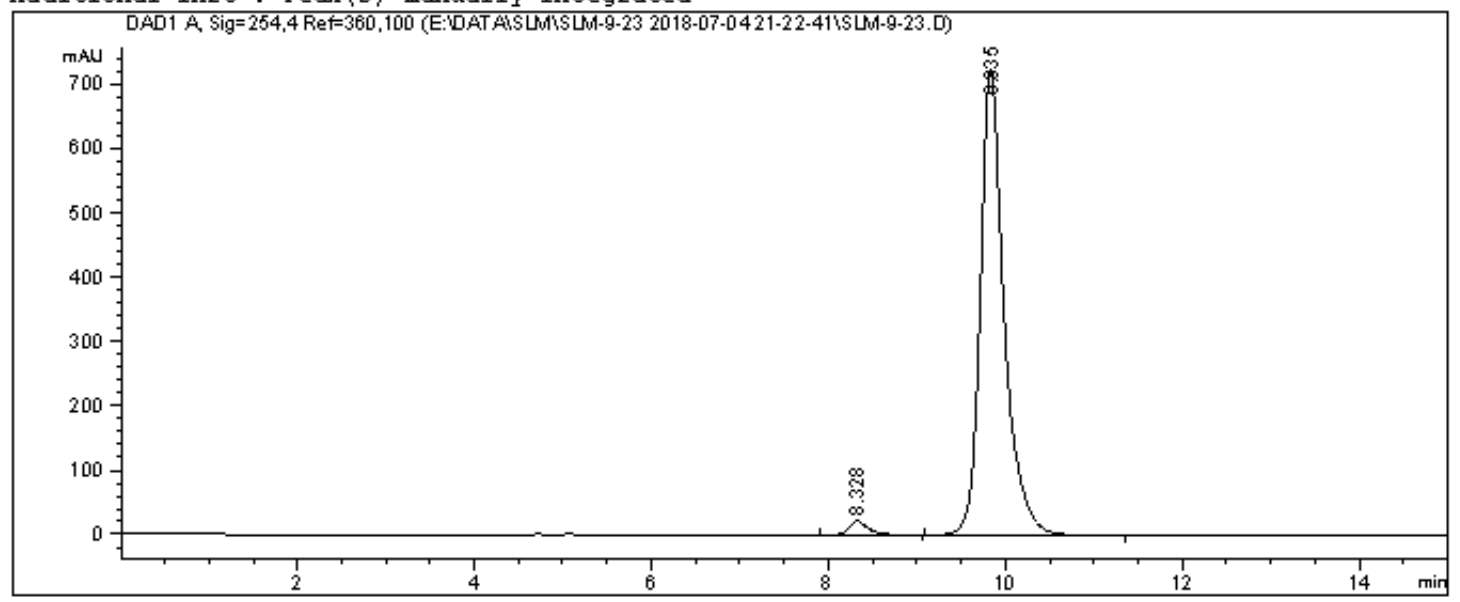

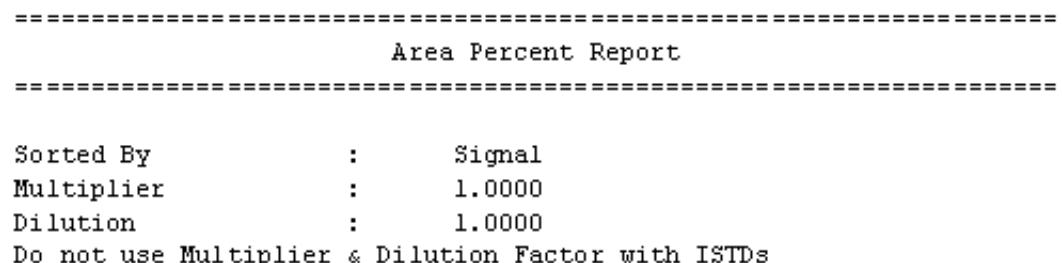

Do not use Multiplier \& Dilution Factor with ISTDs

Signal 1: DADl A, sig $=254,4$ Ref $=360,100$

\begin{tabular}{|c|c|c|c|c|c|c|}
\hline $\begin{array}{c}\text { Peak } \\
\#\end{array}$ & $\begin{array}{c}\text { RetTime } \\
\text { [min] }\end{array}$ & Type & $\begin{array}{l}\text { Width } \\
\text { [min] }\end{array}$ & $\begin{array}{c}\text { Area } \\
{\left[\mathrm{mAU} U^{*} \mathrm{~s}\right]}\end{array}$ & $\begin{array}{l}\text { Height } \\
\text { [miU] }\end{array}$ & $\begin{array}{c}\text { Area } \\
\frac{s}{5}\end{array}$ \\
\hline--- & 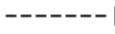 & & 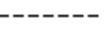 & -------- & ----------1 & -------- \\
\hline 1 & 8.328 & $\mathrm{BB}$ & 0.2297 & 338.37271 & 21.61141 & 2.4309 \\
\hline 2 & 9.835 & $\mathrm{BB}$ & 0.2770 & $1.35811 \mathrm{e} 4$ & 723.62457 & 97.5691 \\
\hline
\end{tabular}

Totals :

$1.39195 \mathrm{e} 4 \quad 745.23599$

ネネー End of Report *ネ 
<smiles>C=CC(c1ccccc1)C1(N)C(=O)N(C)c2ccccc21</smiles>

$8 \mathbf{a}$<smiles>C=CC(c1ccccc1)C1(N)C(=O)N(C)c2ccccc21</smiles>

$8 b$

Data File E: \DATA SLM SLM-7-84\SLM-7-84 2018-07-10 12-56-53\SLM-7-841.D

Sample Name: SLM-7-84-RAC

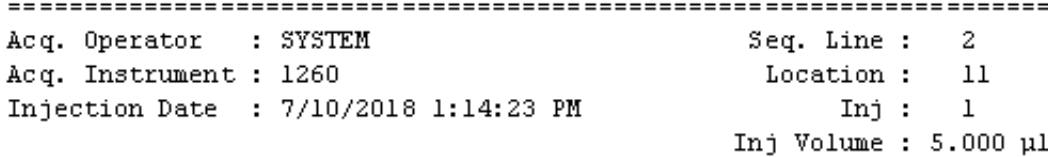

Acq. Method : E: \DATA $\backslash$ SLM $\backslash$ SLM-7-84 \SLM-7-84 2018-07-10 $12-56-53 \backslash$ IE-70-30-254NM-1ML-5UL15MIN.M

Last changed : 7/10/2018 12:56:53 PM by SYSTEM

Analysis Method : E: \DATA SLM SLM-7-84\SLM-7-84 2018-07-10 12-56-53 IE-70-30-254NM-1ML-5UL15MIN.M (Sequence Me thod)

Last changed : 7/20/2018 2:16:14 PM by SYSTEM

(modified after loading)

Additional Info: Peak (s) manually integrated

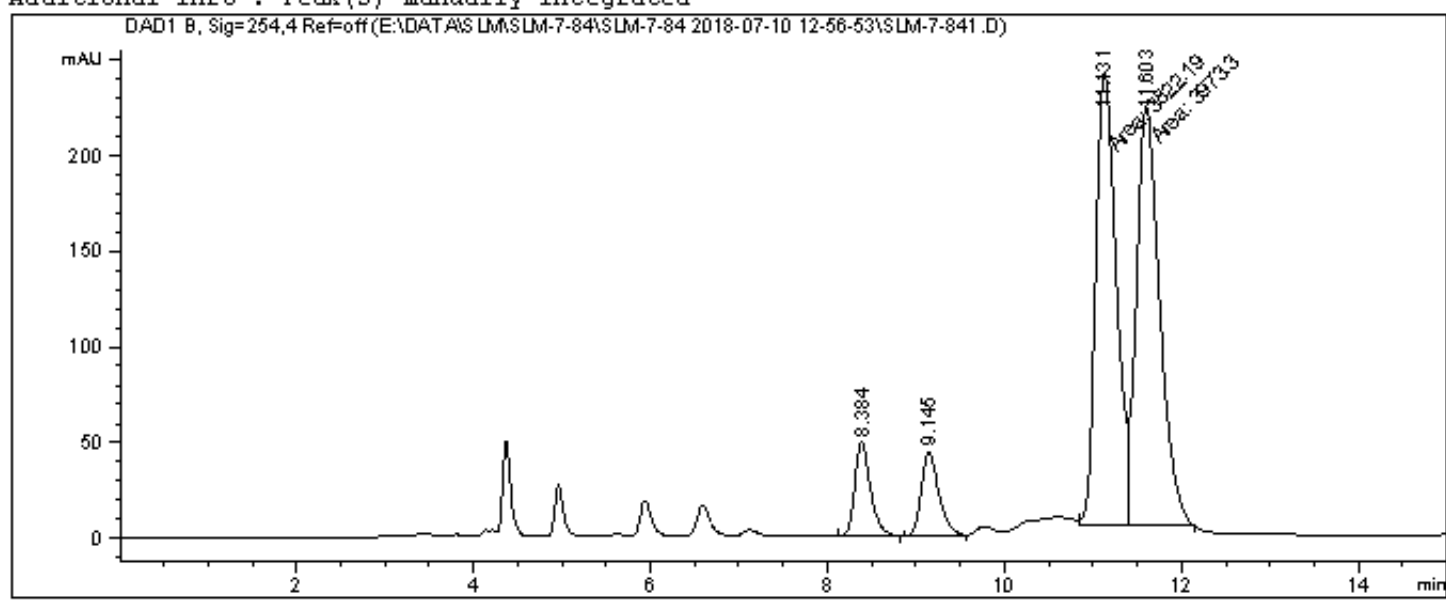

\section{Area Percent Report}

\begin{tabular}{|c|c|c|}
\hline Sorted By & : & Signal \\
\hline Multiplier & : & 1.0000 \\
\hline Dilution & : & 1.0000 \\
\hline
\end{tabular}

Do not use Multiplier \& Dilution Factor with IsTDs

Signal 1: DADl B, Sig=254, 4 Ref=off

\begin{tabular}{|c|c|c|c|c|c|c|}
\hline $\begin{array}{c}\text { eak } \\
\#\end{array}$ & $\begin{array}{c}\text { RetTime } \\
\text { [min] }\end{array}$ & Type & $\begin{array}{l}\text { Width } \\
\text { [min] }\end{array}$ & $\begin{array}{c}\text { Area } \\
\text { [mÂ* } 3 \text { ] }\end{array}$ & $\begin{array}{l}\text { Height } \\
\text { [mîU] }\end{array}$ & $\begin{array}{c}\text { Area } \\
\stackrel{5}{*}\end{array}$ \\
\hline & & & & 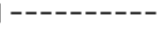 & & \\
\hline 1 & & & & 598. & & 590 \\
\hline 2 & 9.145 & $B$ & 0.2081 & 593.90900 & 55882 & 6.6079 \\
\hline 3 & 11.131 & $M F$ & 0.2691 & 3822.18921 & 236.68582 & 5260 \\
\hline 4 & 11.603 & $\mathrm{M}$ & 0.3029 & 3973.29688 & 218.60509 & 44.2072 \\
\hline
\end{tabular}

Totals :

$8987.89709 \quad 547.45953$ 
<smiles>C=C[C@H](c1ccccc1)C1(N)C(=O)N(C)c2ccccc21</smiles>

$8 a$<smiles>C=C[C@H](c1ccccc1)C1(N)C(=O)N(C)c2ccccc21</smiles>

$8 b$

Data File E: \DATA SLM SLM-7-84\SLM-7-84 2018-07-10 12-56-53\SLM-7-842.D Sample Name: SLM-7-84-CHIRAL

\begin{tabular}{|c|c|c|c|}
\hline Acq. Operator & : SYSTEM & Seq. Line : & 3 \\
\hline Acq. Instrument & : 1260 & Location : & 12 \\
\hline Injection Date & : 7/10/2018 1:30:44 PM & Inj : & 1 \\
\hline
\end{tabular}

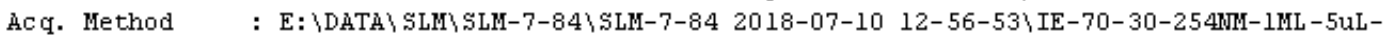
15MIN.M

Last changed : 7/10/2018 12:56:53 PM by SYSTEM

Analysis Method : E: \DATA SLM SLM-7-84\SLM-7-84 2018-07-10 12-56-53 IE-70-30-254MM-1ML-5uL15MIN.M (Sequence Me thod)

Last changed : 7/20/2018 2:16:14 PM by SYSTEM (modified after loading)

Additional Info : Peak (s) manually integrated

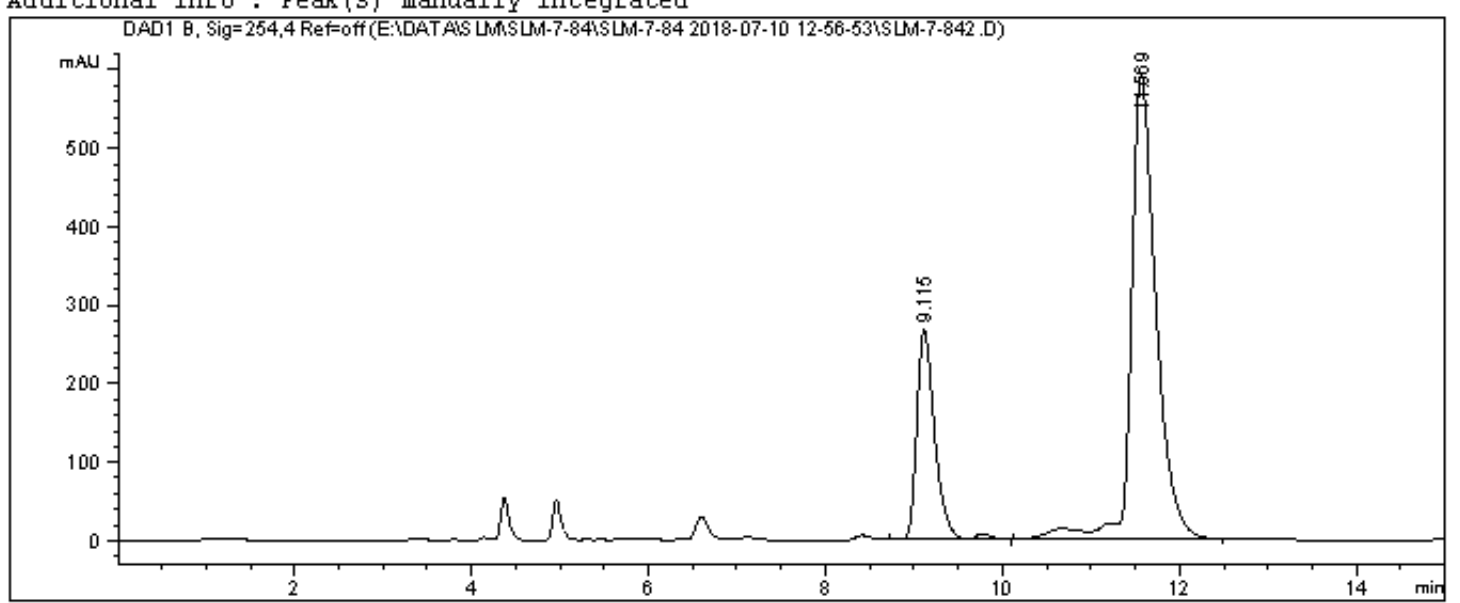

Area Percent Report

\begin{tabular}{|c|c|c|}
\hline Sorted BY & : & Signal \\
\hline Multiplier & : & 1.0000 \\
\hline Dilution & : & 1.0000 \\
\hline
\end{tabular}

Do not use Multiplier \& Dilution Factor with IsTDs

Signal 1: DADl B, Sig=254, 4 Ref=off

\begin{tabular}{|c|c|c|c|c|c|c|}
\hline $\begin{array}{c}\text { Peak } \\
\#\end{array}$ & $\begin{array}{c}\text { RetTime } \\
\text { [min] }\end{array}$ & Type & $\begin{array}{l}\text { Width } \\
\text { [min] }\end{array}$ & $\begin{array}{c}\text { Àrea } \\
\left.\text { [m } \mathrm{m} \mathrm{U}^{*} \mathrm{~s}\right]\end{array}$ & $\begin{array}{l}\text { Height } \\
\text { [mAU] }\end{array}$ & $\begin{array}{c}\text { Area } \\
\text { \& }\end{array}$ \\
\hline \multicolumn{7}{|c|}{ 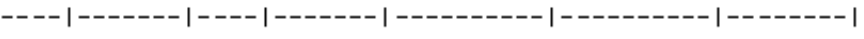 } \\
\hline 1 & 9.115 & BV R & 0.2102 & 3791.23267 & 267.64041 & 24.4920 \\
\hline 2 & 11.569 & VB $\mathrm{R}$ & 0.2808 & $1.16882 \mathrm{e} 4$ & 591.31708 & 75.5080 \\
\hline Cot & : & & & $1.54795 \mathrm{e} 4$ & 858.95749 & \\
\hline
\end{tabular}

*木 End of Report \#* 
<smiles>C=CC(c1ccccc1)[C@]1(N)C(=O)N(C)c2ccccc21</smiles>

$8 \mathbf{a}$

Data File E: \DATA $\backslash$ SLM $\$ SLM-7-84\SLM-7-84 2018-07-10 12-56-53\SLM-7-843.D

Sample Name: SLM-7-84-MAJOR

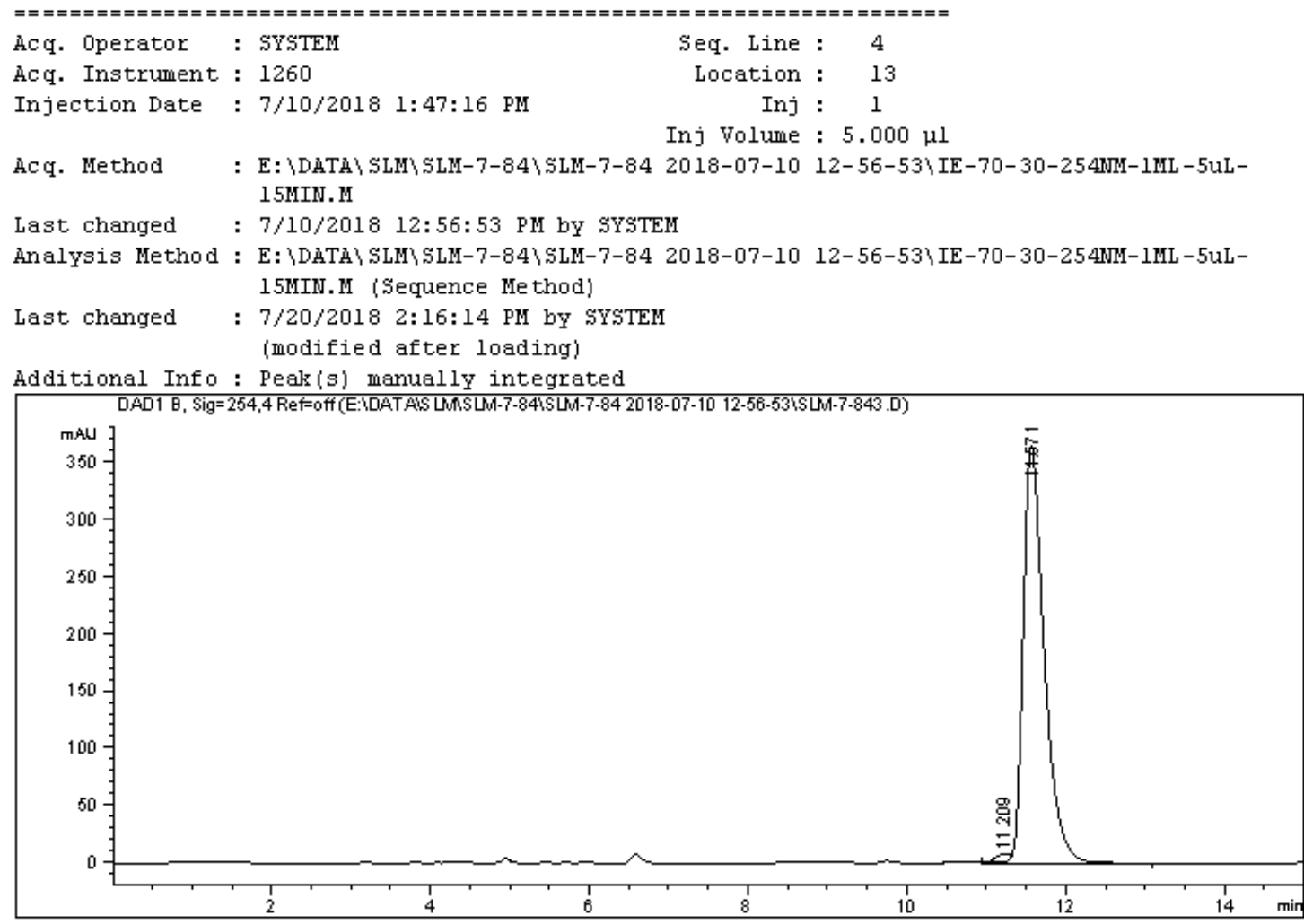

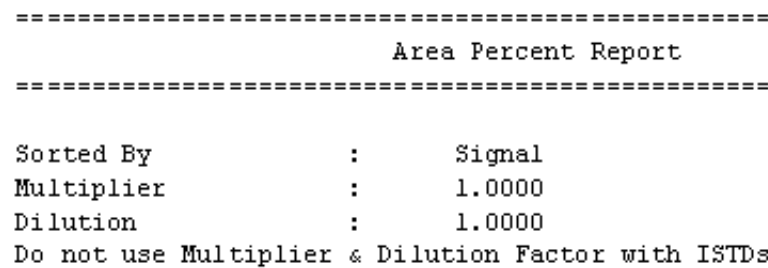

Signal 1: DADl B, Sig=254, 4 Ref=off

\begin{tabular}{|c|c|c|c|c|c|c|}
\hline $\begin{array}{c}\text { Peak } \\
\#\end{array}$ & $\begin{array}{c}\text { RetTime } \\
\text { [min] }\end{array}$ & Type & $\begin{array}{l}\text { Width } \\
\text { [min] }\end{array}$ & $\begin{array}{c}\text { Area } \\
\text { [mAUt*3] }\end{array}$ & $\begin{array}{l}\text { Height } \\
\text { [mAU] }\end{array}$ & $\begin{array}{c}\text { Area } \\
\stackrel{s}{8}\end{array}$ \\
\hline & & & ------ & ------- & ------- & ------ \\
\hline 1 & 11.20 & $\mathrm{~V} E$ & 0.1847 & 87.95282 & 7.14006 & 1.2975 \\
\hline 2 & 11.571 & VB $R$ & 0.2782 & 6690.85693 & 364.37161 & 98.7025 \\
\hline
\end{tabular}

$\begin{array}{ll}\text { Totals : } & 6778.80975 \quad 371.51167\end{array}$ 
<smiles>C=C[C@H](C)[C@]1(N)C(=O)N(C)c2ccccc21</smiles>

Data File E: \DATA $\backslash$ SLM SLM-9-19 \LM-9-19 2018-06-14 21-53-22\SLM-9-19-badouji.D Sample Name: SLM-9-19-badouji-rac

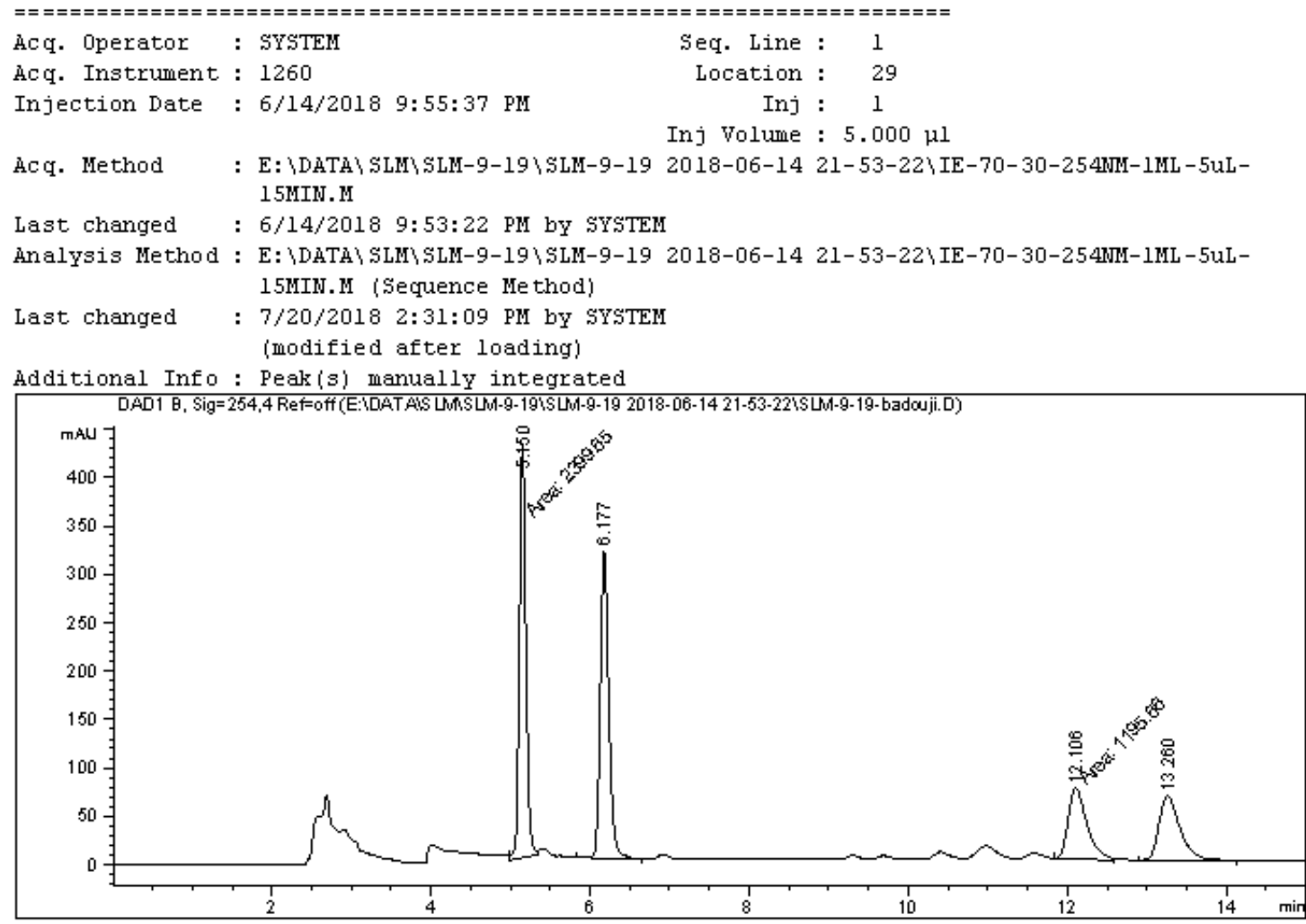

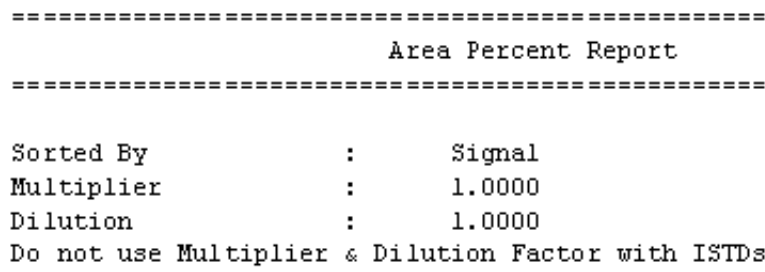

\begin{tabular}{|c|c|c|c|c|c|c|}
\hline $\begin{array}{c}\text { Peak } \\
\#\end{array}$ & $\begin{array}{c}\text { RetTime } \\
\text { [min] }\end{array}$ & Type & $\begin{array}{l}\text { Width } \\
\text { [min] }\end{array}$ & $\begin{array}{c}\text { Area } \\
\text { [mAUt*s] }\end{array}$ & $\begin{array}{l}\text { Height } \\
\text { [mAU] }\end{array}$ & $\begin{array}{c}\text { Area } \\
\stackrel{8}{8}\end{array}$ \\
\hline \multicolumn{7}{|c|}{$----|------||----|-------|---------|---------|-------|$} \\
\hline 1 & 5.150 & MM & 0.0940 & 2399.64795 & 425.61212 & 33.4836 \\
\hline 2 & 6.177 & VB $R$ & 0.1124 & 2360.54639 & 317.81628 & 32.9380 \\
\hline 3 & 12.106 & MM & 0.2732 & 1195.65540 & 72.94909 & 16.6836 \\
\hline 4 & 13.260 & $\mathrm{BB}$ & 0.2748 & 1210.78271 & 66.36588 & 16.8947 \\
\hline
\end{tabular}

Totals :

$7166.63245 \quad 882.74338$ 
<smiles>C=C[C@H](C)[C@]1(N)C(=O)N(C)c2ccccc21</smiles>

Data File E: \DATA $\backslash$ SLM SLM-9-19 SLM-9-19 2018-06-14 21-53-22\SLM-9-19-badoujil.D Sample Name: sLM-9-19-badouji-chiral

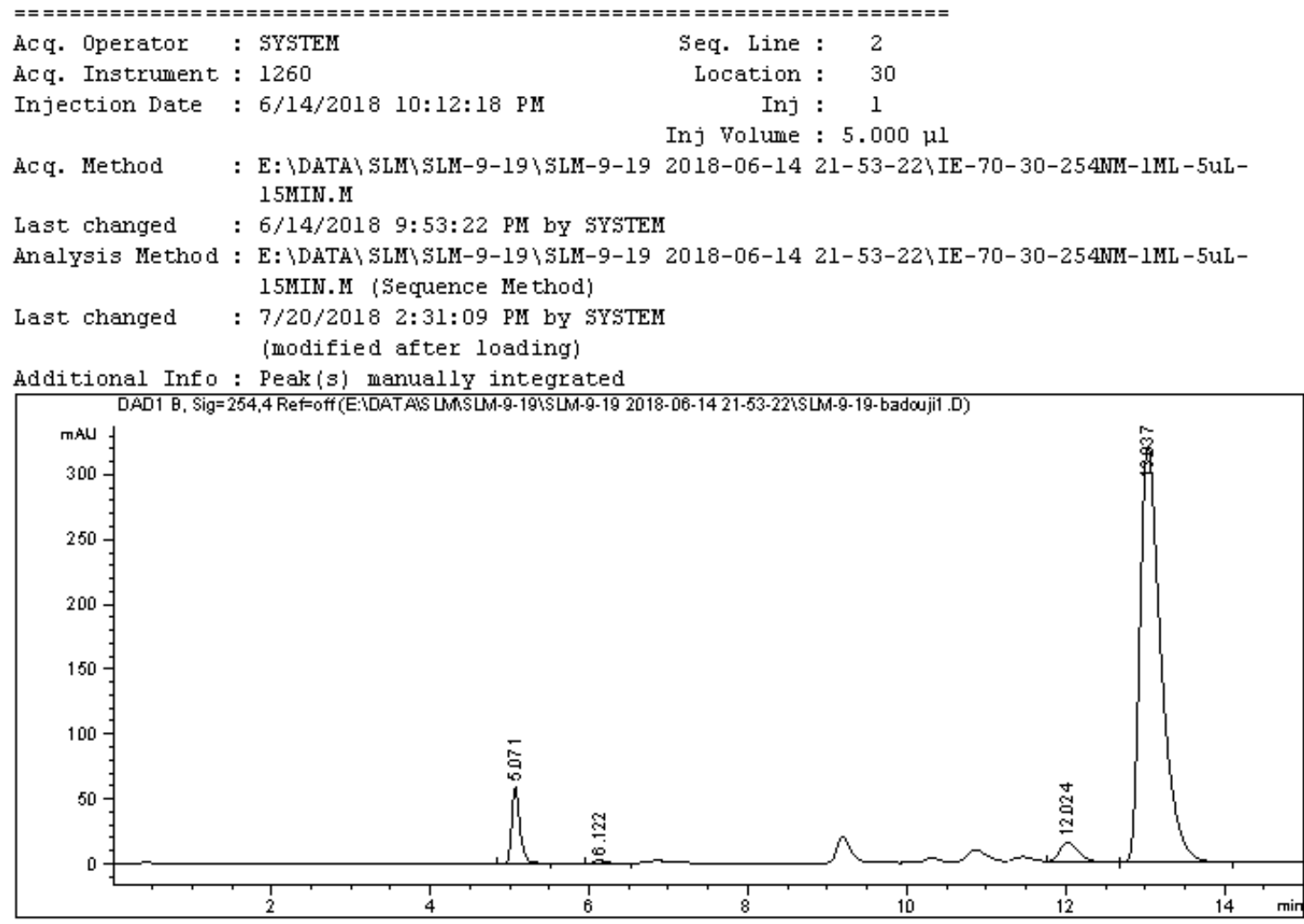

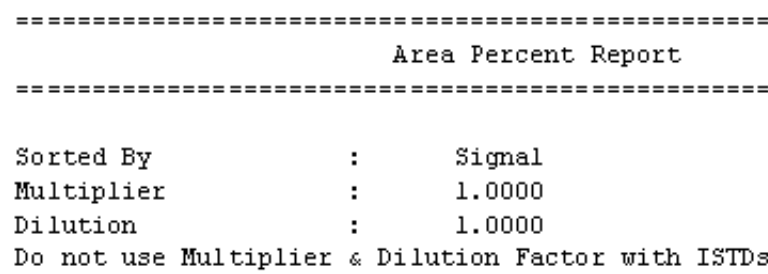

Signal 1: DADl B, Sig=254, 4 Ref=off

\begin{tabular}{|c|c|c|c|c|c|c|}
\hline $\begin{array}{c}\text { Peak } \\
\#\end{array}$ & $\begin{array}{c}\text { RetTime } \\
\text { [min] }\end{array}$ & Type & $\begin{array}{l}\text { Width } \\
\text { [min] }\end{array}$ & $\begin{array}{c}\text { Area } \\
{\left[\mathrm{mAU}^{*} \mathrm{~s}\right]}\end{array}$ & $\begin{array}{l}\text { Height } \\
\text { [mAU] }\end{array}$ & $\begin{array}{c}\text { Area } \\
\stackrel{5}{*}\end{array}$ \\
\hline-- & ---- & & ----- & -------- & ------- & ------1 \\
\hline 1 & 5.071 & $\mathrm{BB}$ & 0.1069 & 420.79059 & 59.20790 & 6.3073 \\
\hline 2 & 6.122 & $\mathrm{BB}$ & 0.1327 & 25.16098 & 2.77778 & 0.3771 \\
\hline 3 & 12.024 & VB & 0.2577 & 277.78165 & 15.75834 & 4.1637 \\
\hline 4 & 13.037 & $\mathrm{BB}$ & 0.2789 & 5947.79248 & 321.43311 & 89.1519 \\
\hline
\end{tabular}

Totals :

$6671.52570 \quad 399.17713$ 
<smiles>C/C=C\CC(N)C(F)(F)C(=O)c1ccccc1</smiles>

\section{$(S, E)-13 a \quad(R, Z)-13 b$}

Data File E: \DATA $\backslash$ SLM SLM-9-88\SLM-9-88 2018-07-13 18-40-37\SLM-9-882.D Sample Name: SLM-9-88-RAC
Acq. Operator : SYSTEM
seq. Line : 3
Acq. Instrument : 1260
Injection Date : 7/13/2018 7:35:24 PM
Location : 6
Inj : 1

Inj Volume : $10.000 \mu l$

Acq. Method : E: \DATA \SL SLM-9-88\SLM-9-88 2018-07-13 18-40-37\0D-H-95-5-1. 0ML-DAD-10UL6OMIN.M

Last changed : 7/13/2018 6:43:01 PM by SYSTEM

Analysis Method : E: \DATA SLM SLM-9-88\SLM-9-88 2018-07-13 18-40-37 0D-H-95-5-1. 0ML-DAD-10UL60MIM.M (Sequence Me thod)

Last changed : 7/20/2018 2:40:31 PM by SYSTEM

(modified after loading)

Additional Info : Peak (s) manually integrated

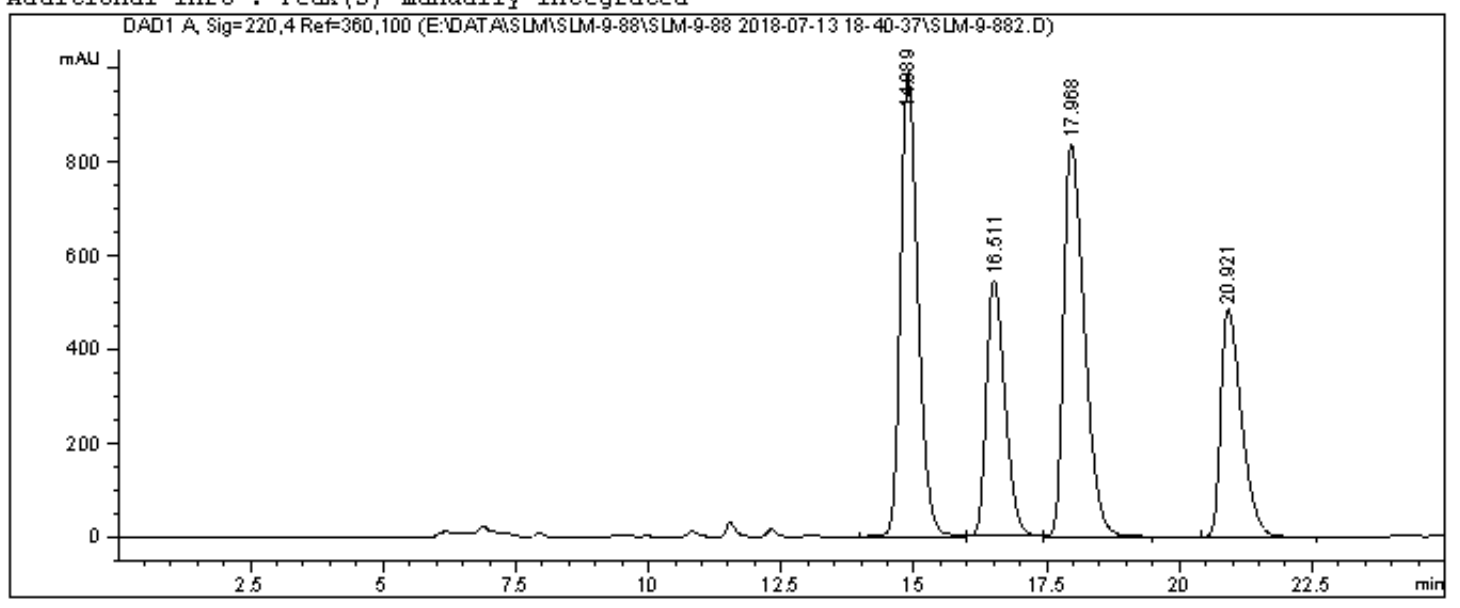

Area Percent Report

\begin{tabular}{|c|c|c|}
\hline Sorted BY & $:$ & Signal \\
\hline Multiplier & : & 1.0000 \\
\hline Dilution & : & 1.0000 \\
\hline
\end{tabular}

Do not use Multiplier \& Dilution Factor with IsTDs

Signal 1: DADl A, Sig $=220,4$ Ref $=360,100$

\begin{tabular}{|c|c|c|c|c|c|c|}
\hline $\begin{array}{c}\text { Peak } \\
\#\end{array}$ & $\begin{array}{c}\text { RetTime } \\
\text { [min] }\end{array}$ & Type & $\begin{array}{l}\text { Width } \\
\text { [min] }\end{array}$ & $\begin{array}{c}\text { Area } \\
\text { [mÂU*'s] }\end{array}$ & $\begin{array}{l}\text { Height } \\
\text { [mAU] }\end{array}$ & $\begin{array}{c}\text { Area } \\
\stackrel{s}{8}\end{array}$ \\
\hline & & & & -------- & 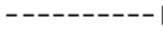 & 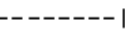 \\
\hline 1 & 14.889 & $\mathrm{BB}$ & 0.3524 & $2.26790 \mathrm{e} 4$ & 989.57526 & 31.5759 \\
\hline 2 & 16.511 & $\mathrm{BB}$ & 0.3755 & $1.31921 \mathrm{e} 4$ & 544.88940 & 18.3673 \\
\hline 3 & 17.968 & $\mathrm{BB}$ & 0.4228 & $2.27104 \mathrm{e} 4$ & 836.45062 & 31.6197 \\
\hline 4 & 20.921 & $\mathrm{BB}$ & 0.4195 & $1.32422 \mathrm{e} 4$ & 485.03186 & 18.4371 \\
\hline ota & : & & & .182 & 2855.94714 & \\
\hline
\end{tabular}

ネネホ End of Report ネネ 


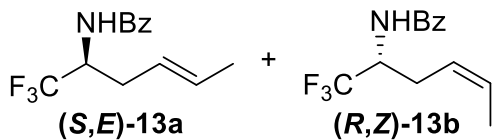

Data File E: \DATA SLM SLM-9-88 SLM-9-88 2018-07-14 15-42-05\5LM-9-88.D

Sample Name: SLM-9-88-36H-CHIRAL
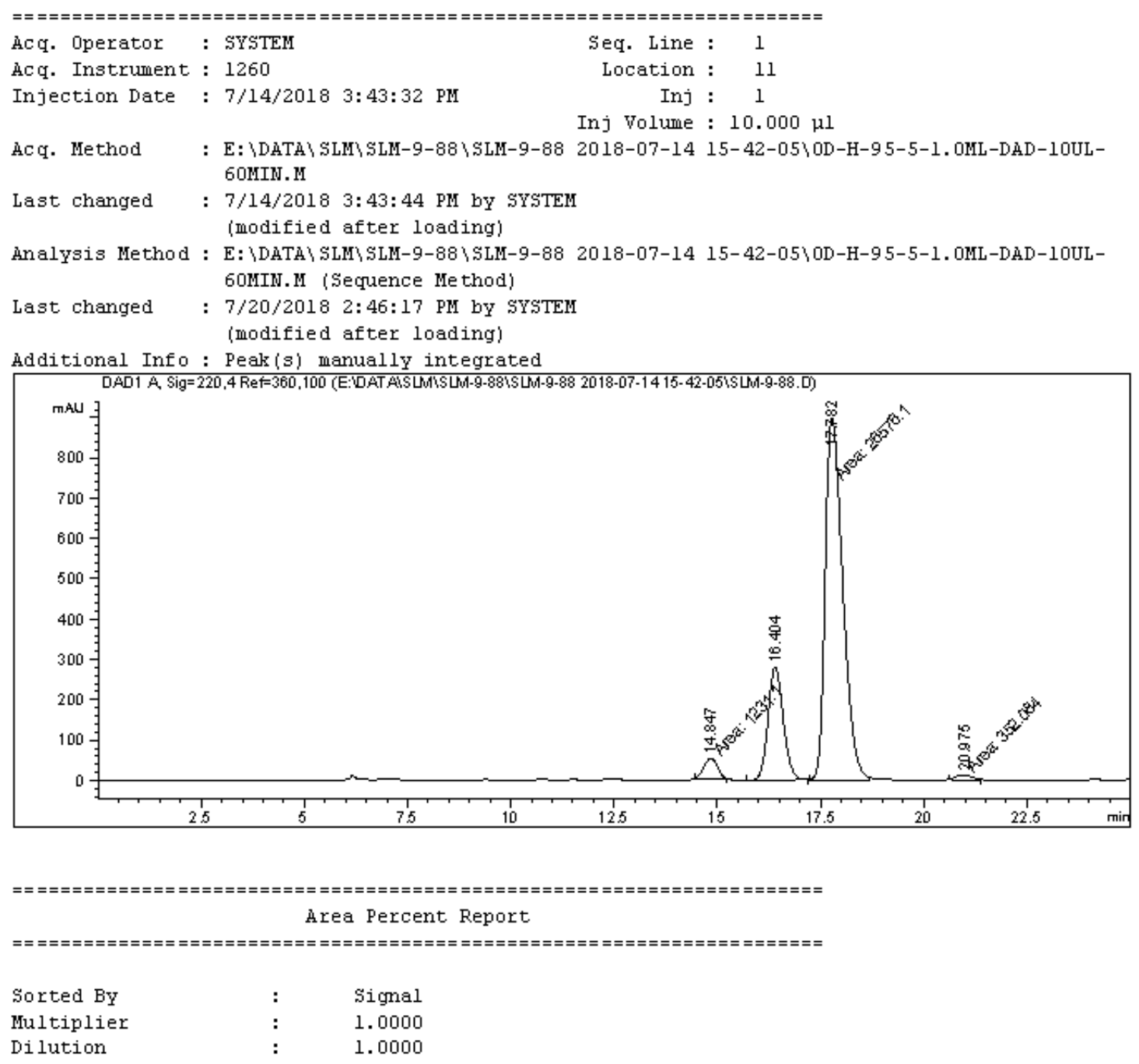

Do not use Multiplier \& Dilution Factor with ISTDs

Signal 1: DADl A, Sig $=220,4$ Ref $=360,100$

\begin{tabular}{|c|c|c|c|c|c|c|}
\hline $\begin{array}{c}\mathrm{Peak} \\
\#\end{array}$ & $\begin{array}{l}\text { RetTime } \\
\text { [min] }\end{array}$ & Type & $\begin{array}{l}\text { Width } \\
\text { [min] }\end{array}$ & $\begin{array}{c}\text { Area } \\
{\left[\mathrm{m} \mathrm{H}^{*} \mathrm{~s}\right]}\end{array}$ & $\begin{array}{l}\text { Height } \\
\text { [miU] }\end{array}$ & $\begin{array}{c}\text { Area } \\
\frac{\Delta}{3}\end{array}$ \\
\hline \multicolumn{7}{|c|}{$----\mid-0$} \\
\hline 1 & 14.847 & MM & 0.3912 & 1231.10352 & 52.45625 & 3.4873 \\
\hline 2 & 16.404 & $\mathrm{BB}$ & 0.3995 & 7143.24512 & 279.15088 & 20.2344 \\
\hline 3 & 17.782 & MM & 0.4934 & 2.6576 le 4 & 897.78119 & 75.2810 \\
\hline 4 & 20.975 & MM & 0.4857 & 352.08435 & 12.08271 & 0.9973 \\
\hline Tota & : & & & $3.53025 \mathrm{e} 4$ & 1241.47102 & \\
\hline
\end{tabular}


<smiles>C/C=C/CC(N)C(F)(F)F</smiles>

$(S, E)-13 a$

Data File E: \DATA SLM SLM-9-88\5LM-9-88 2018-07-13 18-40-37\5LM-9-88.D

Sample Name: SLM-9-88-1.5h-chiral

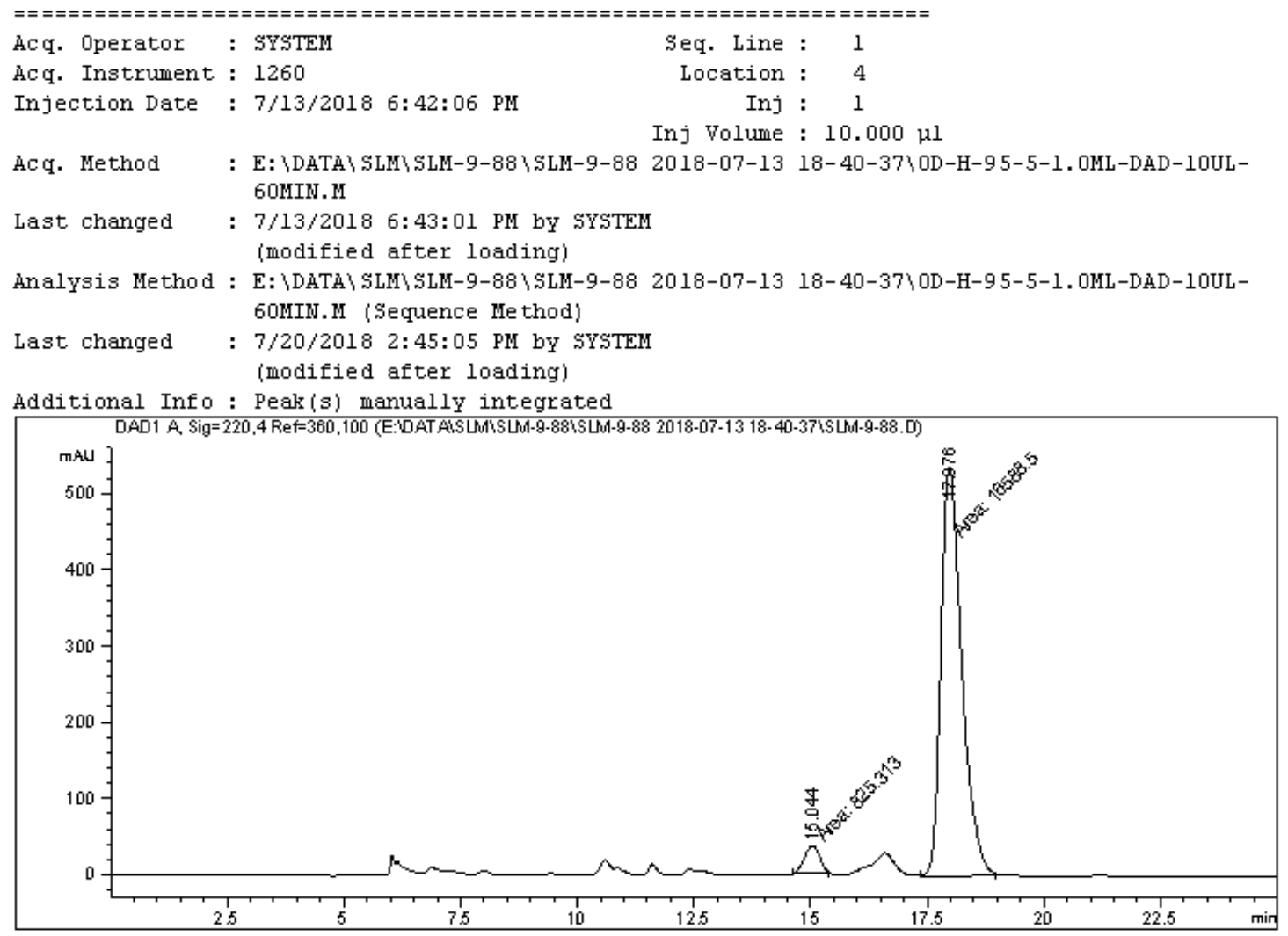

\begin{tabular}{|c|c|c|}
\hline Sorted BY & : & Signal \\
\hline Multiplier & $:$ & 1.0000 \\
\hline Dilution & : & 1.0000 \\
\hline
\end{tabular}

Do not use Multiplier \& Dilution Factor with ISTDs

Signal 1: DADl A, Sig $=220,4$ Ref $=360,100$

\begin{tabular}{|c|c|c|c|c|c|}
\hline $\begin{array}{c}\text { Peak } \\
\#\end{array}$ & $\begin{array}{l}\text { RetTime Type } \\
\text { [min] }\end{array}$ & $\begin{array}{l}\text { Width } \\
\text { [min] }\end{array}$ & $\begin{array}{c}\text { Area } \\
{\left[\mathrm{m} \mathrm{HU}^{*} \mathrm{~s}\right]}\end{array}$ & $\begin{array}{l}\text { Height } \\
\text { [mȦU] }\end{array}$ & $\begin{array}{c}\text { Area } \\
\frac{\hat{5}}{\delta}\end{array}$ \\
\hline \multicolumn{6}{|c|}{$----|-------|----|-------|----------|----------|--------\mid$} \\
\hline 1 & $15.044 \mathrm{MM}$ & 0.3817 & 825.31311 & 36.03351 & 4. 7394 \\
\hline 2 & $17.976 \mathrm{MM}$ & 0.5156 & $1.65885 \mathrm{e} 4$ & 536.17755 & 95.2606 \\
\hline Tota & : & & $1.74138 \mathrm{e} 4$ & 572.21106 & \\
\hline
\end{tabular}

ネネ End of Report 
<smiles>NC(CC=Cc1ccccc1)C(F)(F)F</smiles>

10

Data File E: \DATA $\backslash$ SLM $\backslash$ SLM-7-88 $\$ LMM-7-88 2017-12-13 14-43-22\SLM-7-881.D

Sample Name: SLM-7-88-RAC
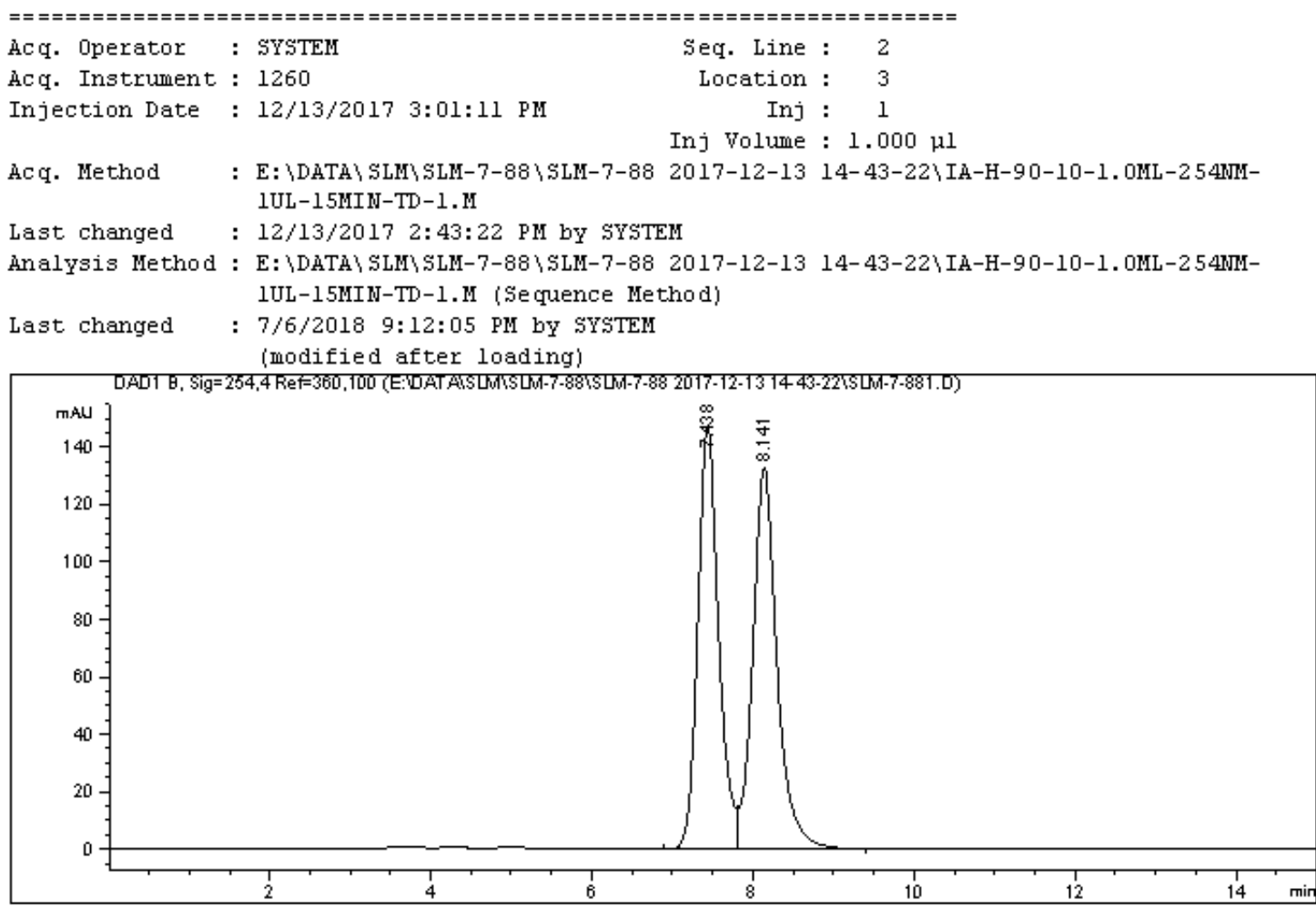

\section{Area Percent Report}

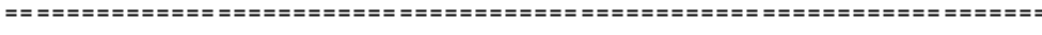

$\begin{array}{lll}\text { Sorted BY } & : & \text { Signal } \\ \text { Multiplier } & : & 1.0000 \\ \text { Dilution } & : & 1.0000\end{array}$

Do not use Multiplier \& Dilution Factor with IsTDs

Signal 1: DADl B, Sig=254, 4 Ref $=360,100$

\begin{tabular}{|c|c|c|c|c|c|c|}
\hline $\begin{array}{c}\text { Peak } \\
\#\end{array}$ & $\begin{array}{c}\text { RetTime } \\
\text { [min] }\end{array}$ & Type & $\begin{array}{l}\text { Width } \\
\text { [min] }\end{array}$ & $\begin{array}{c}\text { Area } \\
{\left[\mathrm{mAU}^{*} \mathrm{~s}\right]}\end{array}$ & $\begin{array}{l}\text { Height } \\
\text { [nAU] }\end{array}$ & $\begin{array}{c}\text { Area } \\
\stackrel{s}{s}\end{array}$ \\
\hline & & & 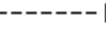 & --------- & 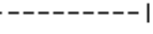 & \\
\hline 1 & 7.438 & $\mathrm{BV}$ & 0.2704 & 2636.53540 & 147.63258 & 48.7275 \\
\hline 2 & 8.141 & VB & 0.3115 & 2774.24146 & 132.90486 & 51.2725 \\
\hline ot & : & & & 5410.77686 & 280.53745 & \\
\hline
\end{tabular}


<smiles>NC(CC=Cc1ccccc1)C(F)(F)F</smiles>

10

Data File E: $\backslash$ DATA $\backslash$ SLM $\$ SLM-7-88\SLM-7-88 2017-12-13 14-43-22\SLM-7-88.D

Sample Name: SLM-7-88-CHIRAL

\begin{tabular}{|c|c|c|c|}
\hline Acq. Operator & : SYSTEM & Seq. Line : & 1 \\
\hline Ac q. Instrument : & : 1260 & Location : & 4 \\
\hline Injection Date : & : $12 / 13 / 20172: 44: 49$ PM & $\begin{array}{r}\text { Inj : } \\
\text { Inj Volume : }\end{array}$ & 1 \\
\hline
\end{tabular}

Acq. Method : E: \DATA SLM SLM-7-88 SLM-7-88 2017-12-13 14-43-22 IA-H-90-10-1. 0ML-254MM1UL-15MIN-TD-1.M

Last changed : 12/13/2017 2:43:22 PM by SYSTEM

Analysis Method : E: \DATA SLM SLM-7-88 SLM-7-88 2017-12-13 14-43-22\IA-H-90-10-1. 0ML-254MM1UL-15MIN-TD-1.M (Sequence Method)

Last changed : 8/14/2018 8:36:50 PM by SYSTEM (modified after loading)

Additional Info : Peak (s) manually integrated

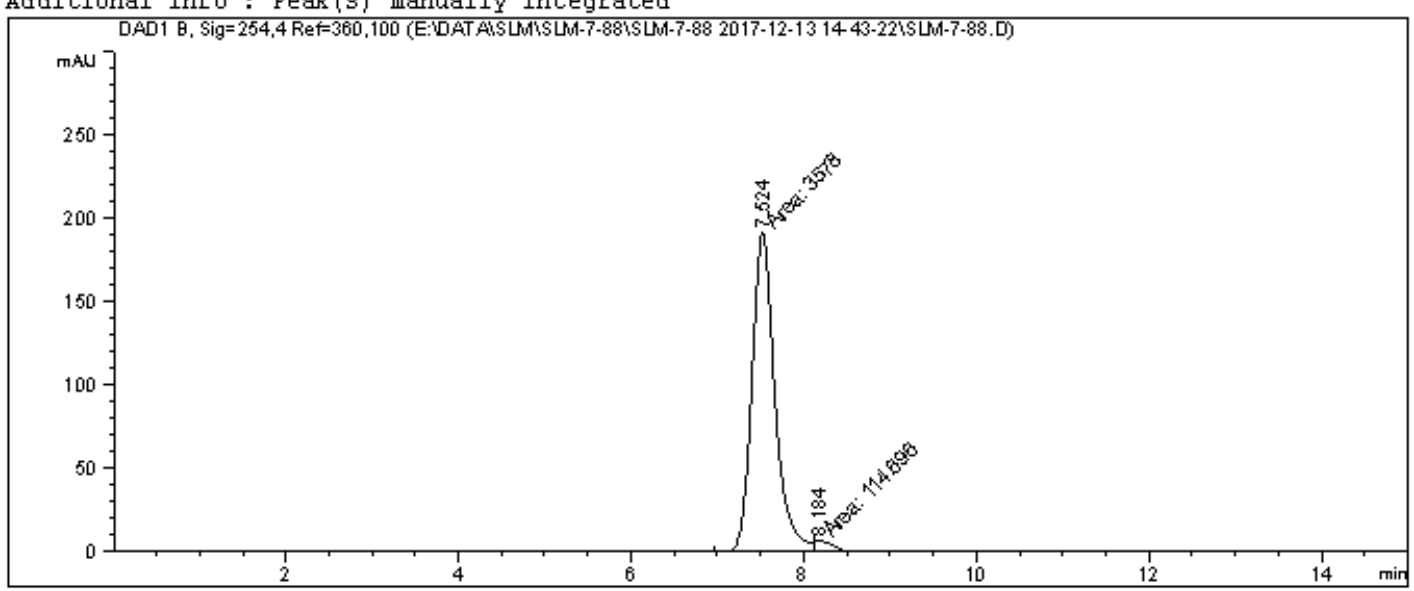

\begin{tabular}{|c|c|c|}
\hline Sorted BY & : & sign \\
\hline Multiplier & : & 1.0000 \\
\hline Dilution & : & 1.00 \\
\hline
\end{tabular}

Do not use Multiplier \& Dilution Factor with ISTDs

Signal 1: DADl B, Sig $=254,4$ Ref $=360,100$

\begin{tabular}{|c|c|c|c|c|c|}
\hline $\begin{array}{c}\text { Peak } \\
\#\end{array}$ & $\begin{array}{l}\text { RetTime Type } \\
\text { [min] }\end{array}$ & $\begin{array}{l}\text { Width } \\
\text { [min] }\end{array}$ & $\begin{array}{c}\text { Area } \\
{\left[\mathrm{m}^{-} \mathrm{H}^{*} \mathrm{~s}\right]}\end{array}$ & $\begin{array}{l}\text { Height } \\
\text { [mAU] }\end{array}$ & $\begin{array}{c}\text { Area } \\
\stackrel{4}{*}\end{array}$ \\
\hline-- & $------1--$ & ------- & ----------- & --------- & --------1 \\
\hline 1 & $7.524 \mathrm{MF}$ & 0.3098 & 3577.99829 & 192.51790 & 96.8940 \\
\hline 2 & 8.184 FM & 0.2719 & 114.69592 & 7.03030 & 3.1060 \\
\hline Tot & : & & 3692.69421 & 199.54820 & \\
\hline
\end{tabular}

ネネー End of Report *ネ 
<smiles>FC(F)(F)[C@@H]1C[C@H](I)[C@H](c2ccccc2)N1</smiles>

11

Data File E: \DATA $\backslash$ SLM $\backslash$ SLM-8-05 \LLM-8-05 2017-12-16 17-13-40 SLM-8-05.D Sample Name: SLM-8-05-RAC
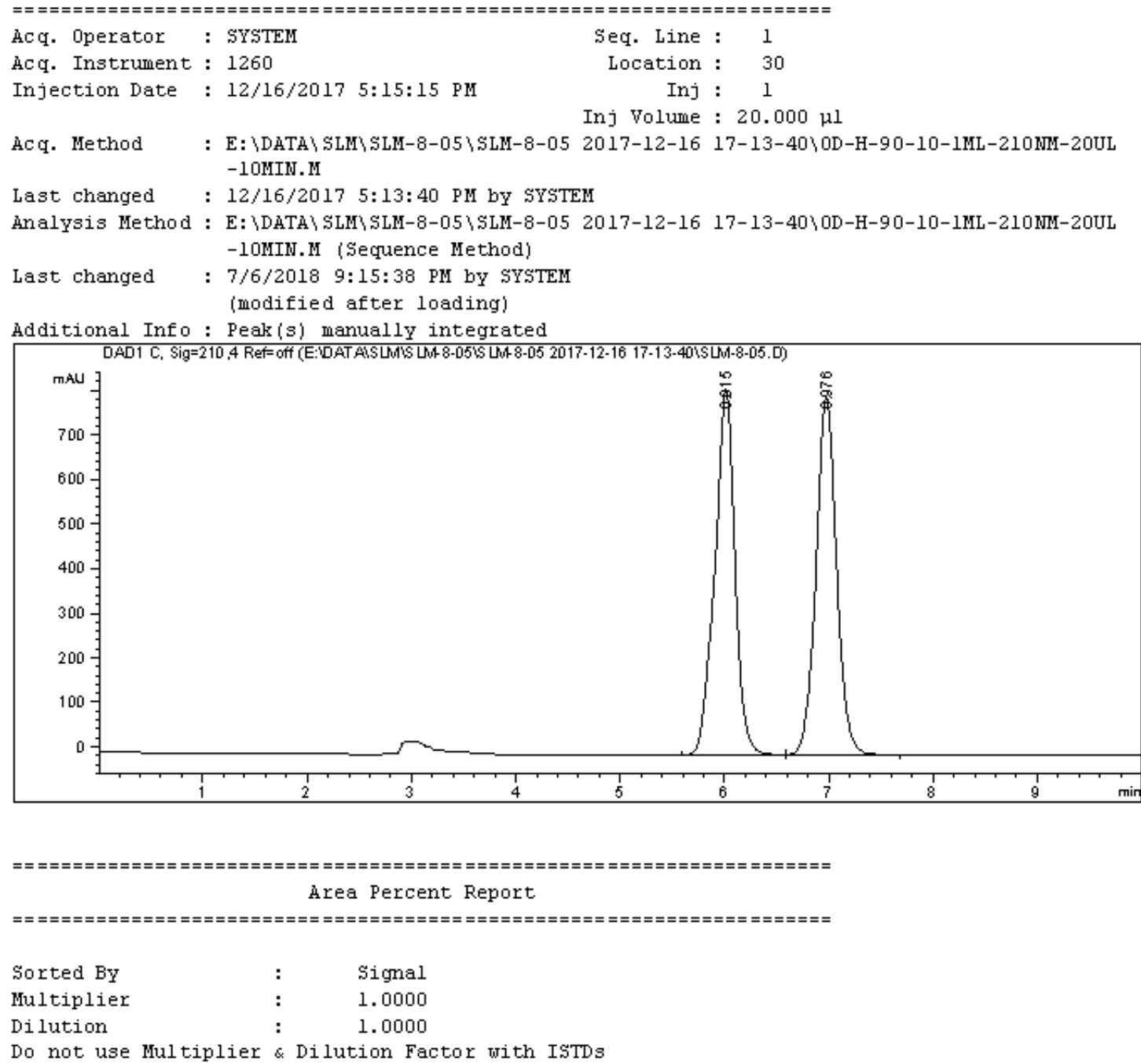

Do not use Multiplier \& Dilution Factor with ISTDs

Signal 1: DADl C, Sig=210, 4 Ref=off

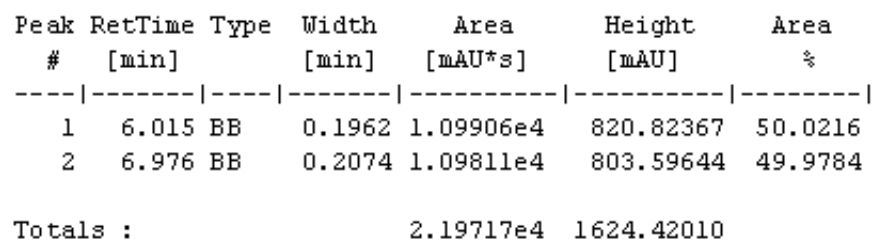

ネネ End of Report ネネ゙ 
<smiles>FC(F)(F)[C@@H]1C[C@H](I)[C@H](c2ccccc2)N1</smiles>

11

Data File E: \DATA $\backslash$ SLM $\backslash$ SLM-8-05 \LLM-8-05 2017-12-18 20-29-08\SLM-8-05.D Sample Name: SLM-8-05-CHIRAL
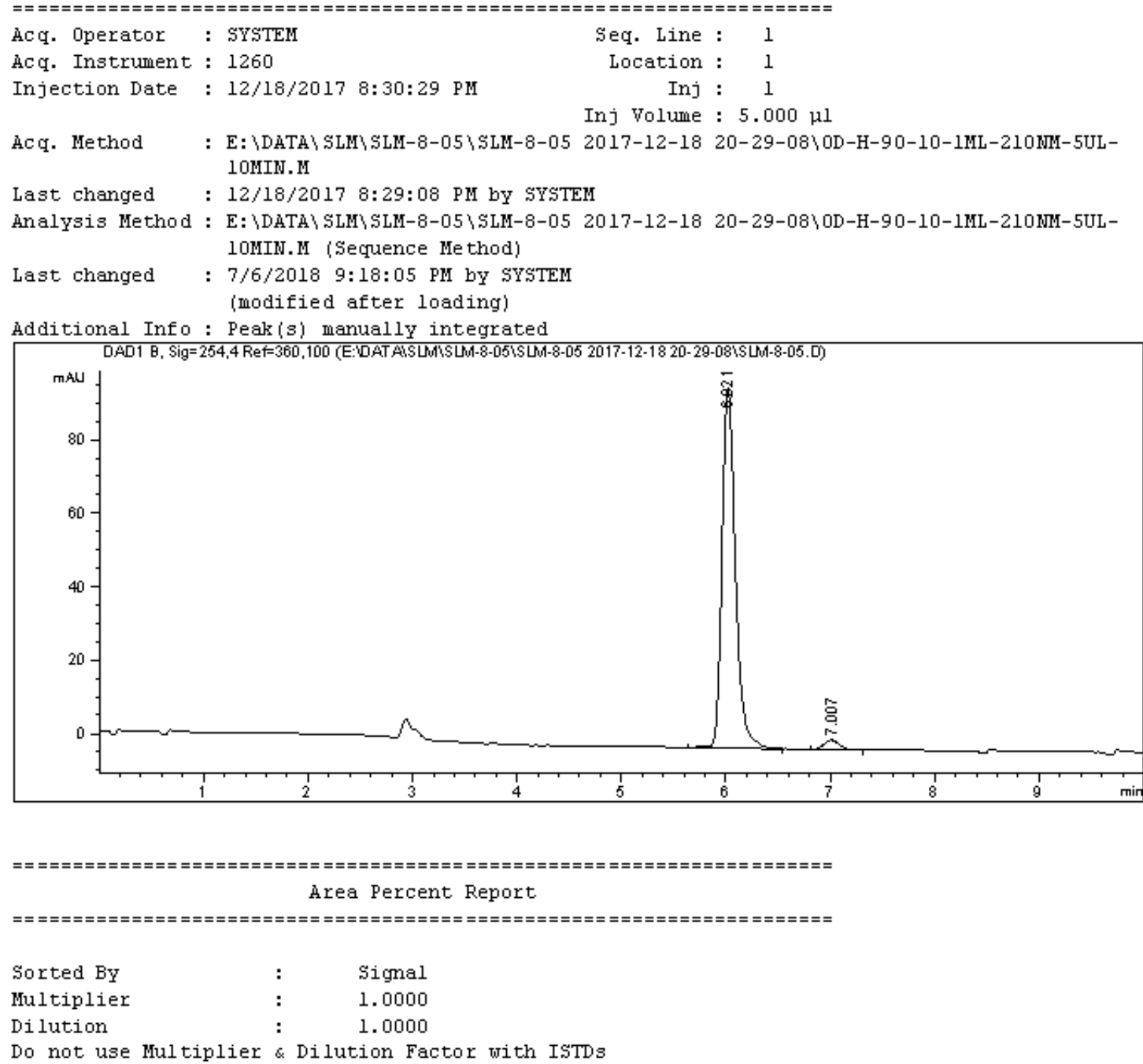

Do not use Multiplier \& Dilution Factor with ISTDs

Signal 1: DADl B, Sig $=254,4$ Ref $=360,100$

\begin{tabular}{|c|c|c|c|c|c|c|}
\hline $\begin{array}{c}\text { Peak } \\
\#\end{array}$ & $\begin{array}{c}\text { RetTime } \\
\text { [min] }\end{array}$ & Type & $\begin{array}{l}\text { Width } \\
\text { [min] }\end{array}$ & $\begin{array}{c}\text { Area } \\
\text { [mAU* }]\end{array}$ & $\begin{array}{l}\text { Height } \\
\text { [mAU] }\end{array}$ & $\begin{array}{c}\text { Area } \\
\stackrel{8}{*}\end{array}$ \\
\hline . & & & & ---------- & ------- & $-------\mid$ \\
\hline 1 & 6.0 & $\mathrm{~B} \mathrm{R}$ & 0.1350 & 873.99567 & 98.04962 & 96.9485 \\
\hline 2 & 7.007 & $\mathrm{BB}$ & 0.1515 & 27.50921 & 2.70942 & 3.0515 \\
\hline
\end{tabular}

Totals :

$901.50488 \quad 100.75905$ 